IISTOEY OF 'THE

$$
\begin{aligned}
& \text { Old Colony } \\
& \text { @ Railroad. }
\end{aligned}
$$




\section{THE NORT H}

A Monthly Illustrated Journal of

Industrial, * Inventive, * Commercial * and Financial * Resources * of * the United * States.

History, Biography, Science and Literature. EDITED AND PUBLISHED BY

H A G E R \& H A N Y , 12 PEARL STREET, - BOSTON, MASS. Special Editions on the World's Fair by our Correspondents. ESTABLISHED 1881

\section{HAGER \& HANDY,} HISTORICAL \& ULLLSTRATIVE PUBLLSHERS,

ART ADVERTISING has its place and in the front ranks are OUR SPECIALTIES.

- PUblishers of -

New England News, The North, History West End Street Railway, History Boston Yacht Club, History Old Colony Railroad. 
(A)

ESTABLISHED 1801.

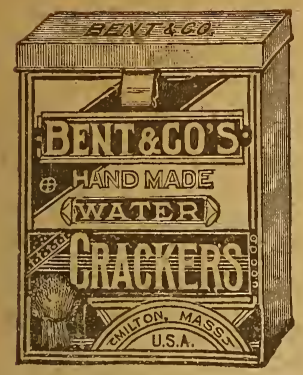

\section{BENT \& CO.'S CELEBRATED HAND-MADE \\ WATER CRACKERS.} THE BEST IIN THE WORLD.

Used by leading hotels and club-rooms. A great relish for invalids, and easy of digestion, and highly recommended by the medical faculty. Keep in any climate. Convenient for tourists and excursion parties. Beware of imitations. The genuine bear our stamp. Sold by all leading grocers.

\section{BENT \& CO.'S GRACKER MEAL.}

Is one of the most extensively used articles now in the market. Used and indorsed by the Boston Cooking School.

\section{Bent's Water Wafers.}

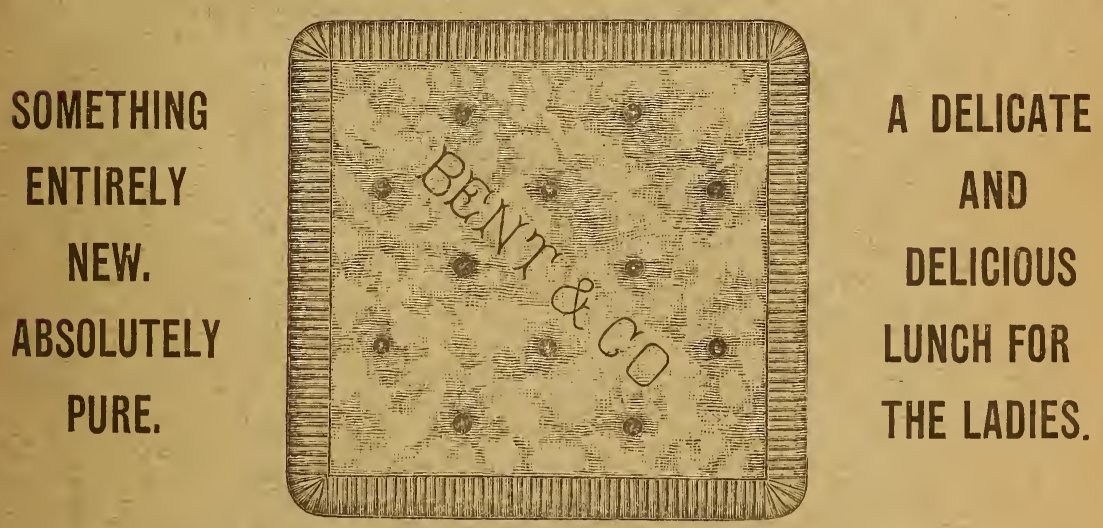

\section{HOME MADE GINGER SNAPS.}

MANUFACTURED BY

THE NEW YORK BISCUIT CO., MILTON, MASS. 

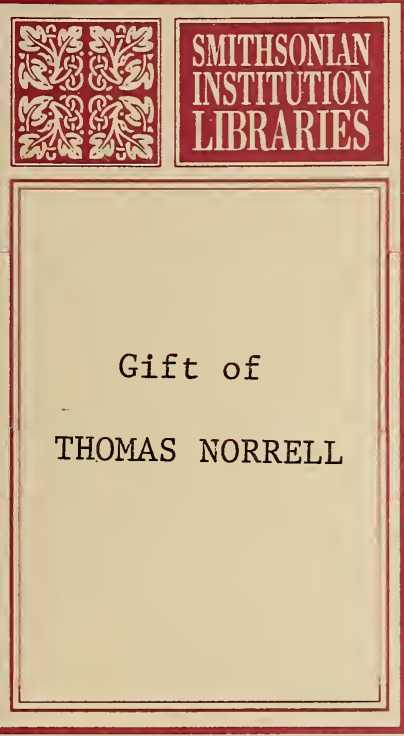

(B)
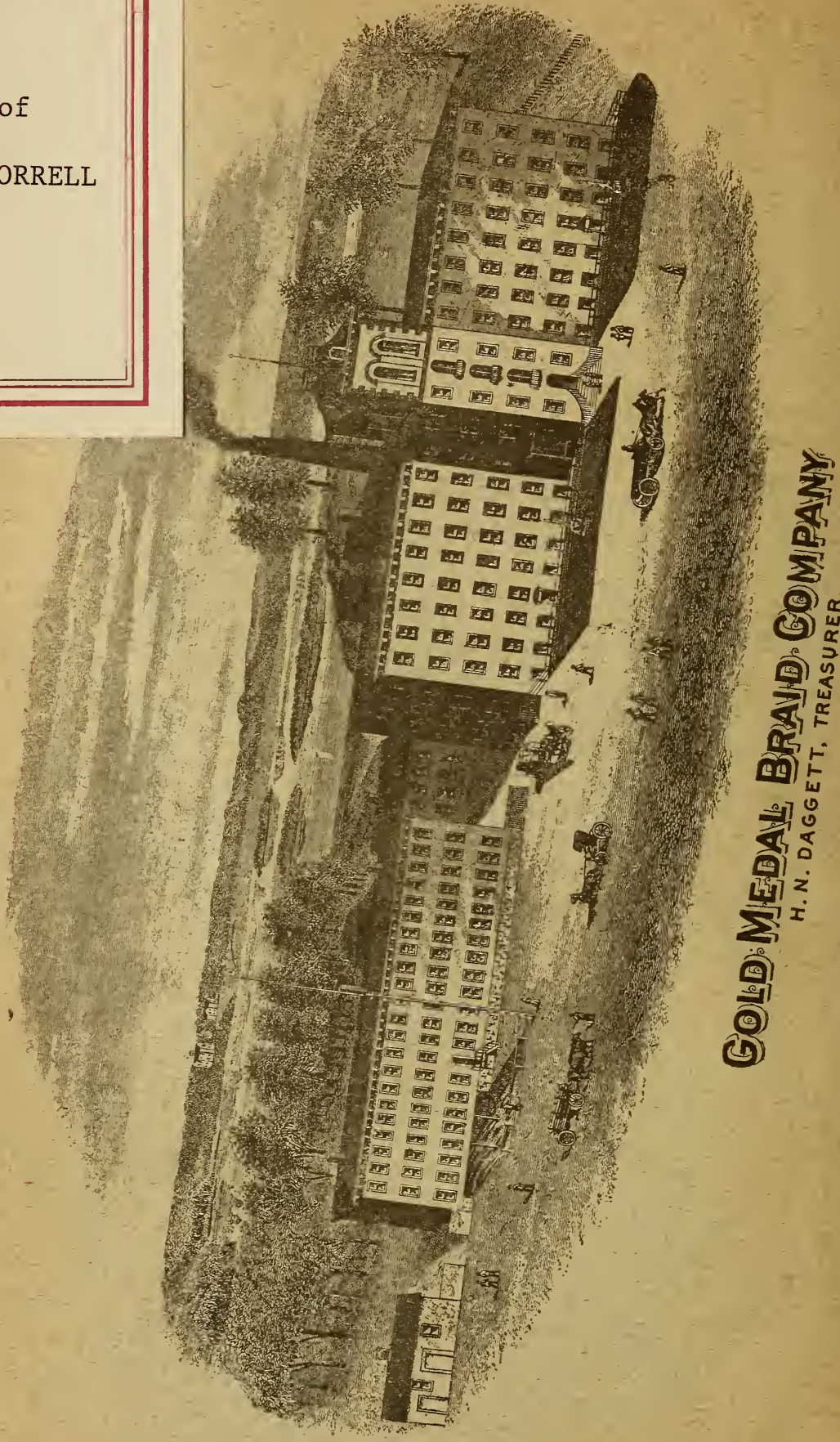
(c)

\section{J. WILLIAM BRADY,}

MANUFACTURER AND DEALER IN ALL KINDS OF

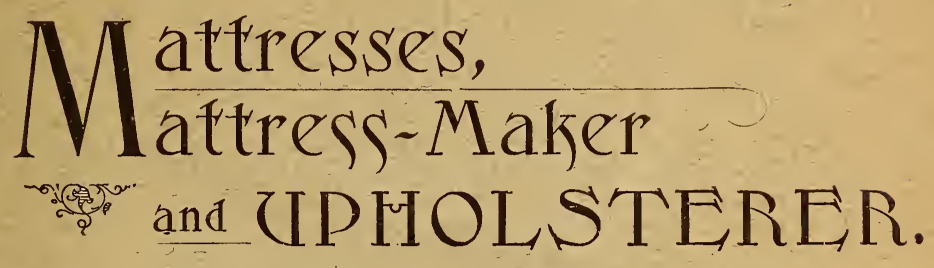

Hotel Work and Church Cushions a Specialty.

Brass and Iron Bedsteads, Spring Cots, etc.

Feather Beds Renovated by all the Latest Improved Processes.

Steam and cold air.

Feathers of all Grades for Sale at the Lowest Prices.

All orders by Mail Receive Prompt Attention.

\section{0 and 272 WEYBOSSET STREET,}

$$
\text { PROVIDENCE, R. I. }
$$

Richmond Building, opposite Snow Street. 
(D)

\title{
THE LEONNNSTER SHIRT COMPANY,
}

\section{MANUFACTURERS OF FINE DRESS SHIRTS.}

\author{
LAUNDRIED AND UNLAUNDRIED.
}

S. A. STEVENS, PREs.

E. F. POWERS, TREAS,

\section{LEOMINSTER, MASS.}

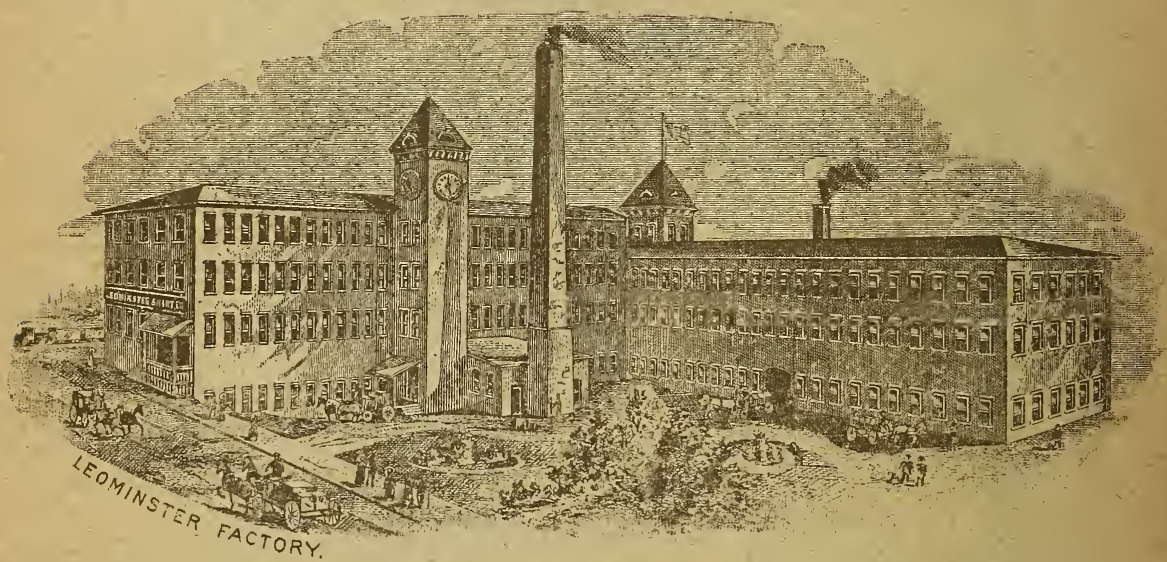

This Corporation is one of the largest manufacturers of this article of gentlemen's apparel in this country.

The Corporalion operate two large shirt factories, both situated on the Old Colony System of Railroads. The first and largest at Leominster, the other at Provincetown, Muss. This concern is one of the oldest esiablishments in this line and their goods have a sale in every city and town in our broad land. They employ some five hundred hands and the capacity of their works is over five hundred and fifty dozens of shirts per day. Twenty-five different styles of shirts are manufactured. They sell to the wholesale trade and the merits of their goods and low prices bring them a most flourishing business. 


\section{JORDAN, MARSH AMD CO.,} BOSTON, MASS.

\section{TO OUR PATRONS.}

We desire to place before all our customers, no matter how distant they may be, some idea of our house. We find it impossible to do this by mere ordinary announcement. We wish each person into whose hands this book falls to have an accurate idea of our firm, our resources, and our goods. When we reflect that our readers number several millions of people, we feel ambitious of providing them with something worthy. We trust we have succeeded. Among this enormous patronage are, of course, thousands who can only know us by our reputation; who can never see for themselves the working of our vast establishment. We are con tent to have it recognized as the great American Distributor, the colossal establishment, where experience, capital, and earnest zeal are the motive power.

We have brought the Mailing Department up to a degree of perfection never before attained. We have a staff of regularly trained clerks. many of them ladies of the best education, and we are in a position to receive and execute \%,000 Orders within Twentyfour Hours. Prices will be found extraordinarily low. The reason for this is we purchase in such large quantities in all parts of the world. Our enormous business is felt in every commercial center, Our Store is an Exposition of the World's Industries.

In Conclusion, we beg our patrons to call our attention to any point in which we may have failed to satisfy them and promise that any suggestions or any views presented by them will be gratefully considered by us

Yours Respectfully,

JORDAN, MARSH \& CO. 

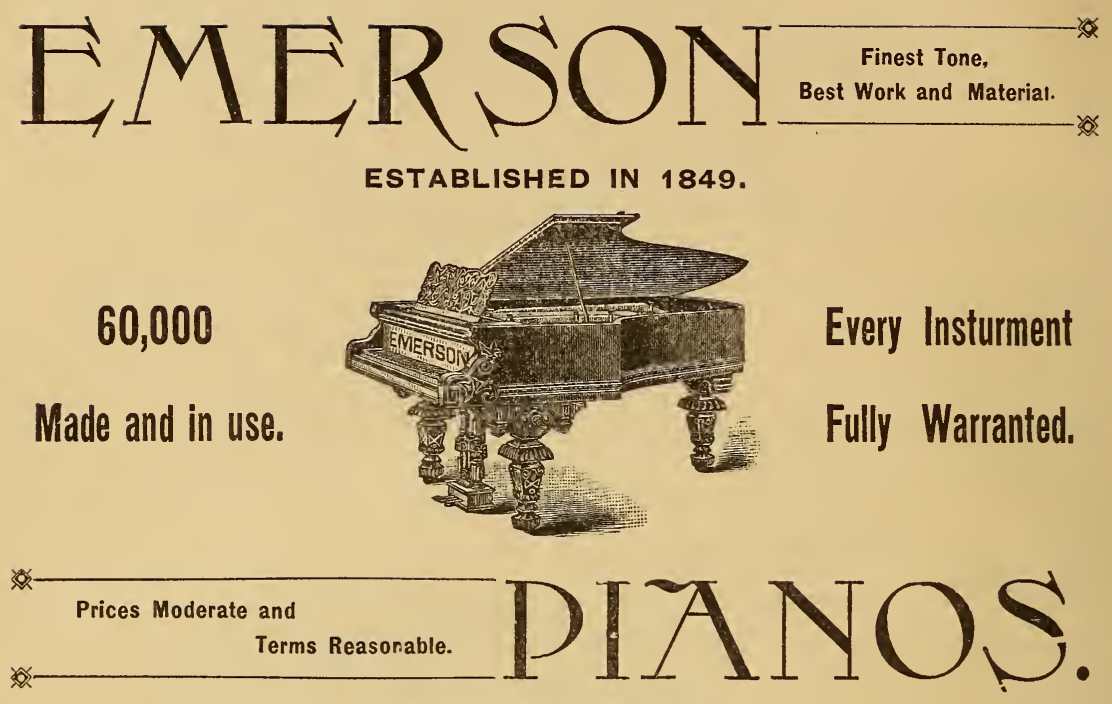

\section{Pianos to Rent and}

on Instalment.

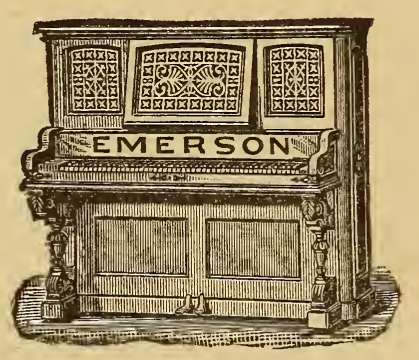

Old Pianos Taken in

\author{
Exchange.
}

THESE instruments have enjoyed a high reputation for more than forty years. Are Brilliant and Musical in Tone, and afford a most beautiful accompaniment to vocal music-the tone having that rare sympathetic quality which blends admirable with the human voice. They are Durable, being constructed of the Best Materials, by the Most Skilful Workmen. They have earned an especial reputation for Keeping in Tune, and also for retaining in a most remarkable degree their original fulness of tone-never growing thin or wiry with age.

The Emerson Upright Pianos especially have obtained a remarkable success during the past few years, and have invariably received a high award wherever exhibited. In all the essential qualities of a

$$
\text { PIRST-CLASS INSTRUMENT. }
$$

they are second to no pianos manufactured in the country.

\section{ILLUSTRATED CATALOGUE FREE.}

\section{EMERSON PIGNO COMPANY,}

Warerooms: $\left\{\begin{array}{l}174 \text { Tremont St., Boston, Mass. } \\ 92 \text { Fifth Ave., New York. }\end{array}\right.$ 


\section{CONTENTS.}

History of The Old Colony Railroad, Part One. - - - - - 9 to 130

History of The Towns and Cities of The Old Colony Railroad,

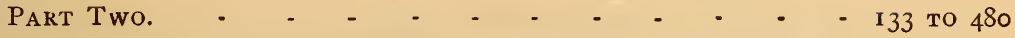

Lease of The Old Colony Railroad to New York, New Haven

\& HARTFORd RAILROAD. - - - - - . - - - - - $\quad$ - 480

INDEX To BRANChes, Towns AND Cities. - - - - - - - $\quad-7$ and 8

Prominent Houses and Index to Descriptive Articles. - - - 505

INDEX TO ADVERTISEMENTS. - - - - - - - - - - $\quad 508$

INTROUUCTION.

Steam Railroads of The United States and Canada. - - - - - 483

\section{LIST OF ILLUSTRATIONS.}

Views in Provincetown.

Views in Newport, R. I.

Views along the shore at Cohasset.

Views along Buzzard's Bay.

Views in Nantucket.

View of Plymouth Bay.

Views in Nantasket.

View of Massachusetts Bay.

View of Provincetown.

View of a group of Whalers at New Bedford.

Views at Martha's Vineyard.

View of Gay Head, Martha's Vineyard.

View of Plymuuth Rock.

Views in North Scituate.

View of Minots Ledge Light.

Views in Cape Cod.

View of the National Monument at Plymouth.

View of the Miles Standish House at Duxbury.

View of Plymouth Rockand Gole's Hill.

Kneeland Street and Park Square Stations of the Old Colony Railroad, also showing the Public Garden and State House.

Attleboro Station.

Middleboro Station.

Harrison Square Station.

New Bedford Station.

North Weymouth Station.

Dedham Station.

Southboro Station

North Easton Station.

Stoughton Central Station.

Steamer "Puritan."

Interior Steamer " Puritan."

Interior Steamer "Plymouth"

Interior of one of the Magnificient Steamers of the Old Colony.

Steamer "Pilgrim" in East River, New York. 


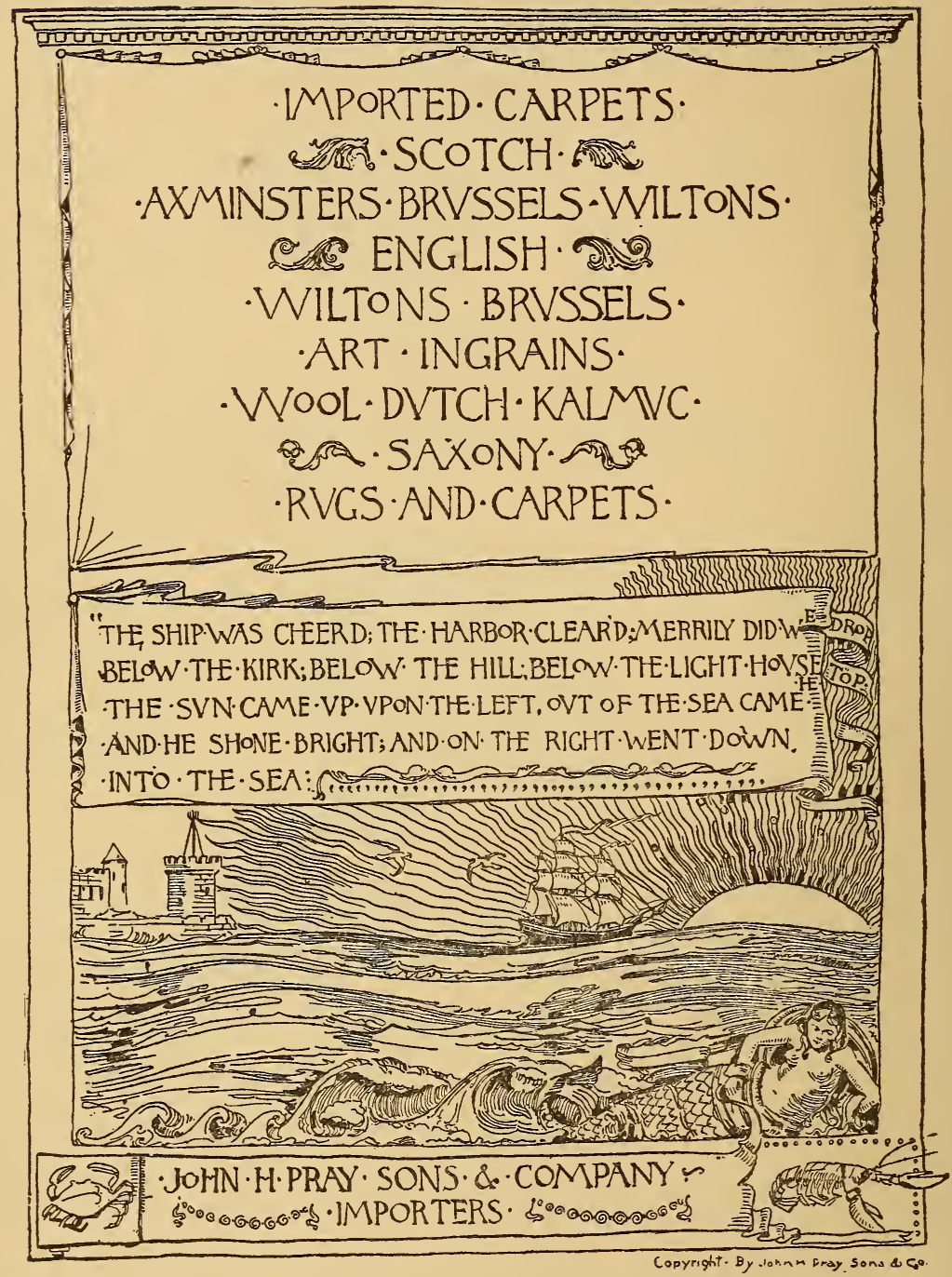




\section{THOMAS NORRELL' \\ DIVISION OF TRANSPORTATION \\ CAT. No. 326,990 ASS, No. 266,009}

\section{H I S T OR Y}

OF THE

Old

Colony

(2)

(2)

(2)

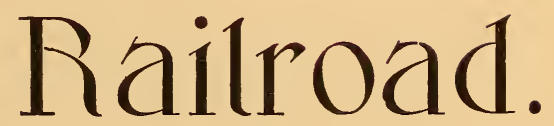

A Conplete History of the Old Colony Railroad From i $84+$ to the Present Time.

\section{IN TWO PARTS.}

Part I. - History of the. Old Colony Railkoad.

Part II. - History of the Towns and Cities on the Old Colony RAILROAD.

\footnotetext{
Also a Review and Trade Directory of the Prominent Houses Located in the Towns and Cities on the Lines Comprising the Old Colony Railroad. Also List OF THE StEam RaIlroads OF the United States and Canada.
}

* II UUSTRATED. *

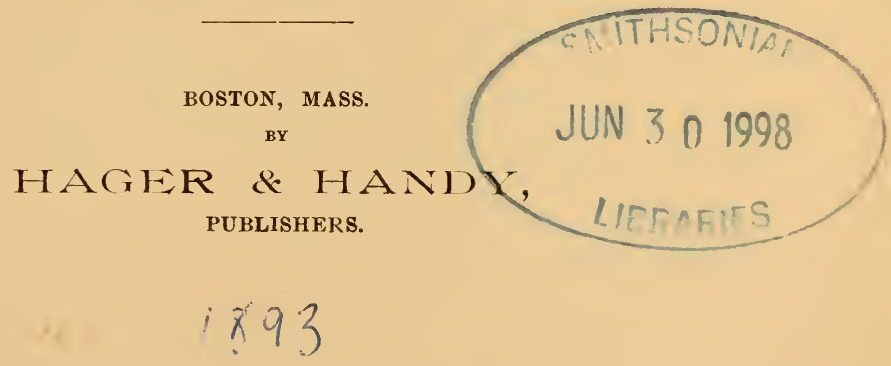




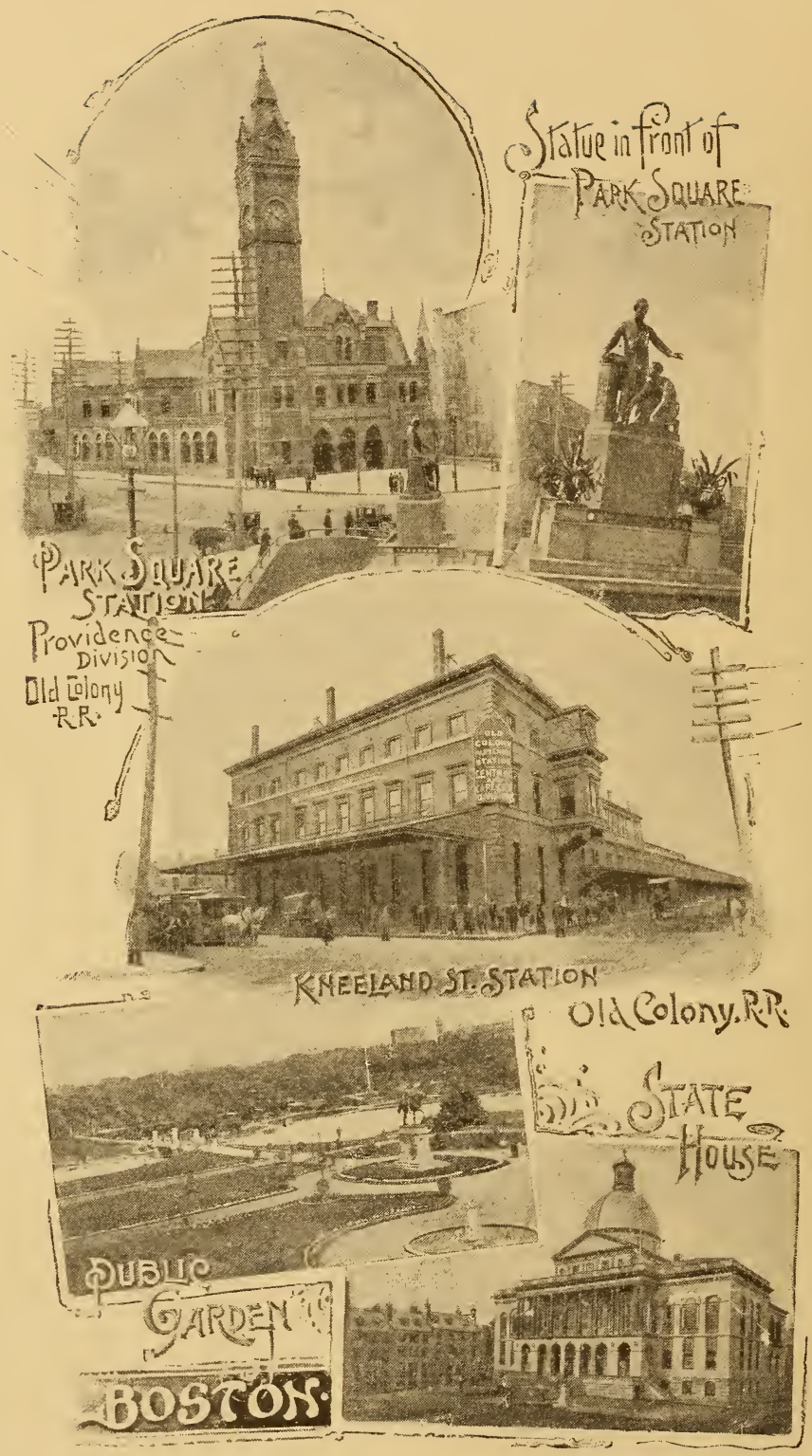




\section{INTRODUCTION.}

In preparing this "History of the Old Colony Railroad" the publishers are not unmindful of the fact that some of the details will appear dry and uninteresting to the general reader; but to those who will carefully peruse its pages and minutely analyze the reports as presented from year to year, much will be found that will prove of interest as well as be instructive on the subject of railway development in New England.

The growth of the Old Colony system presents one phase which is just now of peculiar interest, and which many suppose is a modern feature of railroad management-that of Consolidation. The Old Colony has gained nearly the whole of its present mileage through this process, as will be seen elsewhere in this work, and never in its long and honorable history has this been in a single instance the result of selfish interests or a desire to crush out competition. In sparsely settled districts many lines were early established which, left to themselves, would have died the natural death of all such enterprises, but the Old Colony always stepped into the breach in time to rescue their projectors from financial disaster and invariably supplied the inhabitants along such roads with a service which could never be attained under separate corporations. Such action, while not always proving a source of immediate profit to the Old Colony Railroad Company, has nevertheless shown wise forethought in its management and a keen perception of the future of the country. It is unnecessary for us to say what the result has been.

Passing as this road does through what is known as "The Old Colony," and from which it derives its name, added interest is given this publication by descriptions of the cities and towns along its various branches, with brief sketches of the more important industries carried on in each.

Boston, I 893 .

HAGER \& HANDY. Publishers. 
COPYRIGHTED BY

Louis P. Hager and Albert D. Handy. Editors and PUblishers,

I893. 


\section{INDEX TO BRANCHES, TOWNS AND CITIES.}

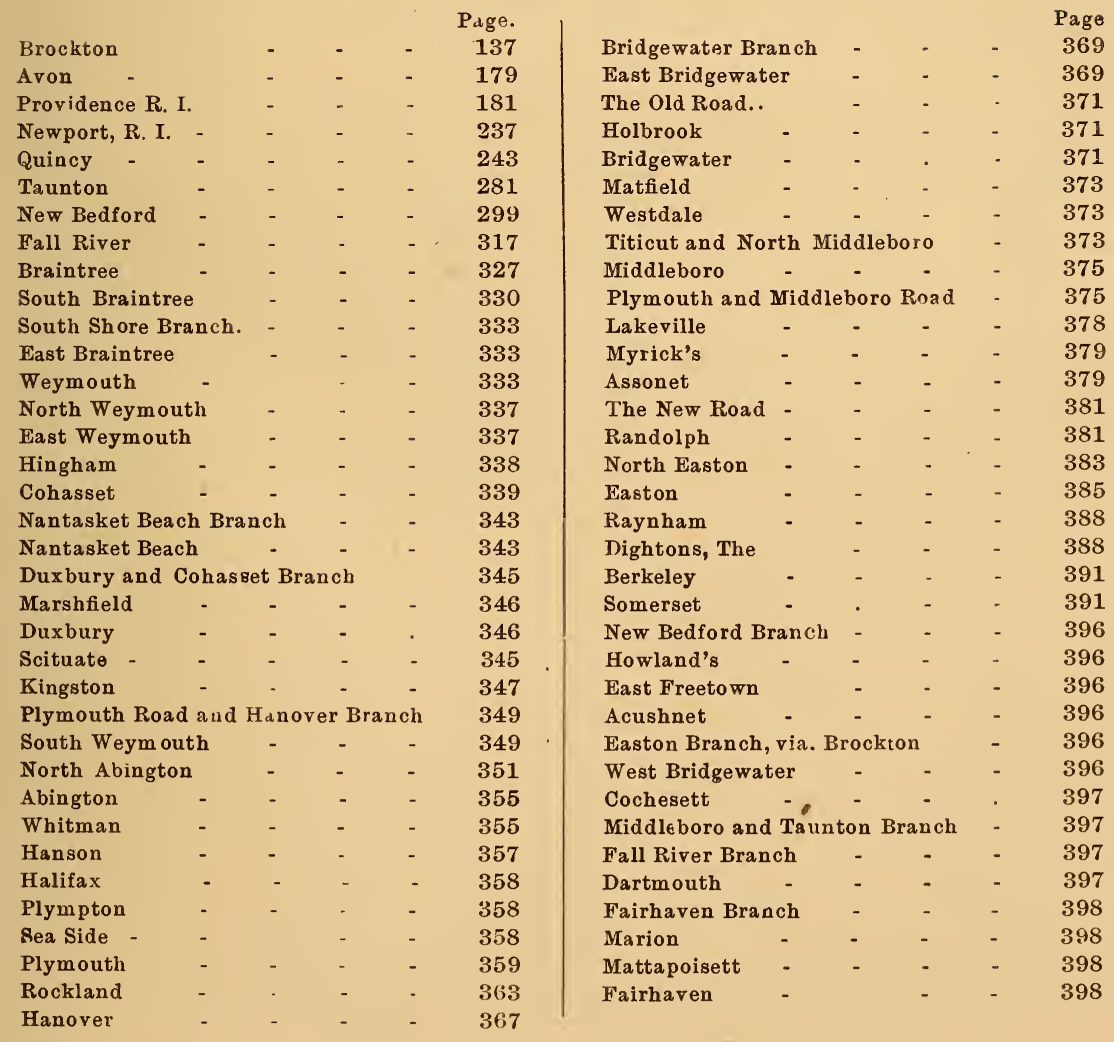


INDEX TO BRANCHES, TOWNS AND CITIES.

\begin{tabular}{|c|c|c|c|c|}
\hline & \multirow[b]{2}{*}{ - } & \multicolumn{2}{|r|}{ Page. } \\
\hline \multicolumn{2}{|c|}{ Cape Cod Division } & & - & 399 \\
\hline Wareham & - & - & - & 399 \\
\hline Bourne & . & - & - & 399 \\
\hline Sandwich & - & - & - & 399 \\
\hline Barnstable & - & - & - & 400 \\
\hline Yarmouth & - & - & - & 400 \\
\hline Dennis & - & - & - & 400 \\
\hline Harwich & - & - & - & 401 \\
\hline Chatham & - & - & - & 401 \\
\hline Brewster & - & - & - & 401 \\
\hline Orleans - & - & - & - & 401 \\
\hline Eastham & - & - & - & $4(13$ \\
\hline Wellfleet & - & - & - & 403 \\
\hline Truro & - & - & - & 403 \\
\hline Provincetown & - & - & - & 403 \\
\hline Woods Holl Bra & $\mathrm{neh}$ & - & - & 407 \\
\hline Falmouth & - & - & - & 407 \\
\hline Martha's Viney & ard & - & - & 407 \\
\hline Cottage Uity & - & - & - & 407 \\
\hline Tisbury & - & - & - & 408 \\
\hline Edgartown & - & - & - & 408 \\
\hline Gay Head & - & - & - & 408 \\
\hline Vineyard Have & & - & - & 409 \\
\hline Nantucket & - & - & - & 409 \\
\hline Northern Divisi & im & - & - & 409 \\
\hline Fitchburg & - & - & . & 409 \\
\hline Leominster & . & - & - & 411 \\
\hline Clinton & - & - & - & 417 \\
\hline Sterling & - & - & - & 419 \\
\hline Northborough & - & - & - & 419 \\
\hline Marlborough & - & - & - & 423 \\
\hline Southborongh & - & - & - & 424 \\
\hline Sherborn & - & - & - & 424 \\
\hline Medfield & - & - & - & 424 \\
\hline Walpole - & - & - & - & 425 \\
\hline Wrentham & - & - & - & 427 \\
\hline Foxboruugh & - & - & - & 429 \\
\hline Mansfield & - & - & - & 431 \\
\hline Lowell \& Frami & ingham & Branch & - & 435 \\
\hline Lowell - & - & - $\quad-$ & - & 435 \\
\hline Chelmsford & - & - & - & 436 \\
\hline Carlisle:- & & - & - & $436^{\circ}$ \\
\hline
\end{tabular}

\begin{tabular}{|c|c|c|c|c|c|}
\hline & & & & & \\
\hline Westford & - & - & - & - . & 436 \\
\hline Acton & - & - & - & - & 437 \\
\hline Cuncord & - & - & - & - & 437 \\
\hline Sudbury & - & - & - & - & 437 \\
\hline Framingham & - & . & - & - & 437 \\
\hline Providence Divi & ision & - & - & - & 441 \\
\hline Hyde Park & - & - & - & - & 441 \\
\hline Readville & - & - & - & - & 442 \\
\hline Canton - & - & - & - & - & 442 \\
\hline Sharon & - & - & - & - & 445 \\
\hline Attleborough & - & - & - & - & 445 \\
\hline North Attleboro & ugh & - & - & - & 453 \\
\hline Attleborough F & alls & - & - & - & 455 \\
\hline Pawtucket & - & - & - & - & 456 \\
\hline Dedham Brancl & & - & - & - & 463 \\
\hline Dedham & - & - & - & - & 463 \\
\hline Roslindale & - & - & - & - & 464 \\
\hline Highland & - & - & - & - & 464 \\
\hline West Roxbury & - & - & - & - & 464 \\
\hline Shawmut and & Iilton $\mathrm{B}$ & Branch & & - & 465 \\
\hline Milton - & - & - & - & & 465 \\
\hline Central Avenue & & - & - & - & 466 \\
\hline Granite Branch & & - & - & - & 466 \\
\hline Stoughten Bray & ach & - & - & - & 467 \\
\hline Stoughton & - & - & - & - & 467 \\
\hline North Stoughto & & - & - & - & 467 \\
\hline North Attleboro & Brancl & & - & - & 468 \\
\hline India Point Bra & nch & - & - & - & 469 \\
\hline Warren \& Brist & ol Bran & $\mathrm{ch}$ & - & - & 469 \\
\hline
\end{tabular}

Suburban Service (Central Division) Savin Hill, Harrison Square, Pope's Hill, Neponset, Field's Corner, Ashmont, Cedar Grove and Mattapan, - 470-47 Suburban Service, (Providence Division) Chickering, Roxbury, Boylston, Jamaica Plain, Forest Hills, Mount Hope 474-475 Plainville - $\quad$ - $\quad . \quad 5 \quad 476$ Norwood - $\quad$ - $\quad$ - $\quad$ - 478 Addenda-Lease of the Old Colony Railroad to the New York, New Haven \& Hartford Railroad - - $\quad$ - 480 


\section{H I S T O R Y}

OF THE

\section{OLD COLONY RAILROAD.}

PART ONE.

CHAPTER I.

"The road-making sons of Vulcan making an uninhabited country habitable."

Aeschvius.

$\mathrm{W}$

HAT changes the builders of railroads have wrought in the landscape of our country! No factor has been so important as the steam locomotive in the development of our nation; in fact, it is to this mighty power that we owe our undivided territory, our large and valuable cities, which embrace within their boundary lines hundreds of thousands of inhabitants, our numerous villages, studded with churches, dotted with schools and filled with happy and comfortable homes and budding souls. The activity of men is quickened by the railroad, while it sends energy and vitality where before were silence and barrenness. But few years have passed since our fathers feared that, on account of its vast extent of territory and consequent divers interests of its different sections, our fair country would be divided. This fear is not to be wondered at when we consider the meagre means of transportation on which they depended for business and social intercourse. This diversity of interests may be illustrated by comparing the states lying side by side, like, for instance, Massachusetts and Connecticut; their commerce is thoroughly characteristic of the state, and each presents different features. In respect to products and outward features, the difference between distant states, as, for instance, between California and Vermont, or between Florida and 
Montana, is as great as the difference between Russia and Egypt between England and Africa. But it is this great diversity of interests, coupled with an essential likeness of the people, which constitutes the peculiar strength of the United States; this world within our borders, all saluting the one flag, draws the bond of our union more closely.

Less than half a century ago the farmer depended upon water communication to carry his produce to market, therefore only the land which bordered upon the streams and canals was valuable. The inducements offered to emigrants were not the most enticing, consequently the rich soil lay uncultivated; but under the magic flight of the locomotive vast tracts of fertile lands have been opened, and the mineral wealth and forest riches have attracted to us the enterprise and industries of the world.

To whom are we indebted for these great changes, and how were they brought about? Like all great inventions, they were the result of years of toil, study and experiment, chances lost, fortunes wasted and hopes crushed; the rude awakening from bright dreams of fortune and success of first one inventor, then another, each in succession taking up the labor where his wearied brother laid it down, until to-day the world admires the seemingly perfect piece of mechanism and triumph of mechanical skill which races over the steel rails.

The story of the early locomotive, both in Europe and America, is familiar to our readers. We will not, therefore, again go over the ground; but in order that you may more thoroughly appreciate the growth and present high state of perfection of the Old Colony Railroad, we will give a few facts regarding the early efforts of the more advanced minds in this country to introduce the railway system.

The means of communication which existed in Massachusetts previous to the establishment of railroads was very meagre. Seated, as she is, upon the sea, and favored with a number of sheltering harbors always open to a ready intercourse with foreign countries, yet she was almost destitute of internal navigation. The Merrimac had in the early days threatened to be to Boston what the Connecticut was in I 825. Immediate steps had to be taken by the people of the Bay State in order to keep New Hampshire from making Portsmouth its distributing centre instead of Boston. No sooner had 
peace been declared, our independence established, and the weapons of war laid aside, than the people turned their attention toward internal improvements. It was then that the idea of the Middlesex canal, which connected the upper waters of the Merrimac with Boston harbor, was conceived. Governor Hancock signed the act incorporating the company authorized to build this canal, in June, I 793. The original plan of the promoters was to connect the Merrimac, at some point in Chelmsford; with the Mystic, at a point in Medford; but the charter was subsequently so amended that the southern outlet was at tide-water in Charlestown, on the Charles. The surveys were made by an English engineer named Weston, while the whole process of the work was superintended by Colonel Loammi Baldwin, senior, who, while surveying the route of this canal in Wilmington, chanced across an apple tree, the fruit of which so pleased him that he took great pains to grow an orchard from that tree, at his home in Woburn, which thus became the progenitor of the famous Baldwin apple.

The canal was twenty-seven miles in length. In receding northward from tide-water it ascended one hundred and seven feet by means of thiiteen locks. It reached its highest altitude in North Billerica, where it drew its supply of water from the Concord river. Then crossing that river it descended twenty-one feet by means of three locks, striking the Merrimac above the Pawtucket falls, in what was then East Chelmsford, subsequently, in I 824, incorporated as Lowell. The bed of the canal was four feet deep and thirty wide. It was navigated by flat boats of twenty-four tons burden, which occupied twelve hours in the average passage through it; and by means of improvements in the Merrimac, water connection was made as far north as Concord, N. H., some seventy-five miles from Boston. This canal was a most costly venture; its construction, together with the improvements in the Merrimac, cost about $\$ 500$, ooo, truly a large amount of capital for those days, when the assessed valuation of Boston was but $\$ 15,000,000$. In I 803 the canal was opened to traffic and continued in use until June I, I853; but disappointment was about all the public and capitalists got in return. The gross annual income of the works was never much over $\$ 20,000$, and during the first half of its existence no dividend was paid on its stock. After I8I8, and until the railroad was built, they 
averaged about one and a half per cent. per annum. Then they ceased altogether, while the Middlesex was in course of construction. The famous. General Knox surveyed a route in I79I for a canal to connect Worcester with the seaboard at Boston, but owing to the opposition of parties interested in a canal along the Blackstone river to Providence, nothing at this time came of either project.

It was not until the early part of the present century that the subject of railroads was advocated in this country, the foremost spirit in the enterprise being Mr. John Stevens This gentleman, who will always be remembered as the inventor of a steamboat, which he exhibited in I 804, was born at New York in I749, and lived to see the development of his favorite enterprise, he having died in I 838. After the failure of the Western Inland Navigation Company of New York State, by whom works were constructed allowing the passage across the summit, along the Mohawk and the rivers interlocking with this and flowing into Lake Ontario, of boats of fifteen tons burden, an effort was made, in I8ro, to re-open the line, and a committee of the New York Legislature was raised to examine the route of the old company with the improvements thereon.

The war of I8I2, which soon followed, put an end to all movements in this direction until the return of peace. This war however, had one good effect,-it demonstrated the imperative necessity of such a work, and in 1816 a Board of Commissioners was appointed to consider the whole subject. This board reported at length and favorably, and on the I5th of April, I8I7, an act was passed providing for the construction of the Erie canal. The work was commenced on July 4 of the same year, and on November 4, I 825, eight years after, the waters of the Great Lakes were mingled with those of the ocean, and Governor De Witt Clinton of New York made his triumphant passage in a state barge from Lake Ontario to the mouth of the Hudson, and symbolized the union of the two by mingling their waters. Previous to the opening of this canal, the cost of transporting a ton of merchandise from Buffalo to Albany, as stated in a report of the Board of Commissioners already referred to, was $\$ I 00$. The time required was twenty-one days. Such a statement affords a good illustration of 
the cost of transportation at the time over ordinary highways. The produce then grown in the western part of New York was floated in arks down the Delaware and Susquehanna rivers to market. For the great interior basin the Mississippi was almost the sole outlet. But the navigation of the river was so expensive and hazardous and so slow as to restrict its commerce to a very few articles of high value in proportion to their bulk. The opening of the Erie instantly reduced the cost of transportation from Buffalo to Albany from one hundred dollars to ten dollars and ultimately to three dollars per ton. It was on the success of this great public work that the western and eastern states immediately undertook the construction of similar works. In Massachusetts it became a matter of very serious consideration. Bostonians wanted to maintain their city as a commercial centre, which could not be continued with such a power as the Erie canal to draw the trade to New York. None of the large rivers in New England were tributary to Boston. The two more important, the Blackstone and Connecticut, flowed, the former by Providence, and the latter by Hartford, which were mere stations en transit to New York. The question confronting the Boston merchants was then how to overcome or at least how to counteract the natural disadvantages of their state. The legislature had, on February 25, I 825, provided for a commission "to ascertain the practicability of making a canal from Boston harbor to Connecticut river" and "of extending the same to some point on the Hudson river in the state of New York, in the vicinity of the junction of the Errie canal with that river." The report in full was transmitted to Governor Lincoln on January II, I 826, which bill was a remarkable illustration of the vast difference between estimate and actual cost. Colonel Loammi Baldwin, Jr., made the surveys. One covered the route from Boston to the Connecticut river, the other that from the Connecticut to the Hudson. Of these routes, two lines were found practical, and each had their champions, but the northern, by way of Fitchburg, was finally recommended. There was in this route but one point at which the Berkshire range could be penetrated by a canal at all, and that was at the point where the Deerfield river on the east side of the Hoosac mountain and the Hoosac river on its west side are but four miles apart, the point where the Hoosac tunnel now is, the idea of which was then first suggested. The report of 
the Canal Commissioners was laid before the legislature in January, I826, when, in spite of the recommendation of the Governor, the resolves under which the investigations were made were repealed, and a resolve to authorize further surveys was laid upon the table.

This decision was arrived at when the cost, $\$ 6,023,172$, and the length of time which would be required to carry it out were considered. These canals were by no means adapted to the demands either of commerce or travel. They were practicable in only a very limited number of routes - liable during navigation to interruption, and wholly closed by ice for a considerable portion of the year, so that with the introduction of steam railroads these constructions were practically abandoned.

The steamboats of New York, by their daily and regular voyages to Providence, to the Connecticut river, to New Haven, and to those points of the Hudson river which lie near the western border of Massachusetts united half the state at least more intimately with New York through her great facilities of commercial intercourse, than with Boston. There were similar diversions of the trade of Boston; in fact, Massachusetts was commercially divided, so much so that the trader from the western part of the state was seldom seen in the eastern market. This could not last, and had not the invention of the railroad been made, Boston would not have been the flourishing city she is to-day; while had it not been for the persistent opposition to railroads by the colonial type of legislators, who were the leaders in the landed interests of the stateand the landed interest was the most prominent at the timeBoston would not have surrendered so much of her commerce to New York.

The torch that kindled the fire of interest in railroads in this country was applied unintentionally by those who were intrusted to erect at Bunker Hill that great shaft commemorating the birth of a nation, who, in their endeavor to obtain the most expeditious mode for its construction, little thought they were creating in the Quincy Railway another monument far greater and more importantan epoch in the history of that nation, the stimulus of which has been felt in every department of national industry and enterprise. 


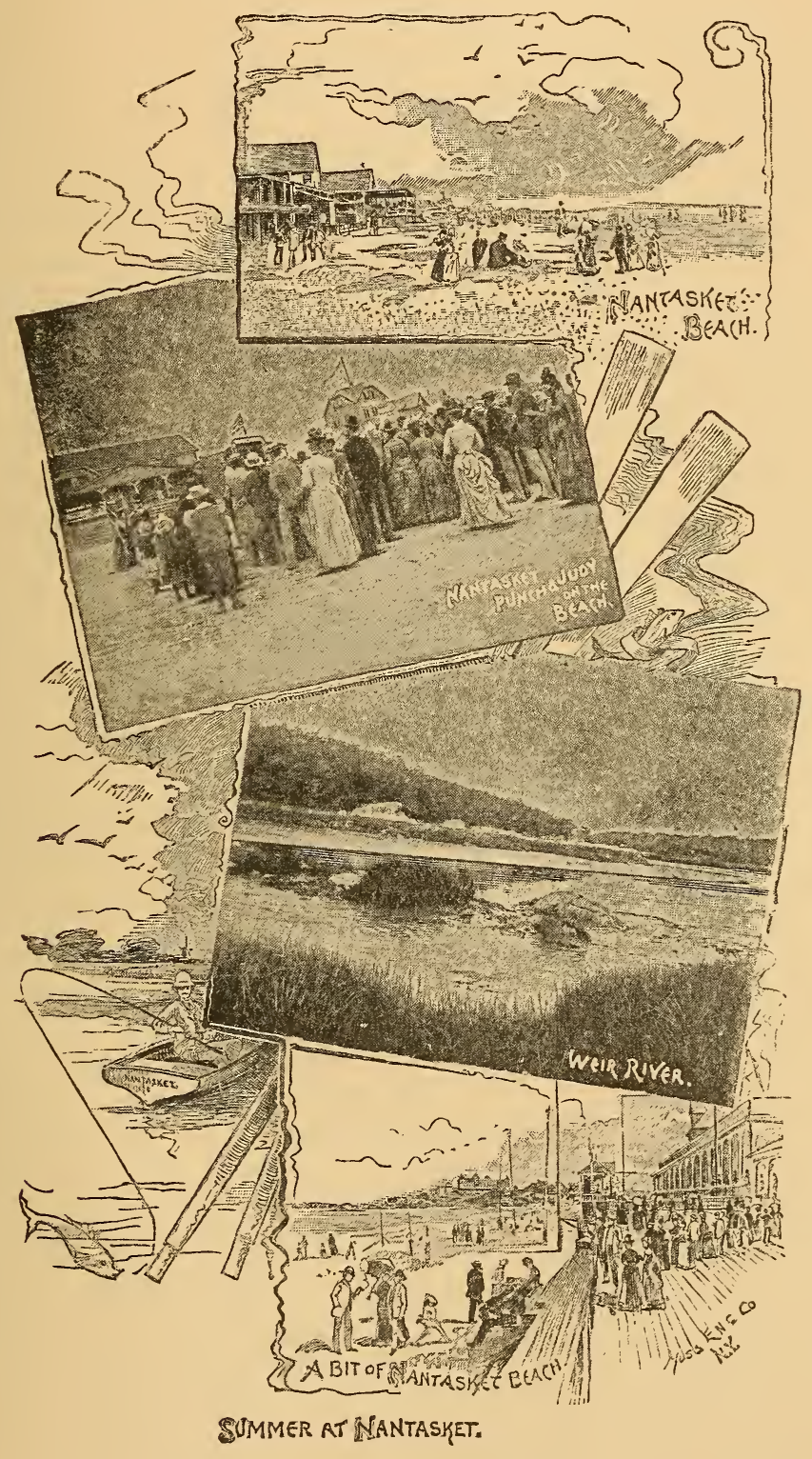



Mr. Gridley Bryant, the genius who planned and built the famous Quincy Railroad, the first in the United States, was not only a builder, but also a self-educated engineer, was born in Scituate, Mass., in I 789, and was thirty-six years of age at the time he undertook the building of this road. The story of the enterprise and its development we reprint from "Stuart's Lives and Works of the Civil and Military Engineers of America."

"The Quincy Railroad was commenced under the following circumstances: The Bunker Hill Monument Association had been formed, and funds enough collected to commence the foundation of the monument, in the spring of 1825 . I aided the architect in preparing the foundation, and on the I7th day of June, following, the cornerstone was laid by General de Lafayette, and I had the honor to assist as master builder at the ceremony. I had, previous to this, purchased a stone quarry (the funds being furnished by Dr. John C. Warren) for the express purpose of procuring the granite for constructing this monument. This quarry was in Quincy, nearly four miles from water carriage. This suggested to me the idea of a railroad (the Manchester and Liverpool Railroad being in contemplation at that time, but was not finished until the spring following). Accordingly, in the fall of I825, I consulted Thomas Handasyd Perkins, William Sullivan, Amos Lawrence, Isaac T. Davis and David Moody, all of Boston, in reference to it. These gentlemen thought the project visionary and chimerical, but, being anxious to aid the Bunker Hill nonument, consented that I might see what could be done.

"I awaited the meeting of our legislature in the winter of 1825 and I 826 , and after every delay and obstruction that could be thrown in the way, I finally obtained a charter, although there was great opposition in the House. The questions were asked: 'What do we know about railroads?' 'Who ever heard of such a thing?' 'Is it right to take people's land for a project that no one knows anything about?' 'We have corporations enough already.' Such and similar objections were made, and numerous restrictions were imposed, but it finally passed, by a small majority only. Unfavorable as the charter was, it was admitted that it was obtained by my exertions; but it was owing to the munificence and public spirit of Colonel T. H. Perkins that we were indebted for the whole enter- 
prise. None of the first-named gentlemen ever paid any assessments, and the stock finally fell into the hands of Colonel Perkins.

"The Quincy Railroad is four miles long, including the branches. I surveyed several branches from the quarry purchased (called the Bunker Hill quarry) to the nearest tide-water; and finally the present location was decided upon. I commenced the work on the first day of April, I 826, and on October 7 following, the first train of cars passed over the whole length of the road.

"The deepest cutting was fifteen feet, and the highest elevation above the surface of the ground was twelve feet. The several grades were as follows: The first, commencing at the wharf or landing, was twenty-six feet to the mile, the second thirteen feet, and the third sixty-six feet. This brought us to the foot of the table-lands that ran around the main quarry; here an elevation of eighty-four feet vertical was to be overcome. This was done by an inclined plane, three hundred and fifteen feet long, at an angle of about fifteen degrees. It had an endless chain, to which the cars were attached in ascending and descending. At the head of this inclined plane I constructed a swing platform to receive the loaded cars as they came from the quarry. This platform was balanced by weights, and had gearing attached to it in such a manner that it would return (after having dumped) to a horizontal position, being firmly supported on the periphery of an eccentric cam. When the cars were out on the platform there was danger of their running entirely over, and I constructed a self-acting guard that would rise above the surface of the rail upon the platform as it rose from its connection with the inclined plane, or receded out of the way when the loaded car passed on to the track; the weight of the car depressing the platform as it was lowered down.

"I also constructed a turn-table at the foot of the quarry, which is still in use as originally constructed. The railroad was continued at different grades around the quarry, the highest part of which was ninety-three feet above the general level. On the top of this was erected an obelisk, or monument, forty-five feet high.

"The road was constructed in the following manner: Stone sleepers were laid across the track eight feet apart. Upon these wooden rails six inches thick and twelve inches high were placed. 
Upon the top of these rails, iron plates three inches wide and onefourth of an inch thick were fastened with spikes, but at all the crossings of public roads and driftways, stone rails were used instead of wood. On the top of these were placed iron plates four inches wide and half an inch thick, being firmly bolted to the stone. The inclined plane was built in the same permanent manner and had a double track.

"The first cost of the road was fifty thousand dollars, and that of the first car six hundred dollars. The car had high wheels, six and one-half feet in diameter, the load being suspended on a platform by chains under the axles. This platform was let down at any convenient place and loaded; the car was then run over the load, and the chains attached to it by being inserted in the eye-bolts in the platform and raised a little above the track by machinery on the top of the car. The loads averaged about six tons each. The next car was made with low wheels, with a strong, massive frame. The guage of the road being five feet, the axles were placed that distance apart, this being the true principle on which to construct railroad tracks, and has been adopted generally in this country.

"When stones of eight or ten tons' weight were to be transported, I took two of these trucks and attached them together by a platform and king bolts. This made an eight-wheeled car; and when larger stones were to be carried, I increased the number of trucks, and this made a sixteen-wheel car. This was used to transport the columns for the court-house in Boston, each one weighing sixty-four tons in the rough. In the course of a few years the wooden rails began to decay, and it was necessary to replace them. This was done by substituting stone in the place of wooden rails, using the stone transverse sleepers that had originally been laid.

"The same mode of securing the iron plates to the stone was adopted, and every part of the track is as perfect now as it was thirty years ago, although it has been in use ever since, and the treasurer of the road says that it has not cost ten dollars a year to keep the road in repair.

"All the cars, trucks and machinery are my original inventions. I never began work of any kind without thoroughly investigating the principles and proportions that would produce the greatest 
effect; and in building the cars, tracks and machinery for the inclined plane, and all the twisting apparatus, none of my first productions were ever altered by myself, nor has any new machinery been substituted or alteration made by those who have had the management of the road from the time I left it to this day, most of my original machinery being in use at the present time." 


\section{CHAPTER II.}

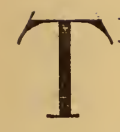

$\mathrm{E}$ car constructed by Bryant had a frame for a body, which consisted of three timbers extending longitudinally and restr ing with each end on a cross bolster, to which they were firmly bolted, there being two of these bolsters, each resting upon and across a four-wheel carriage or truck, having centre plates and side bearings of iron, and secured in the middle to each truck by a vertical king bolt, to allow a horizontal swinging motion between them and the bolsters, similar to the king bolt and bolster of a wagon.

Each truck, or four-wheel carriage, was constructed with two heavy timbers, to each of which was bolted an iron axle-tree. The wheels were of cast iron, with inside flanges and treads running upon edge rails. These wheels were about eighteen inches in diameter and revolved separately upon fixed axles, and not in pairs with the axles, as with the cars now in use.

The distance between the bearing points of the wheels on the rails was five feet in each truck and about five feet between the trucks. Each truck had a platform covering of plank fastened to its frame. They had no pedestals or springs, and could be used separately when needed as four-wheel cars.

The main body or frame to connect the trucks, when used as an eight-wheel car, terminated about eighteen inches beyond the middle of each car. They had no projecting platform or bunter, and in the use of two such cars together, their trucks would collide. They were drawn by horses attached to the trucks, and had no arrangement for draft by the body or for connection in trains, or for general railroad transportation. The cars exhibited the swivelling principle of two trucks connected to one carrying body, adapted to carrying granite or other heavy bodies and not suited to any other purpose. These carriages were continued in use on the Quincy Railroad for twenty-five years.

In the suit of Ross Winans vs. New York and Erie Railroad Company, the Bryant car was put in evidence against the validity of 
the Winans patent, granted for the eight-wheel car, October I, I 834, and the jury found a verdict against the patent, upon a legal construction given to the specification by Judge Hall. From this construction of the patent a writ of error was taken to the Supreme Court of the United States, which latter court confirmed the decision of the lower court. The specifications of Ross Winans drew only a distinguishing line between the eight-wheel carriage and the four-wheel carriage, and claimed the general principle of construction of the eight-wheel carriage, when it should have distinguished between Bryant's car and the eight-wheel carriage as constructed and adapted in its combinations and appliances for use in trains at high speed, and for transporting freight and passengers.

No railroad invention ever gave rise to more controversy than the eight-wheel railway car, and in none was greater talent employed on both sides of the question. About five years of time and two hundred and fifty thousand dollars were expended in the litigation before a final decision was obtained against the patent, which decision, although not benefiting Mr. Bryant pecuniarily, sustained his claim as the first inventor of the eight-wheel car.

Winans died, it is said, worth $\$ 20,000,000$, while Bryant, who not having patented his device, had no legal right to royalty, and never received a cent for his invention of the car. He passed away in 1867 , a poor man.

This effort of Bryant's excited a general interest throughout the breadth of our land. It will be remembered that Stephenson had by this time constructed in a most primitive manner his steam locomotive, three of which were run on the Stockton \& Darlington Railroad, the first successful trial having been made September 27, I 825. No attempt was made by Bryant to adapt his road to steam power, he depending entirely upon horse power, so that in reality his was an improved tramway and not a railroad. But in this was embodied several inventions indispensable to the construction of railroads to-day. They were the switch, or gate, as it was termed, the portable derrick, movable truck for the eightwheel car, turn-table and snow-plow. The latter was used during a storm when the snow was light. $\mathrm{He}$ placed two pieces of plank before the car, which met in an angle in the centre; drawn 
along the rails the snow was effectively removed, so as to render the travelling of the wheels as free as in summer. By this improved tramway the large blocks of granite were taken from the quarry to the wharf at the Neponset river, being then towed around the harbor by a steam tow-boat and landed at Charlestown.

The pioneer roads were rude and unsubstantial structures compared with the permanent and finished work of the present time. They were adapted for neither speed nor heavy tonnage traffic, and those lines that were built were chiefly between the largest eastern cities to accommodate their passenger traffic. It was on the Delaware and Hudson River Canal Company's railroad, which connected their mines at Carbondale with the town of Honesdale, the terminus of the canal, that the first revolution on American soil of the driving-wheel of a locomotive was made. The fame of Stephenson and others in England reached America in 1825, and in $1828 \mathrm{Mr}$. John B. Jarvis, engineer of the Delaware and Hudson River canal, sent over his assistant, Mr. Horatio Allen, to England, to be present at the Rainhill contests of competing locomotives, and commissioned him to purchase three of the best in that country. Stephenson was too busy to build the engine ordered, so it was built by Foster Roswick \& Co., of Stourbridge. It was of the grasshopper pattern and had a lion's head painted in red in front of the boiler, from which it received its sobriquet of "Stourbridge Lion." It was first exhibited at the Westpoint foundry, which was located at the foot of Beach street, New York, and then taken to Honesdale, where the trial trip was made August 28, 1829. The locomotive was a success, but the company was too poor to buy iron rails, and the wooden ones proved too frail for the engine. It was housed in a building on the canal dock, where it lay for years and was destroyed.

The father of the locomotive system in America, Peter Cooper, built the first locomotive in this country. The "Tom Thumb," which name was given it, proved that it could run at a high rate of speed around curves of a short radius. But this was little better than a toy, and was constructed solely for the purpose to pass a curve of 152 feet around Point of Rock, Baltimore, which feat saved from ruin the Baltimore \& Ohio Railroad. This curve had to be 
passed on this line, and the news came from England that Stephenson had claimed that no locomotive could draw a train around any curve shorter than a 900 feet radius. Horse power had been used formerly and proved unprofitable, but Mr. Cooper was equal to the emergency and the road succeeded.

The first American built locomotive for actual service on a railroad was the engine called the "Best Friend," built for the Charleston and Hamburg Railway, of South Carolina, which road was built in 1827 , and the engine was run in 1830 . But it came to a most untimely end by the explosion of its boiler. This catastrophe was caused by one of the negro firemen, who, becoming annoyed at the hissing of the escaping steam, sat on the safety valve. He was never again annoyed by any earthly sound. Soon after, January I 5, I 83 I, the "West Point," another engine, was put in operation, and the anniversary of the road celebrated. A large crowd assembled and a negro band played lively music, but the passengers insisted upon having a car loaded with cotton bales placed between the locomotive and themselves. They were taking no chances of having another impatient darkey vent his spite on the safety valve.

It will be seen from the above that while Boston was engaged in educating local public opinion, the other states were forging ahead with their railroads, in consequence of which she lost the railroad lead, which she will never regain.

Nothing could be better adapted to Massachusetts' physical condition than the railroad system, and soon after the experiments of the pioneers in England our citizens went to work with a will to secure charters from the Government which would enable them to construct railroads in the state, but it was a most difficult task to convince the legislature of its importance. A large part of the public was highly incredulous, and the advocates of the plan were hindered in every possible way. The promoters, however, after a lengthy and hard struggle, succeeded as early as I 827 in having the Massachusetts Legislature authorize the appointment of a Board of Commissioners to cause surveys to be made of the most practicable routes for a railroad from Boston to the Hudson river, at or near Albany. The next year the appointment of a Board of Directors of Internal Improvement, consisting of twelve members, appropriated a fund to pay the expenses of surveys and plans. In March, I827, 


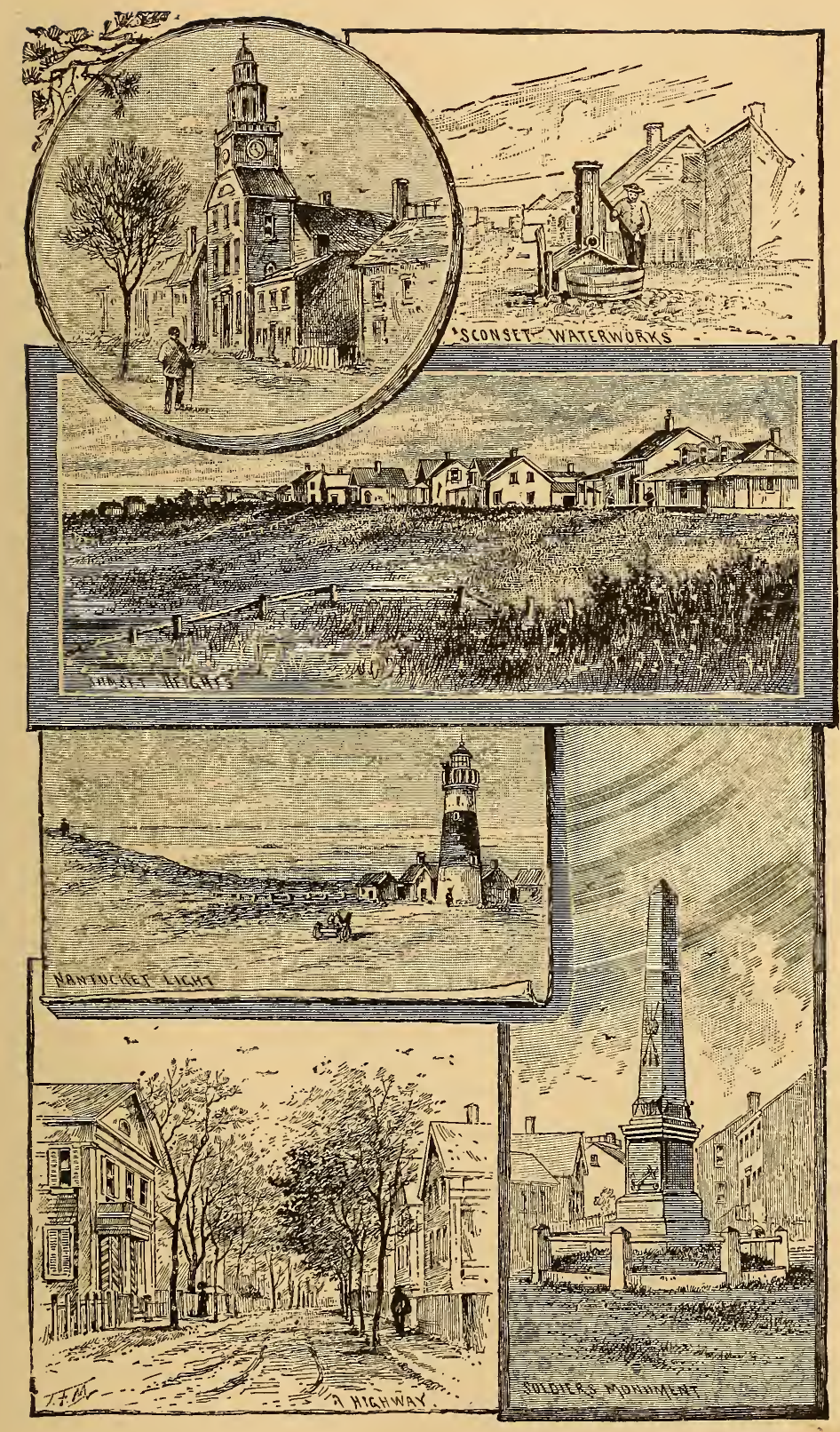



the Committee of Internal Improvement was authorized to survey a route for the projectors of the road between Boston and Providence. One year later the Board of Directors of this branch of the Government was authorized to make a more thorough and complete investigation. The Legislature of the State of Rhode Island, through the influence of the latter board, passed an act granting authority for the extension of a railroad leading from Boston through any part of that state to Providence, with permission to take tolls thereon, while a large number of land owners along the route executed, under seal, agreements to permit the railroad to pass through their estates, they releasing all claims to compensation for the land which should be taken and for damage which should accrue in consideration of the benefits they would receive by the building of the road.

March 2, 1827, by a petition of Whitwell, Bond \& Co. and others, the Board of Commissioners of Internal Improvements was appointed to survey a route to Rhode Island, which report was made and sent in to the legislature by Gov. Lincoln, Jan. 25, I828. The manuscript was a voluminous one, and was briefly reviewed by His Excellency in his message. In this report they claimed that they had no choice between the eastern or western route, and the road would not rise more than thirty feet in a mile, except in a single short section. Horse power was recommended, while foundation tracks of granite, having a flat bar of iron secured by bolts to the upper surface of the stone, on which the wheels were to move, was spoken of, the cost of which was estimated at $\$ 8,000$ per mile, while the income was figured at $\$ 60,000$.

. Messrs. Levi Lincoln, Nathan Hale, Stephen White, David Henshaw, Thomas W. Bird, Royal Makepeace, George Bond, William Foster and Edward H. Robbins, Jr., the gentlemen who constituted this board, said in their report, when referring to the advantages of horse power: "The labor of the horse may be still more relieved by providing a platform, placed on small wheels, on which the horse himself may ride when making long descents. This expedient, singular as it may seem to persons unaccustomed to observe the ease of locomotion on a railroad, is adopted with success on the Darlington \& Munch Chunk Railroad, and the horses eat their provender while they are returning to a point where their labor is to be resumed." 
Despite these recommendations and the resolutions offered by the committees in the succeeding sessions, the legislature refused to make an appropriation of public money, either for undertaking the construction of roads on the public account, or for cooperation with private corporations to be established for that purpose.

In 1830 the Boston, Providence \& Taunton Railway Co. was chartered, with a capital of $\$ 500,000$, to build a road extending from Boston to the Pawtucket river, in Seekonk, on the Rhode Island line, in Pawtucket, and from some part of the road to Taunton. They were given until January I, I835, to finish the line, but in I 83 I the Boston \& Providence and the Boston \& Taunton were chartered in lieu of this company. Several private companies that received charters failed for want of the necessary confidence for raising subscriptions to the stock. Among the early companies who were thus unfortunate was the Boston, Providence \& Taunton Railroad Corporation, which was incorporated March 2, I 830, by Messrs. Frederick Tudor, Richard D. Tucker, John I. Boise, Thomas B. Wales, Leonard Foster and William Foster, to build a road from Boston to Seekonk, or to the line of the state of Rhode Island in Pawtucket, and also from some convenient part of the line to Taunton, to the Taunton river, the capital stock being $\$ 500,000$.

During the session of I 83 I Messrs. John Bryant, Joseph W. Revere, George Hallet and Benjamin R. Nichols were incorporated, June 22, as the Boston \& Providence Railroad Corporation, with a capital stock of $\$ 1,000,000$, to construct a road from Boston to Pawtucket or Seekonk. The charter was similar to that granted to the Boston, Providence \& Taunton. Five years' time was given them to complete the road, which period was extended one year, February 29, I832. On March 31, I834, they were authorized to build a branch road from their main line to Dedham, but the route laid out at this time was slightly altered March 7, 1835. They were also at this date permitted to contract with the Boston \& Providence Railroad and Transportation Co., of Rhode Island, for the use of their bridge across the Seekonk river and of a railroad from thence to Providence, also for a depot. The capital stock was increased April I, I 835 , by an addition of $\$ 50,000$, and on April I6, I836, a like sum was again added. 
The Boston \& Worcester Railroad Corporation was established during I 83I, and the charter of the Boston \& Lowell, granted the preceding year, being amended, these companies were organized by the subscription of the required amount of capital - the Worcester conditionally, with the reservation of the right of the subscribers to withdraw on receiving the report of definitive surveys and estimates. The charter of the Boston \& Worcester Road was the first which contained the express grant of authority to transport passengers and merchandise on account of the corporation, and to purchase and hold locomotives, engines anit cars.

Jurie 22, I 83I, Messrs. Cyrus Alger, Israel Thorndike, Thomas H. Perkins, David Sears, Solomon Willard, Nathan Hale, William Prescolt, Samuel A. Eliot, James K. Mills, Amos Atkinson, William Rollins, Samuel Crocker, Charles Richmond and Edward Dwight were incorporated as the Boston \& Taunton Railway Company, to construct a road from Boston to Taunton, and then to the Taunton river, for which they were allowed a capital stock of $\$ I, 000,000$. They were allowed five years' time in which to finish the road, which time was extended March 7, I 832, one year. No other railroad was to be allowed to be built between Boston, Roxbury or Dorchester to Taunton, or from Boston, Roxbury or Dorchester to any place within five miles of the point where this road should meet the deep water of Taunton river or Mt. Hope bay, unless they would run over the track of this line, paying for the privilege such sum as the legislature should determine.

A great part of the original stock of the Boston \& Providence Railrond was taken by New York capitalists. The Boston \& Worcester Road was partially opened to public travel in April, i 834. On this occiasion, the use of locomotive engines was introduced for the first time in New England. The Boston \& Providence Road was opened in part in June, I 834, and throughout in June, I 835. One of the locomotives introduced upon the Boston \& Worcester Road within the first $y$ ear from its opening was built in Boston. Rails rolled from a pattern prescribed in this country were imported from England, as were the locomotives.

The Fall River Mill Road, Railroad and Ferry Company was incorporated March 3I, I835, by Messrs. Henry Gardner, Andrew Robeson, Harvey Chase, Samuel Rodman, Jr., Charles W. Morgan, 
Leander P. Lovell and William Wilbur, with a capital of $\$ 300,000$, among other things to build a bridge over the narrows on Lee's river, also Cole's river in Swansey, to establish a steam ferry across Taunton Great river, from the easterly shore to the western shore opposite Fall River in Somerset; also to build a branch railroad from the western shore of Taunton Great river opposite Fall River, to meet the Boston \& Providence Road at India Point bridge in Seekonk. The first meeting of this company was held on the first Monday in May, I 835 , and its report sent to the legislature, which was accepted by that body.

The Taunton Branch Railroad Corporation was incorporated April 3, I 835, by William A. Crocker, Charles Richmond, Samuel L. Crocker and David Brewer, to build a road from Taunton to Mansfield, and at the latter place to form a junction with the Boston \& Providence Road. Their capital stock was \$150,000. The latter corporation was authorized to build and equip the road, should both corporations agree. The capital stock was increased $\$ 50,000$ April 16,1836 , and on February 27, I 837, a like sum was added.

This corporation completed its line from Taunton to its junction with the Boston \& Providence Railroad at Mansfield in August, I 836, when the road was opened for passenger traffic, and a little later for freight. It had a contract with the Boston \& Providence Road to forward its passenger and freight cars to the cities of Boston and Providence from that point, which contract expired January, I 85 I.

During the year following, the following charters were granted for the building of roads that in course of time were merged into the Old Colony system: Messrs. Andrew Robeson, Harvey Chase and Charles W. Morgan were incorporated April 16, 1836, as the New Bedford \& Fall River Railroad Company, with a capital of $\$ 300,000$, to construct a road from Taunton to Fall River.

The Seekonk Branch Railroad Company was established April I6, I 836, by Timothy P. Ide, Tristam Burgess and John W. Richmond, to build a line from a point at or near the old Wharf Point on the Seekonk river in Seekonk, to a point on the Boston \& Providence, the capital stock being limited to $\$ 100,000$. The Fall River Mill Road, Railroad and Ferry Company was authorized to lay its tracks at any point. A clause of its charter excludes those 
persons who owned the southern termination of the Boston \& Providence Railroad in Rhode Island from ever having any control of this road, or holding any of its stock.

The charter of the Seekonk Branch Railroad Company was so amended April 25, I 838, as to permit its using its own time in laying rails on that part of its road between Rocky Point and Old Wharf. This road was granted a permit to sell its franchise to the Boston \& Providence, which corporation had the privilege of opening a wharf at the Seekonk depot for the accommodation of steamboats plying between Providence and New York; this in the event of the wharf at India Point, in the former city, being closed against it. Should the railroad corporation refuse to permit this accommodation for steamboat passengers, the commonwealth reserved the right to purchase the branch by paying the same price paid by the Boston \& Providence Corporation.

The act of the legislature of April 16, I836, for increasing the capital stock of the Boston \& Providence to enable it to purchase the Seekonk Road, to an amount not exceeding $\$ 500,000$, was accepted by the stockholders, and the directors caused fifteen hundred shares of $\$ 100.00$ each, being a part of the increased capital, to be apportioned among the stockholders, with the exception of thirty-two shares, which arose from fractional parts not subscribed for, but which were ordered to be sold, and the whole amount of the shares so apportioned were paid into the treasury. A brick freight house was erected during the year, at the depot in Boston. Also a small passenger station at Seekonk, and two additional houses with wells under them, together with suitable apparatus for raising and securing a proper supply of water for the engines on the road. The number of locomotives was also increased to eleven, while arrangements had been made for an additional supply of merchandise and passenger cars. A second track was under advisement by the directors, but they decided that nothing would be done in the matter until the price of iron had been reduced.

For the purpose of securing to the public a continued line of first-class steamboats, in which the price of passage and freight between New York and the southern termination of the Providence Railroad at all seasons of the year should be at fixed moderate rates, 
the corporation on March 18 entered into a contract with proprietors of sundry steamboats in New York by which the above objects were obtained and secured for the term of five years from that date. The original location of the road in the county of Bristol, near the southern terminus, was changed to allow of better running of the trains.

In August the Taunton Branch was opened for the transportation of passengers, and subsequently for the carrying of freight. A contract was then entered into and remained in force until January, 1837, with the Boston \& Providence, by virtue of which the passenger and freight cars of its line should be run between Mansineld and Providence by the locomotives of the latter road.

The Mount Hope Railroad Corporation was incorporated April I 3, I 836, by Messrs. Elisha Burgess, Samuel L. Crocker and Wheaton Luther to build a road from Taunton to Somerset. They were allowed a capital stock of \$150,000, and permitted to enter the Taunton Branch, which road had to be finished in two years. The Boston \& Taunton Company were privileged to purchase the road. 
CHAPTER III.

B

OSTON was now entering the transitory state from a provincial to a metropolitan city. Previous to 1835 , the city was little more than a large town, but still the provincial New England capital. True, the population yearly increased, but the'territorial limits remained the same, and the neighboring towns, such as Dorchester, Brighton, etc.- now merged into the city - were the only country abodes and summer resorts. The seashore residences - since so grandly developed by the Old Colony Railroad were of the future. Business methods were completely revolutionized. The old-time merchants could not understand the change and cried out against it, predicting decay of trade. The new points of distribution and the means of reaching them so rapidly, killed foreign commerce, and those who could not adapt themselves to the new order of things were ruined. The interior of the country was fast being opened up, and Boston was becoming a commercial centre and daily business exchange, for merchants who had their homes in the adjacent cities. New branches of industry were called into existence and they in turn created others, while the vast volume of business done by them was not even dreamed of by the most ambitious merchant of a few years earlier. The city proper was gradually given up to business blocks, and the beautiful suburbs, within a radius of ten miles, taken for dwellings; in fact, the railroad has consolidated this radius, at least, into what is practically one city, and concentrated the energies and public spirit of all into one community.

We must not suppose that riding in these early trains was the hight of comfort or that the new order of things was to the liking of all. The old citizens, used all their lives to make their journeys by stage or private carriage, and stopping en route at the conventional and hospitable inns, - where they leisurely and comfortably partook of such refreshments as the houses afforded -- could not tolerate the stuffy and crowded coaches, the smoke and cinders, the pro- 
miscuous mingling of all classes or the uncomfortable seats. The average speed attained on most of these ancient railroads was about the same as that of a good roadster, i. e., ten miles an hour. When ascending a grade the speed was much less, but on the down grade it was increased as high as fifteen to twenty miles an hour. Farmers, berry-pickers, and girls with country produce would station themselves along the up grades and pass their wares to the conductor, who would sell the articles inthe city.

Of course the wheels, which were spoked; had no brake attachments, and when a down grade was reached a stick of cord-wood was inserted between the wooden spokes of the wheel, which prevented them from revolving. The tender generally had a stage-coach brake worked by the foot-power of the engineer. There was no cab. The engineer stood with one foot on the machine, the other on the tender; and when the rain and hail or the blustering snows of winter beat down upon him he shielded his face with a shingle.

There were no baggage cars or checks; passengers took care of their own "luggage." Generally the fare was less by riding in the forward car where the passengers would have the full benefit of cinders, etc. This car was generally called the "T. D.," after the famous "T. D." pipe, which was very popular with the travellers occupying this car.

One of the important officials of a road was the road-master, whose chief duty was to walk over the line, looking for protruding spikes which held down the iron straps or rails to the plank. These straps were twelve feet long, two and one half inches wide, and three-eighths of an inch thick, and were spiked to stringers of pine plank. The road-master was equipped with a hammer and a basket filled with pine plugs. When he found a loose spike he drove it down, and then forced in beside it one of the plugs to bind it more firmly. Sometimes, after he had been over the line, the strap iron rail, which had a tendency to curl, would pull a spike, and then the end of this rail, catching the bottom of the cars after the locomotive had passed over, broke through with a crash, throwing the train off the track and causing more or less injury to passengers.

The original act to incorporate the Old Colony Railroad was passed April I 3, I 838, the corporators mentioned being Alfred Gibbs, 


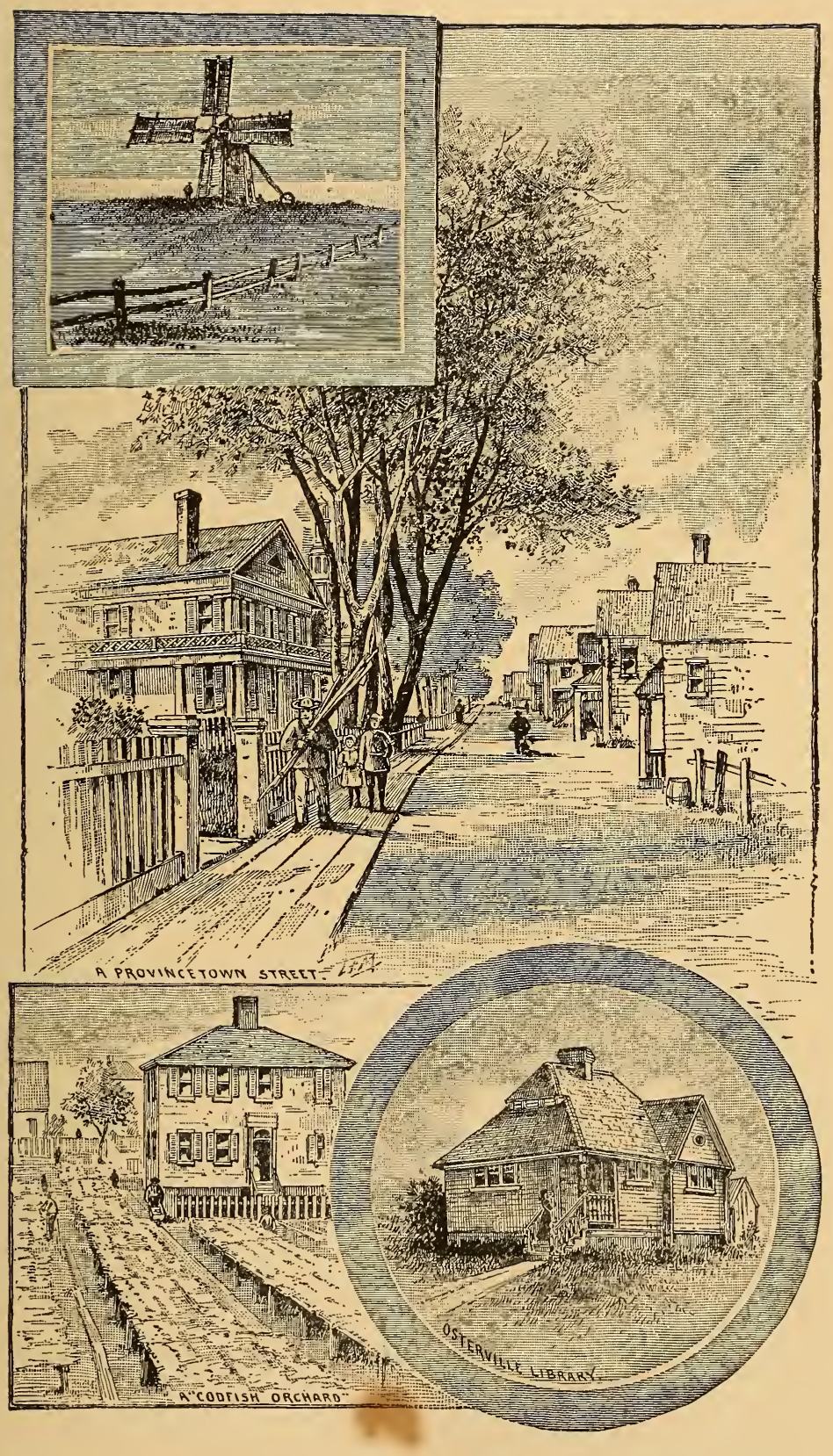



Joseph Grinnell and James B. Congdon, who were authorized to build a road from Taunton to New Bedford, "the course and direction of which was as follows : beginning at the southern termination of the Taunton Branch Railroad; thence southerly and easterly to the Taunton river, crossing said river about a quarter of a mile above the Weir bridge; thence southerly to the brick yards in said Taunton, thence crossing the Pole Plain ridge, passing through the Bear swamp, about half a mile westerly of the new county road, so called, and continuing at about that distance from said county road, to the Middleborough swamp, so called; thence, crossing the road near Bell's bridge, and passing east of the dwelling house of Noah Ashley, and west of the Freetown furnace, and from thence along the easterly edge of Sassalomen pond and running still southerly east of Tarkiln hill, west of the dwelling house of William Hathaway and near the dwelling house of Hayden Coggeshall, to the intersection of Willis and Ray streets in New Bedford aforesaid."

The capital stock was placed at $\$ 400,000$, divided in shares of one hundred dollars each. The state ordered an issue of scrip to the amount of $\$ \mathrm{IOO}, 000$ bearing an interest of five per cent. per annum, which was payable semi-annually at the office of the State Treasurer, and which was redeemable in fifteen years from date of issuing. These certificates were to be considered a pledge of the faith and credit of the commonwealth for their redemption. These bonds were to be delivered to the treasurer of the railroad corporation on the condition that when the corporation had received from asessments $\$ 150,000$, and had expended $\$ 100,000$ in the construction of their road the state was to deliver to the corporation certificates of debt to be issued as mentioned above, to the amount of $\$ 50,000$ : " and when the said corporation shall have received, from assessments duly laid, the further sum of $\$ 100,000$, and shall have expended the one-half of said last sum in the construction of the road in addition to the said sum of $\$ 150,000$, the treasurer of the commonwealth shall deliver to the treasurer of said corporation scrip, or certificates of debt, to be issued as aforesaid, to the amount of $\$ 50,000$; provided, that, before such scrip or certificates of debt shall be delivered as aforesaid, the said corporation shall furnish evidence satisfactory to the governor and council, that the condi- 
tions upon which it is to be delivered as herein before provided, have been complied with."

Section six is important at this day as showing the conditions of this state aid. It says :

"No part of said scrip shall be delivered to the treasurer of said corporation until said corporation shall have executed to the commonwealth a bond, in such form as the Attorney General shall prescribe, conditioned that the said corporation shall faithfully expend the proceeds of said scrip in the construction of said road, or in the necessary appurtenances thereof, and shall indemnify and save harmless the commonwealth from all loss or inconvenience on account of said scrip or certificates of debt, and that said corporation shall and will pay the principal sum of the said scrip, or certificates of debt, and the interest thereon, as the same shall fall due, respectively, and shall also convey to the commonwealth by a suitable instrument, to be prepared for that purpose, under the direction of the Attorney General, their entire road and its income, and all the franchise and property to them belonging, free of all prior encumbrances, as a pledge or mortgage, to secure the performance of all the conditions of said bond; prozided that the commonwealth shall not take possession of said mortgaged property, unless for a substantial breach of some condition of said bond."

Section 9. After the said road shall be open for use, a sum equal to one per cent. on the amount of all scrip, issued as aforesaid, shall be annually set apart from the increase of said road and paid to the treasurer of the commonwealth, and the whole thereof shall be by him placed at interest, and the same, with the interest annually accruing thereon, shall constitute a sinking fund, for the future purchase and final redemption of all scrip advanced, and which shall be advanced by the commonwealth to said corporation.

The name of this corporation was changed March 26, 1839, to the New Bedford \& Taunton Railroad Corporation, and was empowered to change the location of its road, should it think fit, so that it should run westerly of the dwelling house of Noah Ashley, in Freetown, and westerly of Sassalomen pond and of Tarkiln hill in New Bedford, and should it gain the consent of the Commissioners 
of Bristol County, they could construct their track along any of the streets in the town of New Bedford. They were also given privilege to enter upon the Taunton Branch Railroad.

The work on the New Bedford \& Taunton Railroad was commenced in May, I 839, the directors being P. G. Seabury, Jos. Grinnell, Thomas Mandell, Wm. W. Swain, Alfred Gibbs and David R. Greene. The first meeting of the stockholders was held February 6,1839 , when seven directors were elected, and by-laws and constitution adopted. On October 26 , the act amending their charter of March 26, I 839, was accepted.

These roads entered into an agreement on November I, I 839, by which the expenses of the rolling stock, and the expense of running the same over the two roads, and from Mansfield to Boston and return, were to be borne in common between the parties, and profits divided according to the value and earnings of the roads. To take charge of these interests, an agent or superintendent was chosen by the boards of both corporations. On the expiration of the contract, which was to last one year or longer as they desired, the property of both was to be appraised by three disinterested parties. The rolling stock purchased during the term of the contract was to go to the New Bedford \& Taunton Road, and then what belonged to the other road was to be returned to them.

A long and rather bitter controversy was carried on during I 838, between the Boston \& Providence Corporation and the Boston Water Power Company, regarding the filling of marsh land along this line from Boston to Roxbury, as the railroad company desired to widen its road bed in order to lay a second track to that section. The discussion was settled, however, to the advantage of the road. The sum expended for the construction of the main line, including sums paid for land and damages, erection of buildings, amount paid to Boston Water Power Company, completion of second track and other improvements, was $\$ 62,424.67$. Under the authority of the legislature of April I0, 1838 , the Boston \& Providence Corporation purchased the charter and equipment of the Seekonk Branch Railroad Company at a cost of $\$ 3 I, 955.70$. It also erected another large brick storehouse at the Boston depot, for the accommodation of the Taunton and Dedham Branches, filled up a large piece of marsh, and secured the same from the tides by a substantial stone wall. 
The machine shop was also enlarged, while an additional wood-shed and passenger station at Roxbury were erected.

March 23, I 840, this corporation was given authority to contract with the New York, Providence \& Boston Railroad Company of Rhode Island for maintaining a steam ferry boat across Providence river between the two roads, provided it did not pay more than $\$ 6,000$ per year for the privilege, or for more than a period of three years. But this clause was repealed March I 7, I84I.

On March 23, I 840, the fare of passengers between Boston and Providence was reduced to one dollar and fifty cents, and pro rata for the intermediate distances; and on April I 7 the freight of a ton of merchandise between Boston and Providence was reduced from five dollars to three dollars per ton, and in proportion for way stations. This reduction, the opening of the Norwich \& Worcester Railroad, and other peculiar circumstances, caused a diminution of its income during the first six months of the year, and rendered it necessary to encroach upon the reserved fund in making the July dividend. The increase of business, however, during the last six months of the year, enabled the directors to declare a dividend to be made exclusively from the profits that accrued during that time, and convinced them that such an encroachment would not again be necessary.

No change was effected on the Boston \& Providence in its schedule of passenger and freight tariff, except that heavy articles of small value in large quantities were carried for less than three dollars per ton. The expenses of the road were unusually heavy, owing to the alterations in the freight depot at Boston, the taking up of the plate rail on the Dedham Branch and substituting a heavy one, also to altering and increasing its rolling stock and altering several bridges, so as to avoid accidents, by removing the truss frames further from the track, or sinking them below the floor of the cars.

March 24, I 843, the clause limiting the amount to be paid was also repealed, and it was authorized to own in whole or part the ferry communication. Its capital stock was increased February I, I 846, $\$ 400,000$, and it was privileged to purchase the Boston \& Providence Railroad and Transportation Company, should the cost not exceed \$ I 50,000.

They were authorized on March 27 to construct a branch road 
from a point on its main line in Attleborough running westerly near Read's pond, and through or near Attleborough meadows, through Brick hill, the line of the state of Rhode Island in the town of Attleborough; or commencing at some point on the line between Dodgeville and the seven-mile post on the line, extending westerly to Miller's hill, through or near Sweeting swamp to the state line, in Pawtucket or Attleborough. For the construction of this branch they were authorized to increase their capital \$I 30,000. They also petitioned for, and were granted, the privilege to extend this branch so as to connect with the lines of the Providence \& Worcester Road and for the laying of tracks from the point of juriction to Providence.

The express business had its birth about this time. Mr. Wm. F. Harnden was employed by the Boston \& Worcester for a few years, but, being dissatisfied with his position, resigned and went to New York. While there he called on Mr. James W. Hale for advice as to his future movements. Mr. Hale, who kept a popular reading room in the old Tontine Coffee House, at the corner of Wall and Pearl streets, advised him to establish himself as a messenger or parcel carrier between Boston and New York, and suggested the word "Express" as a suitable title for the new business. At that time there were no other means of getting valuable parcels to and fro than by consigning them to the care of some traveller, who was often a complete stranger to the party sending him. The idea of an express business had suggested itself to Mr. Hale from the repeated inquiries at his rooms of parties going to Providence or Boston who could be induced to carry parcels. Harnden acted as advised and advertised himself as an express agent between Boston, Providence and New York. He travelled by the sound steamers, and for some time a single carpet bag held all the matter consigned to his care. A rival soon came in the field in the person of Mr. Alvin Adams, the founder of the great express company.

In June, 1842 , the Boston \& Providence commenced running three separate trains a day each way between Boston and Dedham, over the Dedham Branch Road, which proved most satisfactory to the public and to the railroad corporation. The transfer office at New York was discontinued during the year for want of business, 
while the passenger depot at Boston was enlarged sufficiently to allow passengers to enter and leave the cars under cover. This was done at an expense of $\$ 4,500$.

During the past two years the company was laying new sleepers all along its line and, where it was necessary, substituting gravel for loam and earth for its bed. This greatly improved the road. An arrangement was entered into in September, I 843, between the parties composing the line between Boston and New York via Norwich, and the line via Stonington, by which the rates of freight and fare of passengers by both lines were the same, and receipts from these sources equalized, except that the line which transported an excess over the other retained a reasonable compensation for transporting such excess.

The business of the Boston \& Providence Railroad during I 844 yielded a considerable increase in each branch of trade compared with the three preceding years, without involving any increase in the expenditures. One marked improvement was the opening, in August, of the Long Island Railroad, connecting the city of New York and Greensport, and, in connection with the New England Railroads, terminating on Long Island sound, which afforded a new line of communication between Boston and New York. It was deemed due to the public convenience to make such a connection with the Long Island and Stonington Railroads as should render this line useful by a prompt and uninterrupted passage between the two cities. But so far in its history it did not command sufficient travel to remunerate the Boston \& Providence Road for the expense incurred.

The trade on the Dedham Branch continued to be satisfactory, so much so that during the summer they were obliged to increase the number of trains, also to enlarge the depot at Dedham, while preparations were made, and early the following year completed, for a second track to be laid between Roxbury and the Dedham Branch junction.

The durability of the heavy iron rail was considered a subject of much speculation in railroad circles, consequently this company was at considerable pains to ascertain the state of the rails on its road, which investigation set at rest forever any anxiety as regards their great expense, as they found that in ten years of constant ser- 
vice only 2 I-4 per cent. of renewals had been made, while a large proportion of this number was originally of inferior quality when laid down. Another important transaction of the road during the year was a contract with the contemplated Stoughton Branch Railroad, which entered its road in Canton. In the agreement, entered into January I, I845, this corporation was to operate the rolling stock, for which it was to receive out of the gross receipts $\$ 5,978$, and in addition the following tolls, for the use of its own road between Boston and Canton: Every passenger between Boston and beyond South Canton, twenty-eight cents; between Boston and South Canton station, forty cents ; from any way station on the Boston \& Providence Railroad, two cents per mile; commutation passenger, that proportion of the amount paid which tolls received by the Boston \& Providence Company shall bear to the whole price of the tickets, between the points for which commutation tickets were issued. Each ton of freight between Boston and any point on the Branch Railroad beyond South Canton, fifty-six cents; between Boston and South Canton station, seventy cents; every case of boots, shoes, hats or bonnets, four cents each. The agreement also read that should the proceeds pay less than six per cent. to the stockholders of the Branch Railroad, then the difference to make up that sum was to be paid them. This Branch Road was only allowed by the legislature a capital stock of $\$ 50,000$, while the cost of building the road was over $\$ 80,000$, therefore the balance was borrowed from the Boston \& Providence, which amount it was to convert into capital stock; if not, it was to be refunded to the latter road in five annual instalments, with interest.

Messrs. Isaac Tisdale, Jr., Lyman Kinsley and Martin Wales were incorporated March I6, I 844, as the Stoughton Branch Railroad Company, to build a road beginning at or near the depot of the Boston \& Providence station in Canton, thence southeasterly to Taunton road, to a stone dwelling belonging to the heirs of Elijah Crane, crossing the Forge pond and running east of Bolivar factory in Canton, thence passing near the house of William Henry in Stoughton; thence passing near the house of Lemuel Bird, and terminating near the Congregational meeting-house in Stoughton village, on the land of Benjamin Capen, Simeon Tucker, or Nathaniel Morton, or some other convenient place in the village, for which purpose 
they were allowed a capital stock of $\$ 150,000$, and were permitted to enter the tracks of the Boston \& Providence. The title of the company as above was not given until February I 5, I845. The Boston \& Providence Corporation saw at once that it must control this branch, therefore began operations immediately, with such success that on February 20,1845 , it was allowed by the legislature to subscribe for $\$ 40,000$ worth of the stock.

The trains of the Stoughton Branch commenced running April 7, I845, under the agreement of January I, I 845, with the Boston \& Providence Road, and the $\$ 40,000$ loan was converted into stock of the Stoughton agreeably to an act of the legislature the year previous. The Pawtucket Branch of the Boston \& Providence was finished this year, and cost $\$ I 44,778.20$. This made the length of the entire road 4I miles, I 2 I-2 of which was double track.

The double track to Dedham having been completed, a continuation was begun in the fall between Foxborough and Mansfield station, a distance of 2 I-2 miles, while one from the Dedham Branch Junction to Canton was contemplated at an early day. The engine house and work shop at Roxbury was enlarged, as were the depots at Dedham Village and Jamaica Plain, while depots were built at the Low Plain and Toll Gate.

The tri-weekly day line between Boston and New York, via Stonington and the Long Island Raliroad, was discontinued by the voluntary act of the latter corporation on April 9, the Boston and Providence Corporation being willing to carry it on only for the convenience of the public, as it was a source of no pecuniary profit.

Another item of interest was the fact of the sale of one thousand shares of its stock at a premium of I 2 I-2 per cent. This stock was disposed of for the purpose of paying off the 400 shares of the Stoughton Branch. Water pipes were laid on the side of the track from an ample source in Roxbury, to lead water to the Roxbury station.

The Boston \& Providence made a further reduction in its tariff in May, 1845 , reducing a first-class passage between Boston and Providence to $\$ 1.25$, and a second class passage to eighty-five cents, making a total reduction since the road commenced operation in June, I 845 , of $37 \mathrm{I}-2$ per cent. A reduction of 25 per cent. was 

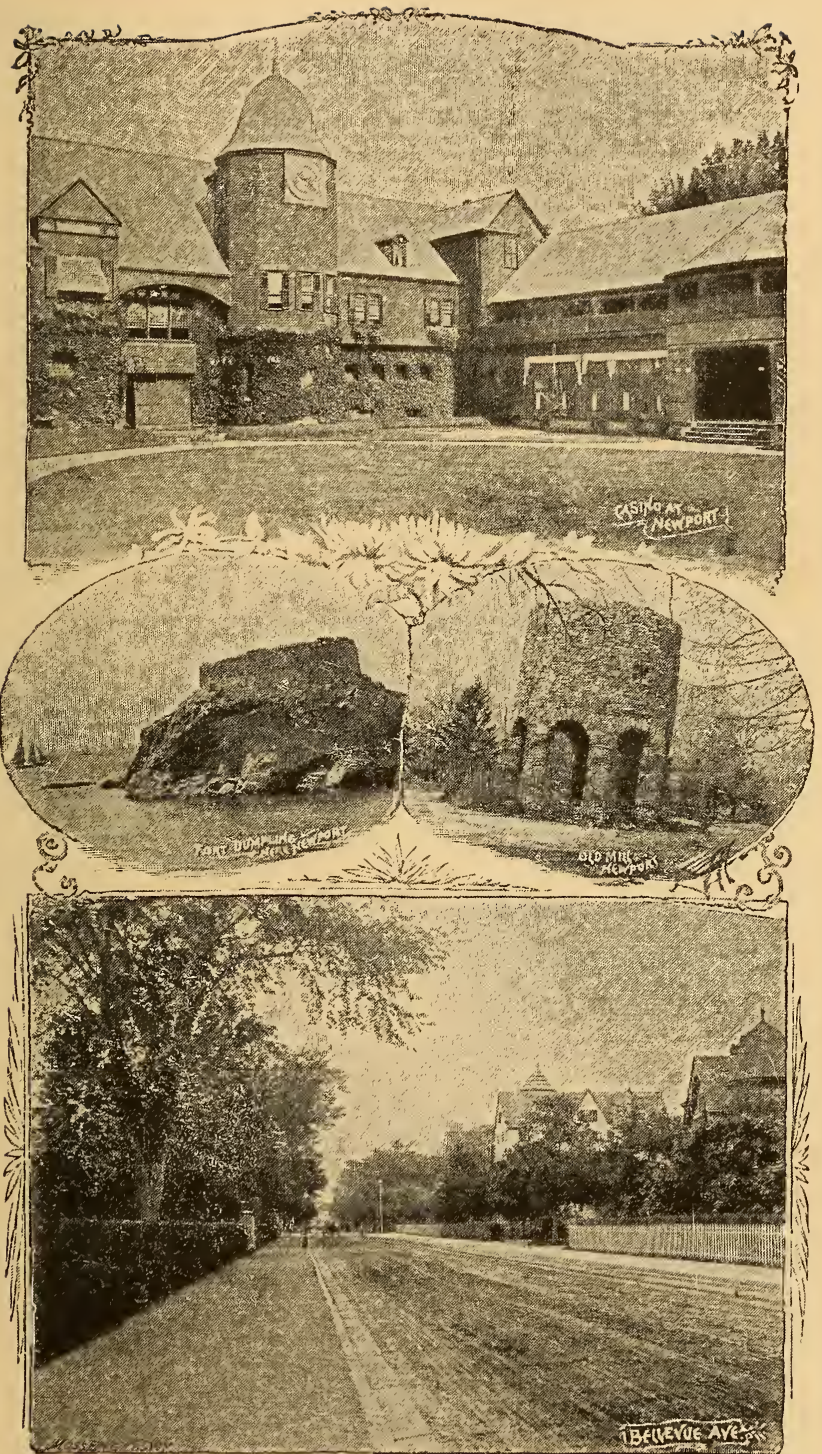

VITWSATNEWPORS RI! 

also made in passenger tolls charged on this road, for passengers carried in the cars on the Taunton Branch, reducing the toll to I. 56100 per mile, or fifty per cent. since the Branch road went into operation. 


\section{CHAPTER IV.}

\section{RHIS year, I 844, the Old Colony was incorporated and entered Boston on the south side of the city, and since its organiza- tion has always pursued a policy of development and ac- quisition. Below, in full, is the act entitled}

\section{An Act to Establish the Old Colony Railroad Corporation.}

SEctron 1. Nathaniel Russell, Isaac L. Hedge, Jacob H. Loud, Nathaniel M. Davis, John Serer, John B. Thomas, Thomas Greenleaf, Francis Jackson, Ellis G. Loring, Schuyler Sampson, William Nelson, Allen Danforth, William Thomas, Isaac N. Stoddard, John Bartlett, 3d, and Anthony Morse, their associates and successors, are hereby made a corporation, by the name of the old Colony Railroad Corporation, with all the powers and privileges, and subject to all the duties, restrictions and liabilities set forth in the forty-fourth chapter of the revised statutes, and in that part of the thirty-ninth chapter of said statutes relating to railroad corporations, and all statutes subsequently passed relating to railroad corporations.

SECTION 2. The said corporation may construct a railroad upon one of the following routes, viz.: Commencing at the point in South Boston near the southerly end of the lower bridge, and thence passing, in a line acceptable to the mayor and aldermen of the city of Boston, to the line of the town of Dorchester, and thence in a southerly direction by a line passing easterly of the house of Thomas J. Viuton, in Little Neck, so called, in Dorchester, and easterly of the house of S. R. M. Iiolbrook, thence near to Savin Hill, not more than four rods westerly from the east line delineated on the Quincy survey, and across Dorchester bay to a point near Preston's picnic grove, and thence to Neponset river, on a line in a place westerly of the most easterly route surveyed and delineated on the plan exhibited for the Quincy Railroad, between said Little Neck and Neponset river, except as aforesaid, and crossing Neponset river easterly of Neponset bridge, thence by a line running within half a mile of either side of Quincy turnpike, to a point in Quincy near the junction of said turnpike with the old Boston road, thence through the towns of Quincy and Braintree to a point at or near the head of or above navigation in Eore or Monatiquot river in Braintree, and thence by a line passing the head of Smelt brook to a point west of the village of South Weymouth, and to a point within half a nile of James 
Tirrel's store, thence in a line passing east of Weymouth Great pond, and through nearly the middle of the town of Abington to a point near where the towns of Abington, East Bridgewater and Hanson meet, thence diagonally through the town of Hanson, and parts of the towns of Pembroke and Halifax, and part of Plympton, to the valley of Jones river in Kingston, and thence to a point in Plymouth convenient for a depot; or, by another route diverging from the preceding in Quincy or Braintree and passing within about one-fourth of a mile from Rev. Mr. Storr's meeting-house in Braintree, and thence by a line passing within about half a mile of Randall's mills, and through the town of Randolph to a point between the villages of Centre Abington and North Bridgewater, and thence by a line passing between the villages of East and West Bridgewater to a point near Sprague's hill in Bridgewater, and thence by a line passing southerly of Robbins' pond, through the town of Halifax near the Congregational meeting-house, and through the northerly part of the town of Plympton, to the valley of Jones river in Kingston, to a point in the route first above described, and thence to Plymouth by the line first above named. And the persons named in the first section of this act shall determine, by a major vote, which of the foregoing routes shall be adopted, and said election of the route as aforesaid shall be binding upon the corporation, upon written notice thereof, at any time previous to filing the location of said road with the county commissioners, as required by law.

Section 3. The said corporation is authorized to construct a bridge over and across the waters of Neponset river, where the line of said railroad crosses said river, for the sole and exclusive accommodation of the travel and transportation on said railroad, and it shall not be lawful for the said corporation to permit the passing of said bridge by carriages of any description, other than those which are adapted for traveling on the said railroad, nor by horses not attached to such railroad carriages, nor by persons on foot, except by such persons, carriages or horses as may be employed in the immediate service of said corporation.

Sectron 4. The said corporation shall construct and maintain a draw in their said bridge across the Neponset river, and in their said railroad across Dorchester bay, if the route of said railroad shall pass westerly of Savin Hill, draws of at least thirty-one feet in width over the channel of said river, and in the deepest water on the line through said Dorchester bay, for the passage of vessels free of toll, and shall also erect and maintain a pier as long as the piles in Neponset bridge and road, for the accommodation of vessels passing through the same, and shall keep said piers planked from the line of low water to the top of high water, and shall also keep said draws and piers in good repair, and shall raise or open said draws. and afford all reasonable accommodation to vessels having occasion to pass through the same by day or night, and if any such vessel shall be unreasonably detained in passing through said draws by the negligence of said corporation to provide agents to discharge faithfully the duties enjoined by this act, the owner, commander or consignee of said vessel may re- 
cover of said corporation therefor, in an action in the case before any court competent to try the same.

SECTION 5. The capital stock of said railroad corporation shall consist of not more than ten thousand shares, the number of which shall be determined from time to time by the directors thereof, and no assessment shall be laid thereon of a greater amount in the whole than one hundred dollars on each share. And the said corporation may purchase and hold such real estate, materials, engines, cars, and other things, as may be necessary for depots for the use of said road, and for the transportation of persons, goods and merchandise.

Section 6. The legislature may, after the expiration of four years from the time when the said railroad shall be opened for use, from time to time alter or reduce the rate of tolls or other profits upon said road; but the said tolls shall not, without the eonsent of said corporation, be so reduced as to produce less than ten per cent. per anuum.

SECTION 7. If the said corporation be not organized, and the location of that part of their road within the county of Suffolk filed with the mayor and aldermen of the city of Boston, and the location of that part of said road in the county of Norfolk filed with the commissioners of that county, and the location of that part of their road within the county of Plymouth filed with the commissioners of that county, all within three years from the passage of this act, or if the said road shall not be completed within the passage of this act, then this act shall be void.

SECTION 8. The legislature may authorize any corporation to enter with another railroad at any point of said Old Colony, and use the same, or any part thereof, paying therefor such a rate of toll or compensation as the legislature may from time to time prescribe, or that may be fixed under the provisions of any general law of this commonwealth complying with the rules and regulations which may be established by said Old Colony Railroad Corporation, provided however, that no other corporation shall enter upon said Old Colony Railroad with any motive power, unless the said Old Colony Railroad Corporation shall refuse to draw over their road, or any part thereof, the cars of any other railroad corporation which may be authorized to enter with their railroad upon said Old Colony Railroad.

March 16, 1844.

The first annual report of the Old Colony Railroad Corporation of its acts and doings, receipts and expenditures, to December I, I 844, was as follows :

The act passed March 16th, 1844, creating the "Old Colony Railroad Corporation." vested in the persons named in the first section of said act the choice of one of two routes. In the exercise of that authority, the said persons, after a patient investigation of the whole subject by a competent committee, adopted 
the route first mentioned and described in said act. Sufficient subscriptions having been first obtained, this corporation was fully organized on the 25 th day of June last by the choice of seven directors and the adoption of the necessary by-laws.

In accordance with the foregoing decisions, after a very thorough and careful survey and examination, the line of the road has been definitely located from Little Neck in Dorchester to Plymouth, and the grading and masonry of the entire line has been put under contract upon terms as favorable as has been anticipated, and the work has been commenced and is now rapidly progressing. The other contracts are in a state of forwardness, and the directors confidently anticipate that the whole line will be tinished and opened for use before the close of the year.

Seven thousand shares of capital stock have been created, on which there has been paid the sum of $\$ 87,820$. The experditures have been as follows: For preliminary surveys, engineering and other expenses, $\$ 3,579.50$; for land and damages, $\$ 31,095.29$; amount cash on hand to balance, $\$ 53,145.21$; total, $\$ 87,820$, all of which is respectfully submitted by John Sever, Addison Gilmore, Uriel Crocker, Isaac L. Hedge. Nathan Carruth, Jacob H. Loud, Wm. Thomas, directors. This report was sworn to before Archibald Foster, Justice of the Peace.

In its second annual report the Board of Directors of the Old Colony, consisting of the gentlemen named in the first report with the exception of Mr. Addison Gilmore, say:- The construction of the road was so far completed, that it was partially open for use on the tenth day of November last (I 844), since which time passenger trains have been run twice each day (Sundays excepted) between South Boston and Plymouth.

The act passed on the I $5^{\text {th }}$ day of March last, by the legislature of this commonwealth, authorizing this corporation to extend its road across the channel between South Boston and Boston proper, above the North Free Bridge, having been accepted by the stockholders, and the consent of the Boston \& Worcester Railroad Corporation obtained, an arrangement has been effected with said last named corporation, securing the entrance of the passenger trains of the Old Colony Road to a convenient station on Albany street, adjoining the passenger station of the Boston \& Worcester Road, which, it was believed, would be advantageous to both corporations.

At the time of making the last annual report there had been paid toward the capital stock $\$ 87,820$, since that time there had been paid in on account of the capital stock, to December I, I845, 
$\$ 800,910$; total amount of capital paid in up to December I, I 845 , $\$ 885,730$; received for interest, $\$ 1,000$; total, $\$ 889,730$.

\section{EXPENDITURES.}

At the time of the last report there had been paid for surveys, engineering and other expenses

Paid for same to December I, I 845

$\$ 3,579.5^{1}$

I $4,962.60$

$\$$ I $8,542.10$

At the time of the last report there har been paid for land and damages

Paid for same to December I, I 845

$\$ 31,095.29$

$282,623.30$

$\$ 3$ I 3,7 I 8.59

$\$ 109,969.30$ $36,827.12$

$57,160.42$

2 I I , 069.43

I I,708.35

$43,588.89$

30,95 I. 35

$56,194.45$

$\$ 889,730.00$

The earnings of the road for the transportation of passengers for the few days prior to the first day of December, I845, amounted to the sum of $\$ 3,827.70$. No freight had been carried over the road prior to that time. The expenses of running the passenger trains over the road for the few days prior to December I, I 845, were charged to account of construction. The number of miles run over the road by the passenger trains up to December I, I 845, was 2,550.

March I 4, I845, the Old Colony was authorized to construct a bridge over the Jones river, in Kingston, with a draw of thirty feet and on March I $5^{\text {th }}$ they were empowered to build their road, com- 
mencing at a point on its road in South Boston, between Turnpike and First streets, nearly opposite the South Boston Iron Foundry, and thence continuing to the northerly wharf of the Iron Company, thence crossing the channel by a bridge, to the depot wharf of the old Boston \& Worcester, now the Boston \& Albany Railroad, and thence to the vicinity of Albany and Beach streets; but was not to extend its road farther than the south-easterly margin of the said channel or to build a bridge across the same, unless an agreement should be made with the Boston \& Worcester Railroad Corporation for the passage of trains over its tracks within these limits. The bridge should have a thirty-one foot draw, and the pier nearest the old South Boston bridge was to be placed on the side of the draw next to South Boston; and the pier nearest the North Free bridge to be placed on the side of draw next to Boston proper, which construction was to be done under the supervision of a commissioner appointed by the Governor and Council.

March 26 they were empowered to construct a branch road from Abington through East Bridgewater by a line passing on either side of Sprague's hill to Bridgewater, to do which the capital stock was increased $\$ 400,000$. They were forbidden to commence the road until after April I, I 846.

The Middleborough Railroad Corporation was incorporated March 26, I 845, the incorporators named being Messrs. Andrew Robeson, Nathan Durfee, Peter H. Pierce and Philander Washburn, with power to construct a railroad "from a point in the town of Bridgewater, on any railroad which may be constructed to that town, and connecting therewith, through the town of Middleborough, and near the four corners in said town, crossing the New Bedford and Taunton Railroad, near Myricks' corner, in the town of Taunton, in such manner as not to interfere with the depot buildings of said road, to a convenient point on the Fall River Branch Railroad, in the town of Taunton."

They had power to enter upon and use the Fall River Branch Railroad. The capital stock was limited to $\$ 250,000$, to be divided into 2,500 shares, while no assessments were to be levied of a greater amount than one hundred dollars on each share. They were given the privilege of uniting with the Fall River Branch and with any other railroad corporation which may have been authorized to 
construct a railroad from the town of Bridgewater to any point on the Old Colony Railroad, provided that the stockholders of the corporation with whom such union was to be made agree to the same, "and when such union shall have been made, said united corporation shall have, possess and hold all the property, rights, privileges and franchises, and be subject to all the duties, etc., which the corporations so united had enjoyed and been subject to under their respective charters: Provided, That in the event of a union between said Middleborough Railroad Corporation and said Fall River Branch Railroad Company they shall, within thirty days after the passage of any vote to make such union, refund to any of its stockholders, who within said thirty days shall demand the same, the amount paid by them on their stock, with interest thereon; and upon such payment to such stockholders the shares which they respectively hold shall be surrendered to said company."

Messrs. Artemas Hale, Nahum Stetson, Aaron Hobart, Solomon Ager, Benjamin B. Howard, D. Fobes, Edward Southworth, Benjamin Kingman, Henry Blanchard, Ebenezer Alden, Royal Turner and David Blanchard received a charter incorporating the Randolph \& Bridgewater Railway Corporation, March 25, I845, " to construct a railroad from some point at or near the village in the town of Bridgewater, and thence northerly on the most convenient lines in the towns of East Bridgewater, West Bridgewater and North Bridgewater in the county of Plymouth, and Stoughton and Randolph in the county of Norfolk, to unite with the Old Colony Railroad in Braintree or Quincy in the county of Norfolk."

They were authorized to enter upon and use the Old Colony Railroad, on conditions usually specified in all other charters of the same order. The capital was limited to $\$ 400,000$, to be divided into 4,000 shares, while three years were given for the filing of the location and six years for its completion. The Old Colony Railroad Company was authorized to subscribe for and hold the whole of the capital stock, "providing they shall, by a vote of a majority in interest of their stockholders, on or before the first day of May next, elect to subscribe for such stock, and shall thereupon subscribe thereto, and, until the expiration of such term of time, they shall have a priority over other subscribers, and, in the event of such subscription, the Old Colony Railroad Corporation shall be bound to 


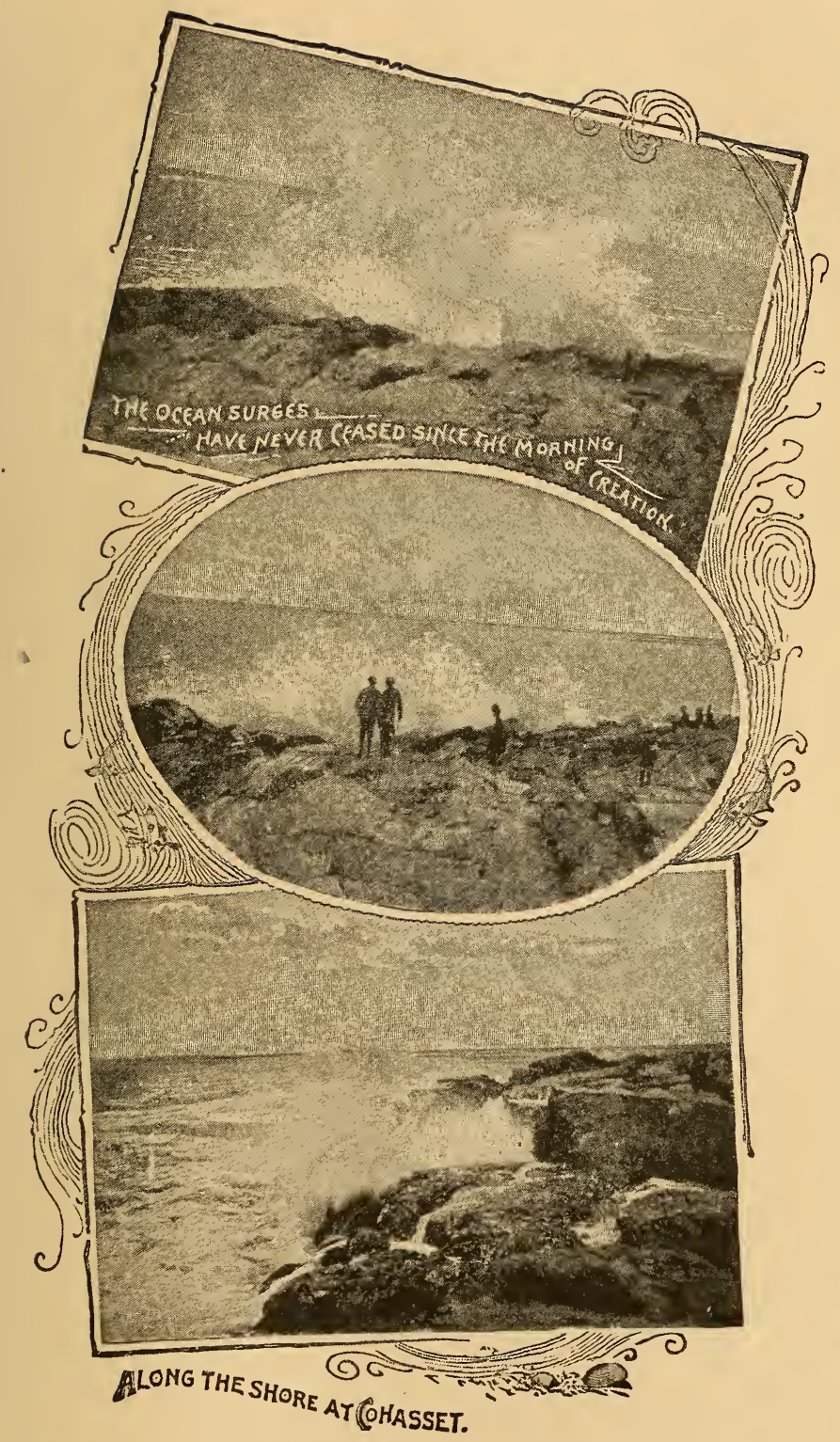



construct such Branch Railroad." In this case the Old Colony Corporation was to accept the act at a legal meeting and complete the road by January, 1847 , and was authorized to increase its capital stock by $\$ 400,000$. It was bound also to complete this Branch Railroad before commencing any Branch Railroad between Abington or South Abington and Bridgewater. This road, as we have before stated, was merged into the "United Corporation," and later on into the present system.

The Fall River Branch Railroad Company was incorporated March I4, I 844, by Messrs. Andrew Robeson, Richard Borden, Jefferson Borden and Nathan Durfee. This road was built to a connection with the New Bedford \& Taunton system at Myricks, and its promoters proposed to continue its line to South Braintree and Boston; but in I 846 the Old Colony people voted to build a spur or branch line from South Abington to Bridgewater, and thus intercept the pushing Fall River Road. This was at once done, with the result that a joint business agreement was made between the two roads, the Fall River Road progressing to South Braintree, to which point it was finished in 1847 . 


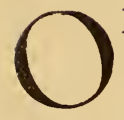

$\mathrm{N}$ the eighth day of August, I845, a union of the stocks of the Middleborough, Fall River Branch and Randolph \& Bridgewater Railroad Corporations was consummated by the organization of the "United Corporation," and all the rights, interests and franchises of each corporation were transferred to said corporation under powers granted to the said Middleborough Railroad Corporation by its charter. 'The by-laws were adopted and a board of thirteen directors was chosen. Of this number we find the names of Andrew Robeson, Royal Turner, Edward Southworth, Jefferson Borden, M. H. Ruggles, Nathan Durfee, Peter H. Pierce, Oliver Bryant, Wm. R. Rodman, Elisha Tucker and Richard Borden.

In their first report, made February 3, I 846, they assert that the sum of $\$ 315,460$ had been paid in to the treasurer, of which $\$ 35,000$ were refunded to the stockholders who withdrew from the corporation. The total amount expended was $\$ 317,805.39$. The earnings were: From passengers, \$1 3,279.II ; merchandise, $\$ 2,227 . \mathrm{II}$, and miscellaneous, $\$ 290.50$. Repairs on the road up to January I, I 846 , were $\$ 1,406.08$; repairs of engines and cars, $\$ 725.80$; services, fuel, oil, etc., $\$ 6,074.05$, while the total number of miles run by engines was 17,800 .

April I6, I 846, the "United Corporation of the Middleborough Railroad Corporation with the Fall River Branch Railroad Company and the Randolph \& Bridgewater Railroad Corporation " was authorized by the legislature to take the name of the Fall River Railroad Company, which company was empowered to build a road "from a point at or near its depot in Fall River, in a southwesterly direction, and westerly of the house of Wm. R. Robeson, to the line of the state of Rhode Island." The act incorporating the Fall River Branch Railroad was to be repealed when the new road should be completed and go into operation from Braintree to the point of crossing the track of the New Bedford \& Taunton Railroad. The time for filing 
the location of that portion of the road of the United Corporation which was authorized by the Middleborough Railroad Corporation was extended to December I, I 846.

The Dorchester \& Milton Branch Railroad Company was incorporated April I6, I 846, by William Richardson, Edmund P. Tileston, Asaph Churchill, Jonathan Ware and Mark Hollingsworth, to build a railroad with one or more tracks within the town of Milton, commencing at the most convenient point at or near the depot of the Old Colony Railroad at Neponset Village, in Dorchester, and thence running through the southeasterly part of the town of Dorchester to Milton, over Milton Hill, then crossing Neponset river, and extending through the northerly part of Milton to a point near the Upper Falls in Milton. The capital stock was $\$ 90,000$, but was increased $\$ 40,000$ more April 20, 1848 . They were allowed two years to complete their road, and to have the privilege of entering upon the Old Colony near the depot in Neponset Village. They were also given the right to convey their franchise to the Old Colony by purchase, when the Old Colony could increase its stock $\$ 90,000$ more to cover the expenses of purchase.

November IO, I 847, the Old Colony leased this road for a period of five years at a rental of six per cent. per annum on the entire cost of the property up to the time when it was declared by Mr. S. D. Eaton, the engineer, as finished, when the Old Colony was to furnish the rolling stock of the road and to run the trains from the terminus of the road at the Upper mills to Boston and return, not less than eight times a day at the same rate of fare as charged on its own road. The total length of this road was 3 miles and I 360 feet, single track. The Old Colony was to pay all damages and to keep it in repair at its charge. It also had the option of buying the road, paying for it in stock of the Old Colony at par value. Should this result not be arrived at within the first five years, it was to remain in force for an additional five years, "provided, however, that for the second five years the party of the second part was to pay the same rents, as aforesaid, without running over the road, if they shall prefer to do so, more than two trips per day."

In 1846 the name of Josiah Quincy, Jr., was added to the list of directors of the Old Colony. On April 6 of this year the company was authorized to increase its capital stock $\$ 500,000$, or 5,000 
shares, for the purpose of completing its road and building a second track wherever it desired.

It was also empowered to extend its road to a point in Boston at the termination of its bridge, at the depot wharf of the Boston \& Worcester Railroad Corporation, and continue thence to some convenient point on Kneeland street, between South street and Cove street, for which purpose its capital was again increased $\$ 100,000$.

On the Providence Division, the Walpole Railroad Company was incorporated April I6, I 846, by Messrs. John A. Gould, Edmund W. Clapp, Joseph Hawes and John Morse, to build a road at or near the western termination of the Dedham Branch Road in Dedham, passing through the southerly part of that town to a point at the centre of Walpole. The capital stock was fixed at $\$ 200,000$, while they were allowed to enter the Dedham Branch on the Boston \& Providence Railroad.

The Cape Cod Branch Railroad was incorporated April 8, I846, by John Reed, William Bates, Clark Hoxie, Joshua B. Tobey, Thomas J. Coggeshall, Nathan B. Gibbs, Sylvanus Bourne, Howard Perry and Minor S. Lincoln, with powers to build a road from a point in the roads of the "United Corporation" near the Four Corners in Middleborough, through that town to Rochester, thence to Wareham to a point near the Tremont Iron Works, thence between the works of J. B. Tobey \& Co. and Burbank's hotel, passing near the Parker Lower Mills, thence passing the factory of S. T. Tisdale in Wareham, extending across the water between Cohasset Narrows and the head of the bay, to a point a few yards south of the house of Benjamin Bourne in Sandwich. Monument river was then crossed above the lower bridge, when it followed the valley of this river to a point north of the graveyard, passing near Atherton's tavern in Scusset, terminating near the glass works in Sandwich. The amount of their capital stock was $\$ 500,000$. They were also permitted to construct a branch not exceeding one mile in length, to connect with the wharves at the Narrows in Wareham, and could enter the road of the "United Corporation," with which road they could consolidate.

This company completed their line for passenger traffic from Middleborough to Wareham on the 26th and extended it to Agawam 
on the 3 Ist day of January, I847, while on the 29th day of May the first passenger train was run to Sandwich. Freight was hauled a few weeks later.

Our railroad system was now so far advanced as to excite the admiration of Europe, and was daily receiving additions and improvements. Ocean navigation in its primary steps had proved very unsuccessful, but it was left to Mr. Edward Cunard to meet the occasion with a spirit that would brook no defeat. Despite the failures met with by our own countrymen to have Congress grant a subsidy for the running of an ocean line, he carried his point with the Government and Parliament of Great Britain. His keen sense of the fitness of things settled upon Boston as geographically the best point for a western terminus, especially as the railroad magnates were contemplating an early connection of the trunk lines with the West and Canada. The fame of Boston's harbors and wharves was world-wide, while our commercial sun was at its zenith. This excellent showing, compared to New York, was most encouraging for his plans, as the piers of the latter city were nothing more than the remnants of the old Dutch civilization. East Boston was selected as the most fitting for a docking place, as the commissioners' line on the Boston side had not been extended to the channel limits, dredging had not been introduced, and the mean depth at low water was comparatively shallow.

In May, I 840, the "Unicorn" sailed from Liverpool, and the "Britannia" from Boston on July 4th, and their trips were continued exclusively from this city until January I, I848, when a service from New York was begun by the sailing of the "Hibernia." In I 864 a new company was formed, composed mostly of Boston merchants, but it became insolvent in I867. At this juncture the Cunard Company made a new move. Its mail subsidy was to be reduced and a change in its method of management was forced upon it. It was feeling the competition of the Inman and other lines at the port of New York, and it would seem that it could not have been informed as to the new spirit of enterprise to which our railroad managers were awakening. It determined, therefore, to withdraw its mail steamers from this port at the end of the year I867, and to send instead cargo steamers, which, after landing their freight here, should proceed to New York to load for 
Liverpool direct. This decision was altered in 1870 , when two or three of their cargo steamers were permitted to load at this port for Liverpool.

Returning to our railway interests, the Lancaster \& Sterling Branch Railroad Company was incorporated April I6, I846, by Amory Holman, Winthrop E. Faulkner, and William H. Wood, to build a road from the Fitchburg road at Concord through Acton, Sudbury, Stow, Marlboro, Bolton and Lancaster to Sterling, which route they selected. The capital stock was limited to $\$ 600,000$, and they were permitted to consolidate with the Fitchburg Railroad, which was at once consummated, and April 24, I847, the filing of their location was extended fifteen months, when the Fitchburg road was authorized to locate and construct the road in sections, commencing at the junction with its road.

Another important organization incorporated this year was the South Shore Railroad Company, whose incorporators received their charter March 26, I 846. Messrs. Gershom B. Weston, Wm. H. Sampson and John Hicks were empowered to construct a railroad from Quincy through Braintree, Weymouth, Weymouth Landing and East Weymouth to the towns of Hingham, Cohasset, Scituate, Marshfield and Duxbury, the capital stock being limited to $\$ 600,000$, and to be in shares of $\$ 50$ each. They were also permitted to unite with the Old Colony and subjected to rules and regulations established by that corporation for their mutual safety and convenience. April 20, I 847, they were permitted to change the location of their route as follows:- Quincy or Braintree, through Weymouth, Weymouth Landing, and East Weymouth and north of Locust Hill in North Weymouth, through Hingham to Cohasset, and the act of 1846 inconsistent with the above was made void. The term of two years allowed for its completion was also on this date extended twelve months, and the clause forbidding the crossing of any navigable waters in Weymouth was also stricken out, and permission given to build a draw-bridge. Stockholders dissatisfied with the new act were permitted to withdraw their subscription any time within six months, and six months' additional time was given on April 24, I848, for the completion of the road.

April I6, I 846, the Granite Railway Company was empowered to extend its road from its terminus near the Neponset river in 
the following direction: "Crossing the Granite bridge road at a convenient angle, and continuing thence to a convenient point on the southerly bank of said river, below or easterly of the creek, owned by the heirs of John Rowe and others, and not more than five hundred feet below the Granite bridge; thence straight across said river to the northerly bank thereof, by a bridge to have the same width of draw as the Granite bridge, and thence in such a direction as to form a junction with the branch to be constructed from Milton to a point on the Old Colony called the Dorchester and Milton Branch Railroad." Should that branch not be finished within three years, it could continue its road along the proposed route of the. Dorchester Branch itself. It was also permitted to construct branches, not exceeding one mile and a quarter each, from any part of its railroad within half a mile of its own quarry to any of the neighboring quarries; and for the convenient shipping of stone to construct a wharf and depot on the river, below the Old Colony Railroad, and a branch from the road to the wharf and depot, it being allowed three acres of land for building purposes and strips of land five rods wide for the extension of its road. It was given a permit to transport freight and passengers as well as stone over these roads, for which it was allowed to increase its capital $\$ 50,000$, and was given the right to sell its entire plant to the Old Colony. This road was purchased March $3 \mathrm{I}$, I 847, by the Quincy Branch Railroad Company and incorporated on that day by Octavius G. Rogers, George Penniman and Joshua Emerson, the capital stock being $\$ 300,000$.

In 1846 the directors of the Old Colony, in their annual report state the following facts:- "The increase of capital since last report was $\$ 500,000$ and the amount paid in was $\$ 310,570$. The increase of the floating debt was $\$ 223,675$. I1, with an average rate of interest of 5 I-2 per cent.; \$29,356. II was paid to stockholders to December, I, I 845 , while $\$ 35,670.56$ was paid for grading and masonry, and $\$ 19,104.25$ for bridges. For superstructure, including iron, $\$ 6$ I, OII.OI was expended, and $\$ 80,582.28$ for station buildings and fixtures. For land damages, land and fences, $\$ 269,966.68$, and $\$$ I $5,722.4 \mathrm{I}$ was paid for locomotives and \$III 72.44 for passenger and freight cars, also $\$ 8,722.30$ for merchandise cars, which sum includes $\$ 2,500$ 
paid for gravel cars. The cost for engineering andother expenses was $\$ 7,070$, and $\$ 17,906.97$ was paid on account of construction of the Abington and Bridgewater Branch. In the expenditures for operating the road $\$ 8,604.06$ was paid for repairs of road, maintenance of way, etc., while $\$ 2,723.2 \mathrm{I}$ was expended for repairs of locomotives and $\$ \mathrm{I}, 950.20$ for repairs of passenger cars, also $\$ I, 599.63$ for putting in shape the merchandise cars. Fuel and oil cost \$II,905.65, while salaries, wages and incidental expenses chargeable to the passenger department amounted to $\$ 12,059.50$; those for the freight department $\$ 5,959.69$. Taxes and insurance $\$ 2$ I0, and gratuities and damages $\$ 655 ; \$ 3,000$ was paid the Worcester Railroad for privilege of crossing their road, and $\$ 8,572.52$ for salaries of president, treasurer and superintendent, office expenses, law expenses, etc. The income from passengers exclusively, on the main road (including the branch owned by the company) was $\$$ I I I , 857.64 ; from freight $\$ 20,403.95$; while the United States mail, rents and miscellaneous receipts amounted to $\$ 3,449.67$, making the net earnings $\$ 68,481.20$. The dividends were $\$ 63,000$, with an undivided surplus of $\$ 5,48 \mathrm{I} .20$. The number of miles run by passenger trains was 63,073 , and of freight trains 22,642 ; other trains 19,750; number of passengers carried, 2I 3,I44 I-2 ; passengers carried one mile, 3,459,27 I ; 16,197 tons of merchandise were carried, and 299,394 tons carried one mile or more; 26,225 passengers were carried one mile or more to and from other roads. The average rate of speed adopted for passenger trains was 20 miles per hour, and for freight trains I 2 I-2 miles.

Messrs. Nathan Carruth and Josiah Quincy, Jr., were succeeded in I 847 by Mr. Elias Hasket Derby in the Board of Directors. In their report they claim that the floating debt had increased to a total of $\$ 452,795.10$, "to meet which debt in part they were possessed of lands and buildings which will not be required for the purpose of the road which are variously estimated at from $\$ 160$,o०० to $\$ 200,000$, which will be disposed of for that purpose." A large portion of this debt was on time, and the directors were arranging to issue new stock with a view to meet the same. The cost for grading and masonry for the year named was $\$ \mathrm{I} 3,986.68$ and $\$ 3,032.29$ respectively; for bridges, superstructure cost $\$ 22,880$.87 , and station buildings, etc., $\$ 53,578.12$. Land damages, land 


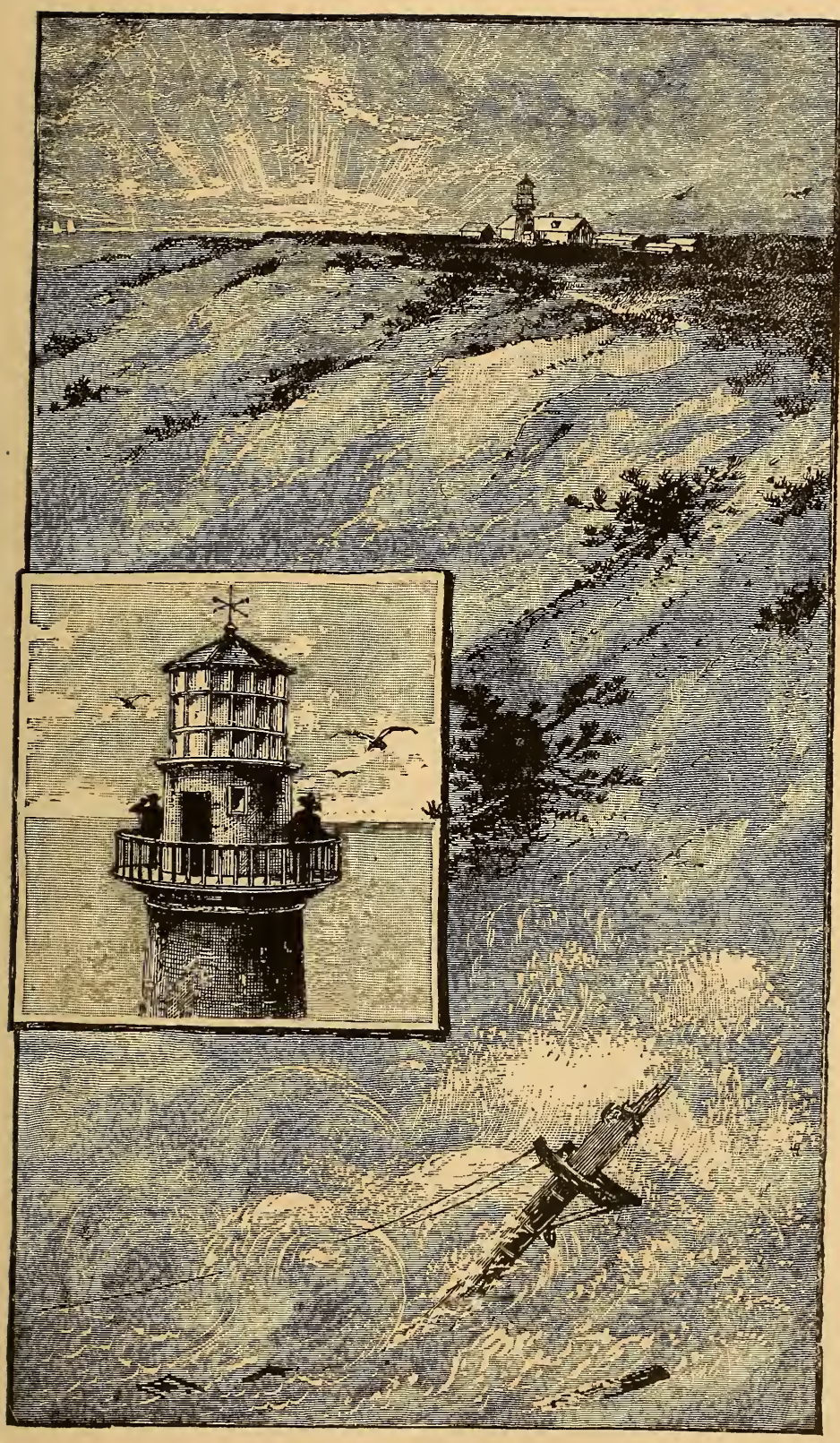

GAY HEAD, MARTIIA'S VINEYARD, 

and fences cost $\$ 22, \mathrm{I} 60.06$, and $\$ 8$, 0 I 5 was expended on repairs of locomotives; that on passenger and baggage cars was $\$ 5,397.50$; merchandise cars $\$ 2, \mathrm{I} 60$; engineering, etc., $\$ 27, \mathrm{I} 29 . \mathrm{I} 6$, making the total cost of equipment $\$ 1,639,632.16$, which amount included $\$ 125$,46I.63 paid for the Abington and Bridgewater Branch, which spur was pushed forward during the year in order to intercept the Fall River road which was rapidly building toward Boston. The amount of business done by the road had considerably increased during the twelve months, as will be seen from the report following: I05, I05 miles were run by passenger trains, and 27,444 miles by freight trains, all others running I9,644 miles. The number of passengers carried was 389,994 ; those carried one mile or more, 4,904,86I ; 42,707 I-IO tons of merchandise were transported and 748,550 6-io tons more than one mile. The number of passengers conveyed one mile or more to and from other roads was I, 256,220, and the amount of freight 219,670 7-IO tons. In the items of expenditures we find the following charges : For repairs of road, exclusive of wooden truss bridges and renewals of iron, \$II,I58.7 I. Repairs of bridges \$I I 7.0I. The items of wages of switch-men, gate-keepers and flag-men are now mentioned, the sum amounting to $\$ 3, \mathrm{I} 8 \mathrm{0}$. Repairs of fences, houses for flag-men, etc., \$326.96. Locomotive repairs, \$7,359. I ; passenger car repairs, \$2,978.34; merchandise cars, $\$ 966,97$; gravel and other cars, $\$ 376.20$. Fuel and oil, $\$ 23,352.45$. Salaries, etc., charged to passenger department, $\$ 16,582.57$, while the same charge to the freight department was $\$ 10,645.57$. Gratuities and damages $\$ 321.00$, and for taxes and insurance $\$ 2,822.76$; station repairs, furniture, etc., $\$ 632.88$. The interest was $\$ \mathrm{I} 2,30 \mathrm{I} .28$, and the salaries of head officials and their expenses were only $\$ 3,202.28$. The gross earnings for the year ending Nov. 30, I 847 , were \$I 7 I, I 53.75 ; net earnings, $\$ 84$, I 33.35 . A dividend of 3 per cent. was paid on the latter, less $\$ 5,478.20$ carried to the surplus account.

The Providence \& Worcester Railroad was completed on October 20th, I 847, as was also the branch of the Boston \& Providence which crossed the Blackstone and connected with the former near Central Falls. In making their first report after the completion of the road the directors state that of the $\$ I, 756,754.99$ paid for the construction, $\$ 222,000$ was expended for the benefit of the Boston 
\& Providence, which was principally reimbursed by them; $5 \mathrm{I}-2$ miles of this road were owned in common with the Providence \& Worcester. The Boston \& Providence paid $\$ 370,403.47$ in settlement of its portion of the expenditure for its branch road.

The city of Boston was authorized April 23, I847, to construct a branch railroad from a point on the Boston \& Providence road near Baldwin Mills; thence running southeast of Baldwin's lot, crossing Tremont, Northampton, Suffolk, Chester, Washington and Springfield streets and Harrison avenue to a point near the southeast end of the sea wall in South Bay, and connect with this road on such terms as might be agreed upon. The road was not to be used to convey passengers and merchandise for hire, and the rate of speed was fixed at five miles an hour. The city also had the right to build branch tracks for the purpose of filling up and grading any street or lands in the city southerly of the Worcester Railroad. But this branch was to be removed on May I, I852. This act was repealed March 3, 1848, when the same privilege was given to the city to build a branch connecting with the Old Colony. The capital stock of this road was again increased $\$ 470,000$. This sum was added to to the extent of $\$ 160,000$, May 9, I 848 , when the corporation was empowered to build a branch line from Dedham along and across the Charles river meadows to West Roxbury, and from thence to the main line at or near the toll gate. It is needless to add that the city did not build this line.

April 2I, I 847, the Fall River Railroad Company was authorized to extend their road from the southern terminus in the town of Fall River, in a southwesterly direction, to the wharf of the Fall River Iron Works Company, called the new Steamboat wharf ; and on March 27, I 848, the New Bedford \& Taunton Railroad Corporation and the Fall River Railroad Company were authorized jointly or severally, to connect the roads of the two corporations near their intersection in the town of Taunton by constructing a curved track, and suitable switches, as that between the city of New Bedford and the town of Fall River, that an engine and cars may be run direct from the one place to the other. This curve was restricted to be of not less than 600 nor more than 1000 feet radius. 
The Cohasset \& Scituate Branch Railroad Company was incorporated April 23, 1847, by George M. Allen, Ezekiel Jones and Charles Vinal, to build a road within the towns of Cohasset and Scituate, starting from the depot of the South Shore Railroad in Cohasset and thence southwesterly, through those towns and through the north part of Scituate to a point near the Union school-house at Scituate Harbor. The capital stock was $\$ 75,000$. They were, of course, given the privilege of entering the South Shore Railroad and to transfer their property to the latter road, for which purpose they were allowed to increase their capital stock by $\$ 75,000$. 


\section{CHAPTER VI.}

\section{$T$}

HE Weir Branch Railroad Corporation was chartered April I6, I 847, by Charles R. Atwood, Hezekiah W. Church and William $\mathrm{H}$. Ingalls, to lay a track from a point on the New Bedford \& Taunton Railroad in Taunton near the stone ware manufactory. To build this they were allowed a capital stock of $\$ 12,000$. They were not to obstruct public travel, and the selectmen of Taunton had the right to regulate the motive power, which was not to be steam. The incorporators had the right to transfer their charter to the New Bedford \& Taunton, or the Taunton Branch Railroads, and in 1847 consolidated with the former, which had two. thirds of the road constructed that year, at a cost of $\$ 8,949.33$. This corporation also began to build a branch road to connect the main line with the harbor of New Bedford, and to build a wharf at its terminus

September 20, I 847 , a consolidation of the Old Colony and the South Shore Railroad Company was effected. By the terms of the consolidation the latter road agreed to construct its road from North Braintree to Cohasset and maintain it for a period of five years for six per cent., payable semi-annually, the first payment to be made six months after the completion of the line. Should this arrangement prove satisfactory and another lease of five years be desired, seven per cent. was to be paid. The Old Colony was to furnish all the rolling stock and pay all the expenses. It had the privilege of running over the line as soon as the tracks were laid from one section to another before the lease was consummated, paying a reasonable sum for the same. It agreed to guarantee the payment of bonds of $\$ 25,000$ as soon as the first six miles were completed, payable in seven years, with interest semi-annually, and a like sum payable in ten years, when the entire road was built. The contract was signed by Caleb Stetson, president of the South Shore Railroad; John W. Loud, clerk, and Nathan Carruth, president of the Old Colony. 
December Ist, of the same year, a contract was entered into between the South Shore Company and the Old Colony, made necessary by the fact that in forming a line of railroad communication between Boston and Fall River via Bridgewater and Middleborough in addition to the line of the Fall River Railroad, it became necessary to use a portion of the road owned by the Old Colony.

January I, 1849, the first train of cars was run over the South Shore Road and continued to do so from that date, under the direction of the Old Colony superintendent, at the risk of and for the benefit of the South Shore Company. The road was, however, far from completed, and would not be until summer. A considerable amount of the stock was taken by contractors in payment for work done.

On May Ist, the Old Colony was authorized by the legislature to lease this line. At the same time the former company was allowed to discontinue and omit any portion of its road in the city of Boston.

An agreement was made in I85 I between the Old Colony and the South Shore Railroad Companies that no payment for rent to the South Shore Company should be made on more than $\$ 400,000$, the value of the road; but should a new lease be made, then the cost should be settled anew.

An act to establish the Agricultural Branch Railroad was passed April 26, I 847, the incorporators being Messrs. Sullivan Fay, James S. Savage, and Curtis Newton, to build a road "commencing near the village of Northborough, extending to the centre village of Southborough, to connect with any branch of the Boston \& Worcester Road, near the centre village of Framingham, and such branch railroad, on its way from this point near Northborough to the centre village of Southborough shall be required to pass to the north of the house of Wm. Newton, Esq., in the southerly part of Marlborough ; provided a suitable grade could be found not exceeding forty-two feet to the mile, and which would cost no more than the average cost per mile of the residue of the railroad hereby authorized." The capital stock of the company was fixed at \$280,000. 'Two years' time was given for its completion, but this period was extended April 2I, I848, one year longer, at which time it was authorized to unite its road with that of the Framingham Branch 
Railroad. This latter company was chartered April I6, I 846, by Rufus Brewer, John Wenzell, Benjamin Wheeler, Horace Heard and Isaac Fiske, with a capital stock of $\$ 200,000$, to construct a road of one or more tracks in or near the centre village in Framingham, extending near Saxonville village, crossing the southerly part of the town of Sudbury, thence to the centre villages of Wayland and Weston, to a point in the latter town convenient for entering the Fitchburg Railroad. The two years allowed for building was extended March i8, I848, until April i6, i 850.

The act to establish the Agricultural Branch Railroad Company, passed April 26, I847, was revived May 7, I85 I, and two years' time given it to build its road; but the stock was to be subscribed for and twenty per cent. paid in. May 5, I852, it was authorized to extend its line from its terminus in Northborough, through Berlin, thence to Boylston, through Lancaster, passing Clinton to some point on the Fitchburg \& Worcester Road in Sterling, and could enter and unite with that of the Fitchburg \& Worcester in Sterling. The right was given to cross the tracks of the Worcester \& Nashua Railroad in Sterling or Clinton, at the same grade with the former road or over it, it to bear the cost, for which the capital stock was increased $\$ 300$,000. The road was to be divided into three sections, the first to embrace that part from Framingham to Northborough; the second from Northborough to Clinton, while the third was from Clinton to the terminus in Sterling. The capital was also divided, that for the first section being $\$ 150,000$; second, $\$ 200,000$, and third section $\$ 100$,ooo. The twelve months' time for filing the claim was extended May I8, I 852, to May 9, I 853, and the time of completion to 1855 . But this period was also extended on April 23, I853, to July I, I856. On the latter date the Boston \& Worcester, Fitchburg \& Worcester, Cheshire, and the Vermont \& Massachusetts Railroad Companies were authorized to subscribe for the stock. The Agricultural Branch Railroad Company was permitted to lease its road or take a lease of any of those mentioned, or consolidate with them. The Ware Branch of the Taunton Branch Railroad was discontinued this year.

The Agricultural Branch Railway Company report that their road was open from Framingham to Marlborough and was operated 
by the Boston $8 \mathrm{r}$ Worcester Road from June to December, rent free. December Ist that portion of the road from Framingham to Marlborough was opened and operated by the same company. The entire system was leased to the latter corporation April 23, I853, to take effect on the completion of the first section of the road which was finished, and the contract dated December I, I 855, and extended for a period of twenty years. The section finished was from Framingham to Northborough.

In the summer of 1847 the Fall River Road became embarrassed with a heavy debt, with a large proportion of it authorized stock unsold; to raise ready funds it sold it to the stock-holders at $\$ 80$ per share. This difference between the amount realized and the par value, was proportioned and charged in its annual report to the several accounts of construction. But the amount received from the stock was insufficient to meet its demands, as the road was incomplete and therefore unable to do a proper business. The legislature was petitioned for an increase of its capital stock. This was granted with the proviso that it should not sell for less than \$IOO per share. But this proved of little help, as the stock of this company could be bought on the market at $\$ 87$ per share, and even as low as $\$ 80$, and the greater part of the stock was left unsold. The only recourse left them was to appropriate $\$ 3 \mathrm{I}, 500-$ equivalent to three dollars for each share - to be taken from their earnings, and credited to the several accounts of construction.

March 27, r 848, the Old Colony was authorized to widen its road twenty feet on either side so as to construct a second track between Boston and South Braintree; also to widen bridges, draws, and streets en route to aid them in so doing. It was also empowered to construct a branch road commencing at some point on the main line in Quincy, " a little south of the turnpike on the southeasterly side of Neponset river, and thence running through or near a certain gravel hill, called Mount Hope, to the Granite Railway, a distance of about one and a third miles." It was permitted to contract with the Granite Railway Company for the purchase of its road. Authority was also given to construct a branch road, commencing on the main line between Neponset river and Harrison square, in Dorchester, and thence running toward Commercial point to deep water, where it was to build wharves 
and suitable depots for transportation of freight by water, for which purpose it increased the capital stock $\$$ IO०,000.

The New Bedford \& Taunton Railroad built in I 848 a branch to connect the main line with the harbor of New Bedford, also a wharf at its terminus, at a cost of $\$ 14,068.38$. It built one-half of a branch to connect the main line with the Fall River Road, and also one-half of the depot at Myricks, at a cost of $\$ 3,036.45$.

In the Old Colony report for the year ending December I, I 848, it is stated that $\$ I, I 99,300$ had been paid in during the year, and that its floating debt was $\$ 509,463.5 \mathrm{I}$. It paid no fixed rate of interest; but paid from day to day the current rates to complete construction and on construction account. The net earnings for this year were $\$ 87,757.46$. A dividend of $3 \mathrm{I}-2$ per cent. was declared in July following and another of 3 per cent. was due in January, which left a surplus of $\$ 8,000$.

Messrs. R. W. Hayward and W. H. Hunnewell succeeded Messrs. Thomas and Loud on the Board of Directors.

March 22, I 848, the New Bedford \& Taunton Railroad Corporation was authorized to build a branch road, beginning at a point on its road about 980 feet north of the north line of Pearl street, in New Bedford, thence to a wharf then being constructed by the corporation on the west bank of Acushnet river.

April 21, I 848, the Taunton \& Middleborough Railroad Corporation was chartered to build a road from a point on the New Bedford \& Taunton Railroad, near the bridge over Taunton river, in Taunton, thence in an easterly direction, through a part of the town of Raynham, near the Old Colony Iron Works, in Squawbetty, to a convenient point on the Fall River Railroad near the depot in Middleborough, and so as to intersect the Cape Cod Branch Railroad near its depot. A capital stock of \$I 50,000 was granted.

The time allowed for the Taunton \& Middleborough Railroad Corporation to construct its road, having expired, it was revived March I 7, I 853, provided the location should be filed before Jan. I, I 854 , and the road completed before September I of that year. The name was then changed to the Middleborough \& Taunton Railroad Corporation, and on March I7, I 853, the Taunton Branch Railroad Corporation was authorized to subscribe for the stock to the value of $\$ 25,000$. 


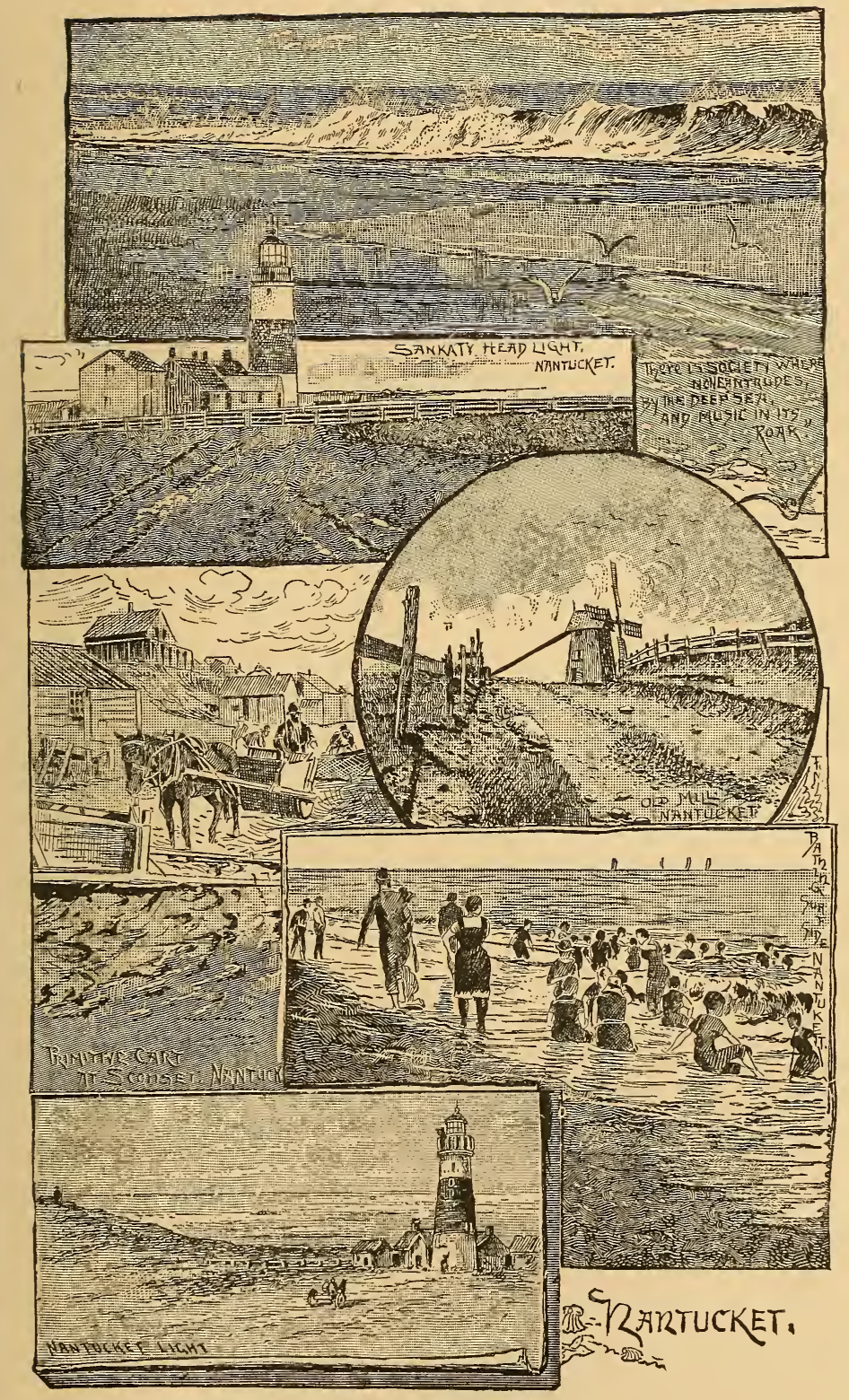



An amendment to the contract existing between the Old Colony and the Dorchester \& Milton Branch Railroad was made and endorsed in June, I 848, as follows: "It is agreed that, if the Old Colony Railroad Corporation shall purchase under the liberty given by the written indenture, the franchise and property of the Dorchester \& Milton Branch Railroad Company, it, said Old Colony Railroad Corporation, shall be required to pay no greater part of the purchase money therefor in its stock, than an amount equal to the stock of the Dorchester \& Milton Branch Railroad Company, valued at par, held by the stockholders thereof, at the time of said purchase. The balance of said purchase money may, at the option of said Old Colony Railroad Corporation be paid either in cash or its stock at par."

This was signed by E. H. Derby, president of the Old Colony, and E. P. Tileston, president of the Dorchester \& Milton Branch.

To this was added, July 26, I $85 \mathrm{I}$, another agreement. In this it was stated that the Dorchester \& Milton Branch was valued at $\$ 125,500$, and that the lease was to run until January I, I 856 . The Old Colony was to run over the former road at least five times daily in summer and four in winter. The bonds guaranteed by the Old Colony were to be renewed by the Dorchester road for five years after they became due, without expense to the former, but to be endorsed by them. A mortgage was given the Old Colony to secure that guarantee and cost of renewal of bonds. All future payments of rents, after the one then falling due, which was to be applied to the payment of its floating debt or to the purchase of these bonds, was to be paid to two trustees, one to be named by each party, who were to apply the rents, Ist, to the payment of interest on the bonds; 2nd, to the payment of three per cent. dividends semi-annually, on any prefered stock, the proceeds of which may have been used to provide for the debts of the company; $3 \mathrm{~d}$, to the payment of the second issue of bonds for $\$ 22,500$, or to buying the same before maturity; $4^{\text {th }}$, to the making of a sinking fund for the redemption of the bonds of the second issue; and, lastly, of the guarantee bonds, but with discretion; both trustees agreeing to buy up bonds of either issue. This article was subject to the rights of the mortgagees. The mortgage or pledge referred to above was, Ist, the mortgage of the rents and profits to the bondholders of the 
second issue of $\$ 22,500$; and, 2 nd, a mortgage upon the house adjoining the station at the Lower Mills.

At a special meeting of the directors of the Dorchester \& Milton Road, October 28, 1856, at the office of the president, N. F. Safford, this contract was renewed for one year, it being understood that the Old Colony \& Fall River road would renew its guarantee of the bonds of the branch to the extent of $\$ 25,000$ for five years from and after the maturity of the then outstanding bonds, which were to be taken up at their maturity by the branch, and the new bonds substituted. This was agreed to by the Old Colony \& Fall River, and the $\$ 5,000$ difference between the issues was to be paid by the branch ; that is, that the former road was to be saved harmless from the guarantee of bonds for this branch for $\$ 30,000$, and they to renew the guarantee to the extent of $\$ 25,000$.

The report of the Old Colony, December I, I 849 reads : "Capital paid in, $\$ 354,8$ I 5 ; increase of funded debt, $\$ 328,685$. Floating debt paid, $\$ 458,890.6 \mathrm{I}$. The average rate of interest paid per annum was, on the funded debt, 6 per cent. on bonds at five years, which were sold at 8 and Io per cent. discount; on the floating debt, about one per cent. per month. The rolling stock numbered I 5 engines, 26 passenger cars, 4 baggage cars, 105 freight cars and 53 gravel cars.

May 2, I 849, the Fall River Railroad was authorized to change its location in Middleborough near the intersection of the Cape Cod Branch, also to increase its capital stock $\$ 50,000$; provided that no shares should be issued for a less sum, to be paid up, than the par value of shares in the original stock. On March 27, I852, Nathan Slade, Abner Slade and Nathaniel B. Borden, proprietors of the Fall River wharf at Fall River, were authorized to build a track from the wharf to Fall River at a point near the range of the northerly line of land connected with the wharf, and to connect with the Fall River Railroad.

The Fitchburg \& Worcester Railroad was incorporated April r6, I 849, by Solomon Strong, Francis Perkins, Joel Pratt, James H. Carter and Caleb C. Field, to build a road from Fitchburg or Leominster to Sterling, and thence to intersect or connect with the Worcester \& Nashua Railroad in Sterling or West Boylston, where they could connect with the former road, and could, should that road 
forfeit their charter by negleet to file their plan, extend their road to Worcester; but this, of course, was never done. The capital stock was $\$ 500,000$, and they were privileged to enter the road of the Fitchburg and the Vermont \& Massachusetts Railroads, and could purchase or hire the Worcester Branch, or consolidate with that corporation. They also had the privilege of uniting or consolidating with the Worcester \& Nashua Railroad Corporation. March 20, I 847, the time of one year for filing the location of the road was extended another twelve months, and again Feb. 29, I848; and this was repeated Feb. I4, I 849, and Feb. 2, I 850. March 3I, I 85 I, they were authorized, in pursuance of their contract with the Fitchburg Railroad Company, to construct a track for the use of freight trains only from their passenger depot in Fitchburg across the land adjacent to the passenger depot of the Fitchburg Road in that city, so as to connect with the Vermont \& Massachusetts. One thousand shares of preferred stock were issued by them in April, I $85 \mathrm{I}$, the value being $\$ I O 0$ each, on which they were to guarantee the payment of three per cent. interest semi-annually; provided they did not dispose of any stock at less than par value. This stock was of course first offered to the stockholders of the company at its par value in proportion to the number of shares they already held, and for each share of the said preferred stock so subscribed and paid for at par. Each stockholder had the privilege of surrendering one share in three of the old stock held by him, and receiving in return one share of the preferred stock. They also had the option of surrendering the old for the new stock. This preferred stock was to be redeemed by the company at any time within ten years, by paying the par value of the same, together with all dividends. An additional issue of $\mathrm{I}, 050$ shares of preferred stock was authorized Feb. 21, I 853, under the same stipulations.

Ebenezer Lobdell, Seth D. Eaton and Ebenezer T. Lobdell were incorporated May 2, I 849, to build the Silver Lake Branch Railroad from a point near the Old Colony Road not more than I,200 feet from the depot at Halifax, and proceed by the Old Colony Road to Jones River Pond, thence branching north and south along its margin a distance not exceeding one and one-half miles, for which they were allowed a capital stock of $\$ 35,000$. They were authorized to sell its franchise to the Old Colony. 
The Mount Pleasant Branch Railroad Company was incorporated May I, I 849, by Isaac McLellan, Marshall P. Wilder, John L. Whipple, E. P. Tileston and F. Gleason, to build a road from a point near the town house in Dorchester, running north about one mile, then near the estate of Marshall P. Wilder, following nearly the course of the Roxbury Brook to Stoughton street; thence east to a point of junction with the Old Colony Railroad near Little Neck. The capital stock was limited to \$1 50,000. 
CHAPTER VII.

W AY I, I 849, the act to establish the Fairhaven Branch Railroad was passed. The charter was given to Nathaniel Church, Warren Delano, Ezekiel Sawin, Zaccheus M. Barstow, Loring Meiggs, Stephen C. Luce and Gilbert Hathaway, to build a road from Fairhaven, in the county of Bristol, intersecting the Cape Cod Branch Railroad at or below the South Middleborough station and the South Wareham station, and to pass within one mile of Mattapoisett, in the town of Rochester, and within three-quarters of a mile of Mendall \& Leonards' store in the scippian quarter of Rochester. They were allowed a capital stock of $\$ 250,000$, and the road was to be constructed in four years. They were permitted to use the roads of the Cape Cod Branch, Fall River \& Old Colony. April 30, I85I, the time of construction was extended one year, provided they did not begin operations until the entire amount of their capital stock had been subscribed for, and ten per cent. paid in ; the capital was at the same time reduced to $\$ 200,000$. On April 20, I 852, one year more of grace was allowed them; and on the 27 th they were given power to extend their road over the burial ground in Fairhaven. April 14, I853, capital was increased $\$ 100,000$.

On the Providence Division, the West Dedham Branch Railroad Company was incorporated May I, I849, by Messrs. Joseph Fisher, Merrill D. Ellis and Oliver Capen, to build a road from West Dedham to the Dedham branch of the Boston \& Providence, to accomplish which they were authorized to issue bonds to the extent of $\$$ I 50,000, and were permitted to use the tracks of the Dedham Branch of the latter road, which corporation constructed and controlled that branch.

The Middleborough \& Plympton Railroad Company was incorporated May 2, 1849, by Zachariah Eddy, Oliver Parker and Ebenezer Lobdell, to build a road from the depot of the Old Colony in Plympton to a point at or near the depot of the Fall River Railroad in Middleborough, the capital stock to be $\$$ I 50,000. 
The annual report of the Old Colony for 1850 gave the capital paid in as $\$ 7,770$; paid on floating debt, $\$ 50,572.90$. Six per cent. was the average rate of interest paid; agencies and expenses, $\$ 144.25$. Total cost of road and equipments, $\$ 2,293,534.83$. No other charges are given in this report except expenditures for working the road. Only two hundred hands are reported as being employed. Net earnings, after deducting expenses, $\$ 80,468.72$; surplus, not divided, $\$ 80,468.72$. The following changes occurred in the Board of Directors: Messrs. Francis B. Crowninshield, Nathaniel Whitney, J. W. Seaver and William Richardson, vice Derby, Loud, Seaver and Crocker.

The Matfield Railroad Company was incorporated by James Brown, S. Dwight Eaton and J. M. Leonard, April 30, 1850, to build a road from a point not more than 300 feet from the East Bridgewater Iron Company, in East Bridgewater, to a point on the Bridgewater \& Abington Branch of the Old Colony, northerly of, and not more than I,Ooo feet from, the depot in East Bridgewater, where they were allowed to unite with the Old Colony, provided they could obtain that permission. They were allowed $\$$ IO, 000 to build the same.

The Cape Cod Branch Railroad Company extended its line on May 2I, I857, from the terminus in Sandwich, through the towns of Sandwich, Barnstable and Yarmouth to the tide-water at Hyannis Harbor in Barnstable, with privilege to build a wharf for the convenience of passengers and freight, for which purpose it was allowed an additional capital stock of $\$ 250,000$, which amount had to be subscribed for and 20 per cent. paid in before operations on the road were begun. The par value of the original stock was reduced to $\$ 60$, and all dividends declared in the future were to be on the original stock at the above value. It could, should it see fit, discontinue as much of the branch at Wareham Narrows as laid below the southeasterly side of Parker Mills wharf. April 20, I852, a further period of two years was allowed to build the road and to act in conjunction with the town of Wareham to maintain the bridge over the river in in Wareham without a draw until further ordered, and on April 28, the town of Nantucket was authorized to subscribe for $\$ 50,000$ of the stock, provided the town pass the order on a two-thirds vote. 
The only change in the Old Colony directory for 1852 was the addition of the name of Mr. Charles B. Shaw. The most important items in the report for this year are as follows: Capital paid $\$ 60$,ooo ; funded debt (bought by the company), $\$ 45,500$; cost of road, $\$ 2,293,534.83$. Passengers carried from the steamboats by the Fall River and Cape Cod Railroads, 2, 144,962. The undivided surplus this year was \$IOI,5 I O.44.

The Marlborough Branch Railroad Company was incorporated April 30, 1852, by Mark Fay, Lambert Bigelow, Richard Farwell and Hollis Loring, to construct a road from a point on the Lancaster \& Sterling Branch of the Fitchburg Railroad in the village of Feltonville, so called, in the town of Marlborough, and extending to a most convenient point near the east or west Parish in the town, or Marlborough. Junction, for which they were allowed a capital stock of $\$ 80,000$, and privileged to contract with the Fitchburg to equip and run their road. In their charter was inserted a clause whereby those shareholders who refused or neglected to pay when due the twenty per cent. of the par value of their shares, or any part of the assessment, were to forfeit their stock and any payments already made.

The name of the Providence \& Bristol Railroad Company was changed May 24, I853, to the Providence, Warren \& Bristol Railroad Company, and allowed a capital stock of $\$ 250,000$. The time for the completion of the road was also at this date extended fifteen months.

In the Board of Directors of the Old Colony, only three names, those of Messrs. Crowninshield, Walker and Hunnewell are mentioned. They report as follows for $1853:$ Funded debt, paid and bought by the company, \$71, I00. Increase of floating debt since last report (difference between notes payable and receivable), \$70,888. I3. Freight cars, $\$ 7,200$. No other expense is reported in maintainance of road.

The Old Colony and the Fall River Railroad Corporations, were united March 25, I854, to be called the Old Colony \& Fall River Railroad Company. Section 3 says: "The first meeting of the corporation hereby authorized, shall be called by the presidents of the two corporations composing its parts ; and of the time and place of said meeting, seven days' notice will be given, by publication in 
two ncwspapers in the city of Boston, and one in each of the counties of Plymouth and Bristol; and at said meeting, persons holding stock either in the Old Colony Railroad Corporation or in the Fall River Railroad Company shall be entitled to vote in like manner as they would have been had these corporations been convened separately. March 3I, I 854, they were permitted to change the location of their road, by enlarging and making more easy of operation, the curves near its southern terminus in Fall River, which if not done within two years would deprive them of the privilege."

The first report of the Old Colony \& Fall River Railroad Company was for I 854 . The capital stock was $\$ 3,300,000, \$ 3,0$ I 5 , IOO of which was paid in; the total amount of their funded debt amounted to $\$ 289,834.65$, the floating debt being $\$ 250,000$, while the average interest paid was six per cent.

The cost of road and equipment in the report for this year is given as $\$ 3,434,164.8 \mathrm{I}$, less $\$ 7 \mathrm{I}, 2 \mathrm{I} 6$ charged to deterioration. By the consolidation the road increased 79 I-2 miles, I I I-2 of which was double track. The total number of men employed, exclusive of those engaged in construction, is given as 340. The income from passengers was $\$ 4$ I 9 , O I 4 ; from freight, $\$ 2$ I 7, I 48.62 ; that from other sources bringing the total up to $\$ 649,656$. I4. The Board of Directors was composed of Messrs. Alexander Holmes, Richard Borden, Peter H. Peirce, F. B. Crowninshield, J. H. Beals, C. C. Gilburt, and William J. Walker.

April 12, I854, the eleventh section of an act passed March 4, I826, entitled "An act to incorporate the Granite Railway Company," whereby the stockholders in said company, are made liable, in their persons and estates, for all debts contracted by that corporation, was repealed, and another act was passed March 27, I 858, as follows :

Section I. Any justice of the Peace for Norfolk County may call a meeting of the stockholders of the Granite Railway Company, first giving five days' notice to such stockholders of the time, place, and purpose of holding the meeting. At such meeting it shall be lawful to choose all officers of the corporation, who shall hold their office until the expiration of one year and until others shall be legally chosen in their place; and to ratify, approve and adopt any 

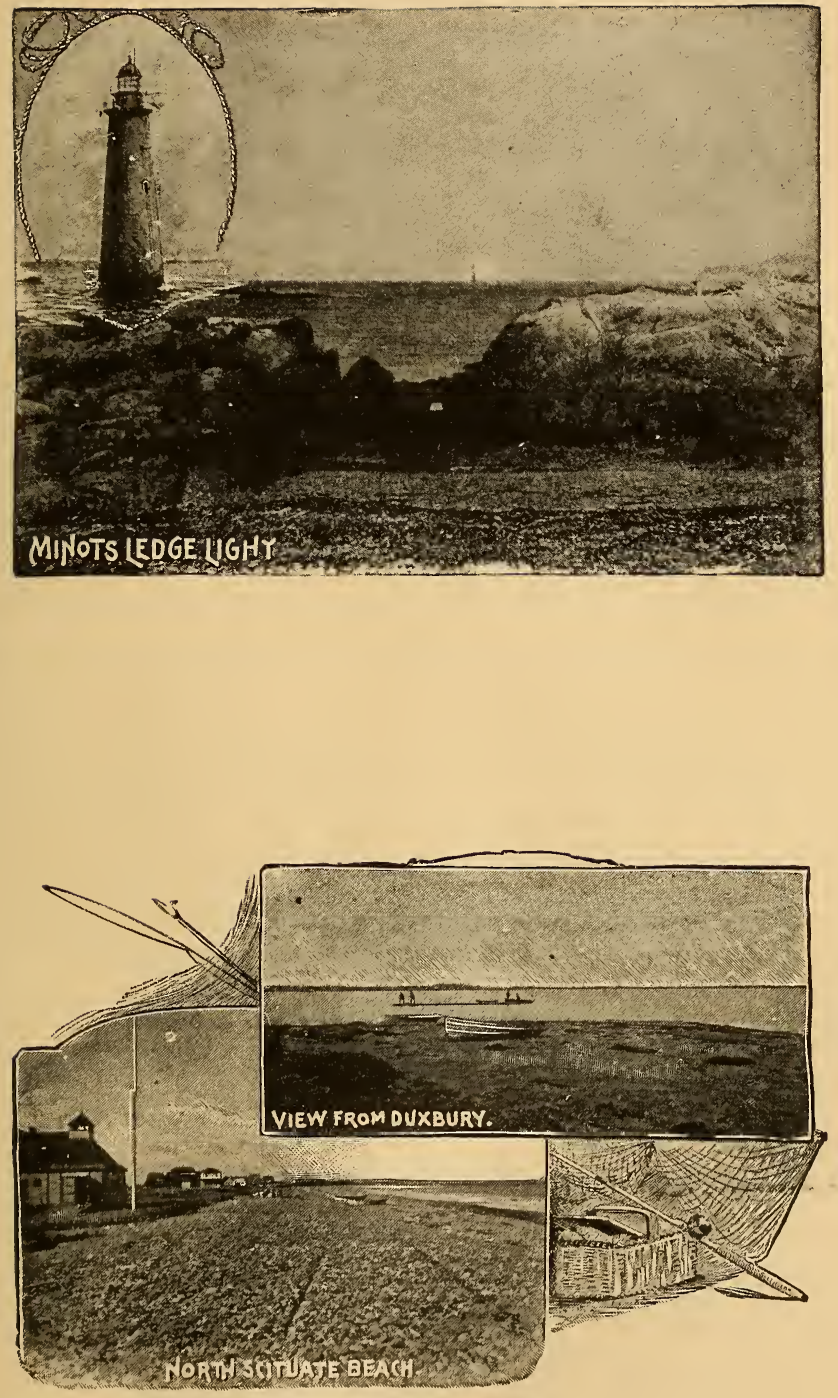

or all past acts of persons who have heretofore acted as agents or officers of said corporation.

Section 2. Any person who has acted as clerk of said company and kept a record of their meetings or doings may append to such record his certificate, under oath, that the same is true; and the same shall thereupon have the same force and effect, and be admissible as evidence as fully as if such person had been duly sworn, and had recorded his oath as clerk at or prior to the time of the making of such record.

Section 3. This act shall not affect any action now commenced, nor any rights now held or acquired by any other corporation or person.

An act to incorporate the Easton Branch Railroad Company was passed March 3, I 854, the incorporators being Messrs. Oliver Ames, Oakes Ames and Howard Lothrop, to build a road for or near the Stoughton Branch Railroad at or near the terminus at Stoughton to the Branch Turnpike to a point in Easton at or near North Easton, and were allowed a capital of $\$ 100,000$; three years were given them to build.

February 22, I 854, the name of the Cape Cod Branch Railroad Company was changed to the Cape Cod Railroad Company and its capital stock increased by the sum of $\$ 60,000$ and on March 5 th, same year, the county commissioners of Barnstable were authorized to entertain jurisdiction of claims for land damages against this road, notwithstanding their interest from being owners of that stock. This was the cause of the above act, as a question arose as to whether the commissioners, being stockholders, could act in this capacity. This line was opened July 8, I 854 from Sandwich to Hyannis.

Messrs. Robert M. Todd, Edward King, and Nathaniel F. Stafford were incorporated April 29, I854, as the Dorchester and Milton Extension Railroad Company, to construct a road from a point on the Dorchester \& Milton Branch west of the station at Milton Lower Mills to a convenient point of intersection with the Midland, thence crossing that road, and extending to some convenient point of intersection with the Boston \& Providence Railroad near the Readville station, and also to terminate their road extending from the Dorchester \& Milton Branch to the aforesaid point 
of intersection or to enter upon, use, or pass over a portion of that road between the point of intersection and the point where the above road crosses the Boston \& Providence Railroad, and to construct a portion of railroad connecting the Midland with the Boston \& Providence, uniting therewith at or near Readville station. Their capital stock was limited to $\$ 50,000$, and a period of three years was granted them to build, and they were permitted to convey their rights to the Dorchester and Milton Branch which was done in I 857 .

The second report of the Old Colony \& Fall River Railroad Company submitted in 1853 , gave the following statistics : Funded debt paid since last report, $\$ 13,134.65$; floating debt, $\$ 9,050$; total amount of floating and funded debt, $\$ 202,650$. The total increase was $\$ 653,499.32$; net earnings, after deducting expenses, $\$ 276,365.70$. Two dividends of three per cent. were paid, amounting to $\$ 180,906$., leaving a surplus not divided of $\$ 95,459.70$.

The Providence, Warren \& Bristol Railroad Company was on April 2I, I855, incorporated under the above name, and was given until February I, I856, to complete its road, while its capital stock was also increased \$150,000, which stock was to be distributed or sold to the stockholders at such rates as they might decide at a meeting called for that purpose. In order to do this it was stipulated that the stockholders should decide the measure by a majority vote; also that the legislature of Rhode Island give its sanction, provided that the act in question was not considered as giving to the company power to add to its capital stock from the stock issued under a like authority obtained from the legislature of Rhode Island.

On February I, I 855, the Marlborough Railroad Company was mortgaged to Francis Brigham, Francis D. Brigham, and Obediah W. Albee, and on March 27, I858, these gentlemen were authorized to associate themselves under any name they should choose to assume, for the purpose of managing the road, which title, amount of capital paid in, etc., was to be published in the daily papers. This arrangement was not in any way to affect or impair any contract existing at the time between the Marlborough Branch Road and any other company, in relation to the use and running of that road, but the corporation under this act was to have all the rights and be subjected to all 
the duties and liabilities of the road under any such contract. The company was also to issue bonds for the purpose of taking up and paying the bonds and other indebtedness of the mortgagees, and the trustees should, in case of the issue of such bonds, hold the property mortgaged as security for the payment of any such bonds so issued. 


\section{CHAPTER VIII.}

1

HE report of the Old Colony \& Fall River Railroad for 1856 , gives the amount of capital paid in as $\$ 3,0$ I 5,100 , and the sum paid on account of the funded debt of the road since the previous report as $\$ 67,100$. The floating debt had increased during that period $\$ 34,500$. The total income from all sources was $\$ 683,356.85$, which, after deducting expenses, left the handsome sum of $\$ 305,139.62$ as the net earnings of the road. Two dividends of three per cent. were also paid this year, amounting to $\$$ I 80,906 , and $\$ 124,233.62$ was carried to the surplus account. These figures while, necessarily dry of themselves, are given for the purpose of comparison and to show the progress of the Old Colony in its first decade of existence. In this sense they can be made interesting to the general reader and instructive to the student of early railroading in this country.

Messrs. Joseph G. Luther, William Pierce, William Wilber, Nason Brown and Benjamin Robinson were incorporated March I 7, I 857, as the Fall River \& Warren Railroad Company to build a road from Swanzey, R. I., extending through Somerset to Fall River, with a capital of $\$ 100,000$. They were also permitted to establish a ferry between the terminus of their road on the northerly side of Taunton river and Fall River, and were to consolidate with any road authorized by the state of Rhode Island to continue on the western terminus with the compact part of Warren. They were, however, not permitted to commence operations until all the stock had been subscribed for, and twenty per cent. of the par value paid in on each share.

The report of the Old Colony \& Fall River Road for the year ending November 30, I 859, showed the number of shares of capital stock issued to be 30,15I ; funded debt paid since previous report, $\$ 27,000$; total amount of floating debt, $\$ 195,400$; maximum amount of debts during the year, $\$ 268,400$; average amount of interest, nearly six per cent. Total cost of road and equipment, $\$ 3,434$,- 
I64.8I, less for deterioration $\$ 7 \mathrm{I}, 2 \mathrm{I} 6.2 \mathrm{I}$; amount of property held in addition to the cost, being the surplus earnings on hand after deducting the dividend to be paid the following January, $\$ 567$, 321.08 Passengers carried, I, 265,354; income from passengers, $\$ 404,0$ I $7.03, \$ 68,6$ r 5 . I 4 of which sum was from other roads; freight, $\$ 219275.01$, of which $\$ 30,861.30$ was from other roads. Mails, $\$ 10,750$. Net earnings, after deducting expenses, \$296,08I.8I. Two dividends of three per cent. were paid, amounting to $\$$ I 80,906 ; surplus, not divided, \$I I 5, I 75.8 I.

Report of the Old Colony \& Fall River for the year ending November 30, I860: Funded debt paid since previous report, $\$ 27$,500 ; increase of floating debt, $\$ 15,600$; total floating debt, $\$ 76$,500 ; maximum amount of debt during the year, $\$ 197,500$; amount of assets in property held by the corporation in addition to the cost of the road, \$70 I,697.22. Number of passengers carried, I, I 22,279; tons of merchandise carried, 207,765. Three hundred and sixty men were employed this year. Income from passengers, \$331,942.44 , of which $\$ 69,568.95$ were from other roads. Freight, $\$ 226$,47 I. 79 , and of this sum $\$ 35,923.44$ was received from its connecting roads. Net earnings, after deducting expenses, $\$ 3$ I 5,282. I4. One dividend of six per cent. was paid amounting to $\$ 180,906$, leaving an undivided surplus of $\$$ I 34,376 . I 4 .

March 28, I 86I, Messrs. Chester Snow, Freeman Cobb, Joseph Cummings, E. W. Carpenter, Joseph K. Baker, Jr., James S. Howes and Reuben Nickerson, Jr., formed a corporation known as the Cape Cod Central Railroad Company. These gentlemen were permitted to build a railroad near Yarmouth depot, Barnstable county, and have it run through the following towns: Yarmouth, Dennis, Harwich and Brewster to Town Cove, a place in Orleans. Their capital stock was not to exceed $\$ 200,000$ : Permission was granted them to transfer their property, etc., to the Cape Cod Railroad Company, when desired, or the Cape Cod Central Railroad Company, and to lease the road, etc., either to the Cape Cod Railroad Company or any other corporation for any length of time, and authority was given to the Cape Cod Railroad Company and the Old Colony \& Fall River Railroad Company to accept such lease when the parties agreed. Permission was also given on this date to the Old Colony \& Fall River Railroad Company to build and operate a railway, 
beginning on Kneeland street, between South and Cove streets, Boston, and running southerly to the channel between Boston proper and South Boston, near Clark's Wharf, then southerly, bearing westerly across the channel to South Boston shore to land belonging to it, and then westerly and curving southerly over the land belonging to the company, near land of the South Boston Iron Company, to Fourth street; then under Fourth street, curving easterly, near land of the trustees of Cyrus Alger, deceased, and over the flats belonging to the Old Colony \& Fall River Railroad Company near the flats owned by or in care of Daniel Denny, and over the flats of the company, and over flats owned by Denny, or the trustee of Alger's estate, to the Boston \& New. York Central Railroad ; then over the same to the present track of the Old Colony near Dorchester avenue. When this railroad was ready for operation, the old track owned by the Old Colony \& Fall River Railroad Company was to be discontinued, and the bridges removed at the cost of this company. The bridge which passes over the Boston \& New York Central Railroad was to be twenty-five feet wide between its abutments and built in a proper manner, and kept in repair by the company; and the bridge over the railway on Fourth street was also to be built and kept in order by this company, and was to be at least fifty-feet wide. The power was also given the Old Colony to raise the grade of Fourth street, together with Dover street bridge, where it passes over the track, twelve feet, according to decision of aldermen. The expense of raising this on the easterly side was paid by the Old Colony, and that on the west side by the railroad company and the city of Boston; provided, that the city was required to pay only what is necessary to put the west side of Dover street bridge in repair for purposes of highway. March 24, 1865, the act requiring this line to raise the grade at Fourth street and build its road across the street was repealed.

The annual report of the Old Colony \& Fall River Railroad Company for the year ending November 30, I86I, shows no particularly marked feature over that of the previous year, except in some slight details of operating expenses and an increase in the passenger and freight service. The maximum indebtedness of the company this year was $\$ 245,278$, the floating debt having been increased from various causes $\$ 45,278$. The fuel account shows 
that coal was fast being substituted for wood, as was the case on all roads at this period. The net earnings, after deducting expenses, were $\$ 208,735.47$. A six per cent. dividend was declared and paid this year, and $\$ 27,829.47$ carried to the surplus account. Mr. George A. Kettell succeeded Messrs. Borden and Walker in the directorate.

On the 9 th of April 186I, the Old Colony was authorized to build and operate a railroad from the end of its track in Fall River, southerly, to a line in Rhode Island, to connect with a railroad to be built from Newport, R. I., to the line of Massachusetts. This road was also authorized to connect with any railroad in Rhode Island, and should, if required by the Bay State Steamboat Company, deliver at Fall River all articles of freight, unless otherwise ordered.

The annual report for the year ending November 30, I862, contains but little of interest to the general reader, with the bare exception that this year the United States internal revenue tax was imposed on the business of the Old Colony \& Fall River Corporation, the amount of such tax for the two months covered by the report being $\$ 1,897.60$. The net earnings were $\$ 293,458.56$. Messrs. John R. Brewer and Benjamin Finch succeeded Messrs. Beal and Gilbert as directors.

In 1862 the Fall River line was extended to the state line toward Newport, under a corporation known as the Newport \& Fall River Railroad. This line was merged in the Old Colony, and the name of the system became the Old Colony \& Newport Railroad. A contract was made January 23, 1862, between the Old Colony \& Fall River and the Newport \& Fall River Companies, to the effect that all the rights of the road were to be transferred to the former company for ten years at a yearly rental of $\$ 30,000$, after the completion of the track, stations, depots, etc., to be paid semi-annually. The Old Colony paid the sum of $\$ 300,000$ in advance for the purpose of building the road, in such sums as were required to carry on the work. This sum was to go toward the payment of the rental, as mentioned above, with interest. But one payment of $\$ 15,000$ was to be made on the day it fell due, with which the interest on the advance payments was to be paid, the balance to go toward the principal. This agreement was signed by Alexander 
Holmes, President of the Old Colony, and Benjamin Finch, President of the Newport \& Fall River Road.

The Vineyard Sound Railway Company was chartered in I86I from Monument Station on the Cape Cod Railway in Sandwich to Woods Holl. In 1868 the name was changed to that of the Plymouth \& Vineyard Sound Railway, and the company was authorized to build a road from Monument station tot he Old Colony at Plymouth. The franchise between Monument station and Woods Holl was subsequently conveyed to the Cape Cod Railway and it began the construction of that road at once.

On February 21, I863, Messrs. William Cobb of Dighton, Job M. Leonard of Somerset, Albert Field, Samuel L. Crocker, and Sylvanus N. Staples of Taunton, all from Bristol county, formed a corporation known as the Dighton \& Somerset Railroad Company. The capital stock of this company was not to be less than $\$ 300,000$, nor more than $\$ 400,000$, and the line of railroad was to commence at a point on the Taunton Branch Railroad, then running in a southerly direction through the towns of Taunton and Dighton to the town of Somerset, upon the line of the Fall River \& Warren Railroad. It could unite with the Fall River \& Warren, Taunton Branch, and New Bedford \& Taunton Railroads, and was authorized to construct a road at grade across the highway in Somerset, to the house of Philip Bowers. Permission was also on April 29 granted to the Old Colony \& Fall River Railroad Company to extend its railroad any time within two years to the line of the state of Rhode Island, from a point in Fall River to a railroad constructed in Newport, R. I., to the former line of the commonwealth of Massachusetts. When this company decided to re-locate or extend its railroad, it was allowed to cross at grade the following streets: Metacomet, Mill, and Broadway, and also was allowed to cross the American Print Works' pond.

The Dighton \& Somerset Railroad Company was on March I7, I864, allowed to build a road from the Old Colony \& Newport Railroad in Braintree or Randolph, through the towns of Randolph, Stoughton, North Bridgewater, Easton, Raynham, Taunton, Dighton and Somerset to Taunton Great. River, then across the river to Storehouse Point, and through a part of Fall River to the Old 


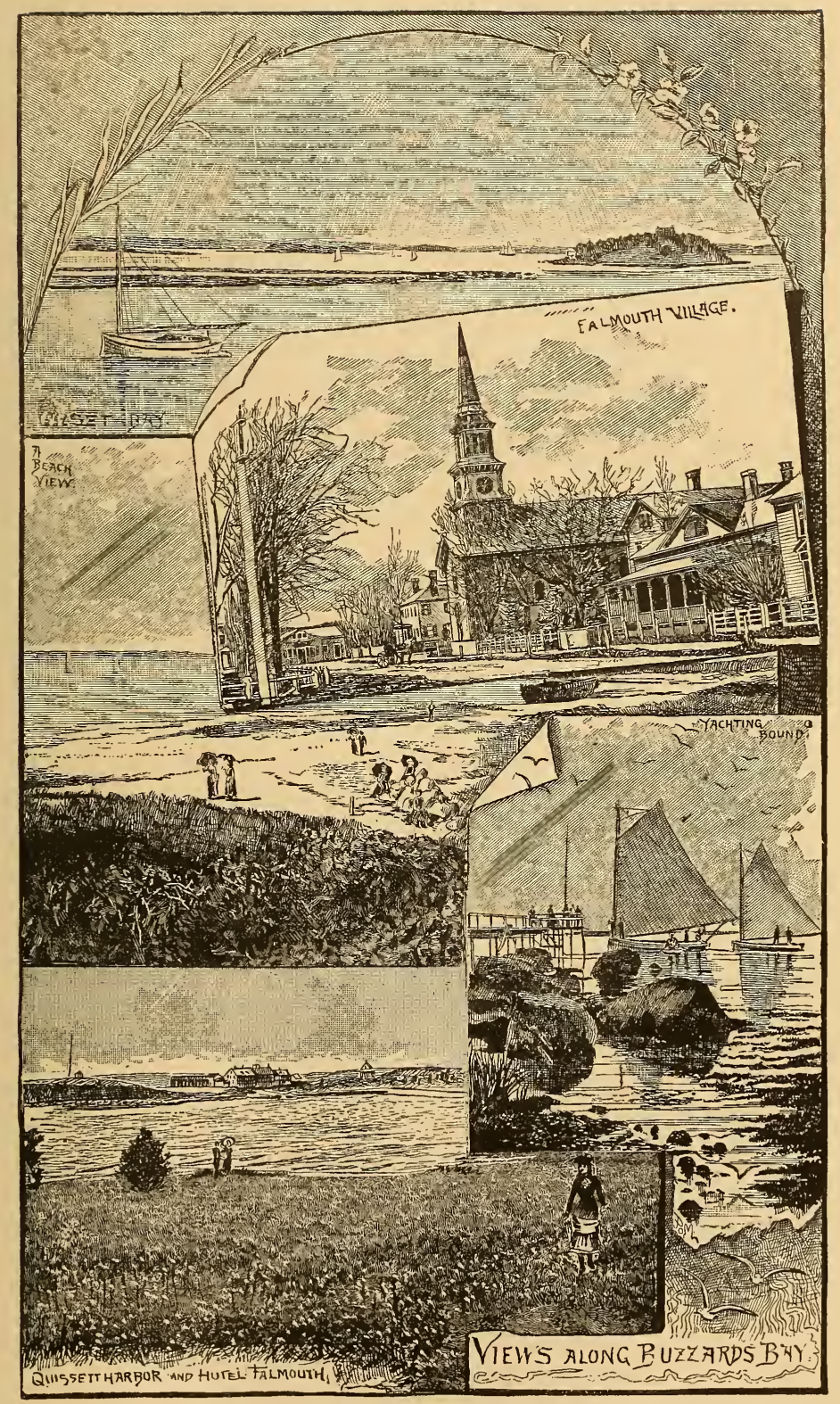



Colony \& Newport Railroad, between Somerset station and Miller's station.

The Easton Branch Railroad was in 1866 bought by the Dighton \& Somerset Railroad Company for a part of its location and for its use, and the Dighton \& Somerset Railroad having been united with and being a part of the Old Colony \& Newport line, the earnings of the Easton Branch for the past year belonged to and were paid to the Old Colony \& Newport, and formed part of the earnings of that company and as such were taxed by the commonwealth, which reduced the stock of the Easton to a nominal value.

The first report of the Old Colony \& Newport Railroad Company for the year ending November 30, I863, was as follows : Capital stock, $\$ 4,000,000$; increase of funded debt, $\$ 65,500$; increase of floating debt, $\$ 205,856.82$; average rate of interest, five per cent.; maximum amount of debts during the year, $\$ 755,914.82$. There were 33 way stations for accommodation trains and I I flag stations. There were I,I94,I6I passengers carried; freight, 23I,360 tons; $\$ 53,942.57$ was laid out for repairs of the road, etc. Wages received another advance, as the average pay of switchmen was $\$ 32$ per month; gate-keepers, $\$ 36$; signal men $\$ 27$; and watchmen $\$ 36$. Interest paid on bonded debts and bills payable, $\$ 28$,I96.65 ; government tax, \$I $2,542.2 \mathrm{I}$; charged off to depreciation, $\$ 40,000$. The income was : from passengers, $\$ 460,9 \mathrm{I} 3.78$, of this $\$ 76$, I 78.4 I was from the other roads; freight, $\$ 204$, I 43.98 from main line, and $\$ 30.560 .33$ from the connecting lines. Mails, $\$ 1$ Io,750 ; rents, \$I 5,20I.46 ; running Dorchester \& Milton trains, \$498.40 ; net earnings, after deducting expenses, $\$ 328,342.70$. A six per cent. dividend was paid, amounting to $\$ 159,482.46$, leaving a surplus, not divided, of $\$ 168,860.24$, which, added to the surplus of previous years made $\$ 993,65$ I.26. Depreciation was estimated at $\$ 40,000$. The changes in the directory of this road were Messrs. Richard Borden, Francis B. Hayes, Uriel Crocker, Minot Tirrell, vice Messrs. J. R. Brewer, Finch and Crowninshield.

In 1863 the Dorchester \& Milton Branch Railway reported that the Old Colony \& Fall River Railroad operated the road under a contract until Jan. 24, I 863, and then ceased the running of the trains. They were not resumed until about October, I 863, when the Old Col- 
ony \& FallRiver Railroad had acquired possession under its mortgage and obtained a transfer of a considerable portion of the stock and bonds, so that no more definite statement could be rendered by that board.

The second report of the Old Colony \& Newport Railroad Company for the year ending November 30, I 864, was as follows : Number of shares of stock issued (in shares and scrip) $\$ 36$,o96; increase of capital, $\$ 594,500$; paid in since last report, $\$ 549,500$; increase of funded debt, $\$ 36,000$; increase of floating debt, \$III,435.I8; average amount of interest, $5 \mathrm{I}-2$ per cent.; maximum amount of debt during the year, $\$ 903,350$; amount expended on the Newport Extension, \$895,430.93, total cost of road and equipment, $\$ 4,258,379.53$. Nineteen miles of new road were built during the year, and one mile of single track on its branches. This gave it four way stations for express trains and thirty-eight for accommodation, also twelve flag stations. Passengers carried, I,54I,849; tons of merchandise carried, 260,653. In the item of expenditures for working the road the principal cost is for repairs, etc., $\$ 77,261.77$. Wooden bridges cost \$9,4I3.16. Again the wages of employees were advanced. This year the average pay of switchmen was $\$ 35$ per month; gate keepers, $\$ 38$; signal men, $\$ 30$; and watchmen, $\$ 40$. The total number of men on the pay rolls was 450 . Three cars were built at the shops of the company and fifty were bought and charged to the contingent fund, the rolling stock, consisting of 26 engines, 5 I passenger, 15 baggage, 488 freight, and 70 gravel cars. The government tax was $\$ 18,963.98$, and the state tax, $\$ 34,393.03$. The income for the twelve months was : from passengers, $\$ 622,025.36$, of which $\$ 101$,I 34.89 was received from their connecting lines; freight, $\$ 276$,I 58.79 ; other roads, $\$ 39,160.53$; mails, $\$ 10,752$; rents, $\$ 15,935.20$; net earnings, after deducting expenses, $\$ 37$ I,391.49. A dividend of eight per cent., amounting to $\$ 300,675.92$, was paid, leaving a surplus of $\$ 70,7$ I 5.57, added to which was $\$ 92,334.35$ left over from last year. The name of Mr. Benjamin Finch was added to the list of directors this year.

April 3, I 865, the Providence, Warren \& Bristol and the Fall River, Warren \& Providence Railways made a contract in which the former was to run a train between Fall River and Warren to con 
nect at Warren with each of the three trains run by the latter, for $\$ 3$ I.30, also the gross receipts from all business over the road of the latter to or from Providence or from any point between Providence and Warren were to be equally divided.

The Old Colony \& Newport Road about I 865 built a new line from Fall River eastward to a junction with the old Fall River Road, via Somerset, Taunton and Randolph and in making this addition absorbed the Easton Branch Road, running from North Easton to Stoughton and there connecting with the Boston \& Providence. The South Shore Road from Braintree to Cohasset was added to the Old Colony system by purchase in 1863 . In 1865 the former line was extended from Cohasset to Duxbury under the name of the Duxbury \& Cohasset Railroad. This road was also merged into the Old Colony and extended from Duxbury to Kingston, making direct connection with Plymouth. Thus the Old Colony became possessed of two distinct roads between Braintree and Plymouth.

The report of the Old Colony \& Newport for the year ending November 30, I 865, showed an increase of funded debt of $\$ 310,500$; increase of floating debt, \$I29,700. The average rate of interest was about six per cent. Maximum amount of debts during the year, \$I,343,550. Passengers carried, I,832,590 ; tons of merchandise carried, 302,642 ; repairs of road, $\$ 76,746.77$. Wages of employes were again advanced this year, the average pay for switchmen being $\$ 40.60$, gate-keepers, $\$ 38.56$; signal men, $\$ 29,73$; watchmen, $\$ 50.90$; while the number of hands employed was 525 . The company had this year 27 engines, 52 passenger, I 5 baggage, 454 freight and 6I gravel cars. The government tax this year was $\$ 42,901.42$, and the state $\operatorname{tax} \$ 4 \mathrm{I}, \mathrm{I} 77.76$. The income from passengers carried on the main line and branches owned by the road was $\$ 699,087.95$, while the connecting lines contributed $\$$ I I 3,240 . IO ; of freight $\$ 324,901.98$ was received on the main line and $\$ 37,877.58$ from other roads. Mails, $\$ 10,750$; rents, $\$ 23,200.40$; total income, $\$$ I,209,058.0 I ; net earnings, after deducting expenses, \$4 I I,387.20. A dividend of 8 per cent. was paid, amounting to $\$ 303966.32$, leaving an undivided surplus of $\$ 107,420.88$. Mr. Oliver Ames succeeded Mr. Borden on theBoard of Directors this year.

The report of I866 is interesting as showing the growth of the Old Colony system, which indeed was rapid, and called for an 
increase of $\$ I, 000,000$ in its capital; the number of shares of stock issued this year was 48,489 . It will also be seen that there were great improvements going on all along the lines of its roads, the sum of \$I I 8,576.0 I having been expended for stations and other buildings, while the land acquired cost $\$$ I 86,948 .o9. The total cost of the road to this date was $\$ 4,578,730.68$. The amount of assets or property held by the corporation at this time, was, in addition to the cost of the road, $\$ 4,507,514.47$. The amount paid on the Dighton \& Somerset Road this year was \$I,509,301.37, making a grand total of $\$ 7,001,074.3 \mathrm{I}$. For the period covered by this report the government tax was $\$ 32,528.24$, which is also strikingly suggestive of the increased traffic. Mr. Onslow Stearns was added to the directors of the road this year.

The name of the Agricultural Branch was changed in 1867 to the Boston, Clinton \& Fitchburg Railroad Corporation. March I 8, I 867, the Foxborough Branch Railroad Company was authorized to take the name of the Mansfield \& Framingham Railroad Company, and to change its location in Walpole and enter the same through the towns of Walpole, Medfield and Sherborn, to some point on the Agricultural Branch Road in Framingham. This company increased its capital stock to $\$ 400,000$.

March I3, I 867, Amherst A. Frazar, Samuel Hall, Joseph O. Cole, Bailey Loring, Nathaniel H. Whiting and Stephen N. Gifford formed a corporation under the name of the Duxbury \& Cohasset Railroad Company, to build a railroad from Cohasset, running thruugh the towns of Cohasset, Scituate, Marshfield and Duxbury. The capital stock was $\$ 350,000$, divided into shares of $\$$ I 00 each. 
CHAPTER IX.

$\mathrm{W}$

HILE we are aware of the fact that railway statistics are not of the most interesting character, especially to those not directly concerned in such matters, we cannot forego giving a detailed report of the Old Colony \& Newport Railroad for the year 1867 , as the figures will be found more suggestive of its progress than columns of words could possibly convey: The amount paid on the funded debt since the previous report was $\$ 27,000$; increase of this debt, $\$ 1,000,000$; floating debt, $\$ 230,000$; maximum amount of debt, $\$ 2,999,000$. Grading and masonry cost $\$ 673,867.69$; wooden bridges, $\$ 193,474.7 \mathrm{I}$; superstructure, $\$ 432,024.04$; stations, etc., $\$ 408,492.14$; land, land damages and fences, $\$ 286$, I 36.49 ; locomotives, $\$ 82,000$; passenger cars, $\$ 40,600$; merchandise cars, $\$$ I 39 ,702.50 ; total cost of road, equipment, etc., $\$ 6,782,845.12$; amount of assets; other than the road, held by the corporation was $\$ 6,7$ I I,628.91 ; $\$ 906,677.58$ was charged to the account of construction. The number of passengers carried was 2,035,709; number of tons of merchandise carried, 369,685 . In the items of rolling stock $\$ 55$,820.98 was spent on repairs of locomotives; $\$ 37,576.30$ on passenger cars; $\$ 15,336.95$ for merchandise cars and $\$ 7,375$ for new ones, together with $\$ 4,004.20$ for gravel cars. This gave the following number of cars, etc. : Engines, 34 ; passenger cars, 59 ; baggage cars, I 8 ; freight cars, 349 ; gravel cars, 80 . Coal cost, $\$ 109,207.40$, and wood, \$II, 108.59. The income from passengers amounted to $\$ 769,9$ II.I 7 ; for freight, $\$ 429,784,05$; mails, $\$ 25,362.24$; rents, $\$ 66,336.26$; miscellaneous, etc., $\$ 3,647.97$; net earnings, $\$ 310,-$ 141.66. Messrs. John S. Brayton and Samuel L. Crocker were added to the Board of Directors.

The sale of the Cape Cod Central to the Cape Cod Railroad Company was made April 21, I868, and the Cape Cod line was extended over the Central from Yarmouth to Orleans, their capital stock being increased $\$ 500,000$. 
April I3, I 868, the Vermont \& Massachusetts Railroad Company, the Cheshire Railroad Company, the Boston, Clinton \& Fitchburg Railroad Company, the Taunton Branch Railroad Corporation, the Boston \& Providence Railroad Corporrtion, the Old Colony \& Newport Railway Company were authorized to take stock in the Mansfield \& Framingham Railroad Company to an amount not exceeding $\$ 25,000$.

The annual reports for the years I 868-i 869 were equally gratifying to the management and stockholders of the Old Colony, and as the latter year was the one in which the Board of Railroad Commissioners was created by the legislature, reference to the duties and powers of the board as it then existed is briefly made.

By section eleven of chapter four hundred and eight of the Acts of $\mathrm{I} 869$, it is provided that the Board of Railroad Commissioners "shall, in the month of January in each year, make a report to the legislature, of their doings for the preceding year, containing such facts, statements and explanations as will disclose the actual working of the system of railroad transportation in its bearing upon the business and prosperity of the commonwealth, and such suggestions as the general railroad policy of the commonwealth, or as to any part thereof, or as to the condition, affairs or conduct of any of the railroad corporations of the commonwealth, as may seem to them appropriate."

In fulfillment of the duty imposed upon them by this section of the act creating the board, the commissioners entered upon the discharge of their duties on the first day of July, I869. The duties of the board were very explicitly defined, its powers limited, and the forms of procedure prescribed in the original act above referred to. Though similar boards have long existed in other states of the Union, nothing of the sort had ever been firmly established in Massachusetts, and both the people and the corporations of the commonwealth were naturally unacquainted with its functions, and even with its existence. The first duty of the commissioners was to examine the railroads of the state, with a view to keeping themselves informed as to their condition, the manner in which they are operated with reference to the security and accommodation of the public, and the compliance of the several railroad corporations with the provisions of their charters and the laws of the commonwealth. In obedi- 
ence to those requirements, the commissioners, either privately, or officially, visited and inspected, with a few exceptions, all the railroads within the commonwealth. As a result they recommended that "the 3oth of September, a recognized quarter day, be fixed as the time for closing the annual accounts of the railroads; that they shall transmit their reports on or before the first day of November following to the Board of Railroad Commissioners; that the board shall make such abstracts and deductions from them as they deem useful, and shall transmit to the Secretary of State such reports and abstracts, together with their own annual report, in season to. be printed and distributed as one of the public documents." In this connection the commissioners further stated, that they had under consideration the form of returns now required, and were comparing it with those of other states, and hoped to suggest some improvements therein.

We find the system is marked by great confusion and governed by no principle. In direct contravention of experience and of public interest it will be found that the through fares and the fares for long distances are the lowest, while local fares are subject to no rule, and, in many cases, are excessive. It is, however, a well established principle that speed is of the essence of all railroad contracts. The travel over great distances, or between termini, is generally carried on by trains which move at very considerable rates of speed and with few stoppages. These are the expensive trains to run, destroying both rolling-stock and road-beds; yet, under the system now prevailing, and the excessive attention which has of late been paid to charges on through travel, these are the cheap train upon our railroads. Turning to the local travel, a wholly different condition of affairs is found to exist. The local trains, be it remembered, are, or should be, the cheap trains of the system; they move at a low rate of speed and with frequent stop pages; they are intended to take passengers up at one station and leave them at another. Upon them, in a densely populated manufacturing region, filled with mills and work-shops, the community depends for that rapid and easy intercourse which is the life of their industry. These are called accommodation trains ; they employ the poorer portion of each company's equipment ; they run at little cost and with little injury to road bed and rolling stock. The tariffs of 
the different roads reveal a most extraordinary condition of affairs in relation to charges on such trains. Fares between termini and great towns, where complaints make themselves loudly heard, are, of course, the same on the accommodations as on the express trains.

Local travel is the manufacturing movement of our community; it is peculiar to it. Railroads through agricultural regions must depend on through travel, for no other exists; those from mining regions look to a mineral movement, and travel is of secondary importance; but with us a ready and economical internal communication is the first essential of development. Unfortunately the cheap and easy intercourse for very shortest distances between all connected neighborhoods is a class of business which the roads do not naturally encourage. It crowds the cars, necessitates frequent stops, the single fares received are small and too often unaccounted for by dishonest conductors, while much labor is devolved on the employees of the roads. The subject, however, is none the less important to the crowded settlements of a manufacturing community, and, from the artisan going from his home to his work, down to the child on its way to school, this question deeply interests every resident on a line of railway.

In 1869 the track of the Boston \& Providence was found in excellent condition; about I 5 miles of steel rails were laid during the year. India-rubber seated chairs were in use on this road to a considerable extent. Cast-steel frogs at the crossing of the Albany road did not wear well, and were soon replaced by the Mansfield frogs, which gave good satisfaction wherever they were used. Improvements in the freight stations at Boston were in progress. A new station was built at Foxborough. At India Point, in Providence, this road had a terminus at deep water with ample room and every accommodation, and therefore had not the same necessity for reaching deep water at Boston that other roads possessed.

The Old Colony \& Neponset Company completed its new passenger station at Boston, which was very spacious and convenient. It also erected large and commodious machine shops at South Boston, where they built both engines and cars. At Quincy a new station was put up, which the commissioners commended as the best that they had seen for the accommodation of the short travel. On 


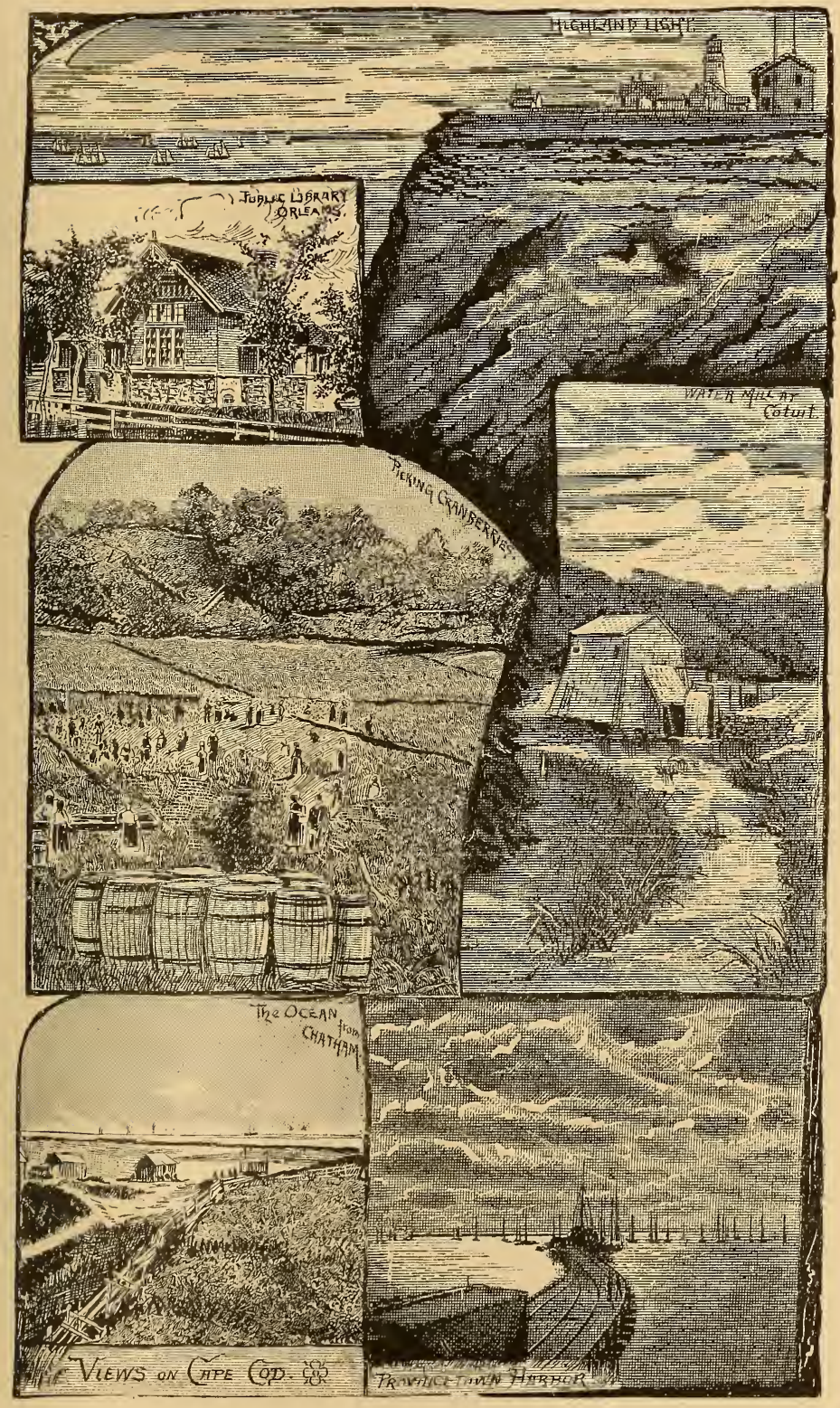



several roads it was the practice for the last few years to put up a shelter shed opposite the station, to shield the waiting passengers somewhat from wind and storm ; but at Quincy there are comfortable waiting rooms on each side of the track, and passengers need not expose themselves to danger in crossing just as a train is coming, nor stand out of doors in bleak weather. At Somerset, on the new line, convenient arrangements were made for doing a large coal business. Most of the country through which this road passes affords excellent ballast; the old road was found to be in very fair order, and the new line in excellent condition.

The Framingham \& Lowell Railroad Company commenced running trains on their road November, I870, but it was not fully completed until October Ist. It was operated by the Boston, Clinton \& Fitchburg. The only important item in the way of construction within this state during 1870 was the completion of the Mansfield \& Framingham Road, which was opened in June, forming the last link in the chain of roads connecting New Bedford with Fitchburg and the northern railroad system. It was operated by the Boston, Clinton \& Fitchburg Road.

On March 23, I 870, Erastus P. Carpenter, Josiah Gates and Hiram A. Blood formed a corporation known as the Framingham \& Lowell Railroad Company, to build and operate a road from the Boston, Clinton \& Fitchburg Railroad in Framingham, through the towns of Framingham, Sudbury, Concord, Acton, Carlisle, Westford and Chelmsford to the city of Lowell.

June I8, the Old Colony and Newport Railroad was authorized to purchase, according to the acts of the year I846 and I848, the railroad and franchise of the Granite Railway Company and were allowed to widen the Granite Railway in order to construct a suitable road from Belknap Square, Quincy to a point of connection with the Mount Hope Branch of their railway, and for that reason were permitted to take land, etc., necessary for its completion.

In a letter to the Board of Railroad Commissioners dated Nov. 5,1872 , the president of the Old Colony thus refers to the coal transportion question which was at that time receiving considerable attention from consumers, and was a source of much complaint : 
I am in receipt of your favor of Oct. I6th, relative to the complaint of parties of a want of transportation for coal on this road. Ia reply I would say that these parties do not reside on the line of this road, but on that of the Hanover Branch Railroad, and have their business connections with that company, which provides cars for its own business to be hauled over our road fur a moderate compensation, fixed by referees. For any deficiency in cars for this business, that company, and not the O. C. R. Co., should be responsible. 'This statement seems to be a full answer to the complaint, so far as this company is concerned.

In this connection it may be proper for me to say something in answer to the somewhat general complaint of a lack of facilities for coal transportation on this and other lines of railroad in the commonwealth; on this line, and as far as my experience extends on other lines. I do not consider this complaint well founded. There is on this line no lack of facilities for transporting coal in a reasonably regular and proper manner, and at cheap rates. The difficulty, when it exists, arises from the utterly irregular and unreasonable manner in which coal is brought to the railroads.

The coal equipment of a railroad can be used for few other purposses than the transportation of coal, and when not used for this purpose must lie idle at considerable expense for loss of interest and depreciation. Every addition to this equipment, beyond a reasonable amount, must add to the cost of tranportation. To illustrate this I refer to the experience of this road for the past two years. In 1871 we carried 46,960 tons, chiefly during the eight months between April ist and December Ist, which may be regarded as the season for shipping coal. In 1872 , anticipating an increase in the business from the reduction in our rates, the freight equipment of this company was increased one-fourth by the addition of I 46 new freight cars, of which a fair proportion were coal-cars, with this increase we could easily and conveniently transport 600 tons of coal per day, or 15,000 tons per month of 26 working days, or 124,800 tons for the season of eight months, which being considerably more than double the amount carried in $187 \mathrm{I}$, was thought to be sufficient, whatever irregularity there might be in the shipments.

We received and transported in the year 83,284 tons, and for this amount, although far in excess of our anticipations, our equipment would have been ample had the shipments been reasonably regular during the coal season. This was not the caise. We received in June fourteen cargoes of less than 4,600 tons; in August fifty-four cargoes with rearly 16,000 tons, and these were not distributed equally through the month, but the vessels came in fleets. On July Ist eight vessels arrived at Somerset, hringing 2,669 tons. The result was that half the time our cars, men and engines stood idle, and wharves empty. At other times we had more work than could possibly be done.

The evil does not end here, it crowds and confuses the running arrangement of the road, causes delay and inconvenience in transportation, irregular employment of labor, delay in return of cars, and other evils which will readily suggest themselves to you. The consignees of coal found equal difficulties 
in disposing of it, and at the very time when we most needed our cars, the greatest difficulty was experienced in procuring their speedy return.

For the irregularity in the shipments of coal, there are several reasons wholly beyond our control. The coal dealers, as wcll as the manufacturers, seek to purchase at the lowest rates, and to take advantage of the lowest freights. The result is that the shipments are extremely irregular. Then, as sailing vessels chiefly are employed in the trade, the arrivals depend upon the wind and weather. Our wharves may be empty in the morning, our men and machinery idle, and a change of wind during the day bring a fleet that tax the full powers of the road to discharge for many days.

There are two ways to remedy the difficulties complained of. The railroad companies may provide sufficient wharves, machinery, labor and equipment to provide for the irregular shipments as they are now made. This will be expensive and must be attended by an advance in rates for transportation of this prime article of necessity in manufactures and in domestic life. Some means may be adopted to make the shipments more regular. This, it seems to me, is by far the easiest and most for the public interest.

If coal purchasers can learn from experience to make their shipments regular during the scason of navigation, but little trouble would be experienced. Possibly this might be effected by introducing a sliding scale of rates of freights upon the railroad, reducing these rates as the shipping freights were raised, and raising them as the latter fell.

But the true and only remedy, in my judgment, is the introduction of steam colliers, making the transportation upon the water as regular as upon the land. If this reform could be effected the railroad companies could well afford to make material reductions in their rates on coal, and the question of a cemurrage on sailing vessels would bc heard of no more.

The charges made for demurrage seem in many cases excessive, and more especially as no allowance is made in case of a discharge within the lay days.

If true statistics could be furnished, it would be an interesting question to determine whether the gain now sought for by dealers in coal to be madc by waiting for cheap freights, is not fully balanced by the amounts paid for demurrage. I am strongly of opinion that it is cheaper for coal dealers to pay the demurrage than to pay the railroad companies a reasonable compensation for the exccssive equipment made necessary by the present irregular shipment. of coal. I may add, in conclusion, that this company, in view of the probable continuance of the present method of shipping coal, will largely incrcase their equipment before the commencement of the next season, and that the large expenditures required for this purpose must preclude the expectation of lower rates for transportation. The public seems to require a mode of transporting coal necessarily wasteful and expensive and so long as this demand continues; we shall endeavor to meet it. 
November 7 th of the same year the Board of Railroad Commissioners addressed a circular to the several railroad corporations of the state, in which it was desired that they give information on the following points :-

First. Have any changes been made in the freight or passenger tariffs of the road under your charge during the past year?

Second. State the nature and extent of such changes, if any were made, and specify in particular what articles of merchandise, or travel from what towns, were affected by them.

Third. What effect, so far as the returns of this year indicate, did any reductions made during the railroad year of I870-7I have on the aggregate receipts of your road for the year I $87 \mathrm{I}-72$ ? As far as you can ascertain, have the aggregate receipts from the towns or business affected by the reductions made in I 870-7I increased or diminished?

We shall be much indebted for any information you may be willing to communicate to us, for our own use in the preparation of the forthcoming report of this board, relating to these or other points of interest in connection with the operation or management of the road under your charge during the year just terminated.

In reply to the above, President Stearns of the Old Colony, Nov. 14, sent the following to the Board of Railroad Commissioners : -

Gentremen: In answer to your circular of Sept. 30th ult., relative to reductions in rates on this road, and the effect upon its traffic, I reply:

First. Reductions were made in our freight and passenger tariffs.

Second. In the passenger tariff local rates were in all cases reduced to three cents per mile, and reductions were made on long distances - as between Fall River ard Boston - of say 6 2-3 per cent. The reductions in the passenger tariff were estimated at $\$ 25,000$ on the business of 1871 .

In the freight tariff reductions were made on first-class freight of about I I I-3 per cent. A new fourth class was established, to which were transferred a majority of the heary articles of merchandise, before included in the third class. The rates for fourth class were reduced about 20 per cent. from third-class rates. A reduction of about I I per cent. was made on coal. That you may understand the extent of this reduction, I enclose a list of articles placed in fourth class. I also enclose a statement of our reductions and the relative business of $\mathrm{I} 87 \mathrm{I}$ and $\mathrm{I} 872$, at ten stations on the road, taken at random, from which you can form your own judgment as to the effect. The rapid growth of Fall River accounts to a considerable extent for the increase there. The estimated amount of our freight reductions was about $\$ 30,000$ on the business of I87I. 
Third. In regard to the effect of the reductions of I870-7 I, I can only say that this is so far blended with the effect of the reductions of this year that $I$ cannot undertake to discriminate. Our gain in passenger receipts for this year is $\$ 121,259.27$; in freight receipts, $\$ 118,355.33$ over 1871 . This increase is pretty uniformly distributed over the road. Our tonnage of freight carried has increased from 395 , I 57 tons in I871, to 510,433 tons in 1872 ; our coal tonnage from 46,960 in 1871 to 83,284 in 1872 . While we show this considerable increase in gross receipts, the net receipts have increased only $\$ 16,549 \cdot 58$. This is in part caused by the increase in work done in our trains, from 990,662 miles in I87I to I, II0,675 miles in 1872 , and in part for the higher cost of inetals which enter so largely into the cost of working the road. Wages for skilled labor have in some cases been increased. Improved brakes and telegraph facilities have added something to our expenses. We have added to our road the past year the Granite Branch. This has added to our freight tonnage about 7,75 I tons of granite. It has probably diverted passenger travel from the main line without much increasing the total amount. That you may have some basis of comparison with the short travel between Boston and S. Braintree, alluded to in my reply to your circular of last year, I would state that the amount of this travel increased from $\$ 146,239.73$ in 1871 to $\$ 155,748.34$ in 1872 . To this may be fairly added the earnings (from the same source) on the Granite Branch $(\$ 8,589.06)$, making the total increase $\$ 18,097.67$. I may say that we endeavor to keep accurate accounts of tile business of our stations, which are open to your examination if they can be of service.

In conclusion, I would add that on the road it has been found advantageous to reduce our rates, whenever business could thereby be stimulated. The immediate result has been to increase gross receipts and, in a much less degree, the net earnings of the road. We indulge the hope that the increase will be permanent and progressive. Our lines of railroad cover a large extent of territory of the commonwealth, and it is in the expectation that this territory can be developed and its business permanently increased, that we have reduced our rates, and added to our train accommodations to some extent in advance of the public demand. If this increase in business continues, we propose to continue our policy of reducing rates and increasing accommodations to that point where our net earnings will be the greatest. If the business decreases, justice to our stockholders must compel an advance in rates. 


\section{CHAPTER $\mathrm{X}$.}

\section{T}

HE Old Colony \& Newport Railroad Company was given authority, Feb. 24, I87 I, to maintain and operate a railroad between the main line and Granite Railroad. The provisions of I 846, I 848, relating to the branch railroads were revived, and the O. C. \& N. R. R. Co. was allowed to build branch railroads, but with the approval of the Board of Railroad Commissioners. This company was allowed to increase its capital stock to $\$ 6,500,000$. Permission was also given, May 25 th, to build a railroad from a point near the Neponset river, Boston, and then running northerly and westerly through the 16th ward of Boston to Park street, and then in an easterly direction on the railroad between Harrison Square and Crescent Avenue stations, and then to cross the Milton Branch Railroad, and the northwesterly part of Cedar Grove Cemetery in Boston, provided that the Old Colony obtained consent of the Shawmut Railroad Company. This corporation increased its capital stock $\$ \mathrm{I} O 0, \mathrm{OOO}$, on account of building this new railroad.

In their report for I87 I the commissioners gave their views as to the policy which might fairly be expected of railroad corporations, in these words: "That policy should be a tentative but a persistent one, - a continual effort to see when and how and where any portion of the burden now pressing on industry could be so removed or so shifted as to enable production to expand, thus replacing in one direction what was conceded to it in another. The commissioners called for no sacrifice of dividends; they did ask for a constant exercise of ingenuity and for a sacrifice of ease." A very excellent illustration of the steady pursuance of such a policy, and the excellent results flowing from it, is furnished in the foregoing statement of the experience of the Old Colony \& Newport Railroad Company. It is full of instruction to all who feel an interest in the study of railroad development. The commissioners fully concurred in the closing paragraphs of this communication. 


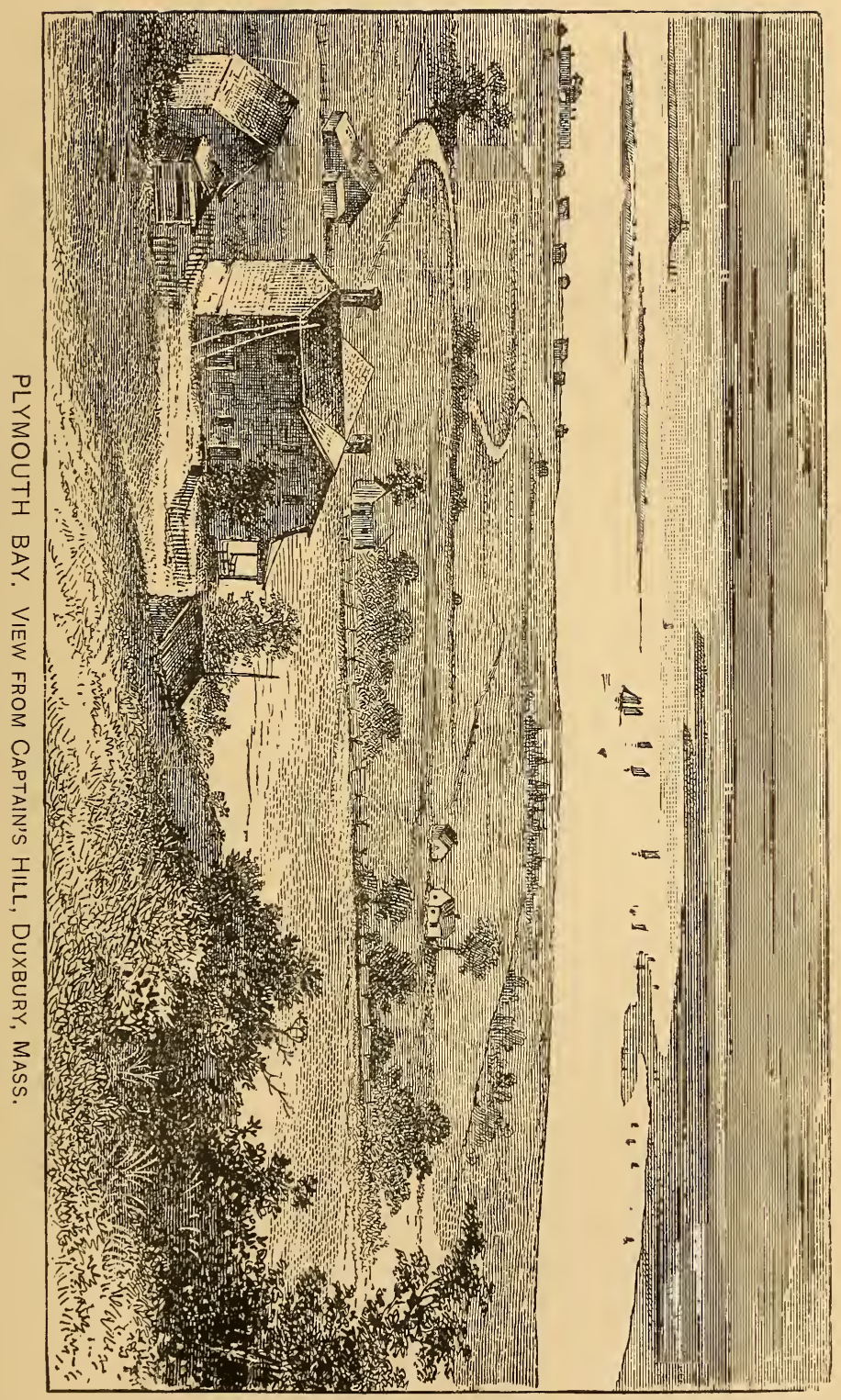



"Considerable reduction has been made during the last year in the local fares and freights, especially in the district within fifteen miles from Boston. This has resulted in an immediate increase in our business; and the development of the towns and villages along the line of the road promises a greater increase in the future." (Report of Old Colony and Newport R. R. Co., I 87I.)

"In I 870, after extension from Orleans to Wellfleet, the tariff for passengers in present use was made, and the rates varied slightly to conform to the following basis,- -three (3) cents per mile for Boston and way stations on the Old Colony \& Newport Railway, and $3 \mathrm{I}-2$ for 60 miles and $4 \mathrm{I}-2$ for 5 miles, and in a proportionate ratio for distances between 5 and 60 miles. On passengers by stages and steamboats to and from us, this company realizes less than three cents per mile, as amount realized by this company is less than regular tariff rates."

Old Colony \& Newport R. R. Co. Boston, Mass., Dec. 23, 1871.

To the Board of Railroad Commissioners:

GentLemen: In answer to your circular of Sept, 30th, I send the enclosed papers, marked $\mathrm{A}$ to $\mathrm{G}$, containing the information sought in questions one to six inclusive of that circular. I also enclose tables giving the rates for transportation on the Old Colony \& Newport and South Shore Raillroads, filled out as you request.

So far as I understand the purpose of your circular, these papers give all the information desired, except as to the effect which the reduction of rates has had upon the business, gross receipts and earnings of the roads.

1 have given much time and labor to an examination of these papers, but the character of the investigation asked is such, and the analysis so intricate, that I am unable to state results satisfactory to myself.

The following facts are shown from the papers: In I 859 a passenger tariff was adopted, which was increased in 1864 , and remained unaltered until $\mathrm{r} 867$, when an average reduction was made of about $73-10$ per cent. Since that time further reductions have been made, reducing the passenger tariff of I87 8 4-Io per cent. below that of 1867 , and I 5 7-8 per cent. below that of 1864 .

A new passenger tariff has been adopted, to take effect January I, I 872 , reducing the maximum rate on local business to three cents per mile, and the average rate to $26-10$ cents per mile.

The average rate from connecting roads is now I 62-100 cents per mile, including season tickets.

The reduction from the passenger tariff of 1866 (estimating for an equal amount of business) would amount to $\$ 8 \mathrm{r}, 425.4 \mathrm{I}$ on the business of $\mathrm{I} 866$; 
while the increase of receipts in $187 \mathrm{I}$ over I 866 on local business is $\$ 182$,668.97. The amount of these two sums, $\$ 264,094 \cdot 38$, gives the apparent effect of the reduction of rates from $\mathrm{r} 866$ to $\mathrm{I} 87 \mathrm{r}$.

The reductions from 1869 to $187 \mathrm{r}$, estimated in the same manner, are equal to $\$ 54,784.70$ on the business of 1869 ; while the increase of receipts of $187 \mathrm{I}$ over 1869 is $\$ 50,206.8 \mathrm{I}$. The amount of these two sums, $\$ 104,991.51$, gives the apparent affect of the reduction of rates from 1869 to $187 \mathrm{I}$.

I presume the greatest effect of reduction in rates would be shown in the short travel near Boston, and here our largest reductions have been made.

Between Boston and South Braintree, from I 866 to $\mathrm{I} 87 \mathrm{I}$, large reductions were made, estimated at about 33 per cent. upon the average, from the tariff of I 886.

The larger part of this reduction was made on Jan. I, I871, and sufficient time has not elapsed to see its full effect. The receipts from business between Boston and South Braintree and intermediate stations were, in 1866, $\$ 102$,598.60 ; in $1869, \$ 150,241.73$; in $1870, \$ 156,555.32$; and in $1871, \$ 63,826.92$. The gain in receipts in 1871 over 1870 was $\$ 7,274.60$, or about 4 per cent. The average reduction in rates in $187 \mathrm{I}$ from 1870 is estimated at 24 per cent.

These results are obtained from the same length of road operated in the different years. But it may be observed that in 1868 the horse railroad to Quincy was discontinued, and in the same year, to meet the public demand, trains were run on Sunday between Boston and South Braintree,--three trains in each direction,_-which have been continued to the present time.

Between Boston and Wollaston Heights the number of passengers has increased from 12,793 in 1869 to 48,270 in 1871 , and the receipts from $\$ 2$,099.50 to $\$ 6,399.91$; while the rates have been reduced about 33 per cent. on single tickets, 25 per cent. on package, and 6 per cent. on the season tickets.

The nominal reduction in tariff rates on freight has been about 6 I-4 per cent. since the tariff adopted in 1866 and revised in I868. By an actual reduction considerably greater has been made by the transfer of many of the leading articles of consumption, and those used in creating motive power, and in building and manufactures, comprising flour, grain, potatoes, apples, coal, wood, lumber, stone, brick lime, cement, sand, slate, pig and scrap iron, ore, cotton, hemp, wool, tar, rosin, spelter, etc., etc., from the first and second classes of the tariff to the third class; and when in large quantities, to special rates less than third class. It would be very difficult to give accurately the amount of reductions thus made upon each of these articles, which constitute nearly one-third the tonnage of the road.

A reduction of, $6 \mathrm{I}-4$ per cent. from the freight tariff of $\mathrm{r} 866$ is equal to $\$ 13,489$.6I on the local business of that year, which was $\$ 215,824.18$, while in I 87 I, the local receipts from freight were $\$ 362,532.04$, an increase of $\$ 146$, 707.86. The amount of these two sums, $\$ 160,196.87$, or about 74 I -4 per cent. gives the apparent affect of the reduction in rates. In 1868 the local tonnage to 
and from Boston was II 7,879 I 4 tons, from which the receipts were $\$ 205$,755.I5. In I $87 \mathrm{I}$ the tonnage was I 58 , I 56 I-2 tons, from which the receipts were $\$ 263,005.40$, showing an increase of about 34 per cent in tonnage, and about 28 per cent. in receipts. The results are somewhat affected by the fact that in I87 I more freight was hauled for short distances than in I869-particular attention having been given to carrying freight between Boston and the neighboring towns.

The gross receipts of the road for the year ending May 3I, I865, were \$I, 06I, 52I.I3, while for the year ending Sept. 30, I87I, they were \$I,687I,$478.5 \mathrm{I}$, an increase of $\$ 609,957 \cdot 38$, or about 57 I-2 per cent.

But while these results have followed the reduction of rates which have been mentioned, it is questionable how far they have been produced by then. Many other causes have co-operated to increase the business and receipts of the road during the same time. The general increase of business caused by the development and growth of the country through which the road runs, and a similar increase and development of business upon the lines of connecting roads, hare done much to produce these results. The policy and efforts of the corporation have been directed to the same end. By the construction of branch roads, about thirty-eight miles of new roads have been added to the line since I 865 . In the construction and equipment of these branches, the rebuilding and enlargement of depots on the main line, and increase of rolling stock and terminal facilities, over three millions of dollars have been expended since I865. The number of passenger trains to and from Boston has increased from forty-four running 349,679 miles in I 865 , to seventy-eight, running 664, I 79 miles in $187 \mathrm{I}$. And many of these are run at much higher rates of speed than formerly. The improvement of the road and its equipment and facilities for doing business, by the expenditure of this large sum derived from increase of capital and not from earnings, together with the reasons stated, and others which might be named, have probably contributed as much as the reduction of fares to increase the business of the road and to swell the amount of its gross receipts. The increase in business, has, thus far, scarcely kept pace with the increase in expenditures for its accommodation. So that the stockholders of the corporation have, as yet, received no adequate compensation for their investment .

In your circular of August 10, enclosed in that of September 30, certain statements and suggestions are made for which you request special consideration and an expression of opinion thereon. In reply to the suggestion that fares and freight should be reduced on account of the reduced cost of operating the roads, I would say that from my experience on the roads with which I am connected, this cost is, as a whole, not less than at any previous time.

It is obvious from the foregoing remarks that the statements in this circular " that the rates were largely increased during the war, and have not since been reduced," does not apply to the Old Colony \& Newport Railway and its branches. The rates were not largely increased then, and they are now, on an average, lower than ever before. Nor does the statement that the " roads have been relieved from the payment of large taxes," apply to this road. This cor- 
poration paid in taxes in $1865, \$ 65,766.82$, and has during the last year paid $\$ 76,400.73$, which is I $8 \mathrm{I}-2$ per cent. of its net income, and has been exceeded only in the years $1867, \mathrm{r} 868$, and 1870 , and then by an inconsiderable amount.

Neither can the suggestion that the reduction of rates should be large, so as to stimulate industry and business, apply with any force to this road; as the great centres of industry upon its line are also accommodaetd by water transportation, giving cheaper transportation for those heavy articles of prime necessity than a railroad can furnish.

The statement that "the roads have added and are now adding immensely to the value of their properties out of their net earnings," cannot apply to this road. While it has been the policy of the managers to fully keep up its property out of its earnings, all additions and improvements have been made from additional capital. And its net earnings have not increased in proportion to the increase of its capital. This increased investment of capital has been made by the managers of this corporation in the belief that increased facilities would build up, attract and create business. During the past five years they have exercised every ingenuity to increase the business of the road, primarily for their own benefit but believing also that this increase of business was co-incident with the development of the industrial interests of the towns and cities upon its line. While the returns to the stockholders have been small, the increase in the value of property in the cities and towns has been large; and it has contributed its full share to the advance in the value of real estate in Boston, which has enabled its owners without effort of their own to more than quadruple their rentals.

If, as is stated by you, the rates of transportation have not been reduced since $\mathrm{r} 860$, it is well to bear in mind the fact that there is scarcely a single commodity in the market, produced by the joint effort of labor and capital, which can today be purchased at less than an advance of 50 per cent. on its cost in I860. If then transportation is no higher than in 1860 , it is, in comparison with the value of money and other commodities, one-third less than it was then.

There is one other fact of great moment, which should be carefully weighed in the consideration of this question of reduction of rates :

The public demand upon the railroad corporations during the past ten years for improved accomodations has been constant, and the managers of this corporation have endeavored to meet it. The increase in the number of our trains has been very great. The increased speed demanded for express trains has been attended by greatly increased expense, requiring more perfect and costly engines; more substantial road beds and tracks; more watehful care in the operation of the road, - in a word, an increased expense in all the materials and labor used and employed by the corporation.

In my view, speaking with the experience of a life-time in railroad management, there is great danger to the public interests in endeavoring to unduly force down rates and fares and freights upon railroads. Our railroads are yet far from perfect; great expenditures of capital must yet be made upon 


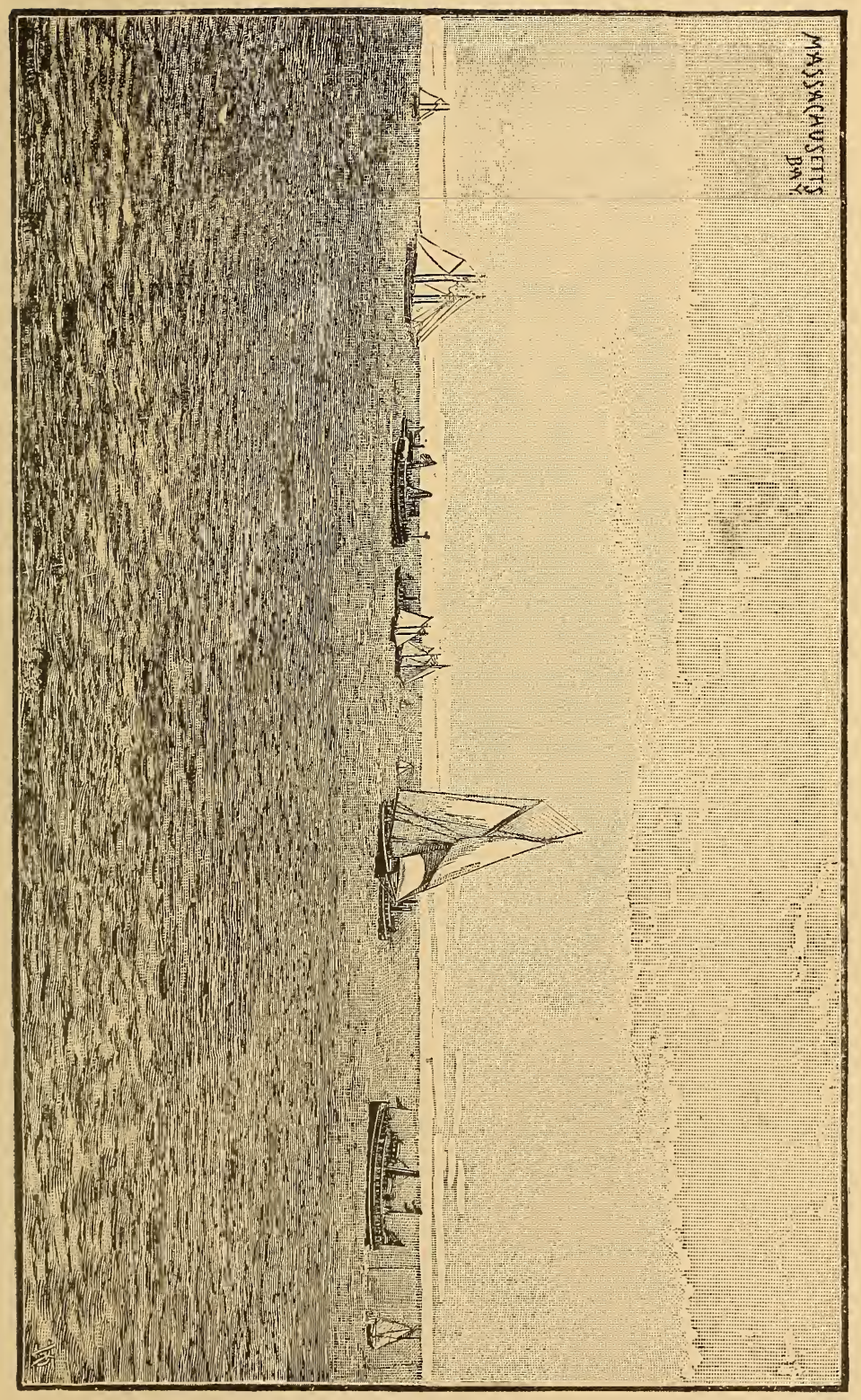



the existing roads, to enable them to render the highest service to the public of which they are capable. Branches must be built, to the expense of which the main lines must contribute. In my judgment, if the feelings of which you speak as existing "in the popular mind and in the legislature," upon the subject of "proper concessions by the railroad corporations," lead to an unreasonable restraint upon the power given to railroad corporations to fix their own fares and freights, the result will be disastrous. The prosperity of railroads is dependent upon and coincident with the growth and prosperity of the community they serve. Hence, self-interest will induce them to make their rates as favorable to the business on their lines as circumstances will allow.

The investment of capital in railroads has been of untold benefit to the people of this commonwealth, while it has hitherto made but moderate returns to its owners.

The roads have been in general economically built and carefully managed. As yet, they have not returned to their builders the ordinary interest of money invested in other pursuits. No one, to my knowledge, has ever paid continuously the ten per cent. contemplated in their charters. If the legislature has the power which is claimed, to arbitrarily reduce rates in spite of the provisions of charters, it may exact cheap transportation, but with it will obtain cheap accommodations.

In my judgment there can be no greater injury to the public interests than such a reduction of rates as will take from railroad corporations fair expectations of paying a reasonable return for the capital which they employ. It must prevent the further investment of capital in the extension of lines which are necessary to make the system co-extensive with the public needs, and it will check that expenditure which is equaliy necessary to improve and perfect the existing lines.

Very respectfully,

ONSLOW STEARNS, President.

March 27, I872, the Old Colony \& Newport Railroad Company and the Cape Cod Railroad Company were authorized to unite under one corporation, in the following manner: If the companies should vote at a meeting to form one corporation then upon the passage of votes the Cape Cod Railroad Company was authorized, according to terms agreed upon, to assign and convey to the Old Colony its franchise and property. This company was also permitted to issue new stock in lieu of the stock of the Cape Cod, but the whole was not to exceed the capital of both corporations. This company changed its name after the union to the Old Colony Railroad Company.

After the uniting of the Cape Cod Road with the Old Colony, the stock of the former was changed for that of the latter, twenty- 
three shares of the Cape Cod for seventeen of the Old Colony. The line was then extended from Wellfleet to Provincetown, a distance of fourteen miles, and the New Bedford line one and one-half mile to the New Bedford wharf. Branches were also added from Buzzard's Bay to Woods Holl, and from Harwich to Chatham. The Stoughton Branch was merged into the Boston \& Providence this year, and the Nantasket Beach line into the Old Colony.

Owing to the rapid filling up of the interior states of the country and the accumulation of wealth, the seaboard of New England enjoys a species of monopoly of the most valuable description. Every year both the desire and the ability of a large class of those living in the inland cities to pass a portion of the summer on the coast become more decided. In consequence of this it needs but a railroad to bring any seaboard town into a place of great resort. This has already been the experience in a striking degree of the towns along the Duxbury \& Cohasset Road.

The Framingham \& Lowell Railroad was incorporated, by Chap. I 3 of the Acts of I870, to run "from some convenient point on the Boston, Clinton \& Fitchburg Railroad, in the town of Framingham, thence by some convenient route through the towns of Framingham, Sudbury, Concord, Acton, Carlisle, Westford and Chelmsford, to some convenient point in the city of Lowell," etc. It had also subsequent legislation by Chap. 24I and Chap. 246 of 1870, and by Chap. 33 of $187 \mathrm{I}$. The road as built commences at Framingham on the line of the Boston, Clinton \& Framingham Railroad, about two miles from the South Framingham station on the Boston \& Albany Railroad. It is an important link in the new chain of railroads between Maine, New Hampshire and northeastern Massachusetts on the north, and Rhode Island, Connecticut and tide-water on the south. It is twenty-six miles long, and cost to Oct. Ist, I87 I, $\$ 797,683.07$, or $\$ 28,803$ per mile between termini.

The Granite Branch was formally opened for traffic on the 9th of October, I87I. It is a branch of the Old Colony \& Newport, leaving that road at Atlantic Station, 5.50 miles from Boston terminus, and, running over the location of the Mt. Hope Branch, originally constructed to bring gravel for filling a portion of the South Cove flats, it strikes the old granite railway a short distance from the original terminus of the latter on Neponset river; it then fol- 
lows the location through Milton to the present terminus in West Quincy.

In 1873 the Old Colony Railroad consisted of the main line from Boston to Newport, via Taunton, 67.79 miles; the Cape Cod Division from Middleboro to Provincetown, 85.77 miles; the South Shore \& Duxbury \& Cohasset Branch, from Braintree to South Duxbury, 29.05 miles; the Dorchester \& Milton Branch from Neponset to Mattapan, 3.30 miles; the Shawmut Branch, from Harrison Square to junction with Milton Branch, 2.35 miles; the Atlantic Branch, from Atlantic to West Quincy, 3.I0 miles; the Abington \& Bridgewater Branch, from South Abington to Bridgewater, 6.99 miles; the line from South Braintree to Plymouth, 25.94 miles; the line from South Braintree to Middleboro, 22.82 miles; the line from Middleboro to Somerset Junction, 14.78 miles; the Middleboro \& Taunton Branch, from Middleboro, 8.04 miles; the Woods Holl Branch, from Cohasset Narrows to Woods Holl, I 7.54 miles; the Hyannis Branch, from Yarmouth to Hyannis, 4.90 miles; the Easton Branch, I.69 miles - making a total length of 294.06 miles.

All of the above is in Massachusetts, except that part from the state line of Rhode Island to Newport, on main line, a distance of I6 I-4 miles.

The road crossed over the Boston, Hartford \& Erie Railroad in Boston by a trussed bridge of timber and iron, and at "Weir Junction" and at "Myricks" it is crossed at grade by the Taunton \& New Bedford Division of the Boston, Clinton \& Fitchburg Railroad, and is intersected by the Fairhaven Branch of the Boston, Clinton \& Fitchburg at Tremont.

The road-bed of this group of roads is generally of a sandy character and well drained, and the bridges are in good condition. The rails are, with the exception of some of the older portions, all laid with side fish-plates, and upon some of the latter, where chairs were formerly used, the rails have been rrilled by hand and fished at joints since coming into the control of the present organization. The description of the road from Wellfleet to Provincetown, I4 I-2 miles, and the Shawmut Branch, from Granite Bridge to Harrison Square, 2 I-2 miles, will be found in the list of new roads.

The Boston, Clinton \& Fitchburg group of roads consists of : Main line from Fitchburg to South Framingham, 37.00 miles; 
Marlboro Branch, from main line to Marlboro Centre, I.47 miles; Worcester \& Fitchburg, from Pratt's Junction to Sterling Junction, 4.4. Total road owned by the Boston, Clinton \& Fitchburg Railroad Company, 42.87 miles.

It operates under lease or contract the following: Framingham \& Lowell Branch, from Framingham to Lowell, 26. I 2 miles; Mansfield \& Framingham Branch, from South Framingham to Mansfield, 2 I.25 miles. Total 47.37 miles.

It also operated by lease or contract: The Taunton Branch, from Taunton to Mansfield, II.I miles; the Attleborough Railroad, from Taunton Junction to Attleborough, 8.6 miles; the New Bedford Railroad, from Taunton to New Bedford, 2 I.46 miles; the Fairhaven Branch, from Fairhaven to Tremont, I 5. I I miles. Total, 56.27 miles. Making a total length of road operated by this company of I46.5 I miles.

The lines north of Mansfield were much improved during the year I 873 by widening embankment, ditching, renewal of iron, and new tracks between South Framingham and Framingham Centre. The passenger station buildings at Fitchburg were wretchedly poor, and the grade crossing at the Fitchburg Railroad, in that city, especially dangerous. The freight buildings at Fitchbnrg were very good. Several bridges upon this part of the line were less than eighteen feet in height above rails, and were without "bridge guards." South of Mansfield, upon the newly acquired lines, the tracks, buildings, etc., were generally in fine condition. The new freight house at Taunton was exceptionally good. The passenger house at New Bedford was as poor as the one at Fitchburg. The extension of tracks to tide-water necessitated the erection of a new station house. This road adopted for its passenger cars the Miller platform and buffer, but thus far hand brakes have been used in controlling the trains. This has been partly owing to the variety of brakes in use by the connecting roads. This road or its branches crosses the Fitchburg Railroad at Fitchburg and at West Concord, the Boston \& Albany at South Framingham, the Boston \& Providence at Mansfield, and the Old Colony at Weir Junction and "Myricks," all at grade, and its connections with other roads were literally too numerous to mention. 
The mileage in 1892 is as follows : Central Division, 273.46; Providence Division, I I I.02; Northern Division, 93.64; Cape Cod Division, I30.38; making a total of 608.50. The steamboat service of the Old Colony system represents $4 \mathrm{I} 8$ miles, divided as follows: New York and Fall River, I 8 I miles ; New York and New Bedford, I85; New Bedford and Woods Holl, I 7 ; Woods Holl and Cottage City, 7 ; Cottage City and Nantucket, 28. 


\section{CHAPTER XI.}

O show the phenomenal progress of the Old Colony system,
brief summaries of the annual reports of its directors are
appended herewith for the past decade; or, rather, from i 873 to and including 1892 . The first mentioned year shows that the total amount of permanent investment was \$IO,97I, I 27.69; total gross income, $\$ 2,377,25 \mathrm{I} .82$; net, $\$ 7 \mathrm{I}, 238.79$. The number of persons employed this year had reached 973. The succeeding year, I 874, the report was varied but little from the previous one, with the exception of the introduction of improved brakes and platforms for its passenger coaches.

In the month of April, I875, an application came to the Board of Railroad Commissioners from some thirty or more inhabitants of the Dorchester district of Boston, asking its good offices to induce the Old Colony Company to put upon its road a workingmen's train similar to that on the Eastern. A few days later, another application of the same character, though much more numerously signed, was received from residents along the line of the Boston \& Maine Railroad. Interviews were at once had with the officers of the two companies, and the matter was set fully before them. It was urged on behalf of the petitioners that these trains were experiments, the object of which was to induce a large class of the community who worked in the shops of the city to move their families into the country. To those disposed to do this, the railroad corporations simply said that they would agree to transport them to and fro from their work at cost, or a very close approach to it, looking for their profit to the natural increase of business which would come from the closer settlement of their territories. The experience of railroads, no less than the statistics of the state, showed clearly enough that every human being along the railroad lines, irrespective of sex or age, was tributary to the railroad corporations. Any increase of population in a given district meant an increase of revenue to the corporation serving it of nearly $\$ 20$ per annum to each person of 
which that increase was made up. Fully appreciating this fact, the various corporations had been for years in the custom of holding out the inducement of special rates to those proposing to settle along their roads,-going so far in some cases as to give one free pass, good for a period of years, to each house built on tracts laid out by certain land companies. A striking example of this policy and the results which might be made to ensue from it was mentioned some years ago in a report of the commissioners, in the case of the Wollaston Heights Land Association on the Old Colony Road. The railroad, in this case, offered one free pass for three years to each house which should be constructed. In less than two years seventy-five houses had been built, and the railroad was carrying that number of persons free of charge to and from Boston. Notwithstanding this, the annual receipts from the Wollaston station went up during these two years from $\$ 2,099$ to $\$ 6,399$ and the number of passengers carried from 12,793 to 48,270 . In other words, those regularly travelling free to and from their work constituted but a small fractional part of those using the road. The workingmen's trains followed out this idea. The corporation simply gave notice that, if people working in the city desired to settle with their families within certain specified limits along its lines, they need not be deterred from so doing by any fear of the expense of getting to and from their workshops. The corporation would see that they had facilities for doing that at cost.

These suggestions were received by the two corporations to which they were addressed in wholly different spirits. The officers of the Old Colony expressed serious doubts whether, under the conditions upon which that road had to be operated, the experiment would prove successful. There was no considerable city like Lynn at the further end of the route proposed for the train; and, as the distance it was to run was less than in the case of the similar train on the Eastern Road, the saving in fares which those using it could effect would necessarily be very small, hardly sufficient to serve as an inducement. At the same time, it was conceded that the arguments in favor of the experiment were plausible, and that the experience of the Eastern Road was entitled to weight. Finally, it was decided to give the experiment a full and fair trial on the terms suggested by the commissioners, with the understanding that if, at the end 
of a reasonable time- "say three years" - the experiment was not a success, the corporation should be at liberty to discontinue it.

A cheap early and late train was accordingly put on the Shawmut Branch of the Old Colony Road, on the 2 Ist of June, and was run daily. The experiment in this case was fully and fairly tried, and in such a way as to make it a success did the conditions necessary to success exist. It was discontinued on June I 5, I876, after two years' trial.

The report for the year 1875 shows a steady gain in receipts and an increase in the road's rolling stock, but nothing else which is of general interest. In 1876 the Fall River, Warren \& Providence branch of the Old Colony was built. It leaves the main line of that road a few rods north of the Bowenville station in Fall River, and extends to a point on the Fall River, Warren \& Providence Railroad, in the town of Somerset, about one-fourth of a mile west of the Ferry station of that road, on the West bank of Taunton river, opposite Fall River, a distance of 2.16 miles. It was built by the Old Colony Railroad Company, and including the bridge across Taunton River, it was an expensive piece of road, having cost about $\$ 400,000$. By its construction an all-rail line was secured between Fall River and Providence, thereby avoiding the ferry at the Fall River end of the route. The grading on both sides of the river was light, involving no heavy excavations or embankments, the main expense being the river bridge. This bridge, including the mechanical structures of the approaches, is about I,300 feet long; and, in its construction, required a high degree of engineering skill on the part of the chief engineer, E. N. Wilson, Esq.

Passing over the report for the year I876, we find that in 1877 there was considerable dissatisfaction existing in regard to the management of the Duxbury \& Cohasset Railroad, and an appeal was made to the General Court for a remedy. That body passed the following resolve in furtherance of the objects sought to be attained :

Resolved, That the petition of Henry W. Nelson, representing the railroad committees of the town of Marshfield, for an investigation and relief under the present management of the Duxbury \& Cohasset Railroad, be referred to the Board of Railroad Commissioners, with instruction to investigate the case and report the result 


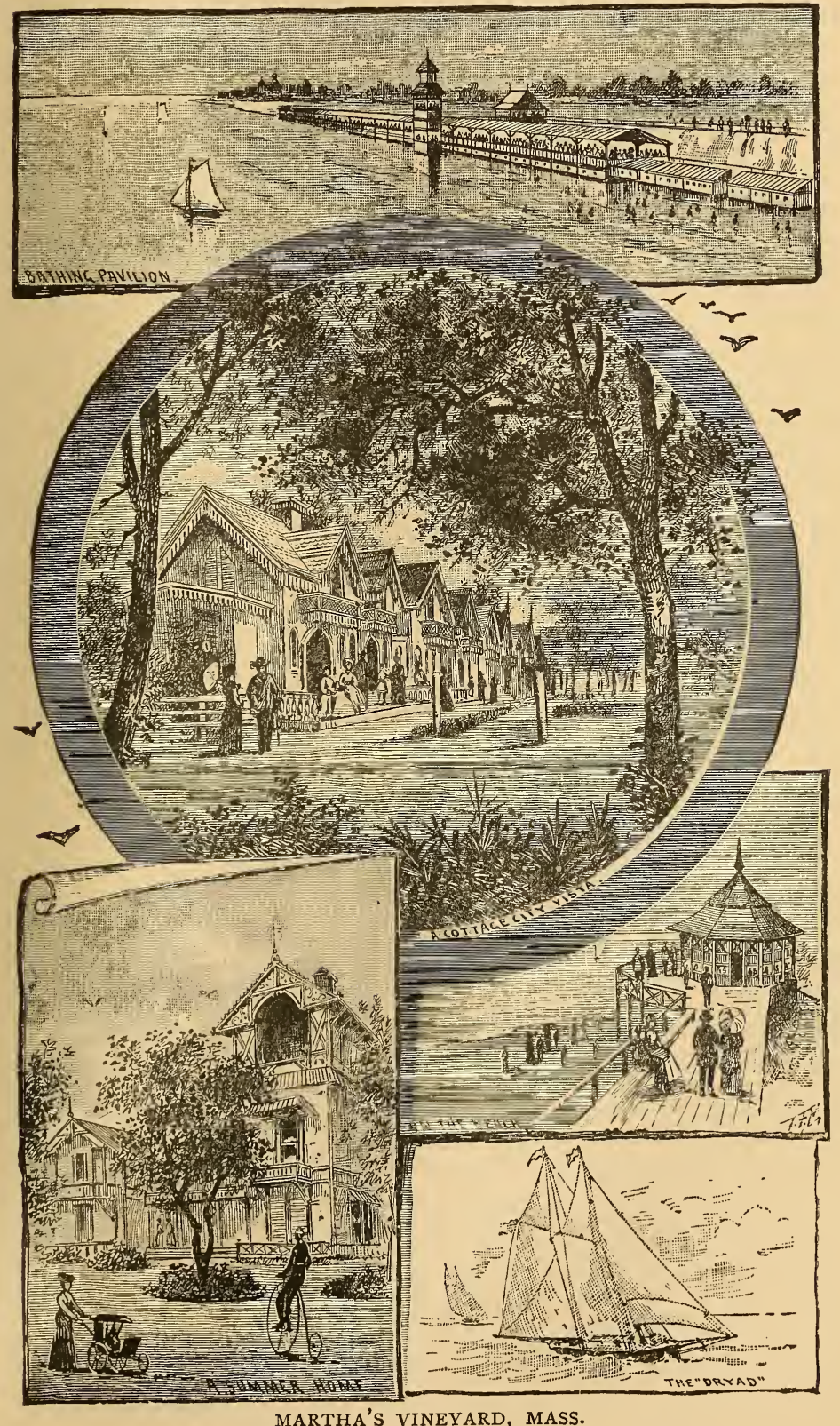



to the parties interested; and also to report to the next General Court, stating what further legislative action, if any, may in their judgment be necessary in the premises.

Under this resolve an investigation into the affairs of the Duxbury \& Cohasset Railroad Company was begun on May Ioth. It included a comprehensive examination of all the books, records and accounts of the company. Many witnesses were called, and the facts elicited were fully discussed by counsel on behalf of the existing management of the road and the railroad committees of the two towns of Marshfield and Duxbury. The public hearing occupied ten days.

The Duxbury \& Cohasset Railroad Company was organized and its roads constructed and operated in a manner wholly peculiar to itself, owing to the fact that its stock was originally subscribed for and the whole of it was for a long time held by the towns through which the road was located, and the Old Colony Railroad Company, with whose road it connected. It was designed to accommodate the three towns of Scituate, Marshfield and Duxbury; which, lying as they do along the sea shore, were wholly outside of the Old Colony Railroad system. Its construction was attended with very great difficulty, not on account of any excessive work involved in it, but through the unpromising character of the line as a business enterprise. The scheme of a railroad along the shore of Massachusetts Bay south of Boston was not new. It had been agitated ever since I 847, when two charters had been obtained; the one for a railroad from Cohasset to Scituate, and the other for a branch from the Old Colony line at Kingston to Duxbury. Again, in I86I, a charter for a street railway from Kingston to Duxbury was granted, and in 1866 a similar charter from Cohasset to Scituate. Nothing was practically done, however, until I 867 , when the charter of the Duxbury \& Cohasset Railroad Company was obtained, under which the three towns of Duxbury, Marshfield and Scituate were authorized, by a two-thirds vote in favor of so doing, to subscribe for $\$ 75$,000 each of the stock of the proposed road. Having secured the charter,the friends of the enterprise caused a preliminary survey and estimates to be made by Mr. H. G. Reed, a civil engineer resident in Scituate, which showed the length of the line to be I 5.83 miles, and its probable cost $\$ 304,093$. The authorized capital was 
$\$ 350,000$; but the town subscriptions, if voted, would aggregate only $\$ 225,000$, and the deficiency between that amount and the total estimated cost of the road had to be made up from other sources. Private individuals could not be induced to subscribe, and those having the matter in charge appealed to the Old Colony Railroad Company to aid in the construction of what promised to be a valuable feeder of that company's line. The Old Colony officials did not, however, care to take hold of the enterprise at this time, and the negotiations resulted in nothing. Meanwhile a considerable opposition existed in the three towns to the large subscriptions proposed, and the necessary two-thirds vote in their favor was not obtained. The next year, however, the charter was amended so that only a majority, instead of a two-thirds vote, was required, and the several town subscriptions were then carried. Having secured this basis for the enterprise $(\$ 225,000)$, its friends resumed negotiations with the Old Colony Railroad Company, and finally a preliminary agreement of a most comprehensive character for the construction, management and operation of the projected road was entered into. It is a fact having a most important bearing on the subsequent history of the road and the relations to each other of those owning it, that this preliminary negotiation was carried on between parties wholly distinct and independent of each other, and no person engaged in it held any conflicting fiduciary relations. At a later period, by virtue of the original agreement at this time made, President Stearns and two other directors of the Old Colony Road became also directors of the Duxbury \& Cohasset Road, Mr. Stearns being president of both corporations; but when the original agreement was made, representatives of the two corporations met as distinct contracting parties, each making the best terms it could for itself. By this preliminary agreement it was provided that the Old Colony or the South Shore Road, they being practically one, should subscribe for $\$ 125,000$ of the stock of the new company, and when an organization was effected, each of the towns holding stock should have one director and the Old Colony and South Shore corporations should have two each. The Old Colony was to enter into contracts for the construction of the road, subject to the approval of a majority of the town directors. If the cost exceeded $\$ 350,000$, the excess was to be met by the issue of 


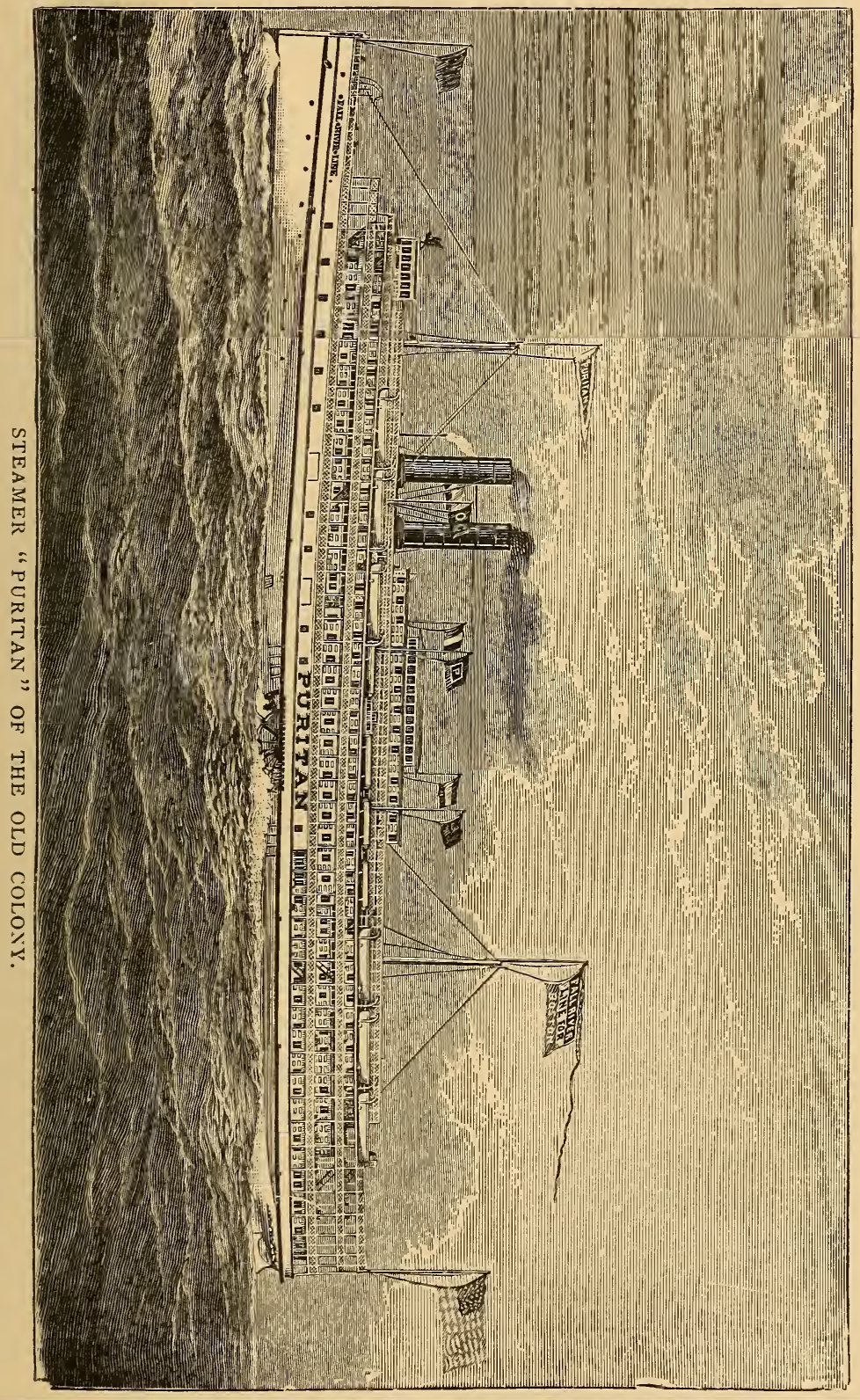



mortgage bonds. The Duxbury \& Cohasset Company was to furnish its own equipment, or the Old Colony would furnish it at a rate per mile run equal to the average cost per mile run of engines and cars (including the interest) on its own road. Finally, the Old Colony was to do the business of the Duxbury $8 \tau$ Cohasset upon the terms fixed by the referees for it to do similar business with the Hanover Branch Railroad Company. This perliminary agreement expressed in fact the terms of the bargain upon which the Old Colony agreed to furnish the funds, without which the projected road could not be built.

Meanwhile additional legislation of a most liberal and even unusual character had been obtained, authorizing the Old Colony not only to subscribe for Duxbury \& Cohasset stock, but also to operate and even to construct that road, while the Duxbury \& Cohasset Railroad Company received permission to issue, if necessary, bonds to the amount of $\$ 100,000$ secured by mortgage. Every difficulty being disposed of, a final survey and estimate were made by Mr. Reed, and during this work Mr. Charles O. Stearns, son of Onslow Stearns, president of the Old Colony Railroad Company, was employed by Mr. Reed as a "transit man." The line as finally decided upon was I7 I-2 miles in length, and the estimate of its. cost was $\$ 403,900$. Upon this survey and the accompanying specifications, proposals for constructing the road were advertised for. A number were put in by various parties, none of which, however, covered the whole or even the same parts of the work. The contract was finally awarded to Mr. Reed, the surveyor of the line, for a gross sum on account of the work specified of $\$ 168,000$, and it was signed on December 7, I870. Work was begun at once, and the road was opened to South Scituate on June I9, to Marshfield on July 3 I, and to South Duxbury August 2 I; the whole I7 I-2 miles having been constructed sufficiently to admit of its being operated in less than eight months from the execution of the contract. The work had been estimated to cost $\$ 403,000$, and it had been proposed to raise $\$ 350,000$ of this amount by stock subscriptions, and the balance by the sale of bonds secured by mortgage. The actual cost, however, was but $\$ 384,519.06$, so that when the road was completed and accepted, the corporation was in debt to the amount of $\$ 34,000$, which sum was advanced to it by the Old Colony Railroad Com- 
pany on current account, and no mortgage was made or bonds issued.

As regards the subsequent operation and management of the road the original agreement was carried out, except that instead of four directors on the board the Old Colony Road had three, the same number as the towns, while the additional director was agreed upon by the parties, the understanding being that in case of controversy he was to act as umpire. During the first full year of its operation the road netted the sum of $\$ 1,433.98$. During the next year the net loss was $\$ 2,000$, and in 1874 the gain was $\$ 2,500$. During none of these years, however, was the interest on the amount of debt due the Old Colony either earned or paid, but it was allowed to accumulate on account current; so that as the net results of the first three years of operating its road the corporation had earned a little less than $\$ 3,000$, and was behindhand on account of the unpaid interest about $\$ 7,000$. The extension of the road to a connection with the Old Colony Road in Kingston was determined on, and three and one-half additional miles were built in the spring of 1874 , at a cost of $\$ 70,000$, of which $\$ 40,000$ was raised by stock subscription on the part of the town of Plymouth, and $\$ 30,000$ was loaned by the Old Colony. This extension did not improve the financial prospects of the company, for in 1875 the net loss of the year's operation was $\$ 3,700$ in addition to $\$ 4,685$ unpaid interest, which loss increased in 1876 to $\$ 7,456$, besides $\$ 4,685$ unpaid interest.

In September, 1876, the town of Scituate sold the 750 shares of stock held by it to President Stearns, who bought them on his own account, but practically in the interest of the Old Colony Railroad Company, which thus obtained the control of a majority of all the Duxbury \& Cohasset stock. No change, however, resulted in the direction or management.

The marked feature of permanent improvement on the Boston \& Providence Railroad during the year I 877 was the completion of the new double-track wrought-iron bridge over Blackstone river near Pawtucket. It is 378 feet long, in five spans, varying from 60 feet to 95 feet in length; an excellent structure in all respects, both masonry and superstructure. About 500 tons of steel rails were laid, and substantial wrought-iron ballustrades and railings were put upon the Canton viaduct to insure safety in case of derailment of 
trains, while a new and convenient station building of brick was completed at Roslindale.

Aside from the usual work of keeping its road in good order, the Old Colony Company also made the following improvements during the year: a freight depot, 320 feet by 32 feet, in Boston, and the drawbridge over Fort Point Channel widened for a third track. About two miles of additional side tracks were laid; also 4,000 tons of steel rails and 1,260 tons of new iron rails. A brick passenger station at Wollaston Heights, and a wooden station at North Harwich were built, and a first class iron drawbridge over Taunton Great river at Somerset, in place of a timber structure at that point.

Seven overhead bridges and 203 linear feet of track bridges were rebuilt, and extensive repairs on others made. An engine house at Somerset, holding five engines, was erected to take the place of the one destroyed by fire. The freight depot at Taunton was enlarged 34 by 60 feet, and Hall's automatic electric signals were put in use upon this road from Boston to Braintree (ten miles), having been extended from Harrison Square to the latter place during the past year.

The report for the year 1878 possessed some features worthy of notice, the local passenger receipts being significant of the traffic which the acquisition of the various roads was gradually bringing to the company, the amount received this year from the source named having reached $\$ \mathrm{I}, 027,202.90$, while the earnings of the freight department footed up nearly three-quarters of a million more. The report for the succeeding year also showed gratifying results in the business of the road. Many improvements were made this year, a notable one being the building of a new iron bridge over the Neponset river at Canton meadows; also an arch bridge over Ten-Mile river in Attleborough. A substantial parapet of wrought iron was also placed upon Canton viaduct to make it of sufficient width for double track, as well as to protect trains in case of accident. Six miles of iron track was relaid with steel rails during the year. The experiment of using steel rails of greater length than usual over bridges, and at the crossing of highways at grade, proved successful. These rails, sixty feet in length, were rolled at the Edgar Thompson Steel Works, near Pittsburg, Pa. The first lot purchased, consisting of twelve rails, were laid in 1876 ; the second lot of fifty were 
laid in the spring of 1878 , and a third lot was purchased in the fall, making about I, IOO tons in all. Two miles of new side tracks were laid; a substantial iron bridge built over Granite street, Quincy, in place of a wooden one; five overhead bridges and one track bridge were rebuilt, and substantial guard-rails were placed upon nearly all these structures; a new passenger station of brick, and a new freight station of wood were erected at Sandwich; new wooden stations were built at South Hanson, South Middleborough, Assonet and Monument, and a large wooden car house at Fall River ; also a large addition to the passenger station at Bowenville. 

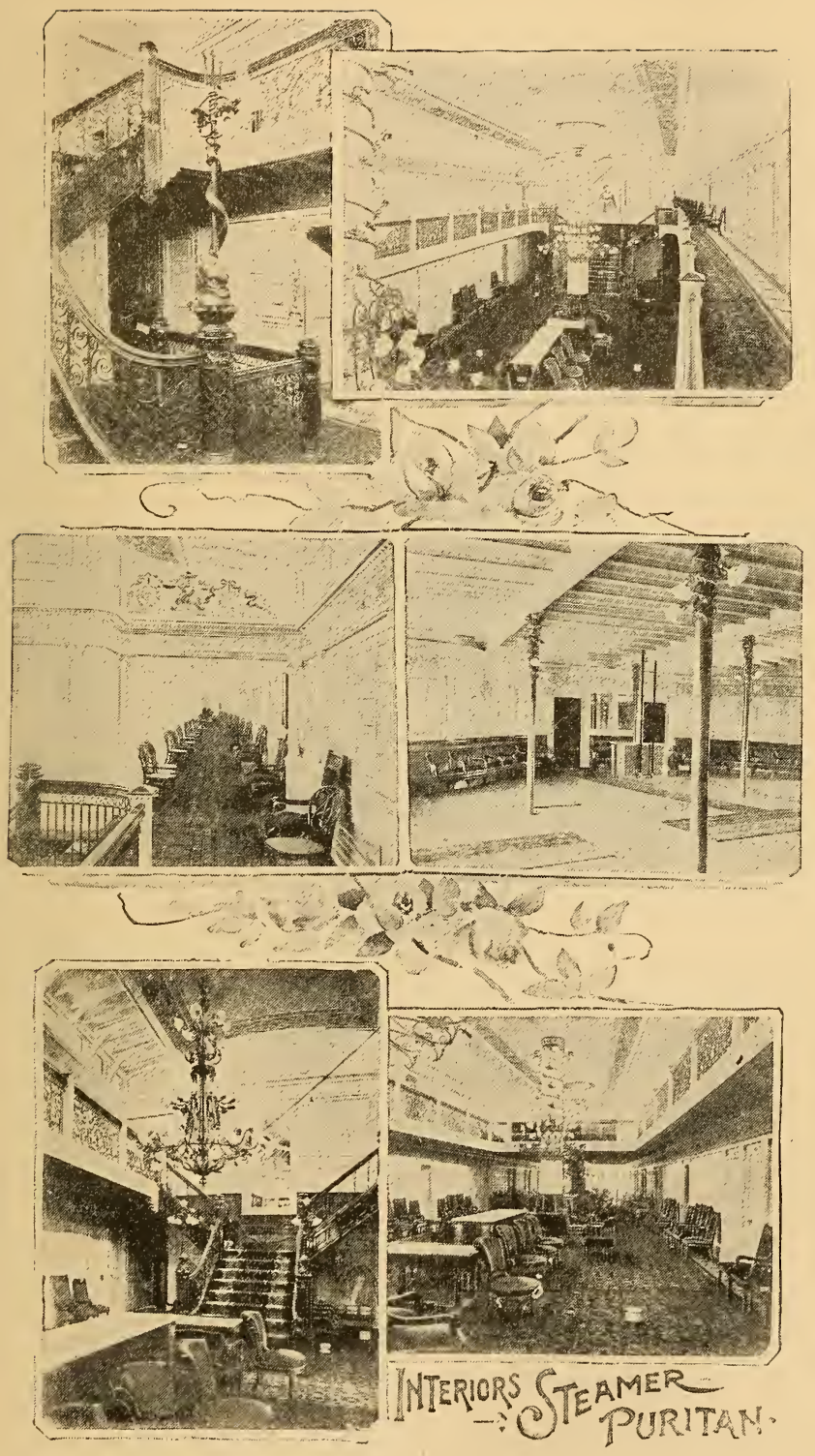



\section{CHAPTER XII.}

T N 879 the Old Colony Railroad Company leased the Boston, Clinton, Fitchburg \& New Bedford Railroad, running from New Bedford to Fitchburg, with a branch to South Framingham and Lowell, and another from Pratt's Junction to Sterling Junction. This line owned a branch running from Fairhaven to Tremont, connecting with the Cape Cod Railroad; the New Bedford Railroad, from the latter city to Taunton; the Taunton Branch, from Taunton to Mansfield and Attleborough; from Mansfield to South Framingham, and from South Framingham to Lowell; the Agricultural Branch, from Framingham to Northboro; the Fitchburg \& Worcester, from Fitchburg to Sterling Junction. The articles of this lease were as follows :-

"This indenture, dated this 3Ist day of January, in the year of our Lord one thousand eight hundred and seventy-nine, by and between the Boston, Clinton, Fitchburg \& New Bedford Railroad Company, a corporation existing under and by virtue of the laws of the commonwealth of Massachusetts, party of the first part, and the Old Colony Railroad Company, a corporation existing under and by virtue of the laws of the said commonwealth, party of the second part,

"Witnesseth, That the said Boston, Clinton, Fitchburg \& New Bedford Railroad Company, its successors and assigns, hereby lease its railroad extending from its terminus in Fitchburg to tide-water in New Bedford, together with its branch from Pratt's Junction to Sterling Junction, the branch to Lancaster Mills, the Marlborough Branch, the branch to the Sherborn prison, the Attleborough Branch, the Weir Branch, the Acushnet Branch, the Fairhaven Branch, and all other railroads and branches of railroads belonging to said party of the first part; and also all the lands on which the railroad of said party of the first part and its branches are or shall be located, or which are connected with or appertain to the uses of the party of the first part, and are its property ; and all the personal property of the party 
of the first part, however the same be described or wherever situate, including all claims against the Framingham \& Lowell Railroad Company and the Fall River Railroad Company, and excepting the items referred to upon the balance sheet of the last annual report of the party of the first part, under the heads of 'cash,' 'station-balances and connecting roads,' except as aforesaid, 'ledger balances,' 'New Bedford Railroad bonds,' 'sinking fund,' 'stock in Oak Bluffs Land and Wharf Company,' or the proceeds thereof, and its stock of supplies and materials on hand.

"To have and to hold the same to the said Old Colony Railroad Company, its successors and assigns, for the term of nine hundred and ninety-nine years from and after the day of the date thereof.

"And, in consideration of the foregoing, the party of the second part agrees to pay to the party of the first part, during the continuance of this lease, as an annual rental, .a sum of money equal to ten and two-thirds per centum of the total gross earnings of the railroads and properties of both the parties hereto, as they are now constituted, including all railroads and railroad properties now leased to either or both of said parties, but excepting any earnings of property of the party of the first part not hereby demised; payments to be made quarterly from and after said first day of February."

This company, including its recent acquisition, then controlled 454 miles of main line, or one-fourth of the whole railroad mileage of the state, of which 15.3 miles were of double and 438.7 miles of single track. The road was never in better condition; and among the improvements made the more important were the placing of substantial guard-rails upon all the bridges of its old property, and upon a portion of those upon the Boston, Clinton, Fitchburg \& New Bedford ; the laying of 2,360 tons of steel rails, and about 194,000 new ties; the construction of 12,750 feet of side tracks; a new iron drawbridge at Tiverton; a new cotton house at Fall River; a new coal shed at Taunton, and new freight stations at East and West Bridgewater and at North Scituate. The passenger stations at East and West Bridgewater, North Scituate and at North Weymouth were also rebuilt and enlarged. This company tried the method of "creosoting" ties at its works at Somerset, which were erected some years previous for creosoting the piles and other timber of Somerset bridge; but it was not a success. 
The figures below show the average rates of fares and freights for five years on this road, also the change in average rates of freight since the year 1875 , that being about the time when the movement for cheap transportation began. The extent of reduction would be more apparent, however, if the returns to the Board of Railroad Commissioners enabled them to state the rates received on business which is really through business. At that time all business was classed as "through," whether it traversed the commonwealth or only passed over one mile of its territory, provided it passed from one road to another: Fares - I875, 2.24 cents; I876, 2.20 cents ; $1877,2.10$ cents ; $1878,2.10$ cents ; I $879,2.00$ cents. Freights I $875,4.04$ cents; I $876,3.98$ cents ; $1877,3.60$ cents ; I $878,3.70$ cents ; 1 879, 2.69 cents. Average rate of local freight per ton per mile on roads operated by the Old Colony Company, I6.8 cents; average rate of freight per ton per mile received from freight to and from other roads, I 8.4 cents.

The year 1880 was not characterized by any important event in the history of the Old Colony other than the additions to its equipment made necessary by the increased traffic on all its lines. The company this year had 109 locomotives, 208 passenger coaches, 5 parlor and sleeping cars, 55 mail and baggage cars, and I,847 freight cars; I,953 men were employed in the various departments. The total income from all sources was $\$ 2,862,575.24$. The Board of Directors this year was composed of Charles F. Choate, Francis B. Hayes, E. W. Willard, Samuel L. Crocker, Royal W. Turner, John S. Brayton, Thomas J. Borden, Jacob H. Loud, Uriel Crocker and Fred L. Ames.

The various systems of signals were eliciting considerable interest at this time, and in reply to inquiries made by the Board of Railroad Commissioners in regard to those employed on the Old Colony lines, Superintendent Kendrick wrote under date of January 3, I880, as follows :-

In reply to your inquiries in relation to signals, I will say that our experience has been entirely with the "Hall" and "Bean" signals. The "Bean" signal is atmospheric, and intended for switches, drawbridges. stations or yards, and has proved very reliable. In connection with the tell-tale bell, to announce the changing of the signal to the person operating it, we should not hesitate to depend alone upon it for the purposes described. It is not a block signal, for 
spacing trains automatically, and does not cover what is claimed for the " Hall" or "Union" system. Of the Union system we have as yet no actual experience, but are equipping three and one-half miles of single track with its signals, with the view of testing its merits. The Hall signals have been in use on our double track for some five years, and have worked generally satisfactory. There have been instances where they have not shown the actual condition or occupation of the section of track they were designed to cover; and we use the system as an additional safeguard, but not as an entire substitute for the former precautions.

The examination of the Old Colony Road from year to year shows a constant improvement in its condition. With its leased lines it operates more miles than any other company in the state, and more than one-quarter of all the railroad mileage in Massachusetts; and the leased roads are assuming the excellent characteristics of the main line. During the year I 880 4,000 tons of steel rails and upwards of 200,000 new ties were laid on the main tracks, and about 5 miles of new side tracks were also laid. A new iron drawbridge across Fort Point Channel, and wooden drawbridges across Neponset river and at Buzzard's Bay were constructed, and new passenger stations built at Monument Beach and Barrowsville, also new freight houses at East Stoughton, Mansfield and Marlborough. The train house in Boston was lengthened 225 feet, and a new freight house of corrugated iron erected at South Boston. At Fall River about ten acres of land were purchased for freight purposes, a mile of new tracks laid thereon and a commodious freight house erected.

With the completion of the stone and brick arch bridge on the Boston \& Providence Railroad at Dodgeville this year, the main line of the road had no wooden bridge more than twenty feet in length. In all other respects, also, it was one of the most substantial and thoroughly constructed roads in the state, and its condition creditable to the management. Among the other noticeable improvements was a new brick passenger station at Canton.

In I882 a law was enacted requiring the examination of railway employees for visual defects, and such persons were also required to be re-examined biennially. When this subject was referred to the Board of Railroad Commissioners two years previously for its examination and report, the existence of such defects was at once recog- 
nized, although its extent seemed to have been exaggerated. The board then recommended an annual examination, both as to color blindness and all other defects of vision, extending to all persons in any way connected with the movements of trains. But it was thought to be unnecessary to compel such examination by the enactment of laws and the infliction of penalties; for it was argued that, as long as the subject had been made familiar to the public, and especially to the managers of railroads, the latter would, of their own accord and in their own interests, provide for such examinations. In this the board was in error. A circular was issued Sept. I 5, I 880, calling attention to the need of annual examinations, and was sent to all the railroad companies of the state. They were also requested to report to the board the result of such examinations.

Only one of the larger corporations (the Old Colony) responded to the circular, and that response showed the need of annual examinations, for three train hands were shown to be seriously defective in perception of color; so that the result of the board's circular demonstrated both the need of frequent examinations, and the necessity of providing for them by statute. The board, therefore, appeared before the railroad committee by its chairman, and seconded the efforts which had been already made for the enactment of a law.

The Whittenton Branch of the Old Colony was constructed during the year I882, and this year also saw the consolidation of this road with its leased lines with the Boston, Clinton, Fitchburg \& New Bedford Railroad, by purchase. The Fall River Branch line also came into the Old Colony system about the same time.

Among the improvements made on the Boston \& Providence Railroad in I 883 was the erection of a new station at Dedham, which, with its beautiful grounds and commanding location, is undeniably the finest piece of railroad property in this state, if not in the entire country. Two bridges and a trestle were also dispensed with on this division by filling, a substantial iron bridge substituted for one of wood, while a brick arch took the place of another bridge. A distant signal was put up east of Canton Junction to show the position of the Junction switch, and designed to prevent a recurrence of such an accident as had previously happened at that point. 
On their inspection of the Old Colony Road this year, the Railroad Commissioners noted many improvements of more or less importance at various points along its extensive lines. The former good condition of the track was more than maintained, and a large amount of new fencing was erected, while Union block signals had replaced the old ones and had been extended to additional tracks; the freight yards at Braintree, Taunton, Somerset, South Abington, and other points had been improved, but the most important innovation was noted at Taunton, the Wales street passenger station. The changes at South Abington were also a marked improvement. In the various branches of construction the new work and repairs were generally of a thorough and substantial character, and wherever the commissioners called the attention of the management to any defects, or methods of doubtful policy, they found a readiness to comply with their suggestions.

In I884 the number of season ticket passengers had reached I,913,406, as against $1,558,961$ in 1882 , and $1,770,443$ in 1883 , while the total income from all sources showed an increase over the previous year's report of $\$ 616,721.90$. This year the Old Colony and the Fitchburg companies availed themselves of the provisions of the clause in section I62, chapter II2, which allows a discontinuance of the stops required at the grade crossings of two railroads when a system of interlocking or automatic signals has been adopted by the railroad companies and approved by the Board of Railroad Commissioners. The number of hands reported was 2,965.

In 1885 a branch line was constructed from Brockton to Easton, which proved a great convenience to residents of those two places as well as a profitable investment for the Old Colony Company.

The annual reports for the years I 886-7 were highly gratifying from a financial standpoint; but perhaps the most remarkable feature of that for the year last named was the fact that, notwithstanding the numerous grade crossings of highways and travelled places on the extensive mileage of the Old Colony system, no accident had occurred. This road has not always enjoyed immunity from this class of casualties, of course, but no corporation has ever shown more persistence in its efforts to abolish these sources of danger. The act of I885, designed to promote the abolition of grade crossings, has proved useful, especially on this road, 
where ten level crossings were abolished this year. The apparent increase of these crossings on the Old Colony, as shown in its returns, arose from the fact that 37 existing on the Framingham \& Lowell Bailroads are this year reported as of the former.

The Hanover Branch Railroad was purchased by the Old Colony in I888, while the Dorchester \& Milton Railroad, which several years previous had become its property, ceased this year to be recognized as a separate organization. The Nantasket Beach Railroad, not having been operated since the fall of 1886 , a hearing on the subject was had before the Railroad Commissioners in July, I 888, who held that it was the duty of its owners to operate the road, but that duty was not fulfilled. The subject of a lease of this road to the Old Colony Railroad Company was pending, in order to secure the operation of the road during the next season by the latter.

A branch line was this year built to Woods Holl, and the Chatham branch, built in I887, was extended so as to unite with the Provincetown Branch. The subject of heating cars had become of considerable importance during this year, and many experiments were made, which were more or less satisfactory, the Old Colony heating its coaches by the Johnson hot water system. Incandescent electric lights were also introduced on some of its lines.

In I 888 also the Old Colony system acquired by lease the Boston \& Providence Railroad, with all its, branches and leased roads, the control of the Providence, Warren \& Bristol Railroad being included in this consolidation, which business stroke was considered one of the most important in the history of the railroad interests of the Old Bay State.

The following year, I889, steam was introduced for heating passenger, baggage and express cars, and in order to test the actual danger which would result in case a pipe heated by locomotive steam should burst or be broken in a car, the Board of Railroad Commissioners, by the kindness of the Old Colony Railroad, which furnished an engine and a car for the purpose, made experimental tests, which resulted in the commissioners' approval of this system as free from danger and altogether the most effective. In I89I, the Old Colony reported that about 52 per cent. of its cars were fitted 
for heating by steam from the locomotive, and that 345 trains would be run without fire in any car.

The most recent acquisition prior to that of the Fall River, Warren \& Providence Railroad, which is mentioned in the foregoing report for the year 1892, was that of the Martha's Vineyard Railroad, which was sold at auction under mortgages held by the Old Colony and was bid in for $\$ 27,500$. The amount of the mortgages and accrued interest was $\$ 5 \mathrm{I}, 000$.

Having followed the annual reports of the directors of the Old Colony Railroad Company closely enough for purposes of comparison, a summary of the 29th annual report is given to close this portion of the work. It will be observed that this report (1892) also contains a comprehensive synopsis of that made for the previous year. Details of both reports are omitted here, for the reason that they are not of general interest to the public.

The earnings, expenses and taxes for the two years ending June 30, I892, were as follows: For the year 1891 - earnings, $\$ 8,376$,452.16 ; expenses, $\$ 6,014,900.04$; taxes, $\$ 455,374.22$; net earnings, $\$ 1$ I,906, I 77.90. For the year I 892-earnings, $\$ 8,744,8$ I 2.23 ; expenses, $\$ 6,253,3 \mathrm{I} 2.72$; taxes, $\$ 44 \mathrm{I}, 073.75$; net earnings, $\$ 2$,050,425.76. This shows an increase in earnings for 1892 of $\$ 368$,360.07 ; expenses, $\$ 238,4 \mathrm{I} 2.68$; a decrease in taxes of $\$ 14,300.47$, and an increase in net earnings of $\$ 144,247.86$. The earnings and expenses of the Providence, Warren \& Bristol Railroad are included in the accounts of 1892 . In the expense for the latter year is also included the balance paid to settle claims growing out of the Quincy accident, which amounted to $\$ 75,473.58$. Number of passengers carried, I89I, 22,395,487; I 892, 23,870,419; tons of freight carried, I891, 3,455,500; 1892, 3,708,480.

The equipment on June 30 , I 892 , including that of leased lines, was: locomotives, 238; passenger and baggage cars, 552; parlor cars, 2 ; freight cars, 4,06I ; caboose and service cars, 392. The whole cost of new equipment for the year was $\$ 438,990$. I9. New stations were built this year at Middletown, Steep Brook and Crystal Springs to replace those burned, and new stations completed at South Braintree and Fall River; a new engine-house and turntable were also built at South Braintree. 


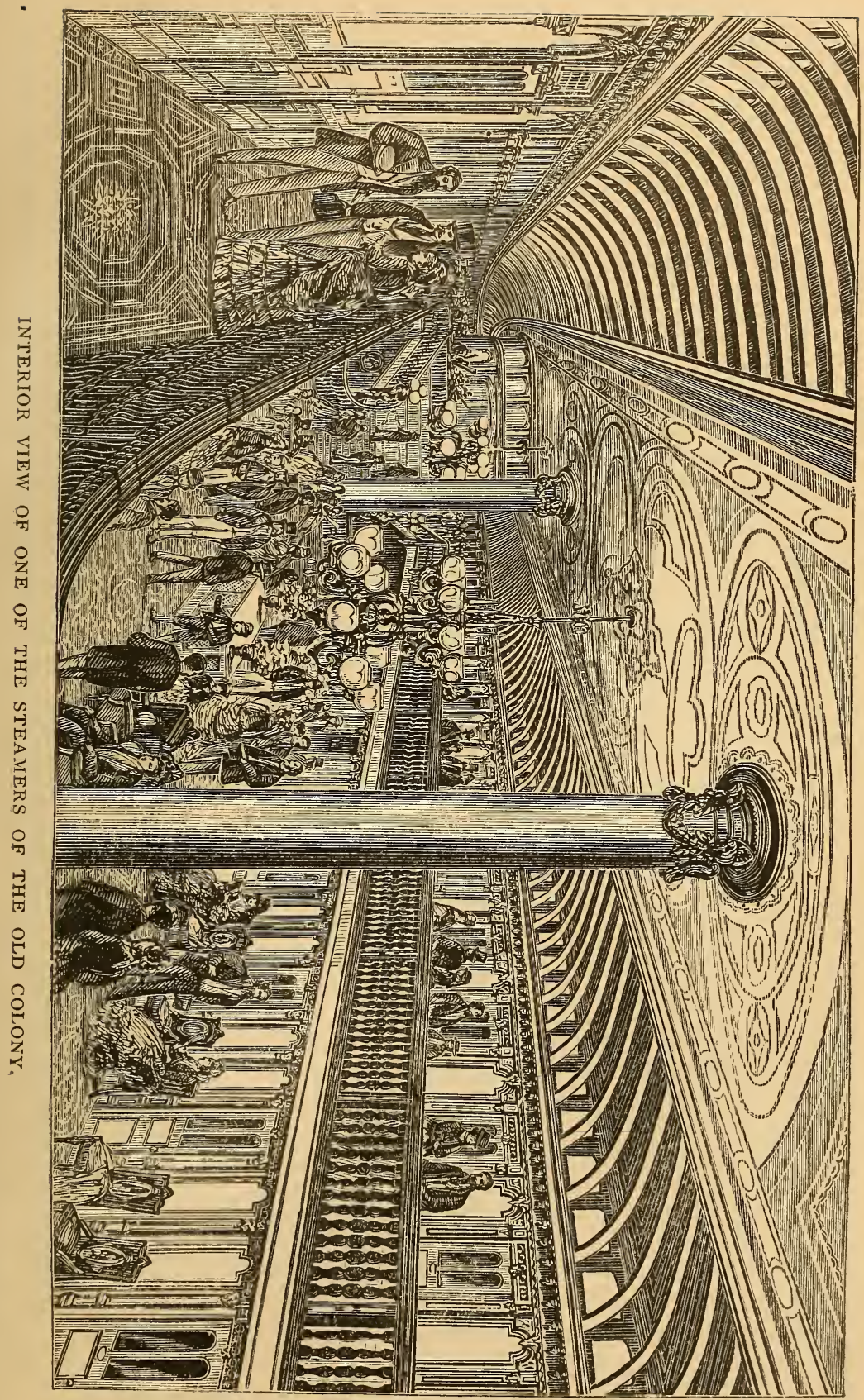



The Walpole and Wrentham Branches were substantially completed, forming a complete line between Dedham and Attleborough. A second track was completed on the Cape division, between South Middleborough and South Wareham, and some work done in the construction of two additional tracks between Boston and Braintree.

The Fall River, Warren \& Providence Railroad was sold under the mortgage this year. The Old Colony owned all the bonds and a large proportion of the stock. The railroad and property covered by the mortgage was purchased at the amount at which the stock and bonds stood on the books of the company, which was $\$ 355$,866.47 .

Under the provisions of an act of the Legislature of Rhode Island, a lease was taken of the Providence, Warren \& Bristol Railroad for a term not exceeding the termination of the lease of the Boston \& Providence Railroad. Fourteen hundred and ninety-one shares out of 1,500 shares of the preferred stock, and I,872 shares out of 2,870 shares of the common stock of the P., W. \& B. R. R. Co. were held by the Old Colony Company under the Boston \& Providence Railroad lease. The lease provides for a dividend of five per cent. on the common stock, and is for the term of ninety-six years, but is to terminate upon any earlier termination of the Boston $\&$ Providence lease.

The new railroad between Plymouth \& Middleborough was completed this year. It is about sixteen miles in length, and its cost about $\$ 300,000$. Its stock is mainly held by the towns of Plymouth, Carver and Middleborough, and it has a mortgage debt of $\$ 225,000$. The directors of the Old Colony made a contract to operate the road for a term of ninety-nine years, paying as a rental thirty per cent. of the gross receipts, and guaranteeing that this rental shall be sufficient to pay the interest on the bonds, viz., $\$$ II,25O per year.

At the time a nucleus was formed for the present great system controlled by the Old Colony Railroad Company, railroading was in its infancy, comparatively speaking; and while it has advanced with rapid strides throughout the civilized and portions of the uncivilized world since that time, it would be difficult to find a more progressive career than that which has characterized this road from its inception 
to the present time. In I 846 its earnings were $\$ 125,000$; in I 892 , $\$ 8,744,8$ I 2.23 . These figures tell the story more forcibly than words, and are suggestive of the farsightedness and eminent business qualifications of those who have guided its affairs. 


\section{CHAPTER XIII.}

I

$\mathrm{T}$ is not difficult to arrive at a correct conclusion on the elements of the great recent growth in all material respects of this commonwealth. It is to be remembered that within the memory of the present generation the whole industrial system of Massachusetts has been revolutionized. From the first settlement of New England down to a comparatively recent date, the prosperity and growth of its people was connected with agriculture and commerce. Their wealth was drawn, partly from the soil, but mainly from the seas. In colonial days, the fishery was held to be "a mine of infinitely greater value than Mexico or Peru" ; it was "a source of luxury and vanity"; it was "of essential importance to us in every branch of our commerce" ; in short, it was "our only staple commodity," and, as such, its freedom was made an ultimatum by the representatives of New England in the treaty of independence. Even as late as the negotiations at Ghent, in I8I4, it had hardly lost its importance. All of the large fortunes accumulated in this part of the country, down even to the time when the railroad system first began to take shape in 1830 , had their origin in the fisheries, in commerce and in the carrying trade. The embargo of I 808 nearly ruined New England, six towns of which then possessed more than one-third of the tonnage of the Union; it "pressed upon all classes, and paralyzed all industry " by "destroying the chief source of wealth and prosperity." The "Cod-fish Aristocracy" gave way to the "Merchant Princes," and each of these carelessly used political and social designations, as well as the more subsequent one of "The Lords of the Loom," represented in truth a distinct and successive phase of industrial development. In the earlier days of the century, accordingly, Newburyport, Salem, Boston and Nantucket were the prosperous centres of Massachusetts. All ideas of wealth and of stable prosperity naturally associated themselves with their pursuits. This fact had ingrained in the New England mind, as the result of two centuries of experience, certain principles, which have not yet lost their influ- 
ence, but have, during the last few years, very largely contributed toward giving a shape to the railroad policy and legislation of the state. It has already been stated that the key to that policy and legislation, has been the idea of through lines of railroad as auxiliaries to a foreign commerce; more through lines to the west to enable the New England seaboard "to compete for foreign trade with the other Atlantic cities ; "to bring," in the ordinary parlance, "the product of the West to tide-water." Though this traditional policy still exists in great force, a very remarkable industrial revolution has taken place since it originated.

As an evidence of the comparative importance of the manufacturing and commercial industries, it may be here added that the entire value of the exports of Massachusetts during the year I 869 was about the gold value of the ready-made clothing manufactured in her shops in 1865 , and one-third of the iron industry. The imports of the year I 869 were about the value of the woolen industry of 1865 , and the whole foreign commerce, if reduced to gold, would amount to but little more than half of the boot and shoe industry of that year (I869), and which itself ranked second only among the industrial interests of Massachusetts. In other words, the interests of this state have so changed within the present century, that, if an embargo like that of 1808 had been placed on her foreign commerce in 1865 , leaving the coast trade and a free importation at other points open, instead of causing the widespread distress experienced in I808, it is doubtful if the loss of net income would have amounted to five per cent. of the whole income derived from her industries. In computing this loss, allowance is made for the smaller percentage of net profit which results from handling importation and exportation as compared with the profits on manufactures.

For more than half a century, Boston has held the proud position of the second city in the United States - second only to New York as a commercial, shipping and business centre - and, by its elaborate railroad facilities and its close contiguity to the Atlantic ocean, the first and most important point of arrival and departure for steam and sailing vessels to every section of the habitable globe. From a commercial point of view, both as regards freight and passenger traffic, the Old Colony Railroad occupies the same relation 
in regard to its traffic connections as Boston itself does to the Federal Union, viz.: the keystone of American commerce, the golden gate of the Eastern and Middle States, and the chief link in the chain which unites the states of the Union with the other continents of the world in one vast and indissoluble whole. Prior to the year I 835 (the year in which the Boston \& Providence line was first opened to public traffic) the means of communication with the metropolis of America (New York) was difficult, uncertain, and at the best, beset with delays equally antagonistic to the comfort and safety of the passengers and the maintenance of our business relations; the perils to life and property in the passage of the Fall River and Narragansett Bay, which the merchant had to encounter - and the tediousness and uncertainty which characterized the land route to New York were matters so formidable as to materially impede our interstate commerce and communication, and, consequently, the opening of the Boston \& Providence line of railroads was hailed by all classes of the community as a Providential solution of all their difficulties, and as a triumphant opening up of a new and unlimited facilities for commercial growth and prosperity. There are still many eminent citizens living who can recall to their remembrance the details of that auspicious and ever memorable event - the inauguration of the Boston terminus of the Boston \& Providence line - which, with the other depots of the Old Colony system, has been universally admitted to be the most elegant, commodious and convenient railroad structure in existence, and situated at the junction of Park Square and Columbus avenue, opening on to Boylston street, the Common and the Public Garden. If any section of the city has a special claim on historic pre-eminence, this is the spot; for, from the time of the formation of the American Republic, this of all others, has been the scene of its struggles and its triumphs - political, social, and commercial.

The Providence Division is, in fact, but one section of a series of lines with which it is directly connected in traffic facilities and general arrangements - the lines being as follows: the Shore Line All-Rail Route between Boston, New York, Philadelphia, Baltimore, Washington and all points South and West; the Stonington Line or inside Route to New York, via Providence and Stonington; the Bristol, Fall River and Newport Line, communicating with 
Providence, Bristol, Warren, Nyatt, Bowenville, Fall River and Newport; the New York, New Haven \& Hartford Railroad, the chief stations on which are Greenwich, Wickford Junction, Kingston, Wood River Junction, Niantic, Westerly, Stonington, Mystic, Nouank, Groton and New London; the Naragansett Pier Railroad; the Providence and Springfield Railroad connecting with Olneyville, Centredale, Georgiaville, Harrisville, Pascoag and intervening towns. Beyond New London the New York, New Haven \& Hartford Railroad, permeates every manufacturing centre in the busy and important district washed by the Connecticut river and its tributaries. The connections of the Providence Division with those having their termini of departure at New York city and Jersey City are so complete and well defined, that through passages to any part of the American continent, and from thence seaward, can always be negotiated and obtained at the Boston terminus at Park Square.

The steamboats of the Fall River Line - if it be not a misnomer to apply the term "boat" in connection with such vast bulks - are owned and run by the Old Colony Steamboat Company, a corporation distinct from the Old Colony Railroad Company, although made up largely of the same owners and officered by the same persons as the last-named corporation. The term "Monarch of Long Island Sound " is not a misnomer as applied to the Pilgrim or the Puritan, or, indeed, to the Plymouth or Providence, since either of these ships is worthy of the designation, and would be a marine monarch, not alone in Long Island Sound, but in any waters in which it might appear in any part of the world. Their vast proportions, immensely beyond those which characterize steamboats elsewhere to be found ; their superb finish and ornamentation; their palatial furnishings and accommodations; the harmony and practical character of all their appointments ; the marvellous adaptation of means to an end, found in all their arrangements and devices; the qualities of safety, comfort, and rapid transit found in their service; - all these have never yet been equalled elsewhere, and cannot be surpassed.

For the essentials of public and private rooms, fine table provision and service, and all the requisites of first-class hostelries upon a grand scale, they are magnificant hotels, lacking in no qualifications as such. As sailing-craft, gliding at rapid speed through the 


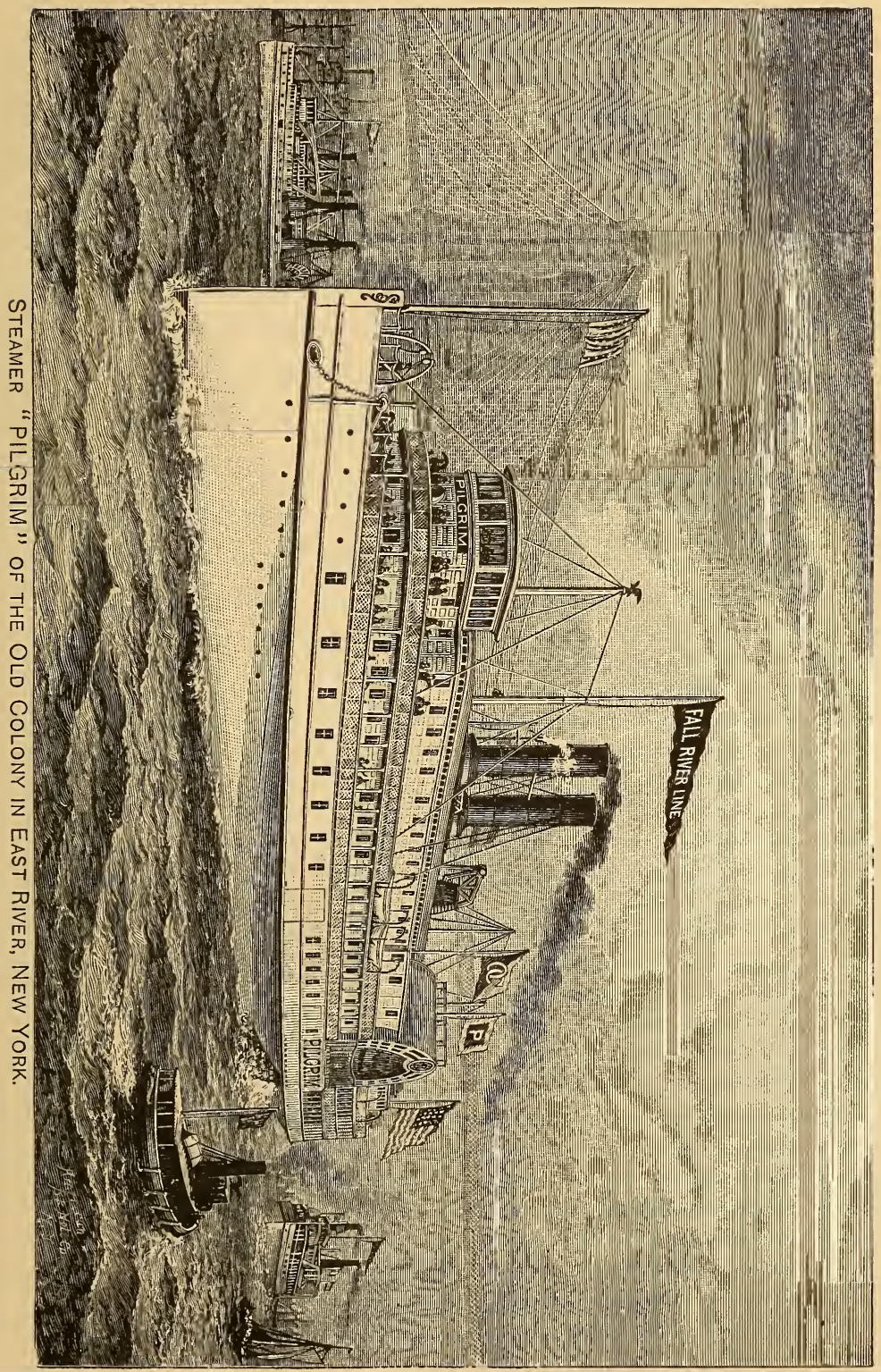



water under all circumstances, and equally safe and available at all seasons of the year, they have no superiors. As wonders of marine architecture, they are models interesting to the ingenious and scientific of all nations. As popular agencies for transportation, ministering equally to the highest and lowest order of patrons and with perfect satisfaction to all, they are universally known.

Four freight steamers also ply between New York and Fall River, named as follows: City of Brockton, City of New Bedford, City of Fall River and City of Fitchburg. Passenger and freight service is performed on Vineyard Sound by the steamers Nantucket, Gay Head, River Queen, Martha's Vineyard, Island Home and Monohansett.

In the important matter of passenger traffic, reference to the early methods of transacting business in this department of railroading may be found interesting to those whose recollections do not extend back to that period. As is well known, in England, railway ticket offices are always spoken of as "booking" offices, and this had its origin in the practice in vogue, prior to 1836 , of accounting for passengers by booking, or registering, their names. In that year a Mr. John Edmonson, who was employed in a little side railway station in the neighborhood of Corlish, England, changed the system Formerly the name of the station to which the passenger was going was written upon the ticket at the time of its issue; later on he invented the numbered ticket. His sons still carry on the business of ticket printing in Manchester, England. The first consecutively numbered tickets used in America were printed for Sanford, Harroun \& Warren of Buffalo, N. Y., by George Bailey, who was sent over by Edmonson with one of his machines in 1855 . Previous to this the ticket was a plain unnumbered piece of card board, good for a single passage. As late as I 860 such tickets were in use on the Boston \& Providence. The coupon tickets are the invention of a Mr. Hubbard and were first used on the Baltimore \& Ohio Railroad. Messrs. John P. Lovell and J. Thaxter Clanes are said to be the first persons to purchase season tickets on the Old Colony.

With the march of improvement and progress in passenger service, this company has in all things kept in the fore front, and its system of handling its vast suburban and through traffic is well 
nigh perfection. Its rates of fares have also been adjusted to meet the wants of its patrons in every conceivable manner consistent with a sound business policy. In short, nothing has been left undone in the work of development all along its lines, and this has not only proved a source of growth to the outlying towns and villages, but an important factor in relieving the over crowded. portions of Boston and providing homes for thousands of its business men and others in the most accessible, beautiful and healthful portions of New England. The growth in population in these districts which the Old Colony Railroad supplies has been in the last few years phenomenal - a fact which may be accounted for by the improvement in the running of the trains and the relatively low rates at which single tickets and commutation tickets are sold, as well as in the natural advantages of the places the road has been instrumental in opening up for business and residential purposes. While this growth has been more preceptible in the immediate vicinity of Boston than elsewhere, perhaps, it has nevertheless been general in its character.

Such is the history of the formation and growth of this great railroad system to the present time, which is largely engaged in the freight and passenger traffic of four of the most important states in this country, viz., Massachusetts, Rhode Island, Connecticut and New York.

There has, from the year of the incorporation of the Old Colony to the present time, been no one on the executive staff but officers specially fitted by their administrative ability, their indomitable energy, their unswerving integrity, their intimate knowledge of the ever-increasing and varied requirements of commerce, and more than all, their engrossing devotion to the interests of both the public and the road. The gratifying position the Old Colony Railroad has assumed among the great systems here in the East, while mainly attributable to the fortunate acquirement of lines and branches which traverse sections peculiarly susceptible of rapid development, is largely due to the excellent management which has always characterized its affairs. Representative men have always been chosen as its officials, who in turn have made wise and judicious selections in the important matter of subordinates. 
Reference having been made elsewhere in this work to those who took important parts in the upbuilding of this great enterprise, it is eminently proper that the names of those who are now at the helm should be known. They are: Chas. F. Choate, president; F. L. Ames, vice-president ; J. R. Kendrick, general manager; J. M. Washburn, treasurer; Geo. L. Connor, general passenger and ticket agent; C. Peter Clark, generai freight agent.

With such a working staff as this, whose every energy is devoted to the public interests, where years of experience in the working of these roads has been one continuous triumph over difficulties, the Old Colony Railroad cannot fail to maintain and retain the public confidence and realize still more gratifying and signal success in the future.

This system ministers to the finest seashore and summer resorts known in the service of any one railroad system. More than six hundred miles of winding sea coast are directly included within its operation, every portion of which has developed or is growing into a centre for summer business. All the shores about Boston on the south and southwest: Hull and Nantasket Beach ; the magnificent Cohasset shores; the south shore from Cohasset and Duxbury, inclusive; historic Plymouth, with its manifold natural attractions; the entire Cape Cod shores, on ocean, bay and sound sides; the Buzzard's and Onset Bay sections ; Fairhaven, Mattapoisett and New Bedford; the Newport shores on every side; Mount Hope and Narragansett Bays, with their magnificent scenery, and Martha's Vineyard - all these sections and districts lie directly within the routes of this railroad and depend solely upon it for their transportation.

While practically not identified with the various lines of railway centering in Boston, there is one railroad which cannot be ignored in speaking of its transportation facilities. Reference is here made to what is now known as the Union Freight Railway, and its functions are fully outlined in the following paragraphs. February $2 \mathrm{I}$, I 863, this road was chartered as the Union Horse Railroad Company, the incoporators being George B. Upton, Alfred C. Hersey and John L. Gardner. This railroad was to be run from the Boston \& Lowell Railroad, through Lowell and Brighton streets, and then over Causeway, Commercial, India, Broad, Federal, Kneeland and Eliot streets, to the Boston \& Providence 
Railroad. The motive power used on this road was to be horse power only. The capital stock was not to be more than $\$ 300$,ooo, and it was permitted to connect with any of the steam railroads having terminus in Boston, provided that it did not apply to the Supreme Judicial Court to appoint commissioners, or to use any steam railroad, and that if the owners of wharves should construct a track, the corporation was required to connect the same with its road. It was allowed to connect with other horse railroads upon consent of the parties. This company was to be deemed a railroad corporation, so far as to make such annual returns to the legislature as may be prescribed by law, and to be subject to all laws that may be prescribed for horse or street railroads.

April 25 Thomas Russell, Edward Crane and Harvey Scudder formed a company under the name of the Marginal Freight Railroad Company. The Commercial Railway Company was authorized to unite with the company and form one corporation. The capital stock was not to exceed $\$ \mathrm{I}, 000,000$. The act was void so far as it authorized the construction of the Marginal Freight Railway over the Commercial Freight Railway or through the streets of its location, unless the Marginal Freight Railway and the Commercial Freight Railway should form one corporation, and agree in all particulars. George B. Upton, Percival L. Everett and Henry S. Russell, May 6, I 872, united under the name of the Union Freight Railway Company for the purpose of building a railroad for carrying freight only, with single or double tracks, and extending over the following streets: Lowell, Brighton, Causeway, Minot, Nashua, Commercial, Prince, Hanover, Fleet, India, Broad, Atlantic avenue, Federal, Kneeland, Cove, Lincoln, Eliot and upon such other streets as the Board of Aldermen might determine; and also to construct side tracks to wharves and warehouses, provided, that no railroad should be laid upon a public street without the permission of the Board of Aldermen, and also provided that the rails were approved by that board. Every other railroad corporation whose road passed the Union Freight were privileged to connect tracks for transportation of freight, and the Union Freight Railway was obliged to deliver cars at each of the connections and carry the same over its road at the established rates. Within four months after passage of this act, this company had power to take the tracks 


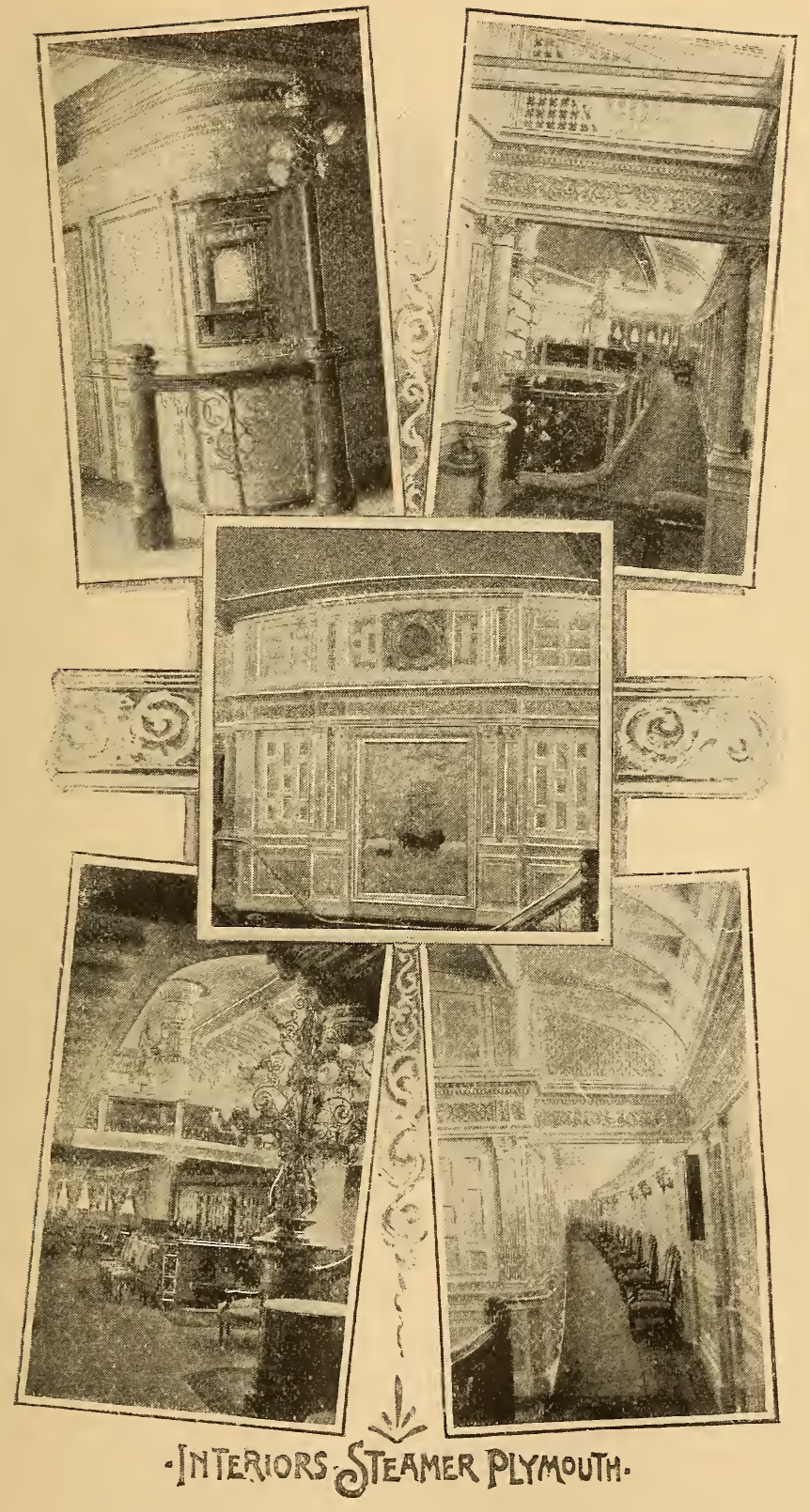



of the Marginal Freight Railway Company according to the law of taking land by railroad companies. The repeal of the act of I 867 to incorporate the Marginal Freight Railway Company, and the act of I 869 relating to the Marginal Freight Railway Company was taken, and the powers conferred by this act ceased unless the Union Freight Railway Company had constructed tracks, etc., within one year, connecting with the steam railroads on the northerly side of Boston with those on the southerly side.

The Marginal Freight Railroad, the Union road, was originally intended as a road to connect stations, and be a means of passing freight cars between the roads of the South End and the roads at the North End. It answered that purpose to a very great extent. Since the road has been built the conditions of business have changed. To-day the Union road is still important as connecting the railroads at the North and South Ends. Its great importance and its great use is its connection of the whole wharfage front of Boston with the whole railroad system. Now it passes by every wharf in the city of Boston, practically every wharf, and all those below the bridges. It connects every wharf, or can connect every wharf, and it does connect the larger part of them with all the railroads. It has done more to keep up business - the commercial business of Boston - than any other one thing, and in the future the merchants of Boston can more easily dispense with almost anything else than that railroad. It connects the markets with the railroads. All the beef which is brought to the city of Boston is carried over that road. The enormous cold storage warehouse is built on the line of that road. It receives its supplies, it receives its ice over the lines of the road. It has a direct connection with the Quincy market. Cars are run directly into the market and loaded and unloaded there. It brings a very large quantity of ice and provisions and produce directly into the vicinity of the principal markets of the city of Boston. It has a large yard on Atlantic avenue and Commercial street, from which a very large distribution of that sort of perishable freight is made, and to the very great convenience of the merchants of Boston. It connects the fish wharves with the railroads. Carloads of fish are taken in that way and distributed from Boston to all points south and west. In fact, the importance of the road is growing day by day, and its importance 
to the commercial business of Boston cannot be overestimated. The result is that freight is distributed to and from the railroads at a minimum. The expense is about 20 cents a ton. There is no other way in which it can be distributed so cheaply. There is no way in which relief can be given to the streets of Boston to such an extent as can be done by distribution of freight which is now done by that road in that form

The officers of the Union Freight Railroad are: Charles F. Choate, president ; J. R. Kendrick, general manager; J. M. Washburn, treasurer ; A. H. Grovenor, superintendent ; C. Peter Clark, general freight agent. 


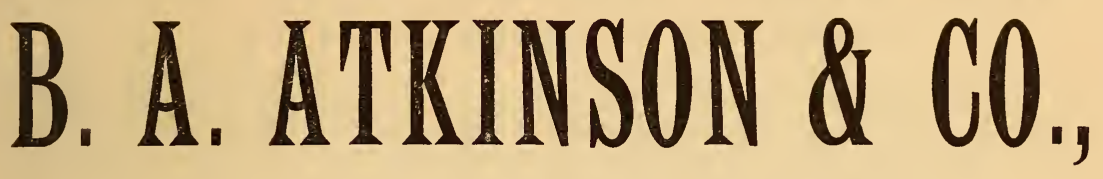

\section{LIBERAL HOUSE FURNISHERS,}

\section{7-WASHINGTON ST.-827}

Cor. Common Street, Boston, Mass.

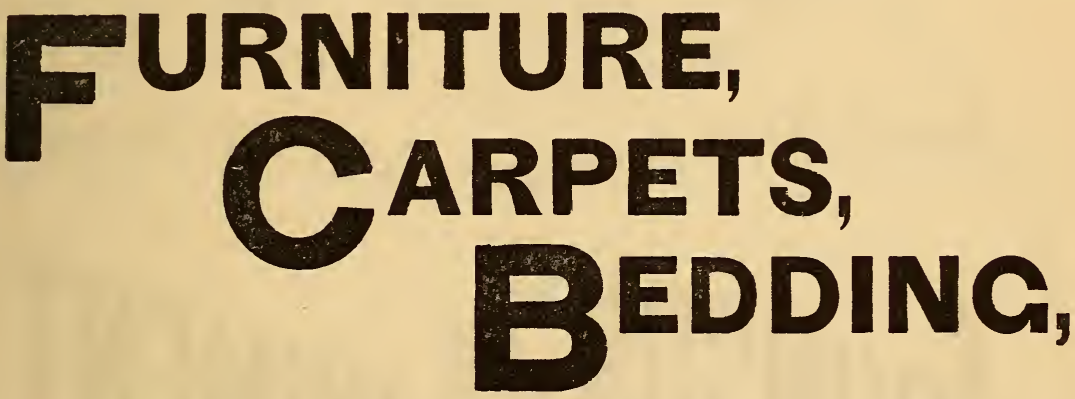

STOVES $\cdot$ AND $\cdot$ RANGES, $\cdot$ AND $\cdot$ ALL $\cdot$ KINDS $\cdot$ OF H(IUSE - FURNISHING - GOODS.

OUR GOODS AND PRICES PLEASE THE PUBLIC. WIIEN

In need of anything in the line of House Furnishings you can depend on finding it here at the Very Lowest Figures.

We have the best assortment of any House Furnishing Establishment in this country. We can show yon what you want at the lowest prices in New England.

We can show you all kinds of Parlor, Sitting Room, Chamber, Dining Room and Kitchen Furniture, including Draperies, Shades, Curtains, Tables, Chairs, Sideboards, Hall Stands, Lamps, Clocks, Dinner and Tea Sets, and all household articles at specially low prices.

CALL OR WRITE FOR ESTIMATE.

CASH OR EASY TERMS.

B. A. ATKINSON \& CO.,

LIBERAL HOUSE FURNISHERS,

827 WASHINGTON ST'., BOSTON, MASS. 


\section{We Are Here To Win! BOSTON ATHLETIC ASSOCIATION.}

Boston, Nov. 20, 1890.

I. S. Johnson \& Co. Dear Sirs:-The Johnson's Anodyne Liniment came to hand in good shape. The boys all like it. For bruises, strains or muscular lameness it most certainly is all you claim for it. Wishing you continued success, I am Yours truly,

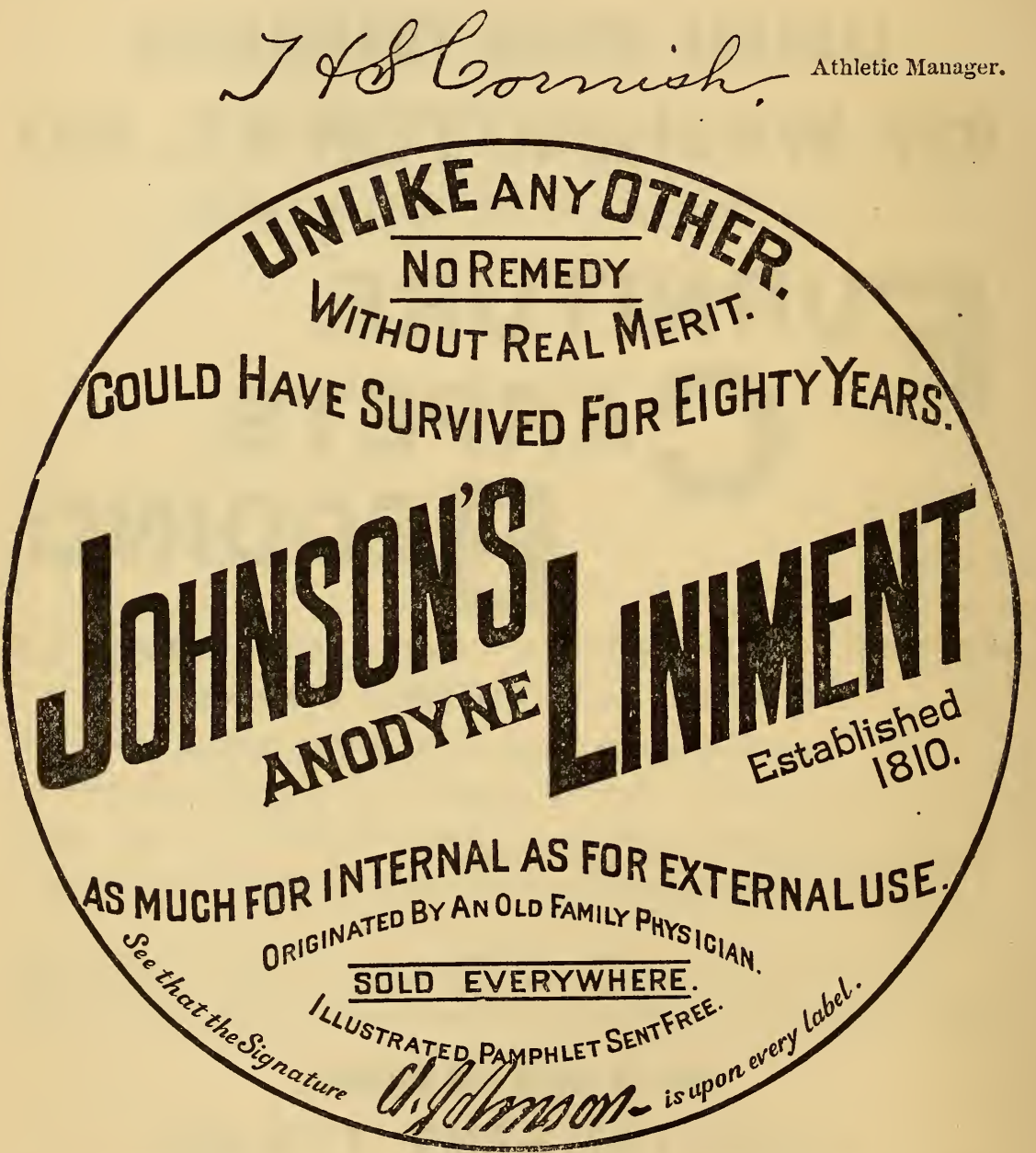

Cures Cramps, Chills, Colic, etc., used Internally.

Why suffer from sore muscles? Johnson's Anodyne Liniment makes them pliable.

A STRAICHT TIP FOR ATHLETES.

Every Bruise, Burn, Cut, Sore Muscle, Stiff Joint or Strain, flees from Johnson's Anodyne Liniment as from a wrath to come. Sold by all Druggists. Price 35 cents per bottle. Six bottles, $\$ 2.00$. Every traveler should have a bottle of it in his satchel; acts promptly; always ready to use; Soothing; Healing; Penetrating. 1. S. JOHNSON \& CO., 22 Custom House St., Boston, Mass. 


\title{
HISTORY
}

\author{
OF THE
}

\section{TOWNS AND CITIES OF THE OLD COLONY RAILROAD.}

\author{
PART TWO.
}

$I^{1}$

$\mathrm{T}$ is an undeniable fact that there is not another system of railroads in this country, if in the world, so entirely unique in all respects as the Old Colony. It has but eleven miles of main line, the balance of its extensive mileage being made up of branches, which, as the reader of the preceding pages will notice, have been acquired from time to time since the inception of the enterprise in I 844. This main line only extends from Boston to South Braintree, and is a four-track road. After leaving this point the branches extend in all directions at various distances along the route, until no town or hamlet in southeastern Massachusetts is left out of the system and scarcely a rod of historic ground uncovered. Leaving Boston at the Kneeland street station, the traveller gets a view of the historic Dorchester Heights and Bay, and the islands in their neighborhoods and waters; the Quincy, Blue Hill, Braintree, Weymouth and Hingham sections, with ancient Hull and Nantasket Beach ; the famed South Shore, from Cohasset to Duxbury, including the Scituate and Marshfield cliffs and beaches and the old home of Daniel Webster; Plymouth, the Mecca of the people of the United States; Cape Cod, picturesque and wonderful in its surroundings and traditions; the far-famed islands of Nantucket and Martha's Vineyard; the Buzzard's and Onset Bay shores, with the beautiful group of the Elizabethan Islands contiguous; Marion, Mattapoisett, Fairhaven and New Bedford. Starting from the Park Square station across to Providence, and from this line southward, 
every place of importance is touched in the states of Massachusetts and Rhode Island. With its adjuncts and auxiliary steamboat lines the Old Colony system comprehends everything of historic interest and all the popular summer resorts included in the broad section lying between the Atlantic coast on the east and Mount Hope and Narragansett on the west, including the Old Colony territory and that almost equally historic area of country lying adjacent ; in fact, it is the only public means of transportation in the sections named, and it ministers with the utmost adequacy of provision to every part.

Not only is this great corporation zealous in the matter of increasing the efficiency of its service, but it aims in every way to make its roads and stations attractive to its patrons. Who would have thought a few decades ago of associating lawns and shrubbery and flower-beds with the ugly cinder-strewn railroad tracks, stretching across the country like long, black serpents, bordered at intervals by shabby station buildings, with nothing to break the monotony of the view from the car window save what kind-hearted nature provided in the way of scenery? Who would have dreamed of railroads hiring skilled gardeners to turn every spare patch of earth into a thing of beauty, establishing conservatories for the cultivation of flowers, and placing their laborers at the service of the floriculturist? Yet all of this has come to pass. The Old Colony Road took the initial steps. For ten years past George A. Parker has been its head gardener, with nothing to do but to study out ways and means of rendering the road beautiful. He has from five to fifteen men, according to the season, to assist him. Should he need carloads of loam, the section train forthwith brings it. If an exceptionally heavy piece of grading is to be done the section gang lends him its assistance. Right in the heart of the city, along the Providence division, probably as unpromising a spot as could be found, a mile of flower-beds has been planted. Even the grimy shops are surrounded by well kept lawns dotted with flowers. As far out as South Braintree most of the stations have received the gardener's attention. At Middleboro the floral features are of an elaborate character; at Neponset finest effects in floriculture are to be seen. The South Boston station has been made a veritable gem. The nursery at Halifax has been liberally provided with every requisite 
for the work of the gardener. The prospects are that in the near future the once generally accepted idea of a railroad station - that it was a dull, dreary, smoke-begrimed spot, will have given place to a conception as pleasant to think of as a vine-clad cottage where roses bloom and violets scent the air.

Plans now matured for improvements in the passenger service of the Old Co'sny Railroad contemplate an expenditure of nearly a million dollars. All the grade crossings will eventually be abolished and the freight department will be removed from the city proper to South Boston, which will make ample room for passenger accommodations at the former place. 


\section{L. \\ RICHMOND \& CO.} DEALERS IN

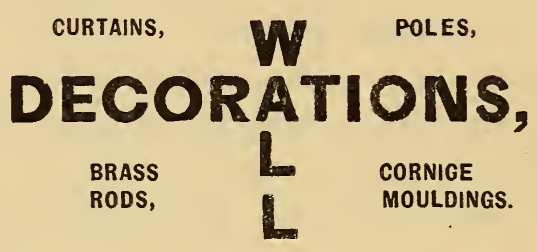

ARTISTS' MATERIALS.

PAINTS, OILS, VARNISHES, BRUSHES, WINDOW AND PICTURE GLASS.

SPECIALTIES: Chemicals, Sponges, Chamois, Dasters and Shoe Finishers' Sapplies. $\quad \therefore \quad \therefore \quad \therefore \quad \therefore$

TELEPHONE No. III-2,

Outside and Inside Painting, Paper Hanging and Kalsomining.

Particular Attention to INTERIOR DECORATING AND HARD WOOD FINISHING.

Contracts taken for Furnishing Houses Complete

EXPERT WORKMEN IN ALL BRANCHES.

$\cong$ WHOLESALE DEALERS IN $\triangle A B \sim$

\section{PAINTS, DRUGS \\ CHEMICALS,}

GLASS, BRUSHES ano DRY COLORS.

56 and 62 SCHOOL STREET, \& 9 LINCOLN STREET, opp. City Hall, 


\section{B ROCKTON.}

HIS is the only city in Plymouth county, and is distant from Boston 20 miles. It is famous for the extent of its shoe manufacturing industry, 97 factories being located within the city limits, the products of which enjoy an almost world-wide reputation for excellence of quality or for some strongly marked characteristic in the manner of construction. This business was founded in Brockton by Micah Faxon, who came from Randolph in the year I8II, and commenced operations on a naturally limited scale, no doubt little thinking at the time that 7 I years would find a city on the spot where he began, and an annual output of boots and shoes closely approximating $\$ 20$,$\infty, 0,000$ in value. It was not until ten years after the arrival of this pioneer in the shoe industry that the place where he settled arose to the dignity of a town, being incorporated June I 5,1821 , as North Bridgewater, the population then being 1480. A post office was first established here in 1815 ; the railroad was built in 1846 , and ten years later the telegraph followed. It was authorized to change its name on March 28, 1874, and on May 5 th following adopted Brockton as the new name. In 1875 part of the town was annexed to South Abington (now Whitman), and parts of the same and of East Bridgewater were annexed to Brockton. The act of incorporation as a city was passed April 9, I88I, and was accepted May 23 of the same year.

Brockton occupies the northwest extremity of Plymouth county, and has Stoughton, Avon and Holbrook on the north, Abington, Whitman and East Bridgewater on the east, West Bridgewater on the south and Easton on the west. The Old Colony railroad has a fine station at Brockton (centre), one at Montello, two miles north; and another at Campello, one mile south of the central station, the latter being a most convenient and perfect structure, and though highly ornamented there is no waste of room. Built of carefully selected red brick, with artistically arranged stone trimmings, the aim of the architect was evidently to combine the utmost solidity with rare grace of outline, and in these respects he was eminently successful.

The districts of the city are known as Brockton, Campello and Montello; the first and third having post offices. The central portion of the territory is quite level, but rises on the east in Carey's and Tower's hills, from both of which there is a pleasing view of the city proper. Toward the northwest is Prospect Hill and an eminence at West Shores, commanding one of the finest inland prospects in the country. The geological basis is sienite. "The most elegant specimen of porphyritic sienite that 1 have met with in the state, "said 


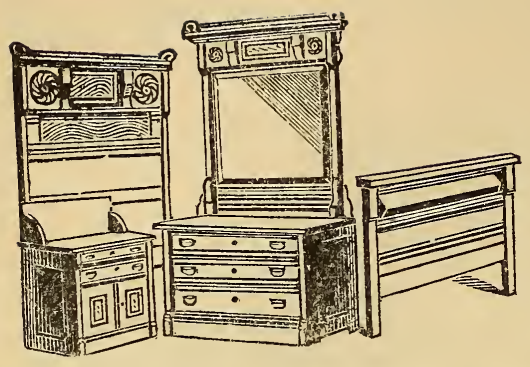

GUY'S FURNITURE MFG. CO,

Brockton, Mass.

n n n

Large Assortment, * * Reliable Goods, Honest Dealing, *

Easy Terms.

E. S. MELLEN. S. FRANKLIN PACKARD.

LUCIUS LEACH.

FRANK E. PACKARD.

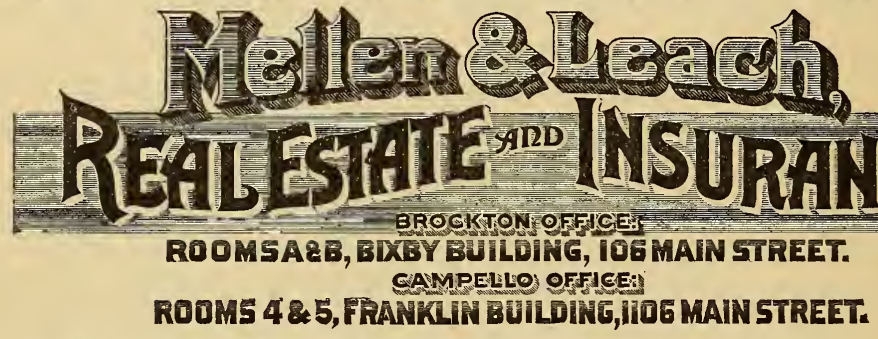

Real Estate of every description bought and sold for cash or on commission.

The settlement of estates and management of business property and tenements for residents and non-residents a specialty. Collections promptly made and statements rendered monthly. Loans Negotiated on Real Estate Security. Insurance effected in reliable companies.

\section{\% AMERICAN HEELING MACHINE C0,}

Brockton, Mass.

\section{The Only Machine Heeling Shoes on the Last.}

* * Forty Machines in use in Brockton. * * $\rightarrow$ Price of Outfit Complete, \$250.00.

GEO. E. KEITH, President,

W. T. COPELAND, Treasurer,

J. H. POPE, Superintendent.

\section{* * J. S. SARGENT\& SON, * * Builders' Hardware.}

Fine Cutlery, Mechanics' Tools, Shoe Tools and Findings, Paints, Oils, Varnishes, Brushes. Farming Tools and Seeds.

* Sole Agents for ENGLISH TINTED LEAD. * 83 Main St., - Lyman Block, - Brockton. 
Prof. Edward Hitchcock, "occurs in North Bridgewater (now Brockton) and in Abington and in other parts of Plymouth county. Its base consists of quartz and felspar, with an abundance of epidote, disseminated and in veins" Peat is also found in several places. Territorially, its greatest length is about one and a half miles from east to west, and five miles from north to south. The assessed area is 10,948 acres, and of this 2,965 are woodland.

The United States census of 1890 , a bulletin of which concerning the industries of Brockton was issued on the Ioth day of November. I892, gives the latest authentic information in relation thereto. In this the number of industries is given as 64, and the number of establishments as 530; capital invested, $\$ 7,533,399$; hands employed, II I II ; wages paid, $\$ 6,566,314$; cost of materials used, $\$ 1 \mathrm{I}, \mathrm{I} 57,552$; value of products $\$ 20,944,705$. The population of the city, according to the above census, is 27,294. A study of these figures reveals some very interesting facts, which may be summarized as follows : Making a fair allowance for the numbers engaged in the various professions, these show that fully 75 per cent. of the population are connected with the manufacturing establishments in one capacity or another, representing a greater number of active workers than any other city alung the lines of railroad with which our work is directly concerned, and, it would be safe to say, exceeding any other municipality in this respect in the United States. The figures also indicate a concentration of industries, which, while not uncommon to New England towns, exist in this thriving city to a greater degree than almost anywhere else, 64 representing the diversity of manufactures in the 530 establishments reported to the census bureau. The wages paid to the employees of these manufactories is a fraction over $\$ 580.40$ each annually, which is a fair income to adult wage earners when due allowance is made for the number of minors and those who are not employed in departments where skill is a requisite.

The city presents many features not common to New England towns. Its people are full of push and enterprise and fully alive to everything calculated in any way to advance the interests of the place. Everybody seems to be stirring and wide awake, and these traits account for its unexampled growth and prosperity. It has fine schools, churches of all denominations, gas and electric lights, an electric street railway extending to the village of Holbrook ; national, savings and co-operative banks; effective fire and police departments; its hotel accommodations second to no city of its size in this country, while its stores, manufactories and public institutions of all kinds are of the most modern type. The citizens of Brockton are also proverbial for the possession of more than the ordinary share of intellectual as well as the solid business abilities necessary to promote the welfare of a city. Swedish immigrants have settled in the place in successive companies for a score of years past, and now form a large, orderly and thrifty part of the community.

The city is noted for its annual fairs, or cattle shows, and the crowds yearly attracted by these exhibitions are simply enormous. Not only do people from the agricultural districts attend them, but extra trains are run from all the surrounding cities, including Boston, so great has become the interest in 


\section{Bay State Carpet Company,}

G. C. LOVELL, Proprietor.

* * Carpets, Rugs, Mats, Etc., * * BAY STATE BLOCK.

53 AND 55 CENTRE STREET, BROCKTON.

\section{WM. A. SWEETSER,}

MANUFACTURER OF

TACK, * SHOE * NAIL, * AND * WIRE * NAIL * MACHINERY, Engines, Boilers, Pumps, \&c., Shoe Machinery, *** *

ShAFTING, HANGERS, PULLEYS, BELTING, \&C.

Special Attention given to Fitting up Shoe Shops and General Repairs.

GOOD WORK.

39 Montello St., Brockton, Mass.

FAIR PRICES.

\section{E. H. REYNOLDS, \\ Fine

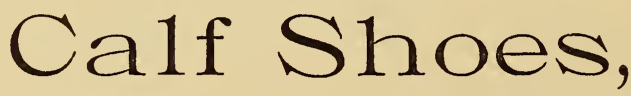 \\ MANUFACTURER OF}

MACHINE SEWED, HAND SEWED,
HAND WELT AND' STANDARD NAILED. * * BROCKTON, MASS,

\section{M. REYNOLDS \& CO.,}

MANUFACTURERS OF

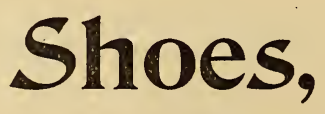

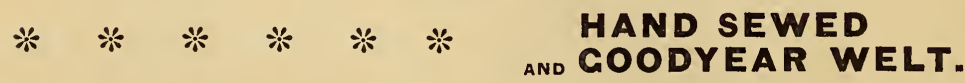

91 BOSTON OFFICE,

BROCKTON, MASS. 
these displays of the manufactures and husbandry of the county. The society under whose auspices these exhibitions are given is composed principally of Brockton's most active business men, and the liberality of its premium list and the diversified character of the program offered make these annual fairs red letter days in the history of the town.

Another feature characteristic of Brockton is the general air of comfort observable upon every hand. There are no extremes of wealth or poverty noticeable in its make-up, but all seem to be in the full enjoyment of those blessings which come of industry, frugality and economy. There are many handsome residences, of course, but none of them bear the impress of the lavish or foolish expenditure of the wealthy snobocrat, nor ape the architecture of feudal lords in their exteriors. In short, Brockton seems blessed with homes for all classes of its population, and this fact at once strikes the least observing person. There are many fine drives about the city, and everything seems well calculated to make life agreeable to the man of business or leisure.

\section{MONTELLO.}

This suburb of the city of Brockton, to which we have before incidentally referred, while largely interested in the shoe industry, is surrounded by a rich and well tilled agricultural country, and considerable attention is giren to greneral farming. The thickly populated portion of Montello is on high ground, and the sanitary conditions, both as to water and drainage, are excellent. It is only one and a-half miles from the centre of the city, with which it is connected by both steam and electric railways. The accommodations for summer visitors are excellent, and the place is a most desirable one for permanent homes. The Old Colony Railroad has a handsome passenger station at Montello, and the train service consists of seven or eight trains a day, to and from Boston.

\section{CAMPELLO.}

This is the southernmost section of the city and contains about one-fourth of its population. Shoe manufacturing is extensively carried on here, and all business is thriving. It has good hotel accommodations, several large boarding houses and a co-operative bank. It is connected with the central portion of Brockton by both steam and electric roads, and its close promixity to the centre makes it a most desirable location for residence. Campello is growing rapidly and real estate is yearly appreciating in value.

Our sketch of this thriving city would not be complete without brief reference to those who have so largely contributed to its growth, and who, by their progressive and enterprising traits of character, are still active in the work of placing Brockton in the front rank of New England's industrial cities. What follows in regard to these representative people will not only be found 


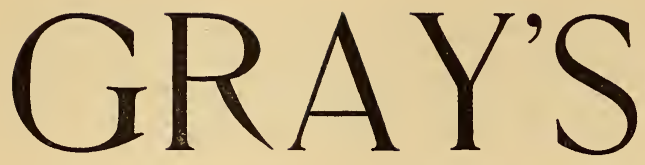

\title{
Boot and Shoe
}

\section{Patterns for 1893.}

STYLE AND PERFECT GRADES GUARANTEED.
米

WILL PLEASE THE TRADE.

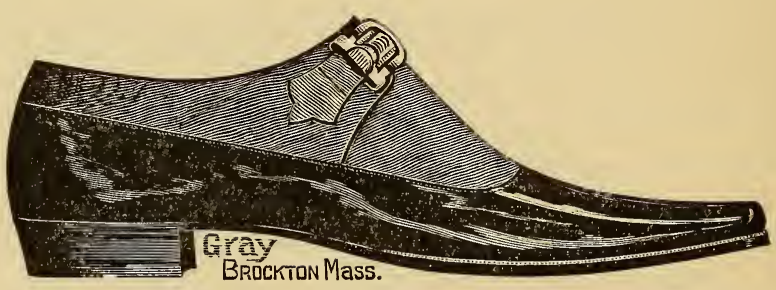

Long experience and study en- \#I bring out leading and novel ables me to produce the best results. ${ }^{*}$ designs in sample shoes made up.

\author{
MANUFACTURERS ARE INVITED TO CALL \\ AND SEE THEM AT OUR OFFICE.
}

\section{W. H. GRAY,}

Up One Flight. Telephone 80-2.
I26 Main St., Brockton. 
instructive, but will serve to give a clearer idea of the busy town than could well be incorporated in a general article on the subject.

The Hub Gore Makers of this city and of 91 Bedford street, Boston, are famous for the inrention of the "Hub Gore." This shoe-elastic is made only for fine Congress shoes. Every piece is dated at the factory when made and issued for one and one-half years. The sales of the " Irub Gore" in this country are laryer than the combined sales of all other fine gores, domestic and foreign. The company owns a large establishment in this city, which is equipped with the latest improvements in machinery. They also own and operate the Hub Gore Mills at Chelsea, Mass., and Camden, N. J. The concern was established in I882, with Albert Herbert as president; E. B. Page, treasurer; and William Rapp, director. An original label is used by them, the trade mark being in shape of a heart, and inside of all insured shoes will be found stamped upon the elastic gore this dated heart trade mark; and without this trade mark none are genuine.

The Columbian Manufacturing Company is composed of many influential men; W. W. Cross being president; F. S. Thomas, treasurer; C. C. Merritt, vice-president and general manager; and C. H. Emerson, assistant manager and general sales agent. The work which is produced by this company here in large quantities aunually, consist in the manufacture of the celebrated Pearsall patent variable hose nozzle, improved pipe wrenches, fine door knobs and other specialties. The spacious factory is conveniently located in the rapidly growing section of Brockton, known as Montello. A competent force of hands find steady employment here, as the goods manufactured by this company are of a superior quality and are in universal demand.

The American Heeling Machine Company, situated 64 and 66 Railroad avenue, is noted for the invention and manufacturing of a wonderful muchine, called the heeling machine. It is a great time saver, in attaching heels to boots or shoes. The machine is capable of attaching heels to twelve or fifteen hundred pairs of shoes a day. This company has a trade which extends all over this country, and to several parts of England, Scotland Sweden, and Switzerland. The president of this machine company is Geo. E. Keith, Warren T. Copeland acting as treasurer, and J. H. Pope being superintendent.

Geo. E. Keith, manufacturer of boots and shoes, commeneed business here in 1874 , and at the present time has the largest factory in Brockton. In the medium grades of men's, boys' and youths' shoes, ranging in price from $\$ 2.00$ to $\$ 5.00$, nearly $1, \infty 00,000$ pairs were made during the last year for the retail trade. The Boston office is located at 56 Lincoln street.

Terry, Ware \& Alley hold a prominent place as manufacturers of men's, boys' and youths' boots and shoes. Their facilities for getting up these grades of shoes are among the very best. They have a sufficient force of skilled workmen, and their factory contains every modern improvement to facilitate the work in hand. The members of the firm are all gentlemen of practical exper- 


\section{RALPH R. LITTLEFIELD,}

MANUFACTURER OF

\section{$\rightarrow \mathbb{C}$ MEN'S \& BOYS' FINE SHOES.}

Machine Sewed and Goodyear Welt. ***

BOSTON OFFICE, 280 DEVONSHIRE ST.

Brockton, Mass.

N. A. W. Ransden, Shoe Stitcher and Shawl Strap Manufacturer,

* 78 Railroad Ave., Brockton, Mass.

*

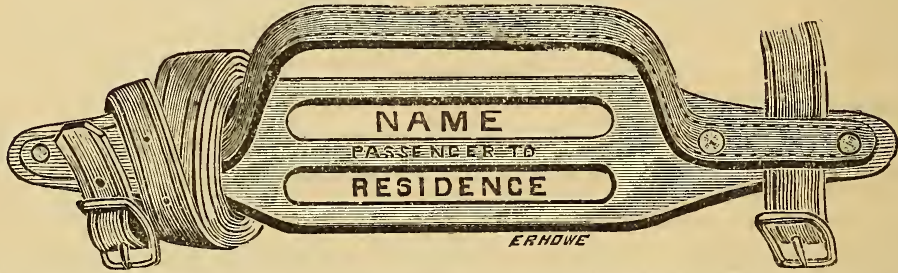

The above cut represents our Patent Shawl Strap, with Metal Base and Handle. They are made of Orange Leather, 5-8 in. wide and 40 in. long. We also manufacture Shoulder Straps. Price, $\$ 2.25$ per dozen. Sole manufacturer for Mass.

: ANDREW F. PACKARD, :

\section{CALFOR KIP SKIRTING. $*$ * *}

FINISHED IN ANY DESIRED MANNER.

Also Machine Pebbling

PRICES AND QUALITY OF WORK GUARANTEED.

ON SHOE TOPS, FOXINGS, TIPS, QUARTERS OR VAMPS.

Shop 24 R. R. Avenue, near the depot, - BROCKTON, MASS.

\section{E. JOHNSON \& CO.,}

DEALERS IN

\section{SOLE * LEATHER * REMNANTS.}

Washer Stock, Cut Lifts, Top Pieces, and Picker Stock.

62 Railroad Ave.s

Brockton, Mass. 
rence and well known to the trade. The Boston office is at 29I Devonshire street.

Guy's Furniture Manufacturing Company is among Brockton's prominent industrial houses, One of its stores is at 59 and 6I Centre street, and the other extending from 52 to 60 Church street. An increasing business, a good reputation, and many other good qualities distinguish this company from many other business houses. The stores of this company contain every thing needed for house keeping, and all the latest novelties, in artistic style and finish, while a full line of carpets are sold at lowest prices, for cash or weekly payments.

Johnson \& Porter are well known as the manufacturers of Johnson's Patent Grooving Attachment, for fair stitch, harness and other machınes. It is manufactured and for sale by the above firm, who are located at 65 Centre street. This attachment cuts a groove to receive the loop, or chain, at the time the stitch is formed by single thread machines. It derives its cutting motion from the rise of the needle bar, and while the feed or needle post is stationery, thereby avoiding all interference with the feeding of the work. On fair stitch work it not only saves cutting off the loop, but makes quite a saving in the quantity of thread used. It also prevents the stitches from loosening and the edge of the shoe from checking. It assists the operator in guiding the work, and also in obtaining more uniform stitches. Besides using this to good advantage in stitching soles to welts, this attachment can also be applied to the National, Nason, and New England machines.

W. H. Gray has won an influential and extensive patronage from shoe manfacturers in all parts of New England through the merits of his boot and shoe patterns; and his patterns for 1893 will meet the approval of the trade. Mr. Gray has had long experience in the business, which enables him to produce the best results. He is located at I 26 Main street, and occupies one floor of a large building.

Baxendale \& Co., who were established in business here in 1872 , are the pioneers in the manufacture of box-toes in leather and leather board for ladies and gents wear in all styles. New customers are yearly added to their lists, so that the box-toe business of Baxendale \& Co. is not only a representative business of Brockton but of the whole country. Mr. Baxendale has for many years been closely identified with many of the interests of this enterprising city. His factory is only a short distance from the Old Colony station situated corner of Centre and Montello streets.

Emery \& Packard, at No. I07 Main street, are dealers in all kinds of sole leather, inner soling, heeling and welting. This firm each year is increasing their facilities, until at the present time they have a large and flourishing trade. The materials are procured in large quantities, while the advantages possessed by the firm. to fill all orders promptly and satisfactory, render them desirable parties to trade with. Their place of business is located at 63 and 65 Franklin street, Brockton.

Mellen \& Leach, at Io6 Main street, Brockton, and I I06 Main street, Campello, were established in 1885 , and the amount of business transacted, since 


\title{
GEO. KNIGHT \& CO.,
}

\author{
MANUFACTURERS AND DEALERS IN
}

\section{SHOE MACHINERY OF EVERY DESCRITIION}

50 Montello St., Opp. Ward St., Brockton, Mass. WRITE FOR PRICES. TELEPHONE NO. 85-2.

Prestõn B. Keith, Manofactarer of *Boots \& Shoes. CAMPELLO, MASS.

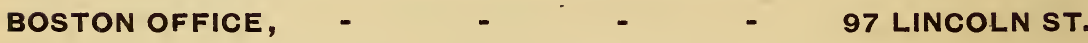

\section{Ellis F. Copeland,}

MANUHACTURER OF

* MEN'S * CUSTOM * SHOES. *

FOR FINE RETAIL TRADE.

Brockton, Mass.

$$
\text { GEO. A. CAR'TER, }
$$

MANUFACTURER OF

\section{TACKS AND SHOE NAILS}

Office and Factory, 41 Maple Ave.

TELEPHONE 103-4.

BROCKTON. MASS. 
that time, and the honorable methods employed by them, is not only a credit to these men, but also to the city in which they hold forth. In addition to the handling of real estate in the way of buying and selling, settlement of estates, collecting of rents and negotiating loans, they do a thriving insurance business, insuring both life and property.

Wendell Leach \& Co., of 50 Montello street, this city, are well known as manufacturers of men's and boys' Goodyear welts. They also turn out in their well equipped factory a splendid line of machine-sewed goods in all the latest styles. This firm is worthy the patronage they are receiving.

T. A. Baxendale, of the firm of Baxendale \& Co,, box-toe manufacturers of this place, has also another large interest on the line of the Old Colony Road in the shape of a twelve-acre island at Cataumet, which he has recently purchased and commenced improving, having already connected it with the main land by a carriage bridge 250 feet in length; driven a fine artesian well; made a careful survey; laying this beautiful spot out into large choice lots, all with fine shore fronts. This island is the gem of Buzzard's Bay, being a succession of bold wooded bluffs and hills, from which the view is magniticent, while its near accessibility, being only ten minutes walk from Cataumet station, greatly enhances its value. Cataumet lies on the Woods Holl branch of the Old Colony some ten miles below the Buzzard's Bay station.

A. P. Reynolds, proprietor of the Brockton Steam Laundry, came into possession of his business in I 886, having been employed by the former owner, M. B. Sumner, about twelve years previously, so that Mr. Reynolds has had over seventeen years' experience in this business, and is consequently well fitted to carry on the largest laundry establishment in this city. The premises occupied by him as a laundry, consist of the two-story frame building at 20 Perkins street, where he is supplied with steam power and all the latest machinery. His office is located at 20 East Elm street. This establishment, which has spared nothing to improve the reliability and efficiency of its laundry, has gained the confidence of the public in a marked and unusual degree.

Andrew F. Packard stands among the leaders in the art of coloring calf and kip skirting, also machine pebbling on shoe tops, foxings, tips, quarters or vamps, which are finished in any quality desired. Having skilled workmen in his employ, Mr. Packard guarantees his work to be of the best. His shop is located at 24 Railroad avenue.

Sargent, Anglim \& Keith, who are located at 106 Main street, are the special agents for the Provident Savings Life, of New York. They also take risks on fire and accidents, and do considerable business in real estate. Though only having been in this business since 1889 , they have acquired a large and flourishing patronage, and number among their policy holders some of Brockton's stanchest citizens, and largest property owners. Mr. Keith, the junior member of this firm, is a resident of the town of East Bridgewater. Their agency covers the entire section of southeastern Massachusetts; they also have an office in Boston at 178 Devonshire street. 


\section{ROBERT CLIFFORD \& CO.}

Crimping, Stamping * Perforating, Pinking and Scotching. and Cording.

NO. 65 CENTRE STREET, BROCKTON, MASS.

TAUNTON LUMBER COMPANY,

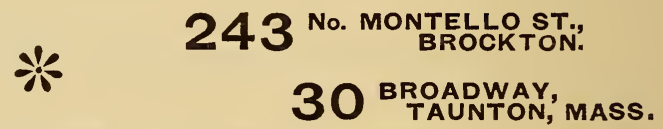

Wholesale and Retail Dealers in

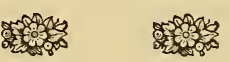

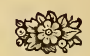 \\ ractions}

We ship direct to any point in New England.

Quotations Cheerfully Given. WM.' H. LEWIS, MANAGER.

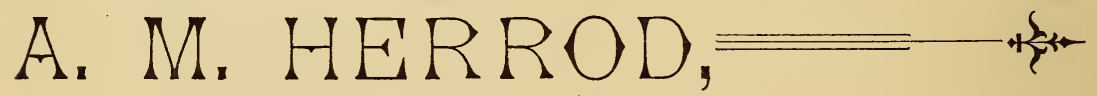
- Maniffactúker of . .

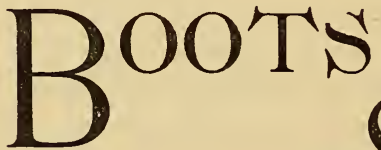

AND

BROCKTON, MASS.

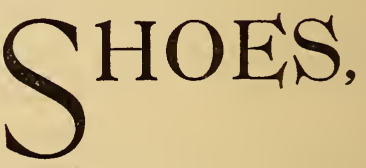

FRANK E. WHITE, * * *

MANUFACTURER OF FINE

Calf, Buff and

Flesh Split Shoes,

Boston Office, 133 Summer St. Brockton, Mass. 
Goddard \& Rogers, who are located at 254 Montello Street, make a sptcialty of general machine jobbing, experimental machines, and patent office models. They are sole manufacturers of the Danion Standard Hollow Auger, used by carriage makers. The excellent reputation that this firm has built up, is due to their pains-taking care that every piece of machinery which is manufactured by them, is the best that can be produced.

Kimball Bros. \& Co., who were established in I867, with E. A. Kimball and J. E. Kimball as partners, for the manufacture of improved tack and nail machinery is another well known firm. In 1875 the partnership was dissolved, and a little later E. A. Kimball went to Cleveland as superintendent of the tack and nail department of the Union Screw Company of that city, and J. E. Kimball began the manufacture of machinery for the Clinching Screw Company of Boston, a corporation organized under patents obtained by Mr. Kimball for the manufacture of nail-making and nail-driving machines. $\mathrm{Mr}$. Kimball invented the entire plant of this company. He continued making all the machinery for this company from 1879 to 1888. About four years ago, $\mathrm{Mr}$. Kimball made another change in his business, and again his brother, E. A. Kimball became a partner in the concern, but at the present time J. E. Kimball is the proprietor of the business. The house claims to have the finest plant of machinery in the city of Brockton. They utilize five thousand feet of floor room and ten expert machinists are employed.

L. Richmond \& Co., about fifty years ago, becane established at 56 and 62 School and 9 Lincoln streets, this city. They are engaged as dealers in paper hangings, curtains, and cornice mouldings, artists' materials, wholesale and retail dealers in paints, oils, varnishes, brushes, window and picture glass. A specialty is made of chemicals, sponges, chamois dusters, and shoe finishers' supplies. This is one of the oldest and nost prominent establishments in Brockton.

Chas. S. Pierce, in 1875 , commenced business in this city, with E. S. Maloon, and later, in $\mathrm{I} 887$, he bought out Mr. Maloon's interest. His factory is situated at 254 Montello street, and is devoted to the manufacture of ladies' patent calf and split shoe tips. One hundred and twenty toe cap machines are in operation in the factory, making tips for both men and women's shoes. A specialty is made of tine machine crimping. Mr. Pierce gives his careful and personal attention to all orders.

J. S. Sargent \& Son are doing an extensive business as dealers in hardware, fine cutlery and tools, paints, varnishes and window glass. Their store is located at 83 Main street in a massive structure known as the Lyman. Block. It is handsomely fitted out with every convenience, and a full line of goods of all grades, from the finest to the most ordinary, is kept constantly on hand.

A. M. Herrod carries on one of the largest shoe factories in the city of Brockton. His work consists in the manufacture of boots and shoes of medium grade for the wholesale trade. The factory was established in 1872 ; it is located at Montello, at 756 North Main street, and is equipped with all modern appliances. Mr. Helrod, the manager and proprietor, is a gentleman of ambi- 


\section{HURAM WADE,}

Lamps, Chandeliers, Crockery, and Glass Ware, Flower Pot Brackets, and Fancy Flower Pots, Vases, Cologne Sets, Moustache Cups, Plated Knives, Forks and CHOICE STAPLE spoons.

\section{LYMAN BLOCK, BROCKTON, MASS.}

$\rightarrow$ BROCKTON * BUTTON * HOLE * COMPANY, \&-

$$
\text { W. H. JORDAN, Proprietor, }
$$

65 Centre Street, Brockton.

Machine Made Button Holes Made to Order at Short Notice.

* * W. P. BOSWORTH, * *

DEALER IN

$\rightarrow$ SOLE $*$ LEHTHER $*$ REMnTHTS, $\rightarrow$

Top Lifts, and Under Lifts Cut to Order.

Washers, Rands and Top. Lifts Stock Bought and Sold.

30 Linden Street,

Brockton, Mass.

\section{BION F. REYNOLDS,}

\section{Hand Sewed and Goodyearr Welt Men's Shoes,}

Specialties The Bion Shoe for Gentlemen.

Brockton, Mass.

BOSTON OFFICE, 302 DEVONSHIRE ST., WITH JAY B. REYNOLDS. 
tion and energy. He is well known in business circles, and gives special attention to the orders of his numerous customers.

S. H. Nichols is well known as the manufacturer of skiving knives. Besides the manufacture of the above line of goods he also manufactures and deals in new and second-hand machinery for the boot and shoe trade. His factory is equipped with steam power, and all modern improvements, and a full force of experienced workmen is employed. His office and factory are at 65 Franklin street.

Frank E. White stands very high as a manufacturer of fine calf, buff and flesh split shoes which are sold to a jobbing trade. The long experience of Mr. White in the business, enables him to meet the demands of his patrons. Always using the best grades of stock in the manufacture of his goods, he has been able to build up a trade which is most gratifying. He has a Boston office at No. I33 Summer street.

Smith \& Wade's is another well known establishment of Brockton. It is conveniently located at II9 North Main street, and a number of experienced hands are engaged as assistants to carry on the work, which is produced in large quantities annually. It consists in the manufacture of patent piping, seam stays and bindings. They are also engaged as dealers in a general line of shoe manufacturing goods, paper, twine and glue. Their goods are sold to a New England and western trade.

N. R. Packard, as a boot and shoe manufacturer, ranks among the leaders of this industry. Mr. Packard has been established here since 1870. His factory is situated at the corner of Centre and Montello streets, next to the Old Colony Railroad station. Here we find a line of hand sewed, Goodyear-welts, machine sewed and standard screw, in all the leading styles. Mr. Packard has the reputation of making shoes fully up to samples and consequently has built up a large trade among the jobbing houses of New England and the west.

George A: Carter has, for the past number of years, been engaged in the manufacture of steel, copper, iron and zinc shoe tacks and shoe nails, McKay and Bigelow machine nails, Hungarian hob and shank nails, copper tacks. brush, gimp and shoe tacks, polished carpet tacks, brads, channel, cigar-box and chain nails, upholsterers' nails, etc. His factory is located at II I Maple avenue, and here we find Mr. Carter busily at work, catering to the wants of his numerous customers. His goods are sold all over the United States and Canada, and are shipped also to Europe.

Preston B. Keith has been established in business since I $87 \mathrm{r}$, and since that time has never known anything but success and prosperity. The premises are confined to a three-story factory, where on an average of twenty-seven hundred pairs of shoes a day are produced. The factory is equipped with all the latest improved machinery, and the people who are employed here, are all experienced. The goods manufactured are of medium grade, machine sewed and standard screw. These goods are made for the jobbing trade in Boston and suburbs. A Boston office is located at 97 Lincoln street. 


\section{MITCHELL \& CO, $\%$ I. MITCHELL \& CO, * Lumber $*$ W W PROMPT AND FAIR TREATMENT. Dealers. \\ HARDWARE.}

338 MONTELLO STREET, * BROCKTON.

We Make a Specialty of

\section{Granite Monumental Work, \\ FRED HANSON,}

81 Railroad Ave., Brockton.

I. P. GAYNER.

E. W. WALKER.

$\rightarrow$ Glanville and California Stay.

BROCKTON STAY COMPANY,

MANUFACTURERS OF

SFIV STAYS Piping \& Lace Fronts, Cork Sole WeltsSEAll SIA N, Bindings \& Welting, Drill Stay. *

Factory at Brockton, Mass.

$$
\text { J. C. TANNATT, }
$$

MANUFACTURER OF

GENTLEMEN'S FINE and MEDIUM SHOES,

Machine Sewed and Hand Welt.

$\rightarrow \quad$ Brockton, Mass. 
Huram Wade started in business here in 1872 , but the present building he occupies was erected in 1876 . He carries a full line of groceries, crockery and glass ware, china ware, lamps and chandeliers, etc. 'The business of the house has steadily increased, it being a most desirable place to buy goods.

Whitman \& Keith and Walker \& Whitman are among the numerous boot and shoe establishments which attract our attention. They are engaged as manufacturers for the wholesale and large retail trade; making a fine line of men's shoes in hand sewed and Goodyear welts. The large trade which this firm has built up, all over the country, is due to the careful and undivided attention which they have given to the goods which they manufacture. The Boston office is located at 96 Summer street.

Swasey \& Grew are among the many enterprising firms who carry on a business contingent to the manufacture of boots and shoes here in Brockton. The firm manufacture shoe tools, and their edge-planes, irons, and cutters are superior to any in the market. They are made from the best of English steel by experienced workmen, and are hand made.

Snell \& Atherton, of 72 Snell street, are manufacturers of shoe tools. They were established in 1853 , and have a large force of workmen employed. Their goods combine all the recent improvements and are in great favor all over the United States.

The Bay State Carpet Company, located in the Bay State Block, 53 and 55 Centre street was founded many years ago by G. C. Lovell, and to-day it ranks with the most famous of Brockton's carpet establishments; it being the only exclusive carpet house in the city. Here we find an endless variety of carpets, rugs, and mats in all the latest styles. The store covers a large area, and all goods are as represented or the money is refunded. Mr. Lovell is a gentleman of great business tact and energy, and is well known and respected by the citizens of Brockton.

The Brockton Stay Company was established in 1879 by Gaynor \& Campbell, but in $1881 \mathrm{E}$. W. Walker bought Mr. Campbell's interest. The specialty of this house is the California stay for front and back seams for men's, womens', misses' and children's boots and shoes. This stay has stood the test after years of trial and makes the strongest seam of any now on the market. Their other lines are pipings, both cloth and leather, in all kinds of colors, also folded stay in glove calf, goat, French and Dongola kid, etc. This company are agents for J. R. Leeson \& Co.'s linen thread, and the McKay and Bigelow heeling and McKay Metalic Fastening Associations and the McKay sewing machine.

C. Wakeling is known as a bleacher and colorer of leather, also as a dealer in remnants. Having had a large experience in this line of business, he is fully adapted to meet the wants of his large and increasing business. His factory, located at 78 Railroad arenue, is equipped with all the latest inventions in machinery for producing the best results in the shortest space of time. 


\section{GODDARD \& ROGERS,}

JOBBING, MACHINISTS and ENGINEERS,

Shafting, Hangers, Pulley Belts and Belt Lacings.

- MANUFACTURERS OF-

1000 POUND LIFT POWER ELEVATOR.

Damon Standard Hollow Augers, Spoke and Dowel Trimmers, for Carriage Makers.

254 Montello Street, Brockton.

Estimates Furnished on New Work.

A M. NILES.

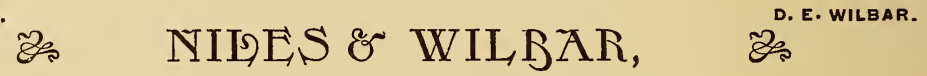

MANUFACTURERS OF

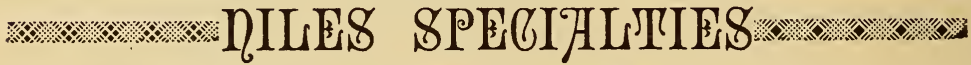

- IN MEN'S SHOES. .

FACTORY, 44 Montello St., Brockton, Mass.

BOSTON OFFICE, 96 1-2 Summer St., Room 23.

A. M. CENTER, Salesman.

CHESTER S. KINGMAN.

WM. P. KINGMAN.

$\rightarrow$ HENRY M. KINGMAN, $3-$

MANUFACTURER OF

\section{¿ MEN'S, BOYS' AND YOUTHS' SHOES. A}

BOSTON OFFICE,

112 SUMMER ST.
FACTORY,

BROCKTON, MASS.
NEW YORK OFFICE, 18 WARREN ST.

WENDELL LEACH.

W. B. ATWOOD.

ШENDELL ФEACH \& CO., MAKERS OF MEN'S AND BOYS'

FINE \& MEDIUM GRADE SHOES. Goodyear Welts a Specialty. 
Burr \& Kingman make a specialty of repairing shoe machinery, bicycles, etc., and are dealers in shafting, hangers and pulleys. The firm make from sampie all kinds of shoe knives and deal in machinery of every description. Their factory is located at 25 High street where all orders are promptly executed.

W. H. Jordan is the proprietor of one of the largest buttonhole manufactories in this state, and which is located in Brockton at $6_{5}$ Centre street. The business has been established for ten years, but for the past three years has been run by the present proprietor. Having a large force of workmen, and all the latest machinery, he is able at short notice to fill all orders no matter how large.

C. E. Johnson \& Co., of 62 Railroad avenue, are dealers in sole leather remnants, top pieces, cut lifts, etc. All materials sold by them are of the best quality. The firm being well-established it is consequently known to all of the principal buyers in this line of goods of which they always carry a full stock.

Willard L. Dunbar \& Co. of Brockton, are among the leading firms who manufacture boot and shoe patterns of every description. Their office is at ro6 Main street, room 32, where they carry on a large and extensive business. They are able to supply the trade in large or small quantities, and their patterns are considered to be among the best in the market.

William M. Thompson's is the oldest fire insurance agency in this city. This house was founded in 1852 by S. A. Hayward, Mr. Thompson becoming his partner in 1873 , and afterwards sole proprietor in 1883 . Some idea of the scope of his business may be derived from the fact that he is agent for some twenty-three companies, and he commands the largest part of the insurance business of this vicinity. Mr. Thompson has resided in Brockton for thirty-five years and is closely identified with its business interests, having assisted a great deal inbuilding up the city. His office is at 286 Main street.

Perkins \& Joyce, engaged in the manufacture of men's fine shoes, in hand sewed, hand welt, Goodyear welt, improved welt, acme welt, and machine sewed, is an old established firm. Their factory, located at $6_{5}$ Centre street, a few steps from the Old Colony Railroad station, covers a large area. It is fitted up with all the latest improved machinery, and gives employment to a large number of workingmen. The members of the firm are well known throughout the country as manufacturers of gents' shoes for the retail trade.

Isam Mitchell \& Co. are dealers in all kinds of lumber, lime, cement, and hardware, and have one of the largest retail stores in this city. The business was established in 1877 by Isam Mitchell, he having previous to that time been a carpenter and builder. His native place is Bridgewater, but he has resided in Brockton for the past twenty years. His son, Herbert I. Mitchell, is the other member of the firm, having been admitted into partnership in 1887 . He graduated from the Brockton High School in I879, and immediately entered his 


\section{N. R. PACKARD \& CO.,}

MANUFACTURERS OF

$\rightarrow$ INIJEN'S AND BOYYS' SHOES. B-

BROCKTON, MASS.

BOSTON OFFICE, 101 BEDFORD ST.

SMITH \& $W A D E$, (Successors to Charles E. Stone,) Manufacturers of

Pipings, Bindings, Seam Stays, Folded and Single Welting,

Folded Stay, Drill Stay, Patent Serated Piping.

Cork Sole Welts, Amazeen Kuives.

117 and 119 No. Main St., - Brockton, Mass., U. S. A.

\section{S. PIERCE,}

MANUEACTURER OP

LADIES' PATENT CALF SHOE TIPS,

I use the famous Cornelius Heyle stock exclusively in my Tips. Factory 254 Montello St., Brockton, Mass.

D. S. PACKARD.

VERANES FILOON.

$$
\text { D. S. PACKARD \& CO., }
$$

BROCKTON. MASS.

BOSTON OFFICE, 138 LINCOLN ST. 
father's employ. They have an immense lumber trade, and carry a large and varied stock with which to meet the demands. 'Their yard has a froritage on Montello street of about 400 feet, and on the Old Colony Railroad of 500 feet. Here is localed their office and storage buildings, stable, etc. The firm employs twenty men and nine horses. Their trade extends all over the city and the surrounding towns.

The Brockton Marble and Granite Works, located at 8r Railroad avenue, formerly at 62 Lincoln street, is one of the oldest establishments of its kind in this part of the state, being founded away back in 1853 , and since its inception it has always done a prosperous business. Mr. Hanson, its present proprietor, succeeded the business in 1875 , and under his management a constant increase in patronage has resulted. A number of skilled hands are employed turning out in the most artistic and elegant designs, marble and granite monuments and headstones, also emblematic work of every description, while work of any style is turned out to order in an excellent manner. Mr. Hanson is an old resident of Brockton, having been here for about forty years.

A. A. Battles is a leading exponent of the book binders' art. His establishment is located at 47 Cuntre street, and is known as the Brockton Book Bindery. Mr. Battles started in business about five years ago in this city and has won for himself a reputation in keeping with the excellent work he turns out. In addition to the legitimate book binding business, he has established here a head quarters for society regalia, jewels, gold and silver trimmings, etc: A specialty is also made of gold lettered badges, and old books are repaired and rebound in a painstaking and thorough manner. A specialty is made of blank books for office use which are well made and strongly bound.

O'Neil \& Howes are engaged in the manufacture of stairs and interior finish. They succeeded to the business of Howard, Clark \& Co., November, 1, I 888. The building which they occupy contains four floors, fifty by fifty feet, fully equipped with all the modern appliances known to the trade, and employment is given to fifteen or more skilled workmen. Before buying out Howard, Clark \& Co., they conducted a stair building business in Thompson's mill, on Railroad avenue, and they now have a large amount of work in this department of their trade. A specialty is made of wood mantles and cutting blocks. Wood carving and designing are done in the most artistic manner. Their work in desk and office furniture is unsurpassed by that of any concern in New England.

Dr. Edward S. Powers, manager of the Brockton Dental Association, is socially and professionally known throughout Brockton, where his skill as a dentist is evident by the large patronage he commands from the best citizens. In July, 1879, he first appeared in Brockton and at once established himself in the high estimation of its people. Ile employs two assistants, one a lady, thus ensuring to his patrons the best of care and professional skill. The operating rooms are localed at 87 Main street and are furuished with the latest improved appliances. The best anæsthetics are employed when desired, aud altogether the establishment is one of perfect appointments. Dr. Powers has also recently 
E. E. SMALL. . . .

UNION MARBLE WORKS,

Marble * and $*$ Granite* Monuments,

TABLETS, HEADSTONES, \&C.

Bettering and Eleaning done in Eemeteries at @bort Potice. NEW DESIGNS CONSTANTLY ON HAND.

514 SO. MAIN ST., BROCKTON, MASS.

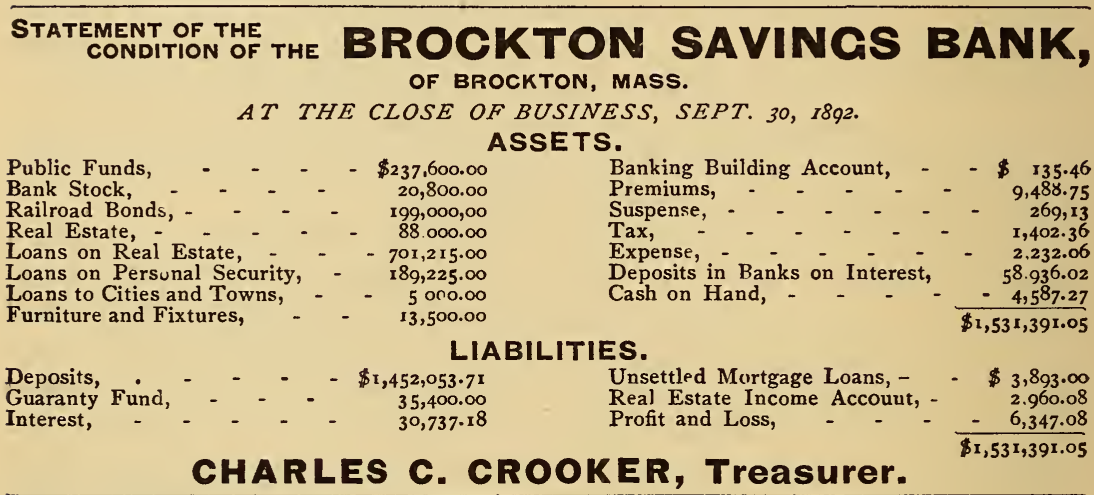

A. C. THOMPSON, 范 and MOULDING MILL,

Brackets, Turning and Jig Sawing, Cutting-blocks Made and Repaired.

RAILROAD AVENUE, opp. the Depot, BROCKTON, MASS.

\section{O'NEIL \& HOWES,}

(Successors to Howard, Chark \& Co.,)

\section{Stair Builderss me Interior Finish Manufacturers.}

CUTTING BLOCKS MADE AND PLAINED.

66 FRANKLIN ST., BROCKTON, MASS. 
become the proprietor of what is known as Smith's vegetable compound, a valuable remedy in the treatment of rheumatism, liver and kidney troubles and blood diseases gen rally. This remedy is in great demand by those who know of its wonderful curative properties, the number of which is increasing every day, as the numerous testimonials he is constantly receiving will testify.

A. C. Thompson, proprieter of the planing and moulding mill on Railroad avenue opposite the depot, is one of Brockton's enterprising men, and does a flourishing busiress in the manufacture of builders' finishings, besides which he does a general line of jig sawing and turning, also makes and repairs cutting blocks and such other kinds of work as may come within his line of business. He established himself here in 1873 and at present occupies several frame buildings of various sizes where he employs about ten men. Mr. Thompson is a trained, practical man, well acquainted with his business in all its details.

Hon. Ziba C. Keith is one of Brockton's most prominent citizens. That he is popular, is attested by the fact of his election to the office of chief magistrate of his native city. He attended the schools in his native town, completing his education at Pierce Academy in Middleboro. After leaving school he entered the employ of his brother in the shoe manufacturing business, and afterwards, in 1863, opened a dry goods and grocery store; which after some years of successful operation he sold out in 1882 , when he was elected the first mayor of the new city of Brockton, which office he continued to hold in r884 and I885, and was again elected in $189 \mathrm{r}$. In addition to this office, he has represented the t'wn in the legislature, served on the board of selectmen, and has been collector of taxes. He is a director in the Brockton National Bank, vice-president of the Brockton Savings Bank, and was for a time treasurer of the Brockton Street Railivay Company, and treasurer of the Campello Co-operative Bank, which institution he was largely instrumental in organizing. He is a member of the various masonic orders, and is organist of the South Congregational Church. He is now in the prime of life, being tifty years of age, and a gentleman to whom the citizens of this city can look up to with satisfaction and pride.

The Brockton Savings Bank was incorporated March 3, 1881. The officers, Baalis Sanfurd, president; Ziba C. Keith, vice-president; Bradford E. Jones, second vice-president; C. C. Crooker, treasurer; are among the city's most public spirited and responsible citizens. The board of trustees is composed of the same stamp of men, and embraces Davis S. Packard, Baalis Sanford, Ziba C. Keith, Wm. W. Cross, George E. Freeman, I.orenzo F. Severance, Patrick Gilmore, George E. Keith, Enos H. Reynolds, Loring W. Puffer, Walter F. Cleaveland, Gardner J. Kingman, A. Cranston Thompson, Elisha H. Joslyn, Bradford E. Jones, Sewall P. Howard, Charles H. Cary : board of investment, David S. Packard, Enos H. Reynolds, Bradford E. Jones, Gardner J. Kingman, A. C. Thompson. The banking house is conveniently situated at the corner of Main and Court streets. 
Boston Office. 138 Lincoln St. e. Aţ Office Wednesdayss and Satardays

\section{BROCKTON LAST CO.,}

... MANUFACTURERS OF ALL KINDS OF BOOT AND SHOE . . .

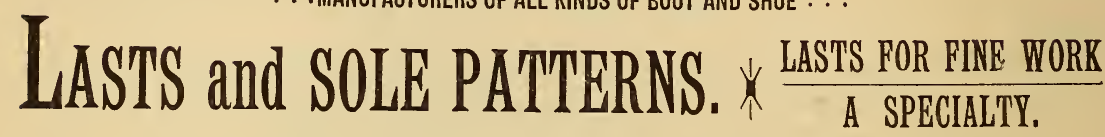
W. H. CARY,
* A. A. DELANO, WILLIAM THOMPSON.

BROCKTON, Mass.

W. W. CROSS,

PRESIDENT.
D. J. PIERCE,

TREASURER.
B. F. PENNINGTON, VICE PRES. AND GEN, MANGR,

LADIES', MISSES', MEN'S AND BOYS' STANDARD Waterproof *

* Garments.

67 CHAUNCY ST.,

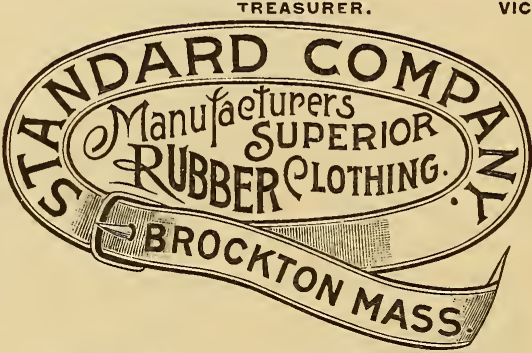

Catalogues and Price Lists Furnished. * SALES OFFICES *

ATTRACTIVE PATTERNS,

STANDARD Mackintoshes. BOSTON. NEW YORK.

\section{SMITH'S VEGETABLE COMPOUND.}

DOES Rheumatism, Neuralgia, Lumbago, Fever CURE and Ague. Kidney and Liver Complaint and prepared only by DR. E. S. POWERS, BROGKTOH, MASS.

Sole Proprietor DR. SMITH'S FORMULA.

* * * WALKING $\boldsymbol{M A D E} \quad \boldsymbol{E} A \boldsymbol{S} \boldsymbol{M}$. * * *

$$
\text { G. W. WILLEY, }
$$

101 Belmont St., BROCKTON, MASS.

Moulds taken of the feet and lasts made * * * * * * to order. * * * * * 
The Union Marble Works, of which E. E. Small and 1. Howes are the proprietors, is a well established concern. They manufacture all kinds of monuments, headstones and tablets of both American and foreign marble. The firm is constantly making new designs for their work, to suit all classes of people. The works are centrally located, being situated at 514 South Main street, this city.

James C. Tannatt we find among the largre shoe manufacturers of this city. He is located at No. 62 Railroad avenue, where he has excellent quarters, fitted up with modern machinery, which turns out annually a large number of gents' fine shoes, which are hand sewed, hand welt, and Goodyear welt. These shoes are of excellent workmanship, and find a ready market among the retail trade throughout New York state, the entire western country, and the New England States.

W. P. Bosworth is a dealer in heel stock and sole leather remnants of all kinds. Being an active and practical man of business he has established a large and profitable business in his special branch. His factory is at 30 Linden street, where a full line of his goods can always be found.

Bion F. Reynolds, who has been established in Brockton for a number of years, has founded an excellent business, and has a trade which extends to all parts of the west and south. He manufactures principally gents' fine shoes, which are hand sewed, hand welt, and also Goodyear welt, which for style, workmanship and fine fiuish are not excelled by any similar line of goods. $\mathrm{Mr}$. Reynold's factory, which is located at 62 Railroad avenue, this city, contains all the necessary machinery for the successful prosenution of the work in hand. He has recently adopted a trade-mark, which is stamped on the bottom of each shoe ("The Bion Shoe,") and all shoes bearing this trade mark are second to none as regards price or workmanship.

J. O. Tougas, who is known as the "Brockton Die Maker," is without doubt the leading die maker in this city. He has been in business for some years, having succeeded the old established house of Duprey \& Tougas. His place of business is located at No. 257 Main street, where all the necessary modern appliances to facilitate the work in hand are to be found, and where a number of skilled mechanics are employed. Mr. Tougas has always made it a point to manufacture dies that are not surpassed in the market. His trade is not only centred in this city but extends to many of the large shoe cities of the west.

H. T. Marshall is one of the oldest of Brockton's shoe manufacturers. His specialty is the manufacture of a lace Congress, which embraces all the features of a Congress shoe. It can be put on and taken off without unlacing, and at the same time the shoe can be laced to fit the foot without in any way binding the instep. The shoes he manufacturers are stylish and serviceable and the best of material enters into their make up. Having a large factory Mr. Marshall turns out many cases of shoes a day. A branch store and office is at No. 220 Devonshire street, Boston, Mass.

N. A. W. Ransden, of 78 Railroad avenue, is a manufacturer of shawl and 
TO GET THE BEST RESULTS USE

THE MILLER
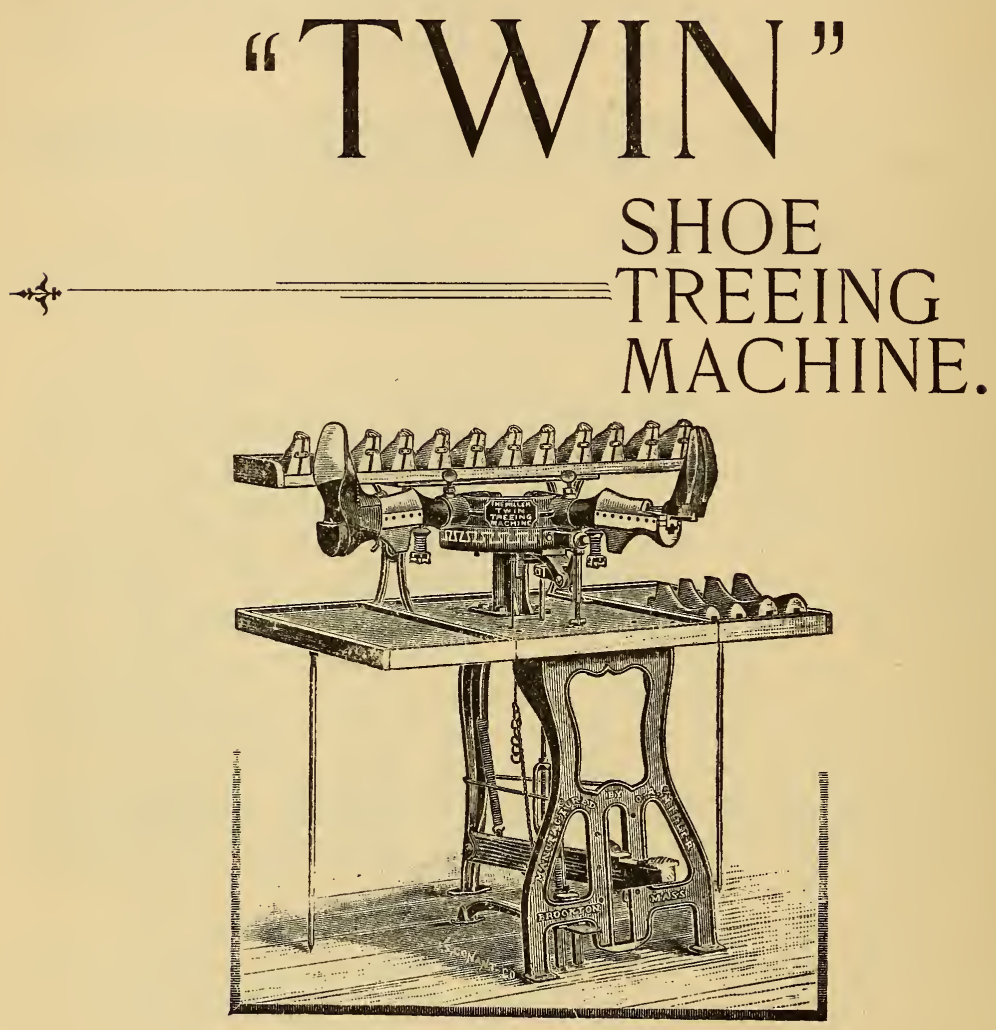

Tw:n Treeino Machine.

FITTED WITH RIGHT AND LEFT TREE LEGS AND PATENT SPLIT FEET.

$$
\text { * * over } 750 \text { now in use. }
$$

Manufactured by .........

$$
\text { O. A. MILLER, }
$$

boston office,
$\mathbf{5 7}$ lincoln street. * * BROCKTON, Mass. 
shoulder straps. He manufactures a shawl strap of his own invention, with metal base and handle. This is made of orange leather, and is one of the best straps ever invented, it beiny adapted for large and small bundles; while his special line of shoulder straps cannot be surpassed in the market. He is the sole manufacturer for this line of goods in the state of Massachusetts. He also makes a specialty of shoe stitching and shoe fitting for the trade, and his prices and prompt manner of doing the work has given him quite a reputation in this line.

Thompsun Bros. of this city, is another important firm which is engaged in the manufacture of boots and shoes of fine and medium grade, in calf, kangaroo, cordovan, and colored fancy stock, while the manufacture of welt goods, both hand andimachine, are a specialty. A large amount of work is produced from this house for the wholesale trade, which extends throughout the country. Their spacious factory is located at Campello.

Woodward \& Wright, last manufacturers, in I880 bought out Churchill, Lee \& Co. About eighteen months from that time Mr. Churchill withdrew from the firm and the business was continued by Lee \& Wright, till 1886 , when Mr. Wright assumed control of the business and formed a partnership with H. F. Woodward, since which time the firm has been known as Woodward \& Wright. Both Mr. Woodward and Mr. Wright are well known business men, and enjoy an enviable reputation, and a lively trade all over the country. Their Boston office is at 16 South street.

R. B. Grover \& Co. were established a few years ago by R. B. Grover, C. O. Emerson and J. F. Hill, who commenced the manufacture of fine shoes in all the latest and popular styles for gentlemen's wear; establishing as their trade-mark the " Emerson Shoe." They operate a large factory which is fully equipped with all the latest and improved machinery for conducting a large business, which is steadily increasing year by year, until they now have twentytwo retail stores situated in the principal cities from Portland, Me., to Washington, D. C., and west to Chicago, 1ll., where they sell the productions of their factories direct to the consumer at popular prices.

Howard \& Foster are among the most industrious firms of the city of Brockton. They are engaged in the manufacture of men's, boy's and youth's fine shoes, in Goodyear welts, hand welts and machine sewed, in calf, kangaroo, cordovan, Dongola and patent calf, etc., for the retail trade, which extends throughout the United States. Their factory is located on Montello and Ward streets, only a short distance from the Old Colony station. Their Boston office is at 96 Summer street.

Averell \& Thayer have been established since I886. Their work consists in the manufacture of blackings and cement, also the seliing of boot and shoe supplies of all kinds, including sand paper, paste, glues, etc. Among this firm's specialties are shank burnishing inks, which are said to be the best inks made for this purpose. Their factory is at 433 Crescent street, also 267 Centre street.

Packard \& Field were established in 1862 in this city. The house makes a 


\section{KIMBaLL BRos. \& Co.'s}

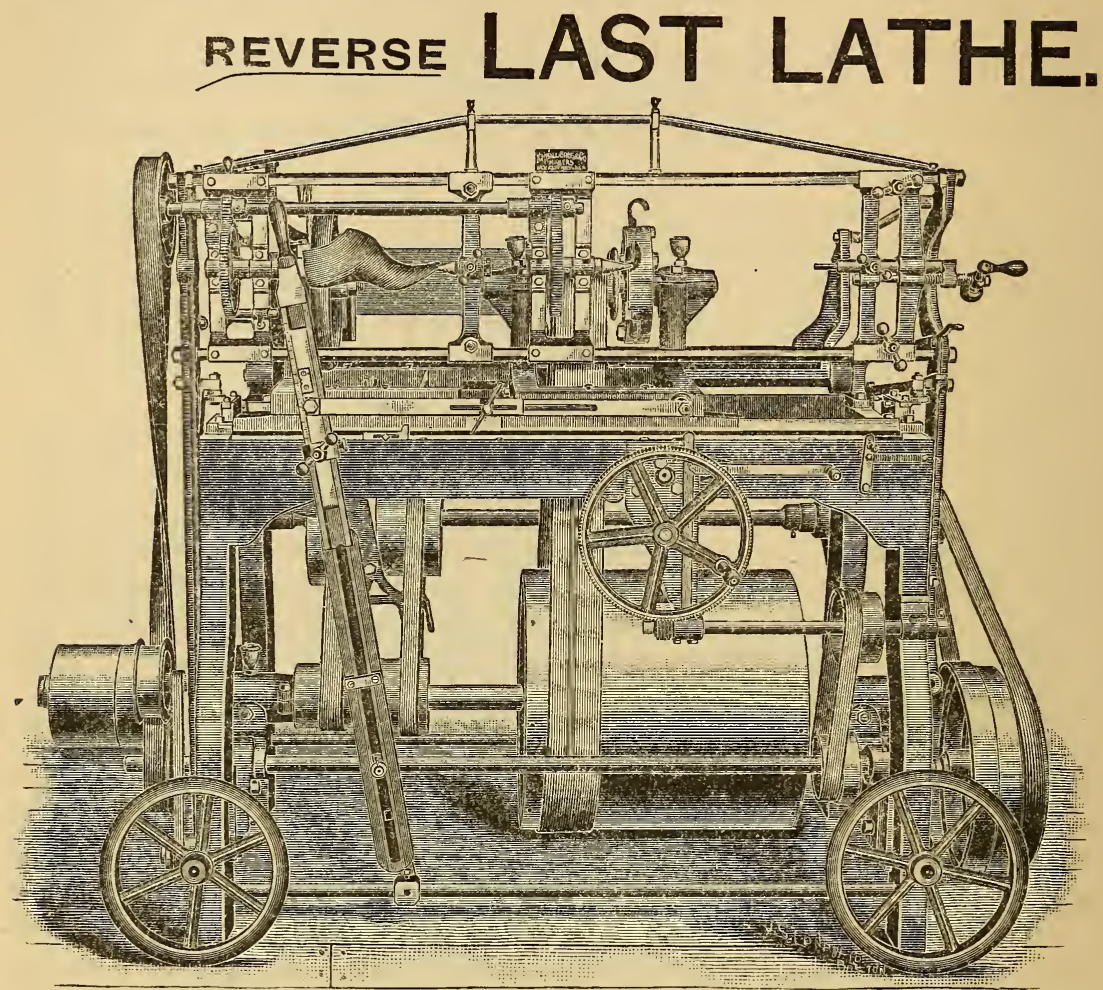

Correct and Sensitive in Action. Perfect in Workmanship. Instantaneous Reverse Movement.

Also Builders of ROUGHING MACHINES, Etc. KIMBALL BROS. \& CO., BROCKTON, MASS., U. S. A.
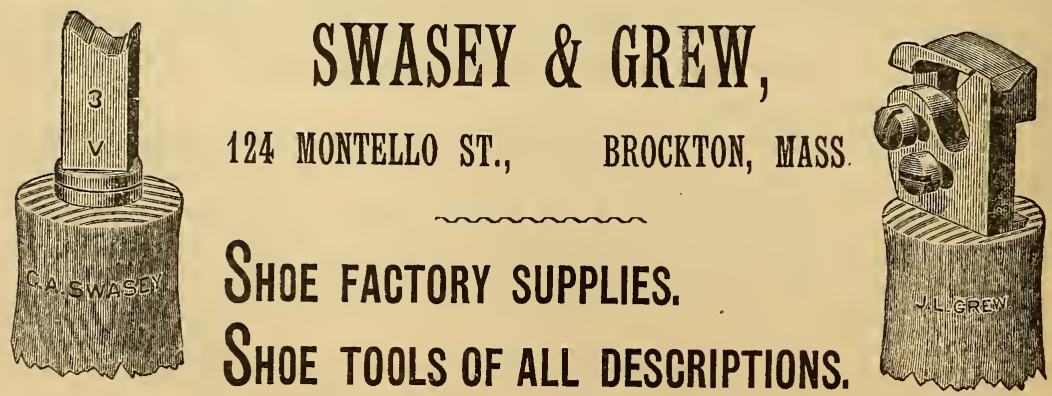
specialty of fine shoes for the retail trade, also a large amount of custom work is produced in all the leading styles for gent's wear. They occupy a large factory located at 259 Warren avenue, their Boston office being located at I 2 I Summer street. The above firm have recently opened a large store in New York city, corner of Park place and Broadway, where they have a large stock of gents shoes for the retail trade. Packard \& Field are the makers of the Burt \& Packard "Korrect Shape" shoes which are noted throughout the country for elegance of fit and their superior wearing qualities.

H. M. Kingman is engaged in the manufacture of men's, boys' and youth's calf, Dongola, buff and veal calf shoes. Their large and commodious factory is near the Old Colony Railroad and can be seen from the train, looking to the left just before entering Brockton station from Boston. Associated with H. M. Kingman are his brothers, Chester S. and William P. This firm commenced their career in I882, starting in a small factory which they occupied one year and then built the front part of the present building. As the demand for their now well known shoes increased, more room was needed, and first one wing then another was added so that the building now forms three sides of a square with a total length of $4 \mathrm{IO}$ feet and width of 35 feet. The 50 horse-power boiler and 25 horse-power engine was originally thought to belarge enough for any growing demands, but recently it has been found necessary to add an entire new steam plant including a Green engine of I 25 horse-power. The daily capacity is 3,000 pair and an extensive business is carried on with the jobbing trade throughout the country. The Boston office is located at I I 2 Summer street, and they also have an office in New York city at 18 Warren street.

Edwin Keith is located near the Old Colony station in that part of Brockton known as Campello. His work consists in the manufacture of men's boys' and youth's machine sewed shoes in calf, buff and veal calf. He also makes a line of fine shoes, with the celebrated Eppler welt, which is noted for its comfort and durability. Mr. Keith also supplies the well known Boston house of Hathaway, Soule \& Harrington with quantities of fine shoes.

Churchill \& Alden are engaged as manufacturers of men's, boys' and youth's medium and fine shoes in all the latest styles. We find this industrious firm doing an important business in Campello, Brockton, they having had an experience of many years. They have an office in Boston at 3 High street.

L.M. Reynolds, the subject of this sketch, made his first pair of shoes when but seven years old, and has been in the business ever since. He worked with his father (Charles T. Reynolds) making custom work, and manufacturing in a small way until he was twenty years of age; he has been connected with some of the largest factories in Brockton, and in $\mathrm{I} 88 \mathrm{I}$, with his brother, B. F. Reynolds, as partner, he started his present business, and Aug. I, I 890 , he became sole proprietor. The line of goods he makes ranges in price from $\$ \mathbf{I} .50$ to $\$ 4.00$ in machine, Goodyear welt and hand sewed, which are sold to the jobing and retail trade. A Boston office is located at 9I Summer street. Reynolds is a name that has been connected with the shoe business further back than that 
PERKINS \& JOYCE, \%o6\%o\%\%

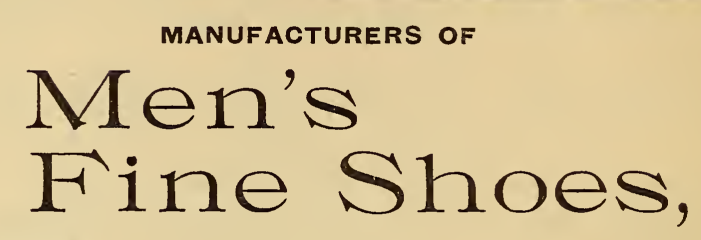

BOSTON OFFICE,

302 Devonshire St.

BROCKTON, Mass.

The Finest and Best Gentlemen's

Shoes in Boston.

$\$ 3$ to $\$ 7$ for H. T. MARSHALL'S make.

$\$$ IO to $\$$ I 5 for LUTHER BELCHER'S.

$\rightarrow$ SFINE CUSTOM SHOES, HAND MADE TO MEASURE+

220 DEVONSHIRE ST., BOSTON.

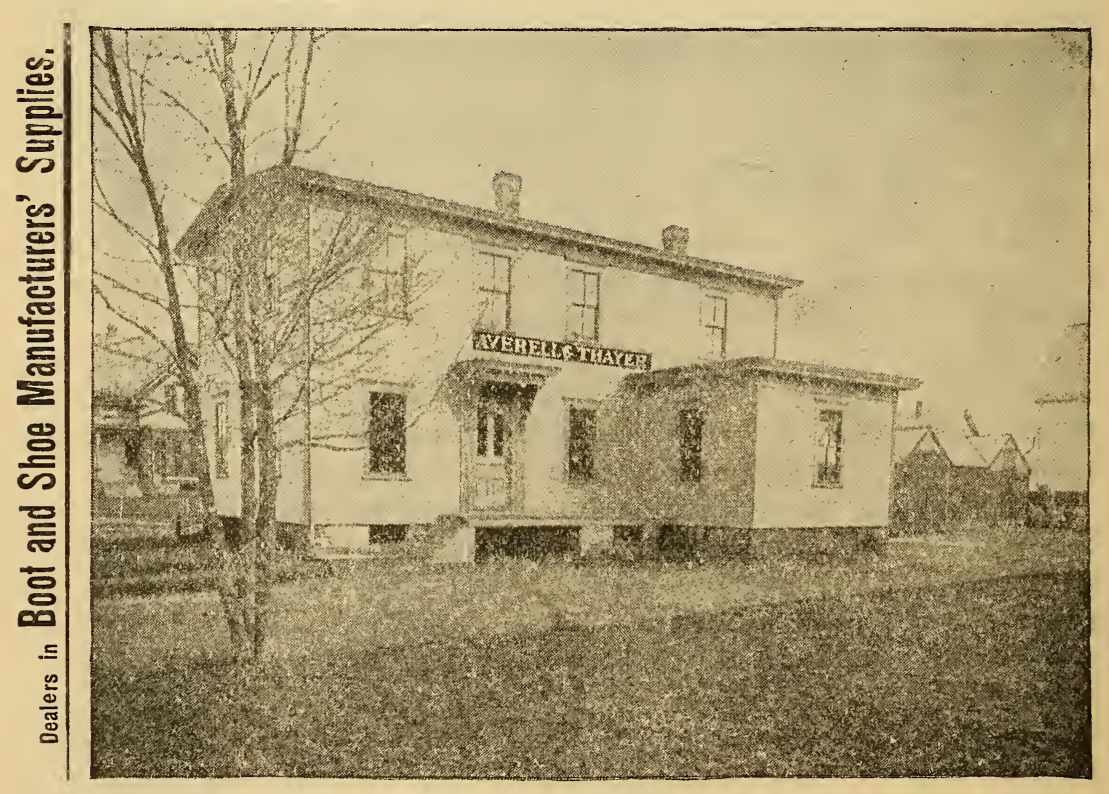

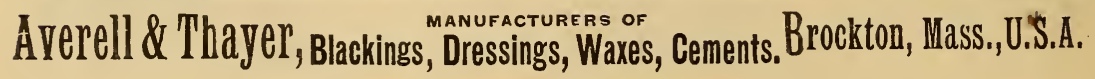


industry is connected with the history of Brockton itself. The past nine generations of the Reynolds family have been shoemakers, and there are a number by that name in the shoe business here in Brockton. Robert Reynolds made shoes and ran a shoe store in Boston in the year 1632. His grandsons, Nathaniel and Thomas, came to North Bridgewater (now Brockton) in the year I 740, where they worked at shoemaking and tanned their own leather. The manufacturers who bear the name of Reynolds are descendants of these two men.

The Standard Rubber Mills are extensive and thoroughly equipped, and when running at full capacity employ I 50 to I 75 hands and turn out I,200 to I,500 garments per day. At these works are manufactured everything in rubber clothing. from the cheap circular and plain rubber coat to the highest priced double and single textures, making a specialty of Mackintoshes. The Standard Company (a corporation organized under the Massachusetts laws) are proprietors of the above mills. Their goods are sold all through New England and the east and as far west as the Pacific coast, and every garment with their stamp on is fully guaranteed. The officers of the company are: W. W. Cross, president; D J. Pierce, treasurer; B. F. Pennington, vice-president and general manager; all of whom are careful and reliable business men. The company have sale offices in Boston and New York, and sales agents in Chicago and San Francisco, and supply their goods to both the jobbing and retail tracle. The catalogues and samples sent out by this company are very attractive, and enable people to purchase of them by mail in a knowing manner.

D. S. Packard \& Co. were established in 1857 . The work of this firm consists in the manufacture of boot and shoe counters. Their factory is a massive building, covering a large area in which are engaged many assistants. The gentlemen who comprise this company are D. S. Packard, V. Filoon, both well known in Brockton. Their Boston office is located at 138 Lincoln street.

Robert Clifford \& Co., of 65 Centre street, Brockton, whose line of trade embraces crimping, stamping, perforating, and pinking, are doing a prosperous business. The firm commenced business in $\mathbf{I} 88 \mathbf{I}$.

William A. Sweetser has been established here since 1869. He has the reputation of making the best tack machinery in the market, which is in use in most of the factories in this country. He has the latest improvenients in choppers, slitters, shears, tumblers, sifters, reed nail machines, knife grinders, and rivet machines.

Ralph R. Littlefield, located at 255 North Main street, produces at his factory a medium grade of shoes in calf and satin calf, buff and veal calf in men's and youths', in machine sewed and Goodyear welt for the jobbing trade. Having the personal supervision of his factory, he is careful to see that none but the best of work goes out from it. He has the reputation of making shoes fully up to sample and at prices that defy competition on similar lines of goods. His Boston office is at 280 Devonshire street.

The Brockton Mallet Co., was established by G. B. Goddard, in I879. The premises utilized are spacious, comprising an entire two-story building, $60 \times 30$ 


\section{TERRY, WARE \& ALLEY.}

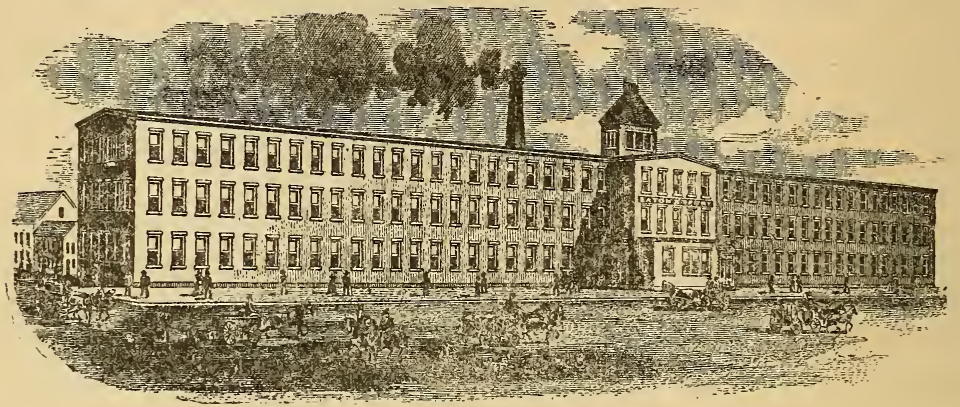

MEN'S, **** BOYS ${ }^{3}$, **** YOUTHS'***

Goodyear Welt, . Machine Sewed, Standard Nailed.

Medium Grade, Calf, Buff, Grain, Satin,"Oil and Flesh Split. FOREIGN GOODS

A SPECIALTY.

* $\quad$ BROCKTON, MASS.

\section{MYRON F: THOMAS,}

Manafactarers of Men's, Boys' and Yoaths' Cordovan, Kangarø, Catf, Veal and Baff $S$ OS.

Hand Sewed, Goodyear Welt and Machine Sewed.

CAMPELLO, MASS. Boston OfFICE: 99 ANd 101 BEdFord ST.

\section{WALKER AND WHITMAN, MANUFACTURERS OF

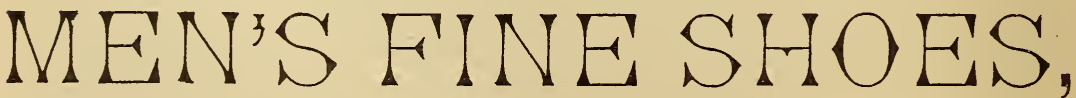 \\ CAMPELLO, MGSS.}

Boston Office: 96 Summer Street. 
feet in dimensions, fully equipped with all the latest improved machinery, appliances, etc., for carrying on the work, including the employment of a number of skilled and experienced workmen. The company are manufacturers of " Goddard's patent-leather handle raw hide mallets," " Goddard's pinking roll," and "Goddard's patent leather-covered chisel handles" for carpenter's, etc. These mallets are made of the best imported raw-hide disks, and are the strongest and best made, being warranted to last three times as long as any mallet yet invented. The "Goddard raw-hide pinking roll" will do more work than any other in the market. This company make a roll that will fit on any pinking machine. These rolls are made under thirty tons pressure. They also give attention to refilling and repairing all kinds of mallets. Their trade is very extensive, and goods are shipped to all parts of the United States, and Canada, and exported to Austria, Belgium, Germany, France, England, Italy and Australia. Every department of this house is in practical hands. The advertising department especially being in competent hands, who fully understand and appreciate this important branch, and at the head of each department is found a prudent and practical man.

O. O. Patten \& Co., manufacture dressings, cements, McKay machine wax, and blackings. This firm has been established since $\mathrm{i} 858$, and since its inception it has year by year done an increasing business, and it is widely known throughout the country, as the goods which they manufacture are noted for their superior quality. Their factory is conveniently located in the business part of Brockton. Many hands find employment here, and all orders are promptly and satisfactorily executed. A Boston office is located at I38 Lincoln street.

E. H. Reynolds, manufacturer of men's fine calf shoes, located at 956 Main street, by strict attention to business and making an A1 shoe at the lowest possible price, has built up a large business.

Gico. Knight \& Co.'s factory is conveniently situated on Montello street, only a short distance from the Old Colony Railroad station. A specialty is made of shoe machinery and its duplicate parts. They also supply the greater part of the machinery used in the Brockton factories, besides carrying on a large trade throughout the United States.

Myron F. Thomas is a manufacturer of and dealer in men's, boys' and youths' tine shoes of veal and buff, in Goodyear, welt, and machine sewed. He is located at I 86 Montello street, and caters for a New England and Middle States jobbing trade and western retail trade. Mr. Thomas is a gentleman well known in both the business and social circles of Brockton.

The Brockton Last Company's originators were the first, it is claimed, to make a factory made last, which was male by hand, in 1825 , while the first machine for making lasts was used in 1833 in Brockton. Cary, Delano \& Thompson formed the company now known as the Brockton Last Company in I 885. This company makes a specialty of men's lasts for fine goods which are known throughout the country as the "Brockton Last." They"give steady employment to a large number of skilled workmen. The firm claim"that for 


\section{SARGENT, ANGLIM \& KEITH,}

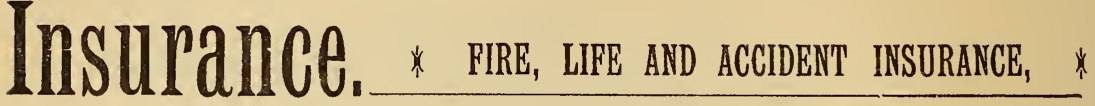 * * ноorreates and bonss. * * Real Estate.} We are General District PROVIDENT SAVINGS LIFE OF NEW YORK, The best Lifelinsurance
Agents for the . . . Pxistence. . . .

Our 10, 15 and 20 Year Bond cannot be beaten as an Investment. IT WILL PAY YOU TO LOOK IT UP. It will also PAY you to look US up if you want ANYTHING in OUR LINE. We can suit you and respectfully solicit your patronage.

FREI) W. SARGENT, HENRY T. ANGLIM,

GOLDTHWAITE'S BLOCK. VICTOR W. KEITH.

\section{MAIN ST., : : BROCKTON, MASS.}

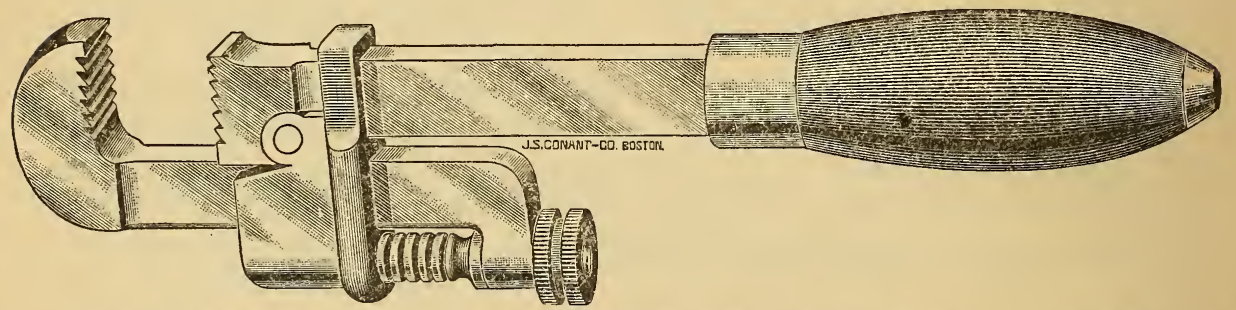

\section{COLUMBIAN - MANUFACTURING - CO.}

- Manufacture - -

The Columbian Pipe Wrench, Columbian and Montello Door Knobs, Pearsall Patent Hose Nozzle, Bowers Improved Patent Guitar Bridge and other Specialties,

Send for samples and prices of any of the above to the general office.

\section{BROCKTON, - " - " MASS.}


taste, style, durability and exactness their lasts cannot be surpassed by those of any other manufacture. They also make a line of ladies lasts for the fine grades of work, besides making a large portion of the lasts used in the Brockton shoe factories; their product is shipped to all parts of the country. The wood used in the manufacture of their lasts is mostly hard maple, and most of it comes from Maine, where the timber is of a close fine grain, and before being used it is thoroughly weather seasoned, thus enabling the firm to warrant thcir lasts not to shrink. The Boston office is located at 138 Lincoln street.

Niles \& Wilbur are among the numerous manufacturers here in Brockton. Their factory is located at 54 Montello strcet close to the station of the Old Colony Railroad. They make a specialty of the manufacture of a shoe for gents' wear which they sell to the retail trade for $\$ 1.60$, which is the best shoe for the money that is manufactured in this city, if not in the United States.

G. W. Willey, Iо I Belmont street, Brockton, makes a specialty of manufacturing lasts, by first taking a mould of the foot in plaster and then making the last from the pattern, thus assuring a perfect fitting shoe. Nothing is more annoying than an imperfect fitting sloe, and in order to have your shoe fit perfectly it is necessary to have a last that is as near the shape of the foot as possible, and by so doing you get not only ease and comfort, but durability in a shoe made from such a last.

Ellis F. Copeland started in business as a manufacturer of men's custom made shoes in 1875 , and caters only for the tinest retail trade, who have customers that want the best shoes obtainable, and are willing to pay for them. Mr. Copeland's shoes are all bench made by old-fashioned custom workmen, from fifty to seventy-five of the most experienced of whom are in his employ. He is making a fuli line of bluchers in patent calf and French enamel, on the famous imported piccadilly last; a lsoa new line of English button boots, with five large buttons, made on an extremely pointed piccadilly last, is a novelty which Mr. Copeland is putting on the market. This is the latest London style and is proving a popular shoe with college students of whose trade he is making a special feature, and is now producing a full line of specialties designed for students. Dealers who may need to meet the demands of student trade will find in Mr. Cope'and's samples, lines which have proven especially popular with students in the leading universities and colleges of the East.

O. A Miller is engaged in the manufacture of the Miller "Twin" shoe treeing machine fitted with right and left tree legs and patent split fect. A great amount of capital and labor has been expended in bringing this machine to its present perfected state, of which there are now over seven hundred and fifty in use. Many of these are in use in Brockton, and all acquainted with its merits are enthusiastic in its praise.

The Taunton Lumber Company are wholesale and retail dealers in all kinds of lumber, while they make a specialty of hard pine and shingles. Their place of business is at 243 North Montello street, Brockton. 'This business was formerly carried on by A. H. Leatherbee, but in January I 892 the present company took charge with William H. Lewis as manager. They also have quarters at 30 Broadway, Taunton, and the large business they enjoy is in keeping with the esteem they command anrong their fellow men. 
THE one invention for which the Hub Gore Makers are

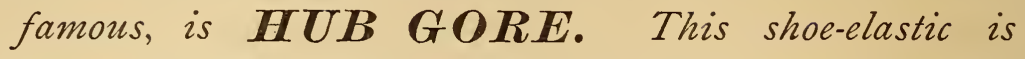
made only for Fine Congress Shoes, and every gore is dated at the factory when made, and is then insured for one and a half years. Hub Gore Makers are the largest manufacturers of fine Gore in the Worla, and the only manufacturers of Gore exclusively in the United States.

They own a large establishment in Brockton, which is equipped with the best up to date machinery. They also own Hub Gore Mills at Chelsea, Mass. and Camden, New Jersey. The concern was established in 1882. Albert Herbert, is President, E. B. Page, Treasurer, and William Rapp, Director. This original label is used by them. $\quad \therefore \quad \therefore \quad \therefore$

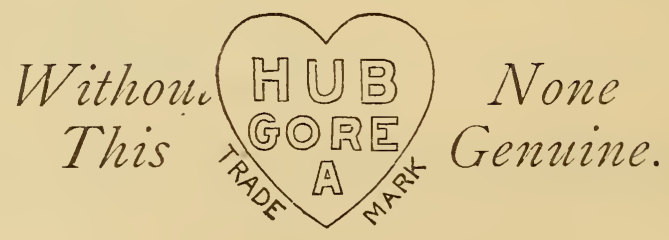

EVERY COMMUNICATION ANSWERED THE DAY OF RECEIPT IF ADDRESSED THUS :

\section{HUB GORE MAKERS,}

9i Bedford Street, * Boston, Mass. 


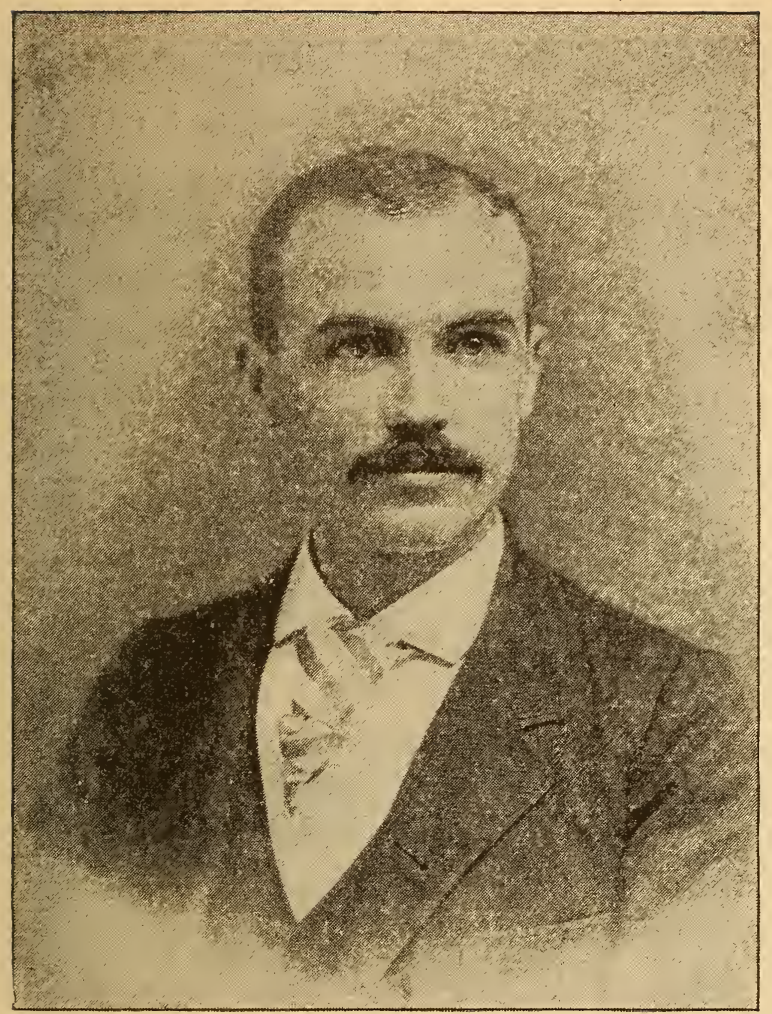

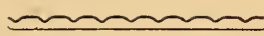

TRY THE *

\section{Brockton}

Steam

\section{Laundry.}

* Office *

19 East Elm St.,

A. P. Reynolds,

PROPRIETOR.

$\Rightarrow C \cdot W A K E L I N G$,

CALF $\odot$ SKIRTING COLORER \& BLEACHER,

78 Railroad Avenue,

BROCKTON, - MASS.

S. H. NICHOLS,

* * SKIVING KNIVES.

ALSO MANUFACTURER AND DEALER IN

NEW AND SECOND-HAND Shoe Machinery,

65 Franklin Street,

Brockton, Mass. 
BAXENDALE \& CO, Established 1872.

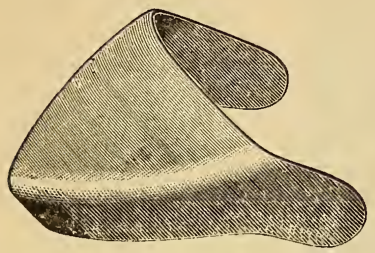

\section{Ladies' and Gents' Box Toes}

Of all Styles in Leather and Leatherboard.

Flexible Leather Boxes a specialty. A perfect fit guaranteed. Send a last for sample lot.

FACTORY AND 93 Centre St., BROCKTON, MASS.

THOMPSOY BROS. *** MANUFECTURERS OF

* BOTS GND SHOES.

FINE AND MEDIUM GRGDE.

\section{CAMPELLO, ** MASS.}

O. O. PATTEN \& CO.,

manvererveres of

ST ANDARD MCKAY

* *

\section{Machine Wax} and Cement,

WHITE AND BLACK LIQUID STICHING WAX, FINE DRESSINGS,

.. EDGE INK, RED, WHITE AND JERSEY STAINS. ....

Sole Proprietors of the

BROCKTON BURNISHING INK.

Boston Office, 138 LinCOLn StReet. * Brockton, Mass.
Factory at BROCKTON, MASS.

All Correspondence Mailed to Brockton. 


\section{Don't \\ spoil \\ BURTP\&ACKARD}

Feet with

Cheap

Shoes:

${ }^{*} * * * *$ If you want PERFECTION in fit, with freedom from CORNS and all DISCOMFORT you will never wear anything except THE BURT \& PACKARD SHOE.

See that EVERY PAIR is STAMPED THE BURT \& PACKARD "Korrect Shape."

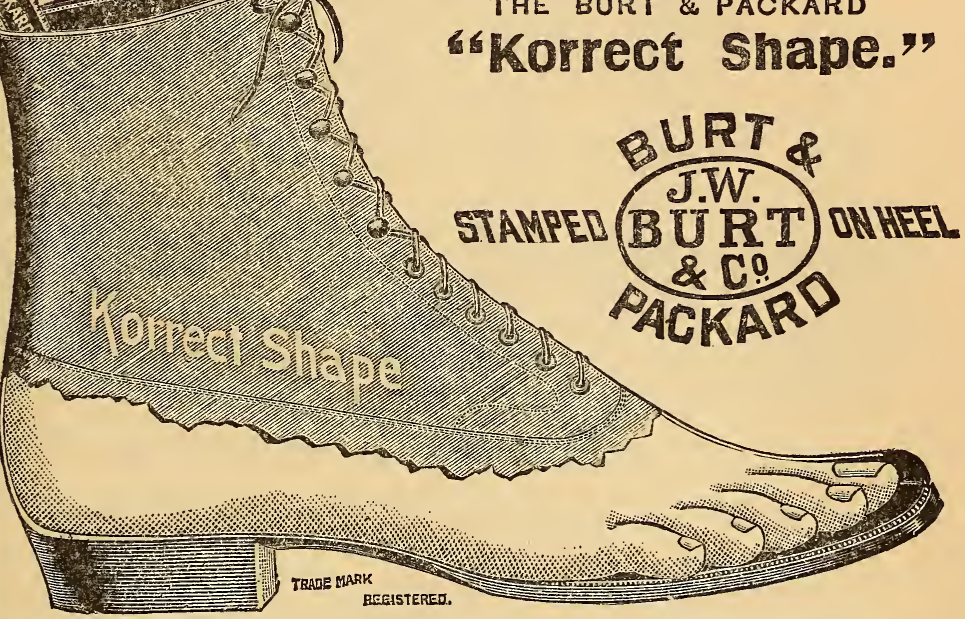

Fire Insurance Agency,

W. M. THOMPSON,

Esta BLIShed 1852.

286 MAIN STREET, BROCKTON, MASS.

FACILITIES FOR LARGE LINES INSUREIAGAINST FIRE AND

IN RELIABLE COMPANIES.

HEADQUARTERS FOR

SOCIETY REGALIA, JEWELS, GOLD AND SILVER TRIMMINGS, ETC., GOLD LETTERED BADGES for all Occasions a Specialty.

Ledgers, Journals and Order Books, Folio and Sample Cards made to order. Old Books re-bound and cased, School and Library Books repaired.

A. A. BATTLES, Prop.,

No. 47 CENTRE STREET,

BROCKTON, MASS. 
JOS. A. BURR. HORACE KINGMAN.

\section{BURR \& KINGMAN,}

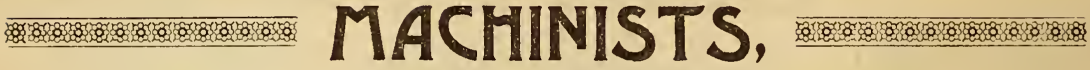

Engine, Shoe Machinery and Bicycle Repairing.

New Machine Work attended to promptly and Satisfaction

Guaranteed. Shafti, g, Hangers and Pulleys constantly on hand.

No. 25 HIGH ST., telephone 165-5 BROCKTON, MASS.

HOW ARD AND FOSTER, manutacturers of

MEN'S, - BOYS' - AND - YOUTHS', FINE. SHOES.

Factory: MONTELLO AND WARD STS.,

BROCKTON, MASS.

BOSTON OFFICE: 96 SUMMER ST.

$$
\text { J. O. TOUGAS, }
$$

MAKER OF BEST QUALITY

\section{GUTTING DIES AND GRISELS.}

For Leather, Cloth, Paper, Sheet Metal, Etc.

257 No. Main St., BROCKTON, MASS.

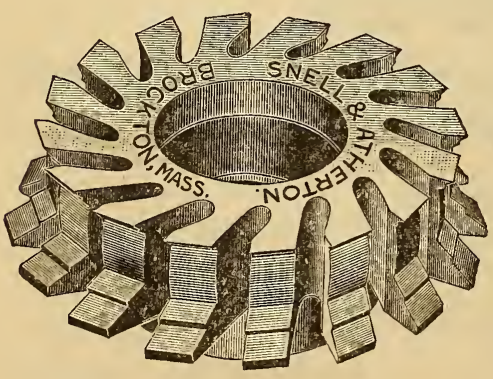

\section{ESTABLISHED 1853. SNELL \& ATHERTON, MANUFACTURERS OF FINE SHOE TOOLS.} TRADE MARKS REGISTERED O. E. $D$.

FOR HOME AND EXPORT TRADE. Edge Planes, Heel Shaves, Welt Trimmers, Burnishing Irons, Edge Setter Irün, Bresting Knives. Knives for Machines made to order.

72 SNELL STREET, BROCKTON, MASS., U. S. A. 
आR Only Patent Leather Handle Raw Hide Mallet Manufactory in the World.

G.B.GODDARD'S PAT.

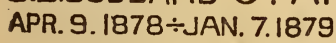

NOV.12.1889.
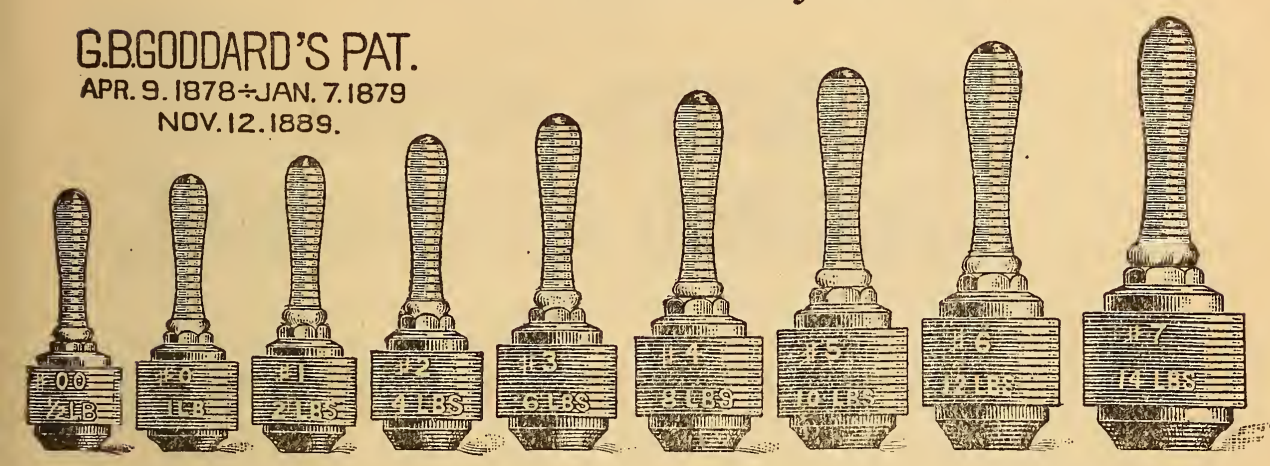

$\longrightarrow v$ ESTABLISHED 1879. $K$

"The ONLY MALLET with a Handle that will not Bend, Brake, Work Lose or Blister the Hand."'

BROCKTON MALLET CO., BROCKTON, MASS.

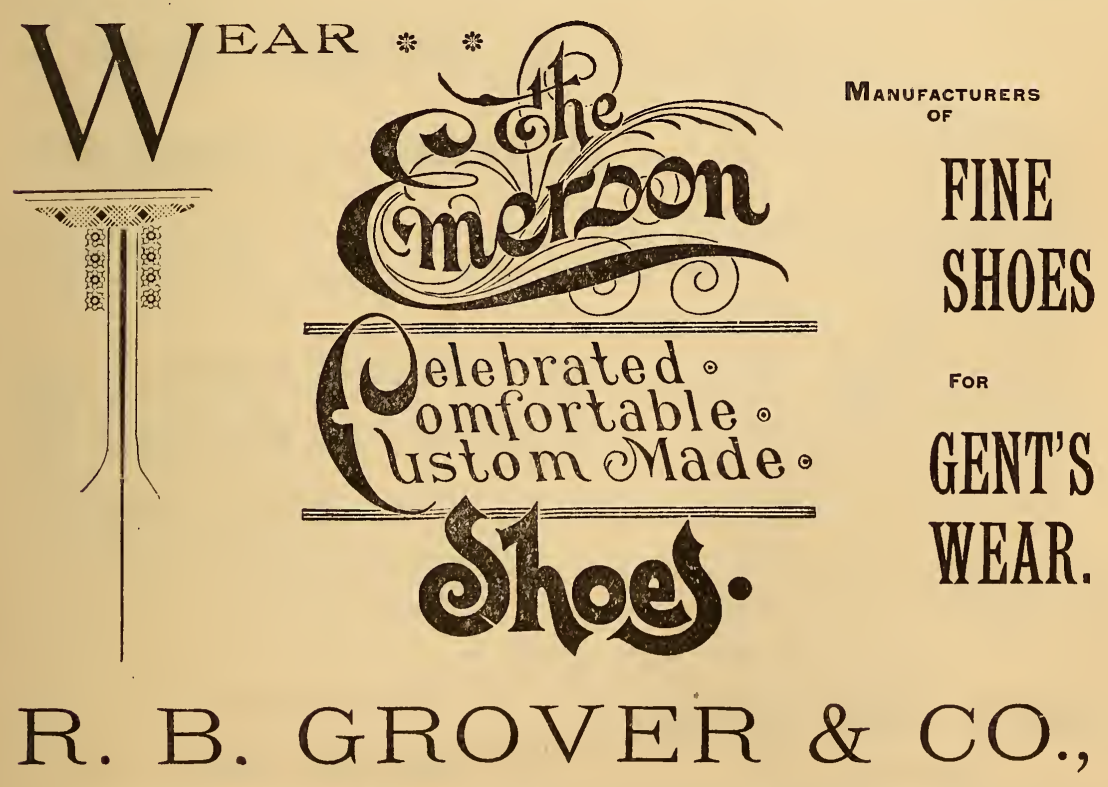

PROPRIETORS, BROCKTON, MASS. 


\section{JOHNSON \& PORTER,}

MANUFACTURERS OF

\section{JOHNSON'S PATENT GROOVING ATTACHMENT,}

FOR

\section{FAIR STITCH, HARNESS AND OTHER MACHINES.}

THIS attachment can be used in stitching soles to welts and can be applied to National, Nason and other New England machines.

\section{Office : 65 Gentre St., Brockton, Mass.}

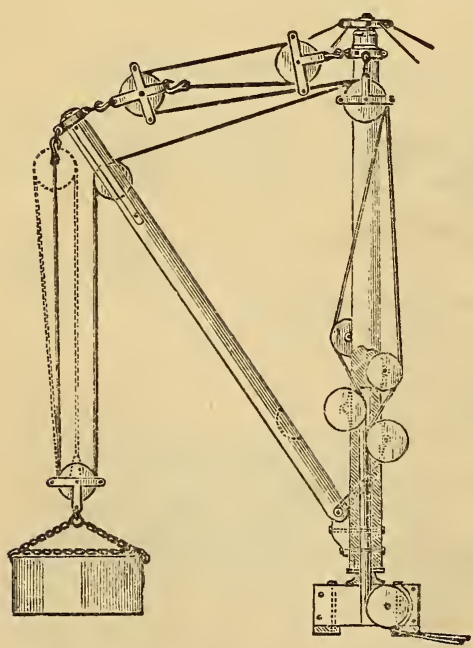

CRAM'S PATENT DERRICK.

PATENTED MAY 1, 1888.

Unequalled for Speed, Durability and Power.
D. HENRY CRAM,

345 WASHINGTON ST., BOSTON, MASS.

CONTRACTOR FOR

- RAILROADS, BRIDGES, -

Hoisting Engines and Cram's

Patent Derricks to Rent.

ALSO GENERAL MANAGER OF

"THE AMERICAN DERRICK CO."

NEW YORK OFFICE - - - 53 BROADWAY. 


\section{A VON.}

HIS picturesque village is three and a half miles from the thriving city of Brockton, with which place and Holbrook it is connected by an electric railway opened the past year. The surrounding country is a prosperous agricultural and horticultural region, peopled by a highly intelligent class, the village itself being largely given up to the shoe industry. It has a population of about 1,300 , and the hilly surroundings present a beauty of landscape seldom met with in that part of the state. It was formerly known as East Stouyhton, is a growing locality, possessing good railway facilities, good schools, and all the requirements for making life desirable.

L. G. Littlefield is among the best known firms of Avon, in the manufacture of boots and shoes for the wholesale trade. Being a house of an enterprising nature it has built up a large trade. The specialty being the manufacture of men's and boys' shoes in Dongola, calf and buff in sewed and standard screw. The trade of this house is done with the best known firms in this line of business. It has always been his ambition and aim to give his customers the best shoes that can be produced for the money. His Boston office is situated at Ior Bedford street.

\section{G. LITTLEFIELD, \\ MANUFACTURER OF}

\section{MEN'S - DONGOLA, CALF, VEAL CALF, BUFF- AND GRAIN - BOYS' \\ SEWED AND ST. SEREW SHOES,}

HACTORY AT AVON, MASS.

Office and Salesroom, 101 Bedford St., Boston.

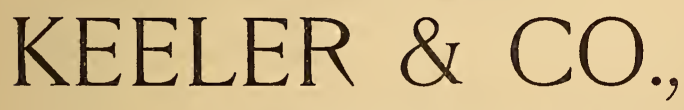

FURNITURE MANUFACTURERS

AND UPHOLSTERERS,

\section{Washington and Elm Streets,}

FACTORY ÁT cambridge, mass. * * BOSTON, MASS. 


\section{Office and Works of GEO. W. STAFFORD MFC. CO.,}

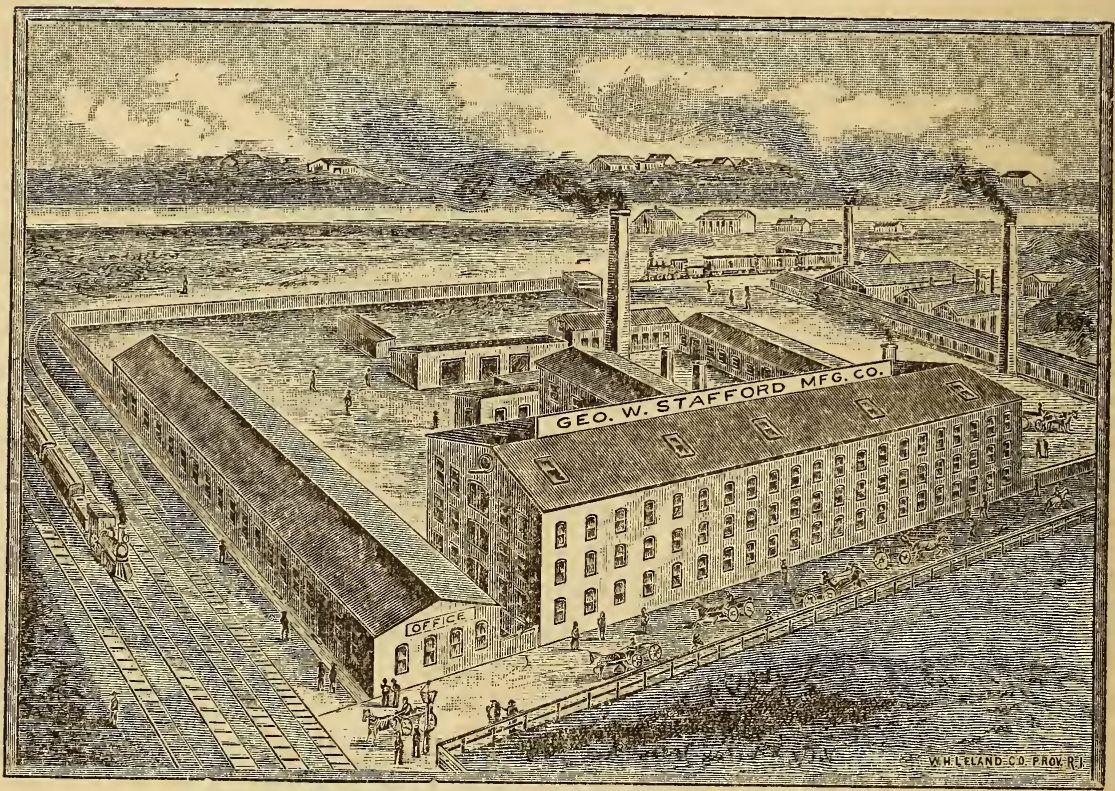

Builders of

\section{LOOMS, JACQUARDS, DOBBIES, \&C.}

Harris Ave., cor. Acorn Street.

Providence, R. I.

ALLEN'S

PRINT WORKS,

Manufacturers of

Standard Calicoes,

Providence, R. I.

\section{STEPHEN PAINE,}

MANUFACTURER AND DEALER IN

OPTICAL GOODS.

SPECTACLES, EYE GLASSES, MAGNIFYING GLASSES, OPERA GLASSES, READING GLASSES, MARINE GLASS ES, MICROSCOPES, TELESCOPES, THERMOMETERS, BARO METERS, HYDROMETERS, COMPASSES.

66 Westminster St.,

Providence, R. I. 


\section{PROVIDENCE.}

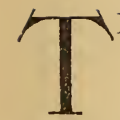

HE early history of Providence is of a most interesting nature, and as this work has principally to do with transportation facilities, brief reference to the city's modes of conveyance, both primitive and modern, will prove of value to those seeking information on the subject. It is altogether a mistake to suppose that the wilderness found here by Roger Williams 250 years ago, was a pathless one. The state of civilization developed among the Narragansetts was sufficiently far advanced to develop roads. Through these roads the Indians traversed the country at all seasons of the year, passing from town to town with their merchandise. The "Pequot path" was the main one, not only of the Narragansetts, but of travellers of other tribes going from the west to the east, or vice versa. It entered the Narragansetts' territory about where Westerly now stands, passed to the north of Charlestown pond near the so-called “Fort Ninigret," over Kingston Hill, through East Greenwich, and following Greenwich, Broad and Weybosset streets, crossed to the head of the bay by a ford from Washington Row to the Ioot of Steeple street.

The town st: eet of Providence was not the first used as a thoroughfare by the white man; for generations before their coming the Indians had used it as such; the Pequot path was there met by other paths - one led up a gorge to the eastward, the site of Meeting street, and thence to a ferry at " Red Bridge," whence the Indians passed over into the country of the Wampanoags toward Taunton and Plymouth. Another path led southward to Power street, where it ascended another gorge under "Bewitts Brow," and passing round under Tockwotton Hill, by another ferry crossed to Watchemoket, and thence to Sowams (Warren) and Montaup (Mount Hope). Another yath went northward up a third gorge (Constitution Hill) to Stampers street, thence outward to Pawtucket Falls, and thence into the Wampanoag country, probably toward Shawmut (Boston). Still a fourth path is known to have passed up Milk street, crossing the Moshassuck by a ford, and following the present Charles street into the Louisquisit country. Other paths followed up the Woonasquatucket valley, and ran from town to town between the main paths. Thus it is evident that according to the development of the Indian civilization, Providence, even before its settlement by the whites, was a centre of quite a system of transportation facilities established by the aborigines.

These " paths," it must be understood, were not the roads of the present day, but were equal to the emergencies for which they were intended, viz: the pas- 


\section{SMITHFIELD GRANITE CO., \\ ALмy MAтнеwson, Prop. \\ Cemetery and Building Work.}

Heavy Foundation and Building Stone a Specialty. JOBBING AND TOOL SHARPENING OF ALL KINDS.

YARD AND OPFICE, 125 GASPEE STREET, * * PROVIDENCE, R. I. Orders left at Box 61, Mechanics' Exchange, or Yard.
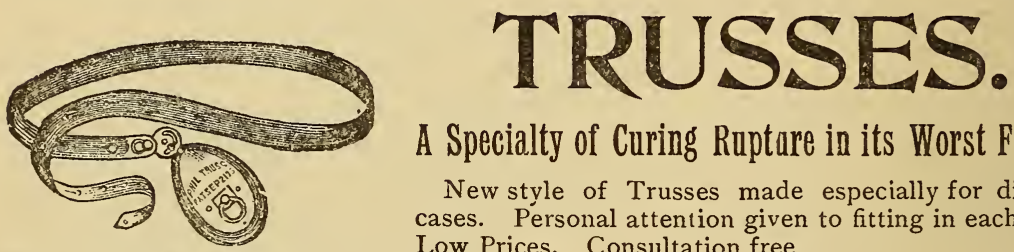

A Specialty of Curing Ruptare in its Worst Forms.

New style of Trusses made especially for difficult cases. Personal attention given to fitting in each case. Low Prices. Consultation free.

T. J. HAMLLTON, Rear 56 Union Street, Providence, R. I.

\section{Langelier MF’G. Co., \\ .... DESIGNERS AND BUILDERS OF .... \\ SPECIAL MACHINERT, TOOLS, ETC.,}

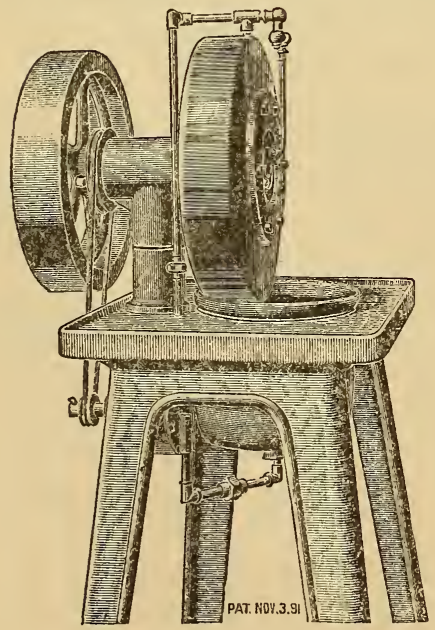

$67 \& 69$ CLIFFORD STREET,

PROVIDENCE, * * R. I.

This Cut represents our No, 2 Reducing or Swedging Machine, which is fitted up with automatic oiling arrangement which is needed when reducing long stock. This Machine is designed for Reducing, Tapering and Pointing all kinds of metal, We build three sizes of Machines, Nos. I, 2 and 3.

\section{All Information will be Furnished} on Application. 
sage of foot carriers and their burdens. Their width varied, probably from six to ten, or, at the outside, twelve feet. The bay was always present, and the means of water transportation which it furnished had been from time immemorial taken advantage of by the Indians, and were readily seen and seized by the whites. The first means of transportation over its waters were the canoes of the Indians, but we find in early days that Roger Willams had a pinnace (probably a square-bowed, square-sterned craft, partialiy decked over at each end, with a mast or masts and sail, or sails in the centre, intended to be propelled by the latter ordinarily, but which in case of emergency could be propelled by oars), which he used on the bay and its head waters as far as Taunton. The facts of the Taunton Iron Works having been early opened, its transacting business with both Boston and Plymouth parties, and that Roger Williams apparently sent his " pinnace" habitually to Taunton, indicate that one of the earliest routes of commercial communication from both Boston and Plymouth to Providence was via Taunton by road, thence by water to Providence.

At the time of King Philip's war, 1676, a communication with other colonies and the West India Islands had been established from Newport and Providence. Williams, at least, possessed a sloop with which he made trips occasionally to Providence from that point, but probably the main means of communication was by canoes and boats; for we find that in 1672 , when Roger Williams was in a hurry to go to Newport in order to take part in a religious discussion, he rowed himself there.

The first development of local transportation facilities after- the King war, was the establishment of a ferry at the present Red Bridge, and of local roads where they crossed the larger rivers. Carts were not much used for transportation of goods till after the beginning of the eighteenth century. For heavy transportation between the different parts of the colony, boats and vessels were used as much as possible, and this fact explains why all the commercial centres were situated on navigable waters.

The first regular stage line to Boston was established by Thomas Sabin, who kept a tavern at the northeast corner of Planet and South Main streets. The line was first advertised by newspaper in 1767 , and the stage made one trip per week from the house of Richard Olney, inn-keeper, who kept a tavern on North Main street, opposite Court House Parade. Stage lines about this time ran in competition with the packets and sloops which plied between Providence and Newport and Providence and New York, the latter starting twice their speed and accommodations were claimed to be unsurpassed.

As late as just before the Revolutionary war the condition"of the roads leading out of Providence was such that a trip from Boston to New York via Providence and New London, the most frequented road in New England, consumed a week. During the Revolutionary war the inland roads of the country were rather improved than otherwise, as they were much used for transportation of supplies, the coasting communication being cut off by the British fleets, and as little had been done in their interests before, what was done then as a military 


\section{B. H. GLADDING \& CO.,}

IMPORTERS AND RETAILERS OF

SILKS, AND DRESS GOODS. FULL LINES OF

PRIESTLY'S BLACK GOODS,

Linens and Housekeeping Goods, Infants and Children's Department, Laces and Trimmings,

\section{CLOAKS AND FURS, CARPETS AND UPHOLSTERY,} 241 and 245 Westminster St:

Providence, $R$. I.

$$
\text { J. H. OEAIJIAII, }
$$

ESTABLISHED 1857.

\section{EIGHT CARRAGE MANEITETURER。}

Any Pattern or Style Carriage Made to Order at Short Notice. REPAIRING OF ALL KINDS PROMPTLY ATTENDED TO.

Worchester St., cor. Union and Fountain, - - - $\quad$ PROVIDENCE, R. I.

\section{J. W. GRANT \& CO., \\ Manufacturing Jeweler's,

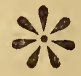 \\ 25 Calender st., PROVIDENCE, R. I.}


necessity served to better their condition. After the Revolutionary war, a great improvement was made in the facilities for transportation, both by water and by land. Vessels were built of greater tonnage than were before used, and lines of vessels running to the coast ports were established. 'The various ferries in the state were then maintained in a state of efficiency before unknown. Lines of stages were established to Taunton and New Bedford, Worcester, Plainfield, Springfield, etc., and the Boston and New York line, via Providence, was so much improved that the time of the trip was reduced to three days. Lines of teams for transportation of goods were also established on the same routes. The great obstacle to rapid (as the word was then understood) communication and transportation by land was the condition of the roads. The citizens along the main lines of communication did not feel called upon to put the roads in first-class order for the benefit of strangers who might want to use them, or for that of foreign stage owners. Nor did the owners of stage and transportation lines care to put the ruads in like order when the residents along the line of the same would get the chief benefit of their expenditures.

This state of affairs led to the introduction of what may be termed the turnpike era in this state. By this turnpike system a corporation assumed the care of a particular road and charged every onc, neighbor or stranger, a given fee for the use of it, every time he made such use, the fee being varied according to the extent of the use made; thus a wagon or team with four cattle was charged less than one with more; a single horse and chaise less than a coach and more horses, etc. The idea of such a guage of rates seems to have been derived from the system on toll-bridges which had been erected before then. The original idea of the toll bridge was that while those originally building the bridge, were entitled to the use of it free, yet strangers using the same ought to bear their fair share of the expenses of maintaining it; thus we find that as early as the time of Roger Williams, the Wapweyset bridge, one of the earliest bridges erected in Providence, was free to all citizens of the town, while strangers were obliged to pay toll for the use of the same. This primitive principle developed in the course of a century or more into the erection of bridges by corporations, as the Washington and "Red," or Moses Brown's bridge, and others, where charges were made against every person, even foot passengers, using the bridge, and in time was transferred to turnpike roads.

The first turnpike road of which we find any record in the statutes was, as might have been expected, on the line from Boston to New York, and was the Providence and Norwich turnpike, which had been commenced in the limits of Rhode Island previous to the year I 798. The Providence and Boston turnpike was in existence previous to the year I800, having been built under an act of the Massachusetts Legislature, and an act to incorporate the same in this state was passed on Oct. 29, 1800. Turnpikes to East Greenwich, Gloucester, the island of Rhode Island, to Smithfield, Louisquisit, Pawtucket, Wickford, the powder mill turnpike, turnpikes to Coventry, Cranston, Foster, Cumberland, Worcester and other places, were incorporated in the course of the next thirty 


\section{J. M. ALPAUGH \& CO.,}

WHOLESALE DEALERS IN
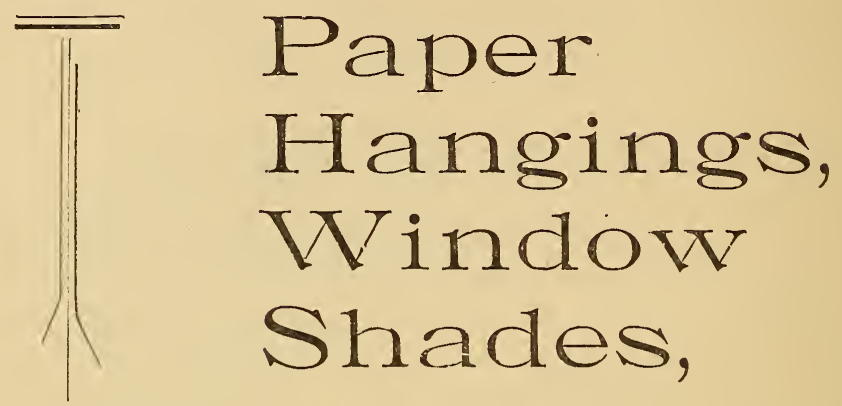

Shade Rollers, Brass and Nickel Shade Trimmings,

Hollands and Upholsterers' Hardware 30 EXCHANGE PLACE,

\section{Gas Ranges for Cooking;}

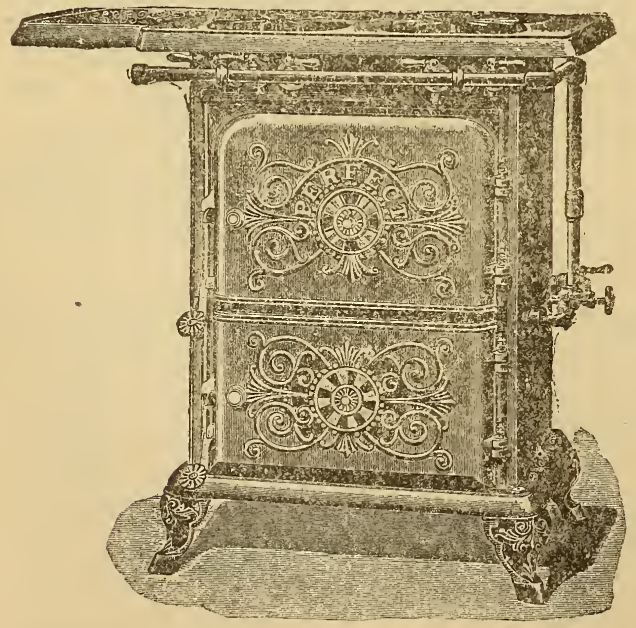

Gas heaters

FOR HEATING

PARLORS, BEDROOMS,

LIBRARIES, OFFICES,

BATH ROOMS AND

NURSERIES.

No Coal, No Ashes, No Kindling, No Dust, Always Ready.

DELIVERED FREE IOF CHARGE.

For Sale by if

\section{THE GAS STOVE STORE,}

15 Market Sq., cor. North Main St.

Providence, R. I. 
years, and before the introduction of railroads the turnpike was considered as the highest development of land communication.

The general adoption of the turnpike system, both in this and adjoining states, led to great improvements in the stage facilities. By the year 1805 the time between Boston and New York was reduced to about fifty hours, and team transportation facilities were increased in like proportion. In all cases where it was practical, water transportation was preferred for the hearier classes of freight, and it was on the water that the first application of steam to locomotive purposes in America, at least, was made.

It is to the credit and at the same time to the discredit of Providence that one of the earliest, if not the first, steamboats ever constructed was made here and plied on Narragansett Bay and Providence harbor. In 1792, years before Fulton's attention was directed to this subject, Elijah Ormsbee constructed his steamboat, the "Experiment," and showed that a steamboat was a practicable, attainable thing, and not merely the dream of an enthusiast, as it was up to that time claimed to be by practical men. This event is a monument to the ingenuity of the Providence mechanic of that day, but the fact that the invention was not utilizer does not speak so highly of the foresight and ability of the capitalists of the town.

The development of steamboats waited-Ormsbee was ahead of his timetill the days of Fulton's "Clermont" on the Hudson, and its successors, and it was Wednesday, the 28 th of May, I8I 7 , before a commercially practical steamboat ever entered Providence harbor. This wais the "Firefly," of New York construction, and the first steamboat that ever rounded Point Judith. She "attracted considerable notice," and on the next Friday made the round trip from Providence to Newport and return in eleven hours. She ran for a time between Providence and Newport, but the enterprise was not pecuniarily successful and was abandoned. Before this time steamboats had been made use of to shorten the trips to New York, the stages running to New London, where the passenger's embarked on a steamer which ran to New Haven, stopped there over night, "wooled up," and reached New York the next day. It was in August, I82r, before a steamboat ever arrived at its wharf direct from New York. This was the "Robert Fulton," on an excursion trip.

In June, I822, a steamboat line between Providence and New York was established. 'The boats made the trip in 23 hours, consuming 44 cords of wood in the passage. The first point to be obtained after the demonstration of the possibility of a steamboat, was the reduction of the fearful expense of running those early boats. In this matter Providence came to the front, and by his "Babcock boiler engine," John Babcosk, a Providence mechanic, ran the steaner "Babcock" from Newport to New York, in August, I826, with a con. sumption of only one and three-quarters cords of wond. These boats were very different from the boats of today. The "Washington," one of the best boats of the time, lost in May, I83r, owing to a collision with the "Chancellor Livingston," was valued at froin sixty to seventy thousind dollars. In August of the same year, the newest and most improved buat on the Sound, the "Boston," 
* * * * DAVID BURTON, ****

WHOLESALE AND RETAIL DEALER IN

\section{Steam, Gas and Water Pipes and Fittings.}

Steam Engines and Boilers, Patent Steam Pumps, Clarke's Steam and Fire Regulators, Low Water Reporters, Steam Traps, \&c. Also Feed and Force Pumps of all descriptions. . Gives particular attention to House Piping and all Public Kuildings, and to the introduction of Pawtuxet Water.

PAGE ST., TELEPHONE 1506-4. PROVIDENCE, R. I.

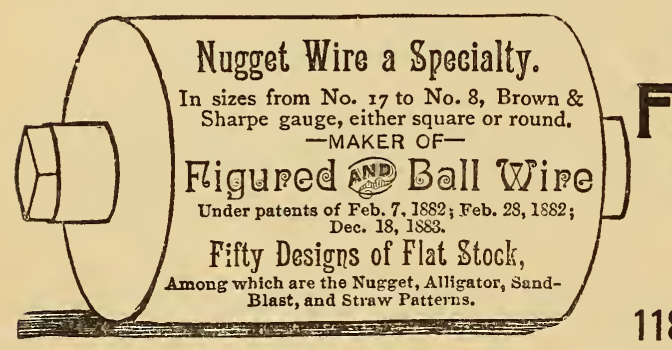

JAS. A. CHARNLEY.

FLAT STOCK

Which can be used in the manufacture of

UTTONS,

ANGLE AND

UGLE BRACELETS.

118 DORRANCE ST., PROVIDENCE.

\section{J. M. WESTMACOTT \& CO.,}

MANUFACTURERS OF

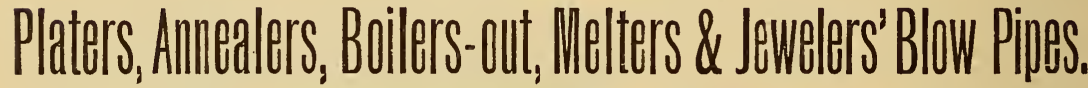

Soldering and Flushing Irons, and all kinds of Jewelers' Findings.

81 Friendship St., Providence, R. I.

H. A. FREEMAN \& CO.

H. A. FREEMAN \& CO.,

. . Workers of Sheet Metal, Iron, Tin, Brass, \% and Copper. Ventilation and Furnace Piping a Specialty. Also Manufacturers of the Acme Rug Tufting Machine and Acme Can Opener 8 I FRIENDSHIP ST., PROVIDENCE, R. I. 
is described as "I 50 feet long, and the Massy copper boilers of her two engines give the most satisfactory assurance of her being an entirely safe boat." "The President," the new wonder of the deep, had three decks, lower cabin, staterooms, closets for washing, etc. It was 160 feet long, thirty-two and onehalf teet beam, eleven feet depth of hold, was of 500 tons burden, had thirtyfour staterooms, I 50 berths, two separate low pressure engines, and Massy copper boilers.

By this time stage lines were running from Providence to Taunton, New Bedford, Worcester, and most of the country towns, as well as on the main line between Boston and New York. The point of starting and arrival for most of them was the Manufacturers' Hotel, where the What Cheer block now stands, and it was no uncommon sight to see a dozen or more coaches, each with six horses, drawn up in the highway in front, above and below this building, and when into this cluster of equipages came the arriving stages pellmell at top speed, each striving to get in first, the scene became one of excitement, and sometimes of danger. With regard to the time made by these coaches, we find in 1832 , the editor of the Gazette proclaiming exultantly, "We were rattled from Providence to Boston last Monday in four hours and fifty minutes, including all stops on the road. If any one wants to go faster, he may send to Kentucky and charter a streak of lightning, or wait for a railroad, as he pleases."

After the New York boats came to Providence their was a special stage line started from the boats to go to Boston, and which came to the boats with passengers from Boston. The keeping and baiting of the horses used on these stage lines formed no inconsiderable business in those days for numerous livery stables. Probably a greater number of them were cared for at what was known as Copeland's stable, than at any other single one. A signal system was established between the stable and Field's Point. The boats arriving there would signal the number of passengers for Boston, the signals were then repeated to the stable, and then there was hurrying in hot haste. The steeds, the mustering squadron, and the clattering coach, went pouring forward with impetuous speed, and swiftly forming in the ranks of stages, thundered down to the wharf, and were there stationed/and ready for passengers by the time of the arrival of the boat.

At this time it was possible to go to Boston and return the same day, spending two hours there, while the running time of the boats between these and New York was reduced to less than seventeen hours.

The next development of transportation facilities was the Blackstone canal, opened in 1828. This was a very useful institution for the city of Providence, and towns along its route, as it enabled freight to be carried at greatly cheapened rates. There were some twenty or twenty-five freight boats used upon it with an aggregate capacity of about eight hundred tons. It was, however, far from a success to those who invested in it. In an experience of some twenty years the total dividends declared upon the stock was $\$ 2.75$, paid during the first eight of those years; the par value of the shares was $\$ 37.50$ each, and when it was finally wound up the whole capital was lost. 


\section{DOUGLAS'S PATENT}

\section{Instantaneous Water Heater}

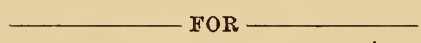

Baths,

Offices and

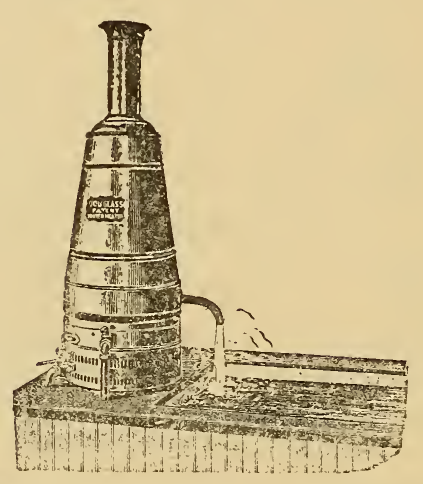

Domestic

Purposes.

The value of an apparatus that will heat water instantly any minute of the day or night, in unlim ted quantities, cannot be over estimated, when the convenience and so often the necessity of getting hot water instantly, is considered. The bath neer not be neglected with the Instantaneous Water Heater which is Economical, Durable and Ornamental, and can be used in any place where gas and water can be obtained.

Send for Circulars or call and examine it.
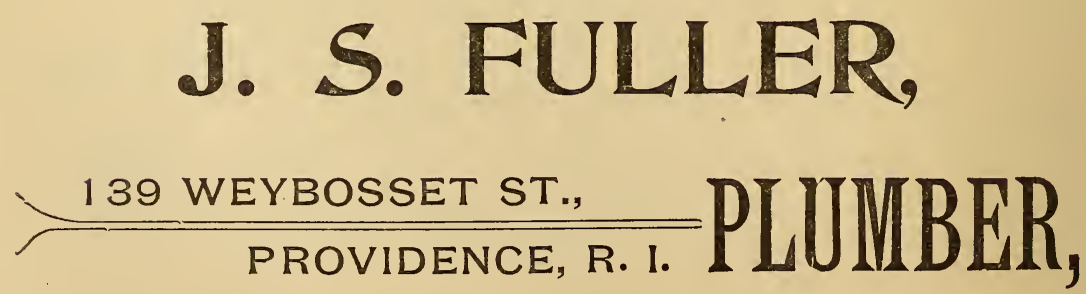

SOLE AGENT FOR RHODE ISLAND. 
By the year I829, the stage coaches and wagon teams over the turnpike roads were considered as too slow and costly, and a railroad was looked to and talked of. An idea of the extent of the business over the turnpike roads of that day can best be obtained by the statistics then compiled. It was computed that twenty-seven thousand tons of freight were carried annually between Boston and the towns adjacent to the road at one end, and Providence and like adjacent towns at the other, whilst of this amount, only 3,400 tons were carried by water, the remainder all going over the turnpike. The number of passengers carried by two lines only of stages between these points was 24, 100.

It was considered that this business could be more expeditiously and cheaply carried on by means of a railroad. It was figured that one horse on a railroad could carry twenty-seven passengers eleven miles per hour for seven hours in a day, and could haul eight tons of freight for ten hours per day at the rate of three miles per hour; that it would cost to build and equip the road $\$ 400,000$. On this estimate the Boston \& Providence Railroad was first planned and chartered. The first charter for this road was afterwards revoked so far as Rhode Island was concerned, but a new charter was granted in I831, under which, in connection with a charter granted by Massachusetts, the road was built, equipped, and operated. It will be noted that up to this time there was no thought of a railway having for motive power a steam locomotive, and that it was expected that every individual could employ his own carriage and horse power on the road, paying toll therefor. In fact it was a railroad turnpike. Without this being borne in mind, some of the provisions of the charter would seem unintelligible; thus, section six provides that the directors of said road may erect toll houses, establish gates, appoint toll gatherers, and collect toll on the road when completed, and upon such parts of the road as shall from time to time be completed. Section five provides that "transportation of persons and property, construction of wheels, the form of cars and carriages, the weight of loads," etc., are to be according to the rules, regulations, and provisions established by the directors.

The first suggestion of a railroad using steam locomotives as a source of power, emanating in print from Providence, was on June 26, 1832, noting a passage by steamboat from New York to Providence in the unprecedented time of fourteen hours and 29 minutes, and that eight coaches of the citizen's line, started with its passengers to Boston, which caused the editor of the Providence Gazette to say: "We hope before many years to see a steam carriage on a railroad between this city and Boston."

His hopes were realized-in I 834 locomotive engines drew cars from Boston to the viaduct at Canton connecting there with stage coaches; and in June, I 835, locomotives ran the whole length of the road to its then Providence terminus at India Point, and the doom of the turnpike and stage coach was sounded in the shrill scream of the locomotive whistle. But one turnpike company was incorporated in Rhode Island after that date; the Peacedale Turnpike Company, in 1842 .

At first the turnpikes and stagę lines made common cause against the rail- 


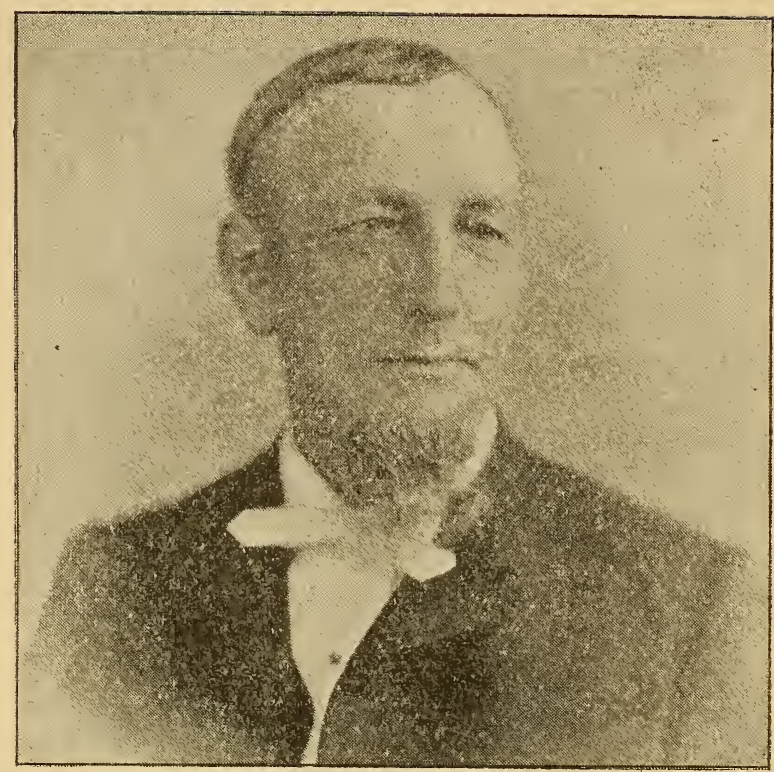

ESTABLISHED 1856 .

STlLLMan Whiтв,

Brass

\section{Founder.}

Sole Manufacturer of

S. WHITE'S

LINING

METAL.

No. 1 Bark Street,

PROVIDENCE, R. I.

STILLMAN WHITE.

\section{HOUSEHOLD SEWING MACHINE CO., PROVIDENCE, R. I.}

MANUFACTURERS OF THE . . . .

Famous "Housshold" Seving Macoline.

Machine, Foundry and Cabinet Work of all Kinds. Office and School Furniture, Cases for Silk, Thread and Braid, Specialties.

\section{GANNETT CO.,}

\section{Electrical Engineers and Contractors for}

\section{ARC AND INCANDESCENT LIGHTING SYSTEMS.}

\section{ELECTRIC MOTORS.}

(e) Electric Wiring in all its Branches. \%..

Swarts Building, 87 Weybosset St., * Telephone 845-4, * PROVIDENCE, R. I. 
road, and attempted to run it out of existence by a vigorous competition, but the railroad could make the trip to Boston in the beginning in two hours and a half, and they gradually reduced the time required till it is now made in one hour. No amount of speedy horses or frequent relays could drive a stage coach from Boston to Providence in two hours and a half. The stage lines then sought business. by lowering the price, but here also the railroad could meet and discount them, and reluctantly the stage lines and turnpike corporations yielded to the inevitable and accepted their fate. The same destiny has since overtaken other lines and turnpike roads as other railroads came into existence, and it is now believed that there is not a turnpike and but very few stage lines in existence in the state.

Before the opening of the Boston railroad, and before the idea of using steam as a railroad locomotive power, in June, 1832, another railroad with rights and powers similar to those of the Boston \& Providence, known as the New York, Providence \& Boston Railroad, was authorized to construct a track from Providence to Westerly. This company, in connection with a Connecticut company, built a line from Stonington to Providence, striking the shore just north of Sassafras Cove, and running up the west side of the harbor to the present Hill's wharf. This line was opened in 1837 . Soon afterwards a steam ferry boat connection was made between the New York, Providence \& Boston Railroad, and the Boston \& Providence Railroad, in connection with steamboats running from Stonington to New York, thus giving a second all steam line from Boston to New York.

The next great movement in the way of increasing transportation facilities, was the building of the Providence \& Worcester Railroad. The Blackstone canal had proved its inefficiency, and in May, I844, the Providence \& Worcester Railroad was incorporated.

This corporation built the central railroad station now in use on land filled in by them from the Old Cove, and made arrangements with the Boston \& Providence Railroad by which the latter, building a branch track from East Junction to near Valley Falls, came into the city on their tracks and used the same central station.

This action was followed by the New York, Providence \& Boston Railroad constructing a new entrance into the city and using the same central station. These arrangements were all completed in 1848 , and since then the main passenger station in the cily has been the central one, and around it are grouped most of the freight stations of the city.

About this time came the development of a means of transportation of an institution that is said to have originated in Providence. We refer to the socalled "furniture wagons," a species of light, strong wagons, which with the development of upholstered seats, have become the "excursion wagon" of the present day.

The "low gear" of Providence, which is seldom seen elsewhere, and when seen is merely a copy of a Providence institution, was also a production of this period. These conveyances are matters which, though calling little attention 


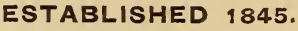 \\ Providence Machine Co.,}

MANUFACTURERS OF

Cotton and Worsted Roving Frames a Specialty. SOLE BUILDERS ㅇ THE HILL SPEEDER.

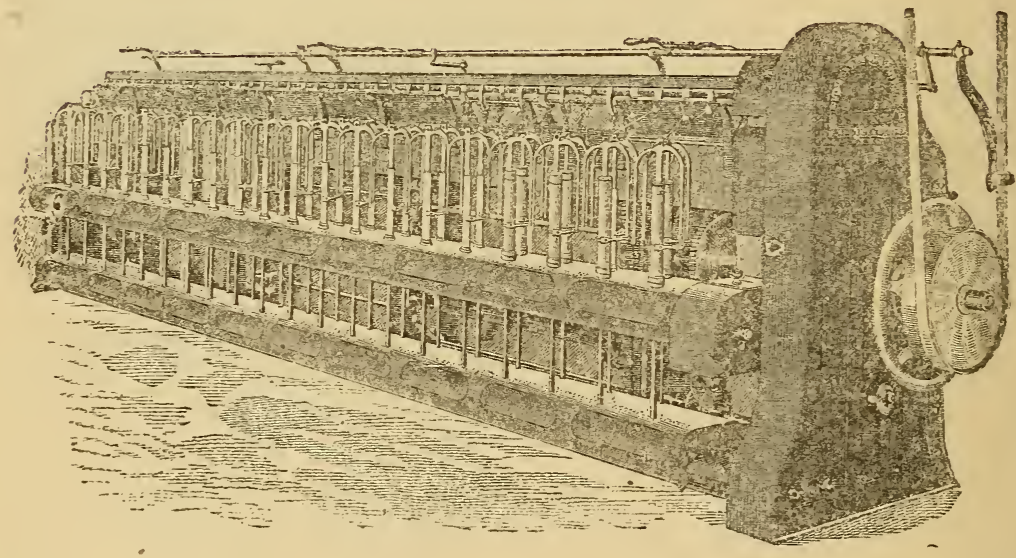

COTTON COMBERS OF THE HETHERINGTON PATTERN.

Lap Winders, Fluted Rolls,

Bolster, Bobbin Gears,

Spindles and Flyers.

Patent Flyers, solid nib with clasp centrifugal presser. Presses

for our own make flyers always in stock, other makes to order.

\section{Eddy St., Providence, R. I.}


from the world at large, are worthy of notice as practical triumphs of Providence mechanical ingenuity.

In 1852 , the Providence, Hartford \& Fishkill Railroad was allowed to enter the city and central depot on land to the northward of that of the New York, Providence \& Boston Railroad. This road, though late in its coming, added greatly to the transportation facilities of Providence. It is now a part of the New York \& New England Railroad system.

Still another means of transportation was afforded in 1854 by the Providence, Warren \& Bristol Railroad to the system centering in Providence. It has proved of great benefit to the commercial and other interests of Providence in bringing her into relation with the towns and villages located on the east side of the bay, and in southwestern Massachusetts.

The city of Providence to-day is the metropolis of the state of Rhode Island, and is one of the most interesting places in the New England states. It is not only a most thriving manufacturing town, but its products are entirely peculiar to itself. The manufactories are the largest and most extensive of their class to be found anywhere in this country, and their equipment unsurpassed, if equalled, by any similar concerns in the world. The city is noted for its cleanliness and healthful conditions, and all places where great manufacturing industries are conclucted partake of the tidiness and scrupulous order everywhere to be observed. Some of the plants devoted to iron-working, which is one of the largest interests here, are simply elegant in their surroundings, and to a stranger might easily be mistaken for a well kept public institution of some sort. The grourds about many of these establishments are laid out into tasteful lawns, with drives, walks, ffowers and shrubbery that would be a credit to a private estate.

Unlike most cities, Providence creates a favorable impression the moment it is entered, passengers by the Old Colony line stepping from the depot into a spacious square, at one end of which is the imposing city hall and the fine soldiers' monument, at the other an equestrian statue of her gallant son, MajorGeneral Ambrose E. Burnside, while directly opposite the station are some of the most imposing business blocks the city possesses. The city is very advantageously situated for commerce. Its harbor is safe, spacious and commodious, admitting vessels of $\mathrm{I}, 000$ tons. Formerly the port carried on an extensive trade with China and the East Indies, but since the marvellous increase in local manufactures the foreign commerce has considerably declined. The principal articles now imported are molasses, sugar and salt, with an occasional cargo from Africa of ivory, gum, tortoise-shell, cloves, dates, etc. The principal articles received coastwise are cotton, flour, corn, oats, wheat and coal. The business of Providence in print cloths and various textile fabrics is extremely large, and in conjunction with other products a large amount of capital is employed. An important industry here is the manufacture of jewelry, for which there are nearly one hundred establishments. There are numerous foundries and machine shops, large manufactories of screws, establishments for the manufacture of muskets, cannon and cannon-balls, locomotives, steam-engines, 


\section{William H. Miller \& SONS,}

Machine and Tool Forging of

* * All Kinds. BLACKSMITHS, BUILDNG WORK.

PJCKS, TONGS, TURNING TOOLS, DIES, HUBS, CUTTER-PIATES, JACK-DIES, PLUN-

GERS and HOLDERS, PLUMBERS' and PIPERS' SCOOPS for TUNNELLING, Always kept in Stock

We also keep in stock JESSOP'S TOOL STEEL, annealed from 1-4 in. varying in size 1-8 inch to $21-2$ inches in diameter, which we are prepared to cut by machine in blanks of any desired length, at short notice.

All Cutter-Plates, Hubs and Conera Blackmithing \& Johhing Done to order at short notice Plungers Furnace Annealed, General blacksmithing \& Jobbing and in workmanilike manner.

194 and 196 Eddy St., - Providence, R. I.

TrLephone Connection.

D. RUSSELL BROWN

H. MARTIN BROWN.

CHARLES H. OHILD.

$$
\text { Brown Brôs. \& Co., }
$$

* GENERAL MILL FURNISHERS. *

MANUFACTURERS OF

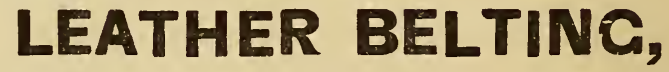

Shaw's U. S. Standard Ring Travelers, Belt Hooks, Loom Forks, Steam Packings, Factory Wire Goods \&c.

Providence, R. I.

\section{MASON, CHAPIN \& CO.'S \\ Anchor Colors \\ in PASTE $\mathcal{A N D}$ LIQUID FORM.}

These colors are manufactured from selected materials and are highly recommended for all kinds of exterior and interior painting. Warranted pure linseed oil paints.

MANUFACTURED BY

MASON, CHAPIN \& CO.,

Providence.

New York.

Boston.

\section{B. H. $M^{\mathrm{C}} \mathrm{CABE}$,}

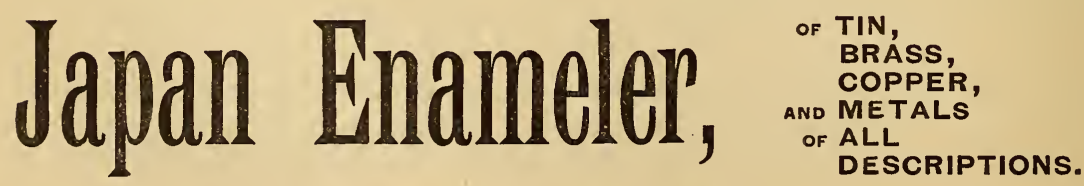

JEWELRY A SPECIALTY.

81 FRIENDSHIP ST., PROVIDENCE, R. I. 
machinery of all kinds, stoves, butts and hinges, nails, pick-axes, and other articles of metal; cabinet ware, carriages, boots and shoes, etc., are also produced in large quantities.

The American Screw Co. was originally instituted in 1838, as the Eagle Screw Co. In 1860 the Eagle Screw Co. was consolidated with the New England Screw Co. which was formed in 1840 , and has since continued the manufacture of screws with uninterrupted success under the present title of the American Screw Co. The extensive plant of this company comprises a number of brick buildings, varying from two to four stories in height, which are completely equipped with special machinery for the work, power being furnished by engines, aggregating about 3,000 horse power, and employment is furnished to eighteen hundred operatives. The American Screw Company also operates factories in Leeds, England, and Hamilton, Ontario, Canada, under the respective names of British Screw Co. Ld. and Canadian Screw Co. Ld. The products of the works comprise all kinds and styles of wood screws, machine screws, tire bolts, stove bolts, rivets, coach screws, ete. The present officers of the company are E. G. Angell, president; Clark Thurston, vice-president; J. A. Nealey, agent; Olney Arnold, 2nd., secretary; G. W. Thurston, treasurer and William A. Cranston, assistant treasurer.

The Rhode Island Perkins Horse Shoe Company is the most extensive -manufacturer of all kinds of horse and mule shoes in the world. This company was first organized as the Rhode Island Horse Shoe Co. in 1867. In I891 its name was changed to its present one, with the following board of officers to manage it: F. W. Carpenter, president; C. ·H. Perkins, general manager; R. W. Comstock, secretary; C. R. Stark, treasurer. Their office is centrally and pleasantly located in the Brownell building on Westminster street, this city. They possess a very large and complete plant at Valley Falls, R. I., which in its entirety covers some six acres of land, and comprises an immense rolling mill four hundred feet long and one hundred wide, while the horse shoe shop, punching room, packing room, cooper shop, foundry, etc., are equally well adapted to their needs. The mill buildings are of iron, of one story in height. They are fitted with the latest improvements in the way of special machinery, the invention of Mr. Perkins, the general manager, which, together with the large force of help they employ, numbering five hundred hands, enables them to supply the large demand from all sections of the globe. In addition to the regular patterns of horse and mule shoes they have several specialties for which there is a large and increasing demand. Perkins' toe weight and side weight shoes are Mr. Perkins' latest inventions. Owing to their peculiar shape these shoes have never before been successfully made by machinery, but Mr. Perkins' inventive genius has finally overcome all obstacles, and the company are now placing before the public a perfected shoe. They also manufacture a line of shoes particularly adapted to horse railroad service, for which there is a large demand. Light steel shoes for fine shoeing have for a number of years been a specialty of the company. In addition to horse shoes they make the celebrated Perkins' toe calks, both blunt and sharp. 
The Brown \& Sharpe Manufacturing Company is one of the most extensive and important establishments of Providence. They are makers of iron castings, sewing machines, machine-tools and small tools for machinists' use. David Brown and his son, Joseph R. Brown, were the founders of this business in I833. Mr. Brown, Sr., retired some years after, and his son in 1853 together with Lucian Sharpe formed the firm of J. R. Brown \& Sharpe, which in 1868 was incorporated as the Brown \& Sharpe Manufacturing Co. Their works situated about a half mile from the business centre of the city, are buildings of exceptionally neat construction, particularly well arranged, and remarkably well equipped, the floor space of which exceeds four acres (a growth from I 800 sq. ft. in 1853 ) and the machine shops are in all respects among the most notable on this continent. In 1859 was commenced the manufacture of the Wilcox \& Gibbs sewing-machines, and the requirements of this work were a great factor

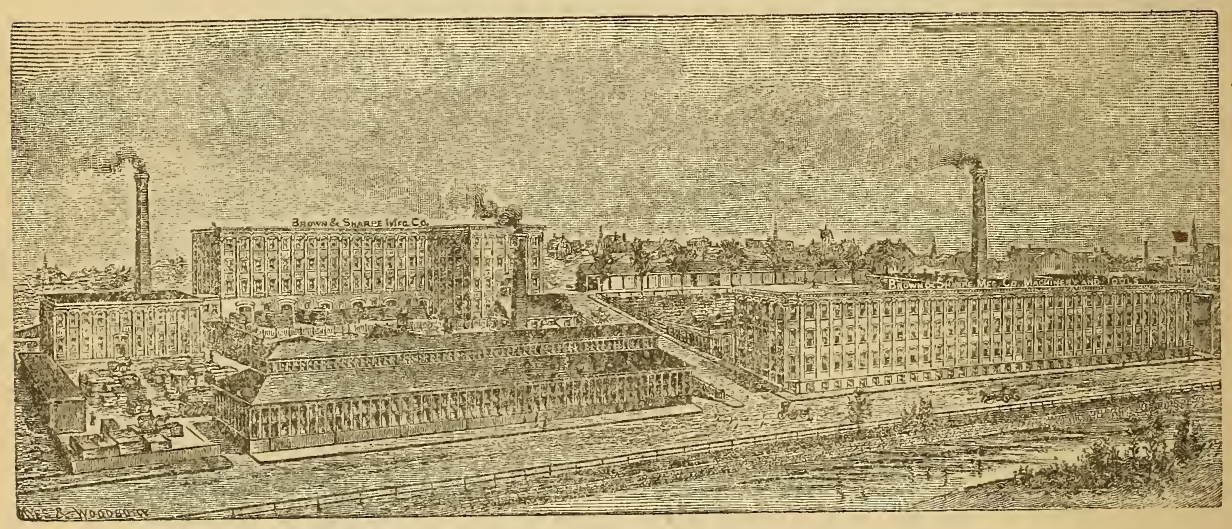

in bringing about the invention and development of milling and grinding machines, the cutters that can be sharpened without change of form, and the standard guages and exact measuring instruments for which this house is noted and which have greatly modified and improved machine-shop practice throughout the world. Heavier and larger machines, some suitable for use in locomotive works have also been recently brought out by this company. More than eight hundred and fifty workmen are employed at these works, which are open to visitors. Leading awards were received at international exhibitions at Paris in 1867 , Vienna in 1873 , Philadelphia in 1876 , Paris in 1878 , and the grand prize at Paris in 1889 by the Brown \& Sharpe Manufacturing Company.

F. J. Gay \& Company is one of those particular manufacturing enterprises that naturally increase, and develope with the growth and extension of all industrial centres. The firm are now one of the largest manufacturers of milling cutters in this section of the country, and making a specialty of special and standard milling cutters, for which they have a well established trade throughout this country and abroad. The products of the house have given the best possible 
satisfaction to the trade; their cutters being made by the best skilled labor, with every regard to accuracy, strength and durability. Mr. Gay, the senior partner of the firm has had an extensive experience in cutter and gear departments, with other large concerns, and was formerly eleven years with the Brown \& Sharpe Manufacturing Company. The firm are also agents for Seebohm \& Dieckstahl, Dannemora Steel Works of Sheffield, England, and supply the trade with the celebrated products of this house at the shortest notice, and in quantities to suit. The plant occupicd by the firm consists of premises located at Nos. 189 and I9r Edcly street, I00 x 50 feet in measurement, and these are fully equipped with suitable mechanical appliances, and employes a number of skilled artisans in its operations.

The Providence Belting Co., 37 and 39 Charles street, was established in 1885 , their business has steadily increased year by year until now they have one of the finest equipped factories in the country, covering an area of 25.000 square feet. Only the best skilled labor is employed in producing the goods, their oak tanned, short lap leather belting is second to none in quality and durability. They are the sole manufacturers of the copper sewed waterproof leather belting, for the manufacture of which the latest improved patented machinery has just been imported. Copper sewed belting is fast taking the place of rubber and fabric belting. They also make a specialty of roll covering for worsted machinery and manufacture the patent folded Twist belting.

The Providence Machine Co. are leaders in their line, which consists in the manufacture of cotton and worsted machinery. This enterprise was founded in 1834 , and has occupied the present location since 1846 . In 1866 , business increased to such an extent as to cause apartments to be added to the plant, and today it is one of the most complete and perfect in the New England states. The main building is three stories in height, and covers an area of two hundred and twenty by sixty feet, the adjoining buildings comprising a foundry, pattern shop, a blacksnith shop, aud numerous smaller buildings. Abont three hundred workmen find constant emplnyment in this factory, which is well equipped with all the latest improved machinery. The work produced here embraces imprived cotton and worsted roving frames, combers and lap winders, patent flyers, etc. They are in use by all manufacturer's here and in some foreign countries. The ufficer's of the company are Messrs. T. J. Hill, president and treasurer; Wm. C. Peirce, secretary and superintendant.

The Providence Coal Co. was founded in 1840 by Samuel R. Jackson and Sterry Clark. This firm were succeeded by Jackson, Clark \& Co., who were in turn succeeded by the following fiıms: S. Clark \& Co.; Clark \& Coggeshall; Henry C. Clark; Clark \& Webb; Tucker, Swan \& Co.; 'Tucker \& Little; and then the Providence Coal Co., was organized in I88I, the proprietors being H. C. Clark and Harry C. Clark. Eighty-five horses, and one hundred and twenty-five men are employed in the conduct of the business. and the trade of the house, which is both wholesale and retail, extends throughout New England. The company handles the best varieties of coal in the market, including Franklin, Lehigh and Cumberland. A specialty is made of the 


\section{Providence Belting Company,}

. . Manufacturers of . , ,

\section{OAK}

\section{LEATHER BELTING ... A AND ...}

Pateat Folded Twist Belequat. OFFICE AND WORKS,

37-39 CHARLES STREET, * * PROVIDENCE, R. I., U. S. A.

A. C. J. LEARNED,

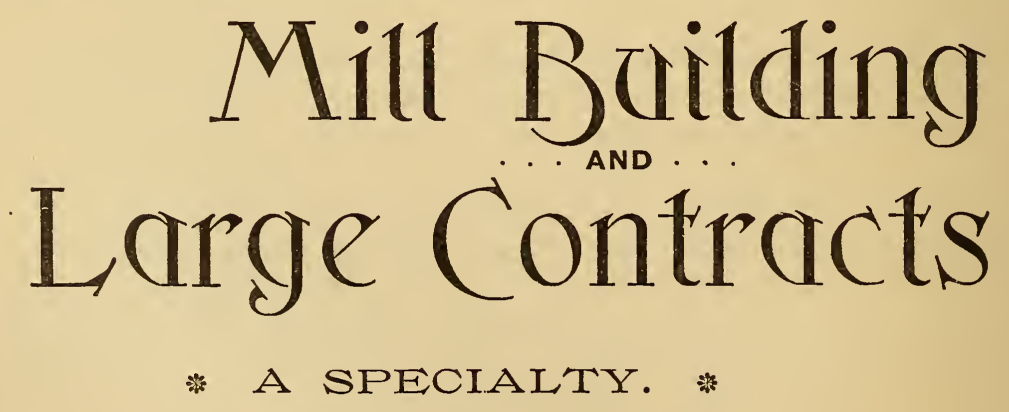

5 Charles St., Providence, R. I.

(G) LONG DISTANCE TELEPHONE. 
celebrated Plymouth coal of which they are the only sales agents in this market.

The George W. Stafford Manufacturing Company is favorably known throughout the textile manufacturing world by their special machines. Since Mr. Stafford founded this business in Providence in 1882 , increasing business has obliged four removals to secure larger accommodations. They finally purchased of the City Machine Co., who were going out of business, the property that they now occupy on the corner of Harris avenue and Acorn street, containing over 60,000 square feet of land on which were buildings having some 35,000 sqnare feet of floor space. During 1892 they built a foundry and other buildings which gave them an additional floor space of nearly 30,000 square feet. They own many valuable patents on their machines, and are continually improving and adding new specialties as they are demanded in the mills. Mr. George W. Stafford, the general manager, and Charles H. Poland, secretary, devote all their time to the business which is continually increasing. Within two years past they have brought out a loom which is meeting with good success in some of the best factories. It is rapid running and very substantial. It is built in plain box and also drop box.

Brown Bros. \& Co., in 1877 succeeded Butler, Brown \& Co., who 22 years ago erected an establishment for the purpose of supplying the wants of cotton, woolen and silk mills. Brown Bros. \& Co's. premises include two floors of the Butler Exchange building; they also operate a factory for the manufacture of leather belting, and leather specialties, also ring spinning and twister travelers. Their goods have always been noted for their excellent quality and embrace everything in the way of mill supplies, such as beltings, leather hooks, wire goods, roll covers, stock and tools. The members of the present firm are D. Russell Brown, H. Martin Brown and Charles H. Child.

The Clurch \& Russell Co., is rapidly becoming one of the best known houses in its line in New England. Its chief dealings are in manufactured iron and steel of all kinds, and in both it represents the most reliable producers in the United States, among them being: Sterling Steel Co., Pittsburg, Pa., Sterling Tool Steels; Carbon Steel Co., ship, boiler, tank, and bridge steel; Linden Steel Cn., Pittsburg, Pa., open hearth bar steel; Lockhart Iron \& Steel Co., Pittsburg, Pa., bar iron and Bessemer steel; Kidd Steel Wire Co., Sharpsburg, Pa., drill rods and drawn wire; La Belle Iron Works, Wheeling, West Va., tack plate. All these firms stand in the foremost rank of the world's steel and iron makers. The Church \& Russell Co., do an extensive business in the higher grades of iron and steel, fine tool steels, polished drill rods, the best grades of bar iron and boiler steel being specialties, holding firmly the trade of manufacturers whose reputation rests on the unvarying high quality of their product. They have furnished all the ship, and boiler plate steel as well as the bar steel used in the construction of the cruisers "Machias" and "Castine" and the harbor defense "Ram" building at Bath, Maine, for the U. S. Navy, and are recognized as a leading house dealing in government material. Alive to all the improvements being made in the manufacture of 
$\longrightarrow$ ESTABLISHED $1830 . K$

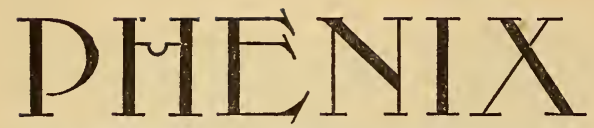

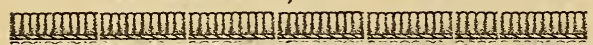

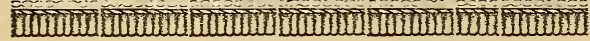

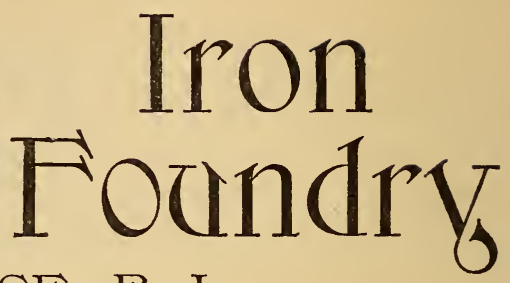

PROVIDENCE, R. I.

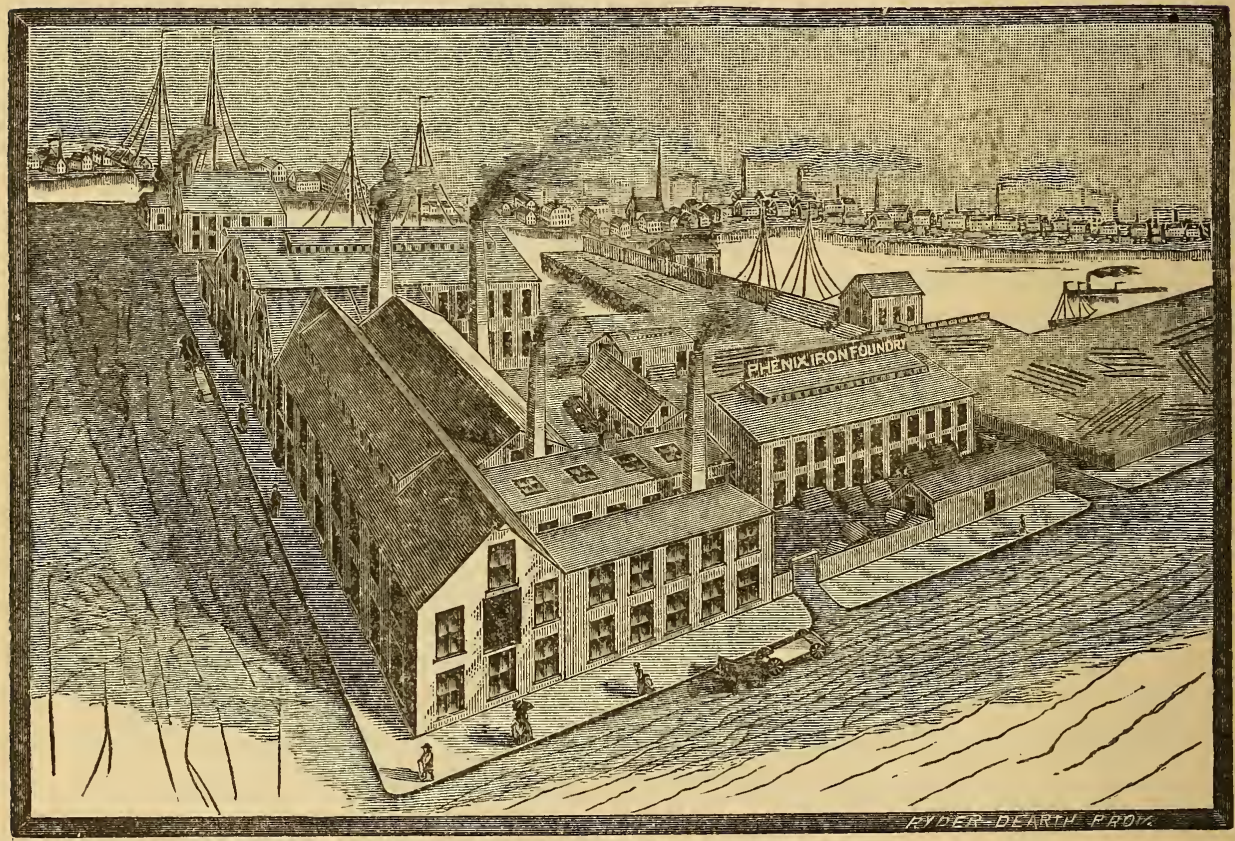

MANUFAC'LURERS OF

Calenders, Starch Mangles, Calender Rolls of Paper, Cotton and Husk,

Bleaching and Dyeing Machinery, Printing Machines, Shafting, Iron Tanks, Expansion Pulley (new), Pulleys, Gearing, Grate Bars, Hydraulic, Presses, Tenter Drying Machines, Cloth Cutting Machines, Silk Lace and Cotton Finishing Machinery.

\section{And Sole Manufacturers of NAGLE POWER FEED PUMP.} SEND FOR CATALOGUE. 
iron and steel, they keep pace with the times and are building up a large and remunerative business, as is evidenced by their increase of warehouse facilties, adding to their territory, etc. This company is composed of gentlemen who have had an extcusive experience in the trade which they represent. They are A. H. Church, president; F. G. Russell, secretary and treasurer; and E. C. Church, assistant secretary. The office and ware rooms, which are commodious and well adapted to the business, are now located at 25 Dyer street.

The Phenix Iron Foundry, located on Eddy street corner of Elm street, is one of the oldest iron foundries in the state of Rhode Island, being founded in 1830 and incorporated in 1832 under the name of Phenix Iron Foundry. The foundry buildings cover an area of sixty-five thousand square feet and the machine shops twenty-six thousand square feet. This company are sole manufacturers of the "Nagle Power Feed Pump", made from first class material throughout. Machinery for all kinds of bleaching, dying, printing and finishing cotton goods, silk and plush; mangles of all kinds, hydraulic presses, and in fact machinery of all kinds is made by them. They are also manufacturing a new Fxpansion Pulley. A large business is transacted by them and the trade extends throughout the United States and Canada. They have a capacity of getting out daily thirty-five tons of castings. In the several departments of this foundry about two hundred skilled workmen are employed, and all orders are promptly filled. They have a fire proof store-house which is used by them for the storage of patterns of their machinery, pulleys, etc. They have the most extensive list of patterns for gears and pulleys of any corporation in the United States. An annual business of upwards of half a million of dollars is transacted by this company. The president and treasurer of this company is Charles R. Earle; secretary, M. W. Gardiner, Jr.; and the agent is Amos W. C. Arnold.

Flint, Blond \& Co's. factory is at 94 Point street with a New York office at I94 Broadway. This firm commenced business in 1869 under the name of Flint, Blood \& Co., later, on the retirement of B. A. Holbrook, becoming Flint, Blood \& Young. Three years ago, on the death of $\mathrm{Mr}$. Young, the original firm name was assumed. The present firm are veterans in the jewelry business. Mr. Flint is a native of Walpole, N. H., but has long resided in this city, following the jewelry manufacturing trade since I $855 . \mathrm{Mr}$. Blood, who came to Providence in $185 \mathrm{I}$ is a native of Ipswich, Mass., and has been engaged in the trade since that time. They are located in the four-story Simmons Building, 94 Point street, where they occupy a shop 40 by 80 feet, with steam power, and furnish work for 20 to 40 hands. Flint, Blood \& Co. manufacture solid gold rings, gold filled rings, a large and superior line of plated rings and collar buttons, which are sold to the jobbing trade only, in all parts of the world. Owing to their superior work and designs the jobbers and wholesale dealers find that their manufactures are in great demand and are ready sellers.

The Hotel Girard during the years 1878 to 1891 , inclusive, was managed 


\section{THE WHITEN-GODDNAG CYCLE CO.,}

Mannfacturers, Importers and Jobbers

Gicycles, Cycle Parts and Fittings,

.. Our Specialties are..

\section{Saladee Saddles. * Universal Whistle.}

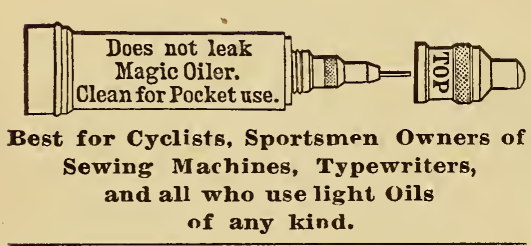

THE "SALADEE" GENTS.

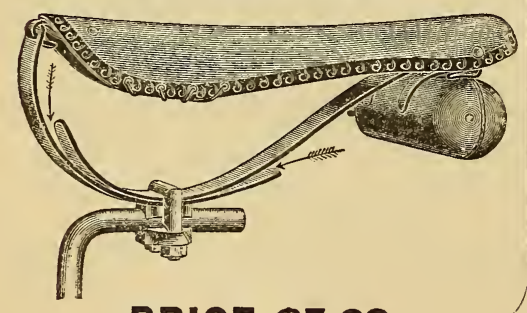

PRICE \$5.00.
THE UNIVERSAL WHISTLE

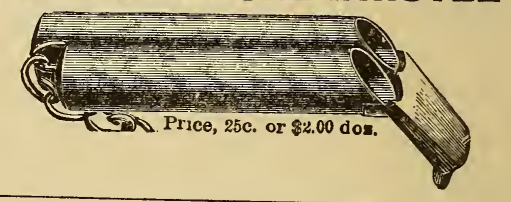

THE "SALADEE" . LADIES.

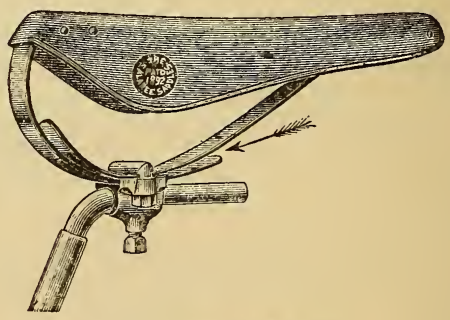

PRICE \$5.00.

The Narragansett Scorcher. Magic Pocket Oiler and Yale Cyclometer. Rims, Tubing and Bicycle Forging.

BRANCH :

125 BELLEVUE AVE., NEWPORT, R. I.
HOME OFFICE :

118, 120, 122 and 124 So. MAIN STREET, PROVIDENCE, R. I. 
by $\mathbf{E}$. W. Tinker, but in the latter year he was succeeded by Jesse Brown, the present proprietor. The hotel is a three-story building, contains twenty-five rooms, centrally located on Eddy street, Nos. 5 I to 55. The hotel is nicely furnished throughout, well ventilated and is kept up in first-class order, contains all the modern conveniences and is conducted on the European plan. Mr. Brown has had many years of experience in this special kind of business. He is well known throughout the city, and has succeeded in building up a large business by his courteous manner.

Mason, Chapin \& Co was founded as long ago as 1815, and is therefore one of the oldest of its kind in New England. The present firm consists of E. P. Mason, W. P. Chapin, S. L. Peck and E. E. Arnold. The business consists in the manufacturing of and dealing in drugs, dye stuffs, chemicals, paints, oils, etc. The premises, which are located from 55 to $6 \mathrm{I}$ Canal street, comprise a building sixty by one hundred feet in dimensions, having six floors, the whole of which is stored with a large and valuable stock. The firm has branch establishments at 58 Pine street, New York, and I4I A Milk street, Boston.

J. M. Alpaugh \& Co., were established in 1889 , as wholesale dealers in paper hangings, window shades, shade rollers, etc. They carry at all times a large and well selected stock of the above articles. The premises occupied are large and well adapted to the business, and contain every convenience known to the trade. The trade of the house extends to all parts of New England, and that they have at all timcs met the requirements of an exacting public is well attested by the constant increase in the volume of business transacted annually. The salesroom and storage house is located at No. 30 Exchange place.

The Providence Gas Company occupies the premises on the corner of Market square and North Main street. They carry a full line of the best and safest gas stoves and ranges with all the latest improvements on the same. By personal supervision and critical examination of all stoves and ranges before they leave their premises, they are sure that no cheap work is placed on the market. They make a specialty of gas stoves and ranges only, and offer them on trial.

B. H. Gladding \& Company, located at $24 \mathrm{I}$ and 245 Westminster street, is one of the oldest firms in the city, having been established in 1805 . The premises occupied consist of five floors, the main store being forty by one huudred and fifty feet. For the past forty years they have been known for the fine quality of linens that they carry, only the pure linen fabrics being sold. They are also leaders in silks and dress goods, having fine importations from Frauce, England, Germany and all the home productions of the best manufacture. In their carpet department can be found a large stock of all the latest productions of the best grades and styles. A full line of Priestly's celebrated black goods are also carried by them. To attend to the wants of their patrons in a prompt manner, employment is given to one hundred and twenty-five hands, some of whom hare been with the firm for twenty-four 


\section{Charles H. Moore,}

Manufacturer of Every Description of

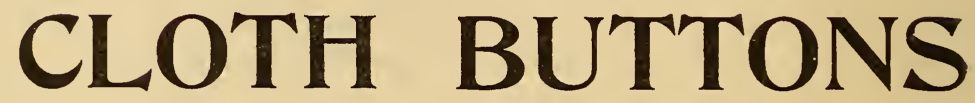

ros Clothiers, Cloakmakers, and Dressmakers, Upholsterers, Carriage Trimmers, Etc., Etc. .,

$\triangle$ SPECIAL ATTENTION GIVEN TO $\triangle$

DRESS PLEATING AND PINKING,

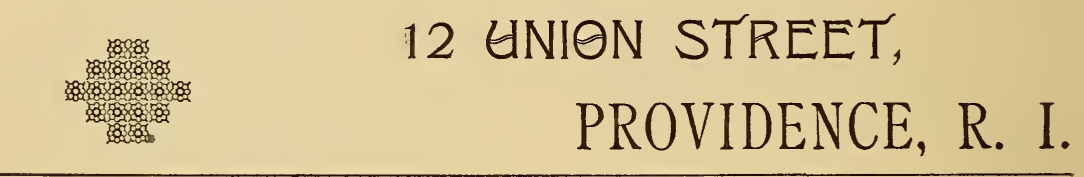

Geo. L. Clafinin \& Co.,

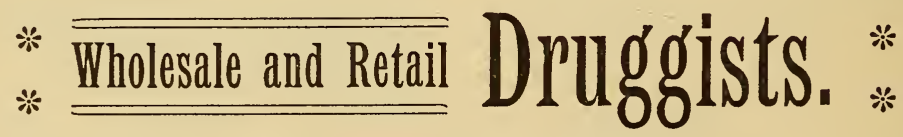

IMPORTED AND DOMESTIC

DRUGS, MEDICINES AND CHEMICALS,

Jewelers Supplies, Sponges, Mineral Waters, Glassware, Chamois Skins, Essential Oils, Etc.

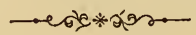

We also carry in stock a large line of

Surgical Instruments, Crutches, Trusses, Supporters, Elastic Stockings, Ear Trumpets, Electric Batteries, Etc.

56,58,62, 64, 66, So. Main St., PRPVIDENGE, B. I. 
years. For the convenience of their patrons an elevator is in the store to carry all patrons to the various departments on the floors above. All members of the firm are thoroughly experienced in the business, but the senior partner has obtained a high reputation for the taste and skill he has used in the selection of furs and fine garments.

The American Ring Traveler Company of 7 Eddy street, Providence, was incorporated in 1882 . They manufacture every description of spinning and twisting travelers. Among their specialties, which they manufacture solely, are the famous Wilson round pointed fast speed spinning travelers, the American U. S. standard square pointed travelers, the Climax patent bronze twister traveler for wet twisting, also the Fowler patent twisting traveler for dry twisting. The premises cover an area of six thousand square feet of floor space, and are equipped with their own special machinery operated by steam power, thus having the facilities for producing a large amount of work. They are also manufacturers of felt hooks, loom forks, reed hooks, weaver combs, and wire specialties of every description. The products of this company are used by most of the mills throughout the country, and are considered to be the best that the market affords. 'Their capacity is an output of many million ring travelers annually, and their trade extends not only throughout the United States, but to foreign countries. C. W. North is the superintendant and A. C. Tingley is the agent. Both these gentlemen have had years of experience.

T. D. Pratt established himself in this city as a manufacturing jeweller in 1885, when he was located on Westminster street. He remained at this location until the early part of $\mathrm{I} 888$, when he removed to his present site, I 26 Summer street, where he occupies a large floor fully equipped with all the requisite machinery and tools necessary in the successful operation of his special line of production. This includes a full variety of jewelry in gold, white stones being a specialty, however, and many handsome designs are shown in this line, with fine white imported stones.

The Whitten-Godding Cycle Co., formerly Whitten, Godding \& Co., was originally established under the name of Whitten \& Co., in I886. The partncrship then formed consisted of William W. Whitten and Edward A. Godding, and was confined wholly to the retail sales of bicycles and sporting goods. By degrees the business was extended step by step, new departments being added from time to time, until at the present time they are supplying the home market with everything in the athletic and sporting line, including guns, boats, fishing tackle and boat hardware. Three years ago the firm began the manufacture of bicycling sundries and the importation of bicycle parts and fittings, and to such an extent has their trade in this line grown that they now are receiving regular shipments of goods from abroad, and havc on their books several hundred accounts of firms situated throughout the United States. The business, originally started in a third story room on Westminster street was moved in the spring of I 887 to I 8 South Main street, in the Iight Infantry buiiding. It soon outgrew this store and the adjoining one was added; this soon proving too small for their rapidly growing wholesale business, they 


\section{PROPHET SPRING WATER,}

\section{ABSOLUTELY PURE.}

The water has all the Curative Powers that other Springs claim

to have and holds its own among its many competitors

Furnished in any Quantity Desired.

E. E. DRAKE, - 41 Dorrance Street, - PROVIDENCE, R. I. TELEPHONE 832-2.

\section{RATHBONE \& SMITH,}

Pure Gold always on hand

for the trade. . . .

Prompt Returns.

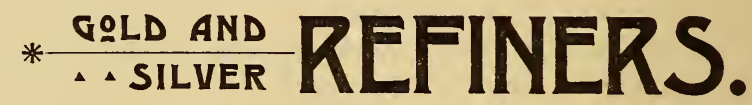

No. 1 to 9 Mathewson St., cor. Cove.

IELEPHONE, 850.

PROVIDENCE, R. I.

\section{THE LATEST GEMS FOR PIANO,}

By Mrs. H. E. LeValley.

The Wa!tz of the Day, Price 75 Cents, March of the Starg and Stripes,

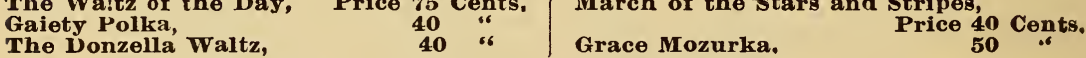

The Donzella Walt pestpaid to any address on receipt of marked price, Address

Mrs. H. E. LeValley, Teacher of Piano,

20 Aborn St., Providence, R. I. and Guitar.

Send for catalogue of Latest Banjo Music by H. E. LeValley. Teacher of Banjo

DRAKE'S LOCAL EXPRESS,

Office, 41 1-2 Dorrance t., cor. Westminster, Providence, R. I.

Orders for Baggage and General Expressing promptly attended to at Reasonable Rates. 
secured two more stores adjoining the other two in the same building, thus occupying one half the ground floor of this large and fine structure. They have the best equipped bicycle machine shop in the country, having special machines built for them for special work in building wheels, bicycle rims, and manufacturing other parts and fittings. A special wheel built by them to order is called the Narragansett, a light scorching or road-racing machine for those desiring a specially light wheel. The new firm was incorporated in May I891, and William W. Whitten was elected president, and Edward A. Godding secretary and treasurer. Both these gentlemen are college bred men with no previous business experience, and whatever success they have attained has come from honest hard work and strict attention personally to every detail of the business. Two years ago a branch store was opened at Newport, R. I., and this has proved a paying venture and is still open, occupying one of the best located stores on Bellevue avenue.

Geo. L. Claflin \& Co., at 56, 58, 62, 64 and 66 South Main street are proprietors of one of the oldest drug stores in Rhode Island. The present company, founded under this name by Geo. L. Claflin in 1873 , in reality dates back to I 8 I 7, when Joseph Balch established a small drug store at the same location. In 1873 Mr. Claflin, together with N. W. Smith and F. J. Phillips, purchased the stand, fixtures and good will of the Balch heirs, on South Main street, and continued the business under the firm name of George L. Claflin \& Co. In I $874 \mathrm{Mr}$. Phillips sold out his interest to C. A. Babcock. In I875 Mr. Smith died and Messrs. Claflin and Babcock continued the business for a number of years, when the latter gentleman retired, Mr. Claflin assuming the entire control, assisted by his son, Arthur W. Claflin, and later by his second son, William L. Claflin. In I 885 Arthur W. Claflin was admitted as partner, and upon his father's death in April, I886, took entire charge, continuing the business until r89o, when his brother, William L. Claflin, was admitted to copartnership, the firm name remaining unchanged. The premises occupied by the concern comprise five stories and basement, at Nos: 62, 64 and 66 South Main street, in which are situated the wholesale department, while the retail store at Nos. 56 and 58 is the largest in the city. This house furnishes complete outfits for retail apothecaries and a very large business has been done in this line. A large and complete stock of drugs and medicines, essential oils, dyestuffs, chemicals, chemical glassware, acids, jewelers' supplies, etc., is constantly carried; while here can also be found a full line of the most valuable patent medicines and pharmaceutical preparations. They have one of the most extensive laboratories of any of the wholesale drug houses in the East, the entire fifth floor being devoted to this department. The fourth floor contains a large stock of drugs and patent medicines in original packages. The third floor is filled with glass bottles of every description, ointment boxes, corks, etc., while on the second floor is the pharmaceutical stock, liquor room and fancy goods department. The offices, salesrooms, order and shipping departments are on the first floor, and two telephones give quick communication with the numerous local and suburban customers. The retail department is in 


\title{
F. J.GAY \& CO., * * MILLING CUTTERS,
}

AGENTS FOR

\section{Seebohm \& Dieckstahl, Dannemora Steel Works, Sheffield, England.}
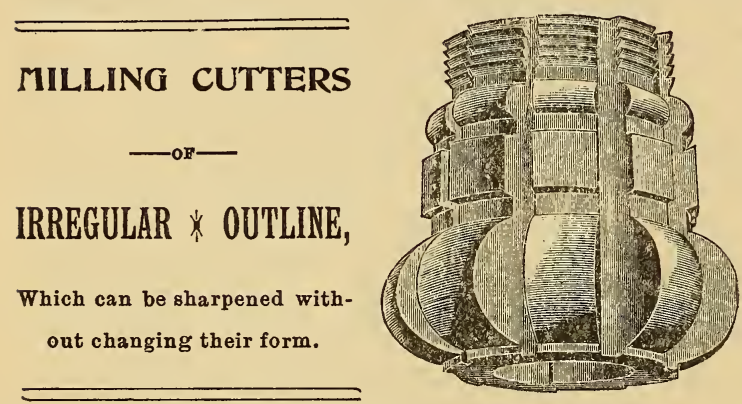

Self Hardening Steel, Best

Warranted Cast Steel.

IN BARS AND SHEETS.

Blanks Cut to Dimensions.

189 and 1.91 Eddy St., Providence, R. I.

\section{BARNARD LUCE, $\quad$ R. W. CROCKER, P. H. SCHOONMAKER, A. M. F. HALL, \\ President. Sup't. of Manul'g Dept. Gen. Manager. Treasurer \\ THE CROCKER HARNESS CO.,}

\author{
WHOLISALE MANUFACTURERS AND DEALRRS IN
}

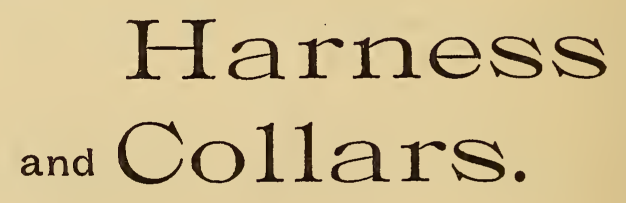

HORSE FURNISHING GOODS OP EVERT DESCRIPTION.

MAIN OFFICE AND WORKS AT VINEYARD HAVEN, MASS.

BOSTON STORE, No. 31 FRANKLIN STREET.

E. F. Wyegr, Manager.
PROVIDENCE STORE, No. 33 WASHINGTON STREET. W. H. Whittemore, Manager 
charge of registered pharmacists, and here everything in the line of drugs and medicines, whether new or old, can usually be obtained.

The Clark Manufacturing Company is located on Ashburton street. This firm is the only one of the kind in Providence that manufactures this line of goods for the trade. The business was established in a small way but has increased every year, and at the present time they occupy a four-story factory and three-story store house. The factory is fitted up with all the necessary machinery operated by a fifty horse power engine which enables them to turn out a large variety of burial caskets, and undertakers supplies. Constant employment is given to forty skilled workmen. The officers of the company are John L. Clark, president; who is the founder of the business; J. E. Clark, vice-president; and Albert $\mathrm{H}$. Clark, treasurer and business manager.

The Combination Ladder Co., of this city, stands in the foremost rank as manufacturers of ladders and kindred articles in New England. C. N. Richardson, the proprietor and general manager of the company has a thorough experience in every branch of the business, and under his energetic management the company has built up a trade extending throughout the entire United States, the new patent fire extension ladders manufactured by the company, having achieved a national reputation. The company occupy a three-story building, the dimensions of which are one hundred feet by two hundred feet. The factory is equipped with all the latest wood working machinery. Besides the company specialties which consist of fire extension ladders, extension mill trestles for staging purposes, the new circular saw guard, which has sprung into instant popularity, fire escape ladders, step ladders, rattan and splint chairs, painters' ladders, park settees and many other articles of wooden ware, they are interested in models for inventors, interior finish for offices and churches, etc. The goods they manufacture are said to be the most perfect in the market. They have a large number of wagons which make periodical tours through the different New England states, carrying a full assortment of samples of goods manufactured, and large sales are effected in this manner. Mr. Richardson has by his push and pluck combined with straight forward dealing constantly enlarged and developed the business, until, to-day he has achieved a national reputation and stands second to no one in the country in his line. The safety lock used on the fire extension ladder, so widely known as the "Providence tire extension ladder" being of his own invention. His office and factory are located at 300 Fountain street, Providence.

The J. J. Ryder Co., located at I 46 Westminster street, Proridence, are designers, engravers, electrotypers and printers. For the past ten years their productions have taken high rank with the best houses in the country, as a result of which their trade extends throughout the United States. Their designs always show a high degree of originality combined with rare artistic worth. Their engraving processes comprehend steel and copper plate, lithograph, wood and photo-engraving, including half-tone engraving. Their phototype process is unsurpassed for the reproduction of subjects with photographic fidelity and is in general appearance, not unlike a photograph, although 


\section{Hotel Girard.}

\section{Nos. 51,53 and 55 EDdY STREeT, PROVIDENCE, R. I.}

\section{This House, * *}

Centrally located, opposite City Hall, on Eddy Street, and but two minutes walk from. the General Passenger Depot, has recently been remodeled, refitted, and newly furnished throughout, is heated by steam and contains all modern conveniences for the comfort of its guests. .

\section{The Table, * *}

On the European Plan, will be supplied with the best the market affords, and it shall be our aim to establish the "GIRARD" a reputation second to no small hotel in the country. $\therefore \quad \therefore \quad \therefore$

Respectfully yours,

JESS BROWN, Prop.

CLERKS,

HENRY TINKER, EUGENE CARROLL.

\section{Private Dining Rooms.}


printed in a printing press. in their printing department they have availed themselves of the best machinery. The electrotype foundry which they have connected with their establishment rounds out its completeness and enjoys an extensive patronage.

David Burton of North Page street is a dealer in steam, gas and water pipes and fittings, and also steam engines and boilers, patent steam pumps, Clarke's steam and fire regulators, low water reporters, steam traps, etc., and feed and force pumps of all descriptions; Mr. Burton also furnishes estimates, and gives his personal attention to the piping of private houses and public buildings, and employs the most skillful artisans in all the work undertaken by him. His connection with the largest manufacturers in the country enables him to be continually supplied with a large and complete stock.

J. S. Fuller, located at 139 Weybosset street, this city, does all kinds of plumbing and gas pipe fitting, and deals in lead pipe, brass and nickle plated faucets, etc. All plumbing, and especially sanitary plumbing is a!ways done by him in first-class style. To conduct his business in a successful manner he employs ten competent assistants. A full line of nickle plated goods is constantly kept on hand. Mr. Fuller is sole agent for the state of Rhode 1sland for the Instantaneous water heater. This heats the water as it passes through it direct from the main supply.

The Crocker Harness Company was established in I884 for the sale of harnesses, collars, and horse furnishing goods of every description. A full and complete line of carriage robes, blankets, whips, boots, and a fine line of light carriages and road wagons are constantly kept on hand. They occupy two stores and a basement, each sixteen by eighty-seven feet in dimensions. W. H. Whittemore has had charge of the business since it was established here, and by his thorough knowledge of the trade has succeeded in building up a large and extensive patronage. The company do both a wholesale and retail trade. Barnard Luce is president, and A. M. F. Hall is treasurer. The Providence office is located at $5 \mathrm{I}$ Washington street. The main office and factory are located at Vineyard Haven, while a salesroom can be found in Boston at 31 Franklin street.

R. A. Melpi, whose premises are located at I 64 North Main street, is one of the popular custom tailors here, having been established for the last six years. He occupies a store measuring $30 \times 40$ feet, which is very neat in its arrangement. He makes a specialty of first-class tailoring and employs a number of the best class of work people, and catering to a first-class patronage only, he naturally carries in stock a full line of fine imported pantaloon goods and vestings, also broadcloths for dress suits, and suitings and overcoatings of both foreign and domestic manufacture.

The Providence Creamery at 89 and 9I North Main street, the object of which was the founding of a depot for milk, plain cream and ice cream at wholesale and retail, was established in 1879 , being the oldest creamery in the state. The quality was such that it soon became to be one of the best appreciated industries in the city. From small beginnings thirteen years ago it has 


\section{RHODE ISLAND CEMENT DRAIN PIPE CO.,}

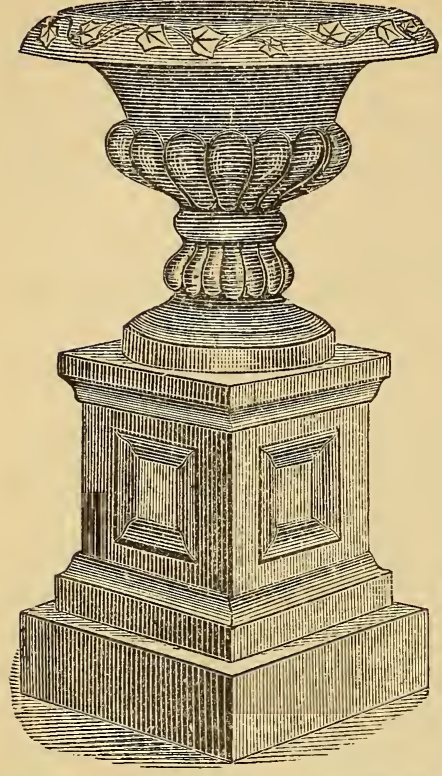

Drain, Sewer, Well and Chimney Pipe. Artificial Stone Caps For Brick Chimneys. Lawn Vases, Etc.

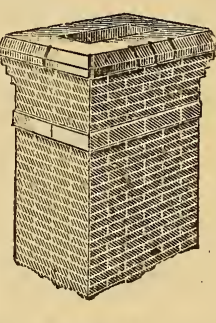

WITH CAP.

To resemble both Granite and Red sand Stone, at less than one balf the cost of natural stone.

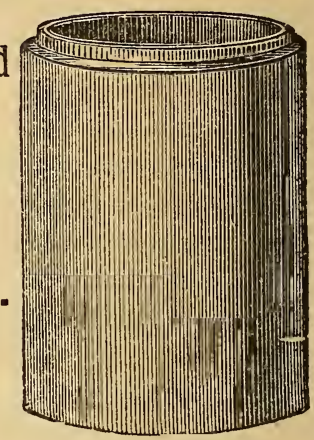

WELL PIPE.

These Pipes exclude all surface water, insects, or other impurities, and cost less than stone.

Artificial Stone Vases for Lawns and Cemeteries.

We have New Designs for the coming season.

Chas. Goen, Agt. F. W. Burt, Treas

Office and Works: - 30 Francis Street, PROVIDENCE, R. I. - Near the Depot.

\section{J. BRIGGS \& \\ \& SONS \\ COMPANY,}

ESTABLISHED 1849.

INCORPORATED 1890.

\section{Gold and Silver Platers,}

\section{Clifford St., Providence, R. I.}

MANURACTURERS AND DEALERS IN

JEWELERS' PLATE, WIRE, ETC., ETC., SQUARE, FLAT AND FANCY WIRE OF ALL KINDS.

Gold on tho Side and Gold on the Edge Wire. Half Round

Ring Wire with Gold Soldered Seam, Making it Seamless.

\section{STRIPED PLATE.}

All Colors and Karats of Flat Plate, any width and thickness desired. GOLD, SILVER AND BRASS SOLDERS. In addition to all kinds of Plate and Wire used in the manufacture of Jewelry.

\section{WE MAKE STOCK FOR}

Cane Heads, Umbrella Mountings, Pencil Cases, Watch Cases, Watch Crowns, Thimbles, Spectacles and Eye Glass Bows, Diamond Mountings, \&c. 
grown to be one of the best equipped places of the kind to be found. Excellence was its motto and it has been maintained.

The Star Carpet Cleaning Wurks, which are located at 25 Calender street, was commenced here in 1887. For its operations the works, of which C. J. Finley is the sole proprietor, occupy two large rooms, roox6o feet in measurement, and these are fully equipped with special machinery, and all suitable mechanical contrivances whereby the work is turned out in the most rapid manner possible. In fact the work is expedited in such a manner that carpets taken one day can be returned, after being thoroughly cleansed, the next day. The works have facilities for the cleansing of 5,000 square yards of carpet per day.

The Smithfield Granite Co., of which Almy Mathewson, is the proprietor has been established for the last five years, and its successful operation has been most beneficial to the building interests of this city and also to that in more distant sections of the country. The yard and offices of the company are situated at 125 Gaspee street in a most desirable location for the business. The yard in itself measures 200 by roo square feet and employment is given thirty to forty skilled workmen in its stone sheds and other departments, one of these being equipped with a large forge for the repairing and sharpening of tools. While the company make a most important specialty of building work, giving particular attention to heavy foundation and building stone work generally; they also do cemetery work as well.

John R. Pearce \& Son, dealers in paper stock, cotton and woolen rags, old iron and metals, whose place of business is located at 95 to ror Dorrance street, was established some twelve years ago by John R. Pearce and in I89r Fred L. Pearce was admitted to the firm. They now occupy a five-story building 58 feet by 104 feet. They also are dealers in rubber goods of all kinds. A large and extensive trade is carried on by them. All the woolen stock is shipped to the woolen manufacturers, and the cotton and rags and paper stock goes to the mills to be made into paper.

J. W. Grant \& Co., founded in 1872 , the proprietor of the firm being J. W. Grant. The house produces a large and most interesting line of jewelry the designing and workmanship of which displays rare mechanical skill in execution. A specialty of the house is fine rolled plate, solid silver chains and charms, which have long since become most popular with the trade. The factory comprises two floors measuring 100 by 60 feet each at 25 Calender street, which are fully equipped with the latest improved machinery and tools, and employs some fifty hands.

Gannett \& Co., succeeded in I 89r the firm of Swarts \& Gannett, which was formed in 1889. The business is electrical engineering and contracting for arc and incandescent lighting plants and electric motors, together with wiring in all its brinches. Their office is located in the Swarts building, 87 Weybosset street, Providence.

Charles H. Moore, about six years ago, established himself at I 88 Westminster street, Providence, but recently removed to I 2 Union street. Although 


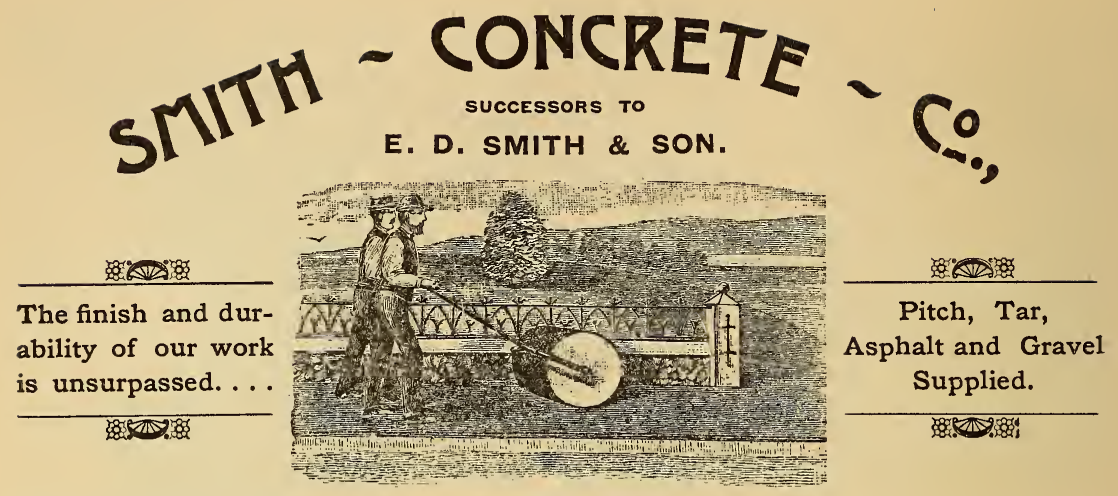

Concrete Driveways, Side and

Lawn Walks, Basement Floors, \&c.

Office: Builders and Traders Exchange,

9 Custom House Street, Providence, $R$. I. TELEPHONE CONNECTIONS: Builders and Traders Exchange. Residence and Yard.

\section{PURE

DELBERT L. BARKER, Contractor.

\section{ARTESIAN AND DRIVEN WELLS.}

Prospecting for Minerals with the Diamond Drill.

Testing.

For Building, Bridge, Pier \& Dam Foundations.

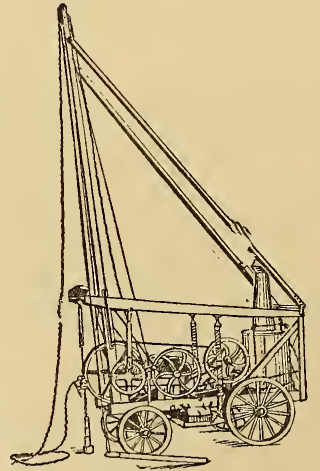

\section{Shafts for}

Hydraulic Elevators.

Pumping appliances, either $\mathrm{H}$ and, Steam, Caloric, or Wind Power, Furnished and Set up.

\section{PROVIDENCE, R. I.}

OFFICE:

SHOP:

9 CUSTOM HOUSE ST., (Builders and Traders Exchange.) - - - - 211 EDDY STREET. 
of recent origin, the trade which Mr. Moore has built up during that time is almost as encouraging as that experienced by business men of longer standing. The work manufactured here consists principally of cloth buttons of every description, for clothiers, cloak and dressmakers. Also upholsterers' and carriage trimmers' buttons, covered tacks and nails. The department for dress pleating is always up to the times with all the latest improved machinery and the most artistic workmen, and all that naturally goes with a business of its kind, such as pinking, sponging, button-holes, stitching, quilting, etc., etc., is done in a strictly first-class manner.

J. William Brady manufactures mattresses of all kinds in great variety, and also parlor furniture, the work being done by a force of twenty-three skilled artisans. Feathers and bedding are carried in stock, and these are also renovated by the latest improved process; either steam or cold air. Mr. Brady has also in his warerooms a fine assortment of brass and iron bedsteads. $\mathrm{Mr}$. Brady's store is located at 270 and 272 Broad street opposite Snow street, and possesses a large frontage and handsome plate glass show windows. It comprises two floors measuring 125 by 70 each, which are fully stocked with a large and most comprehensive variety of the goods mentioned above. The house was established twelve years ago and has long made a specialty of the manufacture of mattresses in which it greatly excels.

Volney W. Mason \& Co. was founded in I860, for the manufacture of friction pulleys, hoisting machinery and elevators. Having an experience of over thirty years, this firm is one of the best known for this kind of machinery. They have built up a trade which extends not only over the United States but in Europe and other foreign lands. They furnished all the machinery for hoisting cattle at the Brighton abattoirs, near Boston, Mass., also at the great hay depot of the New York Central \& Hudson River Railroad in New York. Wherever the machinery of this firm has been shown, it has received the best endorsements of the best engineers. Their factory is located on Lafayette street, between High and Washington streets in Providence.

The Rhode Island Cement Drain Pipe Co. was inaugurated in 1866, F. W. Burt being the treasurer and Mr. Goen the agent of the company. Their operations consist of the manufacture of drain, sewer, well and chimney pipe, lawn vases, artificial stone, chimney caps, well curbs, etc. The plant occupied for the manufacture consists of works located at 30 Francis street, on land 250 by 250 feet in dimensions, upon which are situated a number of buildings, each one of which being devoted to a special branch of the manufacture, and employing in all a large force of workmen.

A. C. J. Learned of 5 Charles street in this city, has been established some fifteen years and occupies a two-story building one hundred by forty feet. A specialty of his being taking large contracts and mill building, also band and jig sawing, planing, and all kinds of machine work, and mouldings of every description are kept on hand. Employment is given to about one hundred hands, and require the use of several teams. All lumber is brought direct from lumber countries. Mr. Learned is probably the best known contractor in 
A. JILLSON.

FRED W. FOLSOM.

\section{JILLSON \& FOLSOM,}
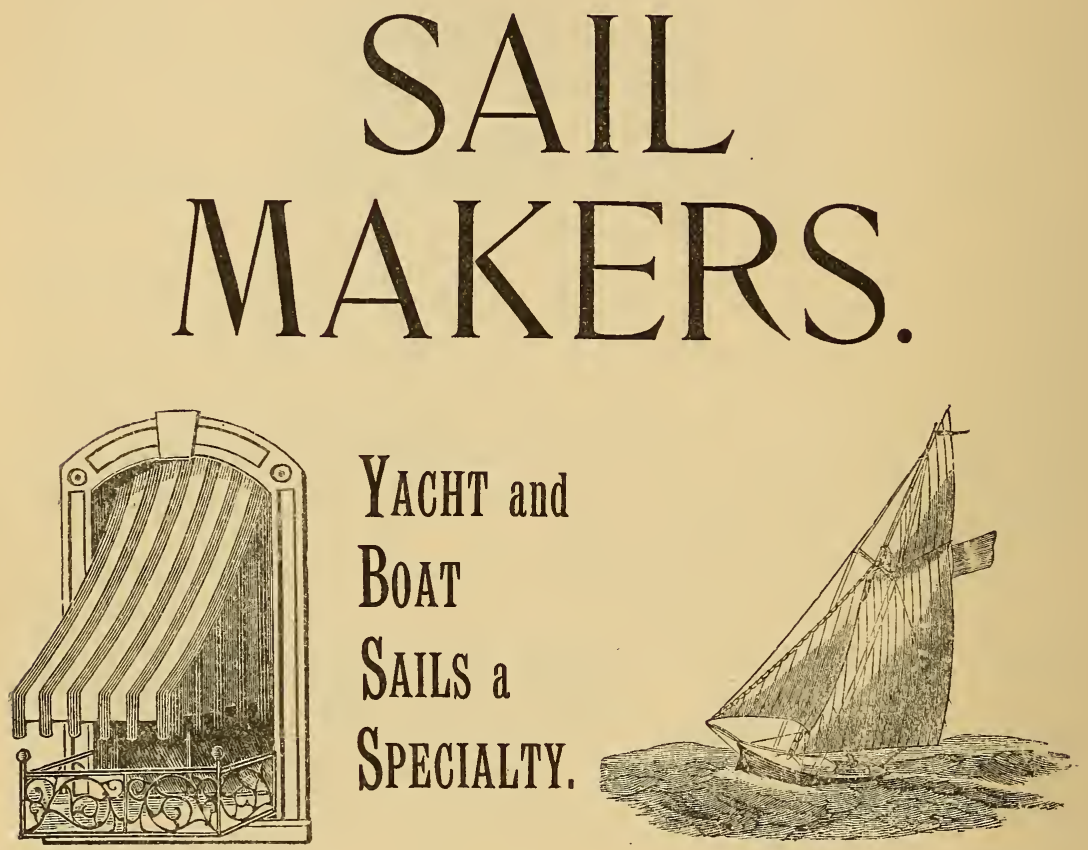

MANUFACTURERS OF

Tents, Awnings, Wagon Covers,

$\therefore$ Hammocks, Flags, Etc. . .

A GOOD STOCK OF SAMPLES TO SELECT FROM CONSTANTLY ON HAND. AWNINGS TAKEN DOWN AND STORED FOR THE WINTER.

\section{SOUTH WATER STREET,}


New England, his thorough knowledge of the business, and the reliable manner in which his work is performed has secured for him a wide-spread reputation.

T. J. Hamilton, of 56 Union street, is well known as a manufacturer of elastic and spring trusses. A large assortment of trusses is kept constantly on hand, and he is fully prepared to treat any case that comes to his notice. He has also a large variety of spring trusses. His elastic truss can be worn day and night without inconvenience to the wearer. The trusses manufactured by him are made upon scientific principles. He is the sole agent for Rhode Island of the new patent elastic truss. Mr. Hamilton has had a long experience in the business, and thoroughly understands it.

The Smith Concrete Co. is an outgrowth of the business established by the firm of E. D. Smith \& Son, in I885. The house has gained a wide spread reputation for the superior excellence of its work, which includes the concreting of driveways, public and private park walks, lawn walks, basement floors, etc. They furnish estimates and contract for this branch of work, furnishing the most experienced workmen and the latest improved machines in its execution. The company also carry a large stock of pitch, tar, asphalt and gravel supplies for the trade, having commodious storage facilities for these supplies at their large yards on Ridge street. The office of the company is situated in the Builders' and Traders' Exchange, 9 Custom House street, where all orders should be sent.

Jillson \& Folsom, located at 34 South Water street, was established in I 88 I by $\mathrm{Mr}$. Jillson, and in $\mathrm{I} 884 \mathrm{Mr}$. Folsom was admitted, when the firm changed to its present title. The special feature of this house is the manufacture of sails, but a large trade is carried on in the making of awnings, hammocks and flags. They are competent to manufacture anything out of canvas to order or for the trade. A full and complete line of awnings, flag and tent poles, wagon covers, boat sails, striped awning cloth, etc., is kept constantly on hand at low prices. Both members have a thorough knowledge of the business.

George H. Thurston \& Co., established here in I887, and composed of George H. Thurston and Walter I. Thurston, devote their attention to the equipment of electric light plants, and it is the largest house devoted to this special industry in the state of Rhode Island. The firm occupy the store and basement measuring 150 by 40 feet in the large building 59 South Main street, where they carry a large and complete stock of electrical apparatus of every description. The members of the firm are practical electrical engineers themselves, and introduce their apparatus in the most approved manner with the assistance of the most skilled and competent workmen. They do all the electrical work for this city, and also for the railroad corporations, and the street railway companies. They furnish estimates for the constructing of electrical plants of the largest capacities.

Rathbone \& Smith, whose refinery is situated at from I to 9 Mathewson street, corner of Cove street, has been established for the last four years. The firm consists of Julian Rathbone and William A. Smith. Both gentlemen are 


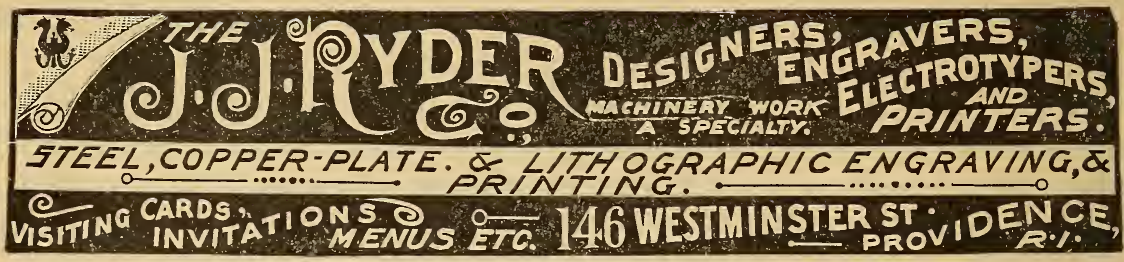

FINE letter press printing. We aim to do the best work in our lines at lowest prices and would be happy to do yours. The Engraving and Printing of Catalogues a Specialty. No orders too large, none too small. Estimates cheerfully furnished. A specialty of Half-Tone and general PhotoEngraving. - Telephone, I357. . . . .

\section{BARKER M'F'G. CO.,}

No. 2

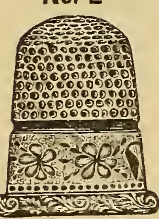

MANUFACTURERS OF THE ORIGINAL. PATENT STIFFENED AND FILLED GOLD THIMBLES. SOLID GOLD AND SILVER THIMBLES. White Stone Ear Drops, Scarf Pins, * * Studs, Etc., Etc. * *

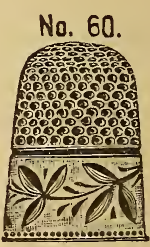

\section{FRIENDSHIP ST., P.0.Box 145, PROVIDENCE, R. I.}

\section{WILLIAM BENS,}

MANUFACTURER OF

Rolled Gold Plate Bracelets, Scarf Pins, Lace Pins, Glove Buttoners, and Novelties. $* * * * * * * * * *$ 
favorably known in the business and social circles of this city, and more distant localities as well. Possessing unequalled facilities for the most careful refining of gold and silver, and also practical assaying, the house has always enjoyed a large patronage in this vicinity.

J. S. Davis and C. W. Davis as a firm was started in 1892 , at Providence, as a New England Agency for blank books, paper boxes, envelopes, paper bags, and manufacturers' products. J. S. Davis was formerly connected with the Davis Paper Company, and C. W. Davis was salesman for the same firm. The firm are also agents Ior Yantic Paper Mills, Taylor Manufacturing Company, American Paper Pail \& Box Company, and many other prominent manufacturers. This firm is the first one of its kind to start in Providence. Their trade is wholly wholesale. Their office is located at 26 Wilcox Building.

Thomas Phillips \& Co., of which George R. and George C. Phillips are the proprietors, has been in existence nearly a century and is worthy of special attention. It was founded in 1804 by Josiah Keene, and conducted by him until I 830 , and was succeeded by Calder \& Phillips. This firm continued until 1853, and they were succeeded by Thomas Phillips \& Co. In 1867 Thomas Phillips withdrew, and the business has since been conducted by George R. Phillips, under the same name. In I89I George C. Phillips was admitted to the firm, and the business was carried on under the old firm name of 'Thomas Phillips \& Co., George R. and George C. Phillips being proprietors. This is one of the largest and leading establishments of the kind in this country, and its history has been an unbroken record of progress. The business now comprises the manufacture of lead pipe, sheet lead, and plumbers' supplies. Another department consists of the manufacture of light and heavy copper work for all uses, - drying machines, slashers, tape dressers, dye kettles, vacuum pans, and an apparatus for use in print works, bleacheries, sugar refineries, cotton and woolen works, cream tartar works, gluecose works, etc. Another department consists of sanitary plumbing. The office and salesroom are located at 75, 77 and 79 South Main street, while their factory occupies the block founded by Benefit, Pike, Traverse and Tockwotten streets. A large machine shop is connected with their works, admirably fitted up with all improved facilities for carrying on their business. They employ one hundred and ninety hands, and all orders are promptly filled.

Delbert L. Barker is one of the most successful and best known contractors for the driving of artesian wells throughout the country. Mr. Barker gives particular attention to supplying cities, towns, and villages and also to making soundings for building, bridge, pier and dam foundations and shafts for hydraulic elevators. He furnishes and sets up pumping appliances for either hand, steam, caloric, or wind power, and also deepens dry weils. As we have said above his reputation is of the highest order. His office is located at Builder's and Trader's Exchange, Providence.

Allen's Print Works were originally established in I 830, by Philip Allen \& Sons, and in 1857 the plant was purchased by Crawford Allen, who continued the business until $187 \mathrm{I}$, under the name of the Woonsocket Company Print 


\section{E. D. CUMMINGS \& CO, OPTICIANS,}

36 Dorrance Street, PROVIDENCE, R. I. 2nd door from Westminster St.

Don't Fail to Try Our Patent Eye Glasses. We cut and set the Glasses in our Spectacles and Eye Glasses, and warrant the Cones and Focus correct.

Special Attention given to Repairing.
49 Exchange Place, $* * *$ PROVIDENCE, R. I. Opp. Union Depot.

Wholesale and Retail Dealer in

CHOICE AMERICAN, FRENCH and GERMAN

* GROCERIES.

IMPORTED AND DOMESTIC DELICACIES,

Fine Teas Coffees and Butter

a Specialty, . . . Telephone 69.

\section{FRED I. MARCY \& Co.,}

SPECIALTIES :

Acme Lever Button. ..

Sensible Collar Button. JEWELERS, .

95 Pine Street,

PROVIDENCE, R. I., U.S. A.

New York Office: 198 BROADWAY.

JOHN R. PEARCE,

Fred. L. PEARce.

\section{JOHN R. PEARCE \& SON,}

Cotton and
Woolen Rags.
Paper Stock.

95 to 101 DORRANCE STREET,

\section{JOHN MASON,}

2858

Pattern and Model Manufiacturer.

IN WOOD OR METAL.

c5is

Particular Attention Given to Helping Inventors.

Models for any kind of Machinery and perfecting the same. All kinds of: Patentable work perfected.

No. 121 Dorrance St., Providence, R. I.

William W. Flint.

Joseph F. Blood.

FLINT, BLOOD \& CO., MANUFACTURING JEWELERS.

$\frac{\text { RINGS A SPECIALTY. }}{\text { *ESTABLISHEd 1869. * }}$

Factory, 94 POINT STREET, PROVIDENCE, R. I.

NEW YORK OFFICE, - 194 Broadway.

Address all Communications to Factory.

\section{\& R. A. MELFI, $\hat{\Delta}$}

The American Tailor.

Fine Imported and Domestic

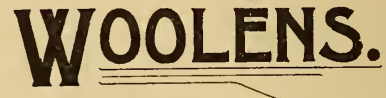

First-class Tailoring at Popular Prices.

68 North Main Street, () () (2) (2) (2) PROVIDENCE, R, I.

American Ring Traveler $\mathrm{Co}_{\text {., }}$ MAKers of

High Class Spinning and Twisting

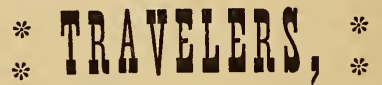

OF EVERY DESCRIPTION,

PROVIDENCE, = R. I. 
Works. In the latter year the present company was incorporated, the owners being the heirs of Crawford Allen. The works cover a large area in the northern part of the city, the buildings are chiefly erected of brick, are thoroughly equipped with the latest improved machinery, are operated by steam power, and furnish employment to about three hundred and fifty operatives. The products are the widely celebrated Allen's Prints, which are the most popular calico goods in the Southern and Western States, of any in the market. These goods are distributed to the trade in all parts of the country, as well as exported, through the selling agents, Lawrence Taylor \& Co., of New York. The management of the business is vested in the hands of John W. Dảnielson, president; John B. Kelley, treasurer; W. J. R. Phillips, secretary ; and James D. Thornton, superintendent.

George A. Peckham, engaged in the preparation and sale of drugs, medicines and grocers' sundries, was established in $\mathrm{r} 86 \mathrm{I}$, and has since enjoyed an annually increasing trade. The premises include two floors, each sixty by one hundred twenty-five ieet in dimensions. All the medicines and other preparations of the house are manufactured under the personal supervision of the proprietor. Mr. Peckham is an enterprising and progressive business man. $\mathrm{He}$ began his business career with the Providence Steam Engine Co. and was afterwards with B. B. \& R. Knight, the great cotton manufacturers. The present enterprise is conveniently located at 22 and 24 Peck street.

Stephen Paine, located at 66 Westminster street, is a manufacturer and dealer in optical goods. The premises occupied are neatly fitted up. His stock includes spectacles, eyeglasses, opera and marine glasses, telescopes, thermometers, etc., in all styles. A line of field and opera glasses are imported by him from the best manufacturers. He carries the largest line of optical goods that can be found in the city. Employment is given to four assistants all of whom are in constant attendance to meet the wants of patrons. Special attention is given by Mr. Paine to examining the eye, who is thoroughly reliable in this respect, having studied with one of the best professors of a medical college in Boston. Having had thirty years experience in this special line of trade, he can be depended on as being a thorough optician.

Edmund Carpenter, for many years has been engaged in handling all kinds of eastern, western and whitewood lumber, at both wholesale and retail. The business was originally established about fifty years ago by $\mathrm{Mr}$. A. Daly, who was succeeded by C. H. \& E. Carpenter, and in 1884 the present proprietor assumed control. The yards utilized for storage, cover sixty thousand square feet of ground, upon which six large sheds are erected. A specialty is made in pattern lumber as well as other kinds of fancy woods for builders' and manufacturers' uses.

Mr. Stillman White, in 1856 established a business house on Bark street, Providence, and to-day his establishment is one of the most prominent in the city. At first the business was carried on, on rather a limited scale, but by industrious working, he became the owner of the present large business house. $\mathrm{Mr}$. White makes all kinds of light and heavy brass, bronze and composition castings. 


\section{T. D. PRAT'T,}

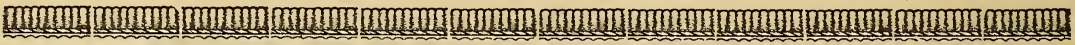

\section{MANUFACTURING}

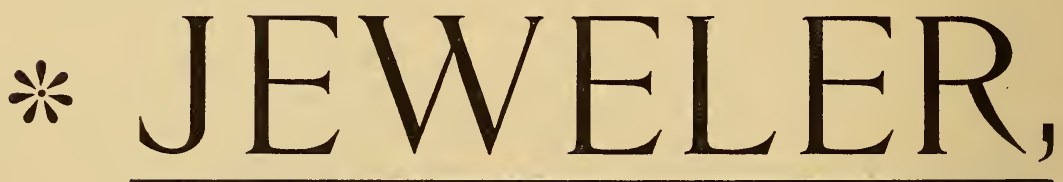

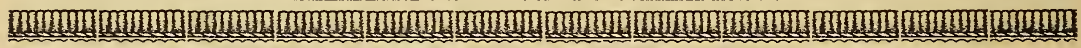

\section{WHITE STONE WORK A SPECIALTY IN GOLD.}

Work of All Kinds Made to Order. PROVIDENCE, R. I. 
The plant is equipped with all the latest improved machinery and all moderu appliances. The above named gentleman is also the sole manufacturer of the celebrated S. White's lining metal, which is known and acknowledged by all business men of the various cities in the United States, to be the best lining metal in the market.

John Mason for forty years has occupied a leading position in the mechanical circles of Providence. With all necessary facilties, and a long experience in the business, Mr. Mason is prepared to make patterns and models for any kind of machinery and also to perfect the same on reasonable terms. Mr. Mason is everywhere recognized as one of the most expert pattern and model makers in the country. The products of the house are sawing and turning, square and oval stretchers for oil paintings, draughting squares and drawing boards

The H. W. Hudson Company's merchant tailoring establishment is located on the Dorrance street side of the Narragansett Hotel in Providence. This company have on hand a fine and selected stock of woolens, worsteds, cheviots, beavers, etc., and all the latest novelties in suitings are always to be found at this store. Mr. Hudson, of this company, has had a long experience in the business, and his excellent taste and good judgment has won a reputation for him second to none in the city. The garments made by the company are noted for fine workmanship, fit, finish and quality of goods used. The prices are moderate and all patrons are sure to be suited.

Chambers, Calder \& Co., who are engaged as wholesale druggists, occupy the entire building located at I I and I 2 Exchange place, including five floors, completely stocked with all kinds of pure drugs, medicines and druggists' supplies for the trade, and makes a specialty of handling acids, chemicals, dye woods, extracts, paints, oils, varnishes, window glass, brushes and painters' supplies. The trade of the house extends throughout New England. The individual members of the firm are R. B. Chambers, G. B. Calder, W. C. Calder and W. S. Chambers. The two former founded the business in 1853 , the present firm having been organized in 1890 .

Oliver Johnson \& Co. is one of the leading business houses in the city of Providence. It was established in 1833 by Oliver Johnson, as a retail drug and medicine business, and until I 865 was devoted to the sale of these goods only. A five-story building sixty feet square was erected for a factory, which is known as the What Cheer Paint Works. The products of the factory are King Philip white lead, villa paints, excelsior paints, Geneva green and colors. At the warehouse, and salesrooms of the firm, consisting of three larye stores, each having tour floors, and a basement, is carried a complete stock of everything pertaining to painters' supplies. The trade of the house extends throughout New England. The entire business is managed by B. N. Spink, who is well known throughout the trade.

The E. H. Reynolds Co. engaged as platers of gold, silver and platinum, and carry a complete line of flat stock and wire, plain and striped. A great specialty is made of stock for watch cases, cane handles, pencil cases, umbrella 
GeO. H. THURSTON.

WALTER I. THURSTON.

\section{GEO. H. THURSTON \& CO.}

Prop's of Providence Electric Supply Co.

\section{ELECTRICAL ENGINEERS.}

MANUFACTURERS AND DEALERS IN

TELEPHONE, - TELEGRAPH - AND - ELECTRIC - LIGHT - SUPPLIES.

Electric Light Plants and Motors installed by skilled workmen.

RESIDENCE AND MILL LIGHTING

A SPECIALTY.

Private Telephone Lines

Constructed and Maintained.

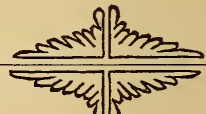

GAS LIGHTING BY ELECTRICITY,

BELLS, SPEAKING TUBES, Etc.,

SELF WINDING CLOCKS and WATCHMEN'S CLOCKS.

59 So. MAIN STREET,

PROVIDENCE, R. I. 
mountings, etc. Their factory is located at II 7 Dorrance street. It is furnished with all the latest improved machinery, and many hands are constantly employed.

M. M. Inman \& Co., which is composed of M. M. Inman and E. D. Browne, was established in $\mathrm{r} 86 \mathrm{r}$ by Serrill Mowery and Gilbert F. Robbins, who first located at 4 Washington Row, from which place in 1883 they were compelled to move in order to accommodate their greatly enlarged business to their present location, I39 and I4I Westminster street, corner of Dorrance street. On removal of this firm in 1883 , the title of this company was changed to Mowery, Robbins \& Co. Mr. M. M. Inman becoming an associate, and in $189 \mathrm{I}$ it changed to the present firm of M. M. Inman \& Co. The late mayor, Gilbert F. Robbins, was a member of the original firm. Here they occupy two commodious and well lighted floors in a four-story brick building. In addition to dealing in ready made clothing, they also sell a superior quality of tailor made clothing to the great satisfaction of their numerous patrons. The firm is composed of M. M. Inman and E. D. Browne, both gentlemen of business ability and thorough knowledge of their trade. With such experienced management, ample facilities, and a large stock, it is easy to account for the prominent success the house has attained.

The Household Sewing Machine Co. was incorporated in August r882, and purchased the plant of the Providence Tool Co., where were made the first Household Sewing Machines. This company operate two extensive plants, the main one on Wickenden street, where the machine and iron work is made together with job work of various kinds; and the other on Crary and Langley streets, which is devoted to cabinet work of great variety. The former plant covers an entire block 250 feet on Wickenden and South Main streets, and I 50 feet on Farthing and Cent streets, upon which is erected a five-story brick building. The cabinet work plant is embraced in a four-story brick building fifty by one hundred and twenty-five feet in dimensions, and a number of smaller structures, covering in all about forty thousand square feet of ground. The whole plant furnishes work for some four hundred skilled workmen. Thousands of the machines produced here: are in use throughout the United State and the British Provinces; they are also largely exported to foreign countries. The officers of the company are Nicholas Sheldon, acting presdent; G. H. Dart, treasurer and Geo. H. Newhall, manager, all well known. The company has offices in New York, Chicago and Boston.

J. E. Crandall, engaged in the manufacture of light carriages, was established thirty-five years ago, and since that time a trade has grown up with the leading business cities throughout New England. The help engaged averages fifteen men, who turn out a large amount of work annually. The spacious apartments are located on the corner of Worcester and Union streets in this city, and comprise a large building three stories in height, covering an area of one hundred by forty feet. The first floor contains the office, repository, blacksmith and woodworking departments. The secondfloor devoted to the trimming shop and storage of carriages, while the third floor is given up to paint- 


\section{THE OLD RELIABLE AND POPULAR .}

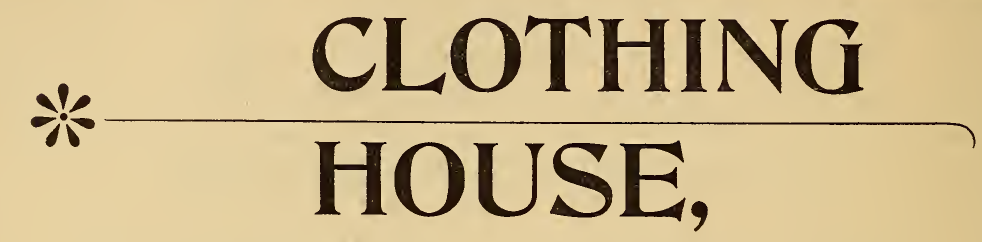

OF

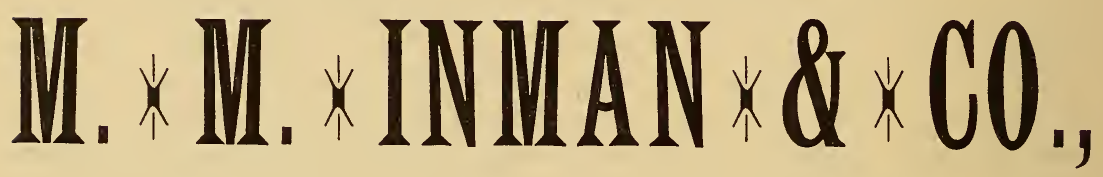

$139 \& 141$ Westminster St., $27 \& 29$ Dorrance St.,

*** PROVIDENCE, R. I. *** *

Are headquarters for Men's, Boys', Youths' and Children's Clothing in all the latest styles and designs, and we are the only clothing house in Rhode Island that sell $\therefore \quad \therefore$

\section{First-Class Tailor Made Clothes,}

(fit and style guaranteed) for just one-half price of any tailor in this city. Also we are Sole Agents. for the $\therefore$

CELEBRATED WORLD RENOWNED FIRST-CLASS TAILOR MADE GOODS OP THE STEIN-BLOCK CO. MAKE OF NEW YORK. ALSO HEADQUARTERS FOR

\section{Hats, Boots and Shoes.}

M. M. INMAN \& CO. 
ing. In this factory any pattern or style of carriage is made to order at short notice.

The Woodward Enterprise Manufacturing Company, located at the corner of Sabin and Calender streets are engaged in the manufacture of fire escapes, fixed ladders, tree boxes and are the only company that manufacture the new combined wire and picket fencing. Their factory is fully equipped with all the latest machinery and constant employment is given to a large number of experienced hands. They are fully prepared to furnish fences of any height and strength from one to seven feet, and also to make an estimate for any kind of work done in their line, and make contracts to furnish posts and fencing. All goods are made from machinery of their own invention; they use galvanized wire only, and guarantee all their work to be of the first quality both in workmanship and material, cedar being the wood largely used. Robert Woodward, the treasurer, gives his personal attention to the supervision of the factory.

E. D. Cummings \& Co., of 36 Dorrance street, dealers in spectacles, eyeglasses, and a general line of optician's goods, was established in $\mathrm{I} 862$ by G. N. Cummings, who conducted the business until 1874 when he was succeeded by the present firm. The premises occupied are neatly arranged, and contain a full line of spectacles, eyeglasses, opera and field glasses, telescopes, etc. of the best makes. A patent eyeglass is made by them of which they are the sole proprietors. All oculists' prescriptions are carefully put up, and they fit all eyes free of charge, and special attention is given to repairing.

The Prophet Spring, located on Mowry's Hill in the town of Johnson, Rhode Island, has gained an enviable local reputation. E. E. Drake is the proprietor of the spring and has an office at $4 \mathrm{I}$ Dorrance street. The water from this spring is absolutely pure, and as a table water or for general domestic use it has no superior. An analysis of this water has been made by Prof. Calder, and he endorses it as being a very pure water. The water is taken direct from the spring and put in barrels and demijohns and is sold in any quantity that may be desired. Teams are in constant use to supply the trade both for hotels, restaurants and families. Since this spring has been brought into notice, a large trade has been established.

Drake's Local Express is one of the oldest in the business having been established since 1871. Expressing of a general character is performed by him in a satisfactory manner. All orders are promptly attended to, as seven teams are in constant use. Particular attention is paid to the transportation of baggage, only experienced and competent men employed. The office is at $4 \mathrm{I}$ Dorrance street, and has telephone connection.

James A. Charnley, located at i 8 Dorrance street, founded the business in 1872 , and his is the headquarters for fancy figured flat stock which is used in the manufacture of buttons, bar pins, bangle and bugle bracelets, etc. The premises used by him are one hundred and twenty-five by forty feet and contain all the improved machinery, and a large number of hands is employed. $\mathrm{He}$ is also maker of figured and ball wire, and carries a stock of fifty designs of flat stock, among which may be mentioned nugget, alligator, sandblast and 


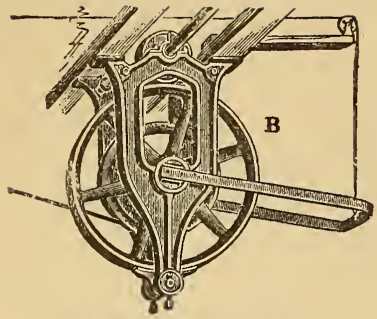

NEW PATENT WHIP HOIST.

\section{VOLNEY W. MASON \& CO.,}

ManUfacturers of

\section{Patent Friction Pulleys,}

FRICTION CLUTCHES,

For connecting Shafting and Gearing.

HOISTING MACHINERY AND ELEVATORS.

PROVIDENCE, R. I., U. S. A.

\section{COMBINATION LADDER CO., PROVIDENCE, R. I.}

*

. Builders of Fire Extension

Ladders and Ladders of every

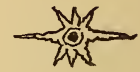

description. . . . . . . .

*

C. N. RICHARDSON, - Proprietor.

\section{THE AMERICAN TOOL \& MACHINE CO., ENGINEERS, FOUNDERS AND MACHINISTS.}

84 KINGSTON ST., BOSTON, MASS.

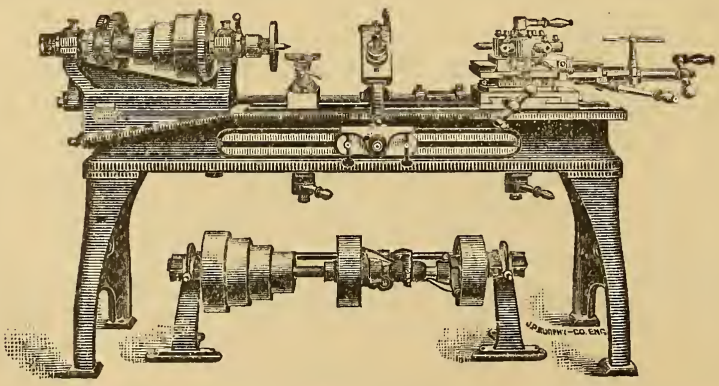

Manufacturers of Turret and Fox Speed Lathes, Leather Splitting Machines (Belt Knife), Shaftlng, Hangers and Pulleys, Centrifugal Sugar Machinery and Hydro Extractors, General Machinery, Foundry and Mill Work. 
straw patterns. He also manufactures metal millinery goods, and figured sheet metal. It is one of the oldest established houses in this line in the city, and is a thoroughly reliable one to deal with.

B. H. McCabe has been engaged in japan enamelling here in this city for the last sixteen years and was located at i 9 Pine street for eleven ycars of this time, when he removed to his present site, 8I Friendship street. Here he occupies two large floors, measuring 40 by 40 , each of which is subdivided into compartments; employing in all some fifteen skilled workmen. The work in hand consists of the skillful japan enamelling of tin, brass, copper, and othe metals of all descriptions. A specialty is made of jewelry and in this work alone Mr. McCabe has gained a high reputation.

J. Briggs \& Sons Co., located at 65 Clifford street, was established in I 849 , but was made a stock company in I 890 , with the following officers: Jeremiah Briggs, president; Charles Briggs, vice president; and George Briggs, secretary and treasurer. They are engaged as manufacturers and dealers in iewelers' plate, square, flat and fancy wire of all kinds, gold, silver, and brass solders, and manufacture stock especially adapted for cane-heads, pencil-cases, watch cases, thimbles, spectacles and eyeglass bows, etc., occupying two floors, each being one hundred by forty feet, where employment is given to a number of hands. Their factory is fully supplied with all the necessary machinery that is required. The trade is wholly with manufacturers and the goods are sold in a rough state to finishers. Having excellent facilities they are enabled to make over two thousand patterns of fancy wire which are far beyond competition in quality and finish.

The Langelier Manufacturing Company, of which A. T. Langelier is president and treasurer, and A. J. Langelier, his son, superintendent and manager, was established about seven years ago, and from the start the enterprise has been a positive and permanent success. This cornpany, located at 67 and 69 Clifford street, are large builders and designers of special machinery and tools for different branches of manufacture. These will include multiple drilling machines for wood or metal, upright drills, metallic tip and needle machines, lock-nut, reducing, swedging and hammering machines, and also jewellers' and opticians' machines and tools. They make many special machines and tools which are original with themselves, and which are not made by other manufacturers. Among these is their special No. 2 Multiple Drilling Machine, which fills a long felt want for drilling a number of holes, differing in diameter, and true in their relative position in one operation, without a jig being clamped to the work and in the time previously taken to drill one. Other specialities of the company are power presses, ball tools, ball rolling, reducing machines, solder cutters, jewellers' drills, etc., particular attention being given to accurate work of all kinds. The company occupy a floor 36 by I oo feet in measurement at the location indicated above, which is fully equipped, and employ fifteen to twenty skilled workmen among whom are electrical and mechanical experts.

J. M. Westmacott \& Co. and H. A. Freeman \& Co., who represent two very important industries at $8 \mathrm{I}$ Friendship street, manufacture platers, melters, 


\section{THE NORTON DOOR CHECK \& SPRING CO.,}

\section{JAMES P. FLYN.N, Pres.; CHARLES S. PENHALLOW, Treas. Office: 505 Sears Building.}

The door check and spring shown in the accompanying cut is really a triumph of mechanical genius and the most perfect practical appliance for the purpose ever devised.

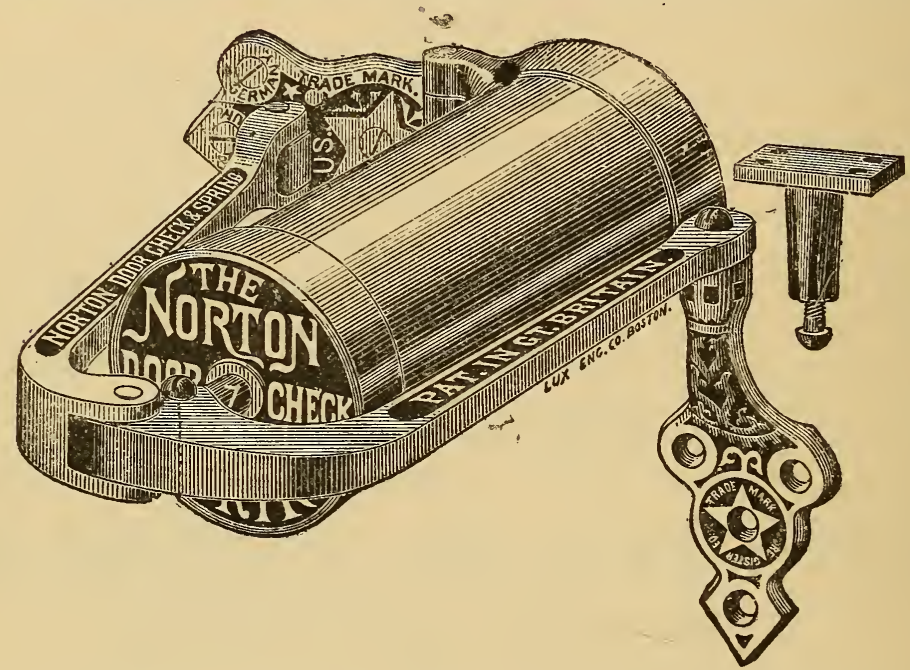

Briefly, the apparatus consists of a cylinder, piston, spring, and self-adjusting valve, the whole provided with suitable brackets and alapted to be attached to the top part of a door and the frame over the door. In it are combined two opposing powers-the spring, for closing the door (drawing with greatest power when nearest closed), and the check. or cushioning of the piston on air, which brings the door to a momentary pause near the jamb, then quietly and surely closing and latching it by the operation of the spring, the operation being regulated by the automatic valve, which permits the air to enter the cylinder while opening the door, and while closing exhausts the air more or less as the force exerted on the door to close it is greater or less. The parts of the device are so arranged together that the greater the force exerted to close the door the greater the resistance offered; consequently no slam or jar can occur. Of all the appliances ever designed for this purpose the Norton Door Check and Spring is the only one that has actually succeeded. Nothing equals it for the noiseless closing of doors and the prevention of glass-breaking, and every hotel, car, steamboat, business house, residence, church, theatre, hospital, public building and office door should be equipped with it. The Norton Door Check \& Spring Company was incorporated in 1881 , capital stock $\$ 200,000$; board of directors - James P. Flynn, president; Col. Charles R. Codman, Frank Wood, Russel Gray and Charles S. Penhallow, treasurer, all of Boston. The office is situated in the Sears Building, and the corporation does a large and growing business, selling in all parts of the world. London, England, is the great distributing point for European countries, and sends out thousands of door checks yearly to France, Spain, Italy, Russia, Egypt, Norway, Australia, etc., while the Boston office is kept busy supplying the United States, Mexican and South American orders. The vast fourteen-story Ames building is fitted throughout with this time-saving, noise-preventing device. Also the steamers of the Old Colony S. S. Co. Sales are effected through agents. Send for circulars to above address. 
annealers, blowers-out, jewellers' blow pipes, soldering and flushing irons, and in fact all kinds of jeweler's findings, for which the firm have a large trade in all the large jewelry manufacturing centres of the country. J. M. Westmacott of the firm is a most practical man and has been engaged in this business for a long number of years, and the boilers-out and annealers made by this firm are constructed from his original ideas. The firm of H. A. Freeman \& Co. are workers of sheet metal, iron, tin, brass, and copper, and make ventilation and furnace piping a specialty, and are also manufacturers of the Acme Rug Tufting Machine and the Acme Can Opener, both specialties which have become popular with the trade.

William Bens, located at No. I02 Friendship street, makes a specialty of the manufacture of bracelets in rolled gold plate, and has a trade for his productions among the wholesale jewelry houses throughout the United States. The premises occupied by Mr. Bens consist of a plant 70 by 40 , located as above, which is fully equipped with everything necessary in a large manufacturing jewelry business. Mr. Bens is also a large manufacturer of scarf pins, lace pins, glove buttoners, and numerous other novelties for which he has a large trade. The business was established some two years lago, and is one of the most successful in its operations in the city.

William H. Miller \& Sons are blacksmiths and do machine and tool forgings of all kinds, building work, etc., being located at I94, 196 and 200 Eddy street. In the line of general blacksmithing, machine and tool forging, etc., none in this city or state maintain a higher reputation for excellent work than this firm. They are also manufacturers of Miller's carriage shaft or thill supporters, with iron socket at top, which takes the nut or bolt which passes through the whiffletree and cross bar holding up shaft when carriage is not in use, which is conceded to be the most perfect, effective and altogether superior device for the purpose intended on the market. It is simple, neat and handy and notably cheap, 25 cents each or five for a dollar, and is rapidly growing in favor all over the country. The Messrs. Miller have a spacious and well equipped shop, six fires, four trip hammers, two milling machines, and two cutting-off machines being in operation here that will cut from $\mathrm{I}-4$ inch in diameter to five inches or 3 I-2 square, while they are prepared to cut by machine, blanks of any desired length at short notice, eighteen skilled workmen being employed. Blacksmithing and jobbing of every description are executed and machine and tool forgings are turned out at short notice, while all classes of building work in this line are attended to in the most expeditious manner. The firm keep on hand a large stock of picks, tongs, turning tools, dies, hubs and cutter plates which are milled to the right bevel and also milled on the face all ready for patterns, they also have jack dies, plungers, holders, plumbers' and pipers', scoups, etc., also Jessop's annealed tool steel, and all orders will receive prompt attention. This business was established in May, I866, by Crowell \& Miller, who were succeeded by Miller \& Sisson, and then by William H. Miller \& Co., and later came into sole control of William H. Miller, who in 1887, took into partnership his sons, J. W. Miller and W. F. Miller. Mr. Miller, the 
Georǵe B. Appleton \& Co., Importers and Dealers in Finest Grades of Table and Pocket -

AND LAROEST AND MOST COMPLETE LINE OF FISHING * TACKLE. TO BE FOUND IN NEW ENGLAND. KODAKS FROM $\$ 6.00$ TO $\$ 65.00$.

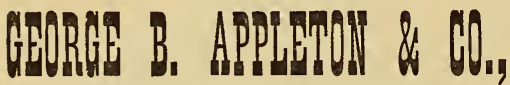
304 Washington St, Second door north of old South Church, BOSTON, MASS.

\section{READ ....}

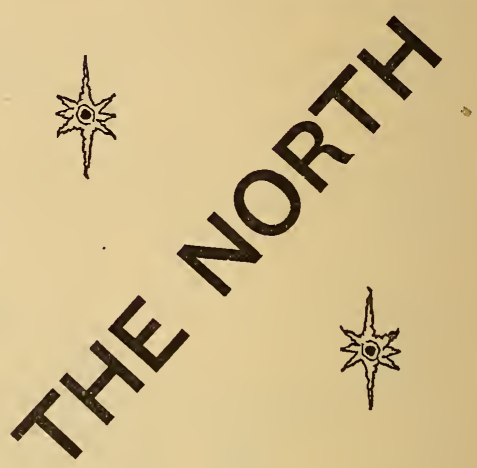

PUBLISHED BY HAGER \& HANDY, BOSTON, - - MASS.

\section{MAGUIRE \& O'HERON,} S

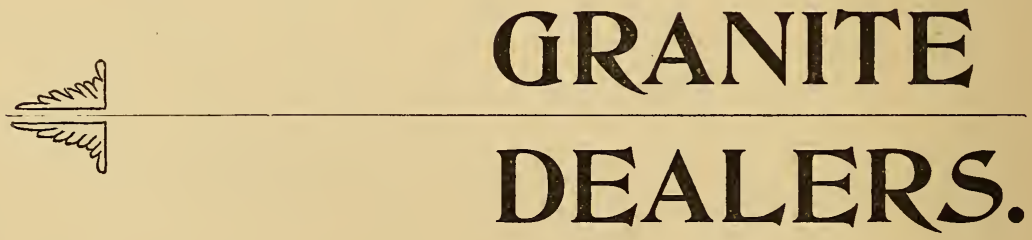

EAST MILTON, MASS, ***

Estimates given on all kinds of Monumental and Cemetery Work. 
elder, was born in Swansea, Mass., and has resided in Providence some forty years, his sons being natives of this city.

The Barker Manufacturing Company, located at 38 Friendship street, are the manufacturers of their original patent stiffened and filled gold thimbles and other products as well. The business of the Barker Manufacturing Company . succeeds that of an old firm which was founded some forty years ago, and the house has always maintained a high position in the trade. The present company was incorporated March I 7, I891, with Wm. L. Lowell as president; J. H. Green, treasurer; and S. A. Barker, secretary and manager. The company have made a specialty of the manufacture of thimbles for the last thirty years, and beside the manufacture of their patented stiffened and filled gold thimbles, they also produce solid gold and silver thimbles, white stone ear drops, scarf pins, studs, and other specialties of a like kind, for which they have a large trade among the leading wholesale dealers throughout the country.

G. B. Darling, whose finely equipped lapidary is situated at Iog Friendship street, is one of the oldest and most experienced lapidarians in the city, being engaged in this work since I852. In 1860 he formed a co-partnership with Mr. Atkinson, the firm being known to the trade as Atkinson \& Co. until i 864 when the partnership was dissolved upon the retirement of Mr. Atkinson from the business. The old quarters were occupied by Mr. Darling until I 874, when a removal was necessitated by the largely increased business, and the present site was fitted up to meet the demands made upon him. The premises occupied at the location indicated above are excellently arranged, the lapidary being the best equipped in important details in the city, and therefore possesses the best possible facilities for the execution of the best order of work. The most careful attention is given by Mr. Darling to special orders from the trade, in the cutting, grinding, and polishing of all kinds of precious stones.

A. P. Possner, of 49 Exchange place, this city, established the business some eight years ago on W.estminster street, moving from there to High street, and from there to his present location. His stock includes everything in fancy and staple groceries, best brands of flour, teas and coffees direct from China and Japan, canned goods, bakers' materials, etc., all of which are the purest and best that can be obtained. To meet the wants of his patrons in a prompt manner, five competent assistants are employed and two teams are used to deliver all orders both in and out of the city. The premises occupied comprise a store and basement, 25 by roo feet in dimensions, conveniently arranged.

H. E. LeValley, dealer in all kinds of musical instruments, books, strings, sheet music, and everything in the musical line, and publisher of piano, banjo and guitar music is located at 20 Aborn street, where for the past eight years he has catered to the wants of the musical people of Providence with success and general satisfaction. The V.ictor guitar supporter and arm rest, an invention of Mr. LeValley's, supplies a long felt; want and is in great demand. Mr. LeValley is a successful teacher of the banjo and guitar, while his wife who has composed some excellent music for the piano is also a teacher of that instrument. 
C. W. LoNG.

\section{LODG \& SHUDDERS,}

W. L. Saunders.

DESIGNERS AND MANUFACTURERS OF

Statuary, Monuments, Tablets, Head-stones, Curbing, Posts, AND ALL KINDS OF CEMETERY WORK, IN ALL OF THE

Foreign and American Granites and Marbles.

All work set in cemeteries under our own personal supervision, and guaranteed satisfactory.

Works at South Quincy, Mass., - Near Quincy Adams Depot

JAMrs McGillvray.

Fred. L. Jones.

McGILLVRAY \& JONES,

QUINCY and other NEW ENGLAND GRANITE,

Polished Monuments, Headstones, \&c.

The Best of Stock and Workmanship Guaranteed.

Granite Works,

Quincy, Mass.

JOHN F. IXEMP,
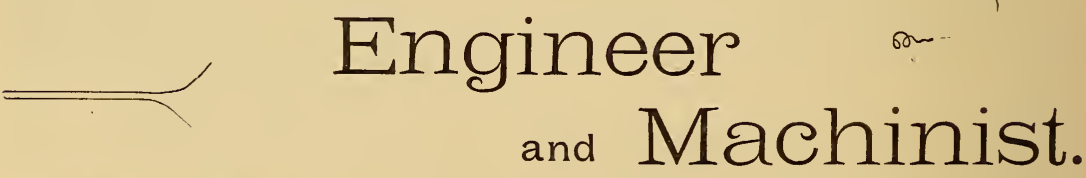

Manufacturer and Dealer in

GRANITE TOOLS.

82 Water St.. SOUTH QUINCY.

\section{QUINCY MARBLE \& GRANITE WORKS,}

McGRATH BROS. Established 1854.

A Large Stock of Finished MONUMENTAL WORKS in Granite and Marble.

$\rightarrow$ Directly on the line of the Old Colony R. R. at

Quincy Adams Station,

Quincy, Mass. 


\section{NEWPORT.}

$\mathrm{T}$

HE whole civilized world is so familiar with this famous resort that to say anything concerning it is a work of supererogation. Its early settlement is contemporaneous with that of other portions of Aquidneck (now Rhode Island), and was the result of a "hierarchal turbulance" developed in Boston in I637, led and championed by Mrs. Ann Hutchinson, who, in March, 1638, was exiled by the church for her antinomian sentiments. This sect of antinomians to which she belonged at that time numbered seventy-five in all the towns of Massachusetts, and two months prior to the banishment of Mrs. Hutchinson, had been required to deliver up their arms and ammunition before the thirteenth of that month (January, I638), unless they would " acknowledge their sin" before two magistrates. Even before this time, in the fall of 1637 , the followers of the persecuted sect, foreseeing the signs of the times, had been looking for a place of refuge without the bounds of the established New England colonies, and had appointed Dr. John Clarke, then (in November, 1637), just arrived from England, to "pitch" upon a place of retreat. His own statement of the course pursued is: "By reason of the suffocating heat of the summer before, I went to the north, but the following winter proved so cold that we were forced in the spring to make towards the south.

"So having sought the Lord for direction, we all agreed that while our vessel was passing about a large and dangerous cape (Cape Cod) we would cross over by land, having Long Island and Delaware Bay in our eie for the place of residence; so to a town called Providence we came, which was begun by one Roger Williams, . . . by whom we were courteously and lovingly received, and with whom we advised ahout our design.

"He readily presented two places before us in the same Narragansett baythe one on the mainland called Sowams, the other Aquedneck (now Rhode Island). We inquired whether they would fall in any other patent. . . . He told us that the way to know was to have recourse to Plymouth; so, our vessel as yet not having come about, and we thus blockt up, the company determined to send to Plymouth and picht upon two others together with myself, requesting also Mr. Williams to go to Plymouth to know how the case stood; so we did.

"The Plymouth magistrates informed us that 'Sowams was the garden of their patent and the flour in the garden.' And when asked ' whether they laid claim to the islands in the Narragansett Bay, and that in particular called Aquednecke,' they all with cheerful countenance made us answer: It was in their thoughts to have advised us thereto, and if the Provident hand of God 


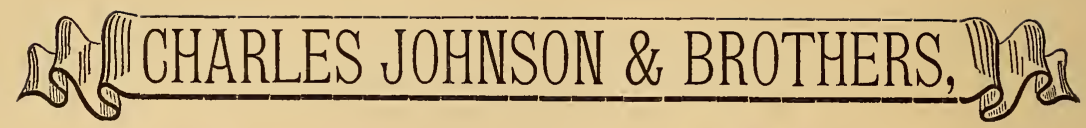
and Building . . CRANITE: QUARRY STREET, $\quad * * *$ QUINCY, MASS.

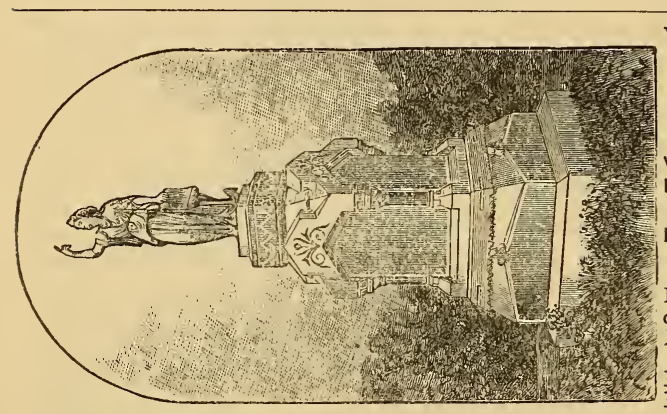

W. R. FEGAN. JOHN c. BALLOU.

FEGAN \& BALLOU,

Successors to Henry Barker \& Sons. Established 1865.

WHOLESALE MANUFACTURERS OF

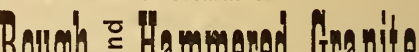

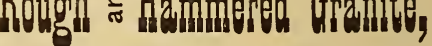

Steam Polishers and Granite Workers. Monumental and Cemetery Work of all descriptions executed in the best style from Dark Blue and Medium Quincy Granite. ( aps, Dies and Second Bases Cut and (aps, Dies and Second Bases Cut and
Polished to suit customers. Sawed and Polished Slabs all sizes constantly on hand. Quarry and Polishing Mills,

QUARRY ST., * P. 0. Address, Lock Box, 49, * QUINCY, MASS. J. A. MCDONNELL. MCDONNELL BROTHERS, WHOLESALE DEALERS IN

Dark Blue and Gray

ALSO CEMETERY WORK OF ALL KINDS

A SPECIALTY.

* Quincy Granite,

SUPERIOR WORKMANSHIP GUARANTEED. POLISHING DONE IN FIRSTCLASS STYLE. ALL ORDERS PROMPTLY ATTENDED TO.

QUINOY, MASS.

\section{JOHNN FATXON \& SONS,}

MANUFACTURERS AND DEALERS IN

\section{Marble and Granite}

QUARRY STREET, **** QUINCY, MASS. 
should pitch us thereon they should look upon us as free, and as loving neighbors and friends should be assistant unto us.

"So we humble thanked them and returned with that answer: So it pleased the Lord by moving the hearts of the natives, even the chiefest thereof, to pitch us thereon. . . . So that having bought them off to their full satisfaction we have possessed the place ever since."

Through the influence of Roger Williams, a deed was soon obtained of the island of Aquidneck, with a right to "grasse" on other islands and shores of the bay. As soon as the deed was obtained, they commenced a settlement at Pocasset, between the cove on the northeast part of the island and the Great Pond to the northwest of the same, in the (now) town of Portsmouth.

There was a broad distinction between the primal fundamental ideas of the colony at Providence and that at Rhode Island. On the island the intent was to form a democratic Christian commonwealth, where every follower of Christ might worship God freely, according to the dictates of his own conscience. The intent at Providence was to establish a community where every man, Jew or Gentile, Christian or heathen, might worship according to the teachings of his mind, and in civil government to be ruled by the principles of democracy. A careful consideration of this distinction will explain some variance in the course of the two colonies before they finally united in adopting the principle of Roger Williams.

It is evident that even at this time, before the colonists had been a year upon the island, they had a far more complete system of civil government than was attained at Providence at a much later date. The settlement had grown much faster; it bad more trade, and had commenced, in an humble way, the business of navigation ; at least, two "shallops" were built or building at that time.

Within a year or thereabouts of its foundation, viz.: on the 28th day of April, 1639, the following article was drawn: "Pocasset, on the 28 th of the 2 d, 1639. It is agreed by us whose hands are underwritten to propagate a Plantation in the midst of the island or elsewhere; and doe engage ourselves equall charges, answerable to our strength and estates in common; and that our determination shall be by major voice of Judge and elders; the Judge to have a double voice."

This article was drawn up with a view to a settlement at Newport, and it is noticeable that all the members of the Pocasset government took part in what may almost be termed the transference of the colony to the latter place. Further, when they removed to Newport they carried with them their records up to that date.

In I645 an Indian war broke out, which was only quelled by the negotiations of Roger Williams; troubles with the Dutch were increasing; and finally after the triumph of the English parliamentary party in the surrender of Charles I., Newport and Portsmouth reluctantly organized with Providence and Warwick under the charter of Providence Plantations, in May, I647.

After the union of the colonies in 1654 , Newport continued in its course of development in trade, and also in the settlement of outlying provinces. In 
Geo. H. Hitchcoch \&̊ Co., Saccessors to Charchill \& Hitchcock,

CONTRACTORS for

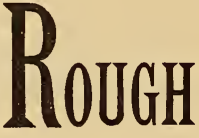

QUINCY, MASS.

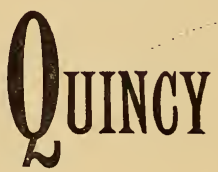

*

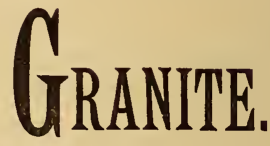

\section{$\frac{\text { GRANITE TOOLS, }}{\text { Alexander Clark, }}$}

$\rightarrow$ All Kinds of Granite Tools,

Best of stock Used, Good Workmanship Guaranteed. Shop at Thos. W. Smith's, Polishing Mill, 138 Water st., Quincy, Mass.

\section{HAYES \& SONS,}

QUINCY * AND * EASTERN * GRANITE. West Quincy, Mass.

\section{William Callahan, 2as zos} MANUFACTURER OF

MONUMENTAL WORK from all grades of QUINCY and other GRANITES, 
trade it had established relations with the Dutch, the other English colonies of North America, the Barbadoes Islands and Jamaica. The outlying settlements of Newport extended over to the mainland to the westward, and it is to be remembered in accounting for the large population of Newport in early days, that the inhabitants of the present towns of North and South Kingston claimed and exercised the privileges of, and were accounted as, citizens of Newport for many years.

In I 743 the interest of the settled part of Newport had become so far separated from that of the "Middle Woods" in the north part of the town, that the latter was set off into a separate town as Middletown. The growth of the town now seemed to reach a point as great as the colony could sustain, and for years its population remained in the neighborhood of 6,500. In I758, the first newspaper published in the colony - the Newport Mercurywas published in this town. After this date, and especially after the peace of I 763, the town again rapidly increased in wealth and population, till, in I774, its inhabicants numbered over 9,000. The townsmen still resolutely maintained their opposition to the acts of the British revenue authorities in opposition to the colonies charter, and after a long course of minor conflicts, on July I9, I 769, the British revenue sloop "Liberty" was destroyed by the citizens in Newport harbor. This conduct of the Newport citizens led to their being more closely watched than the other parts of the colony, and, consequently, when the Revolutionary war broke out a large British naval force lay in the harbor, and the citizens with their whole town under the guns of the hostile fleet, were practically bound hand and foot, and unable to manifest their sympathy with the patriot cause.

In I 776 a British army, under General Clinton, took possession of Newport and held it for three years. This occupation was almost the death-blow to Newport ; great numbers of its wealthier people fled to places of safety on the mainland. Oct. 25,1779 , the British army evacuated the island, after having practically wrecked the town during their stay. After the war was over a vigorous attempt was made to revive the town, and it was incorporated into a city, the first in the state, in I 784. But the community had been too much enfeebled to live as a city, and the paper money issue of the state struck still another blow at it; consequently, in 1787 , it became necessary to surrender the charter and fall back into a town organization.

From this time for fifty years the town remained nearly stationary, the increase of the population being only from 6,I 76 in 1790 , to 8,333 in 1840 . After this latter period the growth of the present Newport, - the fair city of villas and summer dwellings by the sea - commenced.

In 1853 it had become sufficiently strong to again attempt a city form of government, and has since been growing till from a population of about 9,600 , it has grown to have now nearly 20,000 permanent inhabitants. It is a city unique and unapproachable by any other municipal community on the continent. With an unrivaled climate, delightfully cool on the hottest summer day, and having the frigid blasts of winter tempered by 
the warming influences of the Gulf stream, there is no reason why it should not become a favorite winter as well as summer place of residence. Year by year its permanent residents are increasing, and many visitors who spend the summer here conclude that they can find no pleasanter place to pass the winter, and so remain.

\section{H. HARDWICK \& CO., , GRANITE}

H. E. HARDWICK.

C. THEO. HARDWICK.

ESTABLISHED 1848.

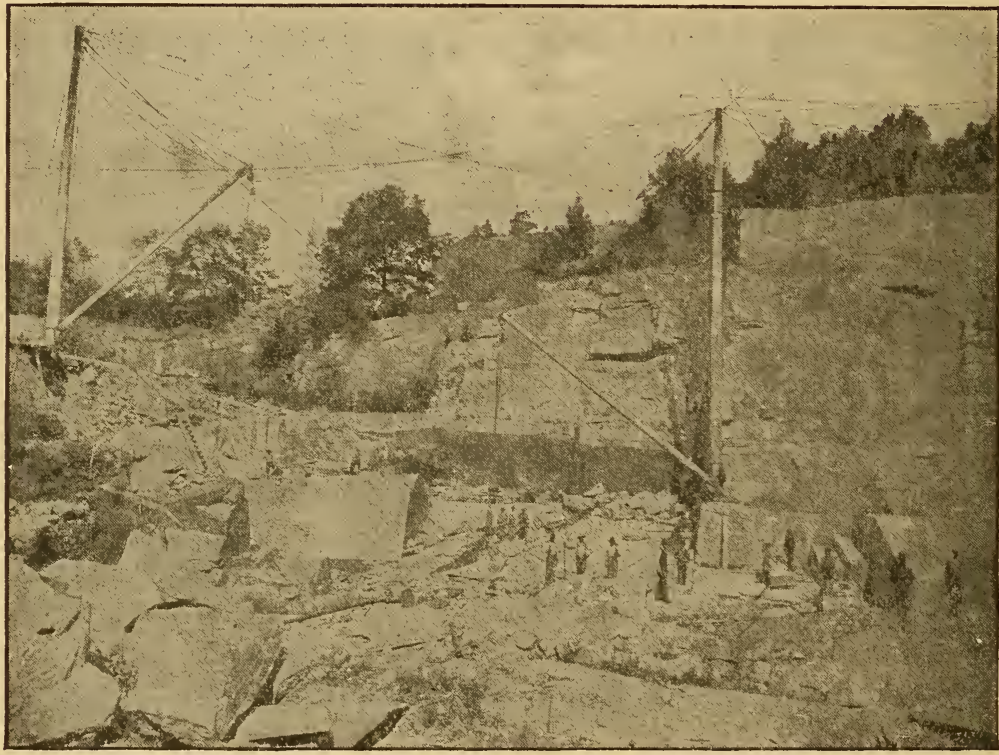

\section{Hammering - and - Polishing - Works.}

Granite Furnished the Trade. . . . .

In Dark Blue, of Medium and Light Shades.

. . Dark Quincy Granite a Specialty.

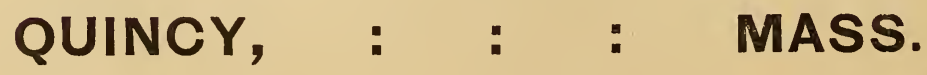




\section{QU I N C Y.}

风

PLACE so intimately identified with the early history of the republic would seem to require no lengthy description here. Quincy has erected a monument to her name and fame as enduring as her granite hills in the Adamses - statesmen and patriots, whose characters were typical of the solid blocks which have since their day entered so largely into all noble structures throughout the land. This grand old place has the proud distinction of being the birthplace of John Adams, second president of the United States, and John Hancock, president of the illustrious Congress of 1776 , the first signer of the Declaration of Independence, and the first governor of Massachusetts under the constitution. It is also the birthplace of John Quincy Adams, sixth president of the United States, and of Edmund Quincy, the patriot. In Revolutionary reminiscences there are few places in the state to compare with Quincy, and many old landmarks still remain as reminders of the struggle for independence and the sterling patriotism of those wholed the movement. Among these are the houses in which Hannah Adams and John Quincy Adams were born. The former is near the railroad on the left, in going south, and the latter near Penn's Hill. Here also is the famous ancestral estate of the Quincy family, one of the most beautiful and well tilled farms in New England. The Adams Temple, erected in 1828 at a cost of $\$ 40,000$, and the gift of John Adams, our second president, contains a fine marble monumeut erected to the memory of the donor and his estimable wife. The great patriot and statesman also gave a lot to the town for an academy and also his library of more than 2,000 volumes.

The city is delightfully located, both for summer pleasures and permanent homes, has excellent streets shaded with noble elms, fine schools, churches of all denominations, first-class boarding accommodations, and its municipal government is of the best. Its early history is one so full of interest as to even attempt an outline of it here would be an impossibility. Volumes have been devoted to that subject already with not altogether satisfactory results. The territory inclosed within the limits of Quincy was formeriy the first and north parish in the ancient town of Braintree, and included what was called "Dorchester Farms" and a point of land called Squantum, between Quincy and Dorchester bays, once the residence of Chickataubut, a celebrated Indian chief. This territory, in common with that of Braintree and Randolph, belonged to Boston until the incorporation of Braintree as a town in 1640 . When this territory formed a part of Braintree it was the first portion settled, and it was 


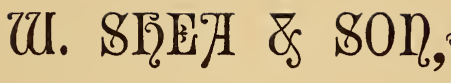
QUARRYMEN AND DEALERS IN

$\rightarrow$ Rough $*$ and $*$ Hammered * Granite, * Post Office Box 61, *

West Quincy, Mass.

W. T. SHEA, PROPRIETOR.

\section{MONAHAN \& BREEN}

MANUFACTURERS AND WHOLESALE DEALERS IN

ALL THE NEW ENGLAND GRANITES,

Monuments, Head-Stones, And all Kinds of

Monuments, Head-Stones, cemetery Work. $\mathscr{Q}_{\text {..- }}$

* * Estimates Given on ALl Kinds of Granite work

WEST QUINCY, MASS.

\section{P. F. HUGHES \& SON,}

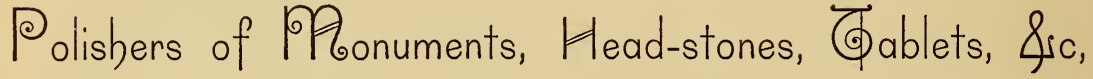

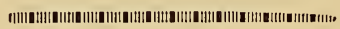

Fornace Ave., West Quincv, Mass.

ABEROGWEN MONUMENTAL WORKS,

JOHN R. WALTERS, PROP.

50 Copeland st., - QUINCY, MASS.

Artistic Memorials Cut to Order, * *

* From all Grades and Colors of Granites.

Order direct from the Manufacturer. Will call with Designs and give Estimates when Desired. 
called Mount Wollaston, in honor of Captain Wollaston, one of the first settlers in $I 6_{25}$. In $I_{792}$ this part of Braintree was made a separate town and called Quincy, to perpetuate the family name of one of its first progenitors, a name revered by the lovers of American liberty everywhere. Atlantic and Quincy Adains are large and growing sections of Quincy, and at these points, and also in the centre of Quincy, the Old Colony railroad has fine stations.

The industries of Quincy are as diversified as those of any other city in this section, if not more so, but the leading and staple business is the quarrying, polishing, and carving of granite, the city being noted from one end of the country to the other for the superiority of the granite taken from its quarries. A large number of firms are engaged in quarrying, others conduct an extensive business in polishing as well as in quarrying, while some are engaged solely in the manufacture of monuments, headstones, etc. 'The first granite quarried in Quincy was used in the building of King's Chapel, Boston, and since then few eities have been built up which have not laid tribute upon its quarries for building blocks, memorial columns, etc. The stones for buildings are often cut, finished, and numbered at the quarries in readiness for laying in their proper places in the erection of edifices hundreds of miles distant.

A range of elevated land, rising in some parts to an altitude of more than 600 feet above sea level, is located about two miles to the rear of Quincy bay. This range contains an inexhaustible supply of that invaluable building material so much used and appreciated throughout the country for its durability and fineness of texture. This range of hills extends through Quincy, Milton and Braintree. From the summits of some of the quarries the most charming views of ocean and land are to be obtained, and the lovers of scenic grandeur find themselves repaid for any trouble they are put to in attaining the highest point of elevation. The first railroad was built in connection with these quarries, reference to which is more fully made elsewhere in this work.

Quincy is bounded on the north by Dorchester, on the east by Boston harbor, south by Weymouth and Braintree, and west by Milton. Hills, valleys and plains are characteristics of Quincy, and the soil is generally of an excellent quality and under good cultivation.

About two miles east from the centre of the city is Quincy Point, at the junction of Town and Weymouth Fore rivers and near Newcomb's Neck, a small territory taken from Braintree about thirty-five years ago. This is an attractive spot and contains many fine edifices of a residential and business character. Quincy Point, with a peninsula near it called Germantown, is admirably located for ship-building purposes. Here some very fine vessels have been built, and every facility is offered for all sorts of maritime operations.

ATLANTIC.

This is the most northerly of the Quincy villages, is not only a popular summer resort, but it is distinguished as the seat of one of the famous Quincy 
MITCHELL GRANITE CO.,

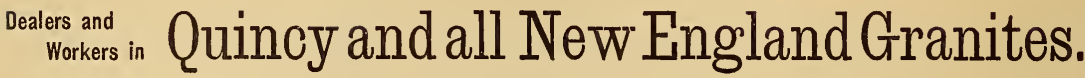

Monuments, Building Work, Statuary, Vaults, Headstones, Platforms. Plain Surface Cutting and Polishing by Machinery.

w. H. Mitchell. Office and Works, QUINCY. MASS., Quincy Adams Station. w. w. Mitchell.

J. ROBBIE.

R. MAVER,

W. REYNoLDS

\section{GLENCOE GRANITE CO.,}

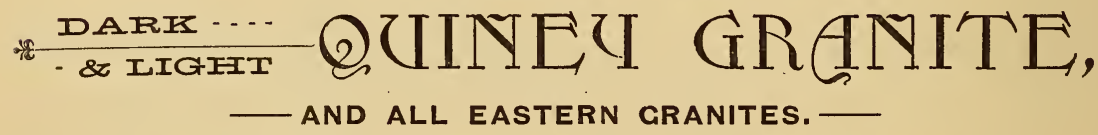

P. 0. BOX, 72. Off Quincy Avenue, SOUTH QUINCY. MASS.

\section{MILLER \& LUCE, manvenceruenes or \\ GEO. L. MILLER}

Wholesale Dealers in QUINCY, SOUHEGAN, CLARK'S ISLAND, DAK HILL, HALLDWELL, CONCDRD, BARRE, BLACK DIAMDND, RED BEACH AND BAY OF FUNDY GRANITES.
FNE

MONUMENTAL

MURK,
LESSEES OF THE

Souhegan Granite Quarry.

OFFICE AND WORKS:

MILLER ST., REAR WILLARD SCHOOL.

BOSTON OFFICE: 94 BOYLSTON ST.

WEST QUINCY, MASS.

W. LiLLICRAP.

J. LiLhicrap.

\section{MOUNT VERNON GRANITE CO.,}

\section{NEW ENGLAND and FORELGN - GRANITE MONUMENTS,}

CARVING AND STATUARY A SPECIALTY.

Office and Works: Cor. Centre and Vernon Sts., Quiney, Mass. 
schools and as the location of the first railroad - Granite Branch of the Old Colony - built in America. It has a population of upwards of 2,000, and this is largely increased in the summer months by those who yearly seek a home by the seashore at Squantum, which is located on the bay and affords fine harbor views, has the best boating, bathing and fishing privileges and is fast becoming a popular resort for the inhabitants of the surrounding cities. It is only five miles from Boston, and enjoys the best transportation facilities.

\section{WOLLASTON HEIGHTS.}

What is known as Wollaston Heights is within the city limits of Quincy and occupy an elevated site, charmingly located on the south shore of Massachusetts bay. It forms one of the most beautiful of the many attractive spots in this locality. Overlooking Boston's magnificent harbor, with its scores of islands and commanding a full view of every passing steamer, it has become a favorite resort for affluence and wealth.

\section{WOLLASTON PARK.}

Wollaston Park is a recently laid out section in the limits of the city of Quincy, and is designed for residential purposes. It is only three minutes' walk from the Wollaston Heights' station of the Old Colony Railroad, and the Boston and Quincy electric road also passes along its entire front. The place is one of the most beautiful in its natural features that could well be imagined. It contains I 53 acres of level land dotted in all portions by trees of long growth, one of its avenues being 80 feet wide and one-quarter mile long, and is bordered on either side by three rows of magnificent elms planted in $\mathrm{x} 793$. The Park has an excellent beach on its eastern side and commands superb views of the harbor, city and surrounding country.

\section{NORFOLK DOWNS.}

This is also a suburb of Quincy and within its corporate limits. It is situated midway between Atlantic and Wollaston Heights stations, and has a handsome depot of its own built by the Old Colony Railroad Compay at an expense of $\$ 10,000$. It adjoins Wollaston Park, is on a tableland some 20 feet above the railroad bed, and like the latter park is provided with excellent transportation facilities by both steam and electric roads. Fine walks and drives have been laid out here, electric lights introduced, and like most of this region an unbroken harbor view is had.

\section{QUINCY ADAMS.}

This growing section of the city of Quincy is a most desirable location for permanent or summer residence, and has many fine private estates. The surroundings are healthful, the streets shaded by stately elms, there is an abundant supply 


\section{THOMAS \& MILLER,}

\section{Statuary, Monuments, Headstones.}

Cemetery Work of all kinds from

QUINCY, WESTERLY, BARRE, CLARK'S ISLAND AND ALL OTHER GRANITES.

AMERICAN AND ITALIAN MARBLE.

Best Stock and Work Guaranteed.
* Quincy, Mass.

WORKS AT QUINCY ADAMS STATION, O. C. R. R.

MCDONNELL \& KELLEY, Numantaremen of

Quincy and other

New England

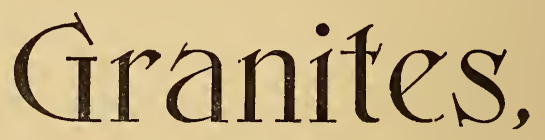

Office and Works, 6-12 BROOK STREET,

Polished Monuments, Headstones, \&c.

Best of Stock and Workmanship Guaranteed,

QUINCY, MASS.

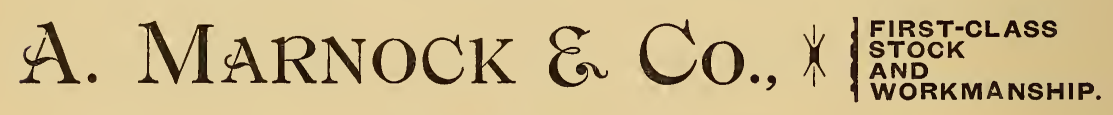

Wholesale Dealers in Fine

SCOTCH, SWEDISH and all AMERICAN

\%8.

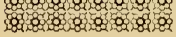

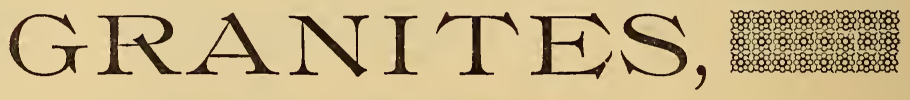
SOUTH QUINCY, MASS,

P. T. Fitzgerald.

T. M. ELcock.

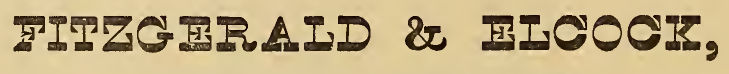

Wholesale and Retail Dealers in Fine

Monumental *and * Cemetery * Work.

FURNISHED IN QUINCY AND ALL NEW ENGLAND GRANITES.

New and Original Designs Constantly on Hand, 5 Minutes Walk from R. R. Station, SOUTII QUINOY, MASS.

Send postal and we will call with Designs and Estimates. 
of excellent water, and every modern convenience and comfort calculated to make life enjoyable. Many summer sojourners find Quincy Adams a delightful retreat during hot weather, as the accommodations for such are first-class and the prices comparatively low for the entertainment afforded. The population is upward of 2,000 .

\section{WEST QUINCY.}

West Quincy is noted for its great granite quarries, which are the most extensive in this country, as well as for the character of the finished product. Many fine specimens of architectural sculpture have emanated from this place, the most notable one being, perhaps, the large emblematic piece which for years adorned the front of the old post office on State street, Boston. When this structure was razed to make way for the present Exchange building this stone was carefully preserved and placed in the wall of the new Chamber of Commerce building on India square. Although black with age it is a fine piece of work, and is in strong contrast with the pink granite of which the building itself is constructed. West Quincy has a population of about 4,000, good schools and churches, and is two miles from the city proper. Thousands annually visit the place to inspect the granite qnarries, and as many of these are located upon a high hill of solid rock, a fine view is had of the surrounding country in addition to the attractive features presented by the granite industry.

The Granite Railway Company, of which Henry E. Sheldon is the agent, and $J$. Albert Simpson the treasurer, was incorporated in 1826 , and its operations are the most extensive in the manufacture of granite here. The company operate two large quarries, one at Concord, N. H., and the other here at Quincy, the latter covering several acres of ground, the granite of which is seen in many buildings in the large cities of this country, and it has also been exported to the West Indies. The stone for many buildings has been cut and finished and numbered at the quarries all ready to lay in its proper place in the building which may be miles away. It is fully equipped with large work sheds, storage sheds and the latest improved mechanical appliances to expedite the work, while employment is furnished to a large number of workmen. The concern are also manufacturers of Chesley's Patent Bush Hammer and Lifing Jack, and occupy besides their quarries large machine shops and polishing works at West Quincy. The company possess superior facilities for being supplied with large quantities of monumental and building granites, and receive orders for the same at their Boston office I66 Devonshire street. The first railroad in this country was built from the quarries of this company and is fully described in Part One of this work.

Swithin Brothers, located on Granite street, Quincy, are among the prominent granite workers of this city, and are entitled to mention in this work. This firm imports Scotch, red Swede, Norway, English and Irish granite, and granite from Labradır, and deal in all kinds of New England granite. 


\section{CINTOSH \& SON, IONUMENTAL WORK.}

Plain and Elaborate. * From all Grades of Quincy and other Granites.

Estimates Cheerfully Given.

P. O. BOX 74 . SOUTH QUINCY, MASS.

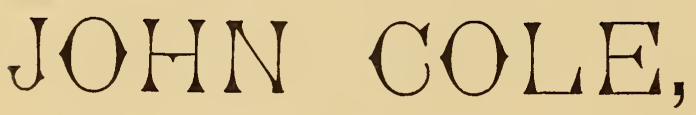

MANUFACTURER OF ALT, KINDS OF
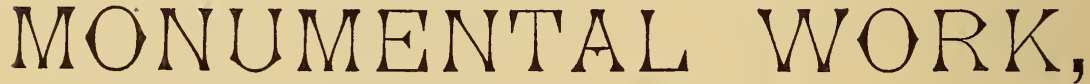
QUINCY GRANITE A SPECIALTY.

SOUTH QUINCT MASS.

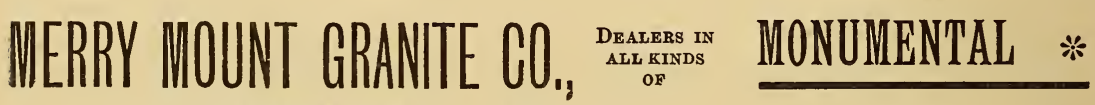

-INCORPORATED DEC. 31, 1861

JOHN LAVERS, Agent.

CEMETERY and *

STATUARY A SPECIALTY.

QUINCY, - - MASS.

BUILDING WORK.

The best of Dark and Light Quincy, Concord, Clark's Island, and all White Stocks furnished. All work guaranteed satisfactory. Orders promptly attended to.

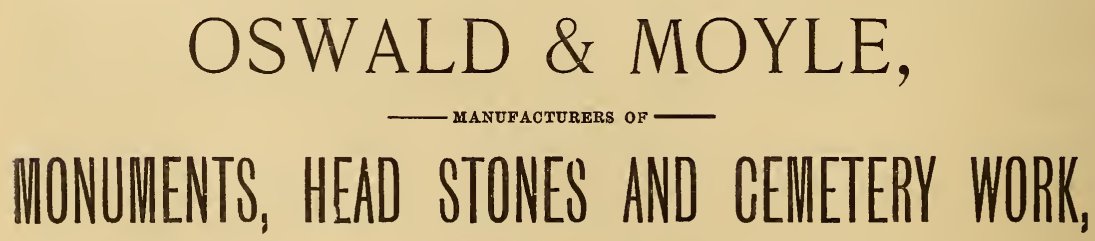

Of all kinds from the best Quincy Granite.

_Light, Dark and Medium Stock. All work Guaranteed.-

Works off Penn St., SOUTH QUINCY, MASS. 
They manufacture monumental, statuary and all kinds of cemetery work, and carry in stock a large and varied assortment of monuments of all kinds of granite. A force of sixty skilled hands is employed by them, and they engage two experienced draughtsmen for monuments, etc. This firm are the leading retail dealers in their line in Quincy, having had many years' experience. The work produced by them is of extra quality. Besides their house in Quincy they carry on a granite and marble business at New Bedford.

E. C. Willison purchased the business of the International Granite Co. last May, the industry being established in $\mathrm{r} 87 \mathrm{I}$. The plant at Quincy, occupied for this business consists of a yard covering over an acre of ground upon which are situated two large work-sheds, one measuring 2 ro by $40 \mathrm{feet}$, and the other 160 by 40 feet. Other buildings besides the sheds mentioned are also occupied and also a fine large office, while a spur-track connecting with the railroad and reaching to the works, afford facilities for the transportation of granite to all sections of the country. Sixty-four hands are employed. Mr. Willison's output consists of large quantities of granite, monumental and finished work, and all kinds of carving, etc., and branch offices are located at Boston and Kansas City, Mo., Aberdeen, Scotland, and at Carrara, Italy.

McDonnell \& Sons was first established in 1857 by Mr. P. McDonnell, who conducted the business until I87r, when his sons, T. H. and J. Q. McDonnell were taken into partnership, and they have continued the business ever since under the above named firm. The business carried on by them is that of wholesale dealers in all kinds of rough and finished granite for monumental and building purposes. The premises cover several acres, having two large quarries, one at Barre, Vt. and one here in Quincy, which are supplied with all the latest improved machinery, appliances, etc. that are necessary in their line of business. The works are ably and systematically conducted. Their products are shipped to all parts of the United States and they have quite a trade in the British Provinces and Canada. They give employment to many experienced workmen who have been in their employ for a number of years. Samples of their work can be seen in the Mt. Auburn Cemetery, also the larger cemeteries in New York state. They have a branch office in Buffalo, N. Y., and their Quincy office is located on Quarry street.

The Merry Mount Granite Company was incorporated in I86I with a capital of fifteen thousand dollars. Its officers are as follows : president, John C. Kapples; treasurer, Patrick W. Driscoll; agent, John Lavers. The business is carried on as dealers in all kinds of monumentai, cemetery, and building work. One of their specialties being the manufacture of statuary. All work produced is of the finest quality, the principal stock that is used consists of the light and dark Quincy granite. They employ a large force of workmen and their works cover an area of twenty-four thousand feet. A large and prosperous business has been built by them, their trade extending to California, Tennessee, and all the Western States. The work of this company is well known throughout the country for the fine finish that is given to it, and the quality of maverial used. The office is situated on Water street, Quincy. 


\section{DEACON BROTHERS,}

Manufacturers of

\section{Granite Monuments,}

Centre Street, South Quincy, Mass. ESTIMATES Given. SATISFACTION GUARANTEED.

SKILL WINS FAVOR. ARTISTIC, PROMPT, ACCURATE.

WM. A. SMITH, Granite Dealer, PENN ST., QUINCY, MASS.

SAMPLES \$1.00 EACH. POLISHING MILL, QUINCY NECK.

S. HENRY BARNICOAT, - Henry Barnicoat. Successor to H. BARNICOAT \& LAWRY,

- MANUFACTURERS OF -

Statuary, Draped Work Monuments, CARVING A SPECIALTY.

Works, CENTRE COrner COLUMBIA STREETS, * * * QUINCY, MASS.

H. NICOLL.

J. MOORHOUSE.

NICOLL'S GRANITE WORKS, Manufacturers of

Quincy * Granite * Monuments. ESTIMATES FREELY GIVEN AND PROMPTLY ANSWERED. 
Joss Bros. was established about the year i 880 as manufacturers and wholesale dealers in all kinds of granites. Their works cover a large tract of territory on Garfield street, Quincy, where may be seen a large variety of monuments, head-stones, tablets, etc. Through their knowledge of the industry they have built up a large business. They make a leading specialty of the finest class of work, their facilities enabling them to produce monuments of the most artistic design and finish. At their works a fine display of sample work is shown. Joss Bros. are prepared to suit the most critical taste, and a great variety of plans and designs may be seen at their office. All orders are filled. promptly and the lowest quotations are given.

McKenzie \& Paterson, located on Canal street, were established in the year 1870 , and now enjoy an excelient reputation and trade which is principally wholesale, extending through the Middle and Western states. McKenzie \& Paterson operate one of the largest quarries in Quincy, which is fully equipped with all the necessary appliances, and employment is given to a large number of skilled workmen, they being the first firm to introduce the polishing of granite by steam power in the United States. The stone obtained from their quarry is the celebrated dark blue Quincy granite, although they handle all kinds of New England granites. The members are Gordon McKenzie and George S. Paterson, both men of thorough experience in their line.

William Shea \& Son is a well known firm that has been established for over twenty-two years in the granite business, getting stock out for all kinds of monumental and building work. The land on Quarry street, Quincy, covered by their works, extend over an area of four acres, and are equipped with the necessary mechanical appliances. They give fourteen skilled hands constant employment, and get out about 10,000 feet of dimension stock per year. The members of the firm are men of energy and enterprise, and they are thoroughly experienced in every detail of the business.

George H. Hitchcock \& Co. succeeded Churchill and Hitchcock in I892, the latter firm having founded the business in 1873 . They are contractors for rough Quincy granite and are prepared to furnish all kinds of Quincy granite in any quantity that may be required. Their trade is increasing quite rapidly as the firm has a noted reputation for producing an extra quality of granite in the rough from their quarries. The office is located on Quarry street, Quincy.

Alexander Clark is one of the prominent mauufacturers of granite tools of every description, at No. 138 Water street, Quincy. In the manufacture of these tools none but the best stock is used and all work is warranted to be satisfactory. His tools consist of all the latest patterns and are made in every style and shape to suit his patrons. By the excellent quality and manner in which his work is produced he has built up a large trade. The repairing of tools by him is done in first class manner.

Lewis Dell \& Co. have been for the past thirty-seven years operating as dealers in building, monumental, and cemetery work of all descriptions, the granite of which is of a medium blue Quincy granite. The works cover an area of five acres of land, and the firm are able to get out fifteen thousand feet 
J. P. DUFFY, * 15 GARFIELD STREet, QUINCY, MASS.

Monumental

and Cemetery Work,

FROM THE VERY BEST
QUINCY GRANITE.

SEND FOR ESTIMATES.

CORRESPONDENCE SOLICITED.

ALLEN \& WALKER,

$\rightarrow$ Quincy Granite

MONUMENTS AND CEMETERY STONE WORK OF EVERY

DESCRIPTION DONE IN A SATISFACTORY MANNER. • .

GOOD STOCK AND GOOD WORKMANSHIP GUARANTEED.

All Orders Promptly Attended To.

ROBERT C. ALlen.
JOSEPH WaLKE.

M. F. O'BRIEN.

J. T. MENEIL.

\section{O'BRIEN \& McNEIL,}

MANUFACTURERS AND

(6)

GRANITE DEALERS

IN FINE MONUMENTAL WORK.

CORNER WILLARD AND WEST STS., * * WEST QUINCY, MASS.

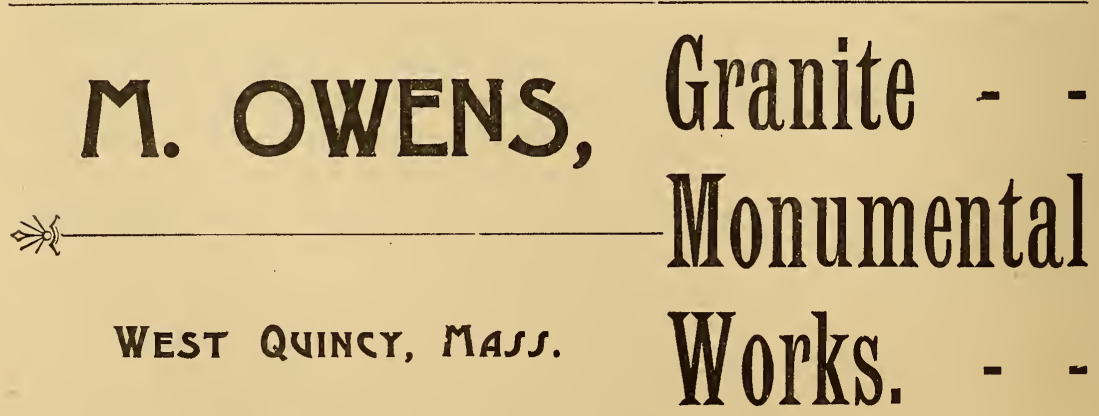


of dimension stock a year, having one twenty horse power engine, and giving employment to twenty skilled workmen. The works are located on Quarry street, Quincy. They have all the conveniences for conducting a large business, and have one of the best quarries in the city. Mr. A. A. Dell, proprietor and manager, has had many years of practical experience, and all work that goes from his works can be relied on as giving perfect satisfaction in every respect. The trade extends over a large territory and the business is rapidly and steadily increasing.

John Thompson \& Sons, located on Quarry street, Quincy, was established. in 1872 for the manufacture of cemetery and building work in all its branches, and also as wholesale dealers in ali New England granites. The works are ably and systematically managed, and are equipped with all the modern appliances. Their products are shipped to every state from Maine to California. They give employment to many experienced workmen who have been in their employ for a series of years, which speaks well for the management as well as efficiency of the work produced. The granite used by them is the best quality of standard Quincy, but all kinds of New England granites are furnished. The firm stand well in the community, and take a keen interest in matters not only pertaining to their trade but public questions as well, the junior partner of the firm having been a member of the City Government of Quincy since its charter. The past two years he has been president of the City Council, the only legislative body, and the general material progress of the city is indebted to gentlemen of like push, energy and public spirit for its rapid advance in the last few years.

C. H. Hardwick \& Co., first established in I 848 by C. H. Hardwick, are proprietors of the largest and one of the oldest quarries here, it having been worked one hundred and ten years ago, and is now one hundred and thirty-five feet deep in its deepest place. The dark blue granite having a rich handsome color, as well as the lighter shade, are both found here and take a fine polish. Many public buildings and hundreds of well known monuments throughout the country contain work cut by this house. In connection with the quarry are a polishing mill with all the modern equipments, stone cutting and carving yards, blacksmith shop and engine house, the entire plant covering about eighteen acres. Both rough and finished stock are supplied to dealers throughout the States and Canada, and the stone has an unrivaled reputation for excellence of quality.

Fegan \& Ballou, in 1890 succeeded Henry Barker \& Sons, who established the business in 1865 . They carry on the business as wholesale manufacturers of rough and hammered granite, and are steam polishers and granite workers. Their monumental and other work suitable for cemeteries is executed in a prompt manner and in the best grade of granite that can be obtained in dark blue and medium Quincy granite from their own quarries. The goods are shipped to all points in the United States. Their works are well equipped with all the necessary machinery. A special feature being the improved saw used in sawing granite, which is the only one in operation here. 


\section{GRANITE}

\section{RAILWAY}

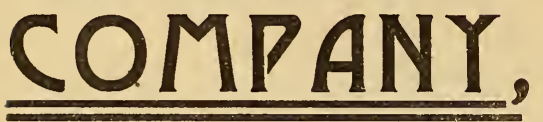

PROPRIETORS

OH

THE

CELEBRATED

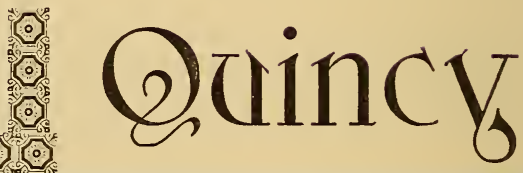

1.1 [0. [0]

(10)

(i) 10 -

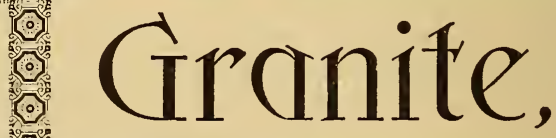

(6)

(0)

ALSO

Concord, N. H. Quarries.

PRINCIPAL OFFICE,

166 Deronshire St., Boston, Mass.
QUARRIES

West Quincy, Mass., Concord, N. H. 
Fmployment is given to thirty-five hands, and the works cover a space of seventeen acres. The office is located on Quarry street, Quincy. The firm consists of W. R. Fegan and John C. Ballou.

William Callahan located at 34 Quincy avenue, Quincy, dealer in dark and light Quincy granite was established in 1889 . He has a large and thriving business, his stock being sent to all points of the United States. In connection he also manufactures work of every description suitable for cemetery purposes. Constant employment is given to eight efficient men and a vast amount of work is produced during the year.

The Glencoe Granite Company of Glencoe place, Quincy, manufacturers of and dealers in dark and light Quincy granite, was incorporated in 1887 with a capital stock of five thousand dollars. The company consists of J. Robbie, R. Maver and W. Reynolds. The manufacturing consists of building work and the making of monuments and all work pertaining to cemeteries in dark and light Quincy, and all eastern granites. A corps of thirty-five men is employed by them, and their plant covers an area of thirteen thousand feet.

McGrath Brothers, located on Water street, are among the oldest establish ments for the manufacture of monumental, statuary, and all kinds of cemetery work in this city. Their works occupy an area of one half acre of land, and employment is given to twenty-five hands. They have constantly on hand the largest stock of finished monuments, headstones, etc., in Westerly, Quincy. Italian and American granite and marble to be found in this vicinity. Having an experience of nearly forty years in the business they have won a high reputation for first class work. Their works being only a few steps from the Quincy Adams station, they are a great convenience to customers along the line of the Old Colony Railroad.

McDonnell Bros., established in 1876 , are among the principal wholesale dealers in dark blue and gray Quincy granite, and are located at 95 to 97 Water street, Quincy. Their trade extends through the Middle and Western states. The firm is composed of J. A. McDonnell and T. McDonnell. The land occupied by them covers an area of fifteen thousand feet, where they employ twenty-five skilled workmen. In connection with the wholesale trade they also manufacture headstones, and do all kinds of cemetery work. They are experienced men and have built up a lucrative business, which is constantly increasing.

C. Johnson \& Brothers have been established on Quarry street, Quincy, about two years, but they have been engaged in the business for a number of years, being at one time the proprietors of the Merry Mount Granite Company. The business they are engaged in is the production of stone in the rough, for monumental and building work. They have in ust one steam engine and employ three expert workmen. The works cover a large tract of land, and have all the necessary appliances that are used in the business. All orders are given prompt attention, estimates being furnished on application, and all work is completed at the lowest rates.

The Galvin Granite Co. was established in I883, and has ever since con- 


\section{MCDONNELL \& SONS, OUARRY OWNERS, QUINCY, MASS., 尔 BARRE, VT.}

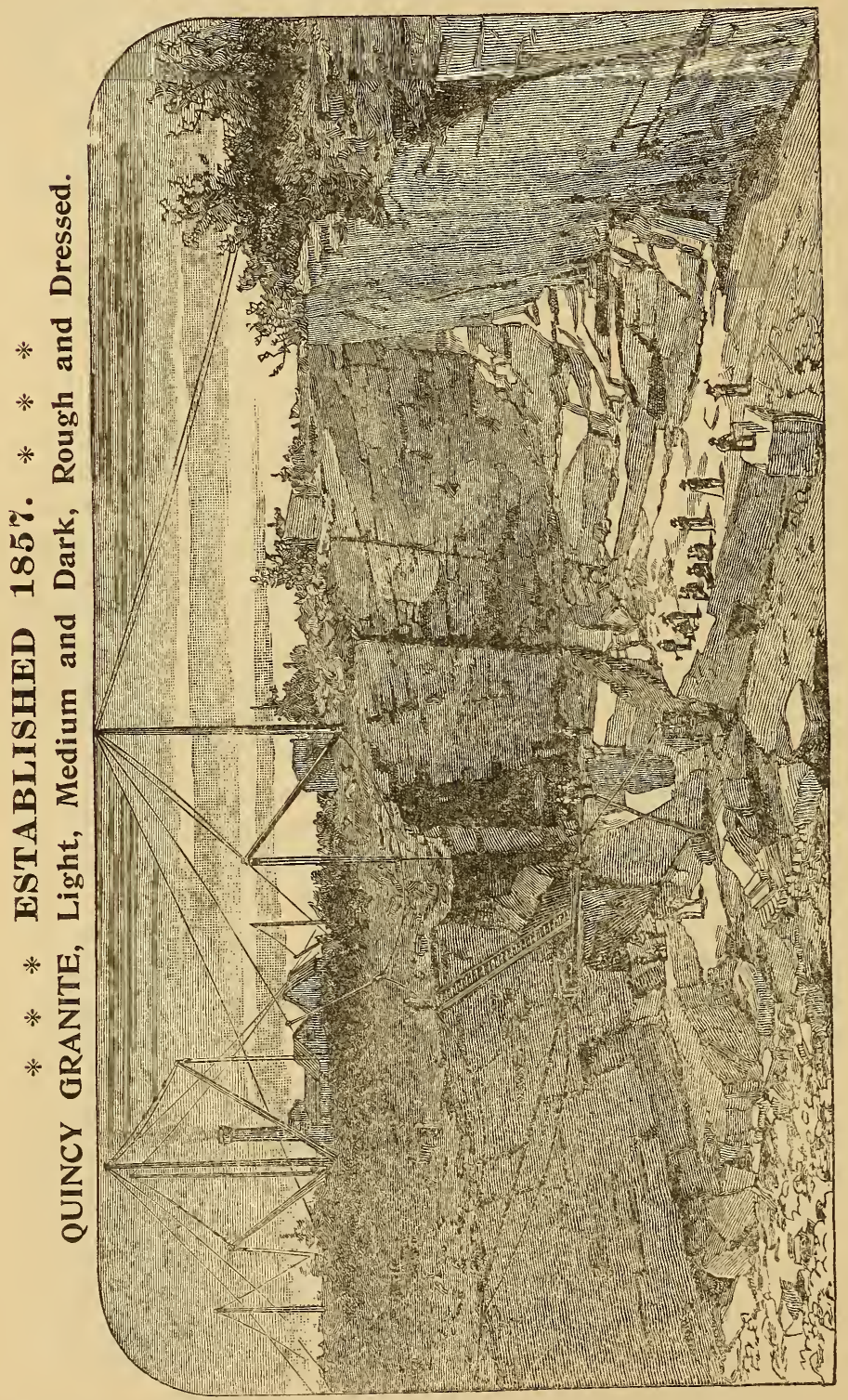

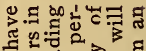

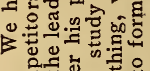

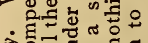
총 今)

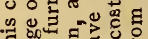
I a हैं 过

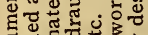

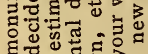

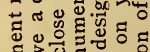

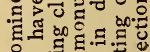
衣记

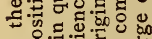

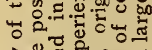

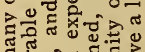

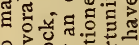

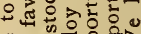

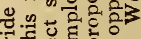

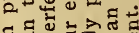

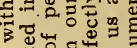

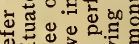

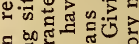
ริ

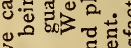
今。 o

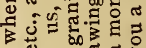
舶 की

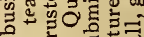

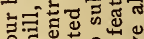
列 政记

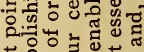

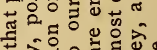
ॠ. 巴ँ

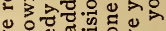

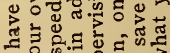

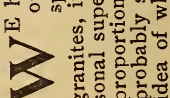
BRANCH OFFICE AND YAID, - - 858-860 MAIN STREET, BUFFALO, N. $\mathbf{Y}^{\bullet}$ 
ducted a large and most successful business. The members of the company are J. P. and J. M. Galvin and T. Galvin, all practical men of long experience in the granite business. Their operations are with the wholesale trade in rough and dressed dark blue and medium Quincy granite, and the manufacture of monumental and building work, polishing, finishing, etc., a specialty, however, being made of rough stock for which they have a large trade throughout the country. The plant occupied by the company consists of a good sized quarry, and works, which cover over a large area of ground upon which are built sheds measuring 60 by 20 feet where some twenty skilled workmen are employed. The quality of stone produced at this quarry is especially desirable for monuments and also for building purposes.

William Turner founded the business in 1882 and is one of the reliable dealers in monumental and cemetery work. The premises are located on Water street, Quincy, and are well equipped with the latest improved machinery and have every facility for the prosecution of the work. Being a man of energy and enterprise, his trade has increased annually until now it is large and flourishing. Employment is given to fifteen skilled workmen who have had many years' experience in this line, and all work is guaranteed satisfactory, nothing but the best material being used.

John P. Duffy, succeeded in I890 Duffy \& White. This concern deals extensively in all kinds of rough and finished granite for monumental and building work, Quincy granite being a specialty. The premises occupied are ample and commodious, and completely equipped. Work of any style is turned out to order in the most excellent and expeditious manner. Mr. Duffy is well and favorably known in the community.

S. Henry Barnicoat is the successor to the firm of H. Barnicoat \& Lawry; who established the business in 1890 . Mr. Barnieoat has had control of the business since June of $189 \mathrm{r}$, and occupies a large plant on Centre street, corner of Columbia street, where he employs twenty workmen. The specialty s statuary, draped work, and other fine monumental work, which calls for fine carving and finishing for which the house has been popular since its foundation.

Franklin Hardwick \& Son formed a part of the original firm of C. Hardwick \& Co., who established the business in 1848 , and who divided the quarry and business in 1880 , since which time Franklin Hardwick \& Son have done business under the present firm style. They are well known as manufacturers of statuary, monuments and a general line of cemetery work. The members of the firm are energetic and possess good business principles, having built up a large and prosperous business, which is constantly increasing. They are able to meet all the wants of the trade, and are well known among dealers. Constant employment is given to a number of hands all of whom are expert workmen. The office is located on Quarry street, Quincy.

John Fallon \& Sons' marble and granite works was established about i6 years ago. The principal business is the getting out of stone for monumental and building work. Their works cover an area of three acres and are fitted up 


\section{MILNE \& CHALMERS,}

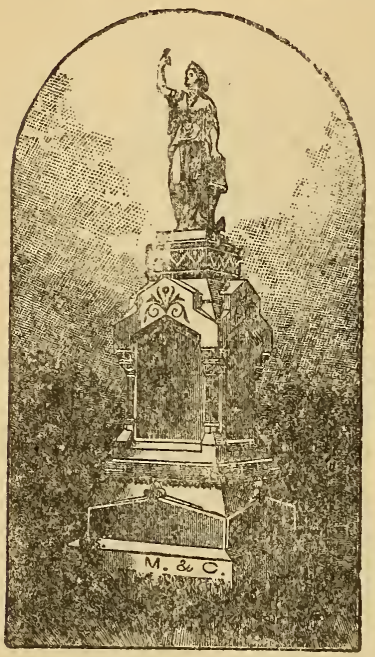

\section{STEAM POLISHING WORKS.}

Manufacturers and Wholesale Dealers in

Granite Monuments, Statuary, Etc.,

Near Quincy Adams Depot, ** QUINCY, MASS.

ENGLISH STOCK AND WORKMANSHIP GUARANTEED.

\section{PROUT BROS. 哓 $\rightarrow$ Granite Company,

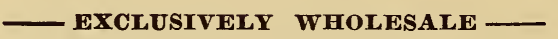

Granite, ${ }^{*}$ Cemetery ${ }^{*}$ and ${ }^{*}$ Building ${ }^{*}$.Work. IMPORTERS OF

\section{All Foreign Granites.}

$$
\begin{aligned}
& \text { QUARRIES, } \\
& \text { WEST QUINCY. }
\end{aligned}
$$

WORKS,
45 GARFIELD STREET,

Boston Office, 154 KNEELAND STREET. * * * QUINCY, MASS. 
with all necessary machinery. They have three thirty-five horse power engines, and produce about ten thousand feet of dimension stock per year. Only firstclass workmen are engaged and forty-five are given employment, while twentysix horses are in constant use. Their goods are shipped all over the country by the Metropolitan Steamship line and the Old Colony Railroad. The granite produced from their quarries is of an excellent quality, and the Messrs. Fallon are at all times prepared to execute all work at short notice. Their business amounts to fifty thousand dollars per year. The firm are located on Quarry street, Quincy.

A. M. Deane \& Co.'s granite works have been established here in Quincy for the last three years and have been very successful in turning out many fine granite monuments in new and original designs. The plant occupied for the industry consists of a yard covering over an acre of ground upon which are large work sheds measuring 75 by 30 feet where twenty-five skilled workmen are employed. The specialty of the firm is granite monumental work in all its branches, including fine carving and polishing, and a good connection has been established with the trade throughout New England.

The Mount Vernon Granite Co. has been established for the last three year's, and has during this time gained a wide spread reputation. The company, which is composed of W. Iillicrap and J. Lillicrap, possesses the best possible facilities for being supplied with New England and foreign granites and make a specialty of carving and statuary work. For its operations a plant is occupied at the corner of Centre and Vernon streets, Quincy, which covers over a half acre of ground upun .which are situated work sheds, 60 by 20 feet in measurement, with a suitable office connected, while a number of skilled artisans are employed.

William A. Smith has been established four years and has control of a large business, requiring for its operations the occupancy of a plant here covering over one half acre of ground with sheds measuring I Io by 25 feet (including excellent winter sheds), a blacksmith shop and also a large polishing shop located at Quincy Point, measuring 100 by 40 feet, where ten polishing machines are in use and fourteen workmen employed. At the works on Penn street sixteen skilled workmen are engaged. Mr. Smith's specialty is monumental work of all kinds, carving, statuary work and general polishing, and his trade connections extend throughout the whole country.

The Nicoll's Granite Works, located on Centre street, have been established for the last four years. The plant occupied for this industry covers over one half acre of ground and is equipped with work sheds 80 by 20 feet in measurement, a well equipped blacksmith shop and office. Some twenty of the most experienced workmen are employed. The specialty of the works is the production of a fine line of granite monuments, including carving, finishing and polishing, and all kinds of cemetery work, for which estimates are furnished in the shortest possible time.

Swingle \& Falconer are well known as manufacturers, importers and wholesale dealers in foreign and American granite. The plant in Quincy, 


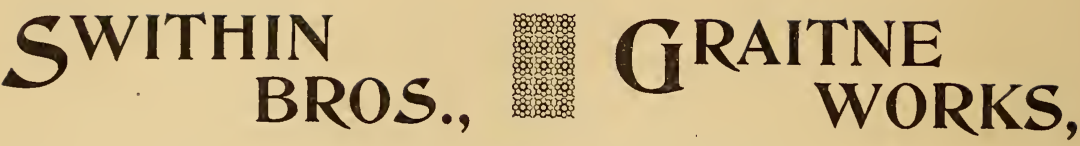 \\ QUINCY, MASS.}

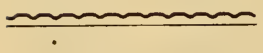

IMPORTERS OF

SCOTCH,

RED SWEDE,

ENGLISH,

IRISH,

NORWAY,

and

LABRADOR.

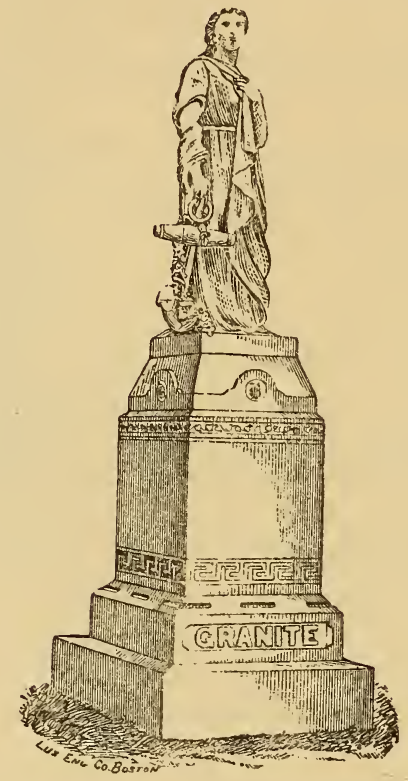

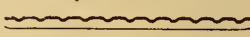

ALSO DEALERS IN

WESTERLEY,

QUINCY,

BARRE,

CONCORD,

PONEWA,

and all

NEW ENGLAND

GRANITES.

After years of careful study and strict attention devoted entirely to our business, following its minutest change as pertaining to the execution and erection of fine monumental work, we are enabled to refer with pardonable pride to the many prominent monuments which we have erected in the Boston cemeteries, as well as the various other cemeteries throughout New England. We keep always in stock at our works at Quincy and New Bedford, a large and varied assortment of finished monuments and tablets, new and original in design, which we cheerfully invite you to inspect. Having in our employ two experienced monumental draughtsmen, we are prepared at all times to submit special designs, original and perfectly proportioned. We have made a special study of proportion-one of the most essential features of a monument. By giviug us an opportunity to submit designs will cost you nothing, and probably save you money, and above all, assure you a perfect monument. Should it be inconvenient for you to call at our works at Quin cy, by sending us your address we will send a competent representative, with designs, to your residence, for you to inspect before placing your order.

FIVE MINUTES' WALK FROM QUINCY STATION, O, C. R. R.

OFFICE AND WORKS,

\section{GRANITE STREET, * QUINCY, MASS.} 88 DARTMOUTH ST., NEW BEDFORD, MASS. 
consists of a yard covering over an acre of ground, in close proximity to the railroad where a spur track of the Old Colony is laid, which affords facilities for quick transportation of granite and finished work to all sections of the country. Two very neatly arranged sheds are situated on the plant measuring Ioo by 24 feet each, where a number of skilled workmen are employed. They have a foreign office at 25 Thistle street, Aberdeen, Scotland.

Fred F. Nourse is a dealer in granite, being located on Hancock street. He has quite a local trade and his products are also shipped to New York state. He gives all orders his prompt and personal attention. He always has on hand a stock of rough and finished granite for monumental and building purposes, which he furnishes to order.

Mathaurs Bros. is a reliable house and has been established here since I89I, and although so recently founded it ranks high among the manufacturers and dealer's in granite. The premises utilized, are located on Quarry street, covering an area of four acres of ground, and well equipped in every respect with the most improved machinery, appliances, etc., while the concern is supplied with ample steam power, and upward of twenty-five skilled hands are employed. An immense and superior stock is constantly carried on hand, embracing rough and dressed granite, monuments, headstones, tablets, etc., and general cemetery and architectural work is executed in the most excellent manner, the trade extending to all parts of the country.

Andrew Erickson, teamster and dealer in rough stone, was established in I 890. The premises utilized cover two acres of land and are located at 27 Morton street. Employing an efficient force of hands, he gives special attention to teaming, and is at all times prepared to fill orders expeditiously and in the most satisfactory manner. Mr. Erickson is a dealer in all kinds of rough granite for monumental and building work, which he sells in the rough to the local trade. His granite works are fully equipped with all necessary appliances for carrying on the work.

The Mitchell Granite Company established in I846, and whose works are located at Quincy Adams, are dealers and workers in Quincy and all New England granites for monumental statuary, vaults and platform purposes. The premises occupied by them cover an area of two acres, and to carry on their work in a successful manner requires forty experienced men. For cutting the granite they have in operation a steam cutting machine, the only one in this city, and the only one of two in operation in this state. A steam derrick is also used by them, and with such facilities they can accomplish a great amount of work in a short time. The firm consists of W. H. and W. W. Mitchell. Both give their personal supervision to every detail of the business, and they have a reputation of high standing, and their work can be relied on as being promptly and faithfully executed.

Fitzgerald \& Elcock comprise a new and enterprising granite firm established during I892, on Penn street Quincy Adams, which gives promise of a brilliant and successful future. They have an extensive and well equipped plant and their large force of superior workmen guarantee execution in the 


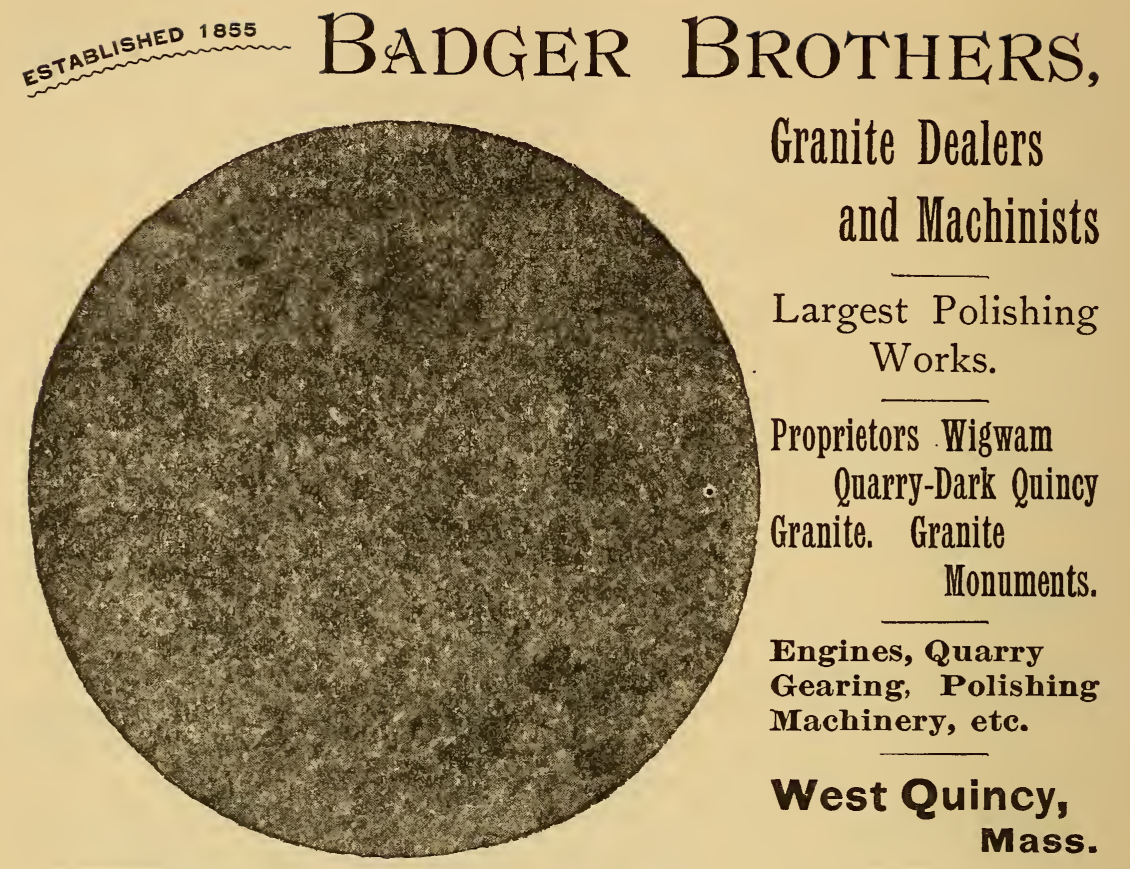

\section{Craig \& Richards Granite Co., GRANITE MONUMENTS.}

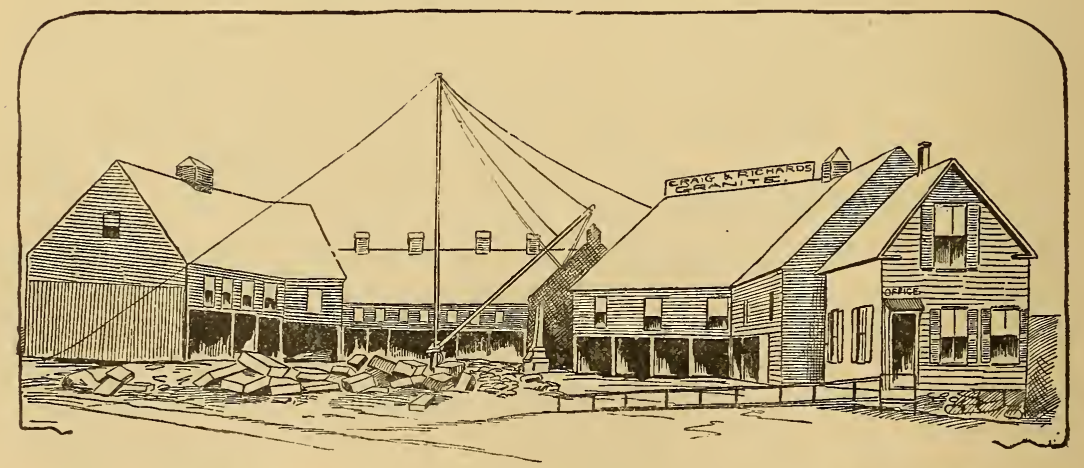

Manufacturers, Importers \& Quarriers,

Dealers in all American and Foreign Granites.

Dark Quincy Granite a Specialty. Estimates Freely Given. 106 Water $\mathrm{St}_{{ }_{3}} \quad$ - $\quad$ Quincy, Mass. 
finest possible manner. From a long and thoroughly practical acquaintance with all branches of the business these gentlemen cannot rail to satisfy any and all purchasers. The strictly honest and thoroughly attentive methods employed by this firm will certainly win a large share of public patronage. Parties desiring designs or estimates on any of the New England granites will receive them promptly on application.

Craig \& Richards situated on Water street, Quincy Adams, are well known as manufacturers, dealers and importers of all kinds of granite for cemetery purposes. The firm occupies an area of two acres of land for their work, and have two acres of quarries. A specialty is the dark blue Quincy granite that is worked by them. Their work is of the very best quality and is sent to all parts of the country and to the British Provinces. They employ a force of seventy workmen all being experienced in the business. All kinds of lettering is done and estimates are promptly given and first-class work guaranteed. They have had a business experience of eleven years and are fully acquainted with all details of the business.

John F. Kemp of 82 Water street, Quincy Adams, is a well known manufacturer and dealer in machinists' and granite workers' tools. He occupies a one-story frame building, which is in dimensions some twenty by thirty feet and an ell of the same dimensions. Employing three able assistants, he produces quite a number of tools of various styles, and does jobbing of all kinds. Having been established only three years, still he has built up a large and increasing trade.

McGillvray \& Jones, granite workers on Liberty street, Quincy Adams, were established in 1878. As manufacturers of polished monuments, headstones and all cemetery work they rank among the first. The premises occupied by them cover an area of three quarters of an acre, and give constant employment to thirty-five hands. Their iacilities for filling orders at short notice are of the best. McGillvray \& Jones at all times invite the publics' inspection of their stock on hand, and will furnish estimates whenever desired. They have a trade which extends to all parts of the United States.

Long \& Saunders are among the prominent manufacturers of statuary, monumental and all cemetery work in granite and marble, located on Penn street, Quincy Adams. This firm was established in 1890 and it has built up a large and prosperous business. The works cover an area of ninety thousand square feet, where fifteen experienced workmen are engaged. All their work is set in cemeteries under the personal supervision of the firm. Their works are near quarries and located on the line of the Old Colony Railroad so that they have advantages for shipping and handling work at low rates.

Thomas \& Miller, situated on Liberty street, Quincy Adams, are among the principal manufacturers of marble and granite, the firm being established in I 885, and ranks now among the first in their line of industry. The granite used by them is Westerly, the celebrated blue diamond, and Quincy, and all others, while the marble is of American and Italian production. They keep on hand an excellent assortment of plain and ornamental monuments, richly 


\section{JAMES F. DESMOND,}

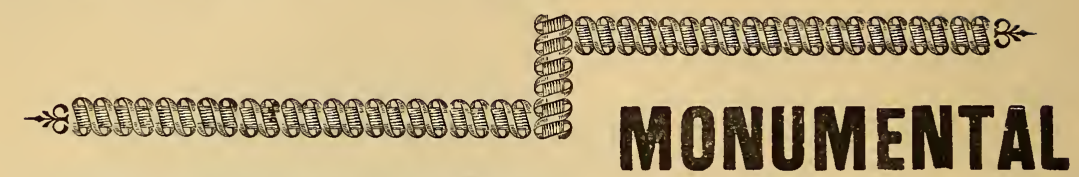

- - - MANUfACTURER OF fINE

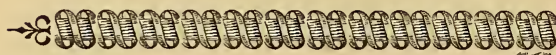

\section{WORK FROM...}

\section{(Cinimi}

(umbing

\section{BEST DARK QUINCY GRANITE.}

Particular attention given to Statuary and Carving.

Designs and Estimates furnished on application.

Office \& Works: MILLER ST., Quarries: . . . . W. QUINCY, MASS.

ESTIMATES FURNISHED ON ALL NEW ENGLAND GRANITES.

\section{BURNS \& CORMACK, mantracervans or}

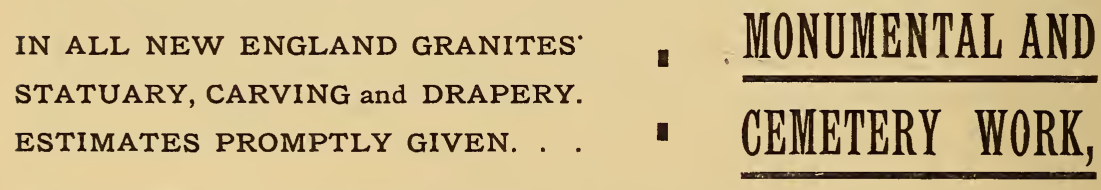

SOUTH QUINCY, MASS. Works: PAYNE ST.

\section{A. M. DEANE \& CO.,}

\section{GRANITE * MONUMENTS}

OF EVERY DESCRIPTION.

\section{QUINCY, MASS. $\frac{\text { New and Orighnal Designs }}{\text { constanty on Hand. }}$ *}


carved tombstones, etc. Their trade extends over a large territory and includes many of the states from Maine to Georgia, as well as Canada and other places. Their works are fully furnished with every labor saving appliance and all necessary implements for carlying on a.large and extensive trade.

A. Marnock \& Co. were established in I 886 as wholesale dealers in Scotch, Swedish and all American granites. They are also manufacturers of all kinds of monumental and statuary work for cemeteries, public parks, or private residences. The land covered by them is eighteen thousand square feet in area, and they give employment to twenty-four experienced workmen. The statuary work produced by this firm is of a very fine quality. The office and works are located at the corner of Quincy and Liberty streets, Quincy Adams.

McDonnell \& Kelley are manufacturers of monumental and statuary and all kinds of cemetery work, their works being located at from 6 to 2 Brook street, Quincy Adams. This firm was established in 1886 , and today their plant occupies an area of forty-three thousand square feet of land. They use all kinds of New England granite, none but the best stock being handled, and twenty experienced workmen are employed. The works are equipped with all the latest implements known to the business. All orders are filled promptly and accurately at reasonable prices.

Milne \& Chalmers, located on Penn street, Quincy Adams, is a firm that has been established for the past ten years as manufacturers and wholesale dealers in monuments, statuary, etc. The premises occupied by them cover an area of three-quarters of an acre, and employment is given to forty experienced and skilled assistants. In connection with their business they have a large steam polishing works used for polishing the granite and marble required in their business. A great convenience is derived by them in having a spurtrack in their yard, so that they are able to load and unload direct from the cars.

E. Bizzozero \& Co., of Willard street, West Quincy are carrying on a business as designers, sculptors, and manufacturers of artistic monuments, headstones and cemetery work. The firm consists of E. Bizzozero, B. Monti, and C. Calderana. The work done by this firm is equal to that done by the other firms and they have a large and extensive trade. The granite used by them is principally Quincy granite and Westerly, and all New England granites are also required. They have a large number of assistants and the plant covers a space of seven thousand square feet. All the members of the firm are thoroughly educated in the business in all its details and all work left in their charge can be relied upon as being satisfactorily completed.

Badger Bros., of Willard street, West Quincy were established in 1855 by C. L. Badger and L. C. Badger, as granite dealers and machinists. In connection with this branch they operate one of the largest polishing works here. They occupy three buildings, use steam power, and give employment to one hundred and fifteen experienced workmen. All work done by them is noted for the excellent quality of granite used and the fine manner in which it is finished. In the polishing shop they have in constant use thirty of the most improved machines for that line of business. Being proprietors of the Wigwam quarry, 


\section{FRED F. NOURSE,}

- Wholegale aNd Retail ManUfacturer of -

\section{Rough and Hammered Granite,}

Monumental and Cemetery Work of all descriptions executed in the best style from Foreign and Domestic Granite.

* New and Original Designs Constantly on Hand. * QUINCY GRANITE A SPECIALTY.

OFFICE, * 302 Hancock Street, QUINCY, MASS. $2 \%$ THOS, F, BURKE \& BROS. Manufacturers of Fine QUINCY *GRANITE MONUMENTS 㒀

Willard Street, West Quincy, Mass.

GRANITE MONUMIFNTS, $\rightarrow$ WILLIAM TURNER, DEALER IN ALL KINDS OF

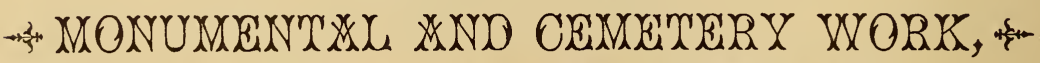
Hamilton Street and Nightingale Avenue, QUINCY, MASS.

Light, Dark, * also * Scotch *and *American * Granites. ALL WORK GUARANTEED SATISFACTORY. 
they are certain of securing the best dark Quincy granite. This firm is one of the oldest in the country in this line of business. Their trade is large and widely extended and the quality of their work is recognized as being of the highest standard.

Prout Brothers Granite Company manufacture all kinds of cemetery work. Only being established since $\mathrm{r} 889$, yet they have succeeded in building up a large trade which extends to all parts of the country, and principally to the west. Having a large force of experienced stone cutters, polishers, and letterers their work is of the best quality. Their quarries are among the best located in West Quincy, the granite obtained from them being of the very best quality and color. They are exclusively wholesale dealers in all kinds of granite, cemetery and building work. Their office is located at 45 Garfield street, West Quincy, and 154 Kneeland street, Boston.

Thomas F. Burke \& Bros. have ${ }^{\circ}$ an establishment devoted to the production of granite monuments, and have been founded some fourteen years. The firm occupy a yard measuring three quarters of an acre and a shed 150 by 20 feet in dimensions, and employ twenty-eight skilled workmen. There is also a large office, and commodious blacksmith shop devoted to the repairing and sharpening of the tools employed at the works. These are situated on Willard street in a most desirable locality, being in close proximity to the railroad and therefore affording excellent facilities for the transportation of finished work in all directions. The firm manufacture all their monuments from the Quincy granite and have turned out many handsome and original designed specimens of their handicraft.

Monahan \& Breen, located on Copeland street, West Quincy, are manufacturers as well as wholesale dealers in all the New England granites, and all kind of cemetery work. The business was established in 1879 , and is each year increasing. The works cover an acre of land and they employ a staff of fifteen hands. The work is done in a prompt and reliable manner, while the prices are reasonable. Both members of the firm have a thorough knowledge of the business and possess great abilities for conducting a large trade,

The Aberogwen Monumental Works, situated at 50 Copeland street, West Quincy, is a large establishment for the manufacture of monuments, tablets, headstones and all kinds of cemetery work in all the leading and foreign granite. John R. Walters, the proprietor, has had a long experience in the business, having been established since r885. His work is shipped to Pennsylvania, Kansas, Vermont and all large cities. One of his specialties is the manufacture of statuary work which is finished in first-class style and the material used is of very fine quality. He manufactures monuments, tablets, etc., from his own special resigns and all work done by hirn is guaranteed to be accurate in every respect as he employs only the very best workmen. The works cover one half acre of land, being easily reached from the Quincy station by the Quincy \& Boston electric cars, as they pass directly by the door.

A. Reinhalter is a dealer in granite. He was formerly connected with his 

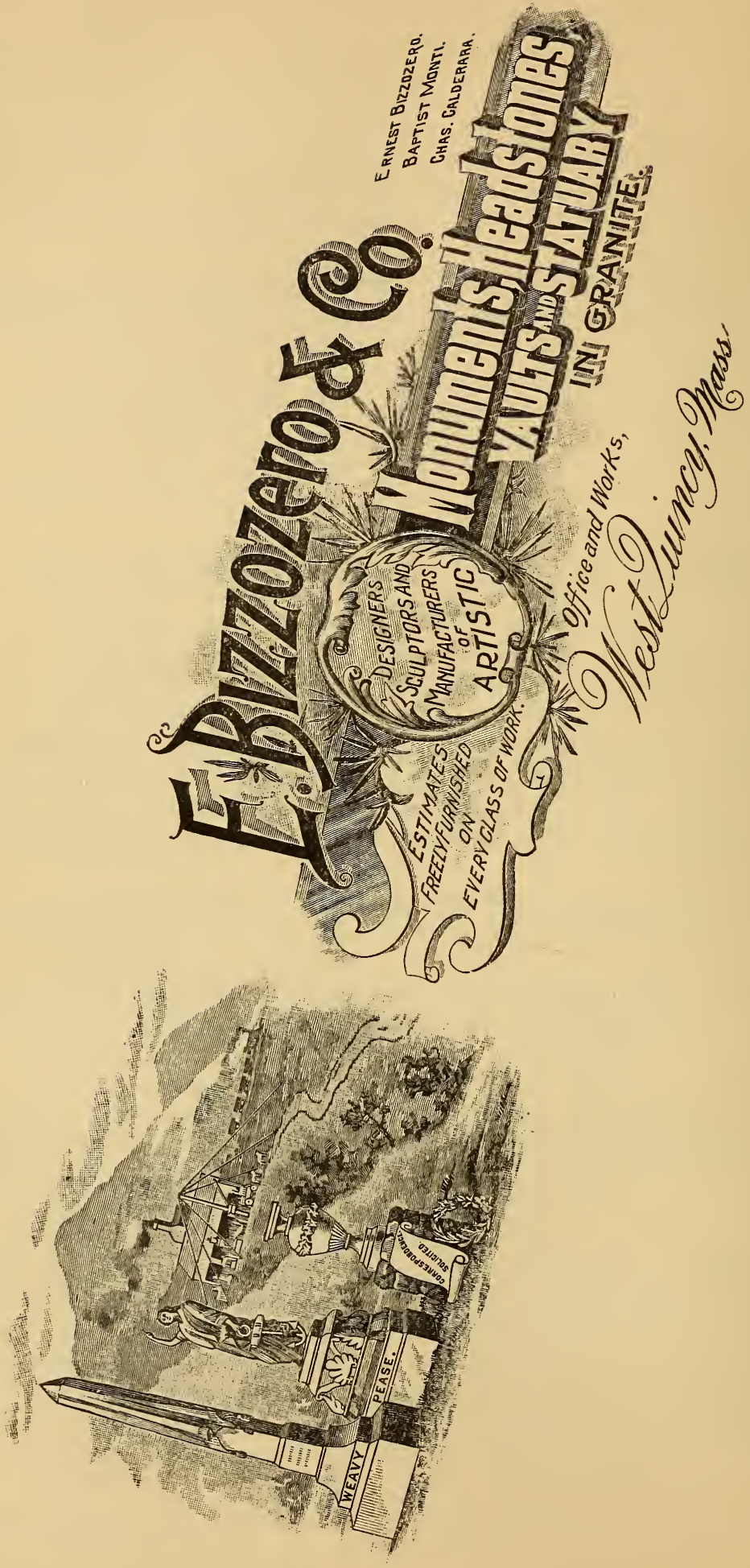
brother, Mr. J. B. Reinhalter, and the establishment was founded in I882. The premises utilized by the present proprietor covers several acres of land, and is well fitted up with all the facilities for carrying on the work, including steam power and the latest improvements in machinery. From eighteen to twenty thousand feet of stone is taken from the quarry every year, and is sold in the rough state, and his products are shipped to the western states. A. Reinhalter is a resident of West Quincy, and is well and farorably known.

D. Hayes \& Sons are among the leading granite dealers in West Quincy, situated on Miller street. The business was first established in 1872 by Daniel Hayes, who was succeeded in 1892 by D. Hayes \& Sons, J. B. Hayes and C. A. Hayes, the present proprietors, as wholesale and retail dealers in Quincy and all eastern granites. Their work is shipped to Massachusetts, New York and New Jersey. They occupy one acre of land, and give constant employment to twenty experienced hands. All kinds of cemetery work are executed by them at short notice, and the work is of the tirst quality.

George L. Miller carries on a business under the firm name of Miller \& Luce, as manufacturers of and dealers in all kinds of granite for cemetery work. Mr. Miller is well adapted to the business, being thoroughly educated in this branch of industry. The work produced by this house is of very fine quality and is done in first-class style. The office and works are located on Miller street, West Quincy.

J. B. Reinhalter, engaged in the granite business was founded by him in I882, has from the date of its commencement always continued to do a prosperous business. This concern does a wholesale and retail business in granite, which is sold in the rough. The premises utilized cover one and one half acres and are fully equipped with the most approved machinery, appliances and appurtenances, and employment is furnished to upward of twenty-five skilled workmen. A superior stock of granite is constantly on hand. Fourteen thousand feet of stone is taken from the quarry every year. The trade is large, extending to all parts of the west.

Elcock \& Sons, quarry owners and dealers in all the best grades of dark blue and medium Quincy granites, is a notable and representative concern, being established in 1876 by the present proprietors. The premises occupied cover an area of six acres of land, and comprise several buildings supplied with the best facilities, and fully equipped with the latest improved machinery for quarrying, polishing and manufacturing, electric power for blasting, and steam power for hoisting and polishing. They own their own quarry, employment being given to seventy-five first-class hands. Granite monuments and headstones are made in the most artistic and elegant designs, also figures, urns, crosses, and emblematic work of every description. There is some beautiful work of this kind done right here in Quincy, and those who doubt this assertion would do well to visit the granite works of Elcock \& Sons, located off Willard street in West Quincy, and they will see some very superior work. None but the best dark blue and medium Quincy granite of superior quality is used for monumental purposes. 


\section{ELCOCK \& SONS,}

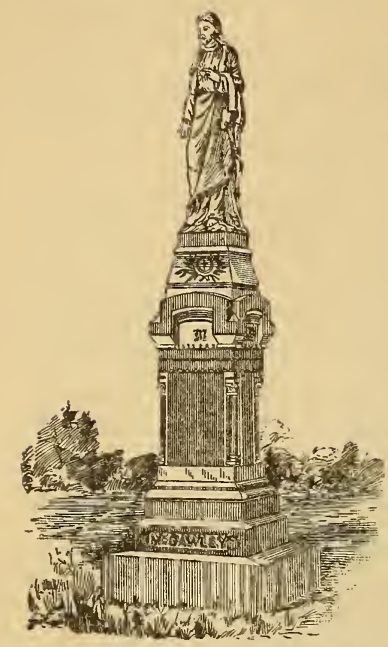

OUARRY $\theta$ WHERS, AND DEALERS IN ALL KINDS OF

Dark Blue and Medium ; . Quincy Granites.

$$
+\infty
$$

Steam Polishers and Granite Workers.

Engraving Showing Our Own Work.

WEST QUINCY, MASS.

$$
\text { WM. T. SPARGO. }
$$

-manuentruan or -

\section{STATUARY, MONUMENTS, HEADSTONES,}

AND CEMETERY WORK OF EAL KINDS.

From Quincy, Westerly, Barre, and all other Granites.

BEST STOCKS AND WORK GUARANTEED * * * SOUTH QUINCY, MASS.
ATLWESTRICES.

\section{F. HARDWICK \& SON,}

STATUARY,

AND a cenerat Lime of CEMETERY WORK. MONUMENTS,

MANUFACTURERS OF

QUARRY ST., QUINCY, MASS. 
James F. Desmond's marble and granite works on Miller street, West Quincy has been established for a number of years and is among the best known in this section of the state. He manufactures all kinds of monumental work from the best dark Quincy granite. Particular attention is given to statuary and carving, and he is prepared at all times to furnish designs, and to estimate on any work. His works are fully equipped with all improved machinery that is used in the business. A large and varied assortment of monuments, tablets, etc., of the most approved and fashionable designs are constantly kept on hand, well worthy of a careful examination by those interested. His facilities for filling orders without delay and at the least possible expense are of the best. Mr. Desmond has had a practical business experience, and has succeeded in building up a large trade.

P. F. Hughes \& Son, located on Furnace avenue, West Quincy, are an old and reliable firm engaged in the business of granite polishing of monuments, headstones, and tablets in a fine style and have the reputation of doing their work in a most thorough manner. The trade is done mostly for the local dealers and manufacturers in granite. Steam power is used, and the firm's plant covers two acres of land, and gives work to twelve men. The members of the firm are practical men in their line of business.

John Cole is a recent addition to the granite business of West Quincy, being established in I891. Mr. Cole devotes his attention to the trade in granite, and also the manufacture of granite monuments, and the finishing and carving of all kinds of granite work. He occupies for his operations suitable sheds, equipped with all the requisite modern mechanical appliances and employs a number of skilled workmen.

M. Owens, who pays special attention to granite monumental work and whose works are located at West Quincy, has been established since I 876 . He occupies a good sized plant for his operations which include large work sheds and storage houses, and employs fourteen skilled artisans. He possesses the best possible facilities for the execution of fine monumental work, both by the matter of being supplied with the most suitable material and the employment of skilled labor. Many fine specimens of the work executed at his establishment are to be seen in the cemeteries at different sections of the state of Massachusetts and also in those of more distant localities, all of which display remarkable skill in design and workmanship.

O'Brien \& McNeil commenced business here in I880, and moved to their present fine large premises last year. The firm has gained a standard reputation for the excellence of its work and is constantly in receipt of orders from different sections of the country. They make a specialty of monumental and cemetery work in granite, and many handsome specimens of their handicraft may be seen at their establishment. The plant oceupied by O'Brien \& McNeil consists of a yard covering 58,000 square feet, and sheds I 20 by 30 , where some eighteen skilled workmen are employed.

Allen \& Walker commenced their operations here some six years ago. The firm, which is composed of Robert C. Allen and Joseph Walker, produce mon- 


\section{TOHN THOMPSON \& SONS,}

MANUFACTURERS AND WHOLESALE DEALERS IN ALL KINDS OF
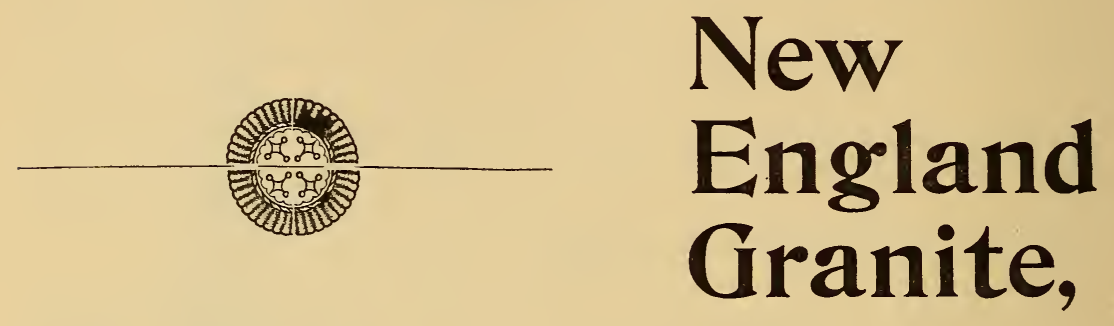

MONUMENTS, TOMBS, STATUARY, BUILDING WORK \&C.

The Finest Grades of Quincy Granite a Specialty.

Office and Works, Quarry St, QUINCY, MASS.

\section{LEWIS DELL \& CO.,}

DEALERS IN-

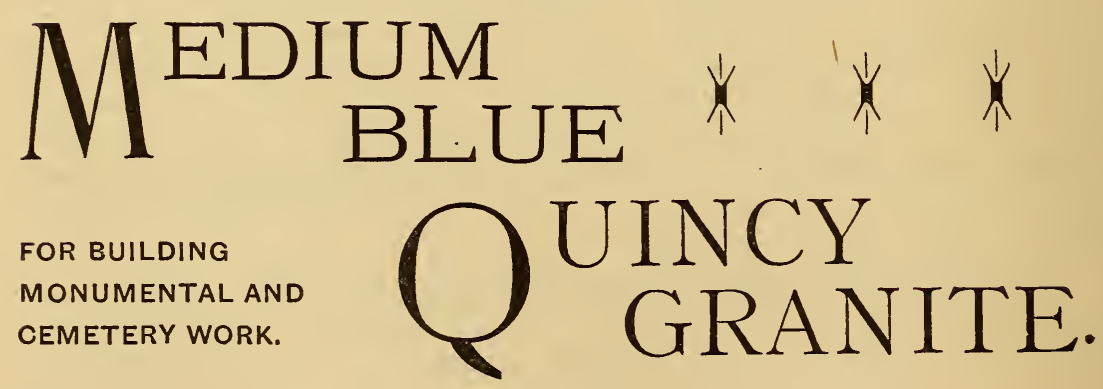

Quarry, Off Quarry street,

A. A. DELL, MANAGER,

QUINCY, MASS. 
uments and cemetery stone work of every description, which is done in the most approved and satisfactory manner. Only the best of selected stock is used in the firm's manufactures, while the work is executed by the most skillful workmen to be found in this vicinity. The works which are situated at West Quincy cover over half an acre of land and are equipped with work sheds measuring 60 by 25 feet, and other necessary buildings, including the blacksmith shop, while employment is given to eighteen skilled artisans.

John Cashman, contractor, was established in 1874 at the present location, and is one of the oldest in this branch of trade. Cuntracts are made for all kinds of teaming, excavating, road building, and stone work. $\mathrm{Mr}$. Cashman owns and works a large quarry, covering two acres of land, and it is well equipped with all modern machinery, steam power, etc., for carrying on the work. All work entrusted to this concern is sure to be executed in a thoroughly practical and satistactory manner. Bridge, cellar, foundation, paving, and edge-stone is furnished promptly, particular attention being given to stone for bridges. He makes a specialty oí building water works, sewers, etc. Upwards of forty skilled workmen are employed, and their work is under the general supervision of the proprietor. Mr. Cashman also has on hand calcined plaster, lime, hair brick, cement and sand, which he sells at lowest market prices. He is an enterprising business man and has had twenty years experience in this line.

McIntosh \& Sons produce a fine line of monumental work from all grades of Quincy and other granites, the specimens shown being either plain or elaborate. The business was established five years ago and the firm have already become popular with the trade. The works are located at South Quincy, comprising large yard room facilities, with sheds measuring 65 by 20 feet, and a blacksmith shop where the tools used by the workmen employed are repaired and sharpened.

Oswald \& Moyle were established four years ago. The firm make a specialty of the manufacture of monuments, headstones and cemetery work of all kinds from the best Quincy granite in light, dark, and medium colored stock for which they have a well established trade extending throughout the whole country. Their works are located off Penn street and are quite large, covering over considerable ground, upon which are situated worksheds measuring 80 by 22 feet where some thirty skilled workmen are employed.

Burns \& Cormack have been established here for the last four years, and operate a good sized plant with works on Payne street, South Quincy. The premises cover over one-half acre of land and arc equipped with large sheds measuring 70 by 22 feet, special machinery, a good sized blacksmith shop, and employs some nineteen workmen. The specialty of the house is monumental and cemetery work, statuary, carving and drapery, for which they furnish estimates at the shortest notice. The trade of the house is by no means confined $\omega$ this locality but extends throughout the entire country.

Deacon Bros. have been established here for the last three years and have been very successful in producing a line of work which has made them popular 


\title{
E. C. WILLISON, \\ MANUFACTURER AND WHOLESALE DEALER IN
}

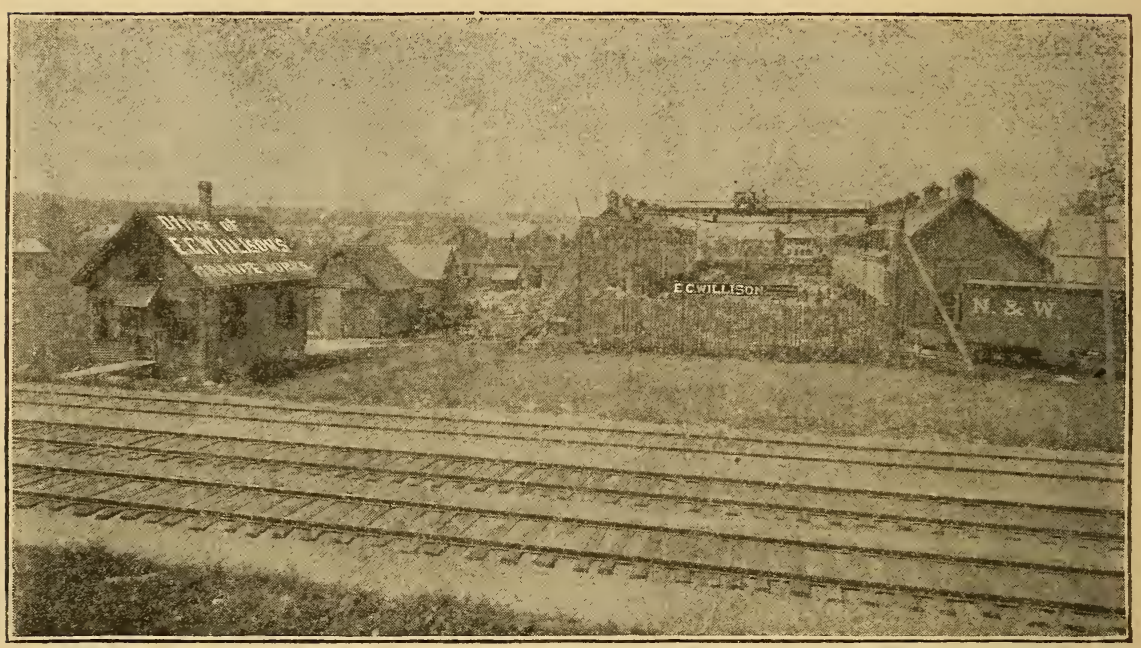

\section{Foreign * and + Domestic}

\section{GRANITES.}

FACILITIES for handling LARGE WORK with quick despatch unsurpassed.

QUALITY of work always of the very BEST.

\author{
CORRESPONDENCE AND TRADE SOLICITED \\ HEADQUARTRRS FOR \\ New and Original Designs. \\ 160 Boylston St., Boston, Mass.
}

AMERICAN BANK BUILDING, KANSAS CITY, MO.. 
with the trade. The specialty of the firm is the manufacture and finishing of monuments and also all kinds of monumental work including carving and finishing. For their operations the Deacon Bros. occupy a yard covering over 25,000 square feet, with sheds thereon 65 by 20 feet on Centre street, South Quincy. These premises are fully equipped with the latest improved modern mechanical appliances and employ a number of skilled workmen. With excellent facilities for being supplied with a superior quality of granite, the firm is rendered capable of filling all orders from the trade at the shortest possible notice.

William T. Spargo is among the representative houses that may be mentioned here. $\mathrm{He}$ is a manufacturer of statuary, monuments and headstones. This business was established in I887. The establishment is equipped with the latest improved machinery and implements known to the industry. Constant employment is given to from fifteen to twenty skilled workmen of many years' experience. Nothing but the best stock is used in the manufacture of his monuments, headstones, tablets, etc., and cemetery work of all kinds, from Quincy, Westerly, Barre, and all other granites. Mr. Spargo is always prepared to execute orders from designs furnished him, or will draft original designs.

The Wollaston Hotel, located at Wollaston Heights, Quincy, Mass., is among the most popular and home like hotels in this town. It has been run by many parties, but for the past twelve years Captain S. A. Merrill has been the proprietor. The hotel is a handsome four-story frame building, containing fiftytwo rooms, all of which are comfortably furnished, clean and spacious. The table is first class, abundantly supplied with the best products of the market. This is the only hotel in Wollaston, and accommodates transient as well as permanent guests, but chiefly permanent.

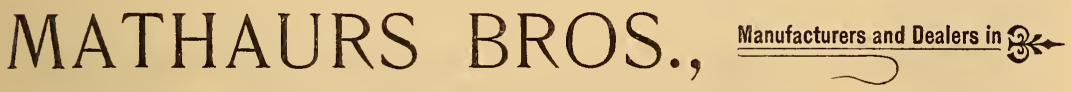

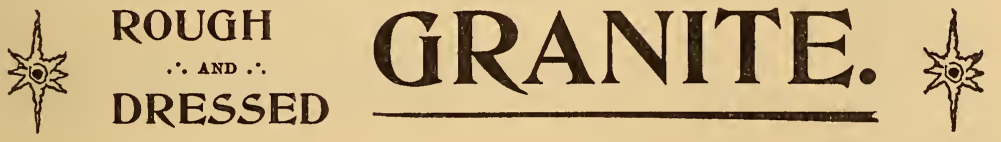

Monuments, * Headstones, * Tablets, * Etc,

\section{Quarry Street, QUINCY, MASS.}




\section{MCKENZIE \& PATERSON,}

\section{$x * x * x$}

Wholesale Dealers in

Rough and Finished

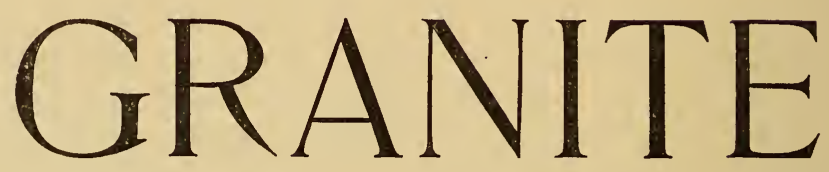

For Monumental and

Building Work.

QuARRY AND WORKS,

QUINCY, MASS.

JOSS

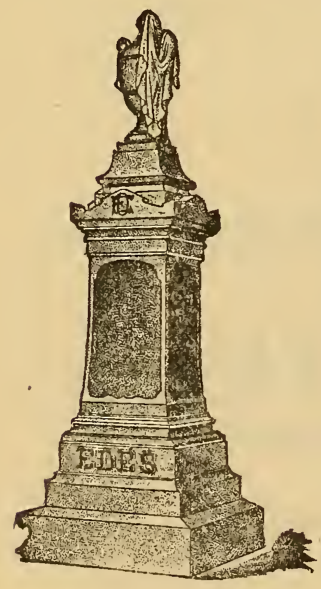

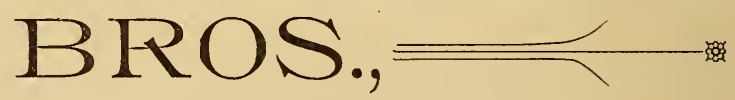

Manufacturers and Wholesale Dealers in

MONUMENTS, STATUARY and

all kinds of CEMETERY WORK.

$\frac{\text { Light and Dark Quincy }}{\text { and all New. England }}$ URANITH.

FIRST-CLASS WORK

GUARANTEED IN EVERY RESPECT.

Office and Works: 10 GARFIELD ST., QUINCY, MaSS. 
J. P. GALVIN,

T. GALVIN.

GALVIN GRANTIE COMPANV, Wholesale Dealers in Rough and Dressed :
Dark Blue and Medium,

Monumental and Building Work, Polishing, Etc.

$=$ ROUGH STOCK A SPECIALTY

续 All orders shipped without delay. $*$ QUINC, MSS.

\section{$A N D R E M R O M O N$}

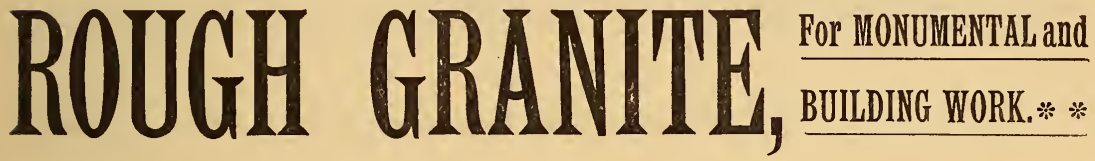

27 Morton St., - QUINCY, MASS.

A. REINHALTER,

DEALER IN

Rough and Dressed Dark Blue and Medium

^QUINCY ^ GRANITE, ^

All orders shipped without delay,

$\checkmark$ WEST QUINCY.

J. B. REINHALTER,

* * Dealer in ROUGH AND DRESSED DARK BLUE * * *

WEST QUINCY, MASS
WUINCY GRANITE* 


\section{ASHMAN.}

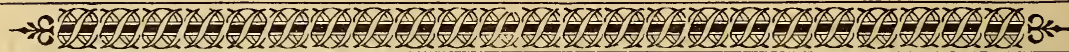

- . . Contracts made for all kinds of Teaming, Road Building, Cellar Foundations, Paving, Eage-Stones, Etc. Water-Works and Sewers a Specialty. Plaster, Lime, Hair, Brick and Sand constantly on hand. Particular attention given to furnishing Stone for Bridge Building. ..... 


\section{TAUNTON.}

HIIS is a city of nearly 26,000 population, and is, perhaps, more extensively engaged in manufacturing pursuits than any city of its size in the state of Massachusetts. Its settlement dates back to nineteen years after the arrival of the Pilgrims at Plymouth, and its boundaries were fixed in 1640 by the famous Miles Standish. It was originally known as Cohannet, and remained a town for upward of 170 years previous to its incorporation as a city, in January, I865. While there are many evidences of its antiquity still remaining Taunton is now rapidly progressing, and building operations are carried on upon an extensive scale, a new opera house and a court house costing a quarter of a million dollars being among the latest additions to its architectural features.

Its principal water courses are the Mill, Taunton, and Three Mile rivers. The Taunton rises in Plymouth county and meets the tides at East Taunton, although Weir village, the 8th ward of the city and one mile from the city square, is the principal port. Light draught freight vessels ascend to this point and considerable shipping is done, mostly, however, by the numerous large manufactories there. The river empties into Mount Hope Bay, I 7 miles below, and is famous for its herring fisheries. Tradition has it that a friendly Indian named Squanto taught the colonists the practice which still prevails of fertilizing their corn with this prolific fish.

As early as I 643 the manufacture of bar iron, from native or bog ore, had commenced in Lynn, on the Saugus, and not long afterwards in Braintree, on the Monanticut; and the discovery of iron ore on the banks of the Three Mile river in Taunton stimulated the forefathers to attempt the same industry. Several of the leading citizens of the place, including George Hall, Richard Wil liams, Walter Deane, James Walker, Oliver Purchis, Elizabeth Poole, and others. formed a joint stock company with a capital of 600 pounds, and built a dam across the Three Mile river, on the road leading to Raynham, and made all the preparations for the manufacture of bar iron from bog ore. Prominent among them was George Hall, the first clerk and manager of the company for many years, and the first "celectman" of Taunton. He continued to be an influential man in all town affairs until the day of his death.

To secure experienced workmen for this new industry, the town voted on the 2 Ist of October, I652, to invite three workmen from Braintree, viz., Henry Leonard and his brother James, and one Ralph Russell, "to come hither, and join with certain of our inhabitants to set up a Bloomery work on the Three Mile 


\section{Atlas Tack Corporation,}

508 SEARS BUILDING, BOSTON, MASS., U. S. A.

BRANCHES.

Donbar, Hobart \& Co., Whitman, Mass. Estaolished in 1810 .

Loring \& Parks, Plymouth, Mass. Established in 1842.

American Tack Co., Fairhaven, Mass. Established in 1867.
A. Firud \& Sons, Taunton, Mass. Established in 1827.

Taunton Tack Co., Taunton, Maøs. Established in 1854.

Oud Colonx River Co., Plymouth, Mass. Established in 1866.

WAREFTOUSES.

NEW YORK,

PHILADELPHIA.

\section{Tack Department.}

Manufacturers of -

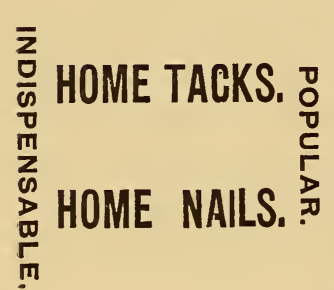

Tacks, Brads, Small Nails, Shoe Nails, Lining and Saddle Nails, Tufting Nails and Button, Wire Nails, Wire Tacks,

Escutcheon Pins, Eyelets, Glaziers Points, Furniture Springs, Rivets, Staples and \begin{tabular}{lllllll}
\hline \hline other Articles. $\therefore$ & $\therefore$ & $\therefore$ & $\therefore$ & $\therefore$ & $\therefore$ & $\therefore$
\end{tabular}

\section{Bed Department.}

MANUFACTURERS OF

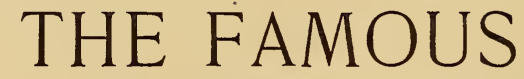

Do You Sleep Pracefully?

atuag Tack Corporation, Boston.

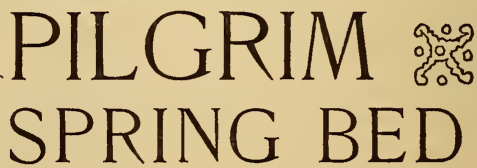

A SPECIFIC FOR INSOMNIA

Exhibited at 2 Hamilton Plack.

SEND FOR PRIMRR.

For Salr by all Reliable Dralers.

and all its attendant ills. 
river." At that time no person could become a citizen of any town except by permission of the same. If the above named three persons all came to Taunton, Henry Leonard and Russell did not long remain, for Leonard is known to have resided in Lynn as early as 1665, and Russell's name does not subsequently appear associated with the enterprise. It would seem that James alone remained, for on June 3, I655, the town conveyed to him individually about fifteen acres of land on the east side of the Forge Pond on the Bloomery, situated next to the old pond adjoining the road to Raynham.

The preparations for this enterprise required some time, and it was not until 1656 that the manufacture of iron actually commenced, and soon afterwards bar iron became a circulating medium in this community in place of money, and so continued for many years. As disaster soon orertook the earlier works at Lynn and Braintree, these may justly be considered the first permanent successful iron works in this country. Other large iron manufactories soon followed and with such an early education and long experience in the manufacture of iron, it is not strange that it should become a flourishing industry.

The first purchase made for the erection of a town resembled in shape a rhombus, or diamond like tract, with parallel sides but no right angles, having its northerly corner or apex near the center of the town of Mansfield. This was called "Cobbler's Corner," because, as it is said, when Miles Standish and his men ran out the boundary line in 1640 , one of them mended or cobbled his shoes at this spot. The extreme southerly point was near the Lakeville line, the easterly corner in the edge of Bridgewater, near Nipenicket Pond, and the westerly angle at the point where Taunton, Dighton and Rehoboth all meet. It was eight miles long on every side, and generally called "The Eight Mile Purchase," or "Long Square " and contained about sixty-four square miles, or over 40,000 acres.

Notwithstanding the extent of this first purchase, the early settlers soon became anxious for more land, and in 1640 , ' $43,{ }^{\prime} 6_{3}$ and ' 65 , various additions were made to the original territory, mostly on the southerly side towards Assonet; but the second great addition was made in June, I668, called the Taunton North Purchase, being the land surrounding the northwesterly end of the old town, and extending northerly to the Massachusetts Colony line, which is now the southerly line of the towns of Stoughton, Sharon, and Foxboro.

This second purchase was bounded easterly by Bridgewater, southerly by the First Purchase, and westerly by Rehoboth, now Attleboro. The northerly line was twelve miles long, the east and west lines about seven, while the south line was made by the apex of the old town projecting into it. The tract contained about sixty square miles, or thirty-eight thousand acres, and cost one hundred pounds. Dorchester and Taunton were thus made adjoining towns, and so continued for nearly haif a century.

But the ambitious forefathers were not yet satisfied. In less than four years after the North Purchase, they were looking with longing eyes to the fertile lands southerly along the banks of the Great River; and after several negotia- 


\section{TAUNTON BRICK COMPANY,}

CHAS. F. JOHNSON, Treas.

* Yard on Old Colony Railroad, at 151 Winter Street, * TAUNTON, MASS.

: PHOENIX NMANUEF'G GO., : TAUNTON, MASS.

MANUFACTURERS OF

PURE CEYLON PLUMBAGO CRUCIBLES

AND

* Woman's Suffrage Stove Polish. *

H. D. ATWOOD, TREAS.

H. C. ATWOOD, SEC.

TAUNTON CRUCIBLE CO.,

MANUfACtURERS OF

BLACK LEAD CRUCIBLES,

Black Lead Stoppers and Nozzels.

office and Factory, $\quad * \quad * \quad *$ TAUNTON, MASS. * * * E. D. PAGE, Agent.

\section{H. I. CUSHIIAN \& CO.,}

- MANUFACTURERS OF -

PAPIER-MACHE SHOE and TUFTING

* * BUTTOINS. * *

TAUNTON, * * * MASS. 
tions, ancther tract on the west side of the river, described as four miles square, though somewhat more, was bought of King Philip for one hundred and ninety pounds, and eighty-three pounds more was paid for a mortgage on the same tract, previously given by King Philip to the Plymouth Colony and by its treasurer assigned to the purchasers. This embraced the territory now constituting the town of Dighton, and contained at least sixteen square miles. These several purchases with some subsequent additions towards Assonet Neck, the whole embracing about one hundred and fifty square miles or nearly one hundred thousand acres (considerably larger than the District of Columbia), and comprising the present towns of Norton, Easton, Mansfield, Raynham, Dighton and Berkeley, constituted the entire township of Taunton until I 7 I I.

In the year I735 a number of Taunton people petitioned the General Court of Massachusetts to be incorporated as a new town on the Connecticut river. Their request was granted, and a new town was created under the name of Township No. One, or New Taunton.

After expending considerable money in building houses, a saw mill and grist mill, and making other improvements, it was ascertained in $\mathrm{I} 74 \mathrm{I}$, and on the resurvey of the boundary line between New Hampshire and Massachusetts, (which latter state had therefore claimed jurisdiction as far north as Concord, N. H.) that New Taunton was several miles north of the true boundary line, and the grant from Massachusetts therefore invalid. The new settlers thereupon sold out their improvements to other parties who had been authorized by Gov. Benning of New Hampshire to take possession, and in 1742 those who had gone to Vermont returned to Taunton where they lived and died.

Modern Taunton has many fine churches; five railway stations on the Old Colony system; the hotels and places of amusement are sufficient in number and of ample capacity; a most valuable public library is maintained; the old Colony Historical Society has its headquarters here, and every facility is afforded for the intellectual and moral development and entertainment of young and old. The business center and residence districts are substantially and handsnmely built, and the suburbs are embellished by many palatial homes. Street car lines traverse the city in all directions, and the transportation question in the city is solved so far as those interested are concerned, while two lines of railroad furnish connection with "the rest of the world." The industries of Taunton are extensive and diversified, and embrace the manufacture of machinery of various kinds, silver and brittania ware, fire brick, tiles, cement, etc., cotton fabrics and yarns, stoves, ranges and furnaces, electrical supplies and apparatus, lumber, windows, doors, inside finish, and minor articles in great variety. The building of locomotive engines was at one time a leading interest, but has declined of late years, the construction of printing presses taking its place.

The Atlas Tack Corporation is one of the oldest and most enterprising, and at the same time most conservative concerns in the country engaged in the manufacture of tacks. For many years its progressive increase in trade and 


\section{WEBSTER FILE WORKS, * manuserverter}

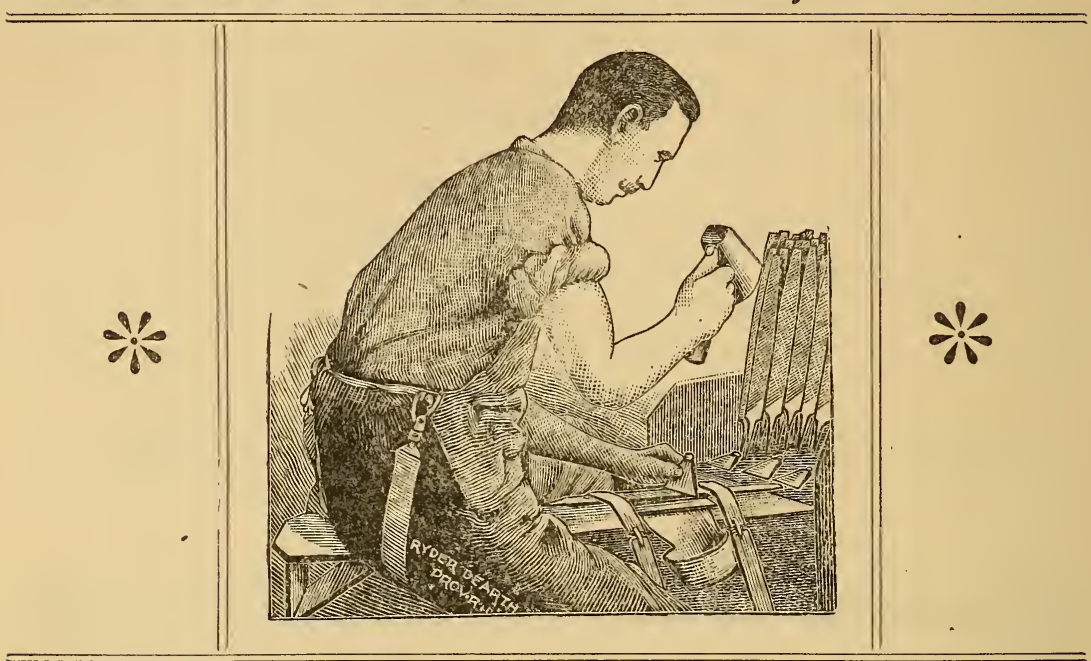

J. WEBSTER HAND CUT FILES AND RASPS.

C. W. WEBSTER, PROPRIETOR.

* * TAUNTON, MASS.

\section{MOORE \& BOOTH,}

\section{Steam Planing and Moulding Mill,}

CABINET AND DOOR WORK A SPECIALTY.

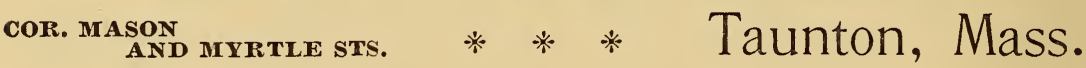

ESTA BLISHED 1864.

\section{Taunton Stove Lining Co.,}

\section{Fire Brick and Stove Linings,}

Office and Manufactory,

$$
\text { * * TAUNTON, MASS. * * }
$$

A. W. PARKER.
W. N. PARKER.

A. W. PARKER, Treas. 
manufacturing facilities has been rapid, and its products embrace the largest assortment and best qualities of goods of this character to be found anywhere in the world. The main office of the corporation is at 508 Sears Building, Boston, with branch offices and warehouses in New York, Chicage, Philadelphia, Baltimore, Boston, Lynn and San Fransisco, with numerous connections abroad. It owns and operates five large mills, each of which is fitted with modern machinery, of the latest and most approved patterns, and has every facility for carrying on its work economically and successfully. This corporation was organized in May I89I, under the laws of Massachusetts, and is one of the largest and most important of the manufacturing institutions on the line of the Old Colony Railroad. It is a consolidation of the following named firms and corporations, viz: The American Tack Company, Fairhaven, which was established in I867; Loring \& Parks, Plymouth, successors to Samuel Loring, established in I842; Dunbar, Hobart \& Co., Whitman, the oldest of all, established in 1810 ; Taunton Tack Company, Taunton, established in I 854 ; A. Field \& Sons, Taunton, the largest of all, established in 1827 ; and the Old Colony Rivet Company, removed to Plymouth, established in 1866 . The consolidation of these old, successful and wealthy concerns results in a tack manufacturing concern by far the largest of any in the world. Its varied product consists principally of tacks, brads, nails, lining and saddle nails, rivets, and innumerable other articles. As is well known, New England produces nearly seven-eights of all the tacks made in the United States, and Massachusetts alone three-fourths of all, and as the Atlas Corporation makes and sells considerably more than one-half of all that are made in this country, its importance to the Old Colony and to Massachusetts is readily apparent. The corporation has a large cash capital, and unlimited facilities for eonducting all branches of its business, under the most favorable auspices, and upon the largest scale. The president of the corporation is Mr. Henry Hobart of East Bridgewater, one of the oldest, best known, and most successful tack manufacturers in the United States. His uncle, Benjamin Hobart, was the pioneer in the tack manufacturing industry of this country. The vice-president is Mr. Thomas J. Lothrop, long and acceptably known in Taunton. The treasurer is Mr. John H. Parks of Duxbury, Mass., (son-in-law of the late Samuel Loring, who was one of the oldest and wealthiest tack manufacturers in the Old Colony). Mr. Parks is well and favorably known in all trade, manufacturing and financial circles. The Atlas Tack Corporation is also manufacturing the celebrated "Pilgrim Spring Bed," which is so rapidly coming into general public favor, and the manufacture of which bids fair to become one of the largest departments of the concern. The officers and directors of the corporation are experienced, able and reliable business men, of high standing in commercial and social circles, and the foundation of the company's success is undoubtedly due to the complete knowledge of the business possessed by its executive management.

The Mason Machine Works are among the largest and most prominent manu facturing establishments of Taunton. The nucleus of this great enterprise was 
UNIVERSAL LOOM CO

- EMERY DUPLEX VERTICAL LOOMS. -

Pres. JOHN E. SEARLES, NEW YORK.

TREAS. W. R. BURNHAM,

VICE-PREs. A. D. EMERY, TAUNTON, MASS. NORWICH, CONN.

ALEXANDER H. WILLIAMS.

GEO. F. WILLIAMS, $2 \mathrm{~d}$.

WILLIAMS BRICK CO.,

BRICK MANUFACTURERS AND DEALERS IN ALL KINDS OF

BUHLOING AND PAVIAG BRICK.

OFFICE AND YARD: WILLIAMS COURT,

Off Somerset Avenue opposite Third Street near Weir Village Station.

***** TAUNTON, MASS. *****

\section{H. L. SEAVER,}

Formerly with P. T. \& H. S. WASHBURN.

\section{FUNERAL DIRECTOR \& EMBALMER,}

14 UNION BLOCK, - - TAUNTON, MASS.

D. D. WHITE SHOE CO, mocoposente 1891

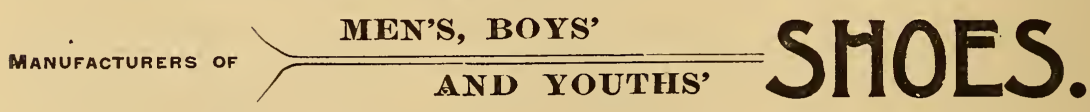

Of all Kinds in Medium Grades, a Specialty for Retail Trade.

TAUNTON, MASS. Boston Office: 91 вedpord STREet.

ALL MAIL ORDERS PROMPTLY ATTENDED TO. 
started in I 845 by Mr. William Mason, who had for several years been engaged in the manufacture of cotton machinery of his own designing, in another part of this town. The new works were devoted exclusively to building cotton machinery until 1853 when he began locomotive building which was abandoned in 1887 . In 1873 his manufacturing business was incorporated with the title of Mason Machine Works, Mr. Mason being its president and holding that office till his death which occurred in the year I883. The officers of the company are men who were associated with Mr. Mason for many years. They are president, Frederick Mason; treasurer, William H. Bent; superintendent, John T. Meats. The principal products of this company are cotton machinery and printing presses, the building of which requires the services of nine hundred men. Ten acres of ground are covered by the plant of this concern with some nine acres of floor space. The great success of the Mason Machine Works may be largely attributed to the high standard of excellence in their output which was fixed in the beginning and has ever been rigidly maintained.

The Reed \& Barton corporation has a most interesting history, which we shall endeavor to briefly trace. The first piece of britannia ware ever produced in this country was made in this city by Isaac Babbitt. He took into partnership a William W. Crossman. Here they produced, in 1824 , the first finished britannia ware made in this country. In three years (or 1827,) after, their business increased to such dimensions that they were compelled to enter larger quarters. In I 828 William Allen West and Zephaniah A. Leonard associated themselves with Mr. Crossman, the firm being known as Crossman, West \& Leonard. It was also in this year (I828) that Henry G. Reed and Charles E. Barton obtained situations in the works, as apprentices. The firm prospered, and organized the Taunton Britannia Manufacturing Company, which was in business for a number of years, when it liquidated all its debts, and left the plant in the hands of two expert workmen, viz: Reel and Barton. In the last year or two of the existence of the old company the business was run down, but under the guidance of Reed and Barton the business was soon in a flourishing state, and they were able to purchase the buildings and plant, although previous to this time the firm was changed to Messi's. Leonard, Reed \& Barton. By the demise of Mr. Leonard in 1845 the style of the firm was again changed, this time to Reed \& Barton, at which time Henry H. Fish was admitted as special partner. In $1859 \mathrm{Mr}$. George Brabrook, an old and faithful employe, was made a member of the firm, which continued without further change till the death of Mr. Barton in I867, when the surviving members purchased his interest, but retained the old name of Reed \& Barton. In I $882 \mathrm{Mr}$. Fish died, when his sons George H. and Frank L. succeeded to his interest. In I 888 this firm was organized as a stock company with a capital of $\$ 600,000$, and known as Reed \& Barton. The company opcrate to-day one of the largest works of its kind in the world. Its goods are found in every principal market in this and the old world. Its facilities for producing sterling silver and electric plate are unsurpassed, and Taunton may well feel proud of such a company.

The Taunton Copper Manufacturing Company, incorporated in I83 I, stands 


\section{TAUNTON COPPER M'F'G CO., TAUNTON, MASS.}

\section{YELLOW METAL. \\ Sheathing, Dimension sheets, Piston Rods, Bolts, Spikes, Sheathing and Slating Nails}

\section{COPPER.}

Ingot, Sheathing, Rolrs, Sheets of any size, Shape or Thickness, Tinned or Untinned; Circles, Bath Tubs and Locomotive Fire-Box Sheets; Boat, Sheathing and slating Nails; Bath Boilers, Stove Boiler Bottoms; Lightning Kods, Calico Printers' Kollers, Tack Plate and solduring Irous.

ZINC.

Spelter, Sheathing, Dimension Sheets, Tack Plate; Sheathing, Shingle and Slating Nails.

CASH PAID FOR OLD GOPPER, YELLOW METAL, BRASS, ZINC, EtC

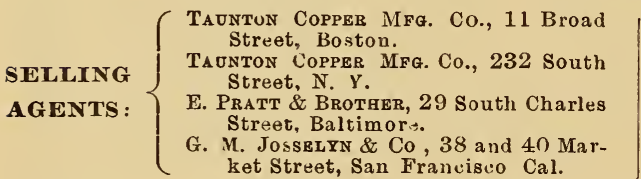

Lxman, Son \& Co., Portland, Me. Gummex, Spering \& Co, 1023 Market Street, Phi'adelphia.

Shoemaker \& Voute, 124 South Dela ware Avenue, Philadelphia.

StaUfFER, Eshleman \& Co,, 7 i Canal Street, New Orleans, La.

\section{REED \& BAR'TON,}

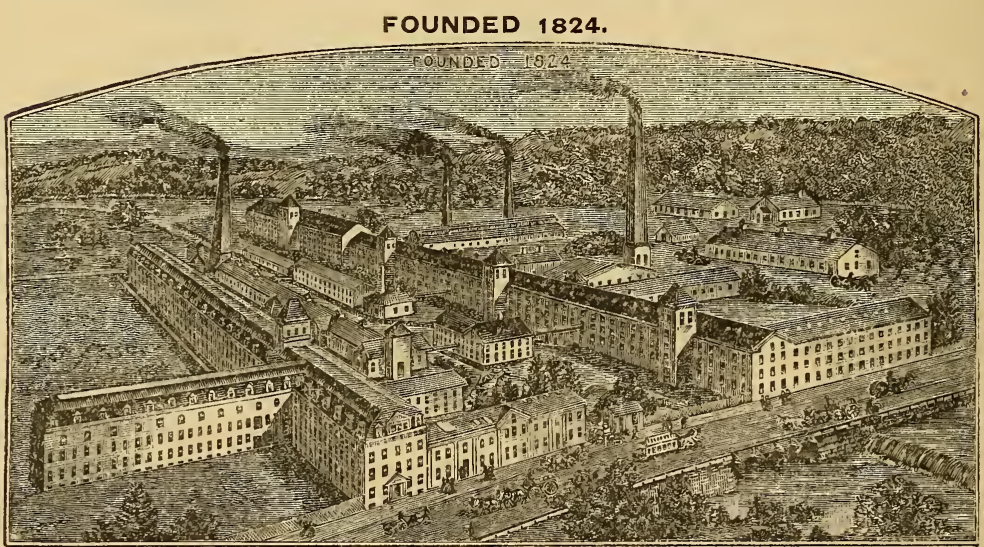

MANUFACTURERS O

Sterling Silver \& Electroplate of Finest Quality and Desiǵn.

Salesrcoms at their Factories, TAUNTON, MASS. and 37 UNION SQUARE, N. Y.

Our Goods sold by the Principal Dealers in silver and Plated Ware. 
to-day among the leaders in its special line of industry. They manufacture yellow metal sheathing, sheet copper, and brass and copper, also copper wire, and have special facilities for the refining of copper. The buildings cover over two acres of area and are equipped with the most ingenious and improved mechanical appliances known to the trade. George M. Woodward, its president, and H. F. Bassett, the treasurer are well known in the commercial world. They have a Boston office at I I Broad street, and one at 232 South street, New York City.

The Presbrey Stove Lining Company are the largest manufacturers of fire brick and stove linings in the United States. The company was incorporated in I866, and was organized to succeed William and Albert Presbrey, who, forty years previous engaged in the same business, occupying two small sheds located opposite to where the present works now stand, which is at 2 I 2 Somerset avenue. Here they occupy nearly four acres of land, about one half of which is covered with connecting frame buildings of two and three stories in height. About seventy-five men and boys are employed, the output of whose work is something enormous in volume and value, comprising every description of fire brick, stove linings, fire clay, fire cement, kaolin, fire sand, etc., which is sent to all parts of the United States as well as exported to other countries. Harry T. Root, a representative Providence stove and range man, is president of this company. B. C. Pierce, a practical and experienced fire clay worker, is treasurer and superintendent, while James T. Maher the wealthy plumber and real estate dealer, D. A. Trefethen, the well known brass founder, and William Miller are member's of the board of directors.

The Taunton Crucible Company was incorporated in 1865 . Their works are on the corner of West Water and Third streets, Weir Village, Taunton. The premises occupied by them is a two-story frame building, two hundred feet long by eighty feet wide. Their business is the manutacture of crucibles, largely used in brass, bronze, silver and other metal foundries, throughout the country.

The Weir Stove Company is one of the largest and best known stove manufacturers. The business was inaugurated in 1875 , and they give employment to two hundred men. The premises occupied by them consist of a number of frame buildings. The special line of manufacture is the Glenwood stoves and ranges. These ranges are made of the very best material that can be procured, and it is claimed give better satisfaction than any other range. Their works are situated on West Water street, Weir Village, Taunton.

The D. D. White Shoe Co. commenced business here in I89r. Mr. White was for twenty years located at Raynham, Mass., when he removed, August, I89I, to the present location at Taunton. The company manufacture a line of men's boys' and youths' shoes in calf, veal calf, buff, Dongola, and Kangaroo, for the retail trade. It has always been their aim to make as good a shoe for the money as can be produced. Mr. White gives his personal supervision to the manufacture of the same, and all orders are carefully filled, shipped to the trade promptly and at the lowest market price. A Boston office may be found at 9I Bedford street. 

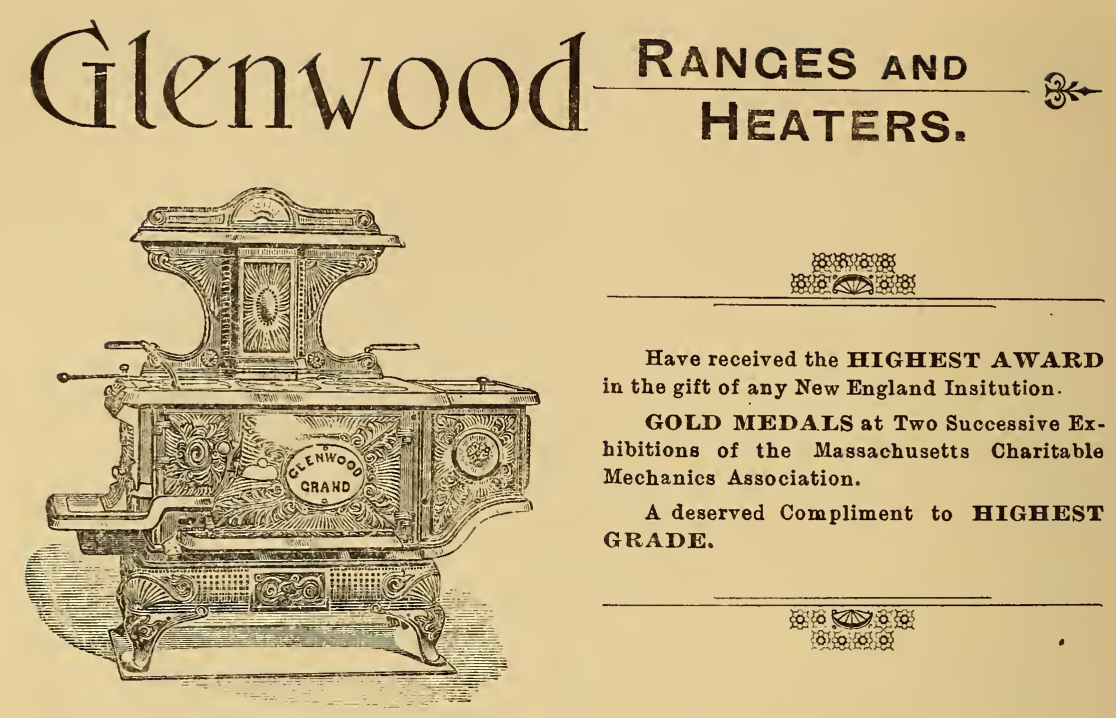

Have received the HIGHEST AWARD in the gift of any New England Insitution.

GOLD MEDALS at Two Successive Exhibitions of the Massachusetts Charitable Mechanics Association.

A deserved Compliment to HIGHEST GRADE.

SOLD BY LEADING STOVE DEALERS.

EStABLISHED 1826.

INCORPORATED 1866.

PRESBREY STOVE LINING COMPANY, * Taunton, Mass.

\section{FIRE BRICK AMD STOVE LININGS,}

Fire Clay, Fire Mortor, Granite Clay, Kaolin, Fire Sand, \&c, ANY SHAPE OR SIZE OF FIRE BRICK MADE TO ORDER FROM PATTERN. B. C. PIERCE, Treasurer. * Office and Works, 212 SOMERSET AVENUE.

\section{ELDRIDGE \& CO., * * * Esratesusto \\ MANUFACTURERS OF $\cdot \cdot \cdot \cdot$}

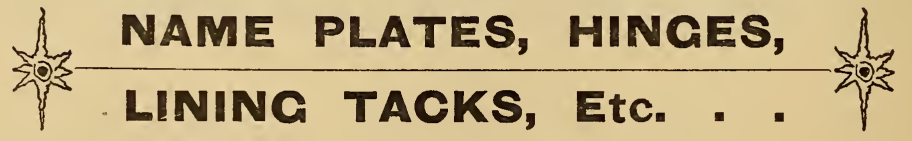

E. H. ELDRIDGE.

J. H. ELDRIDGE.

TAUNTON, MASS.

Our Goods are for Sale by all Leading Jobbers throughout the Country. 
Strange's Machine Works, of which Emerson C. Strange is the proprietor, was founded away back in 1827 by Elias Strange, the father of the present proprietor, who succeeded to the business in 1885 . The building occupied is located at 36 Washington street, and is a three story structure, sixty by eighty feet in dimensions, and is supplied with all the necessary machinery. Here is made cooperage machinery of the latest patterns, box-board machines, combination foot lathes, a specialty being Strange's patent combination vise and drill, which is extensively used by mechanics, amateurs, jewelers, and others. The manufacturing and repairing of bicycles in all its branches is also carried on here.

The Taunton Brick Company is the largest brick manufactory in Taunton. It was incorporated in 1868 , with C. F. Johnson as treasurer. The work consists in the manufacture of building and paving bricks, which are shipped all over the country. Fifty acres of ground are occupied and one hundred and twenty-five men are employed. From seven to eight million bricks are produced annually. The yard is conveniently located at I 5 I Winter street, Taunton.

Charles Webster conducts one of the oldest manufacturing establishments for hand-cut files of all kinds, in Taunton. It was established in I 863 by Joseph Webster. Since 1888 it has been carried on in a successful manner by the first named gentleman. The premises occupied by him are in the American Screw Company's old mill, where one floor, in dimensions, 25 by 75 feet is required. It is fitted up with steam power and all appliances nccessary in the business and employment is given to fourteen skilled workmen. Mr. Webster has the tact of recutting old files so that it is difficult to tell them from a new article. He is located on Court street in Cushing's yard near the Court House.

Moore \& Booth are engaged in the manufacture of all kinds of cabinet work and house finishings on the corner of Mason and Myrtle streets, Taunton. The firm was established in 1878 , employ fifteen men, and have all the latest improved machinery. They are also the inventors and patentees of the Booth window frame pocket machine. All orders are promptly filled, the work is finished in the best style and satisfaction guaranteed.

The Universal Loom Company is engaged in the manufacture of double vertical looms. This establishment, which was incorporated about four years ago, occupies a two story frame building one hundred by thirty-five feet, also a two story ell. This house is located at 234 High street, Taunton, is fully equipped with all the latest improved machinery, and fifteen hands are kept constantly busy. They are the builders of the celebrated Emery Duplex Vertical Looms, which are receiving considerable attention all over the country. The officers are president, J. E. Searles of New York; vice president, A. D. Emery, of Taunton, and treasurer, W. R. Burnham of Norwich, Conn.

The New Process Twist Dril! Company was incorporated in 1886 with a capital stock of sixty thousand dollars. It controls a large and increasing trade in this country and Europe. Neither labor, time or expense have heen spared to attain perfection, and the results have proved to be far above their expectations. By this new process the drill is made of the best imported steel, and is hot forged, not milled. They occupy premises 'fitted up with the latest im- 


\section{THE NEW PROCESS TWIST DRILL CO, - Manufacturers of_-}
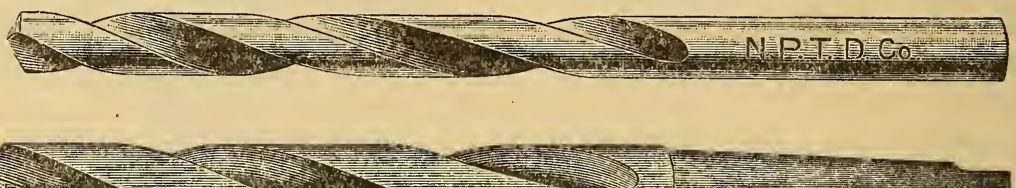
N

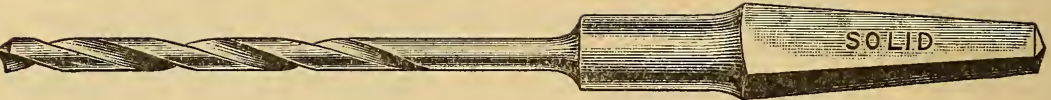

\section{HOT FORGED STRAIGHT LIP INCREASE}

Twist Drills of Every Description. . . Write for catalogue. . .

TAUNTON, . . . . . . . . . MASS.

\section{SOMETHING NEW!}

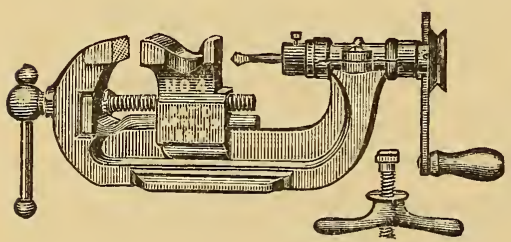

. STRANGE'S .. PATENT COMBINATION VISE \& DRILL, MANUFACTURED BY

Strange's Machine Works, 36 Washington St., TAUNTON, MASS. And now for Sale by Hardware Dealers. Send for Circular and Price List.

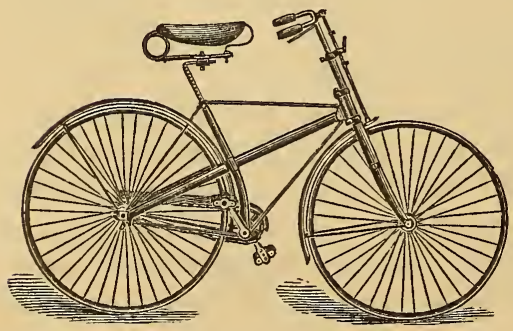

-Also Manufacturers and Dealers in-

\section{BICYCLES.}

WHEELS of every description repaired. Nickel Plating and Enameling. All work promptly executed at reasonable rates. Difficult repairing a specialty. 
proved machinery, and give employment to a large number of tool-makers. They also make complete lines of twist drills for jewelers' sets, etc. The officers of the company are B. L. Dwinell, president; P. H. Conn, treasurer, and A. L. Lincoln, secretary and manager, well known citizens of Taunton. Their factory is situated at No. 34 Court street, Taunton.

The Elizabeth Poole Mills is a well established incorporated company whose factory is located at the foot of Adams street, Taunton. Its officers are William C. Lovering, president, and $\mathrm{Mr}$. Albert E. Swasey, treasurer. The goods manufactured by them consist of high grade cotton flannels. The factory buildings are of brick, of one and two stories in height, and cover over an area of two acres of land. Their appurtenances are of the best, including nine thousand spindles and over two hundred and sixty looms, operated by a duplex HarrisCorliss engine of two hundred and fifty horse power. They employ in the vicinity of two hundred operatives and produce twelve thousand yards daily. Their trade extends all over the United States, their goods being sold through New York and Boston commission houses.

Alexander H. and George F. Williams, whose works are located on Williams Court opposite Third street, Weir Village, are among the oldest brick manufacturers in Taunton. Both members of the firm are well informed men in all branches of their work for which they are supplied with a complete outfit of machinery, while none but experienced men are employed, of whom on an average they have a corps of fifty. The business consists principally of building and paving bricks, which are sent to New Bedford, Pawtucket, Fall River and all points on the Old Colony Railroad. Their works cover a large tract of land, and they turn out in the vicinity of four million bricks a year.

The American Chemical Company, of which H. L. Seaver is the proprietor, is another important industry. The house is conveniently located at I 4 Union building, Taunton. Besides dealing largely in embalming fluid and disinfecting deodorizing compound, he is also in the undertaking business. Mr. Seaver is acknowledged to be one of the best embalmers in the state, parties sending for him from Boston, Quincy and other places. He has been a resident of the place for many years. Mr. Seaver devotes his undivided attention to his work, taking full charge of the affairs.

The Soule Piano and Organ Investment Company, a house that is worthy of consideration in this work was established in 1883 but not incorporated as a stock company until I889. The stockholders of this company are among the most prominent manufacturers and merchants located on the line of the Old Colony Railroad. L. Soule, of Taunton, manager; F. L. Fish, of Taunton, president; Z. C. Keith, of Brockton, treasurer; H. H. Earle, of Fall River, B. B. King, of Taunton, C. H. Packard; of Brockton and M. N. Arnold, of North Abington, compose the board of directors. The Brockton warerooms are at No. I I North Main street, and are commodious and well stocked with the pianos and organs of the following well known and reliable makers: Ivers \& Pond, Mason \& Hamlin, Emerson, Decker \& Son, Krakauer, and others (pianos); Mason \& Hamlin, Packard, Palace and others (organs). They also 
MULES of $1 \frac{13}{16}, 1 \frac{1}{4}, 1 \frac{5}{16}, 1 \frac{3}{8}, 1 \frac{1}{2}, 1 \frac{3}{4}$, and 2 inch gauge of latest improved pattern; lightest running in the world.

LOOMS for Cotton, Silk and Jute; plain, twill, fancy and bags. $* \quad * \quad * \quad * \quad * \quad * \quad * \quad *$

MULES.

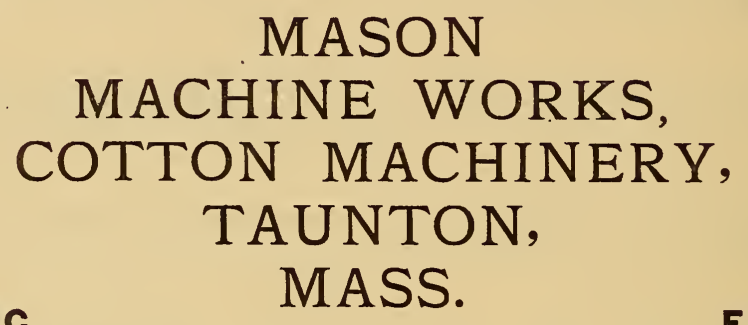

LOOMS.

SPINNING

FRAMES.

DOBBIES of recent invention and with great improvements.

PATENT SPINNING FRAMES, with Rabbeth, Sherman or Common Spindles. Many modern improvements.

The Soule Piano and Organ Investment Company',

ESTABLISHED BY LEADING MUSICAL BUSINESS MEN

OF 5 CITIES AND SEVERAL TOWNS TO FURNISH • . .

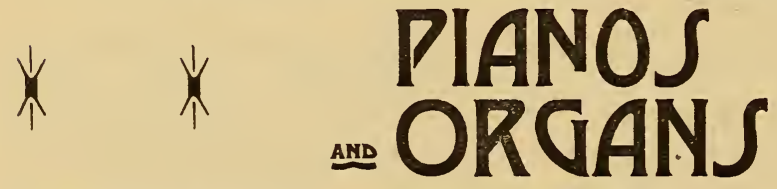

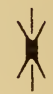

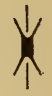

OF EXCELLENT AND UNEXCELLED QUALITY

AND REPUTATION AT

HONEST LOW PRICES,

OFFER TO ALL BUYERS OFWO. EASTERN MASSACHUSETTS.

IO STANDARD MAKES. IO

Pianos. .Ivers \& Pond, Mason \& Hamlin, Decker \& Son, Emerson, Krakauer Bros., Trowbridge and Stone.

Organs. Mason \& Hamlin, Packard, Palace and others.

SECOND-HAND PIANOS AND ORGANS FROM \$10 UP TO \$200.

WAREROOMS, mass. Address: L, SOULE, Manager, Taunton, Mass, 
have offices at Taunton (at No. I 7 City Square, Taylor Block) and at New Bedford (at No. I 47 Purchase street). This company deals only in the very best instruments, and since its inception has built up a remarkably fine trade all over south eastern Massachusetts, more especially in the cities. Mr. Soule, the manager, is an experienced and well known musical business man, having been a leader in and identified with the best musical enterprises for the last forty years.

The Taunton Stove Lining Company, prominent among the manufacturers of Taunton, is engaged in the manufacture of fire brick and stove linings, and their goods are known all over the country. They occupy several buildings, have all the improved appliances in every department, and are capable of turning out forty thousand dollars worth annually of fire brick and stove linings, constant employment being given to twenty-two workmen. Their goods are sold mostly in the New England states and New York, and all orders are filled promptly and satisfactorily. The firm consists of A. W. and W. N. Parker, Taunton.

Eldridge \& Co., are manufacturers of superior white metal and silverplated coffin plates, hinges, lining tacks, etc. The business was established in I 848 by Eli Eldridge, on West Britannia street; later, his son Eli H., who was making a similar line in another place, united his business to his father's under the present name of Eldridge \& Co. Upon the death of Eli Eldridge, in r 875, his grandson, John H., became a member of the firm, and in 1890 another grandson Albert S., was admitted to the company. There has been a constant increase of business from year to year, their goods going to all parts of the United States and Canada, and a few to South America. Eldridge \& Co.'s works, situated on Eldridge street, were erected in 1882 , and consist of two-and-a-half-story frame building, thirty-two feet front and ninety feet deep, fitted up with a twenty-horse-power engine, a forty-horse-power boiler, large and superior power presses, rolling mill, electroplating apparatus and other necessary machinery, and furnishes employment for twenty to thirtv skilled workmen. The specialties made here are coffin and casket name plates, hinges, lining tacks, etc., which are sold to the jobbing trade only. Their goods are kept in stock by all the leading jobbers.

H. L. Cushman \& Co. are among the most extensive manufacturers of papier-mache buttons in this country. This firm is composed of H. L. and David B. Cushman, and is located at 24 Court street, occupying one floor of 7,000 sq. feet, conveniently divided into office, wareroom and factory. They employ specially designed machinery of the most perfect kind, and together with the help of thirty operatives are enabled to produce a daily output of 84,000 gross of buttons in various sizes and styles, which go to supply the dernand from all parts of this continent.

A. B. Hodges \& Company are located in the Taylor building, Taunton, occupying rooms 6 and 7. These men are engaged as Real Estate and Insurance agents for fire, life, marine, and accident. They have been established for the past five years, some of the companies whom they represent being Mutual Life 
Insurance Company of New York, the Middlesex Mutual Fire Insurance Company of Concord, Mass., and other first class companies, including. Orient of Hartford, Spring Garden of Philadelphia, and First National of Worcester. This house makes a specialty of buying and selling real estate and collecting rents. Mr. F. E. White, the partner, is also agent for Sohmer, Lawrence \& Son and Gordon pianos.

John W. Hart \& Co. have for many years been engaged in the manufacture of building and paving bricks, which are sent to Fall River, New Bedford, and surrounding cities. An annual amount of one and a half million bricks are produced here. The premises embrace land covering twenty acres, and the products are shipped direct by cars from the sheds. Mr. Hart is also one of the proprietors of the Weir Brick Company.

The Weir Brick Company is another house of great prominence. The proprietors are John W. and Edward O. Hart, Chester S. Hart acting as treasurer of the company, which was established in 1865 . Over a million of bricks are annually produced, including building and paving bricks, large quantities being loaded into cars direct from the yard.

The Phœnix Manufacturing Co. was established in 1844 , and is the oldest establishment engaged in the manufacture of black lead crucibles in this country. Its wares are specially commended by the officers of the United States Government. Its annual production is upwards of two million five hundred thousand $(2,500,000)$ numbers of crucibles.

\section{A. B. HODGES \& CO., \\ REAL ESTATE AND INSURANCE. GENERA ESTARTE:}

Fire, Life, Marine and Accident Insurance $\rightarrow$ IN THE BEST COMPANIES.ß-

Taylor Building, $=\quad=$ TAUNTON, MASS.
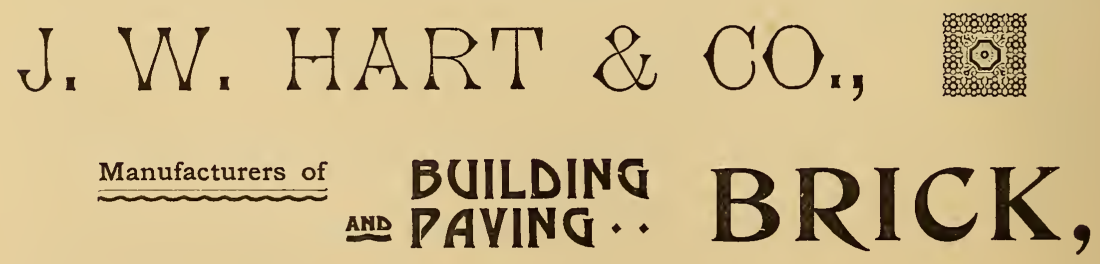


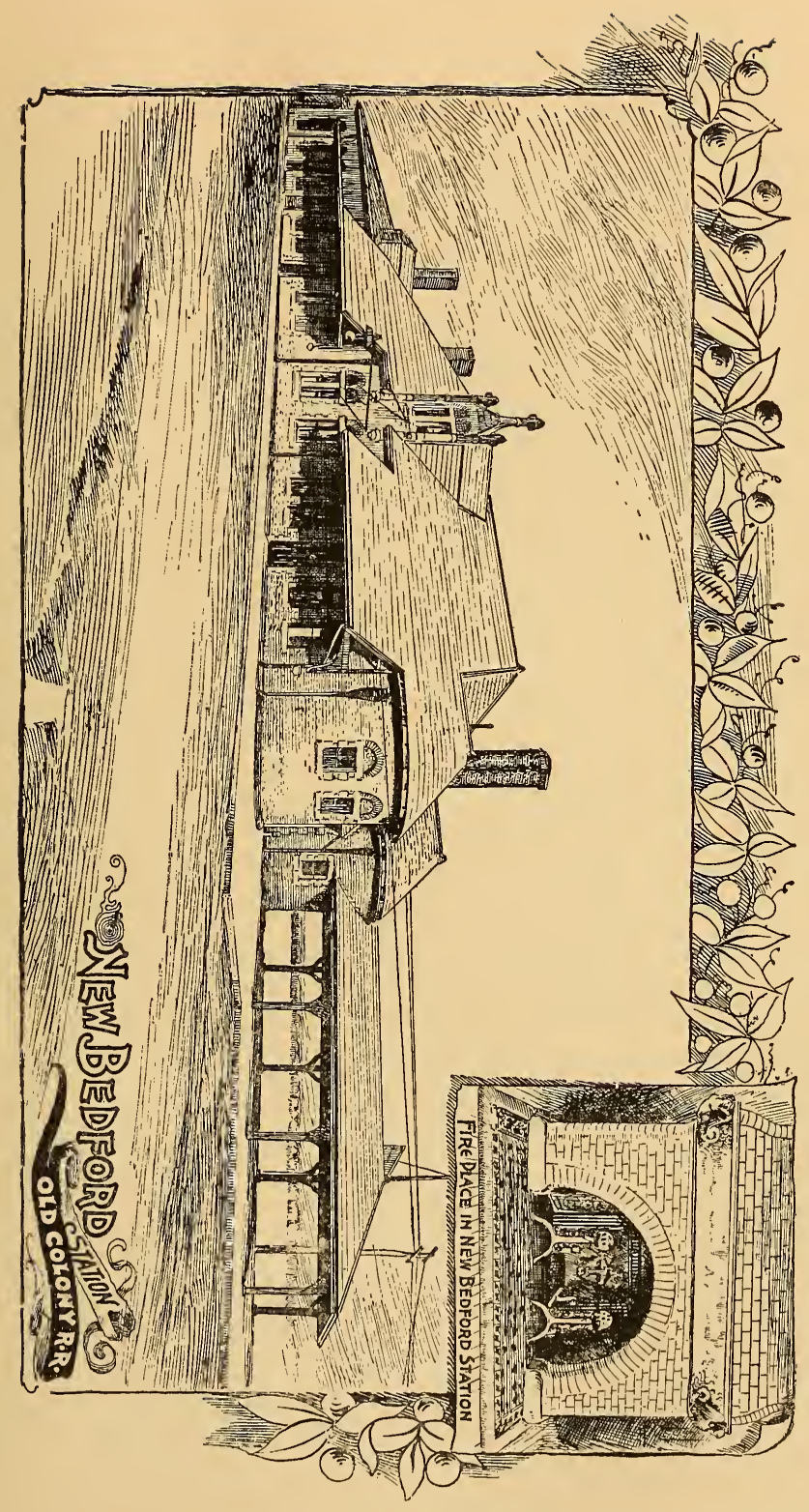





\section{NEW BEDFORD.}

$\mathrm{N}$

TEW BEDFORD, long noted for its whale fisheries and for the wealth and urbanity of its people, is a city of 45,000 inhabitants, delightfully situated on the west bank of the Acushnet river, which here broadens into New Bedford harbor, on the north side of Buzzard's Bay. It is 228 miles northeast from New York, with which it has connection by steamboats; and is 55 miles south of Boston, and connected with that place and the westerly reginns by the New Bedford \& Taunton and the Fall River branches of the Old Colony Railroad; while the Fairhaven branch, just across the river, makes connections, with the eastern towns and Cape Cod. A fine bridge 4,000 feet in length provides easy access to Fairhaven; and street cars run to this and other neighboring villages.

The largest manufacturing establishments are the cotton and woolen mills, employing, in I891, 7,844 hands and a capital of $\$ 9,210,000$, with an aggregate weekly pay roll of $\$ 53,900$. The capital represented by other manufacturing corporations in 1891 was $\$ 6,593,900$; number of hands employed, 2,813; weekly pay roll, $\$ 25,675$. Of manufacturers not incorporated there were $7 \mathrm{I}$ establishments, employing I, 5 I9 hands, with a weekly pay roll of $\$$ I 4,8 II .

The relative importance of the textile industry of New Bedford as compared with other manufacturing centres is best shown in the number of spindles employed, which was at the latest report 834,500 and the number of looms I2,534, working up into various articles 66,550 bales of cotton annually. New Bedford thus stands fourth on the list in the state in textile manufactures, the other cities being Fall River, Lowell and Lawrence in the order mentioned. In the year 1892 four new mills were added to the industries of the city, each with a capital of $\$ 500,000$, but as two of these are not yet completed, we are unable to state what the increase will be in the number employed, weekly pay roll and other details.

Since the decline of the whaling industry, for which at one time New Bedford was the most famous port in the world, much attention has been paid to building up industrial enterprises, and in this matter a lively interest has been taken by the Board of Trade of the city. This organization is composed of some 230 members, every ons of whom is a wide awake and thorough going business man and a powerful factor in promoting the city's welfare. Under its auspices New Bedford is rapidly advancing both in the extent and variety of its manufactures, and il will not be long before she will have attained as great prestige under these new conditions as she formerly enjoyed as a whaling 


\section{BUILDERS' MATERIALS,}

\section{NAT. P. SOWLE,}

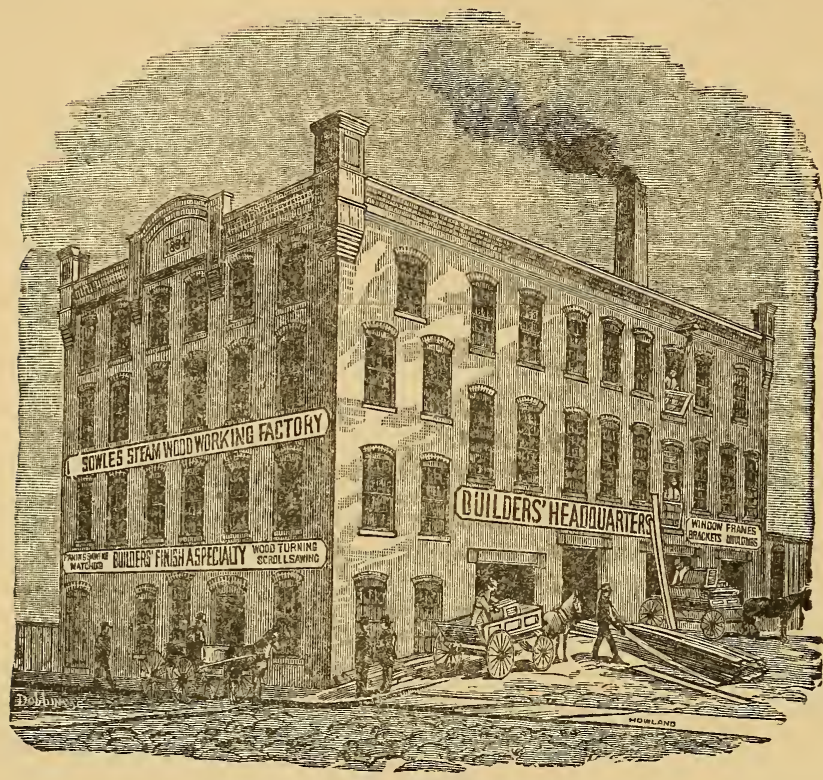

Manufacturer and Dealer in

Doors, Blinds, Sash, Window Frames, Mouldings, Lumber, Turning, Scroll Sawing, Wood Mantles,

Builders' Finish, Window Glass,

Plate Glass, Gutters, Window Screens, Office and Factory,

Cor. Elm and Bethel Sts., NEW BEDFORD, MASS.

Connected by Telephone.

12

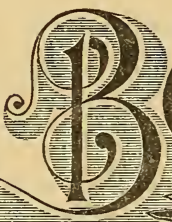


port. It has I 25 miles of streets, the greater part of which are paved or macadamized, with flagged or paved sidewalks. No city in the United States of even double its population has as many miles of curbed, flagged or paved sidewalks as has New Bedford. The streets are beautified by thousands of shade trees, set along the borders of the sidewalks, whose tops meet and arch over the streets. The city is noted for the cleanliness of its streets, credit for which is due the Board of Public Works, and is well lighted by gas and electricity. There are thirty-eight miles of main ventilated sewers under its sloping streets. These are thoroughly cleansed during every shower of any magnitude, and their contents emptying into the river and bay are carried out to sea by the tides twice a day, contributing to the good health of the city.

Extending from the mainland, southward from the city, into the waters of the bay is a peninsula known as Clark's Point, around which, bordering on the shore, is a well-kept driveway, $3 \mathrm{I}-2$ miles in length and 80 feet in width, built at great expense by the city in 1853 . Starting at Cove street and passing along the west side of the drive one has a full view of the bay which makes up into the cove, with Dartmouth across the water. At the end of the point is a granite fort built during the late war, patterned after Fort Sumter, and from this position, across the broad and sparkling Buzzards bay, in full view are Round Hills, Elizabeth Islands, Martha's Vineyard (on which is Gay Head), Sconticut Neck and numerous small islands. Continuing around up the east side, one has a beautiful view of the harbor, the city and Fairhaven. On the left for the entire distance are fields, beautiful groves, with here and there elegant residences having nicely kept lawns. Taken as a whole the view is enchanting and delightful. During the summer the drive is much resorted to by pleasure seekers. No matter how hot it is in the city, there is always a cool breeze on "The Point," and summer evenings it is thronged with carriages and pedestrians. Along the river front are 26 substantial wharves, in good condition and equalling those in every way of much larger seaboard cities. The harbor is large and convenient, enabling vessels of $\mathrm{I}, 700$ tons to come up to the wharves.

New Bedford has a number of fine public and private buildings, and these are being constantly added to. Its school buildings are models in exterior and interior finish. The Young Men's Christian Association has erected a handsome edifice in the centre of the city, costing $\$ 65,000$. The United States Grovernment has also built a new post office of stone. The city is and has been for years the wealthiest of its size in the Union; its wealth being estimated as high as $\$ 100,000,000$.

The site of the city of New Bedford was purchased in I6 62 from the chiefs Wesamequen and his son Wamsutta, its Indian name being Acushnet. Of the first settlers upon the ground were Ralf Russell, his son John Russell, and Anthony Slocum, who later built an iron forge at Russell's Mills, and John Cooke, whose home was at the head of the Acushnet river. The place was a part of Dartmouth until February 23, I787, when it was set off and incorporated as a town. It was first named "Bedford" in honor of the Russells, 


\section{The PAIRPOINT M'F'G. Co.,}

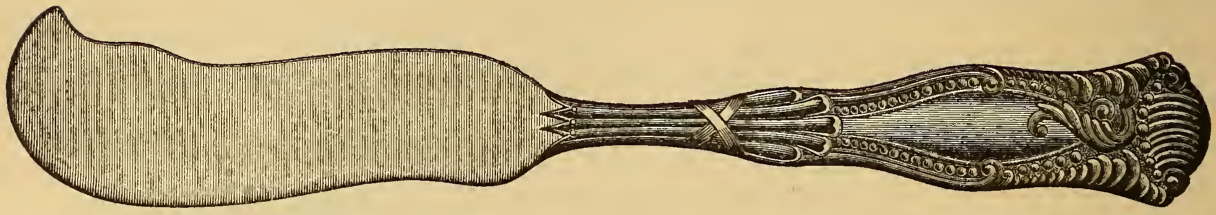

Knives, Forks, Spoons. Everything in Tableware. FactorieS: NEW BEDFORD, MASS.
Quality Guaranteed. Burnished by Hand.

Gilbert allen, president.

H. C. W. MOSHER, CAshier.

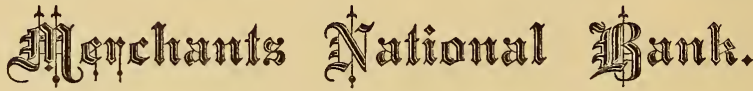

NEW BEDFORD, MASS.

Capital, . . $\$ 1,000,000$.

Surplus, ... 500,000.

Undivided Profits, 122.000 .

* - DISCOUNT DAYS: TUESDAYS AND FRIDAYS.——

NeW Bedford Cordaǵe Co.,

NEW BEDFORD, MASS.

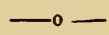

Manufacturers of all classes of Manilla, Sisal and Hemp Rope, and Binder Twine.

S. J. B LOSSOM

Charles Blossom.

\section{BLOSSOM BROS.,}

Manufacturers of and Dealers in

DOORS, SASH, BLINDS, ETC.,

Sawing Planing and Moulding, Wood Turning and Scroll Sawing. Dealers in Polished Plate and Window Glass.

Mill: 238, 240 and 242 North Water Street. NEW BEDFORD, MASS.
WM. W. CRAPO.

PRES.

ANDREW G, PIERCE, Vice Pres.

Capital, . . . . $\$ 600,000$,

THE MECHANIC'S NATIONAL BANK.

Surplus and Undivided Profits, $\$ 392,000$.

JAMES W. HERVEY, LEMUEL T. TERRY, CASHIER.

ASST. CASHIER,

WILLIAM HINDLE,

DraLer in

CHOICE GROCERIES.

MEATS, FIUITS, VEGETABLES, DRY GOODS, ETC. . . . . . .

No. 404 Purchase St.,New Bedford, Mass. 
early settlers of the place, and who were related to the Duke of Bedford. Finding there was already a "Bedford" in the state, the prefix "New" was adopted. The town embraced also certain territory on the east side of the harbor, which, on Feb. 22, 1812, was set off to form Fairhaven. New Bedford was made a city March 9, I 847 .

Denisnn Brothers Company was founded in 1858 under the firm name of Warner \& Denison, and changed to the firm of Denison Brothers in 1873 . In I89I the title was changed to the present one; viz., Denison Brothers Company. This company does an extensive trade in flour and grain, and as dealers in coal, hay and straw. They have excellent facilities for handling these commodities, and are able to carry an extensive stock at all times. The premises occupied at the corner of Hillman and Water streets are large and well adapted to the business. Some two acres of land are utilized, which is covered with mills, office, and coal structures, and an excellent wharf for receiving and shipping purposes. They also have a large mill at the corner of So. Water and School streets. Some thirty hands are employed.

The Pairpoint Manufacturing Company in the manufacture of fine silver plated ware is not excelled by any of its contemporaries at home or abroad. Organized in 1880 with a capital of $\$ 100,000$ in the comparatively short period of seven years it was increased to $\$ 500,000$, where it now stands. The premises first erected and occupied for the enterprise were a three story brick structure, $\mathrm{I} 20$ by 40 feet in dimensions, which was augmented the following year by a three story wooden building, 120 by 30 feet. These were soon found inadequate for the volume of business, and in I882 a brick building, four stories in height and 150 by 40 feet in area, was added to the plant. In 1890 a four story structure was added, some 40 by 80 feet in area, while in I89I another four story building was erected which is 260 by 40 feet in dimensions. A new engine of 275 horse power and a complete electric light plant of rooo lights capacity, were among the improvements made. The present plant has floor space forty feet wide and a half mile long. Here every apparatus for convenience and economy of labor, and facilitating the conduct of the operations has been provided. Machines of the greatest ingenuity and efficiency, apartments occupied by artists and draughtsmen, by engravers, chasers, embossers, die cutters and hardners, fancy case makers in plush, in fact there are departments, machinery and workmen for every process from the reception of the raw material to the delivery of the goods finished, cased and packed for transportation. Employment is found for five hundred and fifty operatives, the weekly pay roll amounting to $\$ 6000$. The goods comprise all varieties of useful and ornamental household goods such as knives, forks, spoons, cake baskets, table ware, hat, hair, clothes and crumb brushes, candlesticks, casters, card receivers, communion ware, ice pitcher sets, epergenes jewei, cigar and cigarette cases, wine coolers, ash receivers, match safes, etc. of the best workmanship and highest art. When it is known that the wood cuts used in illustrating the catalogue of this company represent some ten thousand dollars, some idea may be gained of the variety of their products. The officers are as follows: president, Edward 


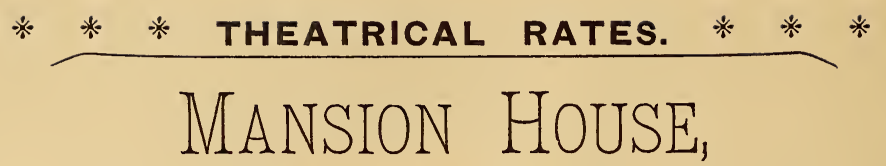

NEW BEDFORD, MASS.

$\left.\begin{array}{l}\text { \$1.75 SINGLE } \\ \$ 1.50 \text { DOUBLE }\end{array}\right\}$ For a Whole Day or More,

LESS THAN A DAY AT RATE OF $\$ 2.00$ A DAY.

STEAM HEAT, ELECTRIC BELLS. EVERYTHING FIRST-CLASS.

\section{ASHLEY \& PEIRCE, Clothiers and Hatters,}

72 AND 74 WILLIAM STREET, NEW BEDFORD, MASS.

Joseph P. Kennedy,

\section{PAPER,}

PAPER BAGS and TWINE.

Manufacturer of and Dealer in NEW and SECOND-HAND

Casks, Barrels, Kegs, Etc., F EVERY DESCRIPTION.

Cooperage cor. Water \& Cannon Sts., NEW BEDFORD, MASS.

Telephone 272-11.

\section{NEW BEDFORD}

\section{STEAM * LAUNDRY}

F. G. TRIPP, Prop.

SHIRTS, COLLARS AND CUFFS A SPECIALTY.

173 and 175 Purchase St. NEW BEDFORD, MASS.
CHARLES S. PAISLER, DEALER IN

Masons' Building Materials,

P!ain, Glazed and Ornamental

Tiles for Hearths and Vestibules.

Lime, Cement, Brick, Flag Stone, Drain Pipe, Granite Curbing, \&c.

160 NORTH WATER STREET, NEW BEDFORD, MASS.

SAMUEL C. HART.

HART \& AKIN,

DEALERS in EVERY VARIETY of

COAL,

For Family Use and Steam Purposes, Bituminous Coal for Smiths' Use. . OfFices. . .

Cor. South Water and WaInut Sts. Tel. 206-2; No. 9 North Water St., Tel. 206-2; No. 84 Pleasant St., Odd Fellows' Building, Tel. 4-6; No 590 Acushnet Ave., foot of Willis St. Tel. 14-12. YARDs: Eddy's Wharf, fnot of Coffin St. and Acushnet Ave, foot of Willis St. New Bedford, - Mass. 
D. Mandell; treasurer and general manager, Thomas A. Tripp; directors, Edward D. Mandell, William J. Rotch, William Baylies, Wendell H. Cobb, and Captain Lewis. The company have branch stores at corner of Maiden Lane and Liberty place, New York city; at the corner of Wabash avenue and Washington street Chicago, and at 220 Sutter street, San Francisco.

The Merchants' National Bank, foot of Williams street was originally established in 1825 and reorganized and chartered in 1865 as a National Bank It is in the front rank as regards character, solidity, usefulness and public confidence -a result referable to the excellent management that from the beginning has marked its course. With a paid in capital stock of $\$ 1,000,000$ and the advantages referred to it is not surprising that the Merchants has proved such a profitable and successful venture. The Board of Directors is composed as follows : Gilbert Allen, president; George F. Kingman, vice president; Andrew Hicks, George F. Bartlett, Wm. R. Wing, Samuel C. Hart, Thomas H. Knowles, Francis B. Greene, Wm. N. Church, Geo. S. Homer, James Delano, and Charles M. Tripp. Henry C. W. Mosher faithfully fills the responsible position of cashier.

The New Bedford Cordage Company was originally established in 1842 by Joseph Ricketson, William J. Rotch and Benjamin S. Rotch, and was organized as a company, January, I 846 , with a capital stock of $\$ 60,000$ which was increased in 1849 to $\$ 75,000$, and today amounts to $\$ 200,000$. The premises, located within a square, bounded by Court. Emerson, Ash and Kempton streets, embrace some four acres of land which is covered by nine buildings, which are used for manufacturing, storage and shipping purposes. The equipment in every department is as complete as long experience, and practically unlimited means can make it, and is unsurpassed anywhere, a 500 horse-power engine being necessary to furnish motive power to the machinery. A force of three hundred and fifty workmen find steady and remunerative employment in the various departments, and $\$ 100,000$ is annually disbursed in wages alone. The leading specialties of the establishment is the manufacture of cables used in boring artesian wells, (which is unsurpassed by anything in the market) binder or reaper twine and cordage, and rigging used on all classes of vessels. J. W. Macomber is general manager of the company.

Hon. Charles S. Ashley was born in New Bedford, Sept. 5, 1858, being a descendent of an old Massachusetts family. After graluating from the Parker street grammar school he entered the Friends Academy at the age of tifteen and after remaining here one year he entered a business life, his first venture being in the provision business, he opening a store on Purchase street. His business augmenting, we find him later engaged in the wholesale pork business, and about the same time he entered into partnership with S. D. Pierce which formed one of the solid clothing establishments of this city. Popular, with a liking for politics, it isn't surprising that in 1885 he was elected to the common council, and for two consecutive years he was a nember of the board of aldermen. He has always been a straight out-and-out democrat, but was nominated by the citizens' party for mayor in 1889 , but was defeated by the fusion candi- 
JOHN H. DENISON, PRES.

HENRY C. DENISON, TREAS.

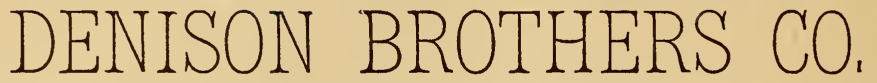

- MANUFACTURERS AND DEALERS IN -

\section{FLOUR, GRAIN, STRAW, HAY \& COAL.}

Cor. Hillman and Water Sts. MILLS- Cor. School and Water Sts.

New Bedford,

PARKER HOYSE,

Holder M. Brownell.

New Bedford,

HENRY C. HATHAWAY,

Successor to J. R. FORBES \& Co., MANUFACTURER OF

\section{FINE CARRIAGES,}

AUCTIONEER AND COMMISSION MERCHANT.

Auction Sales of Horses and Carriages

Every Week. Stable Connected

For Horses.

CASH ADVANCED ON GOODS FOR AUCTION SALES.

33 TO 37 ELM ST., NEW BEDFORD, MASS.

E. B. CHASE \& CO., PICTUUR F FRAMES, - dralers in .

Art Goods. Mouldings Glass, Stationery, Willimantic Cottor, Barbour's

Linen, Eureka Silk. Novelties and Fancy loods.

Sewing Marhine Repairing a Specialty.

- Pianos and Organs Tuned and Repaired.

Headquarters for Pianos, Organs, Sewing Machines, and Oil Stoves.

Nos. 214 to 218 Union and No. 3 Fifth Sts. New Factory, 532 and 534 Acushnet Ave.

New Bedford,

Mass.

Mass.

Mass.

BLISS \& NyE, CHINA, CROCKERY, * * GLASS WARE,

PAPER HANGINGS, Etc., 145 Union St., cor. Acushnet Avenue,

NEW BEDFORD, MASS.

BANCROFT'S

BOARDING « \& LIVERY ST ABLE,

SADDLE HORSES A SPECIALTY. 35 HILLMAN ST, (EAST OF PURCHASE.)

TELEPHONE 8-12. 
date, Walter Clifford. In 1889 he was again pitted against the gentleman, and was again defeated, but by a plurality of but $8 \mathrm{r}$, and after one of the hottest political fights this old seafaring city ever witnessed. In 1890 he was again nominated; this time by the Independent Citizens' Party and easily elected.

The Parker House is a first-class hotel and where one can get all the comforts of home and most satisfactory service. It was founded in I84I and has always held its place in popular favor and today it has an enviable prestige. The location is the most favorable in town. The hotel is three stories in height and 100 by 185 feet in area. It is substantially and comfortably furnished, many of the suites being beautiful; and the one hundred and thirty-five rooms are well lighted and ventilated. The entire house is supplied with all the modern improvements, such as gas and electric lights_bells, steam heat, etc. The dining-room has a seating capacity of two hundred, and the cuisine is most excellent. Some fifty servants are employed who are courteous and well trained. Holder M. Brownell, the proprietor, is an experienced hotel man and is very popular, and merits the great patronage the hotel receives.

Chas. A. Gray, whom we find located at $42 \mathrm{I}$ Purchase street has been general forwarder of the Old Colony Railroad and steamboats in New Bedford since Oct. Ist, I863, and has carried on a most lucrative and successful business as teamster to and from the various railroads and steamboats now controlled by the Old Colony Railroad. Experienced teamsters and special trucks and wagons are provided for moving light and heavy goods. Superior facilities are at hand for promptly meeting the demands of his patrons. Twenty or more hands are employed with teams in quantity and build that the business demands, and both satisfaction and low rates are the distinguishing features of the service of this enterprise. The business is conducted in an orderly and systematic manner which shows a master mind and a watchful eye to be at the head of its affairs. In addition to teaming, in 1872 he was appointed superintendent of the New Bedford and Fairhaven Street Railway, and held the position five years, and was the first one to advocate extending tracks to the south part of New Bedford. He proved the necessity of tracks there by running sleighs in the winter of 1876 , and finally the directors increased the capital stock and extended their road which proved that this was all that was needed to make it one of the best paying roads in this vicinity. In $1887 \mathrm{Mr}$. Gray took the agency of the American Powder Mills and Powder and Aetna Dynamite, and a full stock of all grades are on hand. He was the first one to irduce the city of New Bedford to try dynamite in place of powder, in r888, the city having used large quantities since. He is identified with the business interests of New Bedford, being a director of American Carrier Rocket Co.; director, Safe Deposit \& Trust Company, one of the most successful banks in New Bedford, and director of Pope's Island Manufacturing Corporation who make the celebrated Howard iron noncorrosive metals in silver and gold color; was the first one to start the business that is so well known all over the world today. It is getting almost indispensable in many places. Spermaline made by the same corporation is acknowledged to have no equal as a bearing metal both in light 


\section{DAVID DUFF \& SON,}

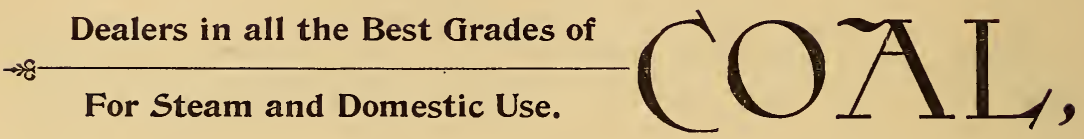

\section{NEW BEDFORD, MASS.}

\section{WILLIAM S. JENNEY,}

Dealer in ......

Groceries, Fruit, Confectionery, Tobacco, Cigars, Etc., cheap for Cash.

Nos. 17, 19, 23, 25 So. WATER ST., NEW BEDFORD, MASS.

Vessels supplied at short notice.

TELEPHONE 17-6 ALSO 293-4.

\section{CHAS. O. BRIGHTMAN,}

CONTRAGTOR \& BULLDER,

Estimates given on all Classes of Work

Factory and Office, 72 No. WATER ST., NEW BEDFORD, MASS.
GOOD

LODGING - ROOMS 常 TO LET,

- APPLY TO -

WILLIAM S. JENNEY,

17, 19, 23, 25 South Water Street, NEW BEDFORD, MASS.

\section{J. D. SULLIVAN,}

Furnishing Uadertaker \& Embalmer, 277 PURCHASE ST.,

TELEPHONE 24-3. NEW BEDFORD, MASS.

Caskets, Coffins and Robes of the

Latest Designs alway in stock.

Residence, Locust Street. . . . . Telephone Connection.

Where night and Sunday calls will be prom ptly answered.

A1so Passage Tickets \& Drafts for Salo
ALFRED P, *

WOODWARD,

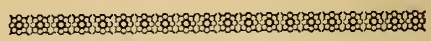
BOARDING * * and LIVERY STABLLE. 
and heavy bearings. Mr. Gray has had charge of the goods stored in New Bedford by railroad companies for the past twenty years, is now running six large store houses used in storing cotton, Jumber, hay, grain, furniture, machinery, etc. He was in the express business in the early part of his life with his father, Gilbert C.Gray, who ran baggage wagons between New Bedford and Boston before any railroad was built, doing the general express and baggage business between the two places, and driving anywhere from 6 to ro horses according to the wheeling; making two round trips a week. When the railroad started he be came associated with A. D. Hatch and later with Smith E. Ladd and went under the name of Hatch, Gray \& Co. for years, when owing to failing health, he had to retire, when the firm name was changed to Hatch \& Whiting. Later, on the death of Whiting it was again changed to Hatch \& Co. and is now known as the New York \& Boston Despatch Express with Geo. C. Hatch as manager in New Bedford.

Blossom Brothers, though founded but two years ago is favorably known to the sash, door and blind trade. The premises of the house consist of a two story mill, 65 by 40 feet in dimensions located at 238, 240 and 242 North Water street. The plant is completely equipped with the latest improved wood working and sash and blind machinery operated by a 25 horse power engine, with surplus boiler capacity, and furnishes eniployment in the several departments of the sawing and planing mill, sash, door and blind shop to fifteen hands. The products of this mill comprise window and door frames, sashes and blinds, of all descriptions, special attention being given to wood turning and pattern making. All manner of planing, scroll and band sawing is done to order, and promptly. The trade of the house extends all over the New England states.

J. V. Bancroft, of No. 35 Hillman street, established the livery and boarding stable Sept. 6, I891. His premises are large and well adapted to the business, being $125 \times 60$ feet in all, and two stories in height. Mr. Bancroft is thoroughly acquainted with the business, and is determined to run an establishment second to none.

J. V. Bancroft who has been in business in this city since 1877 does the principal portion of the sprinkling of this enterprising city's streets. His work is all done for private individuals, who contract for this work for a certain portion of the season. He requires the aid of seven men while some six modern sprinkling wagons are used. His address is 527 Acushnet avenue.

M. F. Kennedy in 1878 laid the foundation of the cooperage house of which J. P. Kennedy became sole proprietor in $\mathbf{r} 888$. This gentleman is a manufacturer of aud dealer in new and second hand casks, barrels, kegs, etc., of every description; his establishment, which is a four-story structure, measuring 72 by 66 feet, being located at the corner of Water and Cannon street is supplied with all the latest improved machinery for facilitating operations. The house does a prosperous business in this line, the trade extending throughuut New England and the Southern States. In addition to his cooperage business, Mr. Kennedy in I890, established himself as a dealer in paper bags 
and twine, making a specialty of printed wrapping paper for drygoods, clothing and boot and shoe houses and also mill wrapping paper. His trade in this line extends throughout New Bedford and vicinity.

The New Bedford Tow Boat Company was founded in 1874 and is receiving the largest share of the business of towing boats. They have first-class facilities; their wharfage being in most excellent condition, some 25 by 100 feet in area. Their steamers are the "Nellie," "Cygnet" and "George W. Hunt," which have no superiors for safety and speed, and are manned by experienced men. The agent of this well known company is Samuel C. Hart, one of this city's popular business men, whose office is situated at the corner of South Water and Walnut streets.

Hart \& Akin of 58 South Water street, conduct the business founded in $185^{\circ}$ by John H. Perry, which was changed to Perry \& Wilson three years later. In I $866 \mathrm{Mr}$. Hart bought out Mr. Wilson's interest in the business, and the title of the house then changed to John H. Perry \& Co. This firm carried on the business till 1874 when Mr. Perry disposed of his part of the business to Mr. Hart, the latter gentleman taking into copartnership at this time Mr. Akin, the name of the firm changing to Hart \& Akin. Samuel C. Hart and Francis T. Akin have built up a large trade in this city. They are dealers in paints, oils, varnishes, etc., which they sell at wholesale and retail. They do a large business as painters of signs, houses and ships, and their work in this line is of a most superior character. In addition to the above they have an extensive trade as wholesale and retail dealers in coal and wond.

Capt. H. C. Hathaway, of this city, was born in New Bedford in I842, and there grew to manhood and received a liberal public school education. He commenced the struggle of life early, making his first trip on a whaling vessel from this port and was away on a two-year's cruise. He followed this business for some time making various trips. One voyage was of special interest as the good ship "Gazelle" of which he was third officer, had the fortune of harboring a no lesser light than John 3oyle O'Reilly, after his escape from English tyranny. After being promoted to first officer on this ship, he cast his fortunes with the ship "Milwood" as its first officer. This ship was wrecked in Cumberland Inlet and Mr. Hathaway remained there some eight months. He retired from this vocation and in 1874 he was appointed assistant marshall of the police force, and in 1875 was made captain of the night patrol. One year later we find him chief of the police, and he remained in this office through i 876 and 1877 . From I 878 to I 882 he commanded the bark Veronica, a packet plying between New Bedford and the Azores Islands and Madeiras. In I 887 and I 888 he was appointed a member of the board of overseers of the poor. He is a member of the Board of Trade, and is connected with many local societies, being a member of the Star in the East, Sutton Commandery, F. and A. M., of the Wamsutta Club, honorable member of the City Guards and Young Men's Christian Association. He is one of the best known real estate men in this city, and annually transtacts a large business. As a member of the board of aldermen of this city his services have always been of the most creditable nature. 
He was elected in 1890 by the Republican party. In 1891 he purchased the carriage business of J. R. Forbes \& Co., which is located at the corner of Elm and Acushnet Avenue, where he carries on the manufacture of carriages, and has in connection with this business at the same location added a sale and auction mart.

The Mansion House of New Bedford is a building which is 75 by 150 feet in dimensions, contains three floors, and sixty-five rooms are utilized altogether for transient and permanent guests, employment being given to twenty-five assistants, all experienced and courteous people. The hotel throughout is elegantly furnished, and supplied with electric light, steam heat, and other modern conveniences, necessary in a first class hotel of to-day. The dining room is commodious and tastefully arranged and the table is all that the most fastidious epicurean would desire. The proprietor of this well known hostelry is C. W. Ripley, who runs the "Sippican" at beautiful Marion. The gerial clerk is James B. W. Bates.

Wendell H. Cobb, first saw the light at Sandwich, this state, 1838 . He attended the public schools in this town, going to Phillips academy in 1855 , were he remained two years. Here he prepared himself for college, entering Dartmouth, from which he graduated in $\mathbf{1} 86 \mathrm{r}$. After leaving college he taught school in Newport, Vt., for about six months, but in 1862 he located in New Bedford, where he took up the study of law under the guidance of that well known firm of lawyers Stone \& Crapo. Soon after the death of Mr. Stone, the law firm of Marston \& Crapo was founded and Mr. Cobb became a member. In I879 on the dissolution of said firm Mr. Cobb became associated with the Hon. George Marston, under the firm name of Marston \& Cobb. By the decease of Mr. Marston, this firm was necessarily dissolved, Mr. Cobb, encering alone into the discharge of his large practice, his office at present being in the Five Cent Savings Bank building. Always active in politics, he first became a member of the School Committee which he held from i 869 to 1873 . In this year he became New Bedford's City Solicitor and for three consecutive years he faithfully and conscientiously served the city in this capacity. That he is popular is well attested by the constant appeal of his friends to put him forward for some responsible position.

Ezekiel Gardiner was born in 1839. At the age of fifteen he removed to Providence, and entered the employ of A. Crawford Greene, where he learned the art of printing. He remained here until the outbreak of the war, when June 6, r 86r he enlisted in Co. D. 2d Regiment, Rhode Island Volunteers, continuing in the service till I864, when he was mustered out. In I 866 he resumed the printing business in Westerly, R. I., thence removing to this city, where he entered the employ of E. Anthony \& Sons, with whom he remained several years. He served most acceptably in the Common Council of I 880 and I 881 , and during I890 did excellent work under Mayor Clifford. He also served the city as alderman. Mr. Gardiner is a prominent Mason and member of the R. I. Peirce Post 190, G. A. R. and is at present Chief of Police of New Bedford. 
L. G. Hewins, the ticket agent at New Bedford is the oldest employe of the Old Colony road. He has becn in continuous service here since I 865 , and has worked his way step by step to his present position, and is held in high estimation by his employers and patrons of the road.

Charles H. Gifford, the postmaster in New Bedford, has for three years administered the affairs of the post-office in a highly creditable manner. $\mathrm{He}$ was born in this city in I833, and after a collegiate education he entered the commercial field, and at once became largely ilentified with the interests of the city. He is a popular man in every respect. His administration of the postoffice has been of such a high character that he has the reputation of having one of the best appointed offices in the country.

The Mechanics National Bank, established as early as I83I, and chartered in 1864, we find in comparison with the same class of organizations elsewhere: solvent, prosperous and useful in the highest degree. The character of the business carried on is of a purely legitimate banking nature and the policy upon which it has been conducted, is amply shown by its statements. The present officers and board of directors are the Hon. Wm. W. Crapo, president; Andrew G. Pierce, vice president; and John R. Thornton, J. Swift, Thos. Wilcox, Edward D. Mandell, Horatio Hathaway, L. Snow, E. Williams Hervey, Henry C. Denison and William C. Taber. Jas. W. Hervey honorably and very agreeably fills the responsible position of cashier.

Nat. P. Sowle, successor to Fred'k A. Sowle is the leading representative of his special industry in New Bedford, and conducts the largest business in the manufacture of house finish in this part of the state. He occupies a substantial brick factory at the corner of Elm and Bethel streets, three stories in height, $50 x 100$ feet in dimensions, and employs on an average thirty-tive sikilled workmen in all departments. His factory is equipped with the latest wood working machines necessary for his line of business, and operated by an engine and boiler of roo horse power each. "The products of the house are doors, blinds, sash, window frames, mouldings, wood mantels, stair rails, newel posts, balusters, brackets, special attention being paid to turning out builders' finish. Scroll sawing and turning is another feature of the business and a large trade is likewise transacted in all kinds of lumber. Mr. Sowle also handles window and cathedral glass, plate glass being his specialty and is the largest dealer in this line in this section. The house was established in 1873 and owing to the increase in business has been several times enlarged until at the present time his transactions aggregate $\$ 75,000$ per annum, and his trade extends all through the southern part of the state.

E. B. Chase \& Co. are engaged in the manufacture of picture frames as well as dealers in -art goods, mouldings, glass, stationery and fancy goods. They are also head quarters for pianos, organs, sewing machines, and oil stoves; tune and repair lpianos and organs and make sewing machine repairing a specialty. They occupy premises 2I 4 to 2I 8 Union street and 3 Fifth street, while their new factory is located at 532 and 534 Acushnet avenue. Since their establishment in I87 I they have erjoyed a steadily increasing and prosperous 


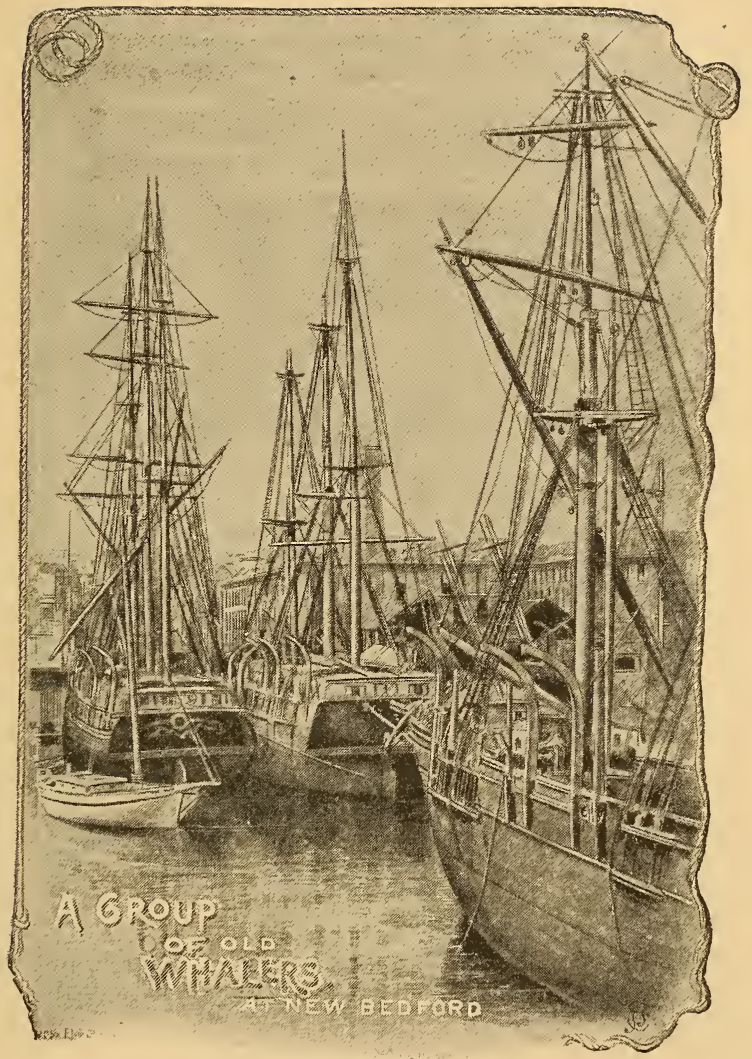



business, owing to good management, square dealing, and the handling of only reliable goods.

Bowker \& Tripp are a most reliable firm of machinists and engineers, which was established in 1874 . They have well appointed shops, provided with all required machinery of the latest improved kinds, and employ a force of twenty workmen, turning out many thousand dollars worth of superior work annually, which is disposed of in all parts of the country. The specialties of the house embrace steam engines, shafting, pulleys, and their appurtenances. They are patentees and sole manufacturers of the matchless steam and fire regulator and matchless single and multiple frictionless dampers for flues and chimneys, which are superior to any device in the market. This house also carries a large stock of valves, check valves, American pop safety valves, Barclay \& Co.'s patent automatic valves and water guages, indicators, pyrometers, injectors, pumps, etc., and are prepared to furnish estimates for steam and hot water heating apparatus for mills, factories, public buildings, private residences, etc. The annual damper business amounts to $\$ 25,000$, which indicates what its extent and possibilities are.

Bliss \& Nye at 145 Union street is one of the old established houses of New Bedford extensively engaged in the crockery and house furnishing goods trade. This house was established in 1845 by Allen \& Woøds, who were succeeded in 1854 by Allen \& Bliss, the present firm assuming control in 1874 . The premises occupied by them consist of the basement and first and second stories of a building three stories high and 22 by 100 feet in dimensions. Their trade embraces the whole of this city and vicinity, and in fact, customers are had from all parts of southern Massachusetts. The stock of goods embraces china, crockery, glassware. paper hangings and house furnishing goods of every description, all at the lowest possible prices. A very active trade, both wholesale and retail is done, aggregating $\$ 50$, 00 per year.

Charles S. Paisler, whose office is at 160 North Water street is well known as one of the largest dealers in builder's' supplies in this city, and supplies many of the leading builders of New Bedford and vicinity. Mr. Paisler is an extensive wholesale and retail dealer in brick, lime, cement, King's Windsor cement, (the new article for plastering) flag-stone, sewer and drain pipe, rough and dressed granite, etc., etc. He also carries in stock a large and fine assortment of plain, glazed and ornamental tiles for hearths, floors and vestibules, which are so universally used at the present time. This establishment covers an area of an acre of ground, and possesses every known facility for the successful prosecution of this important enterprise in New Bedford. This house in its line of trade is the largest in southern Massachusetts, and the heavy demands upon its resources necessitate the carrying at all times of an immense stock, that no delay may be occasioned in filling orders of any magnitude with promptness. Mr. Paisler has been established for so many years here that no personal mention is necessary, but we are at liberty, however, to say that it is an industry worthy of mention in a review of this nature, knowing that those who enter into business relations with Mr. Paisler will always find him honorable to the letter. 
David Duff \& Son was founded in I886 as dealers in coal and general forwarders. In both these lines they do an extensive business in this city and vicinity. They handle all grades of coal which they reeeive direct from the mines in large quantities, some fifteen thousand tons being handled annually. As general forwarders they receive a large share of the business of teaming done by the merchants of this thriving city. Their offices are located on Front street, foot of Middle street, and on Front street, foot of Centre street, while the yard is situated at Fish Island. Their premises are large and well arranged for their special business. Some twenty hands are employed by this house, and thirty teams are required to do the constantly increasing work of this prominent house.

J. D. Sullivan we find engaged in the undertaking business, who commenced in 1890 , and now occupies convenient quarters at No. 277 Purchase street. The stock kept on hand, consisting of caskets, black walnut, rosewood and cheap coffins, together with shrouds of all kinds, coffin plates, handles, etc., is unexceptionally a superior one, and in this establishment may be found every requisite necessary for embalming and undertaking. In every department of the business the greatest propriety and good taste is observable, and the facilities are such that all the resources of the business can be brought into play at a moment's notice. He is also agent for passage tickets on the Cunard, Allan, Anchor, Inman, Warren, Red Star and White Star Lines.

Brightman \& Washburn, located at the corner of North Water and North streets are engaged in the manufacture of builders' materials. This industry was originated twenty-two years ago by Gardner \& Brightman. In I87 I it changed to Jacob Brightman, some six years later L. R. Washburn became associated with him under the present title, and they have since continued to conduct the business with energy and success. They occupy the second fioor of the three-story brick building at the above address, which covers an area of 6,000 square feet, employ twenty operatives and possess all the requisite machinery for executing the work. The products of the factory consist of house and cottage trimmings. window and door frames, brackets, balusters, newels, inside shutters, besides which the work of stair building, pattern making, turning, scroll and circular sawing is undertaken. A specialty is made of mantels and sideboards. The trade is confined to New England, and as none but the most satisfactory work is turned out, the firm enjoy a large share of public patronage.

The New Bedford Steam Laundry, 173 and 175 Purchase street, stands high in the estimation of the people of this city. Here you can send your goods with the assurance of getting fine work, and prompt delivery; and the superiority of the process of doing work over the old style, is such, that no damage is caused to the finest fabrics. The premises are large, being two stories in height, and fitted especially for the business. The first floor is given up to the office, sorting, shipping, and cleansing departments, while the second is devoted to the drying and ironing. The establishment has a steam bar drying room, and is fully equipped with all the latest improved machinery known to 
the business, some twenty hands are constantly employed, and three teams are required to collect and deliver the goods. This laundry was established in 1888, but the proprietorship of the same changed in I89I, F. G. Tripp becoming proprietor. He is a gentleman especially adapted to the business, and with strict attention to every detail he has added to the already large business until he has succeeded in building up a very lucrative patronage.

Charles O. Brightman is among the most reliable and skillful contractors and builders in this city. The enterprise he conducts was inaugurated in 1879 , since which time the business of the house has reached large proportions, and in point of fact it now ranks with the most extensive in the eity. The premises occupied are located at 72 North Water street, and comprise four floors measuring $60 \times 84$ feet. A force of three hundred assistants is employed, and every facility is at hand to work with. Mr. Brightman as a contractor and builder ranks high and he has erected many fine buildings in this city.

William S. Jenny has since $\mathrm{I} 887$ been engaged in the grocery business in this city, and has made a specialty of the ship trade, supplying vessels at short notice with everything connected with this trade. The building occupied by him as a store and warehouse at 17 to 25 South Water street, stands on an area of roo by 75 feet. He does also quite a business in the letting of rooms for lodgings; having apartments in desirable locations.

\section{STEVENS \& WILLIS, \\ - MANUFACTURERS OF ALL KINDS OF-}

Iron, Zine and Copper Shoe Nails and Tacks, : : and Steel Shanks. : :

Hungarian, Clout, Channel, Chair, Cigar-

Box and Finishing Nails.

Upholstery, Carpet, Gimp, Brush, Lace, Carriage, Saddlery and Matting Tacks.

Nails for McKay, American, National and Bigelow Heeling Machines made a Specialty.

Shoe Tacks for Machine Driving made a Specialty.

SOUTH BRAINTREE, NORFOLK, CO.

JAMES T. STEVENS.

GEO. D. WILLIS. 
INCORPORATED 1854.

\section{AMERICAN STEAM GAUGE COMPANY,}

(ORIGINAL STEAM GAUGE CO.)

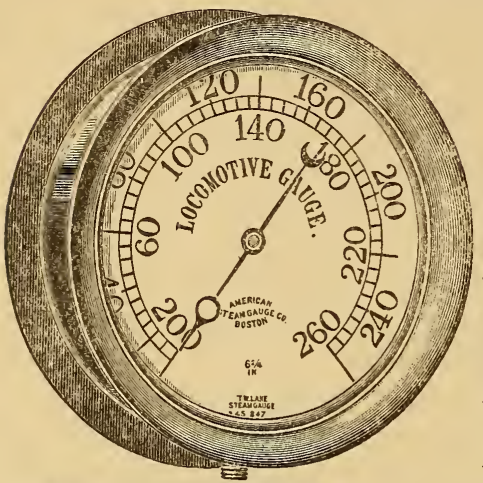

- manufacturers of .

BOURDON * STEAM * GAUGE,

With Lane's Improvement.

Water Gauges, Gauge Cocks, - -

Whistles, Revolution Counters, -

Marine Clocks, Pyrometers, - -

Hydrometers, Salinometers, : -

Etc., Etc.

Also Manufacturers of the AMERICAN POP SAFETY VALVE

For Stationary, Marine, Locomotive and Portable Boilers, also Water Relief Valves.

Sole Manufacturers of THOMPSON IMPROVED INDICATOR. $\because \therefore \quad$ MORE THAN 15,000 IN USE. $\therefore$.

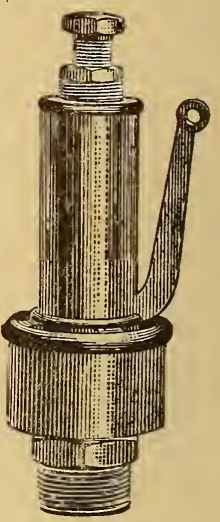

Adopted by the U. S. Navy for use on all the new Cruisers and Gunboats to be built.

36 Chardon St., (Send for Catalogue.) BOSton, Mass.

JOHN T. ROBINSON \& CO., HYDE PARK, * MASS.

- MANUFACTURERS: OF -

Fine Paper Box and Card Cutting Machinery including the celebrated Robinson Scorer, so well known to the Paper Box Fraternity. . . . . Sperial work of all kinds in our line. Corners Cutters, Shears, Thumb Hole Cutters, Rotary Slitters, and Cross Cutters of every description. Correspondence Solicited. 


\section{F A L L R I V E R.}

T

HE busy, bustling city of Fall River is the embodiment of the sagacity, energy, and successful industry of her own people. No city or town engaged in similar pursuits has greater cause for satisfaction, or can refer to stronger reasons for the exercise of a just pride in its achievements. Most of the large manufacturing towns of New England are the representation of the surplus capital of the older commercial cities. Fall River is the outgrowth of home industry and good management, which, under the blessings of a benign Providence, have given her a foremost rank in manufacturing cities, and a continued success rarely enjoyed by those engaged in manufacturing or commercial pursuits. The city has at various times met with reverses, in the way of conflagrations and strikes, but upon recovering from them, increased prosperity has been the result; and whether in manufacturing or other business, the immense capital which is wielded here is strictly within the hands of her own citizens.

The words or motto of her corporate seal, "We'll Try," have thus received a most significant and practical exposition, and, to-day, the swiftly developing interests of Fall River represent a productive force at least double that of any other New Engìand city engaged in the same class of pursuits. Business is managed with a thrift and exactness seldom attained; but thrift and exactness are not allowed to degenerate into littleness, nor are preconceived opinions held with a tenacity which amounts to stubborness. Her manufacturers are conscious that the world advances, and desire to advance with it, adopting those suggestions which are reasonable, keeping fully up to the demands of educated labor, desirous of promoting the interests of their employes in wages, hours of labor, and mental and physical requisites, and making them feel that the interests of employer and employed are one and inseparable.

In union of hydraulic power and navigable waters, it is perhaps without a parallel upon the American continent. Its hydraulic power is derived from a small stream-Fall River - whence the name of the city, which has its sources, or is in reality the outflow of a chain of ponds lying two miles east of Mount Hope bay, a superb harbor overlooked by this flourishing city, and covering an area of some 3,500 acres. The extent of country drained is comparatively small - not over 20,000 acres - and the quantity of power therefore is to be attributed to the rapid fall of the river, which in less than half a mile is more than 132 feet. Within that distance there are no less than eight falls, each occupied by mills. The whole of this fall occurs in a distance 


\section{Massasoit Manufacturing Co.,}

WENDELL E. TURNER, TrEAsUrer,

FALL * RIVER, * * * * MASS,

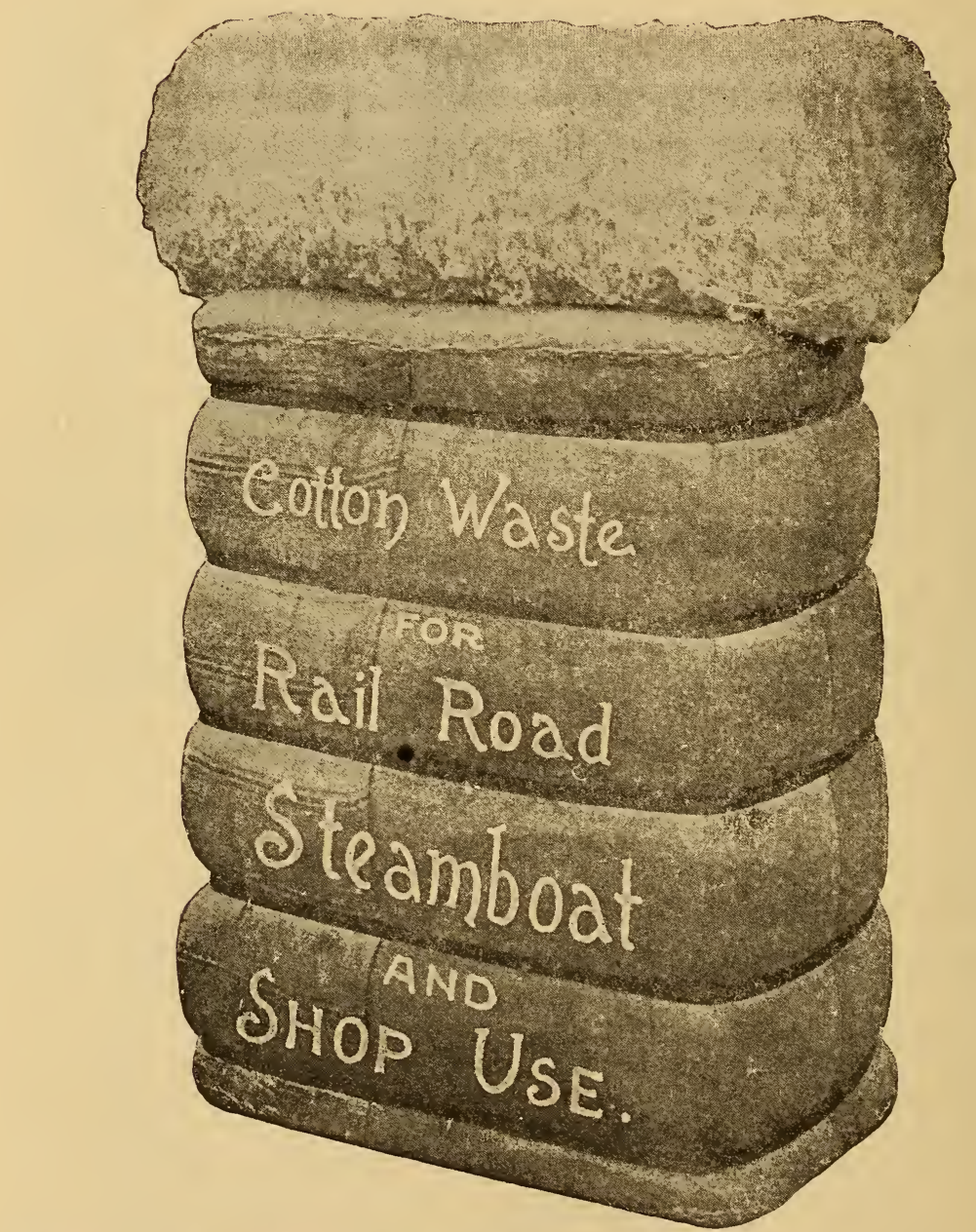

Cotton Batting, Mons, Wick, Quilted Stair Pads, Snun Cotton, Etc.

CONTRACTORS FOR

COTTON MILL WASTE, PAPER STOCK AND BAGGING. 
of 2,300 feet. In one case the falls are only 136 feet apart, and this distance occurs between the two greater falls. The flow of the river is one hundred and twenty-one and a half cubic feet per second, or 9,84I,500,000 imperial gallons in a year of three hundred days of ten hours each.

The growth of Fall River, owing principally to the natural advantages it possesses, has been phenomenal, as is well illustrated by the fact that the population increased from $48,96 \mathrm{I}$ in 1888 to $74,35 \mathrm{I}$ in $\mathrm{I} 890$. It is the greatest textile manufacturing city in this country, especially in the production of print cloths, which industry it practically controls. It has $2,128,228$ of the I I , 900,456 spindles credited to New England.

It was the wealth, tact and energy of Fall River's business men that founded and promoted the famous Fall River Line, and here the palace like steamers of the Old Colony Steamboat Company arrive and depart, making a busy scene about the docks as the throngs of passengers to and from New York and Boston embark or disembark at this point.

The local trade of this important industrial centre is also of a representative character, the advantageous location of the city between the two great commercial metropolis making its shipping facilities unequalled in the New England states All places of business in Fall River, therefore, are noted for the extent and variety of the stocks carried, while its manufactories are the largest of its kind in this country.

The first settlement of the region comprising and immediately adjacent to the city of Fall River was in the regular course of expansion of the Plymouth Colony, about the year I656. In this year, on the third of July, the General Court of Plymouth granted to a number of Freemen of the jurisdiction, a tract of land east of the Taunton river, four miles in width, and six to seven in length, bounded on the south by Quequechan, and on the north by Assonet Neck. Three years subsequently this grant was confirmed by a warrantee deed signed by the local sachems, the consideration being “twenty coats, two rugs, two iron pots, two kettles and one little kettle, eight pairs of shoes, six pairs of stockings, one dozen hose, one dozen hatchets, two yards of broadcloth and a debt satisfied to John Barnes, which was due from Wamsutta to John Barnes." This grant was termed the "Freeman's Purchase," and after incorporation in 1683, Freetown. "The first settlers," says that industrious and correct student of local history, the late Rev. Orin Fowler, in a series of papers published in I 84I, "were principally from Plymouth, Marshfield and Scituate. Some were from Taunton, and a few from Rhode Island. The early names were Cudworth, Winslow, Morton, Read, Hathaway, Durfee, Terry, Borden, Brightman, Chase, and Davis. The purchase was divided into twenty-six shares, and the shares were set off - whether by lot or otherwise does not appear - to the several purchasers. After the division into shares was made, there was a piece of land between the first lot or share and Tiverton bounds, which in 702 was voted by the proprietors to be sold "to procure a piece of land near the centre of the town for a burying place, a training field, or any other public use the town shall see cause to improve it for." Accordingly this piece of land was 


\section{Fall River Machine Co., POND STREET, FALL RIVER, MASS.}

- MANUFACTURERS AND REPAIRERS OF -
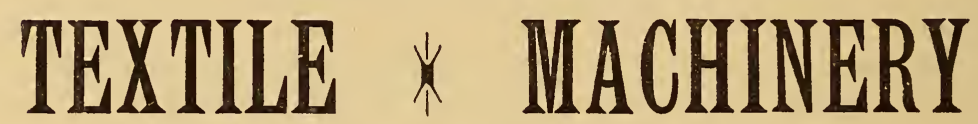

RING SPINNING + FRAMES

(FOR WARP OR FILLING

CARDS, COILER RAILWAY HEADS, DRAWING FRAMES, ETC., - BUILDERS AND REPAIRERS OF -

MARINE AND STATIONARY BOILERS FURNISH IRON AND BRASS CASTINGS.

$$
\text { C. H. Williston, }
$$

\section{ROOHER * AND* CONCRETER.}

Rear 81 PLEASANT ST., FALL RIVER, MASS.

TELEPHONE CONNECTION.

$$
\text { W. G. PEARSE, }
$$

AGRICULTURAL $\nleftarrow$ IMPLEMENTS,

- SEEDS FERTILIZERS, -

Wooden Ware and Baskets,

HARNESSES AND HORSE CLOTHING.

55 to 61 Second St., $\quad$ - $\quad$ - $\quad$ Fall River, Mass. 
sold to John Borden, of Portsmouth, Rhode Island, the highest bidder, for nine pounds and eight shillings, and was the territory on which that part of the village south of Bedford street, and north of the stream, now stands. This John Borden is believed to be the ancestor of all.who sustain his name in this vicinity.

The Hargraves Manufacturing Company, a long established firm engaged in the manufacture of soaps, glue substitute, refined tallow; and packers of tripe, pigs feet, lambs' tongues, etc., was established in I 848, Reuben Hargraves and Thomas Hargraves being the proprietors. The works, situated opposite the Stafford Mills, off Pleasant street, Fall River, are fitted up with the best machinery that can be obtained. An extensive business is carried on by them, and constant employment is given to a large force of hands. They are among the largest producers of soaps of all kinds in New England. Their business of packing lambs tongues, pigs feet, tripe, etc,, is continually increasing, but the members of the firm are fully capable of carrying on their business in a successful manner.

Callahan \& Daley are members of a well known and representative house engaged in the building line. This copartnership was formed about 1878 , and is composed of gentlemen of long experience and good business ability, aud from its inception has carried on a successful and steadily increasing business. They are prepared to furnish plans and specifications and give estimates on all kinds of building, and having 50 skilled men employed they are enabled at all times to fill orders in a prompt and stisfactory manner. In addition to this line of work they have for the past five years carried on the hardware business. They carry a large and varied assortment of builders and general hardware, carpenters' tools, machinists' supplies, butchers' and grocers' tools, and also cutlery of all kinds. Their stock of scissors, shears, and pocket knives is the largest in the city. They occupy large and ronvenient premises at 45 South Main street, corner Annawan, and have done much to aid the substantial growth and enhance the wealth of the community.

Benson \& Austin, successors to the Fall River Miil Supply Company, are extensively engaged in the manufacture of patent loom harnesses and reeds, and the covering of top rolls. The firm is composed of C. E. Benson and James T. Austin, gentlemen of experience, ability, and energy, and public spirited citizens of high personal and commercial standing. They occupy two large floors, each 40 by 65 feet, of a four story building, well fitted with the necessary appliances, and employ a sufficient number of men, the product of whose labor and skill is in demand throughout the North and South. The goods made here are in all respects of the best quality, and the outlook for a prosperous career is most flattering.

Covel \& Osborn comprise a long established and well known firm as dealers in mill supplies and mannfacturers of cotton banding, spindle, braided and loop bands. The business was established in 1873 under the name of Sanford \& Covel, but in 1884 the name was changed to Covel \& Osborn. A full and complete stock of all kinds of supplies for manufacturers, builders, etc. is kept on hand. They are sole agents for Cook's steel loom forks for United 


\title{
Royal Oak Range.
}

NOTHING LIKE IT.
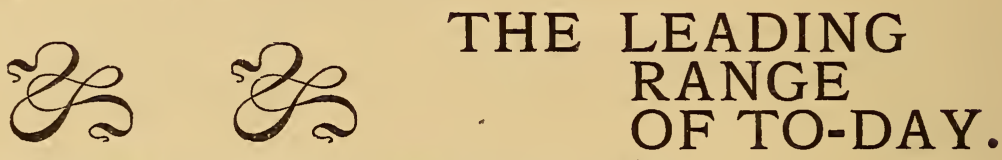

We ask comparison with other ranges. You will find it full size, a perfect baker, and economical worker. Fitted with all modern improvements. ........

\section{IT HAS NO SUPERIOR.}

We place this Range against any first-class make in the market to-day. Made in all the different styles and sizes. For sale by all leading dealers.. . . . . . . . . .

MANUFACTURED BY

\section{Eagle STOVE Foundry Co,}

FALL RIVER, MASS.

C. E. BENSON.

BENSON \& AUSTIN,

JAS. T. AUSTIN.

\author{
SUCCESSORS TO
}

FALL RIVER MILL SUPPLY CO.,

Loom Harness Manufacturers and Top * * Roll Coverers. * *

SATISFACTION gTARANTEED. No, 90 Pocasset St., FALL RIVER, MASS.
teLephone 206-6.

\section{HEYWOOD \& CO.,}

MANUEACTURERS OF

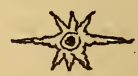

\section{Cotton Banding and Cotton Braids,}

DRUM RIM, SCROLL, SPINDLE, LOOP AND BRAIDED BANDING,

CABLE LAID DRIVING ROPE A SPECIALTY 264 So. Main St., Fall River Mass. 
States and Canada. A force of thirty hands is employed by them in the various departments, and five teams are kept in constant use. The members of the firm consist of T. D. Covel and J. E. Osborn, both of whom are well known residents of the city and have a thorough knowledge of their line of goods. A large trade is carried on by them and all transactions are met in a straight forward and fair dealing manner. The store is located at 7I Pleasant street, Fall River.

U. T. Tripp in 1892 succeeded to the business established in 1878 by William M. Hawes. This house deals in new and second hand machinery, machinists' tools, engines, etc., a specialty being made of boilers, pumps, woodworking machinery, etc. He is also agent for Wm. P. Miller's lubricating compound. Mr. Tripp has had many years' experience in the trade, is a thorough workman and understands every point in the business. Mr. Tripp is well known among the business men of the city, and his stock is one of the largest of the kind. All his goods are first-class in every respect no inferior article being kept by him. The premises occupied by him are located at 131 Central street, where all orders are promptly filled at short notice.

George W. Frye, located at 20 Third street, is an extensive dealer in oils and chemicals, and is a leading representative of this interest in this eity. This enterprise was established in 1872 and transacts a large and growing business with the mill owners and machinists of Fall River and vicinity. Mr. Frye manufactures all kinds of lubricating oils for all classes of machinery, and deals to a considerable extent in E. Sehlbach \& Co., Jebb's Starch and Wattle's Dressine, a compound for the improvement of sizing for cotton warps. The house is in excellent favor with the large mill owners of this city, whom it supplies with a superior quality of lubricants including high-grade cylinder, engine, machine, dynamo, sperm, neatsfoot and spindle oils.

C. H. Williston of 81 I-2 Pleasant street, commenced business in 1877 , as agent for Storey's phoenix brand felt and composition rocfing. 'This compound is the best and cheapest in use, being both fire and water proof. All kinds of mica, and matrials for roofing are always on hand, and all orders are promptly filled at short nowe. The work done by Mr. Williston is always of the best and gives perfect satisfaction, as he employs only tirst-class workmen. Warren natural Asphalt and double roofing is also done by him. He is well known among the business men and has the reputation of conducting a large business in an honest and fair dealing manner.

The Eagle Stove Foundry Company, located on Pearse street, is an important house engaged in the manufacture of stoves, ranges and sinks, and is conducted by the heirs nf the late John Davis. It was established some sixteen years ago and has built up a large trade, especially in the West. The goods manufactured by them are from their own designs and are made from the best material. A force of thirty-five experienced workmen are employed who turn out about three thousand a year. The premises occupied by them consist of a story and a half building, ninety-five feet front and one hundred and ten feet back, fitted up with all the latest machinery. All goods manufactured by the company are warranted 


\section{GALLAHAN \& DALEY,}

\section{CONTRACTORS \& BUILDERS,}

- . AND ALSO dEALERS IN . .

BUILDERS AND GENERAL HARDWARE, CUTLERY, TOOLS, ETC., 45 So. Main St., - Cor. Annawan. FALL RIVER, - MASS.

\section{COVEL \& OSBORN,} MILL FURNISHERS, BUILDERS' SUPPLIES, GENERAL HARDWARE. - . Largest Stock of MILL SUPPLIES in New England. . . . CONTRACTORS FOR SASH, FRAMES AND HARDWARE $\quad \begin{gathered}\text { For Now Buildings of } \\ \text { Every Description. }\end{gathered}$ ... AGENTS FOR ...

The Cook Steel Loom Fork - and - The H. W. Johns' Paint.

71 Pleasant St., Fall River, Mass.

\section{G E O.W. F R Y E \\ - MANUFACTURER AND DEALER IN LUBRICATING- $\rightarrow<$
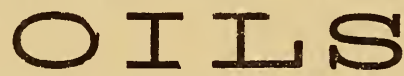 $\rightarrow<$}

For all Classes of Machinery,

SPERM, WHALE, LARD, TALLOW, PARAFFINE, CYLINDER AND SPINDLE OILS. Bingham ton Cylinder Oil, - AGENT FOR -

Wattle's Dressine,

Peter Cooper's Refined Neatsfoot Oil Jebb's Starches.

18 Third Street, Fall River Mass.

\section{U. II. IERIEE.}

. . . SUCCESSOR tO WM. M. HAWES.

DEALER IN NEW AND SEGOND HAND MaghINERY, Machinists' Tools, Engines,

BOILERS, PUMPS, WOOD WORKING MACHINERY, SHAFTING, PULLEYS, HANGERS AND COUPLINGS A SPECIALTY.

AGENCY FO WILLIAM P. MILLER'S LUBRICATING COMPOUND. TRUMPINE POLISHING PASTE.

131 Central Street, . Fall River, Mass.

Orders solicited and Promptly AtTended To. TElephone 254-3 
to be as represented, and inexperienced buyers can trade with this firm with perfect safety and know that they are obtaining the best, at low prices.

M. Heywood \& Company was established in 1869 for the manufacture of cotton banding, cotton braids, and cotton rope. A large and successful busi . ness is carried on by them and the articles manufactured are of the best quality. The machinery outfit includes all the modern improvements manipulated by a large number of assistants of both sexes. A vast amount of work is produced by them each week, which gives perfect satisfaction. The factory is located in the rear of 264 Main street, where all orders receive immediate attention, while especial care is taken to have the wants of their patrons met in a satisfactory manner. The capacity of the factory is three thousand pounds per week.

The Fall River Machine Co., is one of the largest establishments for the manufacture of cotton machinery, ring spinning frames, cards, etc., in Fall River, their premises being located on Pond street. In connection with the above business they have also an iron foundry and boiler works. An extensive trade is carried on by this company and since its incorporation in 1880 until the present time, its trade has increased constantly. The premises occupied by them cover an area of five acres, and employment is given to over two hundred experienced hands. All the latest machinery is used by thern and great pains are taken to have the best results. The company was formed with a capital of ninety-six thousand dollars, and the officers are president, Hon. J. S. Brayton and treasurer, G. H. Bush. These men are well known in business circles, are good financiers and possess all the qualities for carrying on a large business.

The Massasoit Manufacturing Company, of Fall River, located on Davol street, produce cotton batting, cotton waste, mops, wicking, etc. The company was incorporated in 1882 , and their present capital and surplus is one hundred and fifty thousand dollars. A large tract of land is occupied with their buildings which are fully equipped with all the machinery necessary, it being of the latest pattern, while enuployment is given to one hundred and eighty hands all of whom are skilled workmen. The products stand high in the markets and their reputation is well known. W. E. Turner is treasurer of the company.

W. G. Pearse, of 55 Second street, is well known both as a wholesale and retail dealer in agricultural implements, seeds, fertilizers, harnesses, horse clothing, whips, etc. The business was established in 1878 under the name of Peirse \& Easterbrook, but in 1890 the firm was succeeded by W. G. Pearse and the nature of the business changed by adding harness and horse supplies. Occupying the whole of a three-story building is evidence enough that a large and successful business is carried on. His trade extends to all of the surrounding towns and six assistants are engaged by him thus avoiding any delay in filling orders. 
F. L. ROBERTS, Manager.

TELEPHONE No. 23-3.

\section{Hargraves Manufg. Co., .}

\section{Beef Department.}

RECEIVERS OF

\section{CUDAHY PACKING CO.'S}

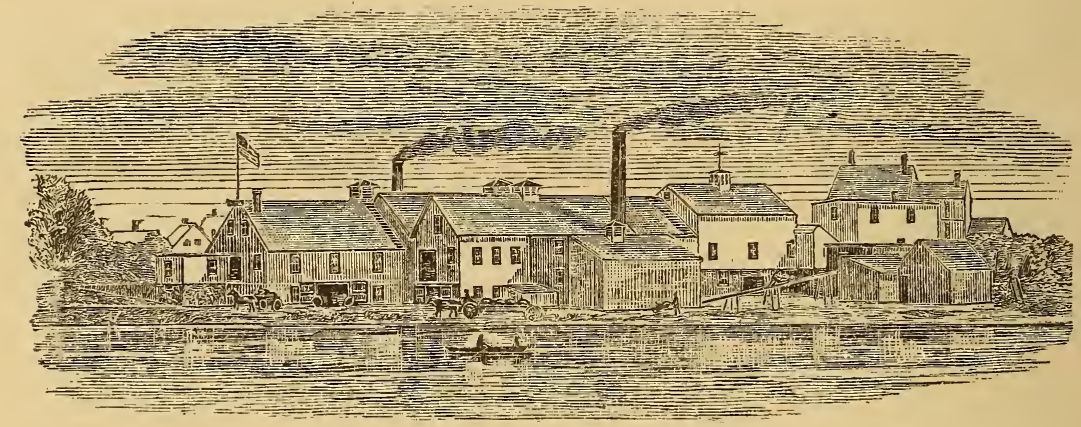

Western Dressed Beef,

$\frac{\text { MUTTON, LAMB, VEAL, }}{\text { PORK, PROVISIONS, Etc. }}$

261-265 PLEASANT ST. STAFFORD SQ.,

FALL RIVER, MASS. 


\section{TOWNS ANDCITIES ON THE BRANCHES OF THE OLD COLONY RAILROAD.}

$\mathrm{H}$

AVING given in the preceding pages somewhat extended historical data and description of several important cities on the Old Colony system, the remaining cities, towns and stations will be found classified on the various branches upou which they are located. We have heretofore referred to the fact that this road has only eleven miles of main line (from Boston to South Braintree) all the rest, comprising upward of 500 miles, being branches; but as our starting point under this classification must of necessity be in the town of Braintree (the various stations included within the city limits of Boston all mentioned as "Surburban Service") a sketch of that town is the first in order on what is known as the Central Division, main line.

\section{BRAINTREE.}

Braintree, one of the most respectable and ancient towns of the state, lies in the northeastern part of Norfolk County, Io miles south of Boston on the Old Colony Railroad. The stations, villages, and post offices are Braintree, South Braintree, and East Braintree. It is bounded on the northwest and north by Quincy, east by Weymouth, south by Holbrook, and southwest and west by Randolph. It contains fine public schools, a public library and many elegant estates, while the Old Colony has here erected an attractive and most conveniently arranged station. There are a number of manufacturing establishments in the town. Of these, the most extensive are the boot and shoe factories, of which there are several. There are several factories for making wood and metal goods, hosiery, knit goods, findings and trimmings, two or three tanneries, a large paper mill, three or four establishments for food preparations, one each for cement, soap, dye-stuffs, furniture, rubber and elastic goods. The town has quarries of excellent granite, from which as early as 1752, Mr. John Hayward furnished the material for King's Chapel in Boston.

The original settlement of the town was in 1625 . Some of the earliest settlers came from the town of Braintree, in the county of Essex, England, and when the town was incorporated May I3, I640, it was under the name most familiar to them. Previously it had been called Mt. Wollaston. The township included what are now Quincy, Randolph and Holbrook. The town purchased the Indian right to their lands, in I679, of Wampatuck, otherwise Josiah Sagamore, the chief of the Indians hereabout; the price paid being $2_{21}$, IOS. In 1792 parts 


\section{WINKFIELD \& GREGG,}

Manufacturers and Wholesale Dealers in

COTTON and

FI,ANNEL $11 N$,

Also Manufacturers of and

Wholesale Dealers in . .

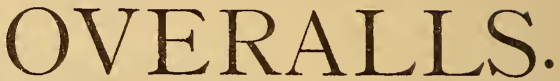

\section{BRAINTREE, MASS.}

\section{WINFRED A. TORREY,}

\section{* * DRUGGIST,}

Cor. Washington St. and Holbrook Ave.,

SOUTH BRAINTREE, MASS.

\section{B. H. WOODSUM \& CO.,}

\section{- MANUPACTURERE OF -}

Tacks, Shoe Nails and Small Nails,

Channel; Countersunk, Hungarian, Chair, Clout, Box, Barrel, Trunk, Cigar-box, Finishing, 2d and $3^{d}$ Nails, Etc.

Upholsterers', Gimp, Carpet, Brush, Card, Lace, Carriage, Miners', Trimmers' Tacks, Etc.

. TINNED AND COPPERED TACKS AND NAILS. .

SHOE NAILS AND SHOE TACKS OF ALL KINDS. SPECIAL SIZES CUT TO ORDER.

\section{SOUTH BRAINTREE, MASS.}

Store: 413 BROOME ST., NEW YORK.

JAEGER \& TIMME, Selling Agents. 
of Braintree and Dorchester were established as Randolph, there being a further annexation in I8II; and in 1856 another part of the town was annexed to Quincy. The part of this territory now known as Braintree was voted to be a distinct parish in I708. The Rev. Hugh Adams, ordained in 1707, was the first minister. Population, I $890,4,842$.

A. S. Morrison \& Bros. located in this town are among the oldest manufacturers in their line in this country. Their specialty being yarns, men's fashioned underwear, French finish jersey cloth, and jackets, etc. At what time this privilege was first occupied we know not, neither by whom the enterprise was first started, but in looking over the records of the town of Braintree we find this mill was first used as an iron foundry, afterwards as a saw mill and grist mill, and about the year 1816 Robert Sugden, a native of England, leasing the premises commenced the manufacture of woolen goods, and carried it on a number of years. In the year i831 Alva Morrison, a native of New Hampshire, leased the privilege and began the manufacture of woolen goods, especially woolen yarns. His business proved successful and he afterwards purchased the property from the Thayer family. He continued to improve it from time to time until he was the owner of the best factory in this section. His prosperity was mainly due to his skill and faithfulness in putting on the market the best goods that were manufactured in his line in this country. Hon. Alva Morrison remained in the town for the remainder of his life, a period of more than fifty years, always taking an active interest in town and state affairs until his death which occurred May 28, I 879. The business is still conducted by his three sons, Alva S., R. Elmer, and Ibrahim, under the name of A. S. Morrison \& Bros. The premises now occupied by this firm consist of two mills, each three stories in height. These mills are fully supplied with all the modern machinery that is required in their business. They have a large electric plant for their own use consisting of two dynamos; they also light this section of the town. Employment is given to about one hundred hands, and they are the only firm that make fashioned underwear in this section. In connection with this they also manufacture hosiery for gentlemen's wear, and are able to turn out about two hundred dozen per day. Their trade extends all over the country and they have gained a wide reputation for the superior quality and finish of their goods. The Boston office is located at I 28 Essex street; they also have an office at 74 Franklin street, New York City.

The Old Colony Cotton Mills were establised in Braintree over a year ago for the manufacture of pure absorbent and medicated cotton, perfumer's' and jewellers' cotton. The premises occupier by them consist of a two and a half story building whose dimensions are sixty by forty feet, while connected with the main building are a bleach house, picker house, drying rooms, etc. The buildings contain modern mathinery of the latest pattern and at present one picker is in operation and one extractor, but arrangements are being made to add other machinery to meet the demands of the increasing business. Constant employmeut is given to twenty hands all of whom are experts at the business. The trade extends all over the United States. A. G. Durgin is treas- 
urer and manager of the mills and has had a large experience in this special line of manufacture.

Winkfield \& Gregg were established in Braintree about the first of 1892 , for the manufacture oi shirts and overalls. They occupy one floor forty by fifty feet where eight machines are in operation. Employment is given to nine skilled hands and the special line of shirts manufactured is cotton and flannel shirts; they are also wholesale dealers in the same. The goods are made from the best material that the market affords and this firm has the reputation for producing an extra fine quality of goods. The members of the firm consist of F. G. Winkfield and R. C. Gregg, both of the firm having had a large experience in this line of business, Mr. Winkfield being at one time connected with one of the largest manufacturing firms located in Boston.

\section{SOUTH BRAINTREE.}

South Braintree is a quiet place and a most desirable one for permanent homes. It is I I miles from Boston, and the seat of the famous educational institution known as Thayer Academy, a preparatory school much patronized by students about entering the universities and colleges of the country. It has a savings bank, fine churches, an excellent railway station with handsomely laid out grounds and flower beds, and everything about its clean and orderly streets bears evidence of the high character of its residents. The extensive building and repair shops of the Old Colony Railroad were located here the past year ( 1892 ), and this is giving impetus to the growth of the place which will materially advance the price of real estate in the near future. Four tracks are laid to South Braintree, and with the added facilities for transportation which this improvement affords, the place cannot fail to become an important section into which large numbers of the urban population will early flock to seek homes and employment. It is surrounded by a fine agricultural district, and all the conditions are most favorable for home-owning and the enjoyment of domestic life.

Stevens \& Willis are manufacturers of all kinds of iron, zinc, and copper shoe nails, tacks, and steel shanks, also Hungarian clout, channel, chair, cigarbox and finishing nails, upholstery, carpet, gimp, brush, lace, carriage, saddlery, and matting tacks, and nails for McKay, American National, and Bigelow heeling machines, while shoe tacks for machine driving are made a specialty. These works were founded in 1868 by J. T. Stevens \& Co., who carried on the business under that proprietorship till I 870 when they were succeeded by the present firm which is composed of James T. Stevens and George D. Willis, men of long experience in the trade. The works comprise two factories of roox30 feet each, which are devoted to the packing, stock and store houses, and covering in all a territory of about one acre of ground floor. The whole is equipped with machinery which is of the latest and most improved patterns, and where some thirty hands are employed, who turn out each day some three thousand pounds of nails and tacks, which are not only sold throughout the United States but are largely exported. Nails and tacks for machine driving are a great specialty 
of this house. The methods of manufacture are such that everything may be designated as first-class that emanates from the establishment, the immense productive capacity of the works combined with the facilities for procuring stock from the best sources of supply, enable them to offer the trade both at home and abroad superior inducements. Being situated only ten miles south of Boston this firm is the only one producing the above line of goods so near Boston, and they are also on the direct route to New York and the West.

The Braintree House, located at the corner of Pearl and Washington streets, South Braintree, has all the comforts of home, besides every civility, attention and convenience possible to a sojourn in a public caravansary. The house is a twostory structure covering an area of $100 \times 30$ feet, and contains sixteen rooms which are neatly and tastefully furnished. The dining room has a seating capacity of twenty, and the menu is abundant, and first-class in every respect. The house has been established four years, C. F. Smart being the proprietor, and during that time has become favorably known to the public.

Winfred A. Torrey is the postmaster in South Braintree, whose appointment dates back to 1885 . He is a native of the town, having been born there in r860, which places him among the youngest postoffice officials in this section. $\mathrm{He}$ is proprietor of a well known drug establishment, having succeeded in $\mathrm{r}_{8} 8$ Elias Hayward who founded the business many years ago. He has been a very successful business man, and his drug store receives the largest share of patronage of any in the vicinity. He is always interested in town affairs and his management of the postoffice here has been most satisfactory to all concerned.

J. R. Hathaway, the station agent at South Braintree is a conscientious man in serving the road, and is very popular with the patrons of the, same. He has been in the employ of the Old Colony Railroad in different departments continuously for twenty-two years, and has been station agent at South Braintree for ten years.

F. J. Powers is the ticket agent at South Braintree. He has thoroughly mastered telegraphy, and he combines this with his other duties.

B. H. Woodsum \& Co., of So. Braintree, are proficient in all the details of the manufacture of tacks and nails. Established eight years ago, each succeeding year has found their trade enlarged, their business to-day reaching throughout the United States and into Canada. A three-story building, $78 \times 35$ feet, with a wing measuring $50 \times 35$, fitted up with all the most improved mechanical appliances is devoted to manufacturing purposes. Six thousand pounds each of nails and tacks are produced here every week, eighteen employes being engaged in the various processes of the work. The products of the house are all of that excellence which make them of staple value to the trade. 


\section{AMBLER Ð HOBART,}

- WHOLESALE AND RETAIL DEALERS IN-

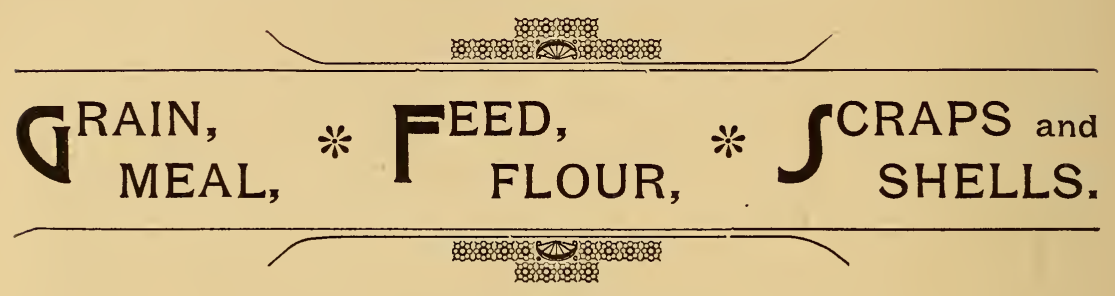

Oats and Corn Ground to Order.

Telephone
Connection. EAST BRAINTREE, MASS.

P. O, Address, Weymouth or East Braintree.

Mills at East Braintree.

L. E. FORD \& CO.,

- MANUFACTURERS OF-

TACKS \& NAILS,

Shoe Tacks a Specialty.

KINGSTON, MASS.

S L. E. Ford.

$\left\{\begin{array}{l}\text { M. W. FORD. } \\ \text { W. FORD. }\end{array}\right.$
H. C. \& W. S. COLE,

KINGSTON, MASS.

- MANUFACTURERS OF-

Tacks for Lasting Machines,

Also Shoe Tacks, Channel Nails, Etc. ****

\section{S. H. SHERMAN, \\ - MANUFACTURER OF -}

SHOE

STOCK.
Heels, Inner Soles, Sock

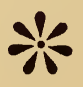

Linings, Taps, Sheet, Heeling, Etc.

P, 0. Box, 522.
Factory: watre street, EAST WEYMOUTH, MASS. 


\section{SOUTH SHOHE BRANCH.}

\section{EAST BRAINTREE.}

T

HIS is a fafming section of the town of Braintree, from the hills surrounding which fine views of the valley of the Monantiquat river may be had. It has the best of accomodations for summer sojourners, increasing numbers of whom are yearly attracted by its quiet and restful scenery and fine tishing grounds.

L. O. Crocker invented the Crocker Punch in the year I 865 , and from that time to the present it has been called the best punch in the market. As a proof of this we call attention to the fact that it is used all over the civilized world, standing the test for twenty-four years. Another evidence of its superiority is the fact that it is imitated by other manufacturers and called the Crocker Punch, but all such are infringements. The true Crocker punch is made only by him and stamped L. O. Crocker, East Braintree, Mass. Over seven hundred patterns are in use by the Boston \& Maine Railroad. Mr. Crocker is also agent for the Yost typewriter, which is considered the ideal typewriter on the market to-day. Railroad corporations are using this machine in preference to all others.

Ambler \& Hobart are located on Shaw street, East Braintree. This house has been established for many years, and always enjoyed an extensive business throughout Braintree and the surrounding towns. They are engaged as wholesale and retail dealers in grain, meal, feed, flour, scraps, shells, hay and straw. A specialty is made of oats and corn ground to order. The mills are fully equipped with all necessary appliances including the latest improved machinery. Six experienced workmen are engaged as help, and four horses and teams are kept continually on the road delivering orders. Mr. Ambler is a gentleman of experience and industry, and this is well known in and around Weymouth, although the business plant is located in E. Braintree. He devotes his undivided attention to the work at the mills.

\section{WEYMOUTH.}

The town of Weymouth is a busy section, industrially, with an element of progress strongly marked in all public and private undertakings. It is situated at the southerly extremity of Boston Harbor, in the northeasterly section of Norfolk county. An arm of the sea, called the Weymouth Fore river, separates the territory from Quincy and partly from Braintree, which form the western 
ESTABLISHED 1866.

J. W. HART \& 60,

- - manufacturers of . .

\section{MEN'S * FINE * SHOES.}

WEYMOUTH, MASS.

Boston Office: 28y Devonshire Street.

\section{GEO. H. BICKNELL,}

- MANUFACTURER OF -

Men's Boys' and Youths'

COUNTERS, HEELS AND INNER SOLES.

\section{WEYMOUTH, - $\quad$ MASS. \\ FORE RIVER ENGINE CO., \\ QUINCY AVE., WEYMOUTH, MASS.}

Builders of STEAM YACHTS and TOW BOATS.

Simple High Pressure, Compound Condensing, and Triple Expansion . . . . MARINE and STATIONARY ENGINES.

Exceptional facilities for Marine Repairs,

MARINE RALLWAY. . • .

SURFACE CONDENSERS, IRON, BRASS Or COP-

PER SHELLS designed with special regard to lightness. . . .

-PROPELLERS OF ALL STYLES AND SIZES OF CAST IRON OR BRONZE.-

Makers and Local Agents for PER- .

FECTED PROUTY PRINTING PRESS.

MILL WORK and MACHINE REPAIRS of all Descriptions.

STEAM AND HOT WATER PIPING.

Complete stock of PIPES and FITTINGS constantly on hand, also OIL and WASTE. Large assortment of SHEET RUBBER, SHEET ASBESTOS and ROD PACKING. BOLTS and NUTS. IRON and STEEL. BELTING and BELT LACING. 
boundaries; and another arm, called the Weymouth Back river, separates it from Hingham, which is the boundary on the east, both bodies of water being nearly three miles in length and receiving strearns as their interior formation. That on the east, the outlet of Whitman's pond, near the centre of the town, has an area of 240 acres. This receives the outlet of Great pond, in the southwest part of the town, which contains about 280 acres, aud has a pretty island in the centre. In 1623 Myles Standish made a terrible attack upon the assembled Indian chiefs in this town, and a year later a company of colonists from Weymouth, England, settled here and gave it the name of the place from whence they came. Weymouth village has a population of 4,000, a national bank, one savings bank, many fine estates, good schools and churches, and is a most desirable section for permanent or summer homes. It is on the South Shore of the Old Colony system, 12 miles from Boston.

The South Shore Branch of the Old Colony Railroad runs through the northern part of the town, having a station at Weymouth Landing, a station at North Weymouth, and one at East Weymouth. The postoffices are Weymouth (village and Landing), Weymouth Centre, East, North and South Weymouth. Other villages are Lovell's Corners and Old Spain.

The Fore River Engine Co., which business was formerly carried on under the name of F. O. Wellington \& Co., is located on Quincy avenue, Weymouth. The premises cover fifteen thousand square feet of floor space, comprising machine, pattern, boat, joiner, and blacksmith shops, wharf and marine railway. A specialty is made of steam yachts and tow boats, and a full line of marine and stationary engines is made. They are also builders of the celebrated Prouty Job Printing Press. All kinds of machinery are designed, constructed and repaired. The marine business last year included a 90 foot tow boat, and 10 steam yachts varying from 60 to 130 feet in length. The business was established in I 885 and has been steadily on the increase. Sixty mechanics find constant employment. The proprietors are T. A. Watson and F. O. Wellington, both prominent citizens.

J. W. Hart \& Co., are manufacturers of men's fine boots and shoes on Hunt street, Weymouth, where they were established in I866. The premises occupied by them are commodious, comprising three stories and a basement, where every convenience and facility are employed by them to transact a large and active business. They give employment to one hundred hands who turn out three thousand pairs a week. The members of the firm are active, progressive business men.

George H. Bicknell, located on Congress street, Weymouth, is well known as a manufacturer of men's, boys', and youths' counters. He started in business in 1870 , and has built up a large and successful trade, extending throughout the United States. A three-story frame building is occupied, where steam power is used and constant employment is given to seventy-five experienced workmen. Having had an experience of twenty-two years, he is well versed in all branches pertaining to his business. All orders by mail receive prompt and careful attention. 


\section{BAY STATE "PERFECTION” HAMMOCKS.}

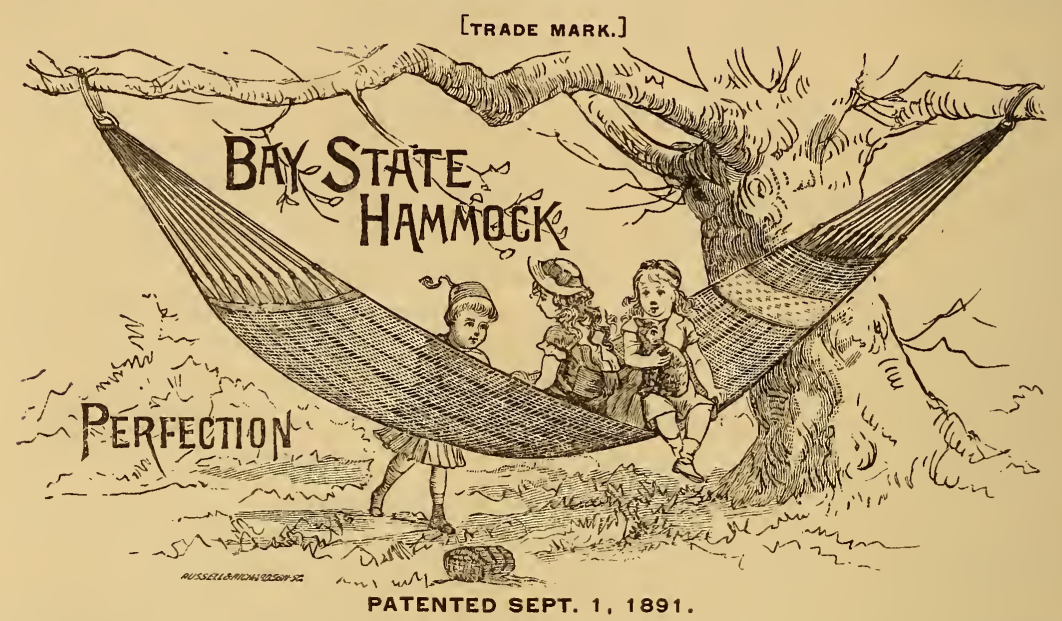

The most beautiful and strongest Hammock in the market. . . Woven bodied. Small opening. ... Cannot pull off the BUTTONS from the clothing. ... These Hammocks have a curved Spreader in one end. . . Manufactured by

BAY STATE HAMMOCK CO., - No. WEYMOUTH, MASS.

\section{GEORGE W. BURR,}

[Successor to DANIEL BASSETT.]

\section{COAL, WOOD, HAY \& STRAW,}

Prepared Wood Constantly on Hand.

OfFICE ON SUMMER ST.. HINGHAM HARBOR. P. O. ADDRESS, BOX 402, HINGHAM, MASS.

LINCOLN BROS.,

- DEALERS IN -

COAL \& WOOD.
All Kinds Coals for Family Use.

Hard \& Soft Wood, Sawed \& Split, or in Clift, constantly on hand.

DEPOT AVE., COHASSET, MASS. 


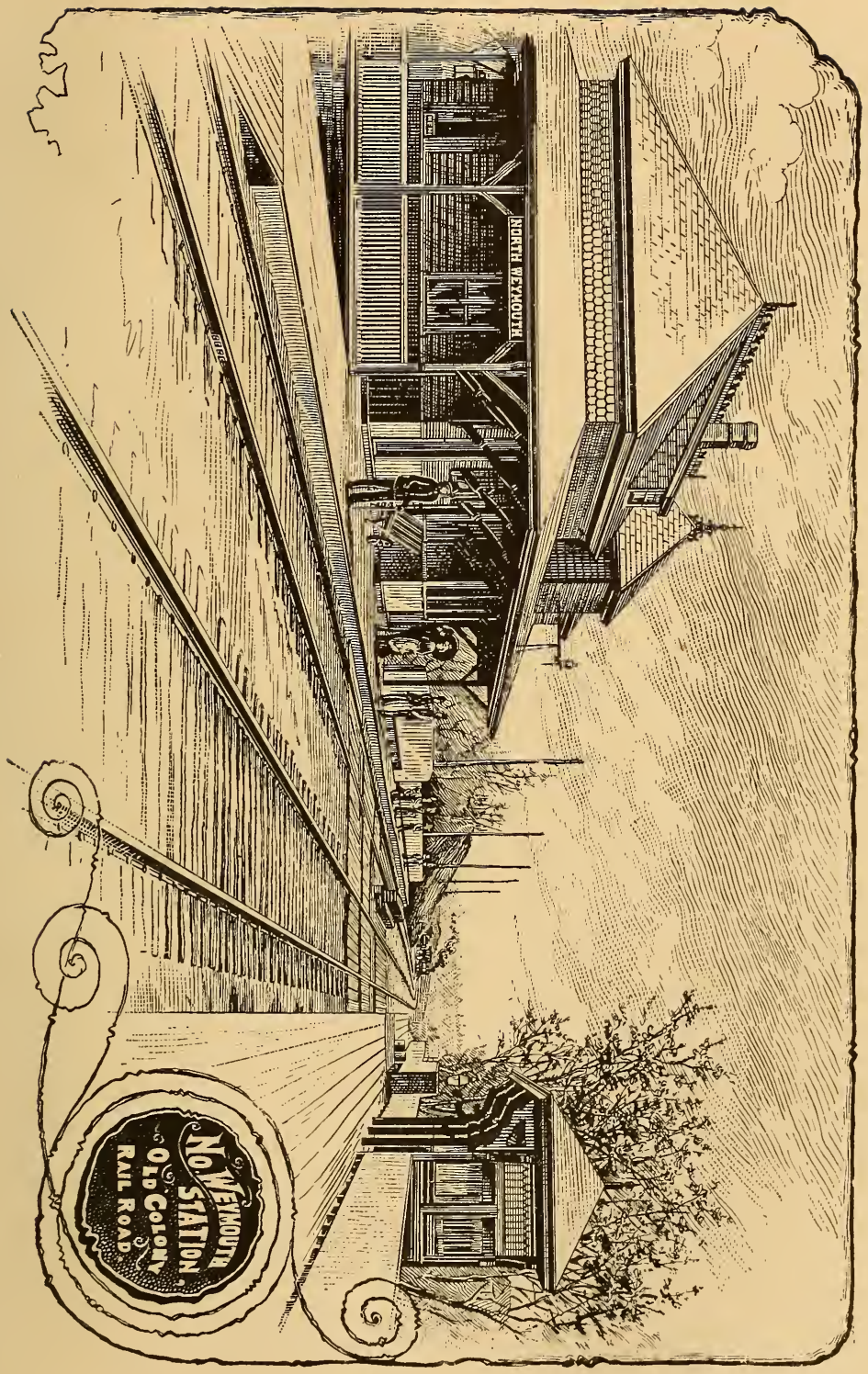



NORTH WEYMOUTH.

A growing and enterprising village of the town, 13 miles out from Boston on the South Shore of the Old Colony system, commanding an excellent view of the harbor and its islands and possessing every requisite for business or residence. It has a population of nearly 2,000 , five schools, four churches, a good fire department, excellent drainage, good water, and accomodations for large numbers of people who each recurring summer make this a place of resort.

The Bay State Hammock Company is located on Sea street, North Weymouth, Augustus Beals being the proprietor. The productions of this company consist of the Perfection Hammock and a general variety of woven articles. A two and a half story frame building, in dimensions thirty by fifty feet is occupied which has every convenience for making fifteen thousand hammocks per year, which are sold throughout the United States as well as in Australia, England and Canada. Mr. Beals has had a long experience in the business, his goods are well known and all hammocks and other articles are sure to give perfect satisfaction.

\section{EAST WFYMOUTH.}

An important village of the town of Weymouth, I 5 miles from Boston, containing 3,500 inhabitants of an enterprising and industrious character. The village has a savings bank, ten public schools, one private school and four churches, an excellent water supply, and all the modern conveniences which go to make life attractive. Like all other districts of Weymouth its principal industry is the manufacture of boots and shoes, several of the largest factories being located here. At this place are also quite extensive iron works.

S. H. Sherman, whose factory is located on Water street, East Weymouth, is identified as a manufacturer of shoe stock. The enterprise was started in I 880 and has been successful from the beginning. A large trade has been established extending to all parts of New England. The premises consist of a factory building 2 I-2 stories in height, 130 by 32 feet in width, and a storage building $90 \times 100$ feet. Both steam and water power are used and employment is given to fifty hands. The house manufactures heels, innersoles, sock linings, tops, sheet heeling, etc., and the goods have a well established and deserved reputation throughout the trade.

Edwin Clapp succeeded in 1883 to the business founded by J. H. Clapp in 1857. The work consists in the manufacturing and designing of the finest grades of boots and shoes for gentlemen. A frame building is occupied which is six stories high in front and four stories in the rear. Steam power is used at the works, and three hundred diligent hands find constant employment here. The products are sent all over the country. Mr. Clapp pays special attention to novelties of personal designs, also all the standard styles in men's fine footwear from the best selection of stock. Three thousand pairs of boots per week are produced, including enamelled, cordovan, kangaroo, French, and American calf. 
The Hotel Derby is very pleasantly located at the corner of Shawmut and Broad streets, East Weymouth. The proprietress is Mrs. Joseph N. MaDan, who has run it successfully for over a year. The hotel is a two-story frame house, with a pleasant, spacious piazza in front. It contains twenty-one ronms. The sleeping apartments are beautifully furnished, and are fitted out with all modern improvements. The spacious dining hall is also elegantly furnished. The table is first class, the meat, fish, poultry, vegetables, fruit, etc. being the best that the market can offer.

\section{WEST HINGHAM.}

A village and station of Hingham, I 6 miles from Boston, rural and attractive in its scenery. It has good accommodations for summer visitors, and is noted for its smelt fishing in the season of that sport.

\section{HINGHAM.}

The town of Hingham dates its settlement from 1635, and is one of the oldest in New England. It is a place of great historic interest, being the burial place of Massachusetts' noted war governor, John A. Andrew, who resided here for many years; and possessess the oldest occupied church in the United States, the edifice being over two centuries and a half old. It has a population of about 5,000 ; churches of nearly every denomination; ten excellent schools (Derby Academy and the Keble Seminary being among the number) a national and a savings bank, two hotels, and fine accommodations for summer visitors, there being upwards of sixty cottages for the the exclusive benefit of this latter class of residents. The water supply is rated the second best in the state. Hingham is justly regarded as one of the most beautiful shore towns, and has the best of drives, good fishing. boating, etc. In addition to its agricultural interests the town has manufactories of cabinet ware, cordage, wooden ware boots and shoes, upholstery trimmings, building materials, worsted goods, - woven, knit and hand-made - iron castings, hatchets, leather and other articles. A little attention is still given to the fisheries. The other station on this branch in the town of Hingham is the Old Colony House, and the villages are Hingham Centre, South Hingham, Downer Landing, Glad Tidings, Palin, Liberty Plain and Queen Anne's Corner.

The Cushing House, of which George Cushing is the proprietor, is among the noted hotels of Hingham. The house is conveniently located directly opposite the depot. It was established in 1876 , and offers unsurpassed accommodations for transient and permanent guests. The house is a three-story frame, pleasantly situated, and is in all a very quiet and comfortable hotel. It contains fifty rooms, clean and spacious. They are well furnished, and fitted up with all modern conveniences. The table is first-class, abundantly supplied with the best food that the market can offer. It is carefully prepared and served by attentive waiters. A large stable is connected with the house, and recently an addition has been made to it, the whole covering an area of one 
hundred feet square. The house also has been refurnished and remodeled throughout. The house has the reputation of being the best in this vicinity. Carriages and barges are let for all occasions and are at the depot on the arrival of the trains and at the wharves on the arrival of the boats. There is also a telephone connection with Boston.

Geo. W. Burr became the proprietor, in 1890 , of the business established by Daniel Bassett many years ago. He is engaged as a dealer in coal, wood, hay and straw, making a specialty of prepared wood which is constantly on hand. Mr. Burr is well known in this section and enjoys the esteem of the public. His trade extends throughout Hingham and surrounding towns, and is principally retail. The house is conveniently located on Summer street of this town. It embraces ten coal bins, each capable of holding two hundred and fifty tons. Six men are engaged as help, and five teams are kept busy delivering orders.

\section{NORTH COHASSET.}

A village and station in the town of Cohasset, 19 miles from Boston, a description of which is included in that of Cohasset.

\section{COHASSET.}

No other town on the seacoast of New England is entitled to more consideration as a summer resort than Cohasset. Of late it has attracted many wealthy people, as well as some high up in histrionic art, such well known names as William Crane, Stuart Robson, and the late Lawrence Barrett appearing among the list of residents. On the famous Jerusalem Road, which overlooks the bay, are many costly structures, the residences of people of wealth and high social position. The shores along the town are rocky and precipitous, against which the Atlantic dashes with incessant roar, mariners being warned of the dangers of the coast by one of the most famous lighthouses in the world - "Minot's Ledge Light." Back from the seashore the town abounds in gently-rising hills and fertile valleys, affording areas for cultivation and dairy farming. Cohasset has excellent schools, churches, and a savings bank, and is provided with all the modern conveniences which those of wealth and high social standing naturally demand. The place is growing rapidly every year on account of the innumerable advantages offered for sporting, gunning, fishing, bathing, and fine drives, as well as the magnificent stretch of marine view to be had from its craggy and rock-strewn shores. Its population in I890 was 2,448. North Cohasset and King street are stations in this town.

Tower Bros. \& Co. were established on Border street, Cohasset in I 858 . They are engaged as dealers in coal, building material of all kinds, groceries, white lead and oil, ready mixed paints, and yachting outfits. Their spacious premises comprise eight buildings, covering about one acre of ground. Their coal bins are capable of holding one thousand tons. They enjoy an extensive trade but it is chiefly retail. The members of the firm are gentlemen of business tact. 
Lincoln Bros. are well known as they have been established opposite the depot in Cohasset since 1879. They are engaged as dealers in coal and wood of all kinds for family use. They enjoy an excellent business in Cohasset and surrounding towns, but it is principally retail. A specialty is made of hard and soft wood, sawed and split, or in clift, which is kept constantly on hand. Their spacious apartments include nine coal bins holding an average of eight hundred tons each. Five hands are here kept busy, aided by three horses and teams. Lincoln Bros. have been residents of Cohasset for many years.

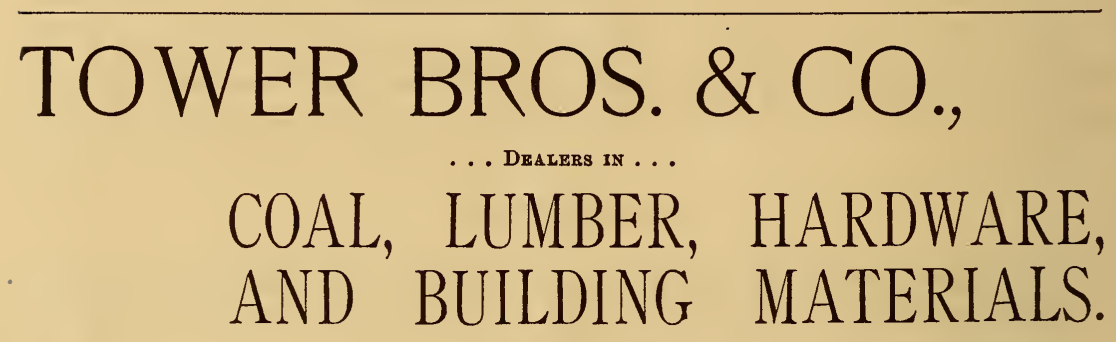

Grocin's White Lead \& Oil; Ready-Mixed Paints \& General Outfits.

Offices and Wharves: BORDER ST., COHASSET, MASS.

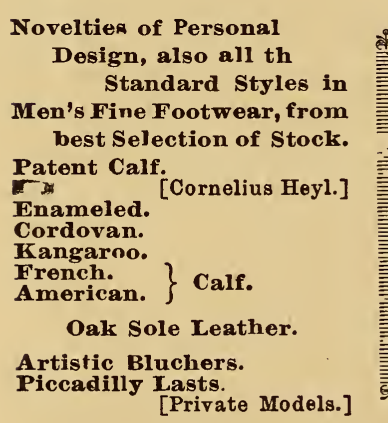

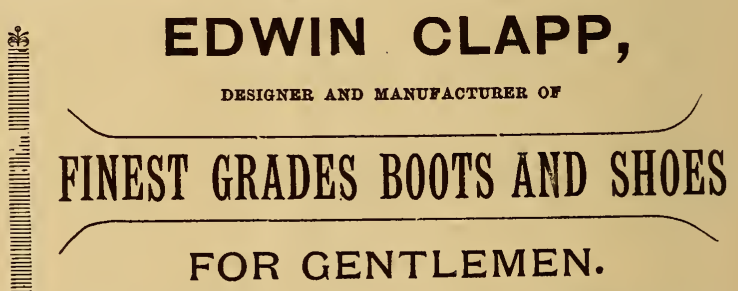

EAST WEYMOUTH, NO. 98 SUMMER ST. MASS.

ADDRESS CORRESPONDENCE TO EAST WEYMOUTH.

\section{PATUXET HOUSE,}

A. B. Lucas, Proprietor.

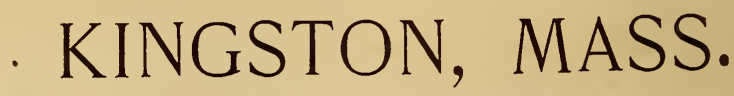

A pleasant and comfortable resort for transient or permanent guests.

TERMS: $\$ 1.50$ to $\$ 2.00$ PER DAY. A Free Carriage for Guests * * * Depot. 


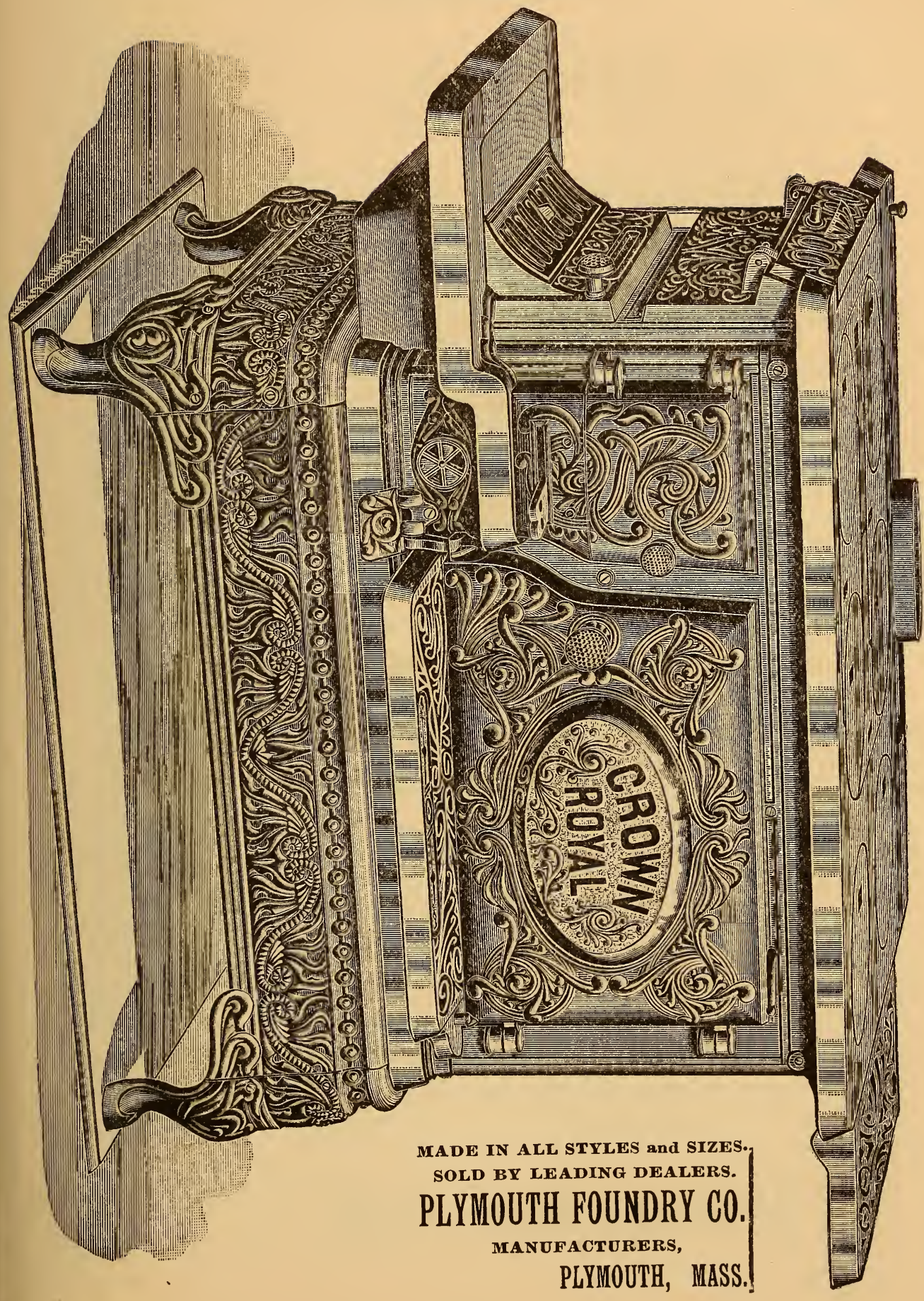




\section{The Atlantic.}

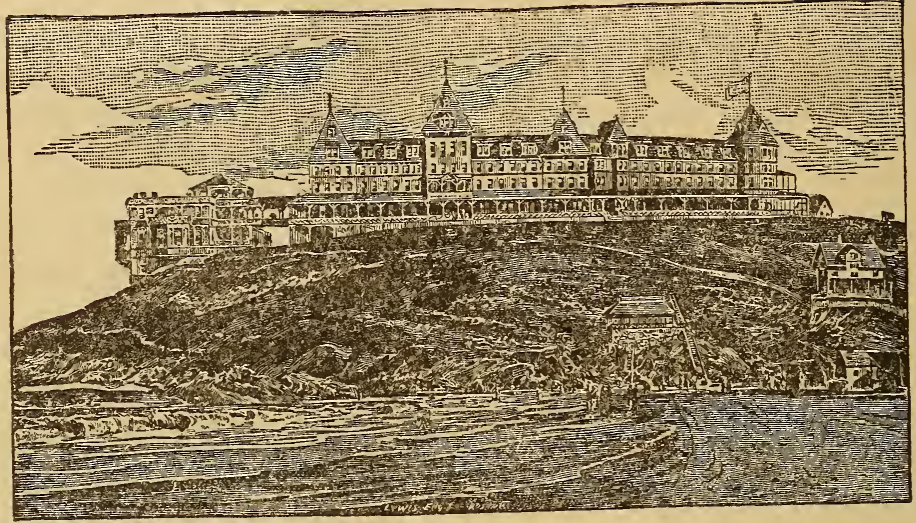

. Situated on Atlantic Hill, one hundred feet above sea level, overlooking the ocean, and the famous stretch of Nantasket Beach. Patronized by the best people. Location unsurpassed on the New England coast. Scenery both marine and landscape, unvivalled in picturesque beauty. Temperature cooled by never failing ocean breezes. Excellent facilities for surf bathing, boating, fishing, driving and tennis. Frequent hops. Most careful attention paid to drainage and all sanitary arrangements. . . . . . Thirteen miles from Boston, reached by modern steamers of the Nantasket Steamboat Co., (hourly from Rowe's Wharf) and by rail via O.C.R.R.

\section{Damon's Sons, Prop's.}




\section{NANTASKET BEACH BRANGH.}

\section{HULL.}

HIS is one of the most picturesque and unique towns in the vicinity of Boston from which it is nine miles distant by water and twenty-two by land. The Nantasket Beach Branch extends from the Old Colony House station in Hingham to Pemberton Point, where it terminates directly in front of the Hotel Pemberton. Hull is the smallest town in Plymouth county, of which it forms the extreme northwestern point, and the sniallest but two in the entire state, having a population of something less than $\mathrm{I}, 000$ permanent residents. Its yachting facilities are unsurpassed, and it has one of the best equipped and largest yacht clubs in this country.

\section{NANTASKFT BEACH.}

This is the second station on the branch, and is justly styled the "Coney Island of Boston." A fine stretch of beach runs along almost the entire sea front of the promontory, affording a most excellent drive and unsurpassed facilities for bathing. The scenes on this beach during "the season" are of the most animated character, 50,000 visitors in a single day being a not unusual number in warm weather. Immense summer hotels have been erected in close proximity to the waters edge, from the ample piazzas of which the visitor can behold a broad stretch of ocean scenery, witness the variuus sports along the beach, or listen to the music of the numerous bands which discourse the most popular airs of the day, from morning until the late train and the last boat departs well into the night. As the width of the promontory is but a few hundred yards at its greatest width, all the most prominent attractions of this great breathing place are but two or three minutes' walk from the railroad station and steamboat landings, the more inaccessible parts of the village on the hill being reached by frequent trips of the street railway. Nantasket is famous for the excellence of its fish dinners and clambakes, and the great facilities it affords for recreation at the seashore at an outlay within the means of the .niddle classes, and is the popular resort of tens of thousands of artisans, mechanics and wage earners from the surrounding cities and towns.

The entire town of IIull is dotted with summer cottages, which are reached from the stations already indicated and those at Weir River, Surfside, Kenberma, Waveland, Bayside, Point Allerton and Stony Beach. 
The Atlantic House is one of the very best hotels situated on Nantasket Beach. It is situated on a hill so that a view can be had of the surrounding towns, and facing the beach as it does it gives its guests an excellent opportunity to witness the breaking of the waves as they dash on the beach. It has a wide piazza all the way around, where the cool breezes from the ocean can be enjoyed in a comfortable way. It was opened in I867 by L. Damon's Sons, and their reputation as hotel managers is known far and wide; they are also managers of the well known Thorndike and Huntington hotels in Boston. The Allantic is furnished nicely throughout; the accommodations are of the best and there is room for five hundred guests. A large corps of hands is employed to the number of one hundred and seventy-five. The stable is one of the best, coaches and barges connecting with all boats and trains and pleasure teams can also be had. The hops given at this house are patronized by the best class of people. The hotel is open from June till October.

The Hotel Nantasket at Nantasket Beach, of which E. F. Sturgis is the proprietor who has the reputation of keeping a well and nicely furnished house. Every endeavor is made to meet all demands for the comfort of his patrons. The hotel has accommodations for three hundred and fifty guests. A corps of two hundred efficient assistants is engaged. A fine view of the beach and all its attractions can be obtained from the piazza of the hotel. This hotel has many attractions for the summer tourist. The Rhode Island clam bakes of this hotel have become famous, and its patronage is increasing every year.

\section{HENRY SAWYER, TREAS. \\ R. S. DOUGLASS, AGT}

\section{PLYMOUTH WOOLEN CO.,}

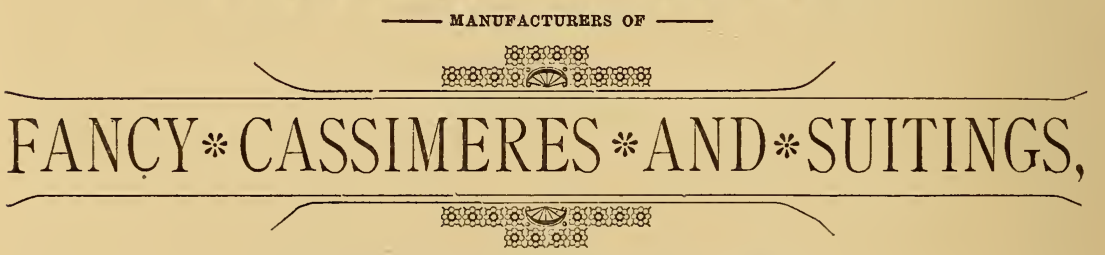

PIYIMOUTEI, MASS.

\section{Old Colony Steam Laundry, sana:gess}

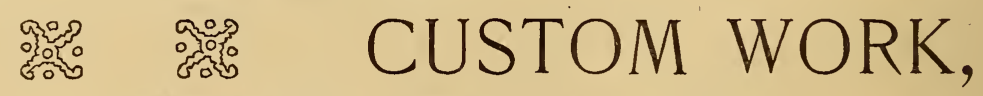

POLISH OR DOMESTIC FINISH.

ALL CLOTHES DRIEU IN THE OPEN AIR.

18 HOWLAND ST., PLYMOUTH, MASS.

CASEY \& SAMPSON, PROPRIETORS.

JAMES M. CASEY.

FRED. A. SAMPSON. 


\section{DUXBURY AND COHASSET BRANCH.}

SCITUATE.

T

HIS tine old shore town is becoming famous as a resort for high-class professional people, several of whom have elegant summer homes here. It is about 25 miles southeast of Boston, and looks out upon the bay through a wide harbor-mouth near by. Its shores rise into a succession of sand cliffs, which form land marks for mariners, as well as objects of interest in its scenic appointments. The town has some fine estates, excellent sanitary conditions prevail, educational facilities are provided by ten schools, while church-goers have the option of half that number of denominations, each worshipping in edifices of their own. There are fine locations along the shore for summer camping, with good boating, bathing and fishing in the bay. The manufactures of Scituate are quite diversified and consist of boots and shoes, readymade clothing, carriages, leather polishes and dressings, lumber, metallic articles, etc. Its population is 2,318 .

\section{NORTH SCITUATE.}

This is a shore village of great attractiveness, located within the town of Scituate. It has good accommodations for summer sojourners, who largely augment its population each year. It is a growing locality, and being near the bay shore, affords every facility for entertainment and pleasure. Its sanitary conditions are well nigh perfect, and it is noted for the large amount of Irish moss which is annually collected for the market, in which product it is unsurpassed anywhere on the Atlantic seaboard.

EGYPT.

Another village of Scituate town, noted as a growing summering place, and as possessing many attractions of land and ocean scenery. The chief industry of Egypt is farming, the land being particularly adapted to this important pursuit, and a ready market for such products is provided in the great influx of visitors who yearly make this a place of resort.

\section{GREENBUSH.}

This is a most interesting village and station of Scituate, and attracts many sojourners, not only on account of its natural beauty, but as the place where Samuel Woodworth received that inspiration to write that world-known song. 
"The Old Oaken Bucket." In its vicinity is excellent fresh water fishing and good gunning in the season of that sport.

The several stations of the town of Scituate are Beechwood, Greenbush, North Scituate, Egypt, and Scituate.

\section{MARSHFIELD.}

This town is best known as the home of America's famous orator and statesman, Daniel Webster, whose house on the farm which he long occupied and often tilled with his own hands, still stands, and which is yearly visited by thousands of tourists, and summer visitors to the various resorts with which the town abounds. It is a beautiful seaboard town, in the northeastern part of Plymouth county, largely devoted to agriculture, although it has several shoe manufactories, five saw mills, three shipyards, a musical instrument factory, tanneries, iron foundries, carriage shops, ete. Its seaside resorts are rapidly growing, each year attracting many sojourners from all parts of the country to enjoy the fishing, boating, bathing, and gunning to be found along the shores. Many interesting anecdotes of Daniel Webster are recorded, one of which, showing that Boston sportsmen visited that locality at an early date in pursuit of game, is worth the telling. Webster was one day engaged in mowing a piece of marsh land on the border of a small stream which run through his farm, when he was accosted by a dude sportsman from the Hub with: ". Say, old man, blessed if I don't give you a shilling if you'll carry me across the creek." The great statesman at once accepted the offer, and, barefooted, waded the stream with the dude on his back, landed him safely on the other side, and pocketed the shilling with many expressions of thanks. When the sportsman reached the highway, a neighbor of Webster who had watched the performance with no little amusement, asked the Boston man if he knew who it was that liad taken him across the stream in such a unique fashion. Receiving a negatire reply from the passenger, it is said the latter nearly fainted with shame and astonishment upon being informed that his ferry was none other than the famous United States Senator.

The town has a resident population of about 2,000 , the stations within its limits being Marshfield Hiils, Sea View, Marshfield Centre, Marshfield, Green Harbor, (formerly Webster Place, the last named being near the old Websterhomestead.

\section{DUXBURY.}

Duxbury, one of the oldest and most notable towns of the state, is situated midway of the eastern shore of Plymouth county. It is 38 miles southeast of Boston, and about 8 miles north of Plymouth, from which it is separated by the town of Kingston and Plymouth Harbor. Its bounding town on the west is Pembroke, on the north and northeast, Marshfield, and on the east are Duxbury Bay and the ocean. The railroad stations are Duxbury, South Duxbury, and Island Creek; these and West Duxbury are postoffices; the villages are Ashdod, Crooked Lane, High Street, Mill Brook and Tinkertown. Duxbury is famous 

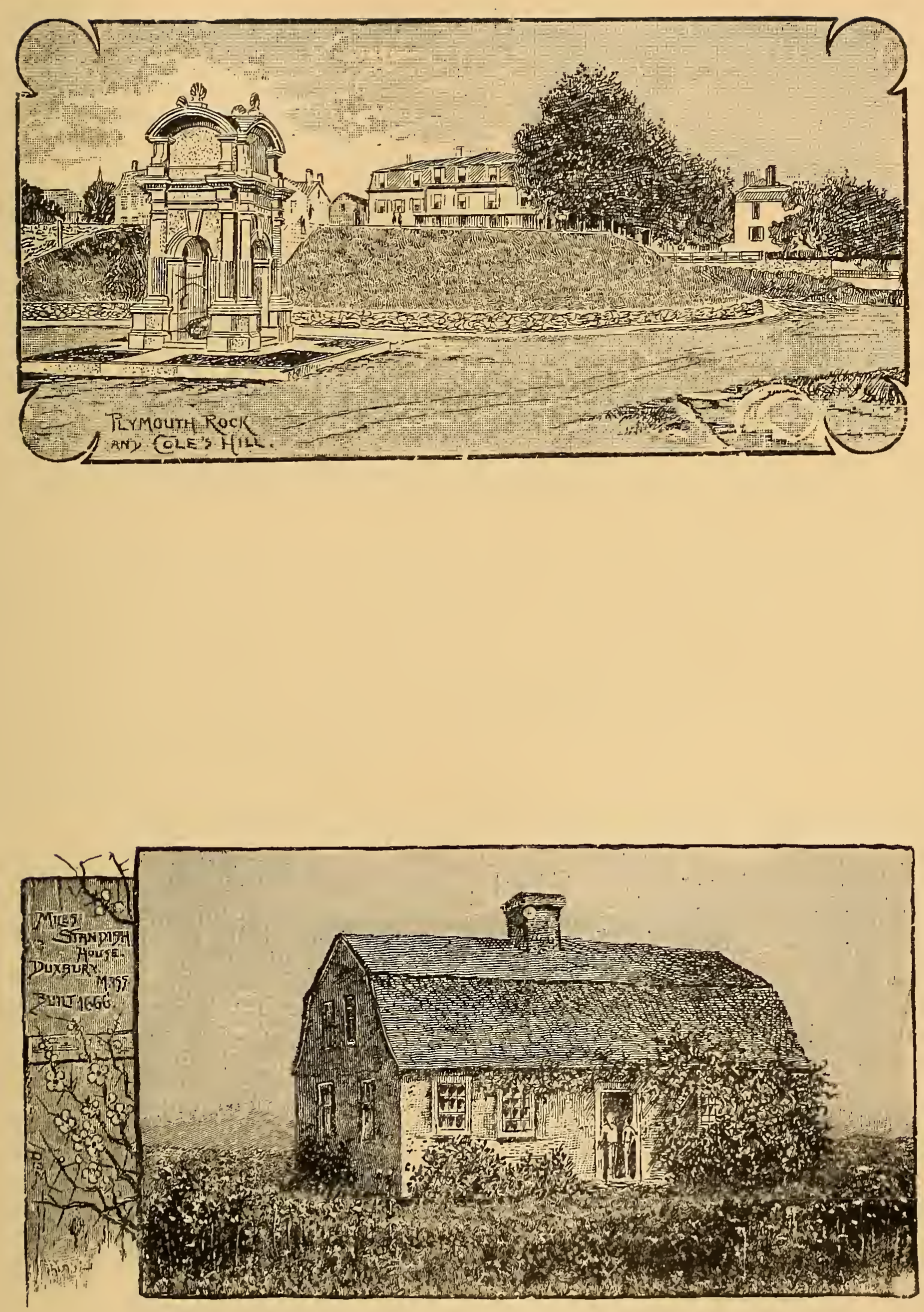

as one of the chief places in the history of the early colonists, as it was here that John Alden, the youngest of the Pilgrims, settled, and the house built by him nearly two centuries and a half ago, is still standing. Population of town, I $890,1,908$.

\section{SOUTH DUXBURY.}

This is an interesting village in the town of Duxbury, and famed as the residence of Capt. Miles Standish, a monument to whose memory and heroic deeds stands on Captain's Hill, near the foot of which he resided. From the summit of this hill fine views may be had of Duxbury bay and its shores, as well as of Plymouth Harbor and its shores, enabling one to trace the course of the Mayflower from the outermost points of Cape Cod to her moorings in the Cowyard off Plymouth.

Island Creek is also a village and station in the town of Duxbury, and a place of much scenic and historic importance.

\section{KINGSTON}

Kingston is an ancient seaboard town in the easterly part of Plymouth County, 33 miles southeast of Boston by the Old Colony Railroad. On the north are Pembroke and Duxbury, on the east, the latter and Kingston Bay; Plymouth lies on the southeast, and Plymouth and Halifax on the southwest and west. The manufactures are quite numerous, consisting of hollow ware, rivets, tacks, carpenters' boring implements, and other iron and steel goods, also lumber, wooden boxes, cotton thread, cordage, leather, shoes, woolen goods, clothing, food preparations, and stone.

The town has a good harbor for small vessels, which opens into Duxbury and Plymouth Bay. Silver Lake (formerly Jones River Pond) is partly in the northwestern corner, and partly in the towns of Pembroke, Halifax and Plimpton, adjoining. The bed rock of this town is principally granite and sienite. Veins of volcanic trap are thrown up in some localities almost like the walls of masonry, especially at the "Devil's Stair," near rocky nook in the southeast. The soil is red loom, intermingled with sand and gravel. The population of Kingston in I 890 was I, 659 .

L. E. Ford \& Co., manufacturers of shoe tacks and nails, stand as high as any house in the trade. The business has always been conducted upon the strictest principles of fairness, to which the firm owe their great success. Their business was established in $\mathrm{I} 884$, and their works comprise two floors in two different buildings, in dimensions $80 \times 25$ feet and $18 \times 22$ feet respectively, containing improved machinery to facilitate the work and where some ten skilled operatives find constant employment. The shoe tacks and nails manufactured by this house, are equal to any in this market, and they have established a reputation for the firm which would be hard to excel. The trade of the house extends to ail parts of the country and is constantly increasing. The members of the fir'm are L. E. Ford and M. W. Ford.

The Patuxet House is a most agreeable and pleasant resort for transient or permanent guests, and the house is at all times comfortably filled with the best 
class of people. The house is finely situated and is a large building, three stories in height, and contains twenty-five comfortably furnished rooms, which are well lighted and ventilated. Attached to the hotel is a well equipped sale and livery stable, which contains some fifteen horses, and a number of fine turnouts. Mr. A. B. Lucas, the proprietor, is a gentleman who thoroughly understands catering to the wants of his patrons.

H. C. \& W. S. Cole, some twelve years ago, engaged in the manufacture of shoe tacks of every description, since which time they have succeeded in establishing such a reputation for their goods throughout New England, that they now have thirty-four tark machines in constant operation and furnish employment to a number of workmen. Their factory located at Kingston comprises the second floor of a building covering an area of I IO $\times 28$ feet, which is thoroughly equipped to meet all the demands of an annually increasing trade.

George H. Bonney, Jr., the postmaster at Kingston, is popular with the townspeople as he is alway on the alert to improve upon Uncle Sam's system of delivering and receiving the mails. He has been in the employ of the government since 1889 and is a native of Kingston, where he is well and favorably known.

J. E. Frizzell, who acts in the eapacity of station agent, has been with the road about four years and during that period he has gained the good will of his employers and the patrons of the road.

\section{Rockland Company,}

- . manufacturers of . .

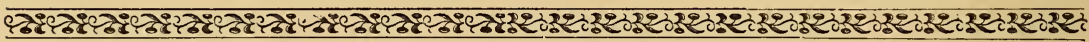
$*$ MEN'S $\triangle$ FINE $\triangle$ SHOES,*

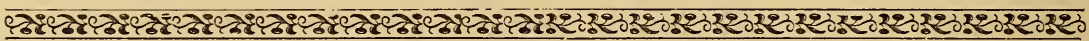

292 Devonshire Street, BOSTON, MASS.

Wm. H. BATES, President. HENRY M. CURRIER, Vice-Pres. Wm. P. TAYLOR, Treas.
FACTORY AT ROCKLAND, MASS. 


\section{PLYMOUTH ROAD AND HANOVER BRANCH.}

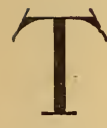

HE Plymouth Road traverses the central portion of Plymouth county, via South Braintree and the Abingtons, and is one of the oldest lines of the Old Colony system, having been opened to Plymouth in the year I 845. From Braintree to Kingston the line is inland from three to eight miles, but points of interest along the coast are of easy access. The Hanover Branch is a short spur of about seven miles in length, extending from North Abington to Hanover.

\section{SOUTH WEYMOUTH.}

This is a village of Weymouth, of about 3,000 population, and is also a shoe manufacturing centre. It has five schools, four churches, two hotels and other accommodations for summer visitors. There is good fresh water fishing and good gunning in the season of that sport. It is a rapidly developing section and contains many fine estates.

E. H. Stetson \& Co., manufacturers of boots and shoes, occupy perhaps the most prominent place in the list of important industries that have reached their largest growth and highest developement in New England. They manufacture men's fine footwear; their Boston office is located at 97 Summer street while their factory is in South Weymouth. The premises are in every way adapted to the business, and are thoroughly equipped with all the latest improved machinery for securing the best results. The superior character of the work turned out has given the house a wide celebrity, and their products are in steady and extensive demand throughout the country, particularly in New England and the West, while the trade affords evidence of constant and substantial increase every year. The members of the firm are: E. H. Stetson, A. C. Heald, and F. D. Blake. They are wide awake business men, and are popular in commercial circles.

H. B. Reed \& Co., was founded in 185 I, and the leading specialty of the house is the manufacture of tine boots and shoes. Their factory at South Weymouth is a large four-story structure, furnishing employment to two hundred and fifty skilled workmen. All the modern improvments in the way of machinery are to be found here. Sixty cases per day is the capacity of the factory, and the goods are of a superior style, a quality for which it has long been celebrated. An extensive trade is enjoyed North and South, East and West. 


\section{HEALEY \& WELCH,}

- MANUFACTURERS OF -

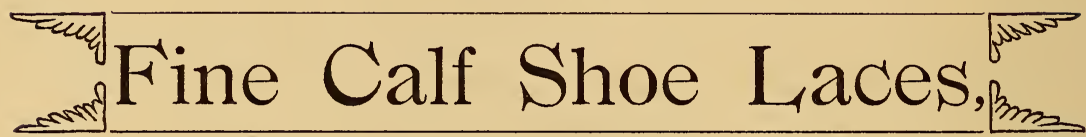

SOUTH WEYMOUTH, MASS.

R. H. HEALEY.

J. F. WELCH.

\section{THE WEYMOUTH MITTEN CO.,}

Successors to HUNT \& ELWELL.

MANUFACTURERS OF

Calf $*$ Skin $*$ Mittens, AND PALMERS OF WOOLEN MITTENS,

\section{T. F. KELLEY \& CO., \\ MANUFACTURERS OF \\ Boots and Shoes,}

SOUTH WEYMOUTH, MASS.

E H. STETSON.

A. C. HEALD

F. D. BLAKE.

E. H. STETSON \& CO., MANUFACTURERS OF

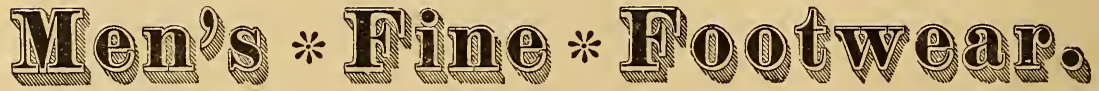
BOSTON : 97 SUMMER STREET.

Factory at 
Healey \& Welch manufacture fine calf shoe laces, being established in I 887 . They are located on Union street. South Weymouth. The building occupied by them is two stories in height and is fully equipped with all the necessary machinery. The capacity of the factory is about four hundred bunches a day. The firm consists of R. H. Healey and J. F. Welch, both of whom are well known among business men.

The Weymouth Mitten Company, of Central street, South Weymouth, has been established for the past fifteen years, succeeding the firm of Hunt \& Elwell, the proprietor now being J. F. Hunt. This company is noted for its manufacture of calf skin mittens and palmers of woolen mittens, in which it has built up a large and profitable trade. A two and one half story frame building is occupied which has all the appliances necessary to facilitate the work, while none but first-class help is employed. The goods are shipped principally to the New England states and the West.

Sidney Greenwood's business was established in I88I, and he has since built up a large and flourishing trade extending all over the country. The premises occupied for this enterprise consists of a building $30 \times 60$ feet in dimensions, having two floors. Here some seventeen skilled workmen are employed steadily the year round in the manufacture of fine calf leather laces, all the operations of the business being conducted under the immediate supervision of the proprietor, who allows no inferior article to leave his establishment. The laces are made from carefully selected calf skin stock, being thoroughly tested so that they can sustain a weight of forty pounds. The daily output of this factory which is divided into its several departments and is equipped with a full complement of necessary tools and machinery, is one hundred and fifty bunches per day, these goods being in steady demand by the trade, and the Boston market being supplied through the well known dealers in shoe supplies, G. F. Daniels \& Co., 190 Congress street; Whitcher \& Emery, 4 High street; Beals \& Co., 33 South street; Winch Bros,, 33 Federal street; Parker, Holmes \& Co., I 4I Federal street; Brooks \& Co., 97 Summer street; Ed. Young, I 57 Summer street and John D. Young, Lincoln street.

J. B. McComber is the station and ticket agent at South Weymouth. He is universally liked by the patrons of the road and does his work in a faithful and conscientious manner.

T. F. Kelley \& Co., began the manufacture of boots and shoes at South Weymouth in 1890 . Their factory embrace, 3,000 square feet of floor room, while the mechanical equipment is in no way inferior to that of any other house in the trade. Some twenty skilled workmen, under the personal supervision of the proprietors, are engaged in the manufacture of a tine grade of boots and shoes, the entire product being taken by the well-known house of $\mathrm{H}$. B. Reed \& Co.

\section{NORTH ABINGTON.}

This is a village of Abington at the northern terminus of the Hanover Branch of the Old Colony Railroad. It is largely devoted to shoe making, and is sur- 


\section{E. P. REED, оEALR IN \\ [-LUMBER • AND • BUILDING • MATERIALLS. \\ NORTH ABINGTON, MASS.}

Spruce, Pine and Hemlock Sawed to Order.

Steam Planing and Saw Mills at Ellsworth, Me.

\section{H. B. REED \& CO.,}

\section{SHOE HAKERS,}

5 High Street, BOSTON.

Factory: South Weymouth, Mass.

J. HOWARD FIELD
The Culleer House,

NORTH ABINGTON, MASS.

Refitted and Remodeled Throughout and Under New Management.

TERMS, \$2 A DAY AND UPWARdS.

Rooms Single or En Suite.

Special Inducements to Families.

CUISINE UNEXCELLED.

A Specialty Made of Private Dinner Parties, Etc. J. R. SMITH, PROPRIETOR.

WM. F. F. IYON, Manufacturer of

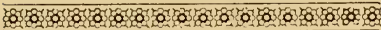

Canvas

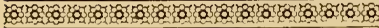

shor

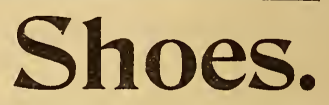

COLORED GOAT, CALF, GRAIN, BICYCLE, LAWN TENNIS - - - AND BASE BALL SHOES.

NORTH ABINGTON, MASS.

F. E. NESMITH \& CO.,

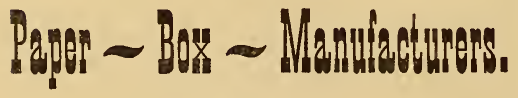

JOB PRINTING AND EMBOSSED WORK A SPECIALTY.

ROCKLAND, MASS.

Telophone Connections.
HOTEL JACKSON,

Newly Opened Nov. 1, 1890.

JACKSON \& CAMPBELL, Proprietors.

RATES \$2.50 PER DAY. Special Rates to Permanent Guests. Public Bath Room Connected.

Corner of Union and Webster Streets,

ROCKLAND, MASS. 
rounded by a fine agricultural district, with many excellent dairy farms. It is one and a half miles from the main village, and is growing rapidly.

William E. Lyon is an extensive manufacturer of lawn tennis, bicycle and base ball shoes, in which particular specialty he has gained a high reputation for the excellent finish and quality of the goods. His factory comprises a threestory structure, some $40 \times 60$ feet in dimensions, with an ell of equal height and about $40 \times 40$ feet in area, all of which is supplied with the latest and most improved machinery and appliances, and conveniently divided into various departments. Here one hundred skilled hands are employed who turn out about eighty dozen pairs per day, which find a ready sale among the wholesale and retail dealers in the principal cities of the New England and Middle States.

E. P. Reed is proprietor of one of the oldest houses engaged in the lumber trade in this section of the country. The business was established in $\mathrm{I} 845$ by A. \& A. S. Reed, afterwards A. S. Reed \& Co, who carried on a successful business till I 870 , when they were succeeded by E. P. Reed, who has succeeded in establishing a trade of large proportions. He deals in lumber, lime and cement, of which he handles large quantities annually; in lumber alone millions of feet are sold yearly in North Abington and vicinity. His yards are one hundred and tifty feet in width and one quarter mile long, where are located ten buildings containing lumber, while three other buildings are devoted to stable, mill and office purposes. The mill is a model of its kind, being equipped with all the most modern improved mill machinery, is operated by a one hundred horse-power engine, and two boilers, Some thirty hands are at all times employed, and a constant increase in the volume of business is one of the features of $\mathrm{Mr}$. Reeu's establishment. He has also two saw mills and a planing mill in operation in Ellsworth, Me., containing all the necessary appliances known to the business.

E. W. Phillips is located in convenient and commodious quarters in the M. N. Arnold building, No. Abington, where for eleven years he has been engaged in the manufacture of the latest jmproved machinery, making a specialty of engine pumps, in the construction of which great care is exercised both as regards workmanship and material. Six experienced workmen are employed under the personal supervision of Mr. Phillips, who is himself a practical machinist. A general jobbing trade is transacted by this house throughout New England.

J. R. Smith is proprietor of the Culver House, located at North Abington. a well appointed hostelry of four stories measuring $100 \times 50$ feet in dimensions, and containing twenty-five rooms which are neatly and comfortably furnished. The dining room, which has a seating capacity of forty, leaves nothing to be desired in respect to courteous attendants or first.class cuisine. A livery stable is connected with the hotel. Mr. Smith thoroughly understands catering to the traveling public, and has made the Culver House a popular resort.

H. B. Wadsworth, the station agent at North Abington, has been with the ()ld Colony road some ten years, during which time he has made himself not 


\section{WhitMan GRAIN \& COAL COMPANY,}

Flour, Grain, Coal, Hay, Straw,

— ETC., ETC.

WHITMAN, MASS.

A. S. STETSON, Manager.

GENRY W. CHANDLER, Treas.

\section{WHITMAN

The Oldest Insurance Agency in Whitman.

Do not go out of town when you can get as good if not better terms at home.

I am the authorized agent of thirtien of the oldest and best Fire, Life and Accident companies in ihe world.

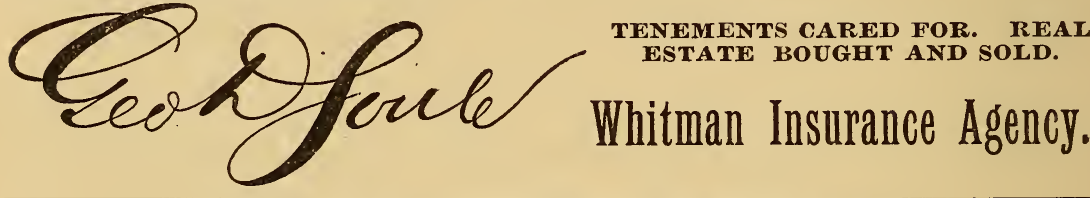

\section{ATWOOD BROTHERS,}

MANUFACTURERS OF

\section{BOOT, SHOE \& PACKING BOXES OF ALL DESCRIPTION.}

ATWOOW'S STANDARD BOTTLE BOXES. THE HONEST MILK MAN'S

SHIPPING CASE AND LOCK CORNER BOXES OF ALL SIZES.

“KANTBRAKEM" B UTTER CASE, PERHECTION EGG CASE.

B. S. ATWOOD. Proprietor.

EAST WHITMAN, MASS.

\section{SMITH \& STOUGHTON,}

- MANUFACTURERS OF-

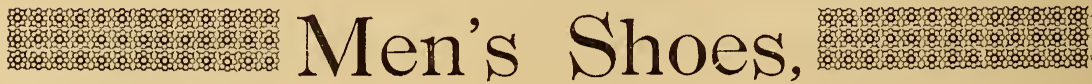

No. g' BEDFORD STREET,

FACTORY, WHITMAN MASS.
** $*$ BOSTON, MASS. 
only popular with the officers of the road, but also with the patrons of the same, and through his courtesy has won the respect of all.

\section{ABINGTON.}

Abington is an important and thrifty manufacturing town in the northwesterly part of Plymouth county, having an area of 6000 acres. Holbrook and Weymouth lie on the north, Rockland on the east, Whitman on the south, and Brockton on the west. It is twenty miles southeast of Boston, and has istations at Abington and North Abington; each of which also have post-offices. The population is over 4,000, with over 800 dwellings. The soil is in some parts very good, the farms are fairly fertile, and the dairies are among the first in the state. The chief manufactures are shoes, and the material and machinery requisite. Other manufactures are clothing, furniture, lumber and wooden goods: The people here are thrifty and the industries of the town are in a prosperous condition.

A. C. Carty is the station agent at Abington and is deservedly popular with the patrons of the road. He has been with the road for ten years, and during that period he has always attended to his duties with precision and courtesy to all.

\section{WHITMAN.}

Whitman, formerly South Abington, is a lively manufacturing town of small area, in the northwestern section of Plymouth county, 2 I miles south of Boston. The post offices are Whitman (village) and South Abington Station. Auburnville is the other village. The town is bounded on the north by Abington, on the east by Rockland and Hanson, on the south by East Bridgewater, on the southwest by the same and on the west by Brockton. Whitman has a population of 4,000 and upward, and has one of the largest tack and small nail manufactories in the United States. There are twelve schools, five churches, good hotels and boarding houses, an efficient fire department, and all the desirable features of advanced modern civilization in the make-up of the community, government, etc. Its present name was assumed when it became an independent municipality in 1885 . Whitman is eight miles from the seashore at Marshfield, and is noted as being situated among fine rural scenery.

Smith \& Stoughton, prominent boot and shoe manufacturers of Whitman, were established in I884, and to-day they enjoy a trade extending all over the United States. Their manufacturing plant comprises a four-story building covering an area of $\mathrm{I} 20 \times 40$ feet with a wing measuring $40 \times 80$ feet. Here two hundred and fifty operatives, aided by modern improved machinery, are engaged in the manufacture of men's and boy's shoes of a style and quality suited to the general trade. The Boston office is located at 77 Bedford street.

The Whitman Grain \& Coal Company was founded about five years ago and is still conducted uuder that name, with A. S. Stetson as manager, and Henry W. Chandler, treasurer. These gentlemen fully maintain the prestige of the company, for they are both thoroughly acquainted with the grain and coal 


\section{Ripley \& Bartlett, Plymouth, Mass.}

\section{IRON, ZINC AND BRASS COUNTERSUNK NAILS,}

\section{Oval Head, Round Head and shot Head HUNGARIAN NAILS.}

Grooved Head, Star Head and Square Head HOB NAILS.

Swedes Iron Tacks, Trunk and Clout Nails, Upholsterers' Tacks, Sho: Tacks, Miners' Tacks, Carpet Tacks, American Iron Tacks, Channel Nails, Iron Gimp Nails, O. H. Shank Tacks, Brush Tacks, Gimp and Lace Tacks. Manufacturers of the Celebrated Cobblers' Tapping Nails, and Countersunk and Corrugated Brass Nalls. Also Tacks made to run in the Boston Lasting Machine.

Any Varıation from Regular Sizes and Shapes Made to Order from Samp!es.

CHAS.A. SMITH,

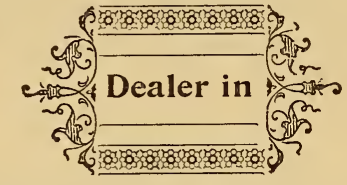

Periodicals

and Stationery,

\section{PLYMOUTH, MASS.}

Daity and IVeekly Papers Delivered at Residences.

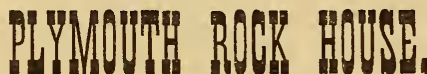

Situated on Cole's Hill, overlooking

Plymouth Rock and the Bay.

STEAM HEAT. ELECTRIC LIGHTS.

House Open all the Year Round.

C. H. SNELL, Prop'r.

PLYMOUTH, : MASS.

WROUGHT STEEL FASTENINGS

for BEDSTEADS, and . .

MACHINERY FOR FITTING.

Manufactured by

\section{BRADFORD JOIHT CO.,}

Plymouth, Mass.
Opp. R. R. Park.

2 Minutes from Depot.

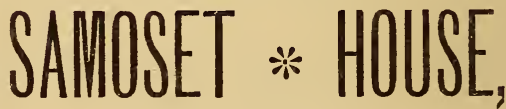

D. H. MAYNARD, PROP.

PLYMOUTH, - MASS.

Livery Stable Connected with House.

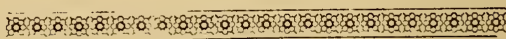

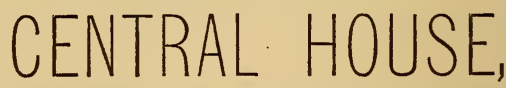

870

\section{SHIRLEY SQUARE,}

\section{Plymouth, Mass.}

A Comfortable and Well Appointed Hostelry,

E. J SHAW, Proprietor. 
tradc in all its branches, and are detcrmined to spare neither trouble nor expense, in serving their customers in the best possible manner. The company's yard and store house cover a large area, and a heavy stock of grain and coal is carried.

Atwoed Brothers, prominently engaged in the manufacture of wooden boxes of every description, was established in 1866 by B. S. and E. H. Atwood, but is now under the entire control of B. S. Atwood, his brother having retired from the business in 1879 . The manufacturing plant, comprising factory, saw mill and lumber yard covers an area of four acres, the factory proper being a four-story structure measuring $80 \times 40$ feet, supplied with every appliance in the line of modern machinery, operated by an 8o-horse power engine; water when sufficient, being also utilized. Eighty-five workmen are steadily engaged turning out boot, shoc and packing boxes of every description, also egg, butter and beer cases, which are in great demand with the trade. The daily output of the factory amounts to between 4,000 and 5,000 boxes which are shipped to all parts of the United States and Canada.

The Whitman Insurance Agency, which was founded in I 883 by George D. Soule, is one of the reliable agencies of this state. Mr. Scule has been a member of the board of sclectmen for seven years, and is now chairman of the board of assessors. He is a business man oi experience and is deservedly popular in his town and the surrounding country. The companies he represents are. among the most solid and substantial institutions in this country, and comprise fire, life, accident and plate glass insurance. Mr. Soule is a very busy man, as he is engaged in the real estate business as well as being a justice of the peace, conveyancer and auctioneer. He is also assistant postmaster at the station post-office, having been appointed in I883; and secretary and treasurer of the Whitman Co-operative Bank. He attends to his various duties with promptness and with a fairness that has gained for him many life long patrons.

James E. Bates, the postmaster at Whitman, was appointed by President Harrison the 7 th of september, I 890 . He is a man of sterling qualities and a thoroughly experienced man for the position. He is most favorably spoken of by his townspeople and he is doing his best to improve the service whenever and wherever necessary.

George A. Jones, for over twelve years with the Old Colony Railroad, is the popular station agent at Whitman, and attends to his duty in a careful and conscientious manner, thereby making himself deservedly popular with the road and its patrons.

\section{HANSON.}

Hanson is a very pleasant and industrious farming and manufacturing town situated in the northern part of Plymouth county, about 25 miles south by southeast of Boston. The railroad runs diagonally through the town, having stations at two post villages, North Hanson and South Hanson. The other village is Gurney's Corners. 'The Hanover Branch of the Old Colony Railroad has a station within a few rods of the northeast of the town. There are low hills at the 
north, three on the eastern side, and an extended elevation at the centre; but with these slight exceptions the surface is nearly a level plain. Population in I 890 , about 5000 .

\section{HALIFAX.}

Halifax lies in the central part of Plymouth county, 28 miles southeast of Boston. The Old Colony passess along its northeastern border. It has for its boundaries, Hanson and Pembroke on the north, Jones river pond and Plympton on the east, the latter and Middleborough on the south, and Bridgewater and East Bridgewater on the west. Its assessed area is 9,378 acres, about onehalf of this being more or less wooded. Excellent gunning for geese and ducks and good fresh water fishing is to be had. It lies six miles from the seashore. Population, I 890,562 .

\section{PLYMPTON.}

A farming town in the central part of Plymouth county, with a population of about 700. Has two churches, four schools, and is much admired by sojourners for its quiet seciusion and excellent sunitary conditions. In this town is losated Silver Lake Grove, comprising some thirty acres of wooded area, which has been fitted up for pleasure parties. Plympton is pleasantly situated on a commanding eminence, and Winetuxet village is upon a beautiful stream of the same name, which with all its affluents flows through the southerly part of the town, and thence through Halifax into the Taunton river.

\section{SEASIDE.}

On the line between Kingston and Plymouth is Seaside, the village being mainly on the Plymouth side, and two miles from the main village of the latter. It overlooks Plymouth and Duxbury harhors, has a population of about 500 , and the largest cordage works in this country.

The Plymouth Cordage Co. is the oldest incorporated cordage company in the United States, and is the most widely known industry of Plymouth. It was established in 1824 by Bourne Spooner, who died in I 870 , and was succeeded by his son, Chirles W. Spooner, who, having been his father's assistant was well qualified to succeed him in the management. Upon the death of Charles W. Spooner in I882, G. F. Holmes, the present treasurer and general manager, was chosen as his successor, who is thoroughly faniliar with the business and is to-day regarded by cordage manufacturers as one of the best posted and reliable men in the trade. The output of this company consists of rope, lathyarn and binder twine, which has achieved a reputation for excellence unsurpassed by any other house in this country. In their factory they are equipped with the most modern improved machinery and employ many skilled hands who have grown up in their service. The company have never departed from the policy originally established by them, of making the best quality of guods possible and have thereby won for themselves the esteem and confidence of dealers throughout the country. The officers of the company are C. W. Loring, 


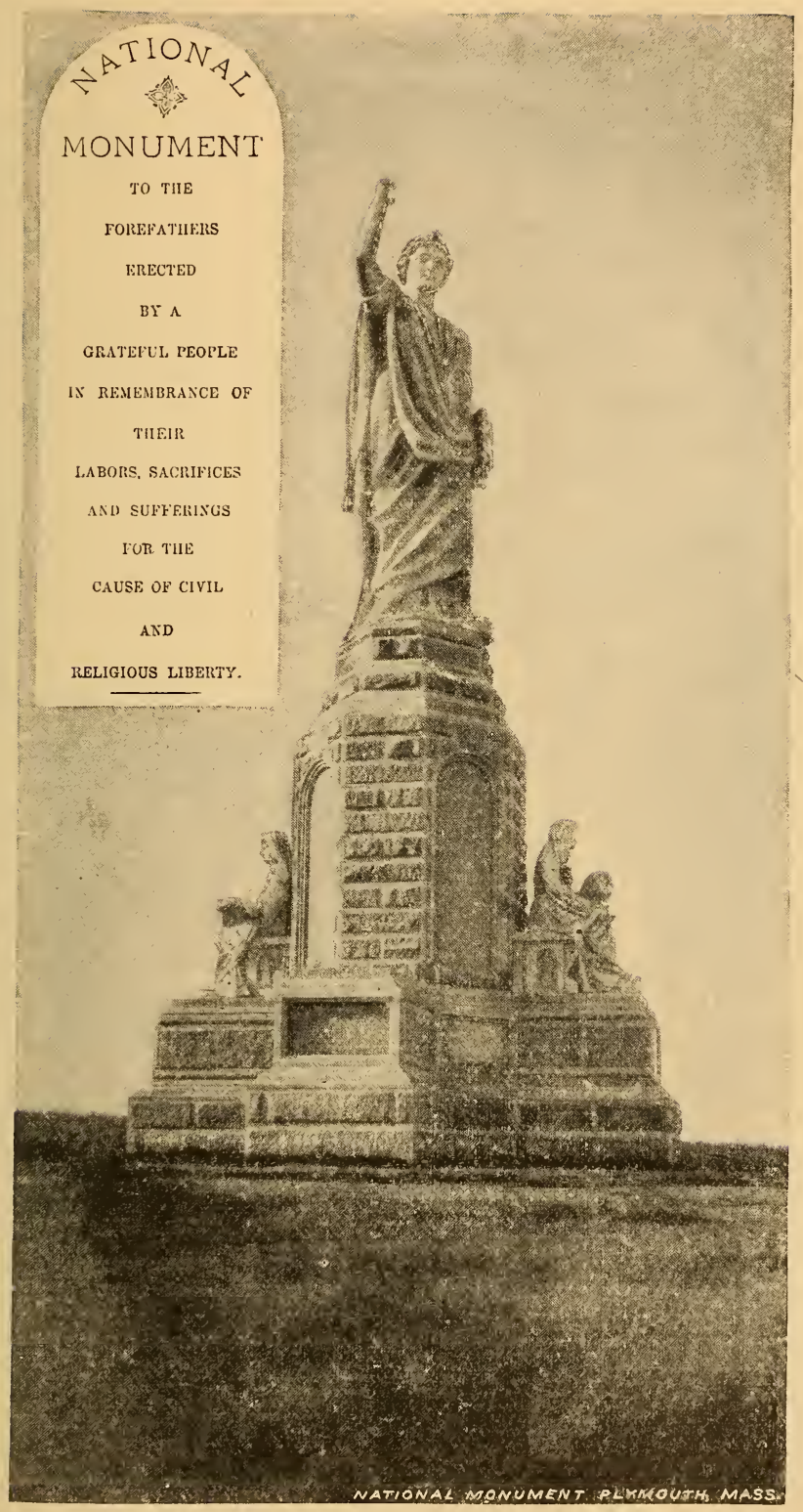



president, G. F. Holmes, treasurer and general manager and R. A. Brown superintendent.

Orick H. Kelley, the postmaster at Seaside has been here in this capacity since December I, I890. He thoroughly understands his business, and is favorably known to the people of Seaside. He is a native of Dennis Mass.

\section{PLYMOUTH.}

Plymouth, ever memorable as the first town settled by Europeans in New England, lies in the southeast part of Plymouth county, 37 miles southeast of Boston. It is a port of entry and the seat of justice for Plymouth county. It is bounded on the north by Kingston, Duxbury Bay and the Atlantic ocean, east by the latter, south by Bourne and Wareham, and west by Carver and Kingston. It is one of the most beautifully situated towns in south-eastern Massacliusetts. Its history dates from the landing of the Pilgrims in 1620 , and satisfactorily proves the difficulties the early settlers had to contend with in "settling" the Indians, who, as a charming variety in frontier life, not unusually "settled" the whites. Lo, having gone to the happy hunting grounds, has left to his victorious white brother his ancestral acres, and the undisputed possession of guns, powder and shot. Various manufactures are carried on in the town, in which may be found many fine buildings, well located on broad streets, while unmistakable prosperity pervades the entire place. The large hotels, situated near the depot, are inviting, and possess elements of comfort to the traveler. On an elevated plain, a little to the west of the depot, stands the National Monument to the Pilgrims, one of the grandest modern works of the kind in the world, and worthy of the events it commemorates. The town of Plymouth is 18 miles long and from four to nine miles wide, very irregular in shape, and on account of the numerous indentations it has a coast line 30 miles in extent. The village has all the appointments of a city, the best water and finest water system in this country; a modern fire department; gas and electric lighting ; 12 churches, 32 public schools; several financial organizations; eight hotels and a large number of boarding houses; a tine public library; electric street railway, and as a county seat has the distinction of possessing the best county buildings in the state. For healthful air, pure water, and all sanitary conditions, and facilities for summer enioyment, it is unsurpassed in the country. There are delightful locations where town and country life are separated by only a few minutes' driving, and either can be enjoyed at will. Visitors from every part of the country and the world sojourn or visit Plymouth during the summer, and the place is the growing resort of wealthy and distinguished people. Deer are found in Plymouth and Sandwich woods, the only woods in the state where this game is. Among the public attractions of Plymouth is Forest Park, a diversified tract of about one-hundred ares of wild woodlands and beautiful lakes. It is situated about a mile and a half from the railroad depot, and is a pleasant drive of one or two hours. Several hours may be enjoyed in walking through the newly 
opened paths which lead to the most attractive parts of this natural park. The population of the town is about 8,000 .

The Plymouth Foundry Co., a representative house engaged in the production of stoves and ranges has been established nearly half a century, doing business under the present firm name since I88I. Such an extensive experience as this cannot have done otherwise than to bring about the great success that has rewarded their efforts, as may be readily inferred when it is known that their goods are extensively sold throughout the United States. The plant of the house covers, with the foundry, office. yard, etc., an acre of land, and comprises four large and several smaller buildings. Here eighty inen find steady employment in producing the celebrated Royal stoves and ranges, but not these alone, for Atlantic cabooses, oil stoves, hollow ware, sinks, etc., combine to increase the list of staple products put upon the market. Mr. E. F. Shaw, the treasurer, is a gentleman of long experience in the business and fully qualified for the responsibilities of his position. The executive officers are all gentlemen of ability who have done much to promote the prosperity of the house and foster an industry that has conduced to the general welfare of the community.

The Plymouth Woolen Company, whose business originated in I864, in Franklin, New Hampshire, and who removed from there to Plymouth some fifteen years later, is one of the most complete establishments of its kind in the country for turning out woolens. Their premises have been several times enlarged and to-day are fitted up with all modern appliances, and supplied with machinery peculiarly constructed and adapted to the business, in fact, this is a model establishment in every way. About 200 hands find constant employment, and the products, which consist of fancy cassimeres, cheviots, etc., are guaranteed all wool and reliable colors. They also make worsteds which are guaranteed either all-worsted or wool and worsted. The building occupied by this successful company, is located on the line of the Old Colony Railroad, and close to the depot in Plymouth. The proprietors of this business are Henry Sawyer, who is the treasurer, and R. S. Douglass who acts as the agent. These gentlemen are experienced business men, and have done nuch toward enhancing the business interests of their town. Their superintendent, C. W. Eaton, who has been with them for twenty-two years, came from Franklin, New Hampshire, and is an experienced man in his vocation.

Bradford Kyle \& Co., proprietors of the enterprise established in 1887 , at Plymouth, are engaged in a business although little known to the general reader is most important on account of the indispensable nature of the production. The business consists of the manufacture of insulated fine electric wire. Their product is such as to be properly classed as superior. This house has earned a well deserved reputation by successfully covering the finest wire made at the present time. They also invent and manufacture their own machinery, all of which is used solely by them in their works at Plymouth.

The Bradford Joint Company established here in Plymouth about twenty years ago has grown to very considerable proportions. The premises occupied comprise an ample factory containing three floors and measuring 40 x 50 feet, 
where with the aid of all necessary appliances, fourteen employees are engaged in the manufacture of steel fastenings for bedsteads and machinery for fitting. The raw material entering into these products is of the best quality, and the product is thoroughly satisfactory to the parties using the goods. So popular have they become they are sold throughout the United States and Canada.

The Old Colony Steam Laundry, located on Howland street, is an establishment that is managed in a thoroughly straight forward manner, and the uniform excellence of its work, really leaves very little to be desired. The proprietors, Casey and Sampson, founded the business in 1888 , and under their direction it has developed and extended with a rapidity as steady as it is surprising. The premises occupied are $50 \times 35$ feet in dimensions, and two stories in height, and contains all the most improved machinery. Some twelve hands are employed who do their work thoroughly, and without the aid of injurious chemicals. Everything about this establishment savors of enterprise and success.

Ripley \& Bartlett, of Plymouth, are classed among the extensive and reliable nail and tack manufacturers of New England. This firm was established some fourteen years ago by the present proprietors, who at once sprang into popular favor, and to-day we find them transacting a most lucrative business. They arc both gentlemen well known to the trade as experienced and reliable manufacturers, their goods being sold throughout the United States, and foreign markets. They manufacture over 600 different kinds of nails and tacks, such as iron, zinc and brass countersunk nails, also oval, round and short head Hungarian nails. They also manufacture extensively grooved, star and square head hob nails, and the celebrated cobblers' tapping nails, and countersunk and corrugated brass nails. A large variety of tacks are also made, such as Swedes iron tacks, trunk and clout nails, upholsterers' tacks, shoe tacks, miners' tacks, carpet tacks, American iron tacks, channel nails, iron gimp nails, O. H. shank tacks, brush tacks, gimp and lace tacks, also tacks made to run in the Boston lasting machine. The productive capacity of the factory, combined with their methods of manufacture, enable them to offer the trade superior inducements.

The Samoset House, Plymouth's favorite hostelry of forty-six year's' standing has always occupied a position in the front ranks of hotels. The house, which was originally erected by the Old Colony Railroad Corporation, but is now owned and efficiently managed by Mr. Daniel H. Maynard, is a four-story building $48 \times 78$ in dimensions, furnished in the best manner throughout, and all desirable appurtenances for the comfortable accommodations of its guests. Located at the head of Railroad Park, it stands surrounded by pleasant lawns and orchards, and affords a most delightful and desirable home.

John S. Robbins is the proprietor of one of the best appointed and most largely patronized steam laundries in this section of the country, known as the Plymouth Steam Laundry, located in Davis building. This establishment was founded in 1885 and its business has been a steadily growing one from its inception. This success was largely due to the enterprise and ability of $\mathrm{Mr}$. 
Robbins, who has been indefatigable in his efforts to improve the efficiency of the laundry, in which every convenience is at hand for turning ont work at short notice. A large number of hands are employed who are under the direct supervision of Mr. Robbins. The very finest goods can be sent here without damage either to fabric or color as no injurious chemicals are employed.

The Old Colony National Bank of Plymouth was organized in 1832, and chartered in 1865 , and has therefore been in existence sixty-one years, during which time it has contributed in a marked degree to the progress of the town. The board of directors is composed of prominent men, with William S. Morrissey, president, and James B. Brown, cashier. The officers, are experienced and capable gentlemen, and popular with the business community. That wisdom as well as liberality characterize the operations of this bank under its present administration is abundantly shown.

W. H. Edson, bottler of Belfast ginger ale, tonic beer, mineral water, etc., produces gonds that are very hard to equal, either as regards their purity or the delicacy and durability of the flavoring; and that the people of Plymouth and the New England States, favor the house is shown by the large and steadily growing demand for the goods bearing its name. The business was begun in 1884 , and now reaches to such proportions that some ten hands are required to supply its demands. The premises located on Water street, consist of two ftoors, some $38 \times 100$ feet in dimensions, together with a store house of considerable capacity. He makes a specialty of Excelsior Hop Beer, which has become celebrated, and he has reason to feel proud of the reputation his productions have in the market for uniform superiority of excellence. Dealers and others find this house an excellent one to trade with.

Charles A. Smith is the genial and popular proprietor of the stationery and periodical store to which, of the thousands of people that visit Plymouth each summer, it is safe to say that 50 per cent. go to buy some memento of the historic town. Mr. Smith is widely known for his honorable dealing and his prompt and polite attention to customers. His store is very commodious and contains a large and well selected stock of periodicals and stationery. The business is an old established one, having been founded 38 years ago, Mr. Smith succeeding to the business in $\mathrm{I} 88 \mathrm{r}$, and by careful attention to the details of his trade he has gained a reputation that stands A No. I in this town.

The Central House, located in Shirley Square, is a comfortable and wellappointed hostelry of 28 rooms, and was established a number of years ago. E. J. Shaw, the proprietor, having had years of experience in the hotel business, thoroughly understands catering to the traveling public, and offers every inducement in the way of first-class cuisine and accommodations, which has given the house a degree of popularity that is peculiarly its own.

The Plymouth Rock House, one of the thriving hotels of this old and historically interesting town, is situated on Coles Hill, within one hundred feet of the rock where the Pilgrims landed. The hotel will accommodate some 60 guests, and is renowned for its hospitality to thousands throughout the country. C. H. Snell, the proprietor, is an experienced hotel man, and thoroughly understands 


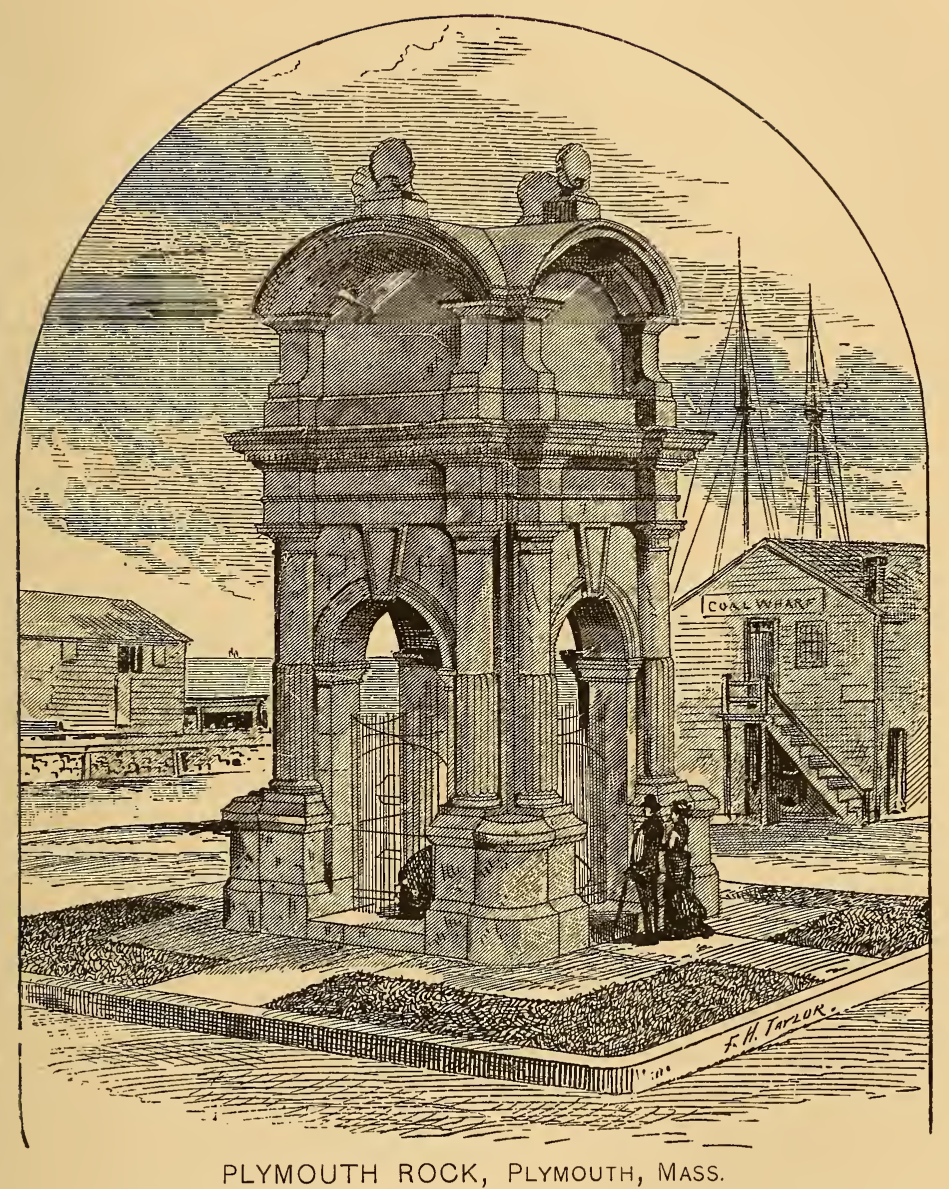



the wants of his customers. This hotel is a well known resting place for families, and to stop here once is to come again.

W. W. Avery was appointed postmaster of Plymouth by President Harrison, and has since so carefully guarded and studied the interests of his position that he has gained popularity among his townspeople. The receipts at the Plymouth office have increased about twenty per cent. since his appointment in 1888 , and in addition to the inauguration of the free delivery system he re-fitted the office by largely increasing the number of lock boxes of modern design, fitting up a money order department, and greatly improved the service by securing additional mails, and at such hours of arrival and departure as to prove a great help to the business interests of the people. He is a gentleman 55 years of age, and was born in Montpelier, Vt., but of Old Colony stock, his ancestors being among the early settlers of Truro, on the Cape. Of sterling integrity and irreprochable character, he has filled, with credit to himself and the town of Plymouth, the position of Representative to the General Court for two consecutive terms, and various offices of trust and responsibility in the Methodist Episcopal church, and several of the leading benevolent, social and charitable institutions of which he is an honored and active member. Mr. Avery is also senior meniber of the firm of Avery \& Doten, publishers of the Old Colony Memorial.

Thomas A. Stevens is one of the oldest employees of the Old Colony Railroad, who for 46 years has honorably served this corporation, in the capacity of fireman, engineer and baggagemaster, the latter position he having held for ten years here in Plymouth, making himself popular with the patrons of the road.

\section{ROCKLAND (HANOVER BRANCH).}

Rockland adjoins Abington on the east. It was formerly known as East Abington, and has a population of 5,213. The principal business carried on here is the manufacture of boots and shoes, in which branch it is fast becoming an important centre. Other manufactures are machinery, tacks, paper boxes, leather, polishes and dressing, carriages, mittens, clothing, lumber and wrought stone, food preparations, etc. It has a savings bank, an effective fire department, good water supply, churches, schools, and fine hotel accomodations. Lying on the northern border of Plymouth county, it has a rich outlying agricultural distriet, which is an important tributary to its prosperity, and its people are wide awake and progressive in all that tends to promote the growth and welfare of the place. Rockland is 19 miles from Boston; the station lies between the centre of the village and Boxborough. The postoffices are Rockland and Hatherly. As a place of residence or for business it is unsurpassed in the state.

The Rockland Company, engaged in the manufacture of men's fine shoes, commenced business seven year's ago, and are recognized as one of the leading houses in the business. Their premises, covering an area of $198 \times 28$ feet, with two wings $40 \times 26$ feet, are three stories in height. On the first floor, the 


\section{J S. TTURNER, \\ -Mandfactiorer OF- \\ SHOES A FOR GENTS WEAR.}

ROCKLAND, MASS.

CHIPMAN, CALLEY \& CO,

ROCKLAND, MASS.

-MaNUFActurers OF-

\section{MEN'S FINE CALF AND KANGAR0O SHOES.}

*** Hand and Goodyear Welts and McKay Sewed. ***

\section{JASON SMITH,}

$\because \therefore$ Manufacturer of $\therefore \because$

SMITH'S FITTING 恐 CHANWELING MACHNE,

Rockland, Mass.

\section{GIDEON STUDLEY, manverectuena or}

NAIL AND LOCK CORNER BOXES Of all Descriptions.

** Beer and Tonic Cases, Egg Cases. **

PRINTED BOXES A SPECIALTY. A ROCKLAND, MASS.

Satisfaction Guaranteed! Orders Solicited. ALL ORDERS FILLED PROMPTLY. 
cutting, finishing and shipping are done; on the second, the bottoming and fitting, and on the third, bottoming. The house has taken advantage to the fullest extent of all modern improvements in machinery, that have been put upon the market, that would in any way aid them in placing their productions before the trade stamped with the brand of excellence. Their goods are found in all parts of the United States, and "speak for themselves." The officers of the company are Wm. H. Bates, president; Henry M. Currier, vice-president, and Wm. P. Taylor, treasurer. Their Boston office is located at 292 Devonshire street.

Chipman, Calley \& Co., manufacturers of men's fine boots and shoes, established about four years ago, are conspicuous among the more recently established and prosperous manufacturing enterprises of Rockland. There is now in process of erection, for their occupancy, a factory four stories in height with monitor roof, covering an area of 200 feet by 40 feet, with a projection for offices, store rooms, etc., 36 feet by 40 feet. The factory is in every way a model one equipped with all the modern appliances and machinery known to the trade, and is to be provided with automatic sprinklers, electric fire alarm, electric lights, and a system of in direct radiation for heating and ventilating. Especial attention has been given to the plumbing, and the latest and most perfect devices for disposing of the sewage have been adnpted. The engine, boiler and dynamo are situated in a brick building detached from the main factory. The firm employs by far the largest number of workmen of any factory in town, producing in the course of a year fully one quarter of all the shoes manufactured in Rockland. They have among their employees some of the most skillful workmen to be found in this region of fine shoe makers, and while they produce goods of fine quality, style and workmanship, they sell them at prices that meet with such popular favor that orders flow in from all quarters of the country, keeping them busy from January to December. They have twice been compelled to enlarge their quarters. Their city office and warehouse are at 83 Bedford street, Boston.

The French \& Hall Company carry on a large business in the manufacture of gentlemen's fine footwear, and the trade they do in the course of a year forms a large item among the other industries of the town. This now extensive business was established in I88I by J. E. French and G. W. Hall, Mr. French having been engaged in the manufacture of boots and shoes for twenty years previous, to that time. The present company name was adopted in I89I, when C. J. Shriner and S. P. Urner were admitted to the firm. The premises consist of a three-story building, $35 \times$ roo feet, where they employ one hundred hands, and. an engine of 40-horse power is constantly at work in supplying power to the necessary machinery used in the establishment: Twenty-five dozen pairs is the daily output, orders for which are being constantly filled and sales made in all sections of the country. Wednesdays and Saturdays the firm are to be seen at their Boston office, 287 Devonshire street.

F. E. Nesmith \& Co., in January, I 884, succeeded C. Littlefield \& Co., who began the manufacture of paper boxes at Rockland in 1883 . They occupy a two- 
story building $225 \times 35$ feet, where are produced large quantities of paper boxes for the local trade, the specialty being folding paper boxes of every description suitable for ice cream, confectionery, patent medicines, nails, etc., which are distributed to the trade all over the United States, and for the manufacture of which they have superior facilities. Fifty skilled operatives are employed who turn out 40,000 folding boxes per day and some 2,500,000 paper boxes per year. In addition to their business as paper box manufacturers, the firm have a finely equipped printing office, where they are prepared to fill all orders in job printing and embossed work in the best possible manner.

Gideon Studley, Jr., is proprietor of a house that has honorably stood the test of commercial fluctuations for nearly thirty years. The business was founded in I 864 by Gideon Studley, who was succeeded by his son, Gideon Studley, Jr., in I883. The house has always had an A No. I reputation as manufacturers of boot and shoe boxes, and is but one of the very few firms whose trade extends to all parts of New England. The premises occupied are well adapted to the business, being large and well equipped with the necessary appliances to ensure prompt and superior work, and employment is given to thirty hands, who are under the supervision of S. B. Besse, the superintendent, a man of experience and ability. Fverything about this establishment denotes enterprise and success, and it is evident that this business is here to stay.

Jason Smith is a manufacturer of shoe machinery, and since the business was first started here a large trade has been built up all over the world. The business was started in 1878 by C. T. Stetson and J. Smith, Mr. Stetson retiring the fullowing year, and $\mathrm{Mr}$. Smith assuming entire control, and since then the business has met with a steady and rapid increase. The factory is equipped with the most perfect machinery and latest appliances. A specialty of the house is the manufacture of Smith's sole fitting and channeling machine, by the aid of which one man can do the work of from two to four men, one man being able to round, channel and groove two thousand pairs per day. None but skilled workmen are employed and they are under the personal supervision of S. R. Wilson, a gentleman thoroughly conversant with all the details of the work, and who has been with the housc for twelve years.

J. S. Turner, manufacturer of the finest grades of gent's shoes for the retail trade, has for over a quarter of a century, been one of the most prominent houses in Rockland. The factory is a two-story structure with floor room of 28,000 square feet. It is divided into several departments, each being especially adapted and furnished with every requisite and modern appliances for manufacturing the very finest class of goods known to the trade. Power is delived from an engine of 25 and boiler of 50-horse power. The establishment is provided with an automatic fire sprinkler, automatic fire alarm and electric lights, Mr. Turner owning his own dynamo. The work produced is of such a kind as to give the house a reputation in all parts of the United States for manufacturing superior goods.

C. E. Lane, manufacturer of fine calf shoes, has for more than eighteen years successfully conducted his business in Rockland, adding to the industrial thrift 
of the town. His plant is a large three-story establishment with the various departments conveniently arranged and fully equipped with modern machinery. A force of seventy-five workmen is employed, whose daily output is twenty-five dozen pairs. These goods stand well with the trade being of uniform excellence as regards style, material and workmanship, as the factory is under the personal supervision of the proprietor. The trade extends all over the United States. At 105 Summer street, room 9, is located the Boston office of this well known house.

Jackson \& Campbell, Nov. I, I 890, opened their new and popular Hotel Jackson at the corner of Union and Webster streets, Rockland, and from that time up to the present it has received a most liberal patronage. The hotel, which is a four-story structure, $38 \times 65$ feet is furnished throughout in a thoroughly first-class style, and is supplied with steam heat and electric lights. The dining room will accommodate fifty-two persons at a time, and too much cannot be said in praise of the cuisine and courteous attendants. The house is liberally patronized the year round. There are thirty rooms in the house, which render it sufficiently commodious for an excellent patronage, and there is also a public bath room connected.

J. S. Smith, postmaster, without doubt one of the most popular men in Rockland, is a native of Edgartown, this state. After receiving a liberal education, he became identified with newspaper work, in which he rapidly gained a reputation as a journalist, so that in I 868 though but twenty-two years of age we find him editor-in-chief of the Rockland Standard, which paper he had no little share in bringing to its present high standard. He has continued editor of the Standard ever since, and in point of continuous service on any single paper is the senior editor in Plymouth county. He was appointed postmaster April I, I 87 I, faithfully serving the government in this capacity till I 886 when he retired to devote his time to journalism. After a lapse of four years, he was again appointed postmaster in July I890, and assuming charge Sept. I of that year. He is eminently qualified for the satisfactory performance of the official duties by a long residence in the town, an extended acquaintance with its people and an intimate knowledge of its affairs. He is a member of the Rockland Encampment, and Standish lodge of Odd Fellows, of which he is a past chief officer and one of the trustees.

\section{HANOVER.}

Hanover is a very pleasant town in the northerly part of Plymouth county, 26 miles from Boston, on the Hanover Branch of the Old Colony Railroad. It is bounded on the north by Rockland and South Scituate, on the east by the latter, on the south by Pembroke and Hanson, and on the west by Rockland. The Four Corners village, at the confluence of the Third Herring Brook and North river (forming respectively the eastern and southern lines of the town) is Hanover station, and the terminal point of the railroad at the southeast corner of the town. Other stations and villages along the railroad are Curtis' Crossing, Winslow's Crossing, South Hanover and West Hanover. Other vil- 
lages are the Centre, North Hanover, and at the northeast corner, Assinippa village, having West Scituate as its post office. There are in the town 99 farms, but few owners devote themselves wholly to agriculture. The manufacture of boots and shoes, nails, tacks, boxes, lumber, etc., is quite extensive here. Population, I $890,2,093$.

E. C. Waterman is a native of Hanover and is thoroughly identified with its commercial as well as its municipal growth and prosperity. His efforts and time in this direction have been devoted to serving three years as selectman, and as representative of Hanover and Rockland from the 5 th Plymouth District. He was for fourteen years a Justice of the Peace, and is at present a Notary Public. In all the trusts delegated to him Mr. Waterman has labored for the good of this community, and well merits the esteem with which he is regarded. His trade is that of ship carpenter and he is prominently identified with the Masons, Odd Fellows, and several other societies.

Willian S. Curtis in 1887 became sole proprietor of the pharmacy established in 1880 by J. J. Estes at Hanover Four Corners. The premises are spacious and convenient, while the stock embraces every article to be found in a well appointed establishment of this kind. Here prescriptions are accurately compounded, medicines prepared, perfumes, toilet requisites and physician's supplies sold at the most moderate prices. Born in Hanover, in I $866 \mathrm{Mr}$. Curtis has identified himself with its growing interests. Appointed postmaster in I 889 he has exhibited that interest in the execution of his duties that entitle him to the respect of this community, aside from the consideration with which he is held in the trade.

A. S. Barnes, the popular ticket and station agent at Hanover, has faithfully served the interests of the Old Colony Railroad for the past two years. Born in 1864 , at Litchfield, N. H., he has made the railroad business his work thus far, and thoroughly understands all the details of his duties. He is well known in this community as a young man of high character, and justly enjoys the esteem of the public.
J. E. FRENCH.
G. W. HALL.
C. J. SHRINER.
S. P. URNER

\section{FRENCH \& HALL COMPANY, \\ -:- MANUFACTURERS OF -:-}

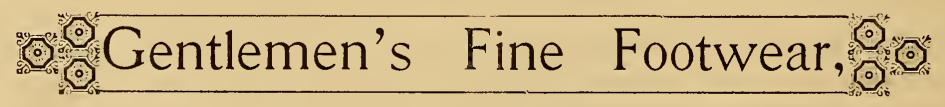




\section{BIRIDGEWATER BRANCH.}

\section{EAST BRIDGEWATER.}

T

HIS is a flourishing manufacturing and agricultural town in the northwesterly part of Plymouth county, on the Pan Handle Branch of the Old Colony Railroad, which passes directly through it. It is bounded on the north by Whitman, on the east by Hanson and Halifax, south by Bridgewater, east by West Bridgewater and Brockton. Its manufactures consist of shoes, nails, cotton gins, bloomeries, foundries, a rolling mill, and several box and lumber mills.

The population of East Bridgewater in I890 was 2,9Ir. Elmwood is a village of this town, where the Old Colony Railroad has a station. Other stations are Brown's and Washington street.

Z. A. Jenkins, a well known citizen of East Bridgewater, is engaged as dealer in flour. grain, lumber, lime, cement, hay and fertilizers; also making a specialty of hardware and farming tools. Mr. Jenkins has been established here for the past six years, and has built up one of the most flourishing trades of the kind, that the town has ever known. He occupies a two-story frame building; conveniently located on Central street, fully stocked with everything in his line, the trade for which is principally retail. Mr. Jenkins is an energetic man and by his pleasant manners, has won the esteem of the public in Bridgewater and vicinity.

The American House, formerly the Crescent House, is a well known hostelry of East Bridgewater of which T. S. H. Rounseville has been proprietor and manager for the past four years. It is pleasantly located on Union street, one of the most desirable streets of the town, conveniently near the depot, and offers excellent accommodations for transient and permanent guests. Competent and obliging help is constantly at hand, and everything is done to ensure comfort and satisfaction to its patrons. A well arranged stable is connected where horses may be hired or boarded on reasonable terms. 
玨INEY J. MI工工耳凡,

- Manufacturer of all Kinds Of-

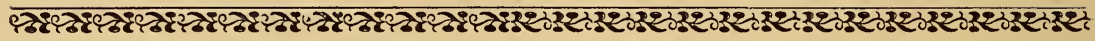

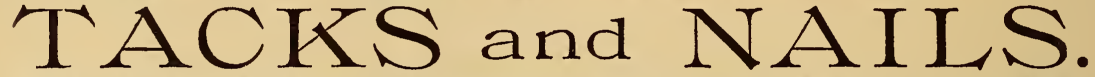

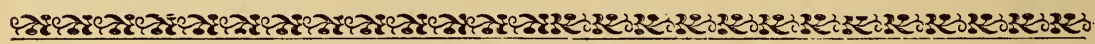

Shoe Tacks and Nails a Specialty.

\section{BRIDGEWATER,}

C. Burrill.
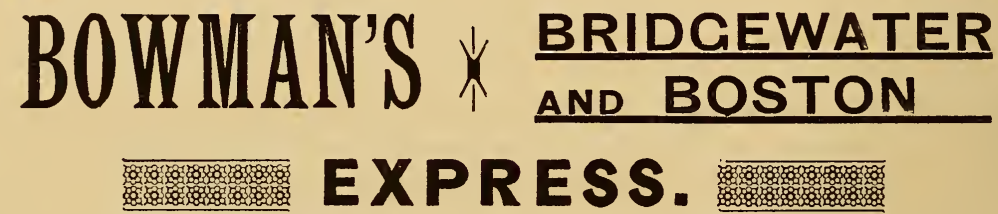

OFFICE, - 105 ARCH S'TREET.

Leave Boston Office, 1 and 4 P. M. Bridgewater, 7.30 and 9.

\section{HOOPER \& CO.,}

Jobbers and Retailers of

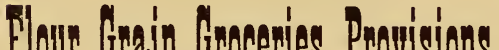

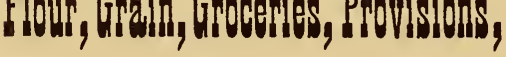

HARDWARE, FRUIT and CONFECTIONERY,

BRIDGEWATER, MASS.

A. F. HOOPER.

Z. A. JENKINS,

-. Dealer in -..

FLOUR, GRAIN, HAY,

Lime, Lumber, Cement,

BUILDING MATERIALS AND

FARMING IMPLEMENTS.

CENTRAL STREET.

East Bridgewater, - Mass.

\section{AMERICAN * HOULSE,}

East Bridgewater, Mass. NEAR THE DEPOT,

T. S. H. ROUNSEVILLE, Proprietor.

Board by Day or Week.

ALDEN \& PRATT,

-Manufacturers of-

Men's Boys' and Youths' Calf, * Buff and Split *

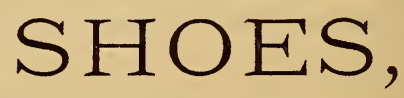

NORTH MIDDLEBORO, MASS. 


\title{
THE OLD ROAD.
}

\begin{abstract}
HIS is another of the older sections of the Old Colony, and runs from South Braintree to Middleborough, via Brockton and Bridgewater, from thence via Myricks to Fall River.
\end{abstract}

\section{HOLBROOK.}

Holbrook is a new and delightfully situated town in the southeastern part of Norfolk county, I 4 miles south of Boston with which it has ready communication by the Old Colony Railroad, passing along its whole western border. The villages and post offices are Holbrook and Brookville. Its boundaries are Braintree on the north, South Weymouth on the east, Abington and Brockton on the south, and Avon and Randolph on the west. The villages of Holbrook and Brookville are surrounded by rich agricultural districts, and those engaged in farming are the most prosperous to be found in this section of Massachusetts. Holbrook is connected with Brockton by a recently constructed electric railway, is largely devoted to shoe manufacturing, and its industrial interests and general welfare are being greatly enhanced each year by an organization known as the Commercial and Social club. Population nearly 3,000.

[For description of Brockton, including the stations in that city, also Avon, se€ preceding pages.]

\section{BRIDGEWATER.}

Bridgewater is a fine old town in the western part of Plymouth county, 28 miles south of Boston on the Old Colony Railroad, the stations being Bridgewater Iron Works, Bridgewater (centre), and Flag street. The post offices are Bridgewater, Scotland and State Farm; the villages being these (except the last), and Paper Mill village and Matfield. In the eastern part of the town there are a paper mill and two or three saw mills making shingles and boxboards. At the iron works is made a variety of cast and wrought iron work, cotton machinery, nails, tacks and other articles. The town also has boot and shoe factories and several brickyards. The largest products are iron and wooden goods. The town is noted for its schools. Bridgewater Academy, incorporated in I799, now furnishes the town high school. The public schools are graded and occupy, aside from the academy, I4 buildings, valued, with attached property, at $\$ 3 I, 4 I 0$. The State Normal School here has been in constant operation since $\mathrm{I} 840$, the attendance now requiring the entire accom- 
modations of its two substantial edifices. Bridgewater enjoys the distinction of being the place where the first machinery for carding, roping and spinning cotton was produced, as well as where the first machine-cut nails were made. In the year 1740 Hugh Orr erected a trip-hammer here on the Matfield river; eight years later he made 500 muskets for the colonists, and these were the first firearms made in America. During the period of the Revolutionary war, this place made large numbers of brass and iron cannou and iron cannon balls for the Continental army, and its citizens were most zealous in the work of furnishing the sinews of war in the prolonged struggle for independence. Population, I $890,4,249$.

The Bridgewater Box Co. are manufacturers of every variety of wooden packing boxes and shooks, making a specialty of lock corner and printed boxes. This company was incorporated in I 890 , with a capital stock of thirty thousand dollars. The president is H. O. Little and the treasurer E. B. Gammons; the board of directors being composed of Dr. L. G. Lowe, S. P. Gates, H. O. Little and E. B. Gammons. The premises comprise four large buildings located on the corner of Spring and Plymouth streets, covering an area of eight acres, and giving employment to fifty hands and from seven to ten teams. Twenty thousand feet of lumber are used daily to supply the large demand, which comes principally from Boston and Brockton.

Henry J. Miller has been for the past ten years engaged in the manufacture of tacks, nails, and box nails; making a specialty of shoe tacks, and shoe nails. His spacious premises are located on Hale street, of this town, on the track of the Old Colony Railroad. They consist of a one-story frame building and basement, covering an area of one hundred by thirty feet where steam power is used and twelve hands are employed. An extensive trade has always been enjoyed, the goods being shipped to neighboring towns, New York, Boston, and western cities. The products amount to one ton of nails per day.

Hooper \& Co., located in Central square, conduct an old established business, it having been founded in 1850 by $A$. F. Hooper of the present firm. In I $873 \mathrm{Mr}$. Clark became a partner, continuing till I 889 when the firm name was changed to its present one. This firm is known as jobbers and retailers of flour, grain, groceries. and provisions, also dealing largely in hardware, fruit, and confectionery. The firm is well known, as it enjoys a flourishing trade in Bridgewater and surrounding towns, and also keeps one of the largest stores of the kind in the town. Nine hands are engaged as help, and five teams are continually on the road delivering orders. The store is large and carries a complete line of the goods mentioned.

A. S. Lyons, who in 1882 started a successful business career in Bridgewater, is engaged as dealer in lumber, hay, lime, cement, and building materials. He occupies premises located on Spring street, covering about four acres of land, where employment is given to six hands. Mr. Lyons is a man of ambition and business tact and carries on a thriving prosperous trade, chiefly in the vicinity of this town. He is well known in social as well as business circles, and enjoys an enviable reputation. 
The Bridgewater \& Boston Express of which J. A. Bowman and C. Burrill are the proprietors, was established about thirteen years ago, and has since conducted a large and prosperous business. They do a general express business between Bridgewater and Boston, shipping freight by the Old Colony Railroad. Three hands are employed, and two teams are kept busy in the delivery of parcels. Thier office is located in Central square, while they have an office in Boston at 105 Arch street.

\section{MATFIELD.}

Matfield is a small village and station of Bridgewater, and is almost entirely devoted to agricultural pursuits.

\section{WESTDALE.}

This is a village of West Bridgewater, the station being formerly known as Satucket. It is in the midst of a farming district and is a most desirable place for those who enjoy the quiet of a rural home. There is good gunning for small game in the vicinity, and the sanitary conditions are of the best, the water being excellent.

\section{TITICUT AND NORTH MIDDLEBOROUGH.}

This is a station on the Old Colony in the town of Middleborough, its inhabitants being devoted to general rural pursuits. It is a growing section of the town, has many fine residences, and offers superior attractions to the summer sojourner and sportsman.

Alden \& Pratt, a well known firm engaged in the manufacture of men's boys', and youths' calf, buff and split shoes; also sole manufacturers of the Perkin's shoe, were established in 1885 . The premises located on Plymouth street, comprise a two-story frame building, ninety-five by twenty-eight feet, fitted with the latest appliances and modern machinery operated by steam power, and furnish employment to seventy hands. Some seventeen cases of shocs are produced daily while the business is steadily increasing. Alden and Pratt have bcen residents of North Middleboro sevcral years and are well known in social as well as business circles.

Hammond \& Richmond located on Plymouth strect are manufacturers of fine shoes in calf, veal, dongola, etc. They are proprietors of the business originally established in $\mathrm{I} 88 \mathrm{I}$ by Alden, Leonard \& Co., they coming into possession by purchase in 1888 . They occupy premises consisting of a two-story frame building with ell conveniently arranged, and employ a force of thirty hands, the product of whose skill and labor is shipped throughout New England. This house is well and favorably known by the trade, and enjoys a prospcrous and steadily increasing business,

Keith \& Pratt are old settlers, well known in this town, and justly entitled to a place in any menton of trade aftairs. This house was cstablished here in 


\section{J. K. \& B. SEARS \& C0., Doakrs in}

\section{WHOLESALE AND RETAIL

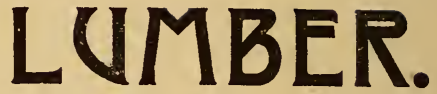

* जutters, Mouldings, Doors, Windows, Screen Doors,

* Window Screens, Hardware, Drain Pipe, Paints, Oils, Etc.

Vine Street opp. Depot.

MIDDLEBORO, MASS. YARDS at Hyannis and Middleboro.

Barnabas Sears. Isåiah C. Sears.

Henry W. Șears.

Nath'l B. H. Parker.

C. W. MAXIM,

SAWING, PLANING, .

Scroll Sawing and General Jobbing.

WINDOW \& DOOR FRAMES MADE TO ORDER,

MIDDLEBORO, MASS.

F.W.HAYDEN,

$\triangle \triangle$ EXPERT \& WATCHMAKER, $\triangle \Delta$

Watches, * Diamonds, * Jewelry,

Silverware, * Clocks, * Etc.

FINE GOLD RINGS A SPECIALTT.

Gold Pens and fountain pens. Gold and Silver Canes and Umbrellas.

Center St., Middleboro, Mass.

N. W. Keith.

H. A. Pratt.

KEITH \& PRATT,

- MANUFACTURERS OF-

MEN'S AND HOY',

FINE SHOES,

North Middleboro, Mass.
JAMES L. TENNEY, -Dealer iN-

COAL AND WOOD,

VINE STREET, Near Railroad Station,

Middleboro, ¿ Mass.

Orders left at Residence, No. 28 Pierce Street, will be promptly attended to.

Orders left with B. F. Tripp. Also Bills for Collection.

Warren B. Stetson, - MANUFACTURER OF-

MEN'S, BOYS' and YOUTHS'

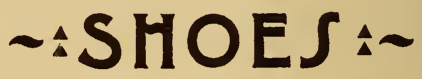

MIDDLEBORO, = MASS.

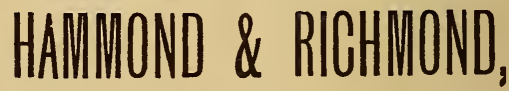

- Manufacturers of -

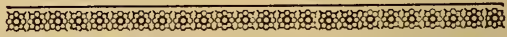

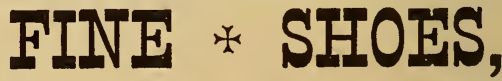

86-

NORTH MIDDLEBORO,

MA $\mathrm{S} S$.

Geo. A. Hammond. E. W. Richmond. 


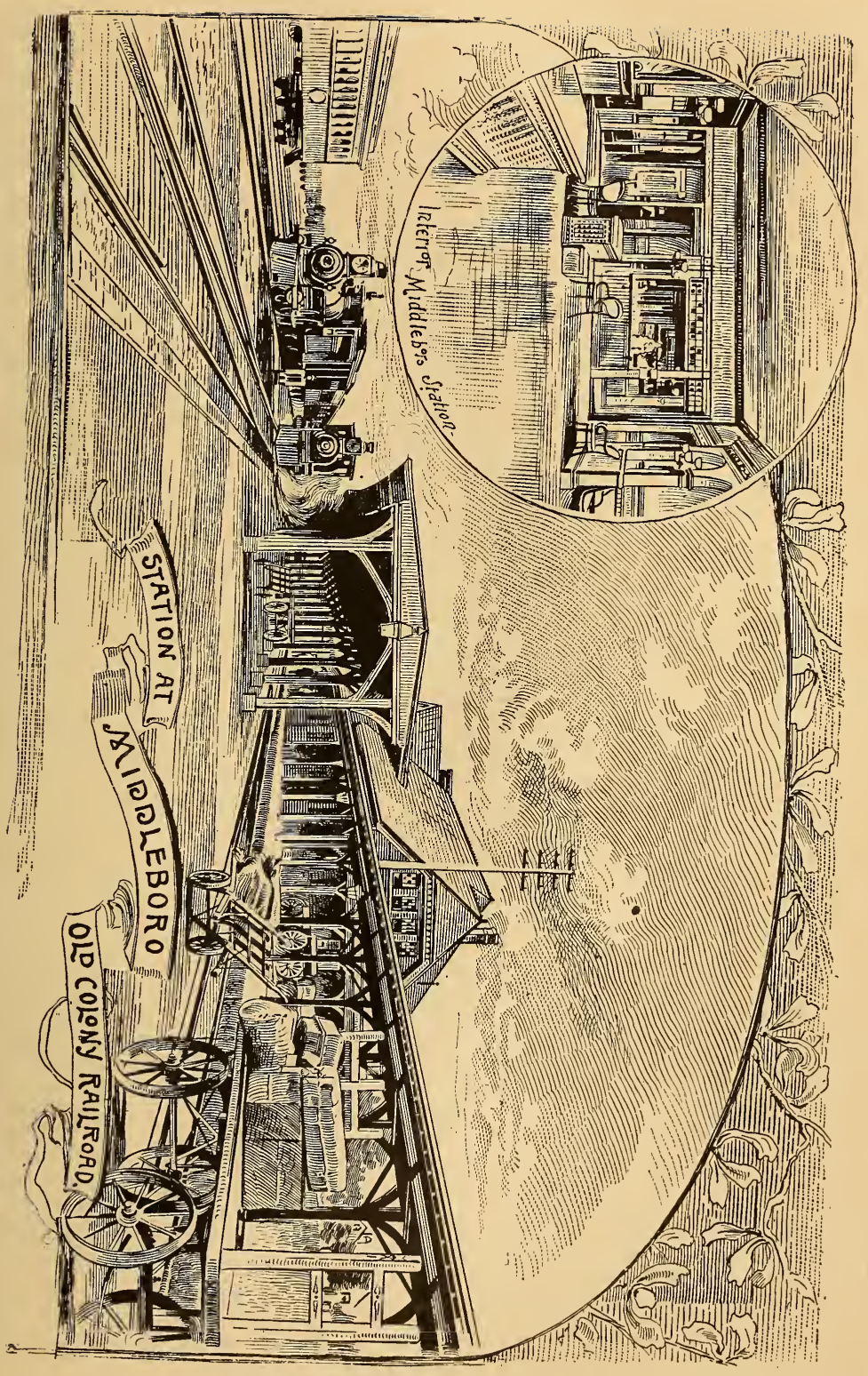



I 878 by the present proprietors. The premises are in every way fitted up, and are well adapted for the business done, which consists of the manufacture of men's and boys' balmorals, button and congress shoes. They occupy a threestory building, measuring $75 \times 30$ in dimensions. In the manufacturing department of their business they have a full assortment of machinery and tools, specially constructed for their trade requirements, and the hands employed numbering sixty are all skillful mechanics. This house is conveniently situated on Pleasant street, North Middleboro. The goods which average twelve cases per day, each case containing twenty-four pairs, are shipped to Baltimore, Philadelphia, and the leading New England cities.

\section{MIDULEBUROUGH.}

Middleborough is an unusually level town of large area, lying in the western part of the southern section of Plymouth County. The Cape Cod Division of the Old Colony Railroad begins here, running to the west of the centre, where it connects near Four Corners village (Middleborough station) with the Newport line and Taunton Branch. It is 35 miles from Boston, 20 from Fall River and New Bedford, 15 from Plymouth, and 10 from Taunton. It has excellent public schor)ls, the Eaton Family school and the famous Pratt Free school. Religious worship is held in three Baptist, three Congregational, two Methodist, and one Catholic church. The village has a savings bank, several good hotels and boarding-houses, and is largely engaged in manufacturing enterprises, among which are boot and shoe factories, lumber mills, box factories, a woolen mill, carriage factories, stone, brick and tile yards, tannery, trunk, and valise factory, etc. The Nemasket river, Assawamsett pond (the largest sheet of fresh water in the state), and several smaller fresh water areas, offer fine sport for devotees of the rod, and add a quaint picturesqueness to the diversitied scenery of the town. Middleborough has also many interesting historic associations and was the scene of some of Myles Standish's most daring exploits. It is a very productive section for horticultural products, apples and berries in large quantities being raised for the various markets. There are numerous fine estates, and the place is growing very rapidly. Middleborough is also a terminus for the Middleborough, Taunton \& Providence Branch of the Old Colony Railroad. There are two other villages in the town - North and South Middleborough, respectively. Middleborough is the terminus of the

\section{PLYMOUTI AND MIDDLEBOROUGH ROAD}

which is the latest addition to the Old Colony system, and extends from Plymouth to Middleborough, a distance of 16 miles. The largest and most important town on this line is Middleborougin, if the town of Plymouth is excepted. The stations on this road are Plymouth, Darby, North Carver, Mt. Carmel, Putnam, and Middleborough.

C. N. Atwood of Middleboro, in that part known as liock, conducts a large establishment for the manufacture of all kinds of wooden boxes. It was first established in 1865 and known as Rock Mill, which was changed in a few year's after 
to H. N. Thomas \& Company, they being succeeded in I879 by C. N. Atwood. The premises occupied for lumber yard and factory cover an area of five acres, and employment is given to thirty-five hands. The business extends over a large territory, his goods being sent to Boston, Providence, Bangor, Worcester and nther large cities, and uses from three to four million feet of lumber per year, a specialty being made of trunk boxes. Being centrally located directly opposite the depot, and possessing unusual facilities for the rapid production of work he is always ready to fill and deliver orders promptly.

J. K. \& B. Sears \& Co. on Vine street and the largest lumber dealers in Middleboro, were tirst established in South Yarmouth, Mass. about fifty years ago, from whence they moved in 1874 to their present location. 'They carry on both a wholesale and retail business in lumber, doors, windows, mouldings, hardware, paint, oils, drain pipe, etc. a demand for which exists from Middleboro to the Cape. They occupy eight buildings, and a large yaid which is directly connected with the Old Colony Railroad, besides yards at Hyannis. On one of their buildings at Middleboro they display every morning at 7.45 the weather signals adopted by the United States Weather Bureau. The firm consists of Barnabas Sear's, Henry W. Sears, Isaiah C. Sears, Nath'l B. H. Parker, who by their courteous treatment and fair dealing in all their transactions have built up a large and prosperous trade.

The LeBaron Foundry Company conducts one of the oldest and most extensive industries in this town which consists of the making all kinds of iron castings, such as are required for machinery, stoves and general jobbing; also all kinds of ornamental work such as lawn vases, settees, etc., while a specialty is made of the Middleby bakers oven which is in demand by bakers generally. The plant in use by this company is a very large and complete affair, covering as it does some three acres of land, and consists of twelve substantial buildings of brick and wood all protected by tirc proof roofs. Power to operate the various machines used here is supplied by a forty-horse power engine, and the services of fifty expert moulder's and assistants are employed. The output of this company is very large, amounting to $\mathrm{I} 200$ tons of iron in a year. This foundry was established in 1856 by the firm of Tinkham \& LeBaron and was operated by them until I 86I, when J. B. LeBaron took sole charge, and conducted the business until r 884 when the present owner E. P. LeBaron bought out the business. He has been a resident of Middleboro for the past thirty years, and has a great interest in the welfare of the place. He is one of the most public spirited citizens, and the town is fortunate in having among its citizens a gentlemen who combines the qualities which bring success to his private business, with those of a personal pride for the best interest of the town itself.

Warren B. Stetson came to Middleboro in 1879 , and engaged in the manufacture of men's boy's' and youths' shoes. The premises occupied by him are situated on Clifford street and consist of a three story frame building where some thirty-five hands are employed. This place was first established in I 846 by E. E. Perkins who was succeeded in 1879 by the firm of Stetson, Holmes \& Hammond, they in turn being followed in $188 \mathrm{I}$ by the present proprietor. The goods man- 
factured here are from a cheap to medium grade and are sold to New England and western parties. Mr. Stetson stands among the leading representatives of Middleboro industries, and is a gentlemen well calculated to enjoy the respect and confidence of his fellow citizens and tradesmen.

M. H. Cushing \& Co, are a firm well known as wholesale and retail dealers in grain, flour, grnceries, hay, lime, cement and hair, and is composed of M. H. Cushing and his son, whom he took into partnership with him in 1887. The business was established in 1866 by Mr. Cushing, senior, and has enjoyed a prosperous run of business ever since. They occupy adequate premises at the corner of Main and Centre streets, consisting of a store $25 \times 37$ feet and three large store houses covering in all about 5,000 square feet of ground, and employ the services of seven hands. Their goods are reliable and their dealing with their customers is of that kind that induces them to be permanent. Some idea of the extent of their trade can be formed when it is stated that two hundred car loads of merchandise are handled by them annually.

F. W. Hayden of Centre street is the proprietor of a thoroughly reliable house engaged in the sale and repairing of watches, clocks, jewelry, plated and silverware, etc. Mr. Hayden, who has been established here for the past eleven years is a practical watchmaker and is thoroughly experienced in the business. The store is of ample dimensions, handsomely appointed and provided with every facility. He carries a good stock of ladies and gents gold and silver watches, French and American clocks, wedding and engagement rings, spectacles, eyeglasses and a general line of things that may be expected to be found in a place of this kind. In connection with these he also carries a line of sporting goods, bicycles, fishing tackle, etc. Mr. Hayden enjoys the reputation of an upright, capable business man and his store is well patronized by the people of Middleboro and vicinity.

The Nemasket House, located on Main street, has been for the past ten years under the mauagement of P. E. Penniman, who has conducted it in a manner gratifying to his many patrons, and with success to himself. The house contains twenty-four rooms nicely furnished, and the accommodations generally are many and adequate. A well kept livery stable is maintained where comfortable teams may be procured, and coaches connect with the trians. Mr. Penniman is ably assisted by his genial clerk J. C. Daggett who is ever watchful for the comfort of guests as well as for the interest of his employer.

James L. Jenney, one of the principal dealers in coal and wood, is located on Vine street, where for the past nine years he has supplied many of Middleboro's families with fuel, as well as supplying many of the manufacturers with coal. He has ample facilities for handling coal in large quantities, which is landed direct to his sheds by the cars of the Old Colony. He has eleven sheds, and employs eight hands and six teams. Mr. Jenney is an old resident of this town having lived here for the past twenty-five years, and is well and favorably known. 
Clark \& Cole, manufacturers fof boot, shoe and packing boxes, represent one of the thriving industries of Middleboro. Though established but four years they are already well and favorably known among the various manuiacturers of New England, where the larger part of their output is sent. The premises occupied by them are located on Cambridge street about one and a half miles from the depct, and consist of a two-story frame building ro5 $\times 35$ feet in dimensions. A force of forty hands is employed and the latest and best kinds of machinery enable them to produce a great variety of boxes for a great variety of uses to the number of 500 to $\mathrm{I}, 000$ per day. Clark \& Cole are young, energetic, and alive to the interests of their customers; and they may well be proud of the high standing and excellent rating which has been accorded them.

C. W. Maxim's sawing, planing, moulding and turning mill is located on Vine street, near the depot in Middleboro, It is a two-story frame building $44 \times 42$ feet in dimensions, and in it are employed none but skilled workmen. In connection with the saw mill he does general jobbing, and all kinds of window and door frames are made to order. He has built up a lucrative business and is well and favorably known.

J. S. Benson \& Son, manufacturers of and dealers in box boards, slabs, wood and lumber, are located upon Wareham street, where they are well provided with arrangements and appliances for carrying on the large and prosperous business which they enjoy. Ten hands are employed, the products of whose labor is in good demand in New York, Philadelphia and other places. This business was originally founded about forty years ago by $\mathrm{S}$. Bensun and occupied the present site of the South Middleboro station. In I $88_{5} \mathrm{~S}$. Benson died and the business came into the hands of the present proprietors who possess a high reputation for business integrity.

E. F. Witham's mlll at South Middleboro was first built in 1872 , and was originally used as a trunk factory until i 1880 , when it was bought by B. F. Leonard, who conducted it up to the time of his death. In I88 5 it became the property of J. F. Witham \& Son. They used it for a box and trunk factory for four years, when E. F. Witham commenced the sawing of lumber, which is obtained within the vicinty of from five to six miles, by his own teams. About two and a half million boards are produced annually, amounting to twenty thousand dollars. They occupy a two-story frame building twenty-five by fifty feet. This mill is operated by steam power, and an average help of about twenty men are employed. Mr. Witham was born in Middleboro and has always resided here.

\section{LAKEVILLE.}

This place derives its name from a magnificent chain of lakes and ponds which lie along the borders of the town. It is one of the best inland summer resorts and dwelling places in the state, and is fast gaining a reputation for the excellence of its fresh water fishing. Assawamsett pond, with an area of five by three miles in extent, being well stocked with fish, includ- 
ing black bass and land-locked salmon. The town has a population of about $\mathrm{r}, 200$, most of whom are engaged in agriculture, and the best accommodations are at hand for camping parties. It is a healthful resort, abounds in picturesque rural scenery, and in the early days of the Old Colony these beautiful ponds were the scenes of many desperate encounters with Indians.

MYRICK's,

is a station on the Old Colony Railroad, and is about three miles from

$$
\text { ASSONET, }
$$

a village of Freetown on Assonet bay, eight miles from Fall River, the stations intervening between Assonet and the latter being Somerset Junction and Steep Brook. (See Fall River.)

The stations on the Newport line are Tiverton, Bristol Ferry, Portsmouth, (see Portsmouth), Portsmouth Grove, Middletown and Newport. (See Newport.)

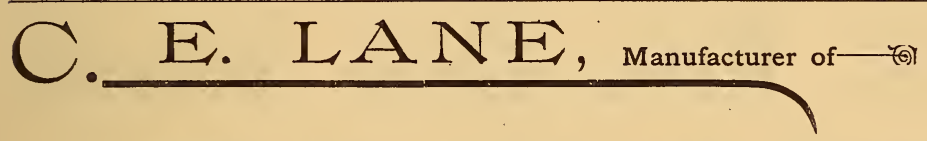

\section{FINE CALF BOOTS AND SHOES,}

BOSTON OFFICE:

105 and 111 Summer Street, Room 11. ROCKLAND, MASS.

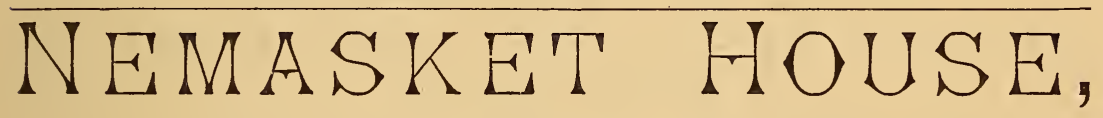
MIDDLEBORO, MASS.

\section{LEBARON} FOUADRY

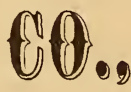

Stove, Machinery and Job Castings.

Patent Window Weights of all, sizes constantly on hand, or made to order. Garden Vases, Chairs and Settecs, Slable Castings, Etc. Also Ship and Boat Ballast.

E. P. LeBARON, Prop. 


\section{PIPER, COTTLE \& CO., MANUFACTURERS OF}

UNION AND HEMLOCK SOLES, TAPS, INSOLES, TOP LIFTS, ETG. Factory:

Randolph,

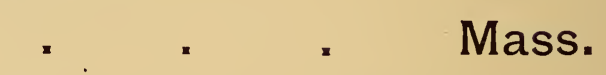

BOSTON OFFICE, 120 Summer Street, - - - - - BOSTON, MASS.

\section{F. \& A. W. STONE, \\ Machine Work, Engine Building, \\ GENERAL REPAIRING.}

Randolph, - - $\quad$ - $\quad$ Mass.

\section{A. J. GOVE'S}

RANDOLPH and BOSTON EXPRESS, BOSTON OFFICES,

174 Washington St., $\therefore$ and $\therefore 15$ Devonshire St.

A. J. Gove's Boarding and Livery stable.

Barges for Excursion Parties. Hacks for Social and Civic Occasions.

Randolph, - $\quad$ - $\quad$ - $\quad$ - Mass.

\footnotetext{
ESTABLISHED 1864.

J. F. TWOMEY, MANAGER.

ESTATE W. P. O'BRIEN,

manufacture aLL Grades

MEN'S AND BOYS' CALF BOOTS,

Randolph, - - - - Mass.
} 


\section{THE NEW ROAD.}

$\mathrm{R}^{\mathrm{s}}$

ETURNING again to South Braintree, this latter place has another connection with Fall River by what is known as the "New Road,' a name used to distinguish the line from the route last mentioned and known as the "Old Road." The road runs via Taunton, the first station from South Braintree being Mayflower Park; other towns and stations follow in their order.

\section{RANDOLPH.}

This town is one of the most interesting in point of scenic features on the line of what is known in the Old Colony system as the "New Road." It is practically what is generally recognized as a "shoe town," that industry predominating in its manufactures, although the suburbs of the villages of Randolph; New Dublin, Tower Hill and West Corners are the finest agricultural sections to be found in this part of the state. The village proper has many fine streets, amply shaded by handsome elm trees, and the most commodious town hall in this section. Its people are highly cultured as a whole, being musically inclined, and are noted for the successful musical conventions for so many years held there. There are some elegant private estates in Randolph, its educational advantages are of the highest arder, and its churches embrace nearly every denomination of Christians. It has several fine stores, its municipal affairs are wisely and efficiently administered and everything about the town is indicative of thrift, progress and domestic comfort. It is located I 5 miles from Boston, and six miles from Brockton, with which latter city it is connected by an electric railroad. The town has a population of nearly 4,000 .

W. P. O'Brien, boot and shoe manufacturer, is a well and favorably known house among the jobbers of these goods. The business is at present being managed by Mr. J. F. Twomey for the estate of W. P. O'Brien. Mr. Twomey has had some twelve years' experience with his late employer and is consequently well qualified to fill the position he holds. This business was originally established by S. O'Brien \& Sun about twenty-five years ago, who were succeeded about ten years ago by the late W. P. O'Brien. The business consists principally of the manufacture of men's boots and is mostly confined to the western trade. The factory, at the corner of North and Plain streets, is thoroughly equipped with the most modern machines and special appliances. This house is in a position to turn out first-class work with promptness and 
reliability, their long experience and excellent business methods building for them a desirable and enviable reputation. A Boston office is maintained at 105 Bedford street. Mr. Twomey, who is managing the business, is also connected with the house of Twomey \& Brennan, gents furnishing goods, boots, shoes, etc.

Twomey \& Brennan are dealers in boots, shoes, rubbers, and a general line of gent's furnishing goods. They are well known business men of Randolph and are conducting a successful and growing business. Mr. Twomey is also managing the business of the late W. P. O'Brien.

Piper, Cottle \& Company was established in 1891 as dealers in sole leather and manufacturers of Union cut soles, hemlock soles, insoles, top lifts, etc. Though established only a short time their business has increased rapidly and their goods are known all over the country. The premises occupied by them are centrally located on the main street in Randolph, and consist of a threestory frame building $100 \times 60$ feet in dimensions. Steam power is used and ten experienced hands are employed who cut about one thousand sides of Union soles a week, and two hundred sides of hemlock in the same time. The men's goods are sold mostly in Randolph and vicinity, while the goods for women are sent to Maine and New York state. Mr. Cottle is a well known resident of Randolph, having lived there for over thirty years, while Mr. Piper has also lived in the place for over twenty-five years. They have a Branch office at 120 Summer street, Boston.

C. F. \& A. W. Stone, a well known firm engaged in machine work, engine building and repairing of all kinds of machinery were established about three years ago. They are located on Union street, Randolph, where they also do a large business in plumbing. They occupy the lower floor of a two-story frame structure whose dimensions are forty-two by seventeen feet, which is lit by electric lights; they being the first to use electricity in the town, and owning their own dynamo. Steam power is used and they employ three hands. Satisfactory work is guaranteed and orders by mail or otherwise receive prompt attention.

Gove's Express, which was established by its present proprietor, Mr. A.J. Gove in 1865 , is the oldest express to run between Randolph and Boston. Before the cars entered this town he made the trips by road entirely. Now the cars of the Old Colony Railroad are used in addition to the trips by road to facilitate the prompt delivery of merchandise entrusted to his care, which through his popularity with the merchants and citizens of this place has developed into a business of no small proportions. In addition to the express business he also carries on a successful and extensive livery stable, where he has excellent facilities for that business in the way of fine hacks for social and civic occasions, barges for excursion parties and well kept carriages for pleasure driving, etc, his outfit consisting of eight single and two double teams, and twenty-five well kept and faithful horses. The premises occupied consist of a large two-story building $190 \times 75$ Ieet in area located on South Main street. Twelve men are employed and under the direction of $\mathrm{Mr}$. Gove, they keep the 


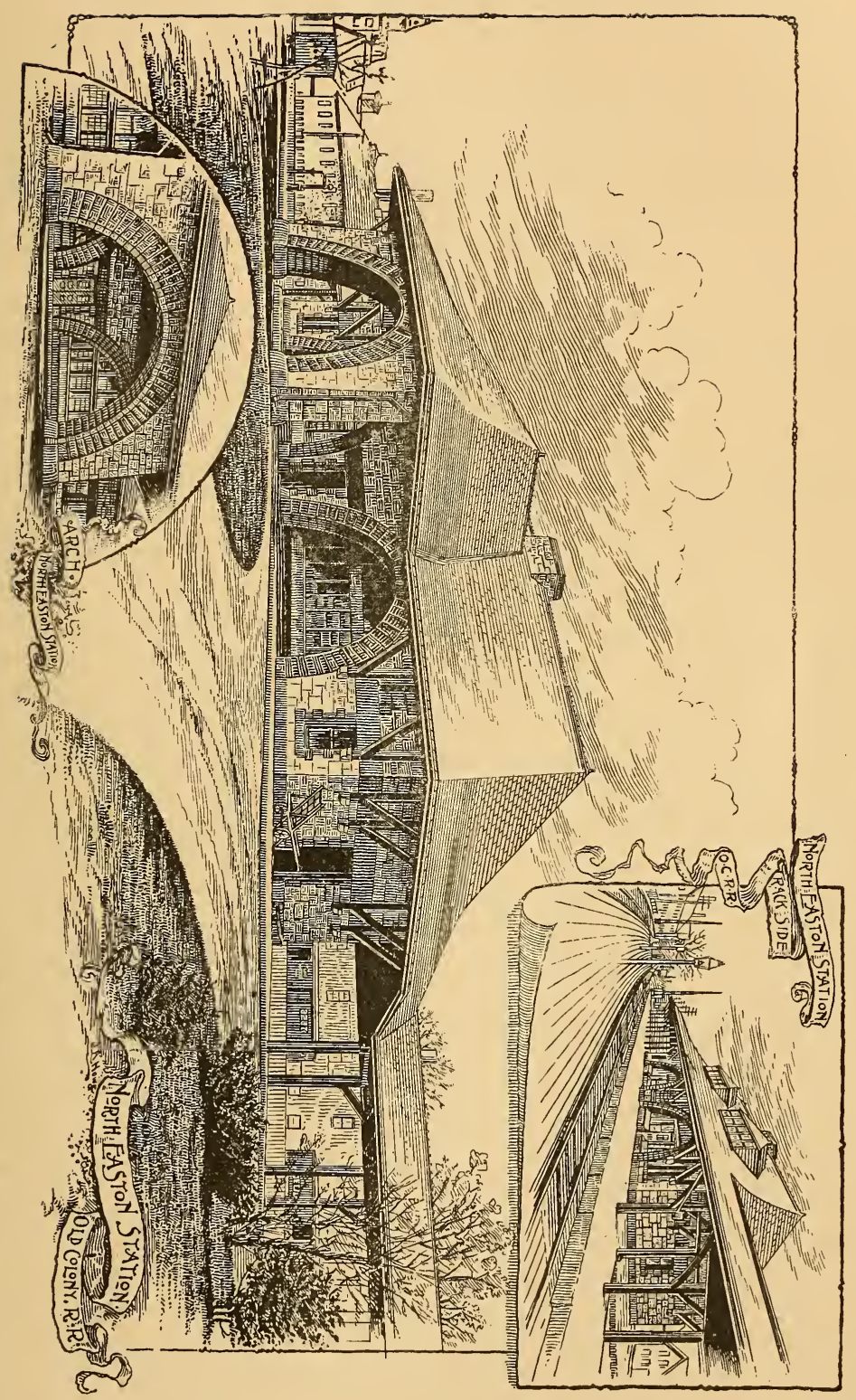



place up to that standard of neatness and general excellence which is characteristic of the man himself. The horses are well fed and well kept, the carriages are of the best, the stable and surroundings are neat and orderly and one is at once impressed, on entering the establishment with a sense of satisfaction, and assurance that in securing the services of $\mathrm{Mr}$. Gove, or in other ways being accommodated by him, he will receive the best that can be had, and it is from this fact that $\mathrm{Mr}$. Gove has attained the success he so well deserves.

\section{STOUGHTON.}

For description of Stoughton and North Stoughton, see "Stoughton Branch," Providence Division.

\section{NORTH EASTON.}

This is a manufacturing and general farming section, but is principally noted for the great production of shovels, more than three-fifths of all these useful implements made in the world being credited to North Easton, it being the location of the famous Ames shovel works. This great industry was founded by the family whose names are still identified with it, and who have beautiful estates in the village. It was the home of Oliver and Oakes Ames, whose names are familiar to all in connection with the Union Pacific Railway, the first trans-continental railway constructed in this country, and which has been instrumental in opening up for agricultural and mining purposes such a vast area of the west. North Easton has a population of 3,000, good schools, one national and one savings bank, several chnrches, and possesses many social advantages not common to a place of its size.

The Oliver Ames \& Sons Corporation of North Easton is well known throughout the world for the mannfacture of their celebrated shovels, spades, scoops, and drainage tools. Their works are the oldest of the kind in the United States, having been established since I776, and also the largest in the world. The premises occupied consist of eighteen large shops, run by steam and water power, and the annual products amount to one hundred thirty-five thousand dozen. They have taken the first prizes at the United States Centennial Exbibition, 1876, at the Paris Exposition 1878, at the Chili International Exhibition, I879, at the Melbourne International Exhibition of 1881 , and at many others. The shovels manufactured here are used exclusively by most of the railroads of the United States, and have a wide reputation the world over, particularly in Australia, South America, Africa and Mexico. The factory furnishes employment to five hundred expert mechanics.

The New England Specialty Company, of North Easton, is extensively engaged as hardware manufacturers ; among their products being screw drivers, can openers, kitchen knives, brad awls, tack hammers, etc. They also make a specialty of nickel plating. The company enjoys an extensive trade, their goods being sent to the leading cities throughout the United States as well as abrcad. The works are confined to a one-story frame building, where water 


\section{J. T. TI MANOFACTURER OF

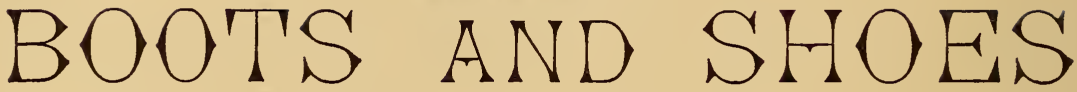

Exclusively for Retail Trade.

NORTH EASTON,

MIASS.

\section{NEW ENGLAND SPECIALTY CO., NORTH EASTON, MASS.,}

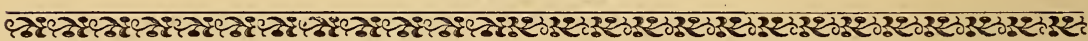

Hardware Specialties and Novelties.

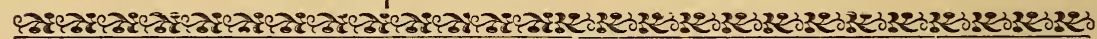
ALSO NICKEL PLATERS.

A. J. LEAVITT, Manager.

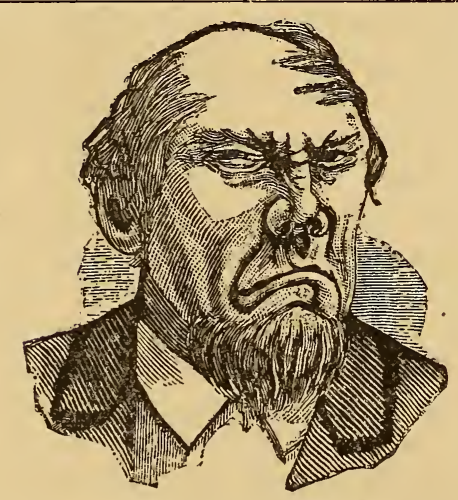

A. A. GILMORE, Treasurer.
Boston Office, 64 Federal St. BRISTOL PRINTING CO.,

\section{MEROANTILE PRINTERS,}

And Wholesale Dealers in Paper, Twine and Bags of all kinds.

We make a Specialty of High Grade Commercial and Ball Work, Engraved Invitations and Cards, and the Finer Class of Printing.

SHOE TAGS AND FACTORY PRINTING AT BOTTOM PRICES.

NORTH EASTON, MASS.

\section{HAYWARD * CARRIAGE * COMPANY, * * eASTON, MASS. * * - . manufacturers of - .
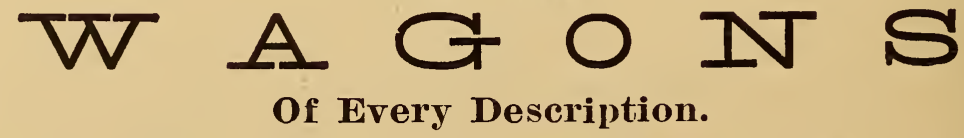

Butcher, Milk, Grocer and Express Wagons a Specialty. 
power is used and employment is given to fourteen skilled workmen. This company which has been established here for the past eleven years, is under the management A. J. Leavitt, the proprietor, who by his energy and business tact, has built up one of the most thriving enterprises in North Easton.

J. B. King, on Centre street, ranks with the first in North Easton in the manufacture of men's boys' and youths' boot and shoes, a business he has successfully conducted for the last twenty years. During this time business has steadily increased so that now sixty hands are employed whose daily output amounts to from twelve to fifteen cases per day, of twenty-four pairs each. The goods are made chiefly for the retail trade, and shipped to the West. The premises embrace a three-story frame building, covering an area of thirty by eighty feet, equipped with all the latest improved machinery operated by steam power. Mr. King, being a native of North Easton, is well known, and highly respected throughout the town.

\section{EASTON.}

Easton forms the northeastern angle of Bristol county, and is 24 miles south of Boston. It is bounded on the north by Sharon and Stoughton, east by Brockton and West Bridgewater, south by Raynham, Taunton and Norton, and west by the latter and Manstield. Its territorial form is quite regular, but with its western side shortest. Easton has many fine estates, excellent sanitary conditions, good schools, churches, a national and a savings bank. It is the centre of a productive farming section, and possesses many features which make it desirable for permanent residents or summer vistors. Population, 4,493. It is located at the junction of the Brockton and Easton Branch of the Old Colony, known as "Shovel Handle." The Indian name of this place was Hockamock. It was originally a part of Norton, from which it was detached and incorporated Dec. 21, I 725, being named, perhaps in honor of John Easton, who was governor of Rhode Island from i 690 to I 694 .

The Hayward Carriage Company, among the notable houses engaged in the manufacture of carriages, it entitled to special consideration. The business was established in 1830. Mr. Hayward has had long and practical experience in his vocation and he supervises all departments of his factory, assisted by competent foremen, thus affording satisfactory results. The company manufacture wagons of every description, which for style, workmanship and durability, cannot be excelled by any other concern in southern Massachusetts. A specialty is made of butcher, milk, grocery and express wagons, only the best and most carefully selected materials being used. The products of the establishment are sent to all parts of the state, and are giving the best of satisfaction. A full stock is constantly carried, special attention being given to order work.

The Belcher Mallable Iron Co. in I 890 succeeded to the business established in 1837 by Daniel Belcher. The work consists in the manufacture of superior malleable iron castings from air furnace iron for machinery purposes, also for gun, rifle and pistol castings, carriage iron, or anything that requires a strong tough casting, Other products are steel castings, tempering pots, chilled rolls, 


\section{T. H. DEAN \& CO.,}

[Formerly T. H. \& J. O. DEAN,

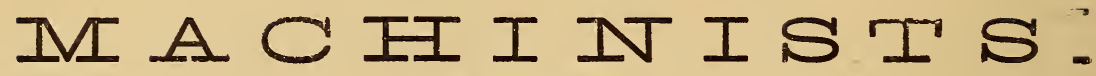

-Manufacturers of-

Piano and other Castors, Winding Machines, Eye Machines, Boring Machines, Drilling Machines, Boring Bitts, Reaming Bitts, a variety of other TOOLS and HARDWARE,

SOUTH EASTON, - - MASS.

\section{S. D. SIMPSON \& SON,}

GARRIAGE MANUFACTURERS,

Butcher, Milk, Express, Farm and other Wagóns

MADE TO ORDER.

Repairing done with Neatness and Despatch.

SO. EASTON, MASS.

\section{SIMPSON SPRING =}

(WHITE LABEL)

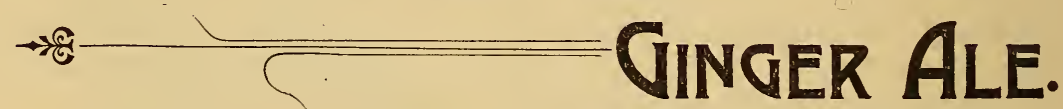

Absolutely free from Capsicum. Will not cause Constipation. Made from the Mildly Cathartic Simpson Spring Water. Purity Guaranteed.

Delicious and Sparkling as Champagne,

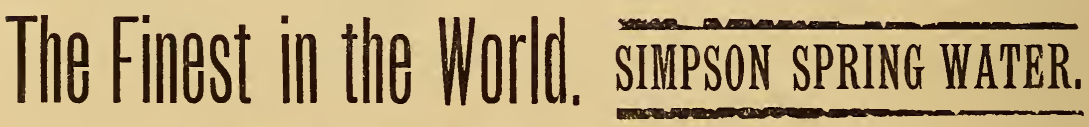

"It is very Palatable AND Absoldtely SAFe."-Prof, RAPHAEL PUMPELLY, Chemist National Board of Health, Newport, R. I.

"I am convinced that its properties are characteristic, and as clinically trustwcrthy as are those of terebinthina, lithia, or many other of the partially proven drugs."-J. HEBER SMITH, M. D., Professor of Materia Medica for eleven years in the Boston University'Medical School.

\section{SIMPSON SPRING CO.}

F. A. HOWARD, Treas. and Manager.

Supt, of Factory: Prof. W. U. BARNES, Chemist and State Assayer.

Office, 201 State St., Boston. 
and plough points. The latter are made from best charcoal iron, and will wear three times as long as ordinary chilled points. Their premises embrace five buildings where thirty-five hands are kept busy producing work which is sent to all parts of New England, requiring a weekly melting of ten tons of iron.

The Bristol Printing Company, Easton, of which A. A. Gilmore is proprietor, was established in I 887 , and does a large amount of shoe factory and other printing; also deals in wrapping paper, twine and bags of all kinds, envelopes, writing papers, blank books, papeteries, toilet papers, Japanese napkins, ice cream and candy boxes, oyster sacks, wood dishes and plates, cutters for paper in rolls, etc. The premises which are corveniently located on Main street, comprise a four-story frame building, covering an area of twenty-two by thirty-three feet, fitted up with steam power and all the latest improved machinery. Mr. Gilmore is well known to the trade, and devotes his undivided attention to all orders which are executed with promptness and satisfaction.

The Simpson Spring, a somewhat celebrated spring, was purchased more than sixty years ago by Samuel Simpson, from whom it takes its name, it beingformerly called Ridge Hill Spring. Its medicinal qualities were tested and utilized by $\mathrm{Mr}$. Simpson, more than fitty years ago and the proof of its beneficial effects in diseases of the stomach, kidneys and bladder became so positive, that in 1878 F. A. Howard, grandson of Samuel Simpson, decided to put the water on the market. "The Simpson" spring supplies a drinking water that is endorsed by physicians, and is highly recommended for people troubled with the diseases before mentioned. The business was commenced in a very small way, and carried on for ten years by F. A. Howard \& Co., when it was incorporated under the laws of Maine with a capital stock of thirty thousand dollars. The present officers are Henry C. Delano, president; F. A. Howard, treasurer and manager. The directors are, H. C. Delano, Oliver Ames, 2d., J. Mott Smith, A. W. Preston and F. A. Howard. The company have excellent facilities for successfully carrying on the work at the spring, their main office and storage rooms being at 20I State street, Boston. They now do a very large business in the manufacture of earbonated beverages, fruit juices, extracts, etc. The company also has a growing export trade to the West Indies, and deals in, and imports fruit juices.

S. D. Simpson \& Son are old residents of Easton and are known as manufacturers of milk, express and farm wagons, also carriages of all kinds. This business was originally founded by Samuel Simpson in 1828 , he carrying it on till I 860, when S. D. Simpson assumed control, who in 1882 took in his son and formed the present company. The premises located on Washington street consist of two buildings, one a two-story frame being thirty by sixty feet in dimensions, and the other a one-story frame, twenty by sixty feet with an ell adjoining, twenty by thirty feet. Seven men are engaged as help, who turn out large quantities of work, which is sent to Brockton, Stoughton and Bridgewater. The gentlemen of this firm are well known to the trade and enjoy an excellent reputation for square dealing and first class work. 
T. H. Dean, a well known citizen of South Easton, has since 1850 been engaged in the manufacture of piano castings and pianoforte machinery of all kinds, in which he enjoys an extensive and flourishing trade, both in Easton and surrounding towns as well as throughout New England. His factory conveniently located on Washington street, covers a large tract of land, and is fully equipped with all the necessary appliances, operated by both steam and water power. Six hands are engaged as help, the products of whose labor and skill is noted for its excellent quality.

\section{RAYNHAM.}

Raynham in the easterly part of Bristol county, and long associated with the cruder manufactures of iron, is 30 miles from Boston, The post-offices are Rarnham (centre) and North Raynham; the other villages, Prattville, East Raynham and South Raynham. Easton bounds it on the north; Bridgewater and Middleborough on the east; and Taunton on the south and west. The largest manufacture of this town at present is boots and shoes. There are also made shovels, nails and iron castings. Population, I890, I,340.

The Diamond Tack and Nail Works of Raynham, Mass., were first started in I 844 by Geo. W. King. Later he was succeeded by Emerson \& Company, who were succeeded by Leeds, Robertson \& Company, and in r89r the present firm comprising C. B. Gardiner and D. F. Ranney, became proprietors of the works. They are fully equipped with all the latest improved machinery, both steam and water power being used. The products, which include tacks and small rails of every description are sent principally to New York and Boston, but some foreign trade is transacted. The premises comprise a one-story frame building, where twenty-five hands, who have all had a practical experience are busily engaged turning out large quantities of tacks annually. Gardiner $\&$ Ranney are well known to the trade, and enjoy the esteem of the public as well as a prosperous business.

Zeno H. Kelley of North Raynham, who is conveniently located near the depot, has been for the past twenty-two years engaged as manufacturer of men's, boys' and youths' shoes of medium grades for the jobbing and retail trade, which are shipped mostly to the leading cities in the West and South, although he enjoys an extensive home trade also. The premises embrace a three-story frame building, where the latest improved machinery is in use, including steam power.

\section{TAUNTON.}

[Whittenton, Whittenton Junction and other stations within the city limits are mentioned elsewhere.]

\section{THE DIGHTONS.}

Dighton lies in the central part of Bristol county, 40 miles south of Boston by the Old Colony Railroad, which runs along the Taunton river (formerly the divisional line on the east) through the entire length of the town. Taunton 
bounds it on the north, Berkeley on the east, Somerset and Swansea on the south and Rehoboth on the west. The post-offices are Dighton, North and West Dighton, and Segreganset. Dighton was originally a part of Taunton, and was incorporated May 30, I8I2. "It was named," says Wm. H. Whitmore, in his able essay on "The Origin of the Names of Towns in Massachusetts," "most probably in honor of Frances Dighton, wife of Richard Williams, one of the first settlers, and sister of the second wife of Gov. Thomas Dudley." There is said to be no other town in the state that derives its name fro:n a woman. The first church was organized in I7IO, and reorganized in I826. Assonet Neck, on which is situated the famous:- Dighton Rock," whose inscriptions have puzzled the antiquaries of Europe and America, lies on the eastern bank of the Taunton river in the town of Berkeley. Three-Mile river forms the line separating Dighton from Taunton at the northeast corner, where it furnishes power for the manufactories of North Dighton village. The Sweganset river, an affluent of the Taunton river, rises in the western part of the town, flows southeasterly, and affords valuable water-power. The manufactures consist chiefly of stoves and the associated articles; paper, paints and colors, carriages, building material, brooms, etc. The Old Colony Railroad has stations at Dighton and North Dighton. Population of the town, I890, I,889.

The Dighton Stove Lining Company, has been established twenty years, but was incorporated as a stock company about ten years ago, with a capital stock of twenty-five thousand dollars. They are engaged as manufacturers of stove and range linings, fire brick, etc. The president is G. C. Francis and the treasurer W. Z. Whitmarsh. The main building covers an are a of one hundred fifty by sixty feet, while they also have a large storehouse adjoining, the dimensions of which are one hundred twenty by twenty-five feet. The factory furnishes employment to twenty men, who are kept constantly busy, producing special work for the Magee Furnace Co., Richmond Stove Co. of Norwich, Conn. and the well known house of Walker \& Pratt Manufacturing Co. of Boston. The products are also sent to Providence, New Bedford and Erie, Pennsylvania. The clay from which these goods are made is procured from New Jersey, the annual production of stove linings, amounting to fifty thousand sets, while twenty-five thousand dollars worth of tire brick is turned out every year.

C. N. Simmons the subject of this sketch, is a life long resident of Dighton, and one of its most prominent and prosperous farmers and strawberry growers. Dighton strawberries are noted throughout the state for their excellent flavor and are grown in great quantities. $\mathrm{Mr}$. Simmons is one of the largest growers in this section, having had as many as twenty-six acres of strawberries under cultivation in a single season. During the season be employs from tifty to one hundred pickers, and a fair average per acre of strawberries picked would amount to 3,200 quarts, which are principally sent to Boston. In addition to the grounds used for the cultivation of strawberries he also owns a farm which is known as Crystal Spring farm of over 200 acres in extent which is said to be one of the best farms in Bristol county where a beautiful grove is situated which is in demand by 


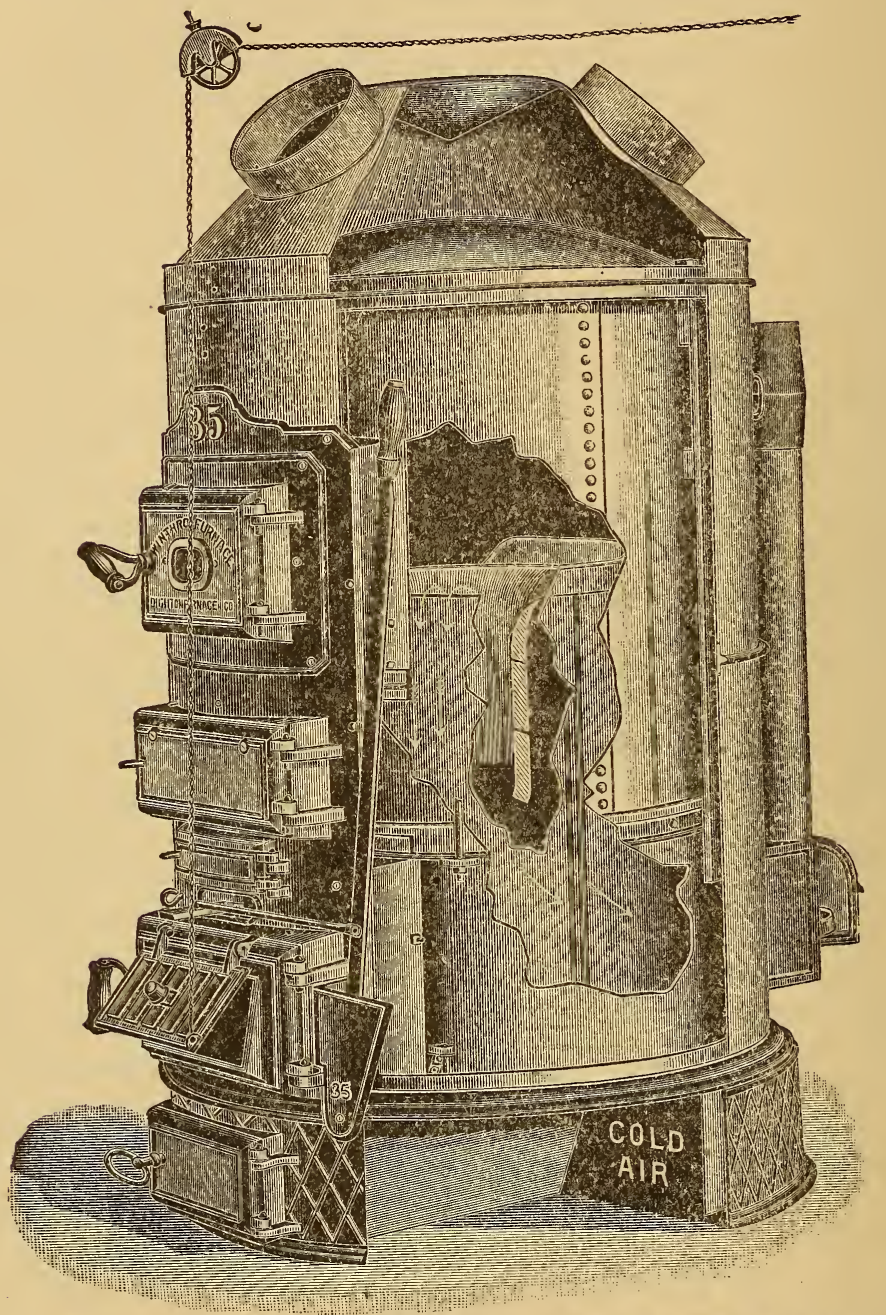

\section{RANGES AND FURNACES.}

HIGHEST GRADE.

thantisumas DIGHTON FURNACE CO., NORTh DIGHTON OR TAUNTON, MASS. 
picnic parties, and the famous clam bakes of the season are held here. One of the finest springs to be found any where in New England is situated here, the water of which is cold, clear and sparkling and from which the farm derives its name. Mr. Simmons is a man of good sound business ability, and respected by all who know him. He is of a cordial and hospitable nature and the success and prosperity he has attained are as well merited as they are prominent.

The Dighton Furnace Company, located on Railroad avenue, North Dighton, has been established since I 858 , being incorporated with a capital stock of seventy thousand dollars. The president is Sylvanus N. Staples, and the treasurer is Fred P. Leonard. This company is engaged in the manufacture of stoves, furnaces, hollow ware, cast iron pipe and fittings. The products are sent all over the New England states, California and Chicago. Their premises cover about three acres of land. Steam power is used and one hundred and twenty hands find employment here.

\section{BERKELEY.}

Berkeley is a small agricultural town situated in the easterly part of Bristol county, about 40 miles south of Boston, and bounded on the north and northeast by Taunton, on the south and southcast by Freetown (from which it is in part separated by Assonet Bay), and on the west by Dighton and Taunton, from the last of which it is divided by Taunton river, here a navigable, broad and beautiful stream. It is watered in the east by Cotley and Quaker brooks, and in the west by several affluents of Taunton river. The villages and postoffices are Berkeley (centre) and Myricksville; and the railway stations are the latter, in the southeast part of the town, on the New Bedford and Taunton line, and Berkeley on the Fall River Branch of the Old Colony Railroad. The termination of the town southerly is a long point of land called Assonet Neck. A little south of it lies Conspiracy Island, probably so named from its connection with King Phillip's conspiracy against the English, which resulted in the Indian war, known by his name.

\section{SOMERSET.}

Somerset, near the centre of Bristol county, lies on the west bank of the Taunton river, opposite the city of Fall River. Dighton lies on the north, and Swansea on the west, also on the north of a southwestern projection, and on the south is Mount Hope Bay. The form is long, narrow and curved southwestward. The railroad crosses the river here, entering the suburbs of Fall River on the other side. The town lies on an elevation sloping gently upward from the bay, and presents many situations overlooking the waters in all directions, of rare beauty. Many desirable summering-places are within easy reach. Population, I 890, 2, 106.

The Somerset and Johnsonburg Mfg. Co. is one of the wealthiest and best known corporations of its kind doing business in this town, and is widely known in the manufacture of vitrified paving brick, fire proof building brick, 
ARNOLD B. SANFORD, PREST.

WARREN H. SANFORD, TREAS. EDWARD D. EMERSON, GEN. MGR.

\section{Somerset and Johnsonburg

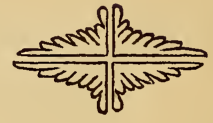 Manufacturing Co.,} *** Capital, 500,000.

MANUFACTURERS OF

VITRIFIED PAVING BRICK. : :

ENAMELED BRICK. ; : : : :

FIRE BRICK. STONE WARES.

CUPOLA and FURNACE LININGS

DEALERS IN

Five Clay, Kaolin, Etc.

CAPACITY $30,000,000$ BRICKS PER ANNUM.

Sole Agents and Owners in

United States and Canada of the FOHNSON PATEN1 Brick Making Machinery.

FACTORIES,

Somerset, Mass., Johnsonburg, Pa.

BOSTON OFFICE.

166 Devonshire St.
NEW YORK OFFICE.

119 Times Bl'dg.
PITTSBURG OFFICE,

712 \& 713 Lewis Block. 
cupola furnace and stone ware also dealers in fire clay, kaolin, etc. It was established as the Somerset Pottery Works, but in I891 it was incorporated under its present name and now has a capital of $\$ 500,000$, and officered as follows: Arnold B. Sanford, president; Warren H. Sanford, treasurer and C. Hathaway, superintendent. The amount of business done by this concern is of great magnitude, dealing as it does throughout the United States and Canada. In addition to the business described they are also sole agents and owners in the United States and Canada of the celebrated Johnson patent brick making machinery. Their factories are extensive affairs covering some four acres of ground and giving employment to nearly 200 hands, and with their large plant at Johnsonburg, Pennsylvania, gives them facilities for turning out $30,000,000$ bricks per annum. The gentlemanly managers of this business are thoroughly energetic, reliable and responsible, and are very popular with their patrons on account of their liberality and the honorable spirit characterizing all their transactions.

The Somerset Stove Foundry Company, one of the influential and flourishing industries of Somerset, was first established in 1858 as the Boston Stove Foundry Co., which in I 868 was succeeded by the Somerset Co-operative Stove Foundry Co., it in turn being followed by the present company which was incorporated in $\mathrm{I} 89 \mathrm{I}$. The officers of the company are president, John D. Flint of Fall River; treasurer, Wm. P. Hood; Hon. Frank S. Stevens, A. A. Hood, A. W. Lincoln and Isaac T. Brownell, with the president and treasurer, constitute the board of directors, and under the able management of these gentlemen this foundry has attained a position in the mercantile world that is in keeping with good management and business integrity. The works on Main street consist of the foundry building with several storehouses, sheds and wharves, the whole covering ground to the extent of nearly two acres. The establishment is well equipped throughout with all desirable appliances, including steam power. and gives employment to fifty skilled moulders; mounters, etc., their product is noted for its excellence of finish and durability, and embraces a full line of stoves, ranges and hollow ware, among the leading specialties of which may be uamed the "Somerset Grand," "Grecian," "Matron" and “Wyoming" ranges.

The Wilson Lace Clasp Co., who carry on one of the important branches of industry in Somerset, are engaged in the manufacture of Wilson's patent improved lace clasps, for use on lace shoes, corsets, gloves, leggings, gaiters, etc., to enable the wearer to securely fasten the ends of the lacing without tying a knot. This company was incorporated in 1889 , with $\$ 150,000$ capital. H. B. Baker of Dighton, Mass., is its president and treasurer. It makes the most practical lace clasp, and the only one which has a medal and diploma for excellence. The clasps are made in black, silvered, copper, brass red and russet, and are extensively used by many of the best makers in the country, among which are Edwin Clapp, Wright \& Richards, J. T. Turner, Stacy, Adams \& Co., Churchell \& Alden, Niles \& Wilbar, L. A. Cresset, Dugan \& Hudson, Torry, Bullivant \& Co., So. Weymouth Shoe Co., Rockland Co., Jay B. Reynolds, Howard 


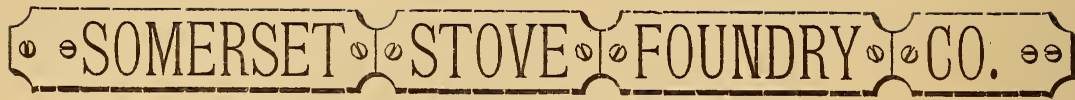

\section{SOMERSET, MASS.}

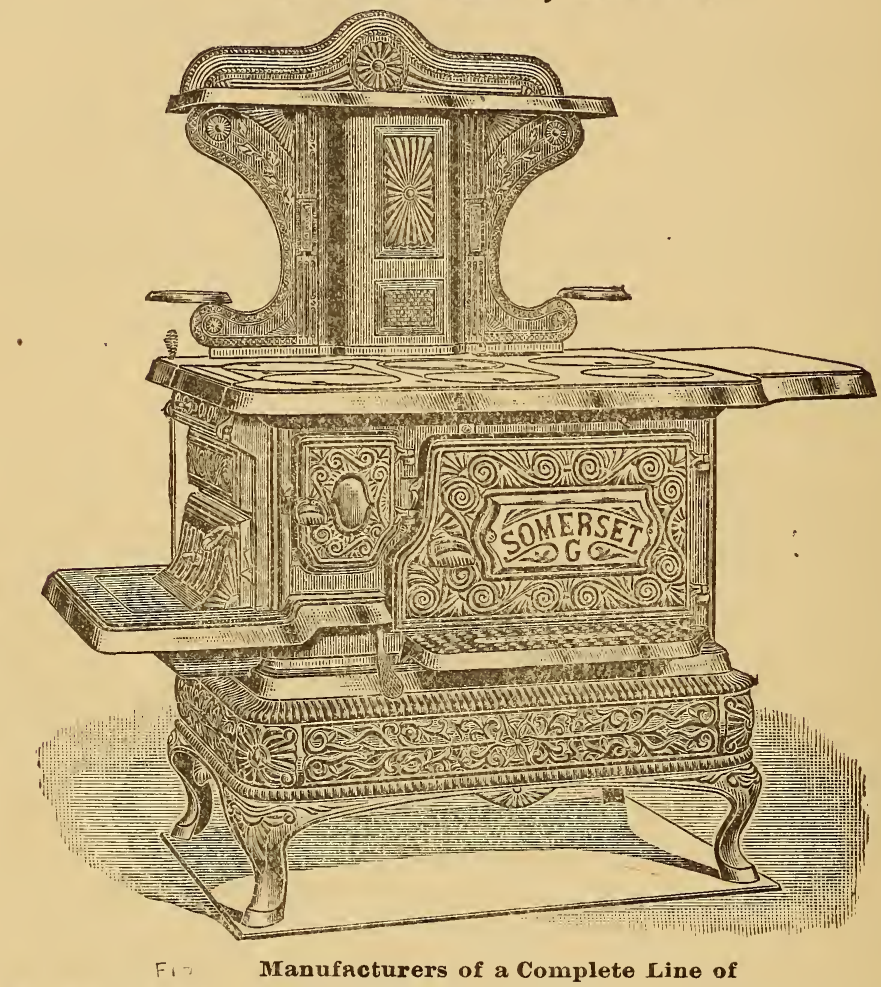

D TICTC Wood and Coal Parlor Stoves, Air Tights, Hollow Ware, RANU HN, Sinks, and best assortment of Common Cook Stoves to be found in New England, viz:

RANGES: Somerset Grand, Somerset G, Somerset, Arion, Matron, Wyoming, Grecian, New Grecian, Harvest and Times.

COOK STOVES: SUPERB, ARION, VESTA and CERES.

PARLORISTOVES: ful Wood Cottage.

Best Hollow Ware in all variety" and Sinks, made in New England; all made from best material by highest skilled labor, carefully numbered, insuring perfection as near as can be reached in working qualities. Ref erence to any in use will establish above fact.

Don't fail to see them before you buy.

For sale by all first-class dealers. 
\& Foster, Geo. E. Keith, R. B. Grover \& Co., E. H. Stetson \& Co., Smith \& Stoughton, Thns. White \& Co., Allison Boot \& Shoe Co., Strong \& Carroll, J. Freman Shoe Mfg. Co., and many others. This company has an office in Boston, No. 280 Devonshire street, which is presided over by its energetic and efficient selling agent, E. B. Webster. They also do an extensive business in Canada and England; the Canada business is taken care of by the home office, but the business in England and the continent, is done through the selling agent, Adolph Riekmann, 59 Knightrider street Queen Victoria street, London, E. C. Eng., who has sold the clasps from England to Australia.-(For illustrations of the Wilson lace clasp see index to advertisements.)

The Mount Hope Iron Company is a large iron manufacturing company in Somerset, the business of which consists of the manufacture of cut nails and spikes, plate and band iron for gas pipes, shovels, etc., of every description. The company occupies two large factories and gives constant employment to a large number of experienced workmen. They have the reputation of producing a fine quality of iron, and with all the improvements and conveniences which they have, are enabled to produce a large variety of work, all orders for which receive prompt attention. Branch stores are located at Boston and Providence. J. M. Leonard is the treasurer and H. B. Leonard agent of the company.

Geo. C. Belcher.

Belcher Malleable Iron Co.,

Successors to Daniel Belcher. MANUFACTURERS OF

\section{Superior Malleable Castings}

FROM AIR FURNACE IRON.

SPECIALTIES: Machinery. Rifle, Gun and Pistol Castings, Cast Cast-Steel for Gears, Pinions, Cams, Rolls, etc. Metal Patterns made from Draft or Sample

\section{EASTON, - Mass.}

\section{ZENO H. KELLEY,}

-:- MANUFACTURER OF -:-

MEN'S, BOYS' AND YOUTFIS

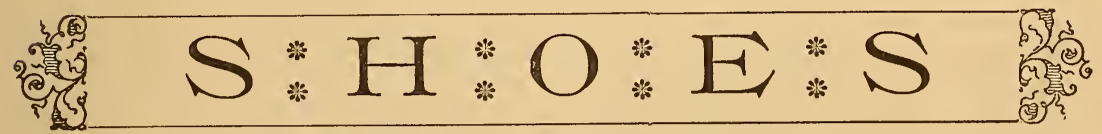

Of Medium Grades for the JOBBING AND RETAIL TRADE. 


\title{
NEW BEDFORD BRANCH.
}

\begin{abstract}
HOWLAND'S.
HIS is the first station on this branch of the Old Colony Railroad, and is 45 miles from Boston. The next one of importance is

EAST FREETOWN:

This is a station in the town of Freetown, which latter is noted for its ledges and large area of forest. It is 45 miles south of Boston, and Brayley's is a station in this town.

ACUSHNET.

Acushnet station is in the pleasant town of that name, located in the southeasterly part of Bristol county. It is bounded by Freetown and Rochester on the north, the latter and Mattapoisett on the east, Fairhaven on the south, and New Bedford on the west. Nearly one third of the original area was annexed to New Bedford in 1875 . It was formerly included in the town of Fairhaven, .having been incorporated on February I3, I860. Its name is from the beautiful river which flows southward along the western side of the bay. Another pretty stream flows along Mattapoisett river in the southeast. New Bedford reservoir, of 280 acres, is located here, and is a very attractive sheet of water. The postoffices are Long Plain, on the eastern side of the town, and Acushnet village on the southwest. Belleville is another small village.
\end{abstract}

\section{EASTON BRANCH, VIA BROCKTON.}

WEST BRIDGEWATER.

W

EST BRIDGEWATER, one of the oldest settlements, is situated in the northwesterly part of Plymouth county, 25 miles south of Boston. The Old Colony has stations at Matfield and Westdale sending from the former a branch to Easton, which has stations at West Bridgewater centre and Cochesett. The last two places and Matfield are the postoffices. The other village is Jerusalem. There are boot and shoe factories, a shovel factory, one making eyelet machines, and others of less importance, while the farming interest is very large. Population, I890, I,91 7 . 
WESTDALE.

This is a station in West Bridgewater, the name of which was formerly Satucket. It is in a quiet rural district, and possesses many desirable features for those who seek the pleasures and health which a country home affords. The sanitary conditions here are of the best, small game is plentiful, the water of excellent quality, and land is comparatively low in proportion to the numerous advantages offered.

\section{COCHESETT.}

A village of West Bridgewater referred to above. Population, 350 . Largely devoted to market and dairy farming, for which the soil is eminently adapted, and the products of which find a ready market in the city of Brockton, from which it is seven miles distant.

[Other stations on this line are Eastondale, South Easton, Easton, North Easton and Stoughton Central, descriptions of which are given elsewhere.]

\section{MIDDLEBOROUGH \& TAUNTON BRANCH.}

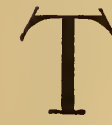
referred to.

HE stations on this branch are Turnpike, North Lakeville, Chace's, East Taunton, Weir Junction and Taunton Central, the more important of the towns and cities in which these are located having been previously

\section{FALL RIVER BRANCH.}

\section{DARTMOUTH.}

$\mathrm{D}$

ARTMOUTH is a large farming, fishing and manufacturing town in the southern part of Bristol county, bordering on the other section of Buzzard's Bay. It is bounded on the north by Fall River and Freetown, and on the east by New Bedford, on the west by Westport, and south by Buzzard's Bay. The Old Colony Railroad station at New Bedford is near and just opposite the middle of the town, and the Fall River Branch has stations at

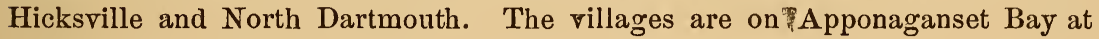
the southeast, on the Pamanset river near the eastern line, in the north part of 
the town on the main branch of the Westport river, and at Westport Mills, on the same river, where it leaves the town on the western side. Other stations on this branch are Mt. Pleasant, Westport Factory, Hemlock, North Westport and Flint Village.

\section{FAIRHAVEN BRANGH.}

MARION.

M ARION is an interesting seaboard town in the southern extremety of Plymouth county, 50 miles south by southeast of Boston. It has Rochester and Wareham on the north, Buzzard's Bay on the east and southeast, Mattapoisett on the south of the western half, and the same and Rochester on the west. The postoffice is Marion. Other villages are Bay View, East Marion, Old Landing and Sippican. The Fairhaven Branch of the Cape Cod Division of the Old Colony Railroad, passing by the head of the harbor, affords convenient land connections. Population, 1890, 871 .

\section{MATTAPOISETT.}

Mattapoisett is a pleasant seaboard town forming the southwestern corner of Plymouth county, 55 miles from Boston. It is bounded on the north by Rochester, also in part by Marion, east by the latter and Buzzard's Bay, south by the last, and west by Fairhaven and Acushnet, in Bristol county. Population, 1890; I, I 48 .

\section{FAIRHAVEN.}

Fairhaven lies on the eastern side of Acushnet river and of New Bedford Harbor, forming the southeast corner of Bristol county, 60 miles south of Boston by the Fairhaven Branch of the Old Colony Railroad. It is bounded on the north by Acushnet, east by Mattapoisett, south by Buzzard's Bay and New Bedford Harbor and west by New Bedford. The soil is loamy and fairly fertile. The place was formerly largely engaged in the whale fishery, but the pursuit has entirely died. The manufactures have flourished, however, and the American Tack Works, with its solid stone factory, and the Fairhaven Iron Foundry, a substantial structure of brick, still lead the industries of the place. There are also four shipyards, a cordage factory, picture frame, clothing, and boot and shoe factories; a printing establishment, and a lively weekly newspaper, the Fairhaven Star. Population, I890, 2,919. 


\section{CAPE COD DIVISION.}

T

HIS division of the Old Colony system has 32 stations, the least important of which will be mentioned in the various towns as they occur. The division begins at Rock station, following which is South Middleborough, both of which have been previously mentioned. Then come stations within the town of

\section{WAREHAM.}

Wareham is a large town in the southerly part of Plymouth county, at the head of Buzzard's' Bay, and 50 miles southeast of Boston. The Cape Cod Division of the Colony Railroad enters the town at the northwest, sends the Fairhaven Branch from Tremont (West Wareham post-office) southward, then swervies to the southeast; the other stations being South Wareham, Parker's Mills, Wareham, (centre and chief village), East Wareham, Onset Junction and Buzzard's Bay. These excepting the last are post-offices. The other villages are Agawam, Onset Bay and Tihonet. The principal industry in Wareham village is iron manufacture, the largest single item being nails. The largest establishments are the Franconia Iron and Steel Works and the Tremont Nail Works. The town contains a saw mill, carriage factories, and factories for leather goods, clothing, etc.

BOURNE.

Bourne occupies the northwest extremity of Cape Cod and Barnstable county, and is about 56 miles from Boston, on the Old Colony Railroad. The stations are Bourne, Bournedale and Sagamore. All these are post-offices. The town is bounded on the north by Wareham and Plymouth, on the east by Cape Cod Bay and Sandwich, south by Falmouth, and west by various bodies of water forming the eastern extremity of Buzzard's Bay. The harbors are Buttermilk, Red Brook, Cataumet and Back River. Population of town I,442.

\section{SANDWICH.}

Sandwich lies on the southwest side of Cape Cod Bay, in the northwestern part of Barnstable county, and is 62 miles from Boston. The stations are Sandwich and East Sandwich; and these, with Forestdale, South Sandwich and Spring Hill, are post-offices. Other villages are Farmersville, Greenville, Scorton and Wakeby. Population, 1890, 1819. 


\section{BARNSTABLE.}

Barnstable extends across the western portion of Cape Cod from shore to shore. It has Yarmouth on the east and Mashpee and Sandwich on the west, and contains about a dozen villages. It is 73 miles from Boston with stations at West Barnstable and Barnstable. These are also post-offices, together with Hyannis Port, Centreville, Marston's Mills, Cotuit, Osterville, Craigville and Wianno; other villages are East Barnstable, Newtown and Old Cotuit. The harbors are Barnstable, Hyannis, Net and Cotuit. A narrow peninsula called Sandy Neck, extcnis from the northwest corner of the town several miles easterly, forming Barnstable Harbor, which admits vessels drawing seven or eight feet of water. Bordering on this harbor are great salt marshes, from which many tons of hay are annually cut. Hyannis Harbor, on the southern side of the cape, is protected by a breakwater, and admits the largest coasting vessels. Cotuit Harbor is formed by Oyster Island and a peninsula projecting from the southwest corner of the town. The manufactures consist of brick, drain pipe, building materials, carriages, and wagons, clothing, fertilizers, leather, wooden goods, etc,. The town has also a large income from its fisheries in which numerous vessels and a large number of its citizens are engaged.

\section{YARMOUTH.}

Yarmouth forms a section of the southern part of Cape Cod, in Barnstable county, 75 miles southeast of Boston by the Old Colony Railroad, which passes through the midst of the town, with a station at South Yarmouth. The township extends from Barnstable Bay (forming the southern portion of Cape Cod Bay) on the north, to the ocean on the south. Dennis bounds it on the northeast and east, and Barnstable on the west. A peninsula of peculiar form, called Point Gammon, projects far into the sea from the southern shore, marking very nearly the middle of the south side of Cape Cod, and enclosing Lewis Bay, which lies westward. Population, I890, I,760.

\section{DENNIS.}

Dennis is a somewhat crescent shaped town in the midst of Barnstable county, extending from one shore to the other of Cape Cod. Its east side is a straight line almost to Cape Cod Bay, on whose margin the township has an eastward projection. Brewster and Harwich bound it on that side, and Yarmouth on the west. Trees have been extensively planted here on tracts which would otherwise have been sandy wastes. The Cld Colony Railroad has a station at South Dennis, and one at the eastern line. The post-offices are Dennis, Dennis Port, and East, South and West Dennis. Other villages are Searsville and South Village. The manufacture of salt, commenced by Capt. John Sears as early as 1776 , has been extensively carried on. Population, $1890,2,899$. 


\section{HARWICH.}

Harwich, one of the most characteristic and pleasant of the Cape Cod towns, lies on the south side, about midway of Barnstable county, southeast from Boston, and about 85 miles distant by the Old Colony Railroad. This road has three stations in the town. North Harwich at the northwest, Harwich (centre) and Pleasant Lake on the north side, Brewster lies on the north, Dennis on the west, while the south side is washed by the waters of the Atlantic. Population r89o, 2,734 .

\section{CHATHAM.}

Chatham occupies the extreme southeastern angle alike of Cape Cod and of Barnstable county; and, being indented by numerous coves, harbors, creeks and inlets, is, topographically, one of the most irregular towns in the commonwealth. It has Pleasant Bay, separating it from Orleans on the north, the ocean on the east and south, and Harwich on the west. It has over 500 dwelling houses, with I,954 inhabitants, who are hardy and industrious people, many of whom are engaged in maritime pursuits. South Chatham, the first station in the town, is 88 miles from Boston by the Old Colony Railroad. The other stations in the town are West Chatham and Chatham. The post-nffices are Chatham, Chatham Port and North Chatham.

BREWSTER.

Brewster lies on the inner side of the bend in the elbow of Cape Cod, 89 miles southwest of Boston by the Oid Colony Railroad. The railway stations are Brewster and East Brewster; the post-offices and villages South Brewster and West Brewster, the latter formerly known as Setucket. About three hundred acres are devoted to the growth of cranberries. Peat of a good quality is dug at many points in the lowlands, and is used for fuel. There is a line of eminences through the middle of the town nearly east and west. One at the northwest was a station in the Trigonometrical Survey of the state, and on its summit stands a packet signal, visible at sea for a long distance. The view from here of the curving line of the shore, from Duxbury to Provincetown, is a rare and pleasing scene.

\section{ORLEANS.}

Orleans is a farming, fishing and manufacturing town in the outer line of Cape Cod, in Barnstable county, 94 miles from Boston. The town is about five miles north and south, and three east and west. The assessed area is 5,025 acres. From Eastham, on the north, it is separated by Rock river, flowing into Cape Cod Bay, and on the ocean side is Nauset Beach, a long and narrow strip of land enclosing Pleasant Bay, which separates it from Chatham on the south. 


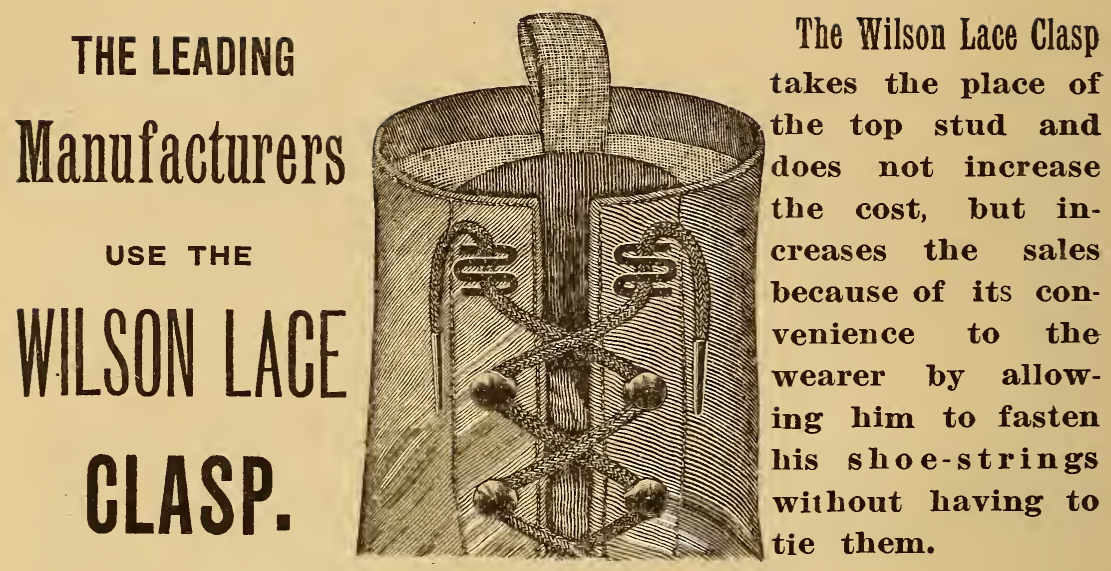

\section{WILSON LACE CLASP C.o., SOMERSET, Mass, $\quad$ Boston Office, 280 Devonshire St.}

Agent", for England and Europe, ADOLPH RIEKMAN, 59 Knightrider St. Queen Victoria St., London, E. C., England.

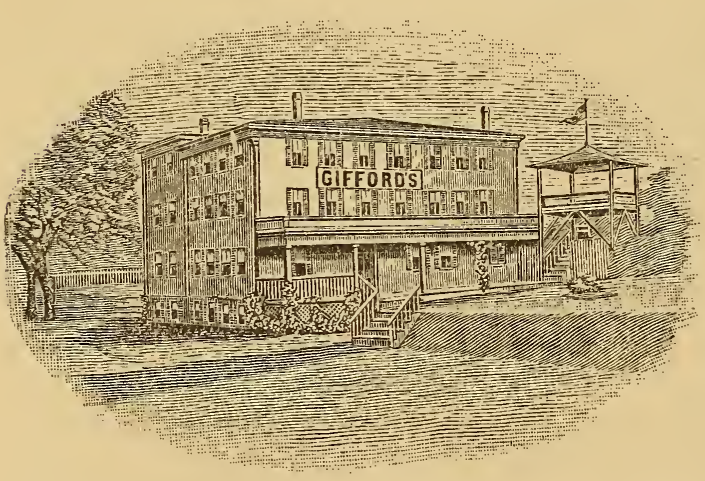

Stop at

\section{GIFFORD'S}

when in

\section{PROVINCETOWN.}

Finely located and First-Class

Accommodations.

Prompt Service and Reasonable Rates.

JAMES GIFFORD, Proprietor.

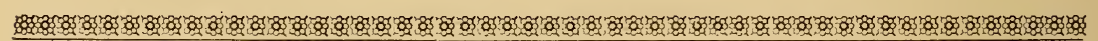

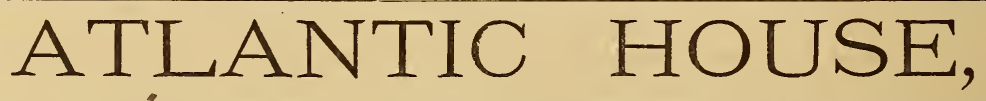

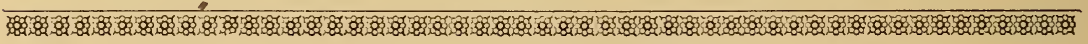
MASONIC PLGCE, Provincetown, - Mass,

FRANCIS P. SMITH, $\quad$ - $\quad$ - $\quad$ - $\quad$ Proprietor. 


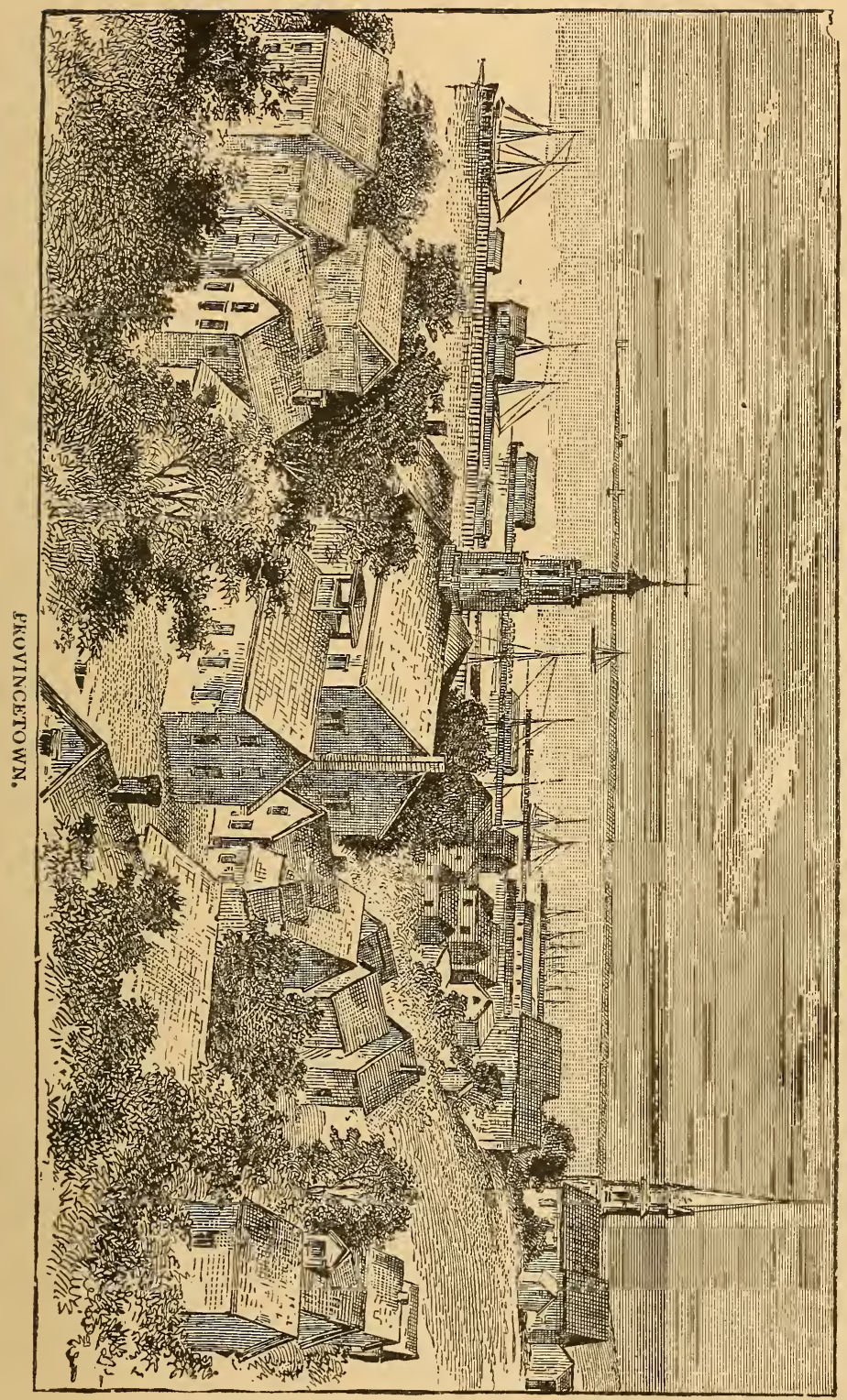





\section{EASTHAM.}

Eastham lies at the middle of the outer arm of Cape Cod, in Barnstable county, 97 miles from Boston with stations at Fastham and North Eastham, which are also the post-offices. The territory is about six miles long by three wide. The assessed area is 4,892 acres, of which 623 are woodland. The annual value of the cranberry crop is about $\$ 3,000$, and the poultry product $\$ 9,420$. The manufactures consist of salt, prepared fish, leather and several others of slight extent. A great variety of fish are taken here though in small quantities.

\section{WELLFLEET.}

Wellfleet is an interesting fishing town in the northeasterly part of Barnstable county, and near the middle of the outer arm of Cape Cod, Io6 miles from Boston by the Old Colony Railroad. The stations are Wellfleet, (village and centre) and South Wellfleet, which are also the post-offices. The other villages are Billingsgate, Dog Town, Fresh Brook Village and Painesville.

\section{TRURO.}

Truro occupies a cross section of the outer portion of Cape (Jod, in Barnstable county, lying somewhat in the form of a slightly curved finger, with Provincetown at its tip and Wellfleet as its base. Its length is 14 miles; its width, at the south is $43-8$ miles; and at the northern extremity about half a mile. The Old Colony has stations at South Truro, Truro and North Truro. Population about $\mathrm{r}, 000$.

\section{PROVINCETOWN.}

Provincetown is one of the most unique towns of the commonwealth. It occupies the extreme northern point of Barnstable county and Cape Cod; and is, with exception of a narrow neck connecting it with 'Truro at the east, entirely enclosed by water. The place is 50 miles from Boston by the course of steamers, and 120 by railrcad. The Old Colony Railroad opened its line to this place on July 22, I873. The outlooks from High Pole Hill and the elevations immediately in the rear of the principal street; the outer shores, with their terrible reminiscences of wreck and sea tragedies; the life saving stations and the performance of their heroic crews; the grand old ocean which now indeed appears outspread without limits, are a few of its sights. To these we must add the harbor views inside, the curving finger of the cape, bending until the point seemes almost to touch the Truro shores, thus making a great circular basin in which the navies of the world might float. Its population is 4,642 .

The Puritan Shirt factory on North Court street owned and operated by The Leominster Shirt Co., of Leominster, Mass., was organized about ten years ago and is a great factor in the financial interests of the town. One hundied and fifty hands are employed, the output of whose labor, amounting to over one hundred dozen shirts per day, is shipped to all parts of the country. The 


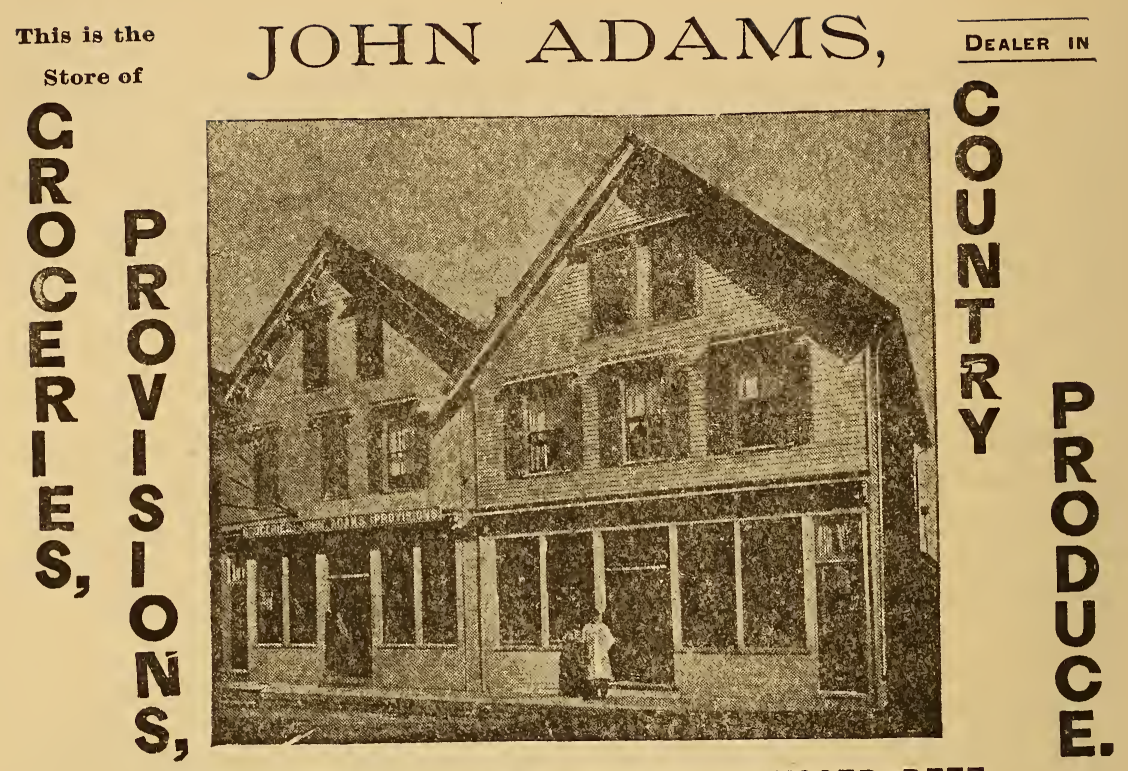

Headquarters for SWIFT'S CHICAGO DRESSED BEEF. 201-203 Commercial St.,

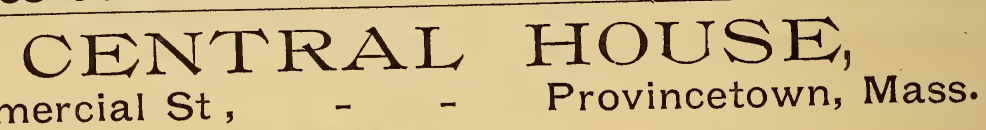
Commercial St,

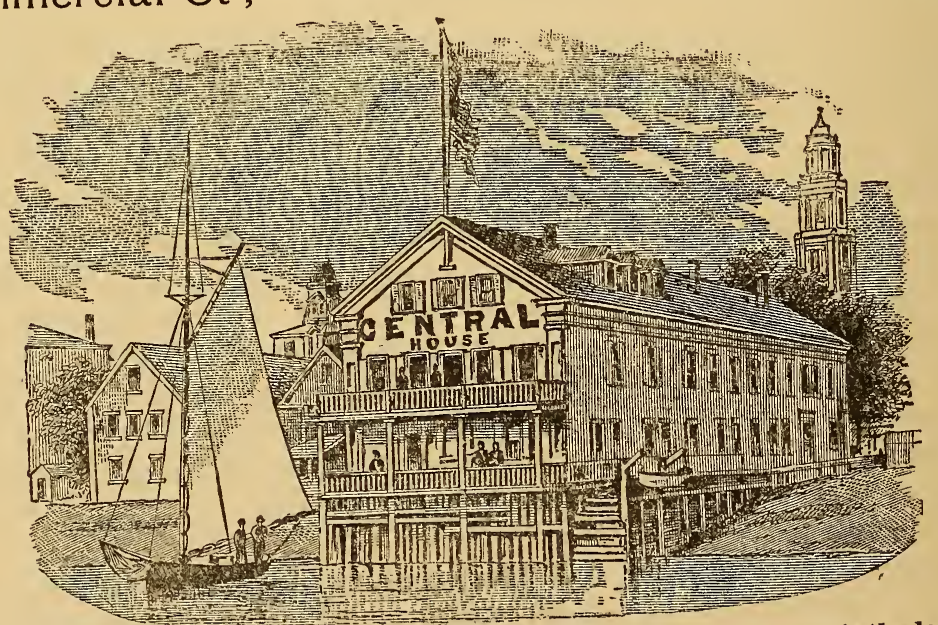

Is about an equal distance from the Depot and Steamboat Landing. It is most centrally located, and the only Hotel

JAMES A. REED,

Proprietor. 
factory is an object of attraction to visitors, and is fully equipped with every facility for manufacturing this important article of male apparel, which is one of the chief industries of Provincetown.

The Central House, one of the largest hotels in the town was established in 1870 by Allen Reed, who continued to run it up to the time of his death which occurred in $188 \mathrm{I}$, when he was succeeded by his son James A. Reed, the present proprietor. The hotel is a two-story building located on Commercial street, about five minutes' walk from the depot and the same distance from the steamboat landing. Being close to the shore, the facilities for bathing, boating and fishing are first-class. It has accommodations for sixty guests, with rooms large and well ventilated. On the shore side and front of the hotel a wide piazza extends for the comfort of the guests. The table is spread with the cleanest of linen. The service is excellent and the food is wholesome and plentiful. Mr. Reed has had a long experience in the hotel business, having been employed by his father when he controlled it.

The First National Bank of Provincetown was organized as the Provincetown Bank in 1854 , it becoming a national bank in 1865 , and the capital stock was increased from $\$ 100,000$ to $\$ 200,000$. The officers at the present time are M. N. Gifford, president, and Joseph H. Dyer, cashier. The board of directors consist of nine members, one of whom was on the board when it was first established, Henry Conk being the gentleman referred to. A general banking business is transacted including the recieving of deposits, discounting notes, etc. The directors are composed of influential citizens of the town, have a high standing both in social and business circles, and are men who are well adapted for the position they hold.

The "Giffords" a summer hotel, and one of the best in the place, was established about twenty three years ago by James Gifford, the proprietor. It is finely situated being on a hill overlooking the town, the harbor and Barnstable bay, and is only a short distance from the shore, while the grounds are arranged for amusement of various kinds. The house has accommodations for fifty guests, is nicely furnished throughout and is kept up in first-class style. The table is supplied with the best the market affords, the service is excellent and the rates are moderate. The reputation of this house is wide spread and a large and profitable business is the result. On the whole the fare and accommodations to be found at "Giffords" are of a superior quality. Mr. Gifford is a gentleman of good business qualities, with a thorough knowledge of his business, and of courteous manner.

John Adams, who is among the prominent business men of this place, is located at $20 \mathrm{I}$ and 203 Commercial street. He commenced business in 1884 as a dealer in groceries, provisions and country produce and now conducts one of the largest stores of the kind in town where may be found a fine line of goods, which embraces canned goods in great variety, flour, coffee sugar, crackers, meats of all kinds, etc., all of which are of the best to be found. Flour is handled by the car-load, and he is agent for Swift's Chicago dressed beef. A specialty is made of fitting out fishing vessels with supplies of all kinds. 
A large and prosperous business is being conducted by him, and with the help of his five competent clerks he is prepared to fill and deliver all orders promptly. Mr. Adams is a well known resident of the town, and has a high standing among the people for his liberal dealings.

D. A. Matheson, who carries on a large business in ready made and custom clothing, men's furnishing goods, boots and shoes, (Douglas' $\$ 3.00$ shoes being a specialty) hats, caps, trunks, valises, etc. was established in 1872 . He is located on Commercial street in the old Post Office building, where he occupies two large ftoors, the upper floor being used for boy's clothing and ladies' and children's cloaks. A specialty is made of seamen's outfits and all clothing is sold at prices consistent with the quality of goods. Courteous assistants are in constant attendance and every effort is made to meet the wants of his patrons. A very prosperous business is being conducted by $\mathrm{Mr}$. Matheson, who has had a long experience in this line and is thoroughly posted in all its details. He is a well known resident of the town, has a high standing in financial and social circles, and conducts his store on the basis of square and fair dealing to all.

The Atlantic House, one of the prominent hotels in Provincetown, of which F. P. Smith is the proprietor, was opened more especially for summer boarders twenty-one years ago. It has accommodations for thirty-five guests, is furnished neatly throughout, and every thing about the place shows that great pains have been taken to keep it in first-class condition. The meals are served in fine style, and food is well cooked. Being situated close to the shore a fine opportunity is offered to indulge in good boating and fishing. $\mathrm{Mr}$. Smith has a thorough knowledge of the hotel business, and by his able management and courteous treatment he has built up a large and prosperous trade. The rates are reasonable, special prices being made for those intending to stay during the summer season.

\section{A. MATHESON, DEALER IN}

\section{Men's Boys' and Children's GLOTHING.}

\section{HATS, CAPS AND FURNISHING GOODS.}

A Full Line of all Kinds of BOOTS, SHOES and RUBBERS.
Also Ladies' Misses' and Children's $\cdot \cdot$ CLOAKS. . . 


\section{WOODS HOLL BRANCH.}

\section{FALMOUTH.}

$\mathrm{F}$

ALMOUTH is a delightful seaboard town occupying the southwest corner of Cape Cod and of Barnstable county. Along its entire western side extends the Woods Holl Branch of the Oid Colony Railroad, terminating 72 miles south of Boston. Its boundaries are Bourne and Sandwich on the north, Mashpee on the east. Vineyard Sound (here six miles wide) on the south, and Buzzard's Bay on the west. The territory extends as a peninsula at the southwest; and on a harbor at the extremity of this is Woods Holl, where are made connections with the Martha's Vineyard and Nantucket steamers. It is noted as the location of the government works for fish-breeding, and as a principal government station for marine surveys and investigations. At the southmost point of this peninsula is Nobska Point and Hill, bearing its well known light. Eastward is a fine beach, extending in a concave line to the first of three nearly enclosed basins of salt water, the eastward one of which constitutes a harbor for Falmouth Village. Population, I890, 2,567. The stations on this branch are Monument Beach, Wenaumet, Pocasset, Cataumet, North Falmouth, IVest Falmouth, Falmouth and Woods Holl.

\section{MARTHA'S VINEYARD.}

His famous island of Vineyard Sound is in such close relation with the Old Colony system of railroads that a brief description of its principal places, as well as that of Nantucket, could not well be omitted here.

Across the sound lies

\section{COTTAGE CITY.}

This popular resort embraces the northeastern extremity of the island of Martha's Vineyard, Dukes county, and is mainly a place of summer residence, having only the business relating to such occupancy. It has, however, a constant population of 709 , of whom 203 are voters. There are now about $\mathrm{I}, 200$ dwelling houses, all of which are inhabited during the warm season. The town has the ocean on the north and east, Edgartown on the south, and Tisbury on the west and northwest. It is separated from the latter town by Vineyard 
Haven Harbor and by Lagoon Pond, the latter partially divided from the harbor by a broad sandbar. The coast is formed by steep sand bluffs, with sandy beaches at their bases. The area, aside from highways and water surfaces, and some sandy marshes, is 1,965 acres. About one third of this is largely occupied by scrub oaks, with trees of larger growth in the vicinity of the camp grounds and some of the older residences. The villages are Camp Ground, Eastville, Lagoon Heights, Oak Bluffs and Vineyard Heights. The latter commence at East Chops, the northeast point, and extend south on the shore to Lake Anthony, where Oak Bluffs commence, extending southward to Farm Pond. The southeastern part of the town is occupied by Sengecontacket Pond, of 650 acres, which communicates with the sea through a break in the long sandbar that forms its eastern shore. Eastville is on Vineyard Haven Harbor, on the west side of the town. Here are the principal landing places of the New York and Portland steamers. This town is reached by regular lines of steamers, chiefly from Woods Holl or New Bedford, where connection is made with the Old Colony Railroad. The town, also, has its railroad, a narrow gauge, connecting Oak Bluffs wharf with Edgartown and Katama. There is a finely equipped fire department and excellent water works. Population, I890, I,, 080 .

\section{TISBURY.}

Tisbury occupies the middle of Martha's Vineyard, Dukes county, 77 miles south of Boston, extending across the island. The capacious harbor called Vineyard Haven, and a connected body of salt water called "Lagoon Pond," separates it from Cottage City on the east; while the portion south of this is bounded on the same side by Edgartown.

\section{EDGARTOWN.}

Edgartown, the seat of justice in Dukes county, occupies the southeastern section of Martha's Vineyard. It lies 85 miles southeast of Boston, and is bounded on the north by Cottage City, on the east and south by the ocean and on the west by Tisbury. The assessed area is 10,988 acres, - of which 1,667 acres are woodland, containing oak and pine. Population, I890, I, 156.

\section{GAY HEAD.}

Gay Head is a new and small town, embracing the peninsula formed by Squibnocket and Menemsha ponds, constituting the western extremity of Martha's Vineyard. These ponds are fed from the sea, with which they communicate by short creeks. Chilmark bounds this town on the east, beirig separated from it by the ponds, except for a large bridge passing over the creek connecting them, and the isthmus at the southwest formed by Squibnocket Beach. The long line of Elizabethan Islands interpose between it and Buzzard's Bay; far to the northwest and west is the dim line of the Rhode Island and Connecticut shores; on the south is the illimitable ocean. Here is also located the noted Gay Head Life Saving Station. Population, I890, I39. 


\section{VINEYARD HAVEN.}

This is the principal village of Tisbury, and its harbor affords safe anchorage for thousands of vessels annually in stress of weather. The United States Marine hospital, a sailor's free reading room, a well stocked library and museum, three churches, seven schools and many other advantages incident to. modern society, are found here. The headland at West Chop bears the famous lighthouse of that name, and is approached by a fine road leading from Vineyard Haven. Other villages which were onited in our mention of Tisbury, are West Tisbury, Middleton, Christiantown, North Tisbury, Choppaquousett (the Indian name of the town), Davistown, Holmes Hole and Okahoma. The postoffices are Vineyard Haven, West and North Tisbury. The water supply of the village is derived from the noted Tashmer Spring, and is of the purest quality. West Chop settlement is a growing and popular summer resort.

\section{NANTUCKET.}

This town embraces the entire island of the same name, and the smallerislands of Tuckernuck, Muskegat, with the three Gravelly Islands; and the town constitutes the entire county of Nantucket. Nantucket is also a name of the principal village, containing court house and jail. It is situated midway of the north side of the island, on a harbor of its own name. This place is I ro miles. southeast of Boston, with which it has communication by the Old Colony Railroad and steamers. Population, I 890, 3.268.

\section{NORTHERN DIVISION.}

\section{FITCHBURG.}

F ITCHBURG is a flourishing manufacturing city, in Worcester county, situated in its northeasterly section, 50 miles from Boston by the Fitchburg Railroad. This road, by a northward curve in the town, following nearly the curve of the Nashua river, connects with the four principal villages, - Crockerville in the suuthwest, West Fitchburg, Fitchburg (centre), and South Fitchburg in the southeast. From the central station preceeds the Cheshire Railroad through Bellows Falls to Lake Champlain and Montreal. At this station also terminates the Northern Division of the Old Colony Railroad, which connects it directly with Framingham, Taunton and New Bedford. The Old Colony also has a station in South Fitchburg, which is within the city limits. Ashby lies on the north, Lunenburg on the east, Leominster and Westminster on the south, and the latter on the west. Paper 


\section{PATON MFG. CO.,}

MANUFACTURERS OF -

$\rightarrow$ Combs, Jewelry AMD Buttons,

Office and Factory, Central St.,

LEOMINSTER,

\begin{tabular}{llll}
\hline C. H. Buswell. J. Q. A. Hubbard. & Jesse Blake.
\end{tabular}

\section{H. BUSWELL \& CO.,}

Tanners and Curriers of

\section{Glove, Grain and Split Leather.}

Tannery at No. Leominster, Mass. Boston Office 137 Summer St. TELEPHONE No, 343.

A. W. COLBURN.

A. W. COLBURN \& CO., - Manufacturers of -

Piano AND Organ Sharps,

Drum Sticks, Fifes, Finger Boards, Bones, Castanets, Bridges, Tail Pieces, Pegs, Pins, Etc.

Shell and Horn Mandolin Picks and Zither Rings, Horn Scoops, Spoons and Spatulas for Druggists' use.

Han dles from Rosewood, Ebony \& other Fancy Woods

Workers of all kinds of Foreign Woods.

71 PLEASANT ST., LeOMinSter, Mass.

ESTABLISHED $1850 . \quad$ INCORPORATED 1887. J. M. LOCKEY, TREASURER.

J. H. LOCKEY * * * PIANO CASE CO.,

- MANUFACTURER OF-

Piano-Forte Cases,

Leominster, Mass.
E. B. KINGMAN \& CO,

Jet, Rubber, Horn and Shell

Hair Pins, Combs, Jewelry,

Buttons and Novelties.

FFice AND Leominster, - Mass.
FACTORY, Salesroom, 419 \& 421 Broadway, N. Y.

\section{UNION HOTEL,}

E. J. SWEENEY \& C0., Props.

Leominster, $=$ Mass. 
manufacture is the largest single product of the city. At Crockerville (named after a former leading manufacturer) are seven or more mills for this article. At other points are cotton and woolen mills, the works of the Putnam Machine Company, and the Fitchburg Steam Engine Company, making fire, locomotive and stationary engines; also establishments for the manufacture of saws, machinists' tools, chairs, rattan and other furniture, edge tools, agricultural implements, bricks, bread stuffs, clothing, palmleaf hats, poots and shoes, hollow ware, etc. Fitchburg is progressive and enterprising in everything, has a good water system, excellent schools, several fine church edifices, an excellent public library, an opera house, and all the modern conveniences known to a stirring and industrious New England community. There are many fine private estates within the city boundary, and the suburbs offer the most desirable locations for residence. The census of I 890 gives the city a population of 22,037 .

\section{LEOMINSTER.}

This flourishing town is in the northeast section of Worcester county, 46 miles northwest of Boston. The Old Colony has stations at West Leominster, Leominster Centre and Gates. Fitchburg and Lunenburg lie on the north, the latter and Lancaster on the east, Sterling on the south, and Princeton and Westminster on the west. The northern and main branch of the Nashua river, issuing from ponds at the north-west, flows northward into Fitchburg, then southward through the eastern part of Leominster, receiving from the west the Monooswock and Fall Brooks, all of which furnish good water power. The manufactures consist of two carriage factories (making baby carriages chiefly) three or four piano factories, two woolen mills, a tannery, two furniture factories, a toy factory, button works, a shirt factory, several factories making combs and other horn goods, a paper box factory, a paper mill, a leather mill, two shoe shops, etc. The first paper mill in the town was erected by Wm. N. Nicols and Jonas Kendall in 1796. The sons of Mr. Kendall made a paper and cylinder machine as early as 1825 , and introduced in 1833 the Foudrenier machine. For a long time this was the leading business of the place. The population of Leominster in I 890 was 7,260 .

The Leominster Shirt Compauy, among the largest and best regulated shirt manufacturing companies in this country, have factories in South Framingham and Provincetown, Mass., and Chatham, N. Y., besides the two factories in the town of Leominster. The president and manager, S. A. Stevens, is a gentleman of high standing and well qualified for this important position; and through his able management and business integrity has built up a very large and important business; the total product of this company is about 500 dozen shirts per day, that of the Leominster factories alone amounting to 250 dozen shirts per day. A force of 250 hands is here employed, who are furnished with the best appliances for first-class work, as well as for their general convenience and comfort. This company has been established ten years and has acquired a reputation throughout the country for excellent goods and upright dealing 
F. A. CLAPP, Pres.

A. A. TISdALE, Treas.

$\sim \mathrm{THE} \sim$
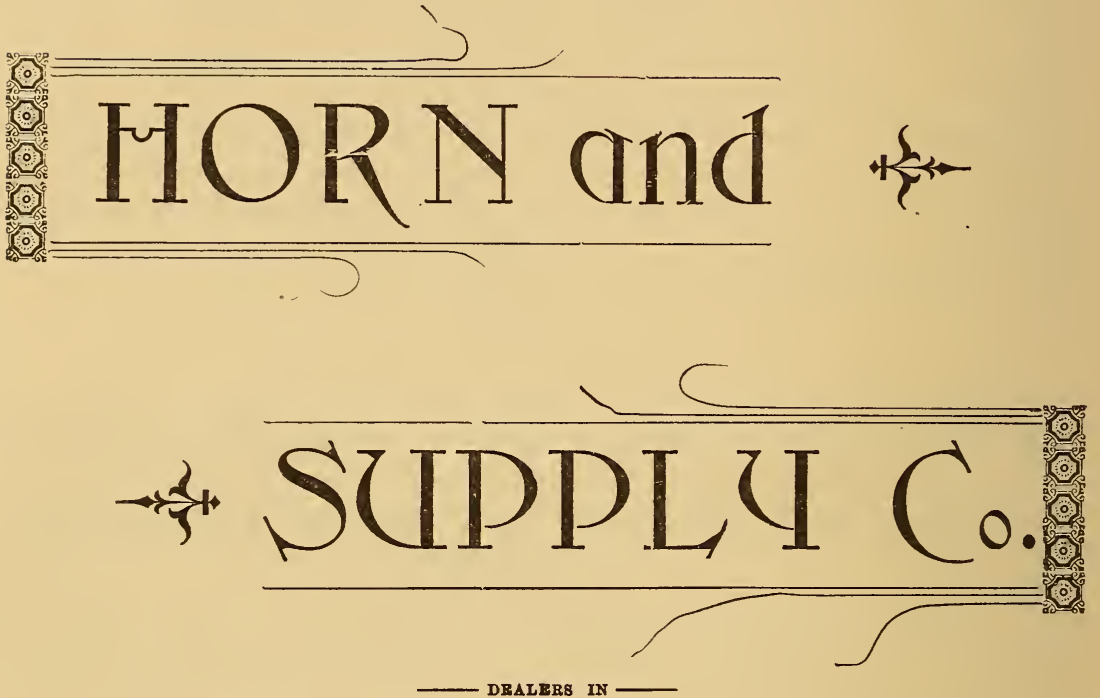

Horns, * Hoofs, * Horn * Tips and Waste.

$\because \therefore$ Manufacturers of $\therefore \because$

EPRESED $\mathrm{HORN}$ AND

Leominster Center, Mass. 
A large new factory and laundry have been added recently to the Leominster plant and is on the line of and plainly seen from the railroad, as it enters the town.

The Bay State Shirt Company are manufacturers of what they term the "Best" shirts. This prosperous concern began operations in I886, and under the efficient and experienced management of its founders has developed into an industrial institution of recognized influence, and accumulating during its career a trade of large and valuable proportions. The works occupy a fourstory building $45 \times 60$ with an ell $30 \times 56$, all fitted up with special attention for the convenient and economical prosecution of affairs, and equipped with an abundant outfit of appliances and devices available in the manufacture. Only first-class help is employed to the number of I 25 hands, whose daily output amounts to Ioo dozen shirts per day, which is shipped to all parts of the country. G. F. Morse, the president, and A. G. Morse, the treasurer, are wide awake business men, thoroughly familiar with the details of the business, and useiul and responsible factors in the growth of Leominster.

J.R. Swift is well known throughout the state, he being the manufacturer of the Swift roll top desk, office furniture and standing desks. The roll top desk has been developed of late years, until, as now constructed by Mr. Swift, it is a veritable cabinet of convenience provided with appropriate and convenient places for everything required in the management of a mercantile or business house. Mr. Swift is a gentleman of experience and gives the work his personal supervision and by his system of upright dealing and prompt execution of orders, has succeeded in satisfying the demands of his numerous customers. He occupies premises at 48 Pleasant street, well fitted with various appliances needed and employs the services of seven hands.

The J. H. Lockey Piano Case Co. is the oldest and one of the most extensive houses in Leominster, engaged in the piano case business. The enterprise was established in 1850 , but in 1887 the company was incorporated with a capital stock of $\$ 30,000$. J. M. Lockey is its president and treasurer, and through his able management, the company has acquired a reputation of high order throughout the United States, for commercial integrity, a high grade of goods and reasonable prices. The works of the company pleasantly located on Mechanic street, consist of some 40,000 feet of floor space, well equipped with improved appliances for the work, while the comfort and convenience of the workmen are carefully attended to. Steam power is employed and the services of some fifty men are constantly required, the product of whose skill and labor amounts to 2,000 cases per year. These productions are first-class in every respect, containing the most recent improvements, of superior finish and appearance, and constructed with a view to durable service. This house is a thoroughly representative one, and prepared to compete successfully with its strongest rivals in any part of the country.

A. A. Tisdale \& Company was founded in 1884 as manufacturers of tables, chairs, baskets, and articles in a great variety known as reed goods, children's carriage bodies are one of their specialties. The premises occupied by them on 
Buy at Manufacturer's Prices.

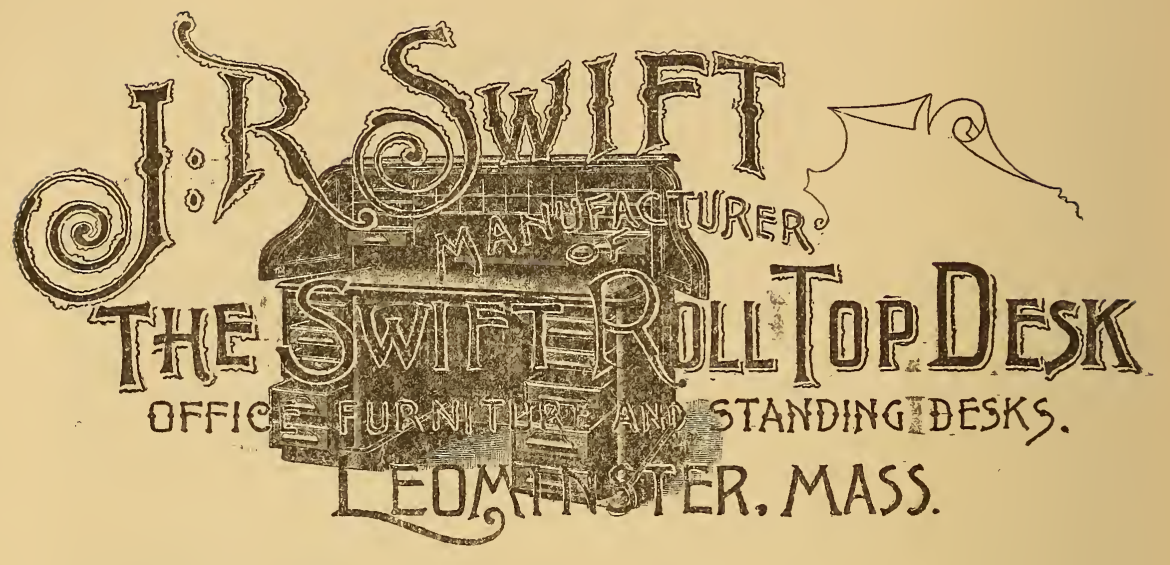

146 Pleasant street.

Send for Illustrated Catalogue.

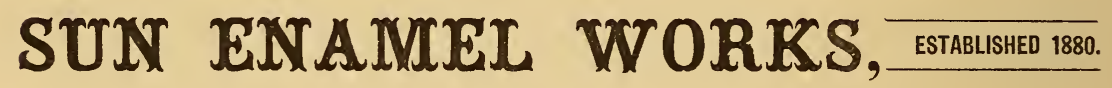

W. N. maYNARd, Proprietor. LEOMINSTER, MASS.

Fancy Enamelling and Japanning, Imitation of Horn and Tortoise Shell and Fancy Woods. . . . Manufacturers of Wood Turned Goods of all Kinds. . . . Fine Jet and Colors. . . . All Kinds of Bobbins a Specialty.

\section{ROBT. W. BAKER,}

Successor to J. H. BAKER \& CO.

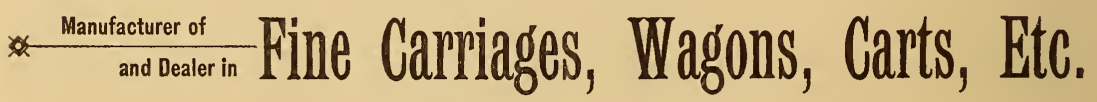

Making a Specialty of Medfield Butcher Wagons.

First-class Work only. . . . . . Repairing promptly attended to.

MEDFIELD, MASS. 
Central street, Leominster, consist of a three-story building thirty-two by eighty feet, and an ell of three stories, twenty-eight by sixty feet. They have all the latest machinery that is required in their business, and a steam engine of six horse power is used. Employment is given to forty experienced hands, and goods of all kinds in their special manufacture are produced in large numbers. The trade extends to Baltimore, Philadelphia, New York, and all the New England states. All articles made by this firm are of a superior quality, their prices being moderate, and every agreement is faithfully carried out. The orders are promptly filled, and delivered at short notice. A. A. Tisdale is the sole proprietor, and is a man of high standing in financial circles. $\mathrm{Mr}$. Tisdale is also treasurer of the Horn \& Supply Company in this place.

The Horn \& Supply Company, an important industry in Leominster, and one closely allied to that of comb and jewelry manufacturing, are dealers in horns, hoofs, horn tips and waste, and manufacturers of pressed horn and hoof. This company was established last year, and incorporated with a capital stock of $\$ 20,000$. The officers of the company are as follows: president, F. A. Clapp; treasurer, A. A. Tisdale, and a board of directors composed of the following well known gentlemen: Geo. E. Rogers and L. J. Gunn. They occupy a large two-story building on Central street, corner of Graham, thoroughly equipped with the necessary appliances, operated by steam power, and furnish employment to thirty-five men. Their goods are mostly disposed of in the United States and Canada, thcugh there is some export trade carried on with England. Though so recently established this house has built up a flourishing business, owing to superior management and thorough acquaintance with the business in all its details.

The Sun Enamel Works are prominent among the branches of industry conducted in Leominster, W. N. Maynard being the proprietor. The works were established twelve years ago, and the business carried on is fancy enameling and japanning, imitation of horn, shell, and fancy woods; also manufacturing of wood turned goods of all kinds in fine jet and colors. Mr. Maynard has had many years of experience, and is fully acquainted with the business in all its details. The premises occupied consist of a two-story frame building, the dimensions being one hundred and twelve feet long and thirty-six wide, where steam power is used, employment is given to 25 hands, who turn out a large variety of novelties. The office and factory are located on Whitney street. Mr. Maynard is well and favorably known in business circles, and stands high in the estimation of all with whom he deals.

E. B. Kingman \& Co. are the most extensive manufacturers of jet, rubber, shell and horn goods in this town. The business was originally established by Joslin, Palmer \& Williams in 1872 , who in 1880 were succeeded by A. W. Williams, he in turn being followed by the present firm in I888. The factory occupied by them is located on Water street and is most thoroughly equipped with modern appliances for rapid and perfect work, while the confort and convenience of the employes is not allowed to go unnoticed. Steam power is used, ard employment is given to one hundred hands, whose yearly output 
reaches a very high mark. The goods are in great demand by jobbers throughout the country, and consist of an almost endless variety of combs, hair pins, buttons, jewelry and novelties. The Messrs. Kingman \& Co. enjoy great prominence and honor in the commercial circles of this town, and their great success is but an illustration of what can be accomplished by the exercise of commercial probity, energy and ability. In addition to the office in Leominster an office is also maintained at 419 and $42 \mathrm{I}$ Broadway, N. Y.

A. W. Colburn \& Co. of Leominster are manufacturers of all kinds of musical merchandise, such as piano and organ sharps, drum sticks, fifes, finger boards, bones, castanets, bridges, pegs, pins, etc., shell and horn mandolin picks and zither rings, horn scoops, spoons and spatulas and workers of all kinds of foreign woods. This enterprise established in 1880 at Northboro by Brooks \& Colburn who in I 884 were succeeded by the present proprietors and in I 886 removed to Leominster is taken as a whole the only one of its kind in this country. They occupy a three story frame building on Pleasant street, thoroughly equipped with the necessary appliances run by steam and water power. Thirty-five hands are employed and their goods are shipped to all parts of the United States. The firm is composed of A. W. and G. F. Colburn, men of practical experience and excellent business qualifications and this house is considered one of the most reliable and prosperous in this country.

The Paton Manufacturing Company among the largest of the manufacturers of horn goods in Leominster, was established in $\mathrm{r} 884$ by A. S. Paton its present proprietor. This house manufactures combs, hair pins and novelties and is well and farorably known throughout this section of the country. Pleasantly situated on Central street, with the best kinds of improved machinery, power furnished by both steam and water, and employing the services of seventy-five hands, they are enabled to turn out gJods in the large quantities which they are obliged to do, in order to meet the demands made upon them. Mr. Paton is in the prime of life, and earnestly devoted to meeting every requirment of his patrons with discrimination, and his upright, honorable principles have won for him the highest esteem of all circles and enabled him to achieve a signal business success.

C. H. Buswell \& Company of North Leominster was established in I884 as tanners and curriers of glove, grain and split leather. The works comprise two frame buildings, one being two hundred and ninety feet long and fifty feet wide the other being one hundred feet long and forty-five feet wide. The firm employs a large force of workmen, experienced in their line of business and tan a large quantity of leather of the best quality per month. They have had a wide experience in this line and have won a high reputation for their fair dealing in all business transactions. The factory is located on Nashua street. The members of the firm are courteous business men and the extent of their business covers a large territory.

The Union Hotel is one of the most popular hotels in Leominster. It was established by the proprietors E. J. Sweeney \& Co., about two years ago, and has been liberally patronized since then by commercial travelers and others. 
There are fourteen nicely furnished, well ventilated and convenient rooms, and the house is prepared to comfortably accommodate about thirty visitors. The dining room is very attractive and will seat over twenty-five persons, and the attendance is prompt, ample, and obliging. The building is heated throughout, and is lighted by gas. The cuisine is all that could be desired, and in short the hotel is excellently and liberally managed and richly deserves the reputation it has attained. The terms of the Union Hotel are uniformly moderate, and in fact may be classed very low, considering the nature of the accommodations.

CLINTON.

This town was originally a part of Lancaster, which bounds it on the northwest and north. It was incorporated as a town in March, 1850. In area it covers 4,907 acres, and owes its early settlement to the fine water power afforded by the north branch of the Nashua and South Meadow brook, which, uniting here, forms the Nashua river. The falls of the latter stream were especially inviting, and here John Prescott erected and completed in I654 the first grist mill west of the Sudbury rivel - the germ from which sprang her present varied industries. The Old Colony Railroad and the Southern Division of the Boston \& Maine have stations at the centre, and the Worcester, Nashua \& Portland Branch of the Boston \& Maine has a station at South Clinton. Other near bystations of the Old Colony system are Bolton, West Berlin and Berlin. The manufactures of the place are extensive and peculiar, consisting of Lancaster ginghams, cotton quilts and counterpanes, Brussels and Wilton carpetings, various articles of ladies' underwear, horn combs, clothing, wire-cloth and machinery. Population I 890, I0,424.

The Bigelow Carpet Co. founded in I 849 has since developed into the most extensive plant in this country, for the production of Wilton, Axminster and Brussels carpet. The original founders were E. B. Bigelow, H. N. Bigelow and H. P. Fairbanks, the company being incorporated in $\mathrm{I} 854$ with a capital of $\$ 120,000$, which has since been increased. E. B. Bigelow was the inventor of the looms used at the begining of operations, which were the first carpet power looms ever constructed. Many improvements have since been made, whereby this company is enabled to compete with the best manufacturers of the world in the production of fine carpets, which fact is very generally recognized by the public, as attested by the immense and increasing demand for their goods. The company also manufacture all of the worsted and woolen yarns required for their own use, as well as selling a large quantity annually. The reputation of the company is world wide and many prizes have been awarded them at various expositions in this country and abroad. The works cover an area of 460,000 square feet and furnish employment to I 200 hands. The management is represented by James N. Beal president; Charles F. Fairbanks treasurer; and C. B. Bigelow as agent, gentlemen well known for their ability, energy, and integrity.

The Clinton Wire Cloth Co. is an important and extensive industry of Clinton engaged in the manufacture of power loom wire cloth and nettings. This 


\section{CLINTON WIRE CLOTH CO., \\ -Manufacturers of- \\ POWER LOOM WIRE CLOTH and NETTINGS,}

INCLUDING

Hardware, Agricultural Machine, Sieve, Riddle, Window Guard,

Locomotive Smoke Stack, Sand, Coal, and Ore Screens.

AISO, CLINTON PATENT PAINTED WINDOW SCREEN, CLINTON PATENT TWIST WARP WIRE LATH, CLINTON PATENT GALVANIZED FENCING,

GALVANIZED HEXAGONAL NETTING, GALVANIZED WIRE CLOTH, PERFORATED METALS, Etc.

New York; Chicago: Boston: General Office:

76 Beekman St. 137 Lake St. Sears B'l'dg. . Clinton, Mass.

\section{Bigelow \\ Carpet

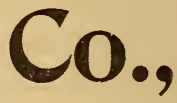

Salesroom: 100 West St., New York.
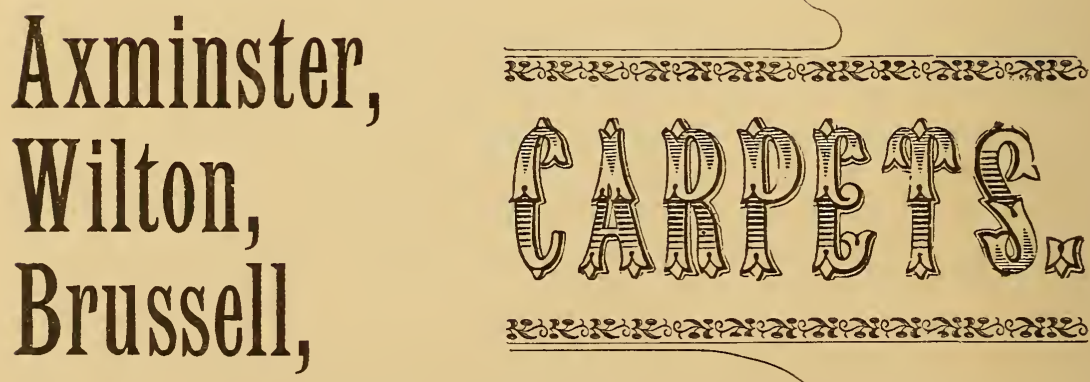
company was organized in 1856 and is now the largest wire weaving establishment in the world. The old methods of weaving wire cloth were set aside by this concern by the employment of a power loom invented by E. B. Bigelow of Bigelow carpet fame, which not only lessened the cost of manufacture but enabled them to turn out work of a far superior quality. Wire cloth of every variety is made from the finest gossamer web to the coarsest coal screen. Poultry netting and ornamental fencing in great variety is made a specialty, an immense amount of which is sold annually. The plant of the company covers an area of 200,000 square feet, is provided with unequalled facilites for the rapid production of first class work and furnishes employment for 400 hands. The capital stock is about $\$ 500,000$ and the board of managers is represented by James N. Beal as president and Charles F. Fairbanks as secretary and treasurer.

Poole's Granite and Marble Company located at I 70 Main street are large manufacturers of and dealers in American and foreign granite for building and cemetery work. This establishment enjoys an excellent reputation for the high standard of the work turned out, and the promptness with which orders are filled. At Boylston Mass. the company operates a quarry of excellent quality granite and employ several skilled workmen. The proprietor H. E. Poole, a gentleman of experience in this kind of work, is a well known resident of Clinton and caters to the best class of trade in this section.

The Clinton House is a well known hotel having been open to the public for the past forty years; but since I 887 when it came under the management of its present proprietor H. C. Gale it has undergone numerous changes and improvements. It is now one of the most comfortable and pleasant hotels in this section of the state, being heated with steam and otherwise provided with modern conveniences. Ample accomodations are at hand for 100 guests, and as the service is first class, and terms moderate, it commands a large patronage. An excellent livery stable is connected, well stocked with carriages of various descriptions and good safe horses. Mr. Gale is a native of Concord, New Hampshire, a good business manager and an agreeable companion and has succeeded in making his house a favorite resort with the travelling public.

\section{STERLING.}

Sterling is a pleasant manufacturing and farming town of 1,244 inhabitants, lying in the northeastern section of Worcester county, 49 miles northwest of Boston, having for its boundaries Leominster on the north, Lancaster and Clinton on the east, Boylston and West Boylston on the south, and Holden and Princeton on the west. It has three postal villages, Sterling Centre, a beautiful place, Sterling Junction, Pratt's Junction and West Sterling. The railroad stations are the above (excepting West Sterling) and Washacum.

\section{NORTHBOROUGH.}

Northborough is a pleasant town in a hilly region near the middle of the eastern boundary of Worcester county, 35 miles west of Boston by the Northern 
Steam Heat. Electric Light.

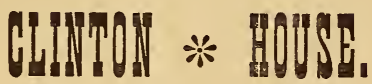

H. C. GALE, - - Proprietor.

CLINTON, MASS.

Billiard Room. Rates, \$2 per Day. GOOD STABLE CONNECTED.
Poole's Granite \& Marble Co.,

Manufacturers of and Dealers in

CEMETERY * AND * BUILDING * WORK

Of American and Foreign Granites and Marbles.

Also Retail Dealers in Portland and Rosdale Cement, Calcined Plaster and Sand.

NO. 170 MAIN STREET, CLINTON,

IMSS.

W. M. FARWELL.

A. C. FARWELL.

W. M. FARWELL \& CO., Manverectuens or

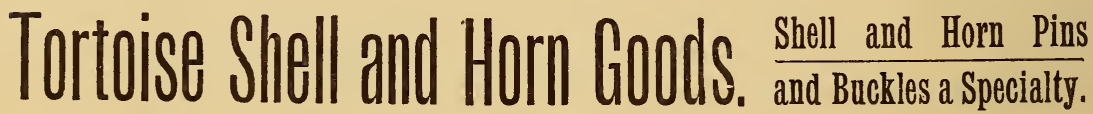
All kinds of Shell and Horn Dressing Combs. Repairing Promptly Executed. $* \quad$ NORTHBORO, MASS.

ESTABLISHED 1847. MILO HILDRETH \& CO., Manufacturers of Real a Tortoise e. Shell e Goods, Plain and Fancy Combs, Hair Pins, Fillets, Mandolin Picks, Jewelry and Novelties.

IMITATION SHELL AND AMBER BACK COMBS AND HAIR ORNAMENTS. CLEAR HORN DRESSINO, BARBER AND POCKET COMBS, BUCK HORN CLOAK AND DRESS BUTTONS, AND IN FANCY COLORS. Special Attention given to the Manufacture of Goods to Order,
and Repairing Shell Combs and Hair Pins. Samples sent by mail. MORTHBORO, MASS.

\section{MOSSO BROTHERS,}

MANUFACTURERS OF 
Division of the Old Colony Railroad, which passes through the central village. It is bounded on the north by Berlin, east by Marlboro and Southboro, south by Westboro, and west by Shrewsbury and Boylston. There are at the central village woolen mills, employing a large number of persons. Establishments making buttons, combs and other horn goods. Pianoforte manufactory, a rubber factory, and boot and shoe making. Other manufactures are boxes, bricks, fertilizers, leather and metallic articles.

Milo Hildreth \& Co.'s establishment was founded in 1847 for the manufacture of real tortoise shell goods, also imitation shell goods, and fancy articles. They occupy a substantial two-story building on Main street, Northboro, using both steam and water power, and employing from ten to thirty hands according to the demand for goods. This house is in a flourishing condition, their goods being in demand throughout the West and South as well as in New England and the Middle States. The output per year is large and consists of a great variety of articles made from real tortoise shell, horn and ivory, such as dressing and pocket combs, plain and tancy back combs, hair ornaments, including a great variety of plain and fancy hair pins, mandolin picks, cloak and dress buttons, jewelry and novelties. This house by its long and honest dealing has established an excellent reputation for square dealing and fine goods second to none, and by thorough acquaintance with the details of the work and steady application to business has well earned the high esteem and large trade which they enjoy. Milo Hildreth, the senior member of the firm, has occupied many important positions of honor and trust not only in his town but in the Commonwealth. He represented the 15 th Worcester district in the lower house of the Massachusetts Legislature, during the session of 1858 . Seven years afterward he represented the Worcester East Senatorial district in the State Senate of 1865 . In 1872 he was a member of the Governor's Council from the $3 d$ Councillor district, and was re-elected the two following years.

W. M. Farwell \& Company, engaged in the manufacture of tortoise shell and horn goods of all kinds; as well as shell and horn dressing combs, were established in 1872 . Since then they have made many additions to their factory which is a two-story frame structure. They employ a force of thirty hands, and have facilities for producing daily fifty gross of horn pins and thirty gross of dress combs which are sent to the South and West. The firm consists of W. M. Farwell and A. C. Farwell, and they are located on Hudson street, Northboro. They are also repairers of all kinds of work which they manufacture.

Mosso Bros. on Boylston street, Northboro', are a large firm for the manufacture of musical merchandise, such as bridges, finger boards, drum sticks, pegs, shell mandolin picks, etc. Occupying a two-story frame building, and using water as their power, they are enabled to tinish a large amount of work each year. A force of expert workmen are employed by them and by giving personal supervision to the work, they are able to detect any flaw that may occur in the manufacture of their wares. 


\section{MARLBORO DYE HOUSE,}

No. 8 Liberty Street, - $\quad$ - Marlboro, Mass.

P. W. MYERS \& SON. Proprietors.

OUR MOTTO: NEAT, CHEAP AND QUICK.

All Kinds of Ladies' and Gent's Garments Cleansed, Dyed and Refinished BY THE MOST APPROVED METHODS.

Goods left by Tuesday will be finished the last of the same week.

Orders sent ly Express receive Prompt Attention.

C. H. HOLLIS.

E. N. DEARBORN.

\section{HOLLIS \& DEARBORN,} MANUFACTURERS OF

Men's Fine Footwear.

CUSTOM WORK A SPECIALTY.

Factory No. 129 Lincoln St., - - Marlboro, Mass.

\section{William C. Lippard,}

-MANUFACTURER OF-

HEELS * AND* PREPARED* TOPS, - ALSO DEALER IN -

LEATHER REMNANTS.

129 Lincoln St., - - Marlboro, Mass.

\section{B. GREENWOOD,}

Manufacturer and Wholesale Dealer in

PURE CIDER VINEGAR And Vinegar Stock. MARLBORO, $\quad$ - $\quad$ - $\quad$ - $\quad$ - $\quad$ MASS. 
MARLBOROUGH.

Marlborough is an ancient and very thriving agricultural and manufacturing town, lying in the southwest part of Middlesex county, about 25 miles west of Boston. Its boundaries are Hudson on the north, Sudbury and Framingham on the east, Southborough on the south, Northborough on the southwest, and Berlin on the northwest. The Marlboro Branch of the Fitchburg Railroad terminates at Marlboro (centre); and the Framingham, Clinton and Fitchburg Division of the Old Colony Railroad crosses the southwest corner and has a station at Marlboro' and Marlboro' Junction. The chief manufacture is shoes, while other manufactures are boxes, carriages, shoe pegs, clothing, textiles, bleachery, and dyed goods, soap and tobacco. The railroad stations are Marlborough and South Marlborough. Other villages are East Marlborough and West Marlborough. Population i 890, I 3,805 .

William C. Lippard, located at 29 Lincoln street, Marlboro' is a well known and reliable manufacturer of heels, and also dealer in remnants. A large force of assistants is employed and all orders are promptly filled and satisfactorily executed. He occupies part of the second floor of a three-story frame building where he is supplied with modern appliances. The output of this house finds ready sale throughout the New England states, and amounts to one thousand pairs per day. Mr. Lippard is one that produces only first-class work, and his goods are well known by jobbers generally.

C. B. Greenwood located on Maple street, Marlboro' is a well known manufacturer of purecider vinegar. This business was established in I 842 by Hiram Greenwood, who, on his death some six years ago was succeeded by his son, the present proprietor. His trade is wholesale and principally with Boston parties. He gives employment to four hands, and occupies a two-story frame building where he has facilities of the best, and turns out about sixty thousand gallons per year. Mr. Greenwood has had many years' experience in this business and is thoroughly acquainted with all its details. He uses only the best stock, and the vinegar made by hin is of that excellence and purity that is desired.

The Marlboro Dye House at 8 Liberty street was established by P. W. Myers \& Son for the business of cleansing, dying and refinishing ladies' and gents' garments of every description. The works are fitted up with all the latest improved appliances that are used to enable them to carry on the business in a successful manner. Steam power is used in pressing the clothing and a large number of hands is employed. Having had many years' experience they understand fully the requirements of the business and no work is allowed to go out unless it is perfectly satisfactory. A large trade is controlled by them which extends to the surrounding towns.

Hollis \& Dearborn, at I3 I Lincoln streets, Marlboro, are an enterprising firm engaged in the manufacture of men's tine grade of shoes of all kinds for the retail trade. The floor they accupy is neatly fitted up with all the latest improved machinery and appliances that are needed in their business. Nothing but the best quality of material is used and an efficient force of skilled workmen 
is given employment, a specialty being made of custom work. Both members possess rare business qualifications and have succeeded in controlling an extensive trade. Mr. Hollis has been a member of the Common Council and is at present a member of the Board of Aldermen. All work done by them will be guaranteed to give perfect satisfaction, and all orders will receive prompt attention.

\section{SOUTHBOROUGH.}

Southborough is a pleasant and thriving town forming the eastern extremity of Worcester county, 28 miles west of Boston. Its boundaries are Marlborough on the north, Framingham and Ashland on the east, Hopkinton on the south, and Westborough on the west; all except the last towns are in Middlesex county. Sudbury river forms the south line, and near it, across the river, runs the Boston \& Albany Railroad, having stations at Cordaville and Southville. The Old Colony Railroad has stations at Fayville and Southborough (centre), and these villages are also postoffices. Population I890, 2, I I 4 .

[For other stations - Framingham, Iakeview and South Framingham - see “ Lowell \& Framingham Branch."']

SHERBORN.

This is the location of the famous Massachusetts State reformatory for women, and is finely situated in the southern extremity of Middlesex county, 20 miles from Boston. The post-offices are Sherborn and South Sherborn, which are also railroad stations. West Sherborn is a village of the town.

\section{MEDFIELD.}

The town of Medfield is in the most delightful part of Norfolk county, having many rich agricultural sections, and a prosperous and intelligent. population. There are numerous diversified industries in the town, good schools, churches, excellent water, fine drives in several directions, and all the surroundings well calculated to make life pleasant and enjoyable. The Old Colony has stations at Medfield Junction and Medfield.

The Elm Tree Inn established in I89r by A. O. Grant is the leading Hotel in Norfolk county. The hotel is very pleasantly located, having a wide piazza in front, and the entrance to it is lined with shade trees on each side of the walk. It is a four story frame building, has ample accommodations for one hundred guests and has all the modern conveniences; being fitted up with electric bells, steam heat, fire escapes etc. The table is first class, and tourists or travellers on business or pleasure will find this an excellent place to stop. It is also a League bicycle house and a large and first-class livery stable is connected. Mr. Grant has the welfare of his guests at heart, providing liberally for their comfort and pleasure at reasonable rates. Many prominent persons of New York, Boston and other large cities make this hotel their summer resort. It is located on North street, within three minutes' walk of Medfield station. 


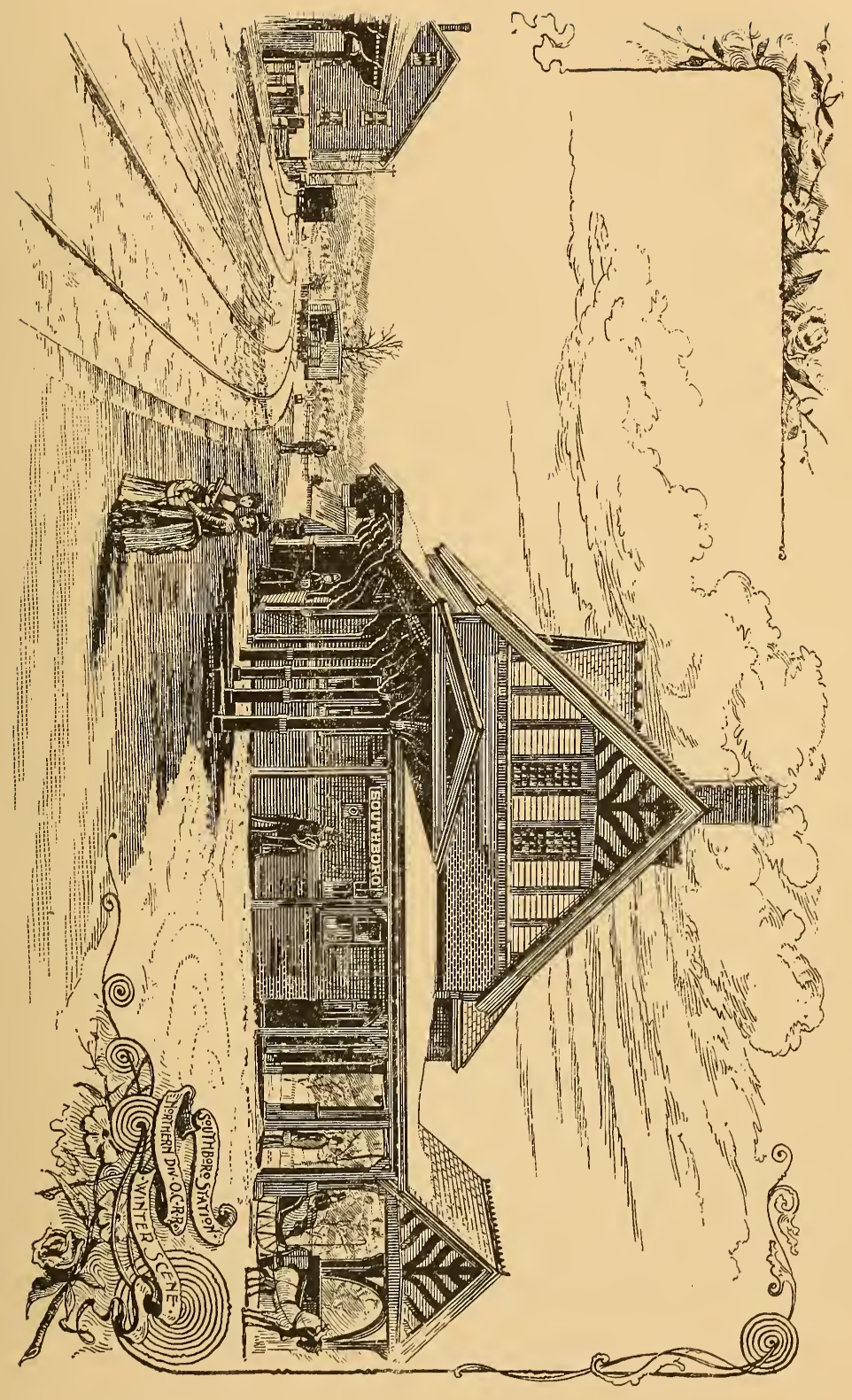



Searle, Dailey \& Co., Medfield, one of the oldest and largest manufacturers of straw goods in this country was established in I 842 and is composed of the following gentlemen, H. A. Searle, G. F. Dailey and Col. E. V. Mitchell. Their plant situated on North street, is one of the largest and most thoroughly equipped in the United States, and discloses a system and completeness in every department, worthy of the highest commendation. The buildings are of large dimensions and subdivided for the convenient and systematic prosecution of the work into various departments. Steam power is used and employment is given to $\mathrm{I}, 000$ to I, 200 hands, whose annual output is in the vicinity of 5,000 cases. All kinds of ladies' and chlldren's straw goods are made and are in great demand by the leading jobbers. The management of the factory is in the hands of Col. E. V. Mitchell, a gentleman practically acquainted with the business in all its branches, and thorougly alive to the best interests of the trade. In addition to his duties here he is also interested in the lumber business, the sales of which last year amounted to $3,000,000$ feet. He is also owner of a large grist mill and proprietor of one of the largest poultry farms in the country. Mr. Mitchell is also interested in politics having at one time served on the Governor's staff and last year was elected to the Governor's Council from the second district. The firm of Searle, Dailey \& Co. is composed of gentlemen of experience, and everything connected with the establishment and its work, reflects the highest eredit upon its proprietors. The sales rooms of the company are located on Broadway, N. Y. and Washington street, Boston.

Blood Bros. located on Park street are among the most extensive dealers in coal, grain, baled hay, flour, poultry food and agricultural implements in Medfield. This firm was established in 1889 and and has built up a large retail trade here and in the surrounding towns. Constant employment is given to four hands and the use of three teams is required. All goods bought of this firm can be relied on as being the best and all orders are promptly filled at short notice. The members of the firm are well known and have the reputation of transacting their business in a straight forward manner.

Robert W. Baker on Frairy street, Medfield carries on an extensive business in carriage manufacturing and repairing in all its branches. This business was first established some fifty years ago by his father, J. H. Baker, who upon his death was succeeded by his son the present proprietor. Five different buildings are occupied and constant employment is given to fifteen skilled workmen. A specialty is made of the Medfield butcher wagon which is used throughout New England and for which a large demand exists. Mr. Baker has a thorough knowledge of the business, which he gives his personal supervision, so that only first class work is produced. All orders are promptly attended to and his prices are reasonable for the fine quality of work done.

\section{WALPOLE。}

Walpole was detached from Dedham and incorporated December ro, 1724 . It was named in honor of Sir Robert Walpole, then prime minister of England. The New York \& New England Railroad and the Old Colony Railroad 


\section{ESTABLISHED OVER 50 YEARS. \\ S. GRAY \& CO., \\ DYERS AND BLEACHERS,}

Proprietors WALPOLE BLEACH and DYE WORKS.

CAPACITY: 6000 POUNDS FANCY COLORS PER DAY.

\section{COTTON SKEIN COLORED}

SPOOL THREAD. KNITTING COTTON. HOSIERY YARNS. JACKET YARNS.
TWINES.

TAPES.

WARP YARNS.

GINGHAM YARNS.

\section{IN}

SUSPENDER YARNS. JUTE YARNS.

BRAIDS.

LINEN.

Matching to Shades required.

Send for Sample Colors and Prices.

OfFICE AND WORKS: - WALPOLE, MASS.

\section{Neponset Water-Proof Fabrics}

Are necessary in the erection of every wellconstructed building.

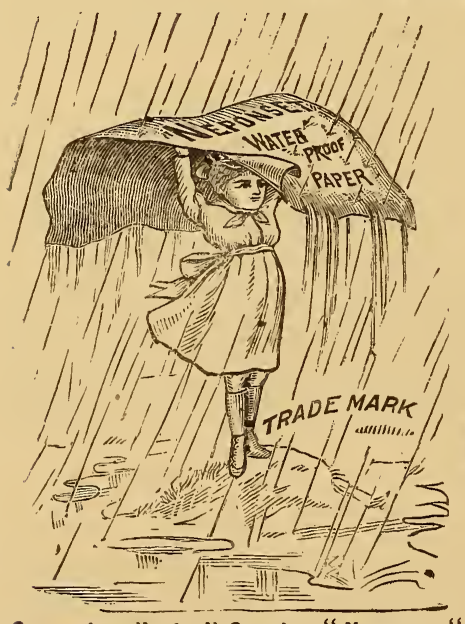

On each roll of all Genuine "Neponset."

\section{Reliable Architects all Indorse them.}

Better and Cheaper than Back Plaster and does not crumble. Always in place.

Samples and Full Information Free.

\section{F. W. BIRD \& SON,}

Sole Manufacturers,

East Walpole, - Mass. 
intersect each other in the central village, thus affording fine facilities for transportation. The postal centres are Walpole, East Walpole and South Walpole. Other villages are Plimptonville, Tilton's and North Walpole. The town is situated in the interior of Norfolk County, I9 miles from Boston, and its boundaries are Dover on the north, Dedham. Norwood and Sharon on the east, Foxborough on the south, and Norfolk and Medield on the west. The stations of the town are Walpole, Walpole Junction and South Walpole. Population, $1890,2,604$.

S. Gray \& Company's bleachery and dye works, is an old and reliable house of- Walpole, engaged in bleaching and dyeing cotton yarns and threads. The premises occupied by them cover an area of two acres and are fitted up with every appliance used in the business. S. Gray \& Company, the proprietors are always prepared to fill large orders at lowest prices, and their trade extends to all parts of the United States. They employ a force of twenty-five hands, and the house has always had the reputation of producing first-class work. The capacity of the works is 5,000 pounds of fancy colors per day. This establishment is one of the oldest, having been in operation for fifty years, now owned by R. S. Gray.

F. W. Bird \& Son, engaged as paper manufacturers, succeeded to the business established in I8I 8 by F. W. Bird's father in a mill that stood where Hollingsworth \& Vose's factory is now located in East Walpole. In I833 F. W. Bird became associated witl his father and in $1838 \mathrm{~F}$. W. Bird started in the mill that was used for manufacturing eotton where his mill now is. In r $882 \mathrm{~F}$. W. Bird sold the mill that hestarted in first to Hollingsworth \& Vose and bought the property now occupied by him. In 1885 he took his son, C. S. Bird, in as a partner. The business consists of manufacturing paper of all grades for wrapping and for paper boxes, and also Neponset waterproof paper, of which they have exclusive control. They occupy twenty-two buildings and give employment to one hundred and fifty-two hands, aided by both steam and water power. Their goods are sent to all points in the United States, but export some to South America and England, and the business has increased very rapidly in the last few years.

\section{WRENTHAM.}

This town is on the Walpole and Wrentham line, and is an old farming town lying in the southwest corner of Noriolk county, about 27 miles southwest of Boston. It has six pleasant villages - Wrentham (centre), South Wrentham, West Wrentham, Plainville, Sheldonville (which are post-offiees), and Shepardville. The principal manufactures are straw goods and jewelry, for which there are several establishments each. There are also two mills for crude woolen gouds, and four or five saw and grist mills, Some boots and shoes, leather, furniture, boats, carriages, wrought stone, beverages and food preparations are made. The stations are Wrentham, Wampum and Plainville. Population, $1890,2,566$. 
FOXBORO

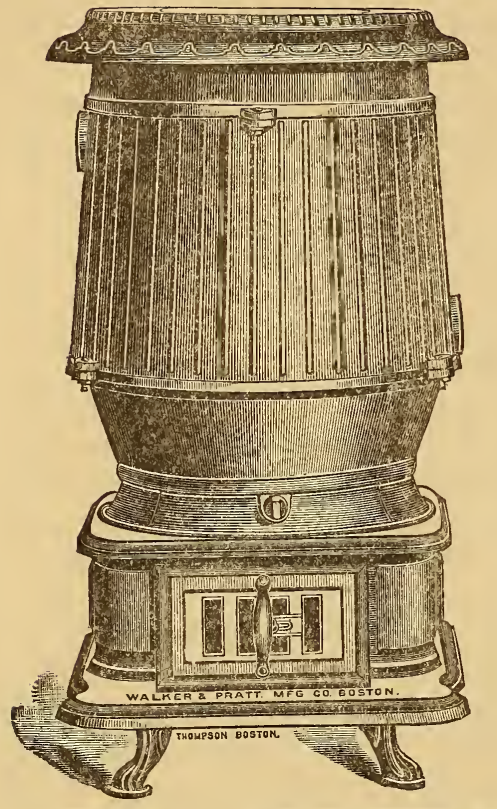

\section{FOUNDRY,}

Located at Foxboro, has been in continuous operation since I78I.

It is now doing a large business in general castings, the quality of which is

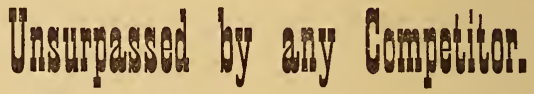

They make several lines of Furnaces, Hot Water and Steam Heaters, Presses, etc. More than 7500 heaters of the style of accompanying cut are in successful operation in Baptistries, small conservatories, stables, hotels, henneries, etc.

\section{FOXBORO FOUNDRY, FOXBORO, Mass., U. S. A.}

\section{A. F. BEMIS HAT CO.,}

Factory, Union Straw Works,

Foxboro, Mass.

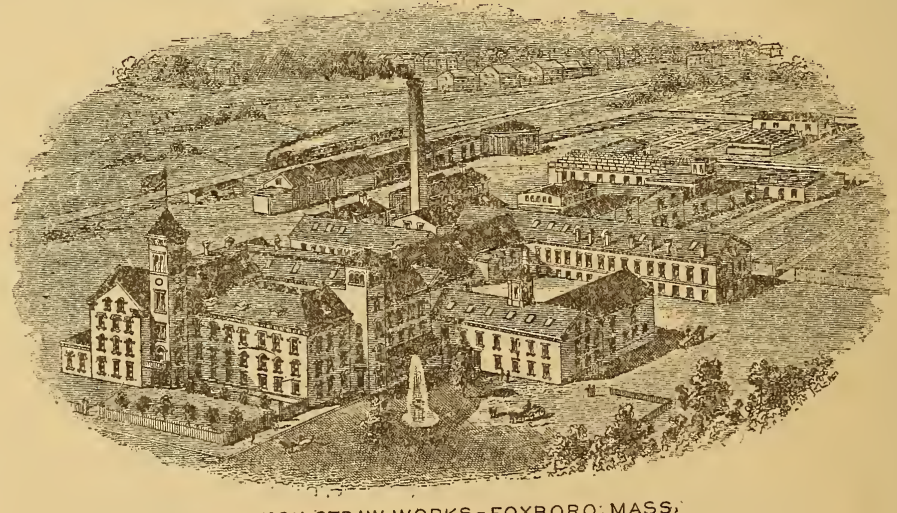

UNION STRAW. WORKS-FOXBORO; MASS:

Manufacturers of Men's, Boys' Children's, Misses' and Ladies' Straw Hats of every description; also of the celebrated "Corey Brim" Manillas, which have a world wide reputation.

The U. S. W. makes the best finished Manilla hat in the world. 


\section{FOXBOROUGH.}

Foxborough is a busy and prosperous town in the southwestern part of Norfolk county, about 20 miles southwest of Boston. The Providence Division and the Northern Division of the Old Colony Railroad pass through it, having stations at Foxborough (centre), East and North Foxborough. The other villages are West and South Foxborough, Foxvale, Foxborough Furnace, and Donkeyville. Walpole bounds it on the north and northwest, Sharon on the northeast, Mansfield on the southeast and south, and Wrentham and Norfolk on the west. For many years this was a leading town in the straw goods business in America; and at one period it sent out more hats and bonnets of straw than did all the rest of the country together. The manufacture was begun here by Elias Nason as early as 1812. Daniel Carpenter, at a later period, developed the business to such a degree as to be properly regarded as the founder of the business. Machinery has been introduced, making better goods at a cheaper rate, and the town has now several rivals. Four firms and about $\mathrm{r}, 000$ persons are employed in this industry. Other manufactures are boxes, soap, sewing machines, leather, etc. Population, $1890,2,933$.

The Union Straw Works was the first factory in this country to commence the manufacture of straw goods. The plant was built in I 853 and in 1855 it received its title-“U. S. W." The space occupied by the buildings and dry yards covers 145,000 square feet. Numerous additions have been made from year to year and the establishment as it now stands, ranks among the first in size and in capacity for turning out a large amount of goods. In I889 a stock company assumed control of the works under the name of A. F. Bemis Hat Co. and they are now carrying on a large business, renting the plant and having a capital stock (or working capital) of $\$ 30,000$. The business carried on is the manufacture of men's, boys' children's and ladies' straw hats of every description. The number of hands employed in the works is about three hundred and fifty, and additional work is done outside. The quality of the work and the materials used are the very best. The factory is fully equipped with all the latest improved machinery and has a capacity for an annual output of two million hats. The members of the company are men who possess the qualifications necessary for successfully carrying on a large business. Their goods are known throughout the country and all their transactions are conducted in a straight forward manner.

The Foxboro Foundry and Machine Co., was incorporated in 1888 with a capital of $\$ 20,000$ and officered by the following gentlemen: H. C Williams, president, and B. F. Boyden 2nd, secretary and treasurer. This enterprise was originally established in $\mathrm{I} 78 \mathrm{I}$ for the purpose of casting cannon, shot and shell for the Continental army, and during all this period of one hundred and eleven years, these works have never been closed, excepting for improvements or repairs, while numbers of other similar concerns have been formed, failed and been forgotten. About forty hands are employed who turn out goods to the amount of $\$ 40,000$ to $\$ 50,000$ per year specialties being made of presses, 


\section{THE RISING SUN STOVE POLISH.}

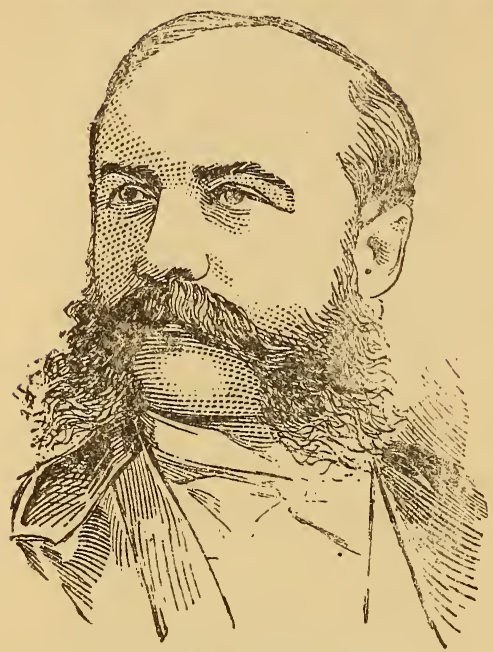

HON, ELIJAH A. MORSE, M. C.

For beauty of gloss,

For saving of toil,

For freeness from dust,

And slowness to soil.

Of all imitations

'Tis well to beware,

The half risen sun

Every package should bear.

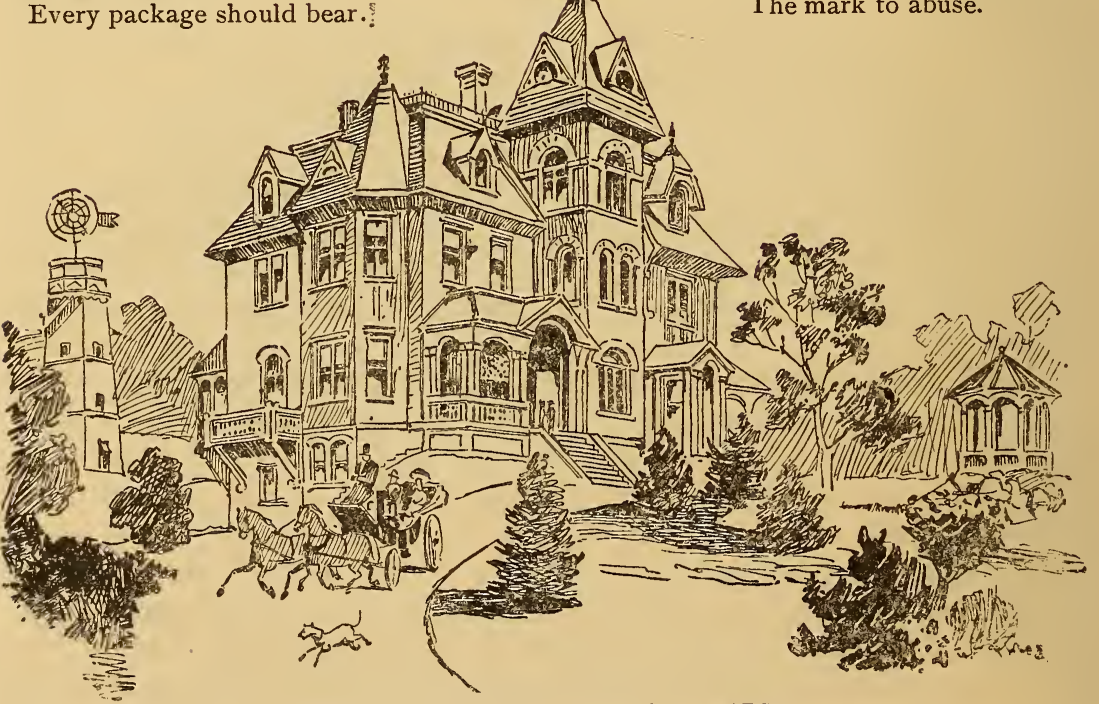

RESIDENCE OF HON. ELIJAH A. MORSE.
For this is the trade mark The Morse Brothers use, And none are permitted The mark to abuse. 
stampers, flats and pressing jacks for straw goods manufacturers, furnaces, hot water and steam heating apparatus. These goods are shipped throughout the United States. The active management of the business is under the control of Mr. Boyden and by his skillful management has largely increased. For many years past Jarvis Williams has had charge of the machine shop. The plant comprises five one story buildings for the various kinds of work and sereral warehouses. Water power is used most of the time, a twenty-five horse power wheel being supplied with water from the Wading river. The business is a growing and profitable one and may be ranked among the most important of Foxboro's industries.

A. H. \& A. F. Young on Granite street Foxboro carry on a large establishment for the dyeing and bleaching of manillas, chips, leghorns and all kinds of straw hats. They were established in 1884 and have built up a large and successful business. All work receives prompt attention and is given the utmost care, and all work is guaranteed, a force of twenty hands is given employment by them and they occupy several buildings. They are also manufacturers of felt hats and during the season have the facilities for turning out two thousand dozen. They make a specialty of getting out their work promptly in a first class manner.

\section{MANSFIELD.}

Mansfield is an agricultural and manufacturing town lying on the northern border of Bristol county, 24 miles southwest of Boston by the Providence Division. This is intersected at Mansfield centre by the Taunton and New Bedford and by the Framingham and Mansfield lines of the Old Colony Railroad system. There is much variety of manufactures, iron and metallic goods being the chief products, and consists of stoves, furnaces, windlasses, artisans' tools, cutlery, tacks, brads and jewelry. Straw goods, wooden goods, basket work, lumber, arms, ammunition, earriages, stone, soap and tobacco, are also important manufactures. Rockdale is a near by station, being one mile from the centre.

Richardson \& Bottomley carry on a business established in Attleboro about thirty-three years ago by O. P Richardson, but in I 890 they moved to West Mansfield, on Otis street, their present location, where they are engaged in the manufacture of shuttle irous of every description, which are in demand from all parts of the United States and Canada. They occupy premises conveniently arranged and equipped with modern appliances, using both steam and water power. Eleven experienced workmen are employed, whose weekly output is twelve hundred setts, the work being of the best quality and finish. The members of the firm are enterprising and progressive business men, ever alive to the wants of their customers and the best methods of supplying them.

P. A. Drew \& Company, one of the principal contractors and dealers in wood, coal, hay, straw and masons' materials, are located off Rumford street, near the station in Mansfield. This house was established in 1877 and has built up a large retail business. They have nine coal bins, earh holding an 


\section{[NEW' \\ - . MANUfACtuRERS OF . . \\ * Reed and Rattan *}

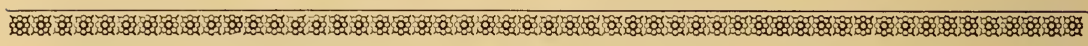

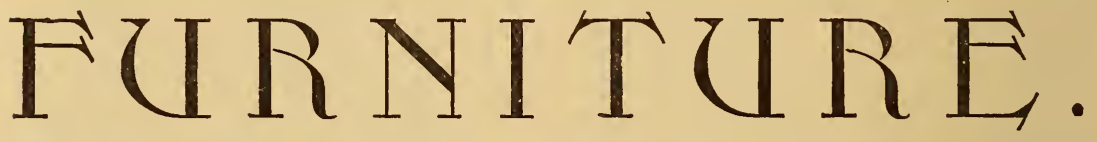

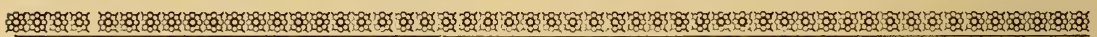

South Framingham, - _ - Mass.

W. E. RYAN, Manager and Treasarer.

\section{AUBURN LAST COMPANY,}

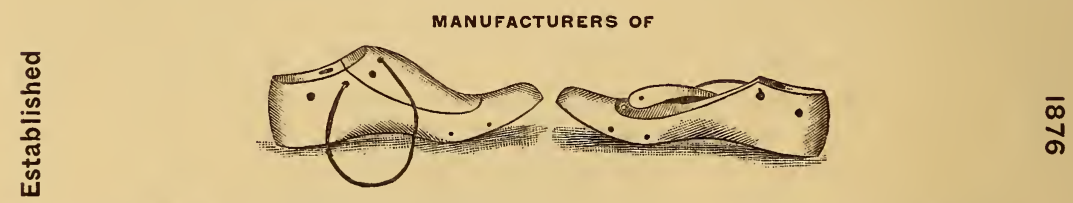

\section{South * Framingham * Hotel,}

W. AlLEN, Proprietor,

South Framingham, Mass.,

Opposite the Depot.

Terms, $\$ 2.00$ per day.

Special Rates to Commercial Men. C. W. Allen, Clerk. 
average of about two hundred tons each, and employ two hands and two teams, and all kinds of jobbing are promptly attended to. A large stock is constantly kept on hand of all kinds of coal and wood, and orders are filled at short notice. Coal is discharged direct into the bins from the ears thus giving their patrons the benefit of the saving in expense in getting the coal from the whar.

S. W. Card \& Company, established in 1875 , are engaged in the manufacture of machine screw taps, tap wrenches and screw plates, which are known the world over. The premises occupied are lucated on Runford avenue, Mansfield, and consist of a two-story îrame building, thoroughly equipped and affording employment to fifty hands. A large stock of their goods is kept on hand, thus enabling them to fill all orders at short notice. The facilities of this house and the policy adopted by its managers has secured for them a reputation of a high order as well as an extensive trade. Mr. Card is a weli known resident of Mansfield and is one of the directors of the Mansfield Co-operative Bank.

Evans, Cobb \& Co. stand among the first in Mansfield as manufacturers of jewellers' findings, charms and chain bars in rolled plate, sterling silver and fire gilt. The material used is of the best and perfect satisfaction is guaranteed to all their patrons. They occupy a two story frame building ninety feet by forty feet, located on Spring street, water power principally being used and give constant employment to forty experienced hands the output of whose labor amounts to four thousand dollars per month. By their enterprise, ability and constant attention to business they have built up a large and extensive trade, and during the eleven years they have been established have gained the esteem and confidence of all with whom they deal.

The Mansfield News a paper of very interesting reading matter to the inhabitants of Mansfield and vicinity was first started in 1873 by S. B. Pratt. He was succeeded in a short time by Thos. S. Pratt, who in I88I associated with Mr. William White under the name Pratt \& White, Mr. White assuming entire control in I89I. The office is located on North Main street and is fully equipped with steam presses, paper cutters and other appliances used in the printing business. A large jobbing business is also done by him and five experienced workmen are employed. The paper is published weekly and has a circulation of one thousand copies per week. Mr. White is a man of experience in this line of business and all work executed by him is satisfactory. He is also publisher of the Fuxboro Times.

George A. Robinson of Williams street is a well known and enterprising manufacturer of cutlery in West Mansfield. Starting in 1861 a partnership was formed with Mr. Moran and William N. Moran, his grandson, which continued for a few years when the elder Moran died, the younger Moran retired and $\mathrm{Mr}$. Robinson became and still remains the sole proprietor. The premises occupied by him consist of a substantial one story building forty by sixty feet and is thoroughly equipped with the necessary appliances. About ten skilled workmen are employed in the production of high grade knives for butchers, cigar makers, fishmen and shoe makers, in some six hundred styles, from the best stock, thoroughly made and sold by the trade all over the United States • 
The business has been steadily increasing, and the goods are well and favorably known owing to the superior ability and long experience of an industrious proprietor.

C. D. Lyons \& Co. are manufacturers of all kinds of jewelry making a specialty of watch chains. Their factory is located on Otis street, West Mansfield and consists of a two story frame building well supplied with the best kinds of machinery driven by water power. Many hands are constantly employed, the product of whose labor is in good demand. This firm is composed of C. D. Lyons and F. H. Reed gentlemen of long experience, excellent business ability and possessed of that sort of character and reputation which compels the esteem and confidence of those with whom they deal. They devote their entire attention to the business, and are in the best possible shape to meet the requirements of the trade in this branch of commerce. They have now been established about five years, and have built up a trade extending all over the country and embracing the leading jobbing houses as their customers.

\section{zas The Mansfield News, abs} is issued every Friday at 42 North Main St.

WILLIAM WHITE, (2) (2) - (3) Editor and Proprietor. TERMS : $\$ 2.00$ per Annum.

Advertising Rates : \$1 per inch, first insertion;

We have Complete Facilities for doing any kind of

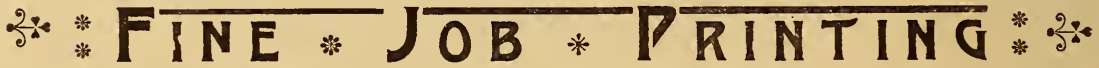

Promptly and at reasonable prices. Orders for Advertising or Job Printing, by mail or express, carefully filled.

P. A. DREW.

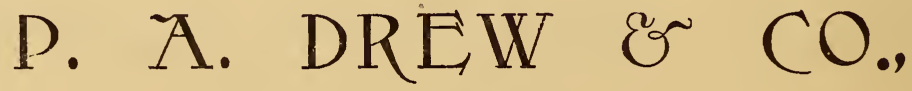

\section{Coal, Hay, Lime, Hair, Cement and Brick.}

All kinds of Jobbing and Contracting promptly attended to. 


\section{I,OWELL \& FHRAMINGHAM BRANCH.}

\section{LOWELL.}

HIS great textile industrial centre is second in number of its looms and spindles in the United States, standing next to Fall River in this respect and employing a capital of $\$ 12,300,000$ in this branch of manufacture alone. Besides its extensive textile manufactories there are a large number of establishments devoted to the building of machinery for woolen and cotton goods, several of which are the largest in this country and the most perfect in their appointments. The city is located in the northeasterly section of Middlesex county, on the Merrimac river, the stream being controlled by a series of canals which afford excellent power for the great factories which lie along its course for several miles. Although the city is a "factory town" in the strictest sense, being known as the Spindle city, its educational, religious and social status is of the highest order, and it possesses one of the finest public libraries to be found in the East.

Lnwell has an interesting early histnry, being named after Francis Cabot Lowell, whose career, in connection with Patrick T. Jackson, in the founding of the cotton industry at Waltham and subsequently at Lowell, is more fully outlined in the history of Newburyport, Mass., of which both were natives. Soon after establishing the cotton industry in Lowell, Boston merchants began buying up the farms on which the city now stands, and on one occasion they sent a man from there to negotiate for a particularly desirable and centrally located farm owned by one of the earliest settlers in that section. The young man took things leisurely, and passed much of his time in fishing and hunting, each day making the farmer an offer for his property, only to find the price doubled on every such occasion. When asked the reason for such a course, the farmer explained that he had recently seen two men sitting on a rock on the opposite side of the Merrimac river, where they were engaged in earnest conversation. Soon they arose and "one went up the river and the other down. They returned in about half an hour, talked earnestly for some time and then went away." Being asked what significance such an incident could possibly possess, the farmer rereplied "I didn't know what it ment, but I thought something was in the wind, and I just made up my mind to double up on you every time you asked the price of my farm." And he did "double up" from $\$ 1,000$ to $\$ 6,000$, at which figure the bargain was closed and the building of the future great city 
begun by Boston capitalists. The above incident is recorded as happening about the beginning of the war of 1812 , which was about the time of the introduction of textile manufacturing in Massachusetts, and which has proved such a source of wealth and prosperity to the Commonwealth.

The growth of Lowell has been a steady and healthy one and to-day it has a prpulation of 78,000 . It is abreast of the times in everything, and its railroad facilities are of the best. It is on the Lowell \& Framingham Branch of the Old Calony system, with stations in the city and Golden Cove, two lines of the Boston \& Maine also being located here. The post-offices are Lowell and Middlesex village; the several outlying districts of the city and within its limits are known as Belvidere, Bleachery, Centralville, Highlands, Meadowville and Pawtucketville.

\section{CHELMSFORD.}

Chelmsford is an ancient and pleasant town in the northern part of Middlesex county, about 26 miles northwest of Boston. Tyngsborough, Dracut and Lowell bound it on the north, the latter with Billerica on the east; Carlisle on the south, and Westford on the west. The Merrimac river forms the line along the Dracut border. The villages are Chelmsford (centre), North, South, West and East Chelmsford, which - except the last - are also post-offices. The Ayer Junction Branch of the Boston \& Lowell Railroad has stations at North and West Chelmsford, and the Old Colony Road at Chelmsford and South Chelmsford. Population, I 890, 2,695.

\section{CARLISLE.}

Carlisle is a small farming town of $48 \mathrm{I}$ inhabitants, situated in the central part of Middlesex county, about 20 miles northwest of Boston. Carlisle station, on the Old Colony Railroad, is in the northwest part of the town, and Bedford station, on the Boston \& Lowell Railroad, accommodates the southeast portion. The post-office in at the centre.

\section{WESTFORD.}

Westford is a prosperous farming and manufacturing town, occupying an elevated site between the Merrimac, Concord and Nashua rivers, near the centre of the northern section of Middlesex county. The Stony Brook Railroad, passing across the midst of the township, is intersected at Graniteville, in the western part, by the Nashua \& Acton Railroad. The Lowell \& Framingham Branch of the Old Colony, by its station at South Chelmsford, is convenient to the southeastern part of the town. The post-offices are Westford (centre), Coldspring, Forge Village, Graniteville and Nashua. The other villages are Chamberlain's Corner, Parkeville and South Westford. The town has Tyngsborough on the northwest and north; Chelmsford and Carlisle on the east; Acton on the south; Littleton on the southwest; and Ayer and Groton on the west. Population, $1890,2,250$. 


\section{ACTON.}

Acton is one of the old towns of this section and is noted for many fine farms and the general beauty of the surrounding districts. It is adjuining the town of Concord and has many features characteristic of that place being largely devoted to agricultural pursuits, in which the inhabitants are progressive and prosperous. The stations are Acton and North Acton.

\section{CONCORD.}

Concord, the scene of our first triumph in the conflict that made us a Nation, is situated in the central part of Middlesex county, 18 miles northwest of Boston, by the Fitchburg Railroad. The Lowell \& Framingham Branch of the Old Colony Railroad, and the Southern Division of the Boston \& Maine Railroad also pass through it, the Old Colany having a station at Concord Junction. The villages are Westvale, Warnerville and Nine-Acre Corner. Concord is bounded on the north by Carlisle on the northeast by Bedford, on the southeast by Lincoln, on the southwest by Sudbury, and on the west and northwest by Acton. It is "one of the quiet country towns," says Mr. Alcott, "whose charm is incredible to all but those who by loving it have found it worthy of love." The Concord river flows leisurely through the town from the south, receiving near the central village the waters of the rapid Assabet. The latter, with affluents, affords some motive power, which is made use of at West Concord by a woolen mill and factories for pails and other goods. Carriages, furniture, leather, clothing and building stone, are other of the town manufactures. Along the streets, especially in the central village, are numerous well-grown elms and maples, lending added charms to the excellent drives to be had in nearly every direction. It is the location of the largest public institution in the state - the Concord Reformatory. Population, I890, 4,427.

\section{SUDBURY.}

The ancient town of Sudbury has been immortalized by Longfellow in his "Tales of a Wayside Inn." It is in the southwesterly section of Middlesex county, 26 miles by highway from Boston, and containing I, 65 inhabitants, and three postal centres - Sudbury (centre) North Sudbury and South Sudbury. which are also stations on the Lowell \& Framingham Branch of the Old Colony Railroad. The Southern Dirision of the Boston \& Maine Railroad also has stations at East Sudbury and South Sudbury (Mill Village.) It has Maynard and Concord on the north, Wayland (from which it is divided by Sudbury river) on the east, Framingham on the south, and Marlborough and Hudson on the west.

FRAMINGHAM.

Framingham, one of the most beautiful towns in the commonwealth, lies in the southwestern part of Middlesex county, some 20 miles southwest of Boston, and nearly the same distance from Worcester. It is bounded on the north by 
Sudbury, east by Wayland, Natick and Sherborn, south by Ashland, and the west by Southborough and Marlborough. At South Framingham the Boston \& Albany Railroad intersects the Northern Division of the Old Colony; and from its large and excellent station sends out a branch southward to Milford, and another northward to the central village; while a third branch connects with Saxonville, noted for its woolen blankets and carpets. The other villages are Nobscot, Hastingsville, Millwood and Parker's Corner. There are manufactur es here of rubber clothing and other articles of this material, a large product of straw hats and bonnets, of boots and shoes, lasts and carriage wheels; also carriages, trunks and valises, furniture, wooden boxes, etc. The stations are North Framingham, Framingham, Lakeview and South Framingham on this branch of the Old Colony Road.

E. D. Stone of Clark street South Framingham a well known manufacturer of lasts and sole patterns conducts business under the name of the Auburn Last Company. This business was established in 1876 at Auburn, Maine, but in 1882 was transferred to its present location, and is the only one of its kind in this section. Ten hands are employed who with the excellent equipment at hand are enabled to turn out three hundred pairs of lasts per day. Mr. Stone is a gentleman of large experience in this line and his goods are widely and favorably known. He is also well known in social circles and is a member of the I. O. O. F.

About the year I 882 the Auburn Last Company located on Clark street began the manufacture of lasts for rubber shoes, which are now in demand by the leading manufacturers of rubber shoes of New York, New Jersey and Connecticut. Possessing superior facilities for producing first class goods this house lias built up a large trade and is noted for its reliability and prompt attention to details.

A. Fales \& Sons building contractors and manufacturers of all kinds of builders' finish is one of the largest and most reliable houses in this line of business located on the line of Old Colony R. R. They are also dealers in lumber, hardware and all kinds of building materials. The business was established in I 876 and is managed by A. Fales and his sons F. H. and H. T. Fales. Their shops and yard are located on Beach street and consist of a mill and other buildings occupying about an acre of ground and giring employment to fifty men. They take contracts for all kinds of buildings and several of the stations and round houses on the Old Colony R. R. have been built by them. Messrs. Fales \& Sons are well known throughout this section of the country and have established for themselves a reputation of a high order, and their success in business may be attributed to enterprise, industry and the faithful performance of their agreements.

The New Fngland Rattan Co. are among the noteworthy firms engaged in the manufacture of reed and rattan furniture. 'The business was established in I 887 but two years afterwards was made a stock company with a capital of twelve thousand dollars. The officers are president W. E. Ryan; treasurer and manager, W. E. Ryan. The furniture made by this company is of an extra fine quality of rattan, and is well known throughout the country. The premises 
consist of a four story frame building fully equipped with all the latest appliances used in the manufacture of their line of goods. Only first class workmen are employed by them to the number of from eighty to one hundred. A large variety of goods is manufactured by them the daily output being one hundred pieces. The business is increasing very rapidly, and now yields an income of one hundred and fifty thousand dollars per year.

Thomson Bros. engaged in the manufacture of carriages and wagons of every description, are located on the corner of Cedar and Waverly streets, South Framingham. This house makes all kinds of business wagons, do a first class horse shoeing business and are also carriage painters and repairers in all its branches. Harnesses, wagons and sleighs are kept on hand in which they enjoy a good trade. All orders are given prompt attention and perfect satisfaction is guaranteed in every detail of their work. This firm was established in I 889 and has built up a large and prosperous businesss. Employing six first class workmen they are able to meet all demands for work at short notice. They occupy a three story building sixty by thrty feet, using the first floor for storage purposes, the second floor for the blacksmithing and wheelwright departments. and the third being used for the painting and varnishing.

The South Framington Hotel of which W. Allen is the proprietor and C. W. Allen, clerk, is without doubt the leading and most popular hotel in this section of the country. It is centrally located, being opposite the railroad station and convenient to the business quarter of South Framingham. The building a three story structure two hundred by two hundred feet in dimension was erected and open one hundred and fifty years ago and contains some twenty-six rooms, supplied with modern improvements and comforts. The table is first class, abundantly supplied with the best meats, poultry, fish, vegetables etc. in the market, skillfully prepared and served by attentive waiters. A well equipped livery stable is connected with the hotel. Mr. Allen devotes his entire time and energies to securing for his house a liberal support from the travelling and boarding public, and has made his house one of the most popular stopping places in this part of the state. No pains are spared to make guests comfortable and at home, and rates are reasonable.

\section{A. FALES \& SONS, * Building * Contractors. * \\ And Manufacturers of all kinds of $\rightarrow$ * BUIIDERS" * FIINISII * $\rightarrow$ DEALERS IN \\ Building * Materials, * Lumber, * Masons' * Supplies, * Hardware, * Etc. Dealers in Iamber and Hardware. \\ South Framingham, A. FALES. \\ F. H. FALES. \\ Mass,}


Aubarn Last Company,

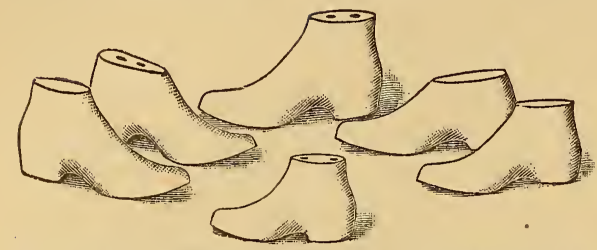

\section{Rubber Shoe Lasts.}

We have had twelve years experience on Rubber Lasts, and offer you the best Last at Lowest

Prices. Send for Price List.

98 CLARK STREET, SOUTH FRAMINGHAM, MASS. E. o. Stone, treas. and SUpt.

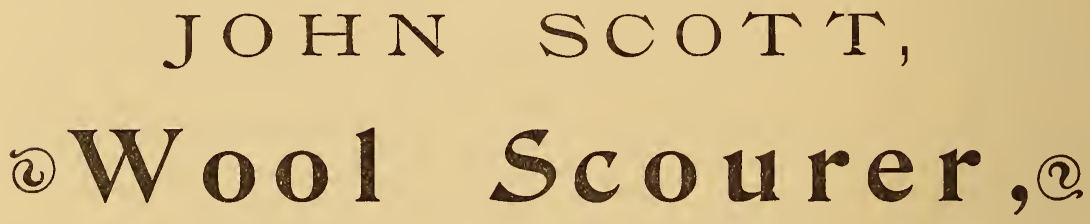

620 Atlantic Ave., Boston, Room 21.

Mills at Hyde Park,

Mass.

\section{T. H. GRAY \& CO.,}

Manufacturers of and Dealers in

Wol Shodies, Wol Extracts, WOOL WASTE AND FLOCKS.

Colored Stocks a Specialty.

Boston 0ffice, 154 Federal St.

Mill at HYDE PARK, MASS.

A. E. Houghton, -Manufacturer of-

Door and Window Screens,

NORTH MAIN STREET,

MANSFIELD, - MASS.

General Jobbing. Terms Reasonable.
CHAS, A. LUTHER \& CO., [Manufacturers of Patent

\section{CLOTH STRETCHERS,}

Thread Dressers,

Improved Thread and Yarn Reels, and 4-Color Yarn Printing Machines.

187 No. Main St., PAWTUCKET, R. I 


\section{PROVIDENCE DIVISION.}

T mentioned under " suburban Service."

\section{HYDE PARK.}

Hyde Park, situated in the northeastely part of Norfolk county, adjoining Boston on the south, is a beautiful and progressive town. The West Roxbury district bounds it on the northwest, the Dorchester district on the northeast Milton on the southeast and Dedham on the southwest. It is extensively engaged in manufactures, has fine schools and churches, beautiful residences and is noted for the number and extent of its social and other organization. It is eight miles from Boston on the Old Colony and has a population of 10,193 , a large proportion of which is made up of Boston business men. Clarendon Hills is a village and station in the town of Hyde Park, with about 1000 population, and located one mile from the centre. It is a growing section and contains many costly modern built residences. Many people find this a most agreeable place in which to pass the summer.

The American Tool and Machine Co., manufacturers of general machinery and tools and various kinds of special machinery, are among the most extensive of Hyde Park's industries. The company was incorporated in 1864 under the laws of Massachusetts, and is now governed by the following board of officers, viz: president and general manager, Benjamin F. Radford; treasurer, Wm. O. Lincoln; directors B. F. Radford, Wm. O. Lincoln, Geo. H. Fox, Jacob Thaxter, W. M. Bacon. A celebrated product of this company is a belt knife leather splitting machine which is used extensively in the leather currying establishments of the principal nations of the world. The centrifugal sugar refining machinery and Weston's "hydro extractor" for drying all kinds of fabrics, both the invention of the first president David M. Weston are also widely used and specially noted. In fact all their goods are favorably known throughout the world for their excellence, which has secured for this company the faith and confidence of the industrial world. They have an extensive and perfected plant of ten buildings covering an area of eight acres, and giving employment to some three hundred hands. The annual output reaches a very large volume and is constantly on the increase which is an excellent indication of the superiority of its products. The principal office of the company is at 84 Kingston street, Boston. 
J. T. Robinson and John R. Fairbanks, under the firm name of John T. Robinson \& Co. at I 25 Business street, Hyde Park, are manufacturers of paper box and card cutting machinery. They occupy a two story brick building, whose dimensions are one hundred and fifty by fifty feet. The material used by them is of the very best and their machinery is sent to all parts of the world, while an efficient corps of skilled workmen are able to fill orders promptly.

T. H. Gray \& Co. were founded in 1872 and the business consists of the manufacture of wool shoddies of all grades and colors. They also deal in wool, wool noils, camels' hair, flocks, waste etc., etc. Their factory located on Business street is a substantial structure two hundred by fifty feet with two storehouses and employs some twenty-five to thirty-five hands and they are now building a new mill which will employ ten more men. The products are sent to all parts of the country. Mr. Gray the manager is an enterprising and progressive merchant and manufacturer, has had years of experience and is thoroughly alive to the wants of the trade, and has built up a valuable aud close connection with woolen and woolen goods manufacturers throughout the country. Mr. Gray is a resident of Boston and has an office there at I 54 Federal street.

The Wilton Mills of Hyde Park were established in 1874 at Milton, but in I 88I moved to Hyde Park, and since their removal to this place owing to the large increase of their business, they have been obliged to build two additions to their building and have added new machinery both for drying and scouring wool. The dimensions of their building are two hundred and thirty-four feet long and fifty feet wide, in which steam power is used and contsant employment is given to about fifty experienced workmen. The wool is sent principally to Boston, and the mills scour in the vicinity of eignt thousand pounds per day. Mr. John Scott the proprietor is one that thoroughly understands his business, and has a reputation for honest realing in all transactions. The mills are located on Wilton street, Hyde Park, and the Boston office is located at 620 Atlantic avenue.

\section{READVILLE.}

This is another village of Hyde Park, and the residence of many wealthy Bostonians in summer. It has several fine estates, an excellent trotting pari, and is about three miles from the observatory on the summit of the Blue Hills. Population about I, ,oo. Green Lodge is a near by station.

CANTON.

Canton is an active minufacturing and farming town, lying a little east of the centre of Norfolk county. The railroad station at South Canton (Canton Junction) is 20 miles from Boston, and Ponkapoag Village, in the northeast part, is about 12 miles in a direct line. The latter and Canton are the postoffices, and the villages are the same, with South Canton, Canton Corner, Dedham Road, Farms, Springdale and Stone Factory. On the northeast side lie the towns of Milton and Randolph, on the south and southwest are Stoughton and Sharon, and on the northwest is Dedliam. The general 
form of the territory is that of a common kite. The manufactories consist of a branch shop of the Ames shovel factories, an iron foundry, cooper works, one factory for making shoe tools, two for cotton spinning rings, one for stove polish (Rising Sun), one making paper boxes, one for catton, one for twine, one for fish lines, one for oil-cloth, six for fancy woolens, and one for silk goods. Population, I $890,4,53 \%$.

The Rising Sun Stove Polish and Black Lead Works of Morse Brothers was established by the present proprietor Hon. Elijah A. Morse, M. C., in Canton in I 864. At that time Mr. Albert F. Morse was associated with the founder as his superintendent, while $\mathrm{Mr}$. Abner L. Morse the manager entered the business in 1884. Since which period the firm has obtained influential and permanent patronage. The works cover four acres, and it required four millions of bricks to construct the buildings. This is the largest establishment of the kind in the world and is equipped with all the most improved machinery, appliances and appurtenances necessary for carrying on the business. Employment is given to a large force of skilled workmen, and the machinery is driven by a one three hundred horse power steam engine and another of one hundred and twentyfive horse power. The rising sun stove polish for brilliancy, durability, no odor when heated, and cheapness is absolutely unrivalled in the United States or Europe. This house has acquired a high reputation for the excellence of its productions, and the trade extends throughout all sections of the United States, Canada and England. Hon. E. A. Morse, the originator of the famous rising sun stove polish, is not only known in connection with his mercantile enterprise, but is equally prominent in political circles in the state, having been a member of the House of Representatives in 1876 , and a senator from Norfolk county in 1886 and 1887 , and was on the Governor's council in I888, and a member of the 5 Ist and 52 nd Congress, and was elected to the 53 rd Congress by a plurality of 4,600 , running 1,600 votes ahead of the ticket. He is an earnest advocate of all measures of reform for the advancement of the public interests and the welfare of the community.

A. Folsom \& Sons was established in I 824 by A. Folsom as manufacturer of narrow floor oil cloths. He was the originator of the oil cloth known under the name of the New England floor oil cloth. They occupy five buildings three of which are frame, the dimensions being one hundred and thirty by forty feet, the remaining two buildings are iron and are thirty by sixty feet. The firm moved from Roxbury to Canton junction abcut four years ago and at present a force of thirty hands are employed by them, who turn out one thousand yards of oil cloths per day. The firm have had a long experience in the business, and have the reputation of producing a fine quality of oil cloth.

G. H. Mansfield \& Co. are manufacturers of braided fishing lines, silk and linen braids. This business was established in I 865 by G. H. Mansfield, and was the first manufactory of braided fishing lires in the United States. The present members of the firm are brothers, all natives of Canton. 'The product of their factory is noted for its excellence and is sold in all parts of the country. 


\section{A. FOLSOM \& SONS,}

\section{- MANUFACTURERS OF \\ FLOOR \\ OIL \\ CLO'THS,}

Canton Junction, Mass.

Thomson Brothers, CARRIAGE AND WAGON BUILDERS. Horse Shoeing a Specialty.

Express Wagons for Sale....

... Light Order Wagons a Specialty. Carts, Wagons, Sleighs, Pungs and Traverse Runners made at short notice.

All kinds of Repairing and Carriage Painting done in First-Class Shape.

SPECIAL ATTENTION GIVEN TO ALL WORK. BUILDING IRONS A SPECIALTY.

GIVE US A CALL. We Guarantee Satisfaction.

SHOP, Corner Cedar and Waverley Streets, South Framingham, Mass.

\section{D. CODDING,}

-.- MANUFACTURER OF -..

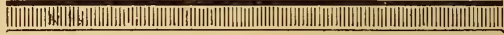

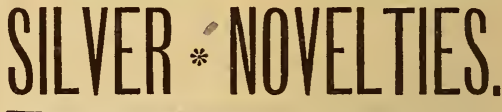

FACTORY, North Attleboro, Mass,

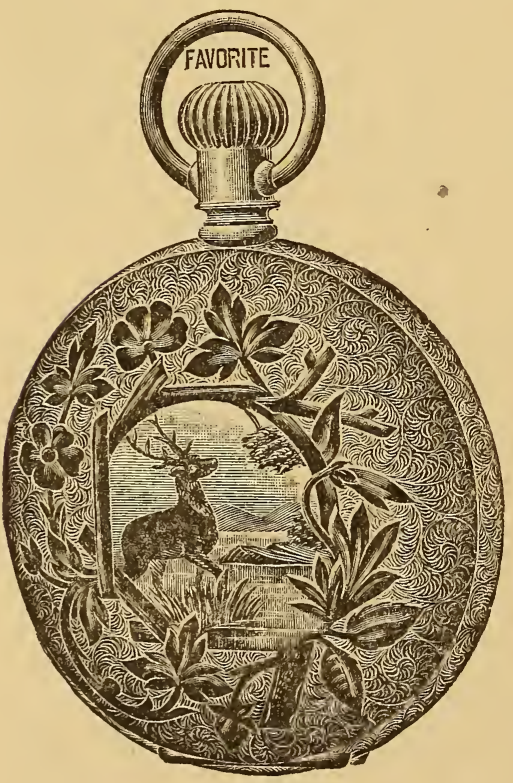

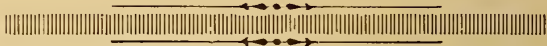

$B A T E S$ \& BACON'S Gold Filled Watch Cases are not surpassed either in quality, design, or finish. Ask your jobber for them. Factory at Attleboro, Mass. New York Office, I94 Broadway. 
SHARON.

Sharon occupies the highlands which form the water-shed of streams flowing in opposite directions - northeasterly towards Massachusetts or southwesterly towards Narragansett Bay. It has for its boundaries Norwood on the north, Canton on the northeast, Stoughton on the east, Easton and Mansfield on the southeast, Foxborough on the southwest, and Walpole on the west. It lies at the middle of the southern side of Norfolk county, 22 miles southwest of Boston, with stations at Sharon and Sharon Heights, and Massapoag Pond in summer. The post-offices are the first and East Sharon.

[See Foxboro and Mansfield under “Northern Division" of the Old Colony.]

Atla Heights, located in the easterly part of the town adjacent to the towns of Canton and Stoughton, and one and one-half miles from Canton station on the Old Colony Railroad, is a beautiful tract of land. The merit of this place as a health location is receiving considerable attention by our best class of people. An Artesian well brings up a subteranean water of remarkable purity. Here is situated the residence property of F. W. Mansfield, which is one of the finest in Sharon.

C. S. Harper, of Cottage street, Sharon, is a well known carriage manufacturer. The vehicles made by him are adapted to meet the wants of his patrons. In connection with this he has a repair and blacksmith shop, occupying seven buildings covering an area of two and a half acres. There are twenty-five hands employed who are able to produce about one hundred and fifty new carriages a year. The work from first to last is conducted with a care and skill that go far to explain why the productions of this house are so durable. Mr. Harper is well known in the New England states.

H. A. Lothrop Manufacturing Company is located on Ames street, Sharon. It was incorporated in $\mathrm{I} 882$ with a capital stock of forty-five thousand dollars. The premises occupied by them consists of three frame buildings, and give constant work to sixty experienced workmen, while the goods are sent to all points in the United States as well as to Havana and Vera Cruz. The company have had long business experience in this line of industry, and have the reputation of producing first-class work in every respect.

\section{ATTLEBOROUGH.}

Attleborough is a town of many villages, devoted to a great variety of manufactures. It is situated on the northwestern part of Bristol county, having North Attleborough on the north, Norton on the east, Rehobnth and Seekonk on the south, and the town of Cumberland, in Rhode Island, on the west. The post offices are Attleborough, South Attleborough Hebronville, Dodgeville and Brigg's Corner. Attleborough, Hebronville, Dodgeville and East Junction are stations on the Providence Division of the Old Colony Railroad, the first being 32 miles from Boston on the line of the Providence Division. A branch railroad connects with North Attleborough on the northwest and with Taunton on the east. The Indian title to 
ADVERTISEMENTS.

J. $M$.

* $\quad * \quad *$

CHARIS

FISHER

Manufacturers of

AND

$\&$ CO.,

* * *

LOCKETS,

ATTLEBORO, MASS.

REGNELL, BIGNEY \& CO.,

SPECIALTIES:

Lace Pins, Bracelets, Novelties

and Enamel Goods. . ... .

* Manufacturing Jewelers,

ATTLEBORO, MASS., P. O. Box 596.

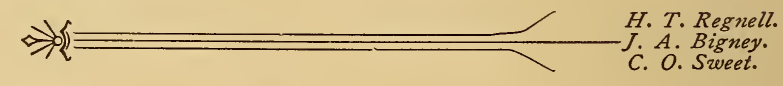

\section{WHEATON, RICHARDS \& CO.,}

\section{$10 \frac{\text { Sleeve and Collar Buttons, Cuff }}{\text { and Bar Pins and Children's Sets, }}$ \\ Solid Silver and Gold Front Goods.}

M. O. WhEATON,

J. S. RICHARDS, * * ATTLEBORO, MASS.

J. G. Trafton.

\section{STIITH}

LACE PINS, CUFP BUTTONS, DROPS, COLLAR BUTTON, STUDS. ALL HAND ENGRAVED.

*6

MANUFACTURERS OF

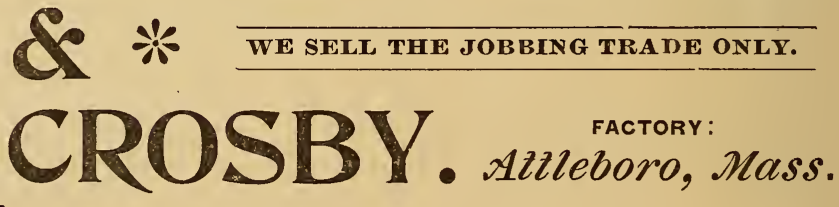

The Finest Quality of Solid Gold Front Work 


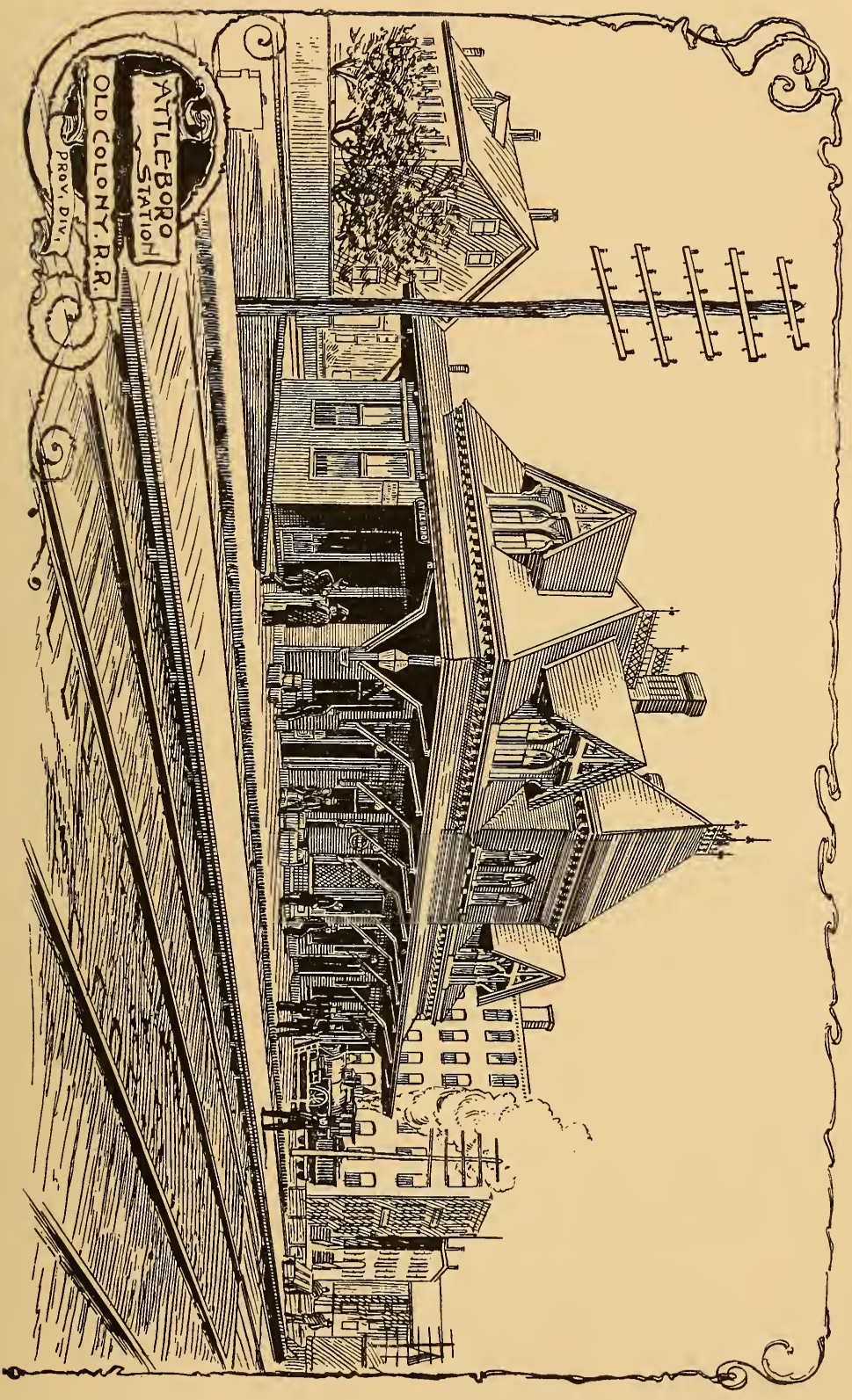



the territory out of which has since been carved a part of Rehoboth, Seekonk, Attleborough and Cumberland (R. I.) was purchased in I66r by Captain Thomas Willett on behalf of Plymouth Colony from Wamsutta, son of Massasoit and elder brother of Metacomet (afterward distinguished as King Philip.) The land - then called the North Purchase - was subsequently cut up into fifty-acre tracts and divided by lot among original and incoming settlers. In October, I694, the town of Attleborough (named for Attleborough, Norfolk county, England) was incorporated, and then contained about eighty square miles. There was a good deal of bloodshed within the limits of the town during King Philip's war, and the people have in all subsequent wars distinguished themselves for their loyalty and patriotism. Cumberland was separated-from Attleborough in I745. The distinguishing industry of Attleborongh is the manufacture of jewelry, which is said to have had its origin here in the unpretentious labors of a solitary French worker in the precious metals, who settled here in I 780 . Even his name is forgotten, but the seeds he planted have brought forth abundant fruit, and Attleborough, after a century of growth and development in this direction, is now one of the most important jewelry manufacturing centers in the world. In connection therewith the construction of jewelers' machinery has reached a wonderful degree of perfection here.

The Opera House Hotel and Cafe has been known under this name since I889. Before this time it was known as the Park Square Cafe, J. M. Bates being the owner as well as the proprietor, while Everett W. Eddy is the manager. It is handsomely furnished and fitted up with all modern improvements. Mr. Bates is well and favorably known in Attleboro and adjacent towns. In I 885 he erected the Opera House, which bears his name. The building is of brick seventy feet front, on Park square, and forms a part of the Bates block. The body of the auditorium, dress circle, parquette and orchestra has seating capacity for one thousand people, and there are four elegantly furnished boxes, the stage being sixty feet high and forty feet wide. People who have had the pleasure of visiting the Bates Opera House pronounce it to be handsomer than any in the surrounding towns.

The Bates Button Co. is located in Attleboro. It enjoys a lively business, amounting to from sixty to eighty thousand dollars a year, a specialty being made of ladies' and gentlemen's cuff and collar buttons. The trade extends abroad and all over the United States. The work is confined principally to the second floor of the three-story building. The dimensions occupied being one hundred fifty by forty-five feet. The firm employs sixty hands who have had practical experience, and all the latest improved machinery are in use at the factory.

The establishment of Bates \& Bacon, situated in Attleboro, occupies a part of the handsome four-story building known as the Bates building, It is fitted out with all the latest improved machinery and gives employment to one hundred skilled mechanics. The house makes a specialty of a full and complete line of gold filled watch-cases of various styles and different grades. This is the only house in Attleboro which manufactures watch-cases. Over seventy-tive 
Goe. R. Vanier.

M. J. Slattery.

VANIER \& SLATTERY,

Plumbers * and * Tinsmiths,

Steam, Water \& Gas Piping and Stove Repairs.

Workers in SHEET IRON, ZINC, TIN and COPPER.

JEWELERS' WORK AND BUILDERS' CONTRACTS A SPECIALTY.

ATTLEBORO, MASS.

S. Williams.

\section{THE ATTLEBORO WATCH CASE PENDANT CO.,}

ATTLEBORO, MASS.

Gold, * Silver *and * Filled * Pendants

Made in One Piece a SPECIALTY.

S. WILLIAMS, - - Patentee.

\section{SPIER \& COLES,}

\section{DIE-SINKERS and} TOOL MAKERS,

ATTLEBORO, MASS.

BATES BUILDING No. 2.

\section{ELLIS, LIVSEY \& BROWN,}

-Manufacturers of-

* * LADIES' * *

Victoria and Neck Chains,

CHARMS, LOCKETS, SWIVEL SPRING RINGS, AND CHAIN BARS IN ROLLED PLATE. .

ATTLEBORO, - MASS.

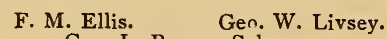

Geo. L. Brown, Salesman.

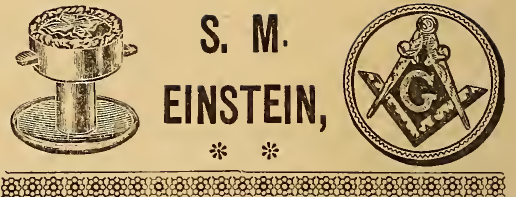

* MANUFACTURING * JEWELER, * 18

SPECIALTIES: Separable and Lever Sleeve and Collar Buttons, Studs and Scarf Pins.

ATTLEBORO,

MASS.

M. B. Short. Peter Nerney. J. J. Horton.

\section{Short, Nerney \& Co.,}

Manufacturing

ATTLEBORO,

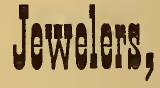

(e) MASS.
GOLD PLATED CHAIN A SPECIALTY.
Hayward \& Sweet. PINS, * * BUT'TTONS, JERSEY PINS, BRACELETS, Collar Buttons, Link Buttons,

Ribbon and Cord Mounted Vests and Guards, Bracelet Chain, Eye Glass Chain, Hooks, Bars, Box and Glass and O. F. Pins, Seals, Charms, Crosses, Hair Chain Mountings, Ribbon Fobs, Keys, Ear Hoops, Etc., Etc.

ATTLEBORO, MASS.

W. D. Fisher. Wm. M. Fisher. M. B. Mackreth.

W. D. FISHER \& CO., MANUFACTURING

JEWELERS.

Spring Swivels, Spring Rings -and all kinds of-

Chain Trimmings,

In Rolled Plate and Sterling Silver. ATTLEBORO FALLS, - MASS. TrLePHONR, 5532-4. 
thousand dollars is invested in special machinery used in the manufacturing departments by the proprietor. J. M. Bates, the owner of this factory, is also owner of seven other factories occupied by about thirty tenants. He takes a personal interest in all the work, and carries on a large trade throughout the United States, southern countries and Canada.

Dagget \& Clapp was established ten years ago in Attleboro Falls, but business having increased to such an extent as to cause them to remove in I 886 to Attleboro. The extensive trade calls for a large amount of manufactured jewelry, including all the latest novelties in sterling silver combs, hat pins, etc., ladies' goods, badges, buttons campaign goods, etc. About eighty hands are engaged on the upper floor of a four-story building.

J. W. Luther \& Co. first embarked in the business of Lapidaries in I 855 and pearl working in 1890 , when they established a factory in Attlebero. The firm consists of experienced, practical men who devote their undivided attention to the business, and have consequently made it a success. Twelve hands are engaged in the work, and the premises occupied by this properous firm are in the basement of a four-story building, fifty by thirty-flve feet in area. All the latest improved machinery is in constant use at the foctory.

J. T. In:nan \& Co., of Aitleboro, are manufacturing jewelers. It is only within the past few years that this business has been established, but since that time the trade has steadily increased. An extensive trade is carried on through all parts of the United States. Employing fourteen or more hands, the firm makes a great specialty of lockets and various kinds of silver novelties. The portion occupied for working purposes is in the third floor of a four-story building, covering an area of fifty by forty feet.

Marsh \& Bigney have been engaged for the past eleven years in the manufacturing of fine rolled plate chains. The work is confined principally to the second floor of a four-story building. The dimensions are one hundred by thirty-five feet. The trade extends all over the United States, and thirty-five hands are employed to carry on the work. The firm makes a specialty of Victoria chains, ladies' vest charms and gents' fancy and plain link chains in stamless gold filled wire.

J. M. Fisher \& Co. were established in I88I in Attleboro. The work consists in the manufacture of charms and lockets. The trade is in a growing and prosperous condition. The work is carried on in a handsome building by competent workers ranging from fifty to sixty in number.

Bliss Brothers are among the industrial houses of Attleboro who have been established since I873. They are engaged in the manufacturing of jewelry, making a specialty of charms, lockets and bar pins. The trade of this establishment extends all over the United States. Forty to fifty hands turn out a large amount of work.

Wheaton, Richards \& Co., manufacture gold sleeve and collar buttons, cuff and bar pins, and children's sets, also a fine line of solid silver and gold front goods. This house has been established for the past five years, having a trade with the various houses in the principal cities of the United States. The work 
is performed by skilled operatives, who have all had a practical experience in other business factories of Attleboro.

F. W. Weaver \& Co., located in Attleboro, were established nine years ago. They manufacture jewelry, and make a specialty of high grade rolled gold, lace pins, scarf pins, drops, charms, gold plate, and sterling silver hair pins, etc. The trade lies principally in the United States.

F. H. Sadler \& Co., of Attleboro, were established in I880, and by steady work and use of best inventions and machinery have brought the business up to a first class standard. They manufacture a special line of rings, drops, scarf pins, and studs in white stone using the Borneo diamond, of which they are sole proprietors, also they use the ruby, emerald, garnet, pearl and moonstone in all goods, besides a large line of lace pins, bracelets, etc., and confine their business to the jobbing trade. Their present factory is 120 feet long, 50 feet wide, with the best machinery that can be found for the jewelers' use. IVe should recommend all jobbers to examine their samples believing that they are saleable.

Spier \& Coles, located in Attleboro, has been established since I891, engaged in the manufacture of die sinkers and as tool makers. Their trade is local and the facilities are such that they are rapidly building up a reputation second to none.

Ellis, Livsey \& (Yo., located in Attleboro, has been established since I 890, in the manufacture of ladies' Victoria and neck chains, ladies' charms and lockets, swivel spring rings, and chain bars in rolled plate in various kinds and latest styles. This firm has an extensive trade throughout the United States and Canada.

Short, Nerney \& Co., are an enterprising firm located in Attleboro, who have been established since 1876 in the manufacture of a very fine quality of jewelry, making a specialty of gold plated chain. The trade of this firm is remarkable, as they do a business oü about one hundred and fifty thousand dollars a year. They have a vast trade all over the world. The dimensions of the working department are two hundred by thirty-five feet on the upper Hoor of a three-story building, where they employ a force of seventy-five hands.

Smith \& Crosby, an old firm, have been established in Attieboro since 1874. These gentlemen are engaged in the manufacturing of jewelry, and have been successful, making for themselves a high reputation, and an enviable place in the trade. The firm makes a specialty of solid gold front goods and have a large trade extending all over the United States. About forty-six hands are employed and the factory is equipped with a full and complete line of all the latest improved machinery. The premises occupied by the above named firm cover an area of one hundred by forty feet, on the first floor of a large structure, four stories in height.

Regnell, Bigney \& Co. are a well known firm engaged in the manufacture of jewelry, which business has been established since $\mathbf{1} 888$, on the fourth floor of a massive four-story building. The firm makes a specialty of lace pins, bracelets, novelties and enamel goods. They enjoy a splendid trade all over 
the United States and in foreign countries. The dimensions of their working apartments, are one hundred by thirty-five feet, where employment is given to some forty hands.

Vanier \& Slattery have been engaged in Attleboro for the past four years as general plumbers and tinsmiths, do steam, water and gas piping, and stove repairing; they are also workers in sheet iron, zinc, tin and copper. The house makes a specialty of jewelers' work, and builders' contracts, their trade being principally within the local districts of Attleboro. About seven hands are employed about the premises which are situated in the basement of a fourstory building, and contains the latest improved machinery operated by steam power. Prompt attention is given to orders for work in any branch, and those who have had occasion to require their services speak in praise of the promptitude and liberality of the firm. A large and growing patronage among manufacturers, builders, etc., in this and surrounding villages shows the energy, perseverance and business tact of this house.

W. H. Wilmarth is the proprietor of the business established by Wilmarth, Holmes \& Co. in r89r. The work consists of the manufacture of rolled gold plate jewelry; such as ladies' lace pins, ear drops, chains, and chain trimmings. The business done has been large and is still on the increase, the profits amounting to about ten thousand dollars a year. The trade extends throughout the United States, Canada and foreign countries. The premises occupied are thirty-five by seventy feet, on the second floor of a four-story building where employment is furnished to twenty-five competent mechanics.

The Attleboro Watch Case Pendant Co. is another firm whose business has been successfully carried on within the past two years by a well known gentleman, S. Williams. A speeialty of this company is gold, silver and filled pendants, made in one piece. The firm has the benefit of a remarkably guod trade, they having the facilities for manufacturing one thousand pendants per day. The principal trade is within the United States. This firm occupies the first floor of a two-story building, the dimensions being fifty by twenty feet.

The D. F. Briggs Co. was established five years ago by Tappan, Berry \& Co. In 1890 it was changed to present name. They are engaged in the manufacture of rolled plate vest chains. The Company is represented by $\mathrm{W}$. C. Tappan, one of the proprietors. They do an extensive business of one hundred thousand dollars a year and their chains are growing more popular every year. They sell only to wholesalers in Canada and all over the United States. The present firm occupy the first floor of a large five-story building, employing about seventy five hands and run as steady as any manufactory in the business through the year.

S. M. Einstein has for the past three years been engaged in the manufacture of jewelry in Attleboro, making a specialty of separable and lever sleeve and collar buttons, studs and scarf pins. On the first floor of a handsome five-story building, is an excellently arranged workroom, thoroughly equipped with special machines and appliances for the work, afforling constant employment to a large number of skilled hands. The output of this house is large and in 
C. E. W. SHERMAN. W. W. SHERMAN, ESTABLISHED 1854.

C. E. W. SHERMAN \& SON. GOLD AND * * SILVER REFINERS.

North Attleboro, - Mass.
D. E. CODdING.

D. E. CODDING \& CO.; .. MANUFACTURERS OF ...

Solid Gold and Fine Plated Jewelry. Bracelets, Lace Pins, Brooches, scarf Pins, Drops,

In White Stone and Moonstone Goods. North Attleboro, - - Mass.

Represented by N. F. SWIFT.

\section{SANDLAND, CAPRON \& CO.} MANUFACTURING * * * JEWELERS. and Nickel Chains.

North Attleboro, Mass.

NEW YORK OFFICE :

18 Cortlandt St., Room 514.

R. BLACKINTON

W. BALLOU.

\section{R. BLACKINTON \& CO.} meg MAKERS OF O

Solid * Gold, * Silver AND PLATED JEWELRY.

NEW YORK OFFICE,

No, 182 Broadway.

FACTORY,

North Attleboro, Mass.
North Attleboro, - - - Mass.

Thos. G. Sandland, Henry B. Capron' NEW YORK OFFICE :

176 Broadway.

J. R. Palmer,

Codding Bros. \& HeillBorN, в$\therefore$ MANUFACTURING $\therefore$

JEWELERS

और
SILVERSMITHS,

North Attleboro, - - Mass.

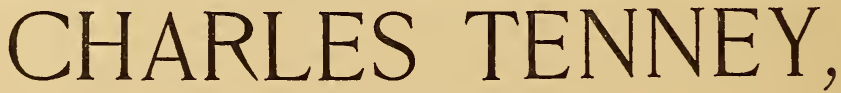

Manufacturer of

MEN'S AND BOY'S

FINE* CALF * SHOES, STOUGHTON, MASS. 
demand throughout the New Engiand states and the west, where Mr. Einstein has established himself in the favor and good will of all who know him.

\section{NORTH ATTLEBOROUGH.}

North Attleborough is a prosperous farming and manufacturing town forming the northwest angle of Bristol county. A branch road four miles in length connects North Attleborough - the northern village - with Attlehorough station, 32 miles from Boston, on the Providence Division of the Old Colony Railroad. The uther stations are Farmer's and Falls Village. The post-offices are North Attleborough and Attleborough Falls. The leading occupation of the people is the manufacture of jewelry, nearly the entire population being employed in this work, the products being shipped to all parts of the world. The town is an outgrowth of Attleborough. The extraordinary growth of the northern half of the old town led to the settling up and incorporation of the new one, which was carried into effect by the act of the legislature approved July 30, r 888 . Population, I890, 6,727; assessed valuation, $\$ 3,708,678$. The town contains two post-offices, Attleboro' and Attleboro' Falls.

D. E. Codding \& Co. extensively engaged in the manufacture of solid gold and fine plated jewelry, are well and favorably known to the jobbers of the New England and Middle States. The specialty of this firm is the manufacture of bracelets, lace and scarf pins, drops, etc., in white stone and moonstone goods. Employing a large number of hands and having all the necessary appliances in their factory enables them to turn out these goods in large quantities. With a long business experience, they have obtained a high reputation for honorable methods in their business transactions. A complete line of goods is constantly kept on hand, and prices are low.

Sandland \& Capron located at 44 Chestnut street, are among the prominent firms of North Attleboro, manufacturing rolled gold plate and sterling silver jewelry. They occupy one floor sixty by one hundred feet in the Union Power Company's building, where they employ forty-five hands. This firm was established in 1876; and produces a fine line of bracelets, bangles, drops, lace and jersey pins, hair ornaments, and ladies' sets in all the latest styles. Their goods are made of the best quality of stock, and give perfect satisfaction in all cases. A department in which they excel is the manufacture of gentlemen's scarf pins in all the latest novelties and from their own designs. A branch office is conducted by them at $\mathrm{i} 6$ Broadway, New York, and buyers are cordially invited to call and inspect their stock. The members comprising the firm consist of Thomas G. Sandland and Herny E. Capron, who have a high standing in business circles and have the reputation of conducting their trade on honest business principles.

C. E. W. Sherman \& Son are among the prominent firms of Attleboro, engaged in the business of gold and silver refining, and the only house in North Attleboro engaged in this line of work. Employing a number of experienced hands, they are enabled to conduct a large business in their specialty of 
smelting, refining, assaying and the preparation of gold, silver and copper for the jewelry and silverware trade. The firm has had a business experience of nearly forty years and enjoys a reputation of producing a fine quality of material in their line. All parties trading with this house will find that their business transactions are conducted in a straight-forward manner and all material producediby them will be found as represented. The individual members comprising the firm are C. E. W. and W. W. Sherman.

Codding Brothers \& Heilborn, manufacturing jewelers and silversmiths, are among the enterprising firms of North Attleboro engaged in the manufacture of jewelry, etc. They occupy the ground floor in the Codding building on Jay street, near Elm, which is fully equipped with machinery of the latest patterns for rolling, stamping and pressing jewelry. The facilities of this firm are first class and suited to the rapid and economical production of their specialties, which embrace the latest designs in rolled gold bracelets and bangles for export, also souvenir spoons the "Birthmonth" being a popular novelty. Employing fifty hands they are able to produce over $\$ 100,000$ worth of goods per annum. This firm supply all the leading trade centres of the United States and Canada. The firm is composed of Arthur E., James A. and Edwin A. Codding and Leo. A. Heilborn. Arthur E. Codding is a trustee of the Attleboro' savings bank, and holds the position of town treasurer. The New York office and salesroom is located at I 78 Broadway.

O. M. Draper, an old and reliable manufacturer of rolled plate, fire gilt, and nickel chains, commenced on a small scale in I 862 but by giving close attention to business has built up a reputation and trade that extends from the Atlantic to the Pacific, as well as abroad. The premises occupied on Elm street, are thirtyfive by two hundred feet, consisting of one floor in the Richards building on Elm street, and is fitted up with a complete plant of improved machinery. His products embrace all the popular novelties and styles in charms, swivels, nickel chains, etc. Employing ninety hands on an average, enables him to produce a large variety of goods, which are of tirst class quality, and give perfect satisfaction. New designs are being constantly brought out by him and the jobbing trade is supplied with an almost endless variety of novelties through his traveling salesmen. Branch offices are at 18 Courtlandt street, New York, and I 55 State street. Chicago. Mr. Draper thoroughly understands the business in which he is engaged, and is held in high esteem among the trade.

R. Blackinton \& Company among the oldest manufacturers of solid gold, silver and plated jewelry in Attleboro, were established in I862. They are located in the Whitney building on Chestnut street, which is completely fitted up with the newest and most improved machinery that the market affords, and where they give constant employment to one hundred skilled operatives. The Jine of jewelry manufactured by them includes all the latest novelties in solid gold, silver and plated jewelry, also the largest line of fancy souvenir spoons in the market. A large and extensive trade is conducted by them, which extends principally to the eastern, southern and western states. The firm is composed of Roswell Blackinton and Walter Ballou, who are held in high esteem both in 
social and business circles. Mr. Blackinton is also a director of the North Attleboro national bank. The factory is under the charge of Mr. Ballou, foreman, who thoroughly understands the business in all its details. A salesroom is maintained at $\mathbf{I} 82$ Broadway, New York.

\section{ATTLEBOROUGH FALLS.}

This is also a busy industrial village, and is widely noted for the manufacture of jewelry. It is in the town of North Attleborough, a few miles from the centre, with which it is connected by an electric road.

D. Evans \& Co. are manufacturers of fine quality gilt and silver plated buttons that are required for the army, navy, militia, police, livery, etc. The house was established in 1848 , succeeding the firm of R. \&W. Robinson. During the war the house acquired a reputation for the excellence of its goods. A large proportion of the army and navy buttons used by the Union forces, especially for officers' uniforms, were the product of this company, and no manufacturer in either of the Attleboros was so widely known during the period of the civil war as the late Daniel Evans. Since his death, (which occurred in May, I892), the business has been continued under the same firm name by his son, Edwin L. Evans, who is thoroughly acquainted with the business in all its details, and who is well able to maintain the fine reputation which the house has acquired.

The Gold Medal Braid Company was incorporated in 1879 for the manufacture of worsteds, silk, linen and cotton braids. Handel N. Daggett and Harvey Clap became the sole proprietors in March, I89I, and conduct the business as a firm but under the original name. The premises occupied by them on High street, opposite Commonwealth avenue, this place, consists of a five-story stone building sixty by one hundred and sixty feet in dimensions. The factory has both steam and water power, is fully equipped with all the latest improved machinery. They employ from one hundred and twenty-five to one hundred and tifty hands, and fifteen hundred braiding machines are used by then. The goods manufactured by this firm are sold throughout the United States and in forejgn markets. The names on their products are known as "Golden Fleece," 6r Braid, and "Atlas" which embraces the finest grades of worsted alpaca, silk and cotton braids of all widths and styles for dress bindings, and other purposes. Both members of the firm are experienced, capable and successful business men. Mr. Daggett being the treasurer, and Mr. Clap the secretary of the company when it was conducted as a corporation. The selling agents of this firm are the Willimantic Linen Company of Boston, New York and Philadelphia.

W. D. Fisher \& Company, a progressive and successful firm engaged in the manufacture of spring swivels, spring rings, and chain trimmings of all kinds in rolled gold, plate and sterling silver, are located in the Daggett building, 8 Mill street. Here they are completely equipped with improved machinery and give employment to a force of fifty hands; the product of whose skill and labor is in demand by manufacturing jewelers and jobbers generally. The members 
of this house are well known residents of Attleboro Falls and gentlemen of fine business qualities, ever alive to the demands of the trade and conducting their extensive business in a manner satisfactory to their numerous patrons.

\section{PAWTUCKET.}

The city of Pawtucket presents many features not common to New England towns, and is in some respects entirely unique. Its settlement dates some twenty years after that of Providence by Roger Williams, and was made by Joseph Jenks, who is credited with being the first founder who worked in iron and brass on this continent. It is on record that the General Court of Massachusetts granted to him a patent for fourteen years for the sole manufacture of engines to be driven by water, mills for making scythes and other edged tools, and a newly invented saw mill. This occurred in May, I646, and in May, I655, another patent was granted to him for seven years for the manufacture of an improved scythe for eutting grass. Inasmuch as the manufacture of tools, farming implements, and household utensils is a peculiarly important branch of industry in a new country, it may be inferred that $\mathrm{Mr}$. Jenks found ready demand for the products of his skill in the adjoning settlements. Scarcely could he have dreamed, however, that his little forge was the germ from which would spring the great industrial center of today and a flourishing city of 30,000 inhabitants, with over a hundred different and extensive industries.

King Philip's War devastated Pawtucket in common with all the surrounding colonial settlements, and for nearly a century after the above date the place made but slight progress. Toward the middle of the last century, however, Hugh Kennedy began the manufacture of linseed oil, and in I 770 Ephraim Starkweather purchased a potash factory which had been started by some Boston merchants several years before. The war of the Revolution also interferred materially with the prosperity of the community, but shortly after the close of the struggle activity began to manifest itself in many departments of industry.

About I77I Oziel Wilkinson and his five sons, blacksmiths, removed from Smithfield to Pawtucket, and commenced manufacturing anchors, heary iron implements, farming tools, oil presses, stoves, castings, and other articles upon quite a large scale. The elder Wilkinson had long been engaged in manufacturing cut nails, and is supposed to be their inventor. His son David was the inventor of the side lathes, for which Congress awarded him, fifty years after the patent was granted, $\$ 50,000$. Oziel Wilkinson built a small air furnace for casting iron and some time subsequently he, with others, built a furnace in which cannon were cast solid, and this was said to be the first successful effort of the kind by any one.

The most notable event in the whole history of Pawtucket occurred in I 790, when Samuel Slater erected the first water-power cotton factory in America. Young Slater married one of the daughters of Oziel Wilkinson, and received much valuable aid from the male members of that ingenius family. The build- 
ing known as the old Slater mill, on Mill street, erected in I793, still stands, and it is about the most noted landmark in the city. In the early part of the present century Pawtucket was the seat of ship-building and of considerable commerce. Manufacturing industries soon after predominated, and these have been steadily growing ever since, until they have assumed great magnitude.

Pawtucket was made a city Jan. 4, 1876, and was, prior to obtaining its charter, the largest place in the United States under a town form of government, having a population rising 20,000 . The city is situated on both sides of the navigable Pawtucket river, (Blackstone river above the falls) and presents many attractive features, apart from its advantages as a manufacturing center.

Up to 1862 , what was known as the town of Pawtucket was in the state of Massachusetts. 'The east side of the river originally formed a part of the old town of Rehoboth, which up to $18 \mathrm{r} 2$ had also embraced Seekonk. The Township of Pawtucket was organized under an act of incorporation from the Massachusetts General Court, March I, I828. In the course of time the west side of the river - the Rhode Island side - became the most important. The fact that the village of Pawtucket was situated in two different states was frequently the cause of contention, and with a view to obviating all further trouble arising from clash of interest and authority by reason of the separate jurisdictions, the town. of Pawtucket was ceded to Rhode Island in 1861 , and in March of the following year the act took effect. Some changes took place subsequently in the local boundary lines, and a new act of incorporation was issued in May, 1874 .

The Providence Division of the Old Colony Railroad and the Providence \& Worcester Railroad run through the city, and there is besides a branch line of railroad from Valley Falls to East Providence which passes through Pawtucket. Altogether Pawtucket presents all the features of a progressive and prosperous New England city, and is rapidly increasing in material wealth and population. Pleasant View is a local station near by. [See Providence in preceding pages.]

The Pawtucket Furniture Co. was established about eighteen year's ago, when their working apartments were confined to a building which covered an area of twenty by sixty-six feet. Since this time, by close attention to business, the firm has built up a trade, which surpasses many other business houses in Pawtucket. In consequence of this increase in business, they have enlarged the building to the present size. It is an elegant structure three stories in height, covering an area of fifty by sixty-six feet. It is handsomely stocked with mattresses, curtains, spring beds, bedding, stoves and tin ware, carpets, oil cloths, etc. They are also sole agents for the celebrated Glenwood ranges and parlor stoves. Mr. Fifield, the proprietor, has had an experience of many years, and fills his position with great satisfaction.

The Star 'Tanning company, among the foremost manufacturers in Paw tucket, are engaged in the manufacture of improved raw hide lace and picker leather, oak tanned leather belting, loom straps of all descriptions, etc. Only 


\section{Pawtucket Furniture Company}

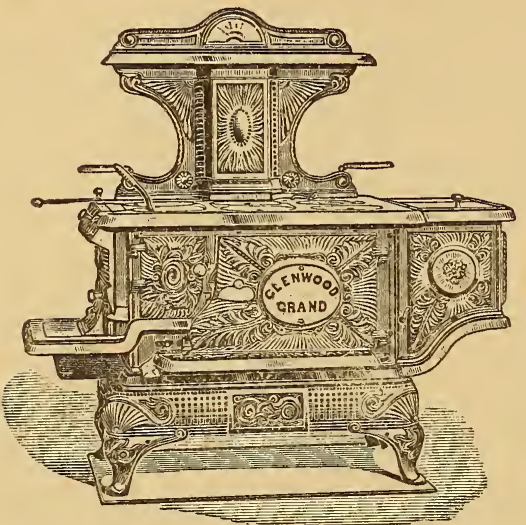

39 No. IMain street, PAWTUCKET, R. I.

Headquarters for bargains in Furniture, Carpets, Glenwood Ranges and Parlor Stoves, Bedding, Spring Beds, Curtains, and everything with which to furnish a house. Do not buy until you have seen us.

WE SELL FOR CASH OR CREDIT,

THE LOWEST IN THE STATE.

ROBINSON BROTHERS,

Manufacturers of

Jewelers'

\section{Findings,}

Swivels and Bars a Specialty.

Plainville, - - $\quad$ Mass.

J. B. MAINTIEN.

W. F. MAINTIEN.

J. B. MAINTIEN \& SON,

PLAIN AND FANCY ENAMELING.

Plainville, - - $\quad$ Mass.

Established 1855 .
ESTABLISHED 1876

W. F. WADE. E. P. DAVIS. $\quad$ C. A. WHITING.

WADE, DAVIS \& CO.,

MANUFACTURING

JEWELERS,

Plainville, Mass.

New York Office,

198 Broadway.

\section{PLAINVILLE STOCK CO,}

Manufacturing * Jewelers,

Pins, Drops and Sets a Specialty.

Plainville, - - $\quad$ Mass.

New York Office, $x 76$ Broadway.

D. H. Corey, Supt. W. S. Metcalf, Treas. 
the finest grade of leather is produced by them, and a specialty is made of picker leather for which there is a large demand, their trade extending throughout the United States. Pickers of all patterns are made to order at short notice, and belts of every description are repaired. A large stock of manufactured goods is always carried to supply the immediate demands of the trade. The individual members of the firm are Oscar A. Jillson and Robert Bellew, both of whom are men of long experience in the business and their successful career is due, to a large extent, to their carefulness in producing only first class work.

C. A. Luther \& Co. is the style of the firm of which Messrs. Peck and Burnham are the members, and who are engaged in the manufacture of cloth stretchers, thread dressers, improred thread and yarn reels and four color yarn printing machines; also model making and general machinery repairing. The business was originally founded in 1834 , by D. L. Peck, who, in 1858 took into partnership C. A Luther, the firm adopting the name it is now kuown by. In I883 Mr. Luther died and Mr. Peck continued alone until I890, when he became associated with E. A. Burnham. The trade extends throughout the United States and foriegn countries, and is annually increasing. The plant is well equipped with the latest improved machinery and affords employment for many skilled workmen.

Dawson \& Co. at 22 Broad street are well known in this city as dealers in bicycles, tricycles and accessories; and do all kinds of repairing in a thorough and prompt manner, being fitted with special facilities and possessed of a thorough knowledge of its details. Since their establishment here some four years ago, they have built up an excellent business, and have won a deserved reputation for fair dealing, numbering among the patrons many of Pawtucket's best citizens. They carry a good stock of safeties of standard makes, which they sell for cash or credit on the most farorable terms. They also conduct a riding school, where with competent teachers in attendance the art and pleasure of riding may be acquired with safety and confidence. Dawson \& Co. are young men full of energy and ambition and attentive to the wants of their customers.

J. L. Spencer is the manager of one of the oldest establishments in Pawtucket, namely the old Slater Mill. This mill, the first cotton mill in America, was built in I793, by Sanuuel Slater, after whom it was named. The present company carries on a good trade, throughout the United States, the work consisting of the manufacture of cotton yarns, twines and threads, fancy twines being made to order. A specialty is made of machine thread on large spools and cones. The factory is equipped with machinery adapted to the work, and engages hands numbering about twenty-five. It is a large building about three stories high, covering an area of two hundred by fifty-five feet.

H. L. Spencer, a well known gentleman of Pawtucket, established himself in the bicycle business at 7 Slater avenue, in 1882 , since which time he has built up a large and prosperous trade. He is sole agent in this city for Columbias, Victors, Hartfords and others, and his is the leading house of this 


\section{STAR TANNING CO,}

\section{RAW HIDE LACE \& PICKER LEATHER,}

Oak Tanned Leather Belting. White Picker or Moccasin Leather. Also of Patent Lace and Picker

Leather, Loom Straps of all descriptions.

Pickers of all Patterns made to Order and Belts Repaired at Shortest Notice. OSCARA. JlLEON.
ROBERT BELLEW. 140 to 146 FRONT ST, PAWTUCKET, R. I.

\section{0 to 146}

Successor to BOWEN \& LANE.

Boarding and Livery Stable,

No. 2, 4 and 6 Mason St..

Corner Railroad Ave.,

Pawtucket, - $\quad$ R. I.

TELEPKONE.

ESTABLISHED 1882.

*H. L. SPENCER,*

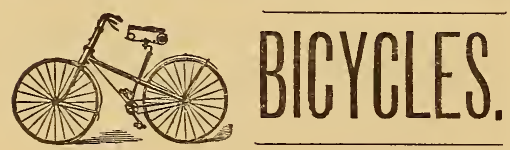

No. 7 Slater Ave., Pawtucket, R. I.

"Old slater milli."

J. L. SPENCER, AGENT, Cotton Iarns,

$$
\text { Twines \& Threads, }
$$

Pawtucket, - $\quad$ - R. I.

\section{K. XXYYXXEXY.}

\section{Manufacturer of}

TIN WARE

2I Exchange St., Pawtucket, R. I.

Mill Work and General Repairing Promptly attended to.

A Specialty made of

Copper Working Bar Drainers.

EXCELSOIR

\section{NORWOOD STEAM LAUNDRY,}

BROADWAY.

C. J. SULLIVAN, Manager.

Cleansing @ of $\odot$ Kid @ Gloves.

LADIES' AND GENT'S SUITS A SPECIALTY.

Satisfaction Guaranteed. Norwood, Mass.

\section{JOHN FRENCH,}

\section{Marble and Granite,}

11 and 13 Exchange St.,

Pawtucket, $={ }^{\cdot}=$ R. I.

Opposite Depot. Telephone. 
city dealing in these goods. In a large building three stories in height, covering an area of fifty by one hundred feet, we find Mr. Spencer and his three employees busily at work attending to the wants of their numerous customers.

Carpenter \& Co. is an old and reliable firm engaged as importers, manufacturers and wholesale and retail dealers, in complete house furnishings, office furniture, etc. In January 1858 , this house was established, and is now located at 26, 28, 30, 32, 34, 36 North Main Street Square. An extensive trade is carried on throughout the New England states, requiring the services of thirty-two competent hands.

A. E. Tenney, about twelve years ago, established the business which is now known as the A. E. Tenney Mfg. Co. Since the beginning, and also at the present time, their goods are sent throughout the world. The work consists in the manufacture of patent adjustable barrel rod, Marsden \& Simmons cloth stretchers, pattern making, model work, general machinery, and specialties. The work is confined to the second floor of a handsome four-story building, covering an area of one hundred fifty by fifty feet, also an ell, fifty by fifty feet in dimension. The factory is equipped with all the latest improved machinery and about forty hands are employed.

John French is owner and manager of one of the oldest business houses in Pawtucket, it having been established since I 844 and although the trade lies in the local districts, it is one of the best in the city. Mr. French is a dealer in marble and granite and is well and favorably known throughout the state. With the aid of ten competent workmen, he carries on a large and profitable business. His workshops comprise a building two stories high, together with adjoining sheds, in all covering an area of 2,000 square feet and located at I and 13 Exchange street.

C. L. Whitten in r 887 began his successful career at 2r Fxchange street, Pawtucket. Since this time he has enjoyed an enviable trade, in the adjoining cities, also in the larger cities of the United States. He is engaged in the manufacture of tinware, does mill work and general repairing, a specialty being made of copper bar drainers. Mr. Whitten and his skilled mechanics, numbering about five, occupy a building three stories high, covering an area of sixty by eighteen feet.

C. A. Spooner \& Co. is a well known firm engaged in the manufacture of jewclry. This house was established in $\mathrm{I} 89 \mathrm{I}$, since which time they have enjoyed a prosperous and increasing trade all over the United States. A large amount of brooches, scarf pins, drops, studs, hair pins, etc., is annually produced, and lace pins, a specialty is made of wire novelties. Their factory is located in the old Slater Mill, occupying the second floor, and covering an area of fifty by sixty feet where employment is given to ten experienced workmen.

George A. Lane since 1872 has been proprietor of the boarding and livery stable located at 8 Mason street. This is an old established business having been founded some thirty-five years ago by D. Briggs, who was surceeded in I 868 by Bowen \& Wightman. In I $872 \mathrm{Mr}$. Wightman retiring, Mr. Lane became associated with $\mathrm{Mr}$. Bowen, which continued for a short time, when Mr. Lane became 
sole proprietor. He is one of Pawtucket's leading men and enjoys a fiourishing and increasing business. The stable is three stories high, covering an area of one hundred by thirty feet, where six experienced workmen are in attendance.

The Hotel Aumann, one of the best hotels in Pawtucket, is largely patronized although it was only built about four years ago. It is located at 79,81 and 83 Broad street, immediately next the depot. It contains twentyfour rooms, handsomely furnished in the latest style, the dining room being also handsomely furnished, where a first class table is set. The hotel itself is a handsome brick structure four stories in height, which together with the grounds cover an area of one hundred by one hundred lifty feet, and nothing is left undone that can be done for the comfort of guests. William H. Gurney is the proprietor, and Thomas H. Houston and S. Sullivan, clerks: These gentlemen are among the oldest residents of the city, and enjoy the confidence and esteem of the public.

\section{GEO. S. LEEDS \& CO.,}

FACTORY :

BLUE HILL AVE.,

FRENCH HAT - AND

MATTAPAN, MASS.

OPP. N. Y. \& N.E.R.R. DEPOT.

BONNET FRAMES.

\section{Office: 48 SUMMER ST., BOSTON.}

\section{THE KNAPP WARREN CO.,}

\section{MANUFACTURING}

\section{JEWELERS.}

Plainville, $\begin{aligned} & \text { Via North } \\ & \text { Attleboro, }\end{aligned}$ Mass.

Telephone Connections. $\rightarrow$ Providence Creamery

The Oldest in the State.

... No Finer or Better...

* ICE CREAM *

Can be found in New. England than is sold at the Creamery.

89 and 91 North Mrin St., PROVIDENCE, R. I.

Packed either in Bulk or Bricks. All flavors same price. Sweet Gream and Milk in their purest condition, Orders large or small filled at short notice. 


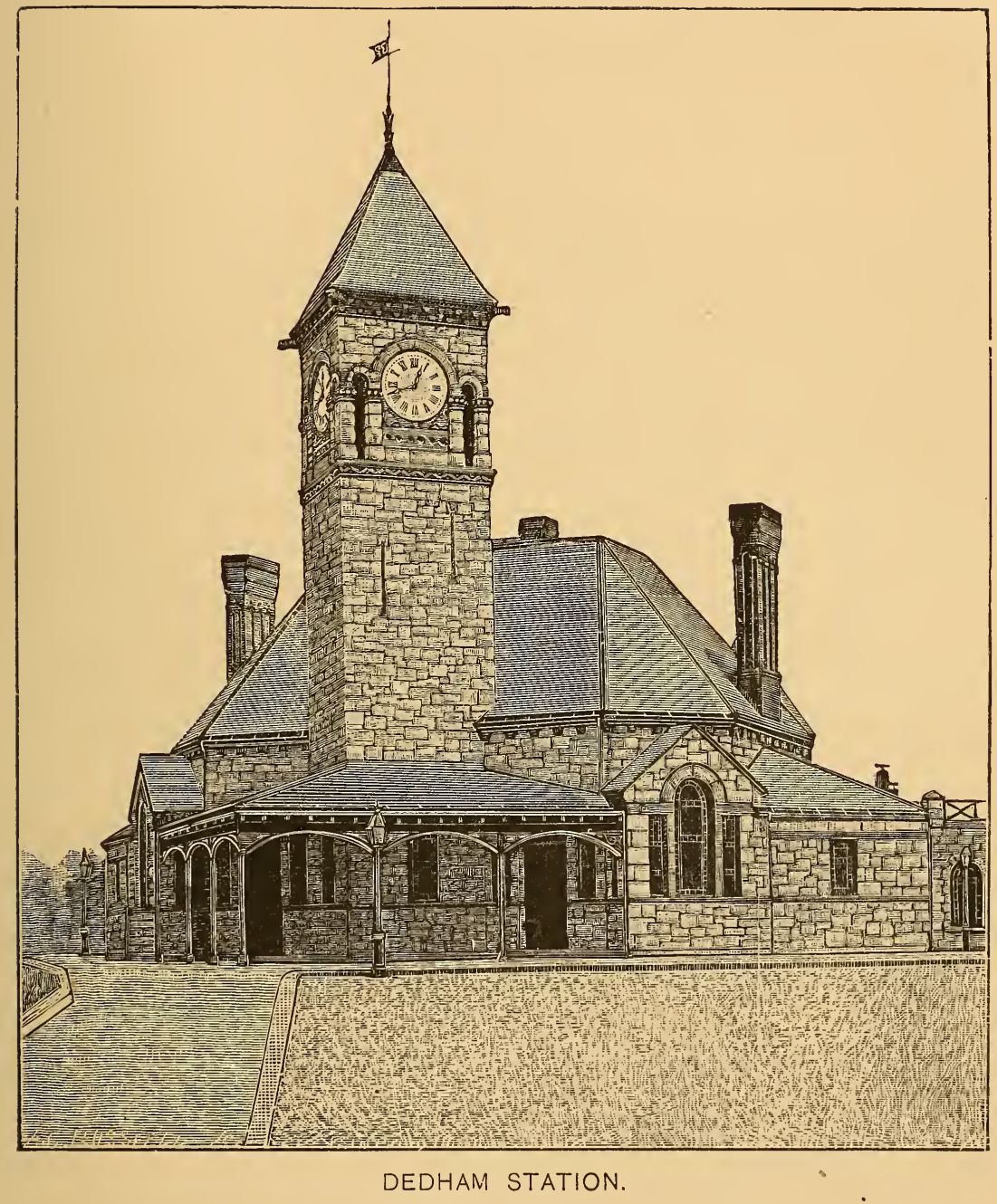





\section{DEDHAM BRANCH.}

\section{DEDHAM}

$\mathrm{D}$

EDHAM is a fine old town, the seat of justice of Norfolk county, about ten miles southwest of Boston. The northeastern part has two branches of the Providence Division of the Old Colony Railroad, which has a beautiful station of Dedham granite in the principal village. The town is bounded north by Needham and West Roxbury district (Boston), east hy Hyde Park and Canton, south by Norwood and Walpole, and west by Dover. The Charles river forms a part of the northwestern line, and the Naponset the eastern line. On this stream are two woolen mills, dye-works, a factory for hosiery, an iron foundry and machine shop. At West Dedham are malleable iron works, a wood turning mill and furniture factory. Population, 1890, 7,I23. Other stations on this branch are Walnut Hill and Stone Haven. [See “Suburban Service."]

George W. Toomey, livery and boarding stable, is in all respects an admirably conducted establishment, and receives a substantial patronage. It is also the oldest, and has been in existence for many years. It was established on the site of the "Phenix Stable," built in the time of the Revolution and started the "Old Coach line" to Boston before the railroad was built. The present proprietor, Mr. Toomey, succeeded the business in $188 \mathrm{r}$ and has carried it on successfully since then. The establishment is at once a livery, sale and boarding stable and carriage repository, and everything is of the best. He occupies a fine large stable two stories in height and $30 \times 80$ feet in dimensions, capable of accommodating from twenty-five to thirty horses and several carriages, and provided with every modern convenience applicable to the business. Among the carriages kept on hand are coaches, hacks, light wagons and vehicles of every description, while hacks are at the depot for all rains.

H. L. Wardle, Ph. G., druggist and apothecary, is located at the corner of High and Washington streets. This business was originally established by Henry Smith, succeeded by B. F. Smith in I873. The present proprietor succeeded Mr. Smith in 1882 , and has carefully maintained its previous high and enviable reputation. The store is neatly and handsomely furnished. The stock consists of a carefully selected assortment of pure diugs and chemicals, proprietary medicines of acknowledged merit and reputation, toilet and fancy articles, perfumery, and everything usually found in a first class pharmacy 
Mr. Wardle is a thoroughly educated druggist and pharmaceutical graduate, and gives his personal attention to the compounding of physicians' prescriptions and family recipes, which are always prepared in a prompt, accurate and satisfactory manner from fresh, pure drugs.

\section{SPRING STREET}

is a part of West Roxbury district, and has many fine groves and walks in the immediate vicinity of Charles rirer. Passenger service and fares same as West Roxbury.

\section{ROSLINDALE.}

HIS is a growing suburb of Boston, from which it is the same distance as Mount Hope. It is a most attractive place for residence, and many

1 business people have humes here. Rents are low and land is comparatively cheap for such an accessible and desirable location. The famous Bussey Park is located here, and there are many other scenic attractions in the immediate vicinity. Seventeen trains to and twenty from Boston week days, five trains each way Sundays. Fare one way, I 2 cents; roo-ride ticket, $\$ 6.75$.

\section{HIGHLAND.}

The rural features of this place are very attractive, and although the station, a fine structure, is but seven miles from Park Square, there is good gunning and fishing in the neighborhood. Highland has numerous modernbuilt residence and and is rapidly aequiring popularity as a place for homes. Seventeen trains th and 20 trains from Boston week days, five trains each way Sundays. Fare one way, I 4 cents; Ioo-ride ticket, $\$ 9$.

\section{WEST ROXBURY}

is a suburb almost wholly given to residences, many people doing business in the city having pleasant homes here. It is seven miles from Boston, with i 7 trains to and 20 trains from that station week days, five trains each way Sundays. Single fare, 25 cents; roo-ride ticket, \$9.

Chas. W. We!ch, Pres. Frank F. Baldwin, Vice-Pres. E. Morton Elmes, Treas.

\section{J. G. PHINNEY COUNTER CO.,}

MANUFACTURERS OF

\section{SOLE LEATHER BOOT AND SHOE}




\section{SHAWMUIT \& MILTON AND GRANITE BRANCHES.}

MILTON.

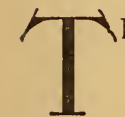

HIS is an old suburban town of much picturesqueness in scenic surroundings, and is separated from the Dorchester district of Boston by the Neponset river, a stream navigable up to Milton Lower Mills, near the Old Colony station. Many estates in this place partake of the baronial character, being extensive in area, and the fine old as well as modern mansions are set in the midst of beautiful trees, with handsome lawns and drives to their approaches. Milton is largely a residential place, many wealthy business men of Boston having residences there, although there is some manufacturing going on, the most prominent of which is paper-making and the manufacture of crackers and biscuits, the latter an industry which was established nearly roo years ago. The famous Blue Hills are located in this town, from the highest altitude of which the observatory forms a conspicuous object for many miles around. The summit of these hills forms the highest point of land in this part of Massachusetts, and affords the grandest views of harbor, bay and inland scenery to be had any where. The drives through the town are unsurpassed, being broad, well shaded, and mostly laid with macadam, affording equipages of every character long and pleasant runs, bicyclists especially making use of the fine avenues in great numbers. The population in 1890 was 4,278 . The town has fine schools, good churches, excellent water, perfect drainage, an elegant public hall and is well governed.

Walter Baker \& Co., proprietors of the oldest and largest chocolate works on this continent, are located partly in Milton, but principally in the Dorchester district of Boston, on the banks of the Neponset river. The business was first established in the same place by J. Hannon in 1765 . He died in 1780 and was succeeded by Dr. James Baker who subsequently left the business to his grandson, Walter Baker, in whose name it has since been conducterl. 'This establishment now comprises five large mills built of brick, is equipped with the lates' and most improved forms of machinery and gives employment to a large number of hands. The annual output which consists of breakfast cocoa, and other cocoa and chocolate preparations, is rery large and is noted for its purity and general excellence. The long experience of this house has enabled it to reach that high degree of perfection for which it is noted, and the large and increasing demands for its products is good proof of the high esteem in which this house is held. 
The Bent \& Company branch of the New York Biscuit Company, located a Central Avenue station, Milton, is one of the oldest manufacturers of crackers in this country. It was first established in I80 I by Josiah Bent who in I 890 was succeeded by the New York Biscuit Company, with a capital of $\$ 10,000,000$. The president of the company is William H. Moore of Chicago; treasurer, George P. Johnson of New York; and manager, J. G. Young, Jr., of Milton. A specialty is made by this company of Bent \& Company's crackers and fancy biscuits. The premises occupied by them consist of a large brick building where a large force is employed. The company manufactures the finest quality of crackers of all kinds, their fancy and water crackers being unexcelled, and their reputation being known all over the world. They have large factories in Chicago, New York, and all large cities throughout the country, and their biscuits are used by the best hotels, restaurants, and families both in this country and in Europe.

\section{CENTRAL AVENUE.}

Central Avenue is a village and station of Milton of unusual natural attractions, many palatial estates, fine drives, and quite a number of truck and dairy farms.

The stations within the city limits of Boston on this branch are: Field's Corner, Shawmut, Ashmont, Cedar Grove, Granite Bridge, and Mattapan.

\section{GRANITE BRANCH.}

This branch leaves the main line of the Old Colony Railroad at Atlantic station (See Quincy) near the south bank of the Neponset river, running through East Milton and West Quincy to Braintree, where it again joins the main line. The stations are Montclair, East Milton and West Quincy.

Maguire \& O'Heron, dealers in granite, are among the representative business enterprises of the town. Established here in 1888, they have by close attention to business built up a prosperous and rapidly growing trade. The premises, located on Willard street, cover an area of twenty thousand square feet, and comprise several buildings supplied with ample steam power and equipped with the most improved machinery, while upwards of fourteen skilled hands are employed. A superior stock is constantly on hand, embracing rough and dressed granite of every variety, monuments, headstones, tablets, etc., and general cemetery and architectural work is executed in the most expeditious manner, the trade extending as far west as Ohio. The firm use Quincy granite mostly, but deal some in New Hampshire granite. Maguire \& O'Heron are prepared at all times to give estimates on all kinds of monumental and cemetery work, and all orders entrusted to them receive prompt attention. Both members of the firm have resided in East Milton for several years and are well and favorably known. 


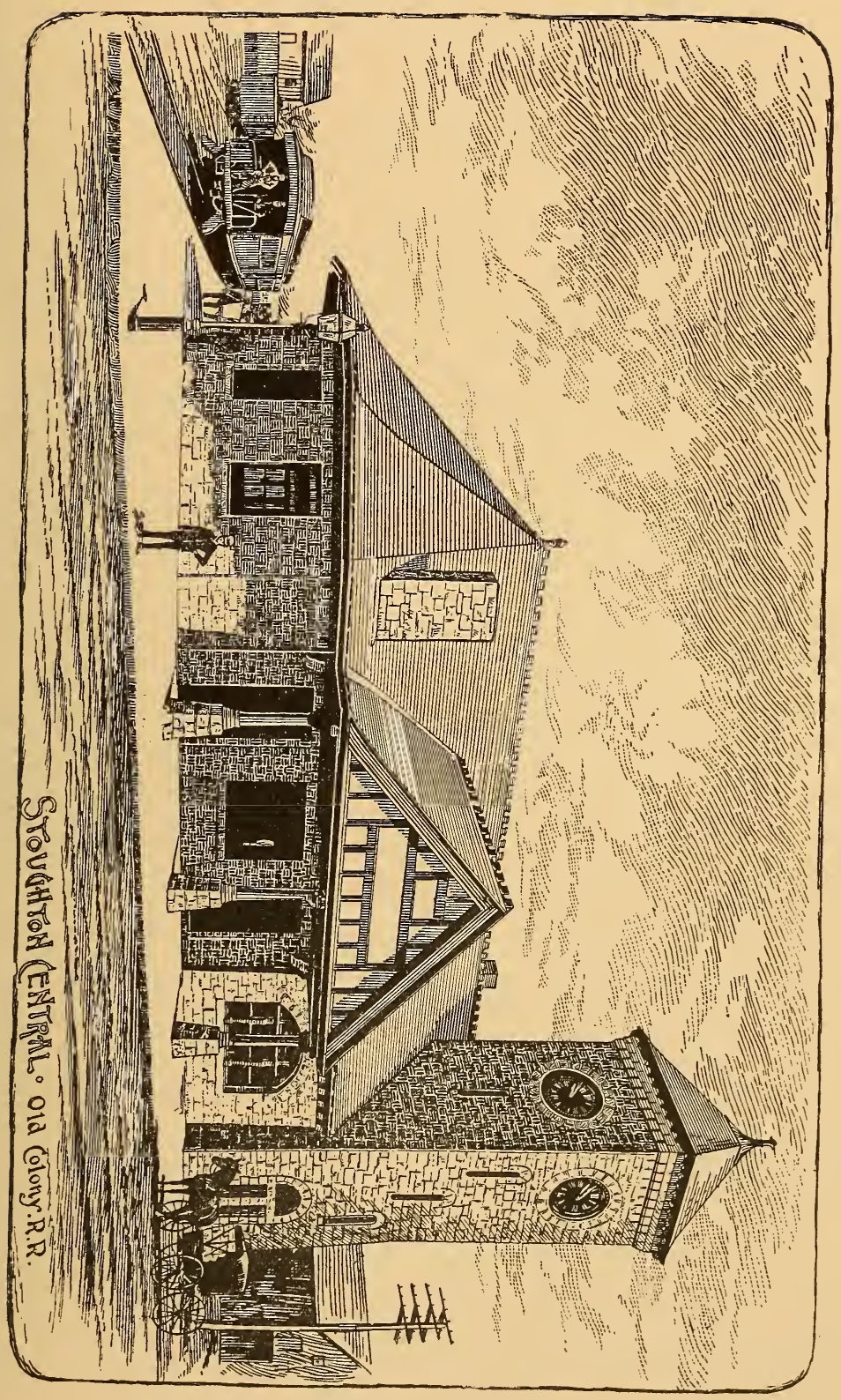





\title{
STOUGHTON BRANCH.
}

STOUGHTON.

\begin{abstract}
S
TONGHTON lies in the southwesterly part of Norfolk county, 18 miles south of Boston. The Stoughton \& Easton Branch from the Providence Division runs through the centre and connects with the Taunton \& New Bedford line in the southern part of the town, all being of the Old Colony Railroad system. The post-offices are Stoughton and
\end{abstract}

\section{NORTH STOUGHTON.}

The latter situated upon the highest land between Boston and Newport, is unsurpassed for its fine drives and picturesque features. The other villages are Belcher's Corner, Dry Pond and West Stoughton. Canton bounds the town on the north, Randolph and Avon on the east, Easton on the south, and Sharou on the west. The surface is pleasantly diversified with hill and valley; the highest point of land being "The Pinnacle," from which may be seen the islinds in Boston harbor, a wide extent of sea coast and many pleasant landscapes. The rock is sienite, in which beds of iron ore occur in several localities. In the northwest is a group of several small ponds, and between the hills in the southwest section lies the long "Ames Pond," the reservior for the principa power at North Easton. The drainage of the town is by affluents of the Neponset and Taunton rivers. There are several boot and shoe factories, employing a large number of persons, and a woolen mill and dyehouse. Other manufactures are leather, knit hose, rubber goods, shoe lasts, machinery, artisans' tools, paper boxes, carriages, clothing, dress trimmings, soap and food preparations. Steam is the chief power used. Population, about 6,000. The stations on this branch are Canton, Springdale, (both of which are mentioned elsewhere. See “Providence Division,") West Stoughton and Stoughton Cen tral.

The Flexible Shoe Manufacturing Company, Stoughton, was first established under the name of the Patent Flexible Shoe Co.,in 1882 , but in 1891 it was made an incorporated company, and the name was changed to the present title, with a capital stock of ten thousand dollars. The president is Hannibal Folsom, and the treasurer Christopher Farrell. The work consists in the manufacture of men's fine shoes, also Folsom patent shoe in all sizes and styles for the retail trade. The premises embrace a two-story frame building fully equipped with all necessary appliances including steam power. The members of this company are well known in social and business circles, and enjoy a lively trade which extends throughout New England. 
Charles Tenney has, since I867, been engaged as manufacturer of men's and boys' fine calf shoes. His factory conveniently located on Porter street, comprises a three-story frame building one hundred thirty-five by thirty feet in dimensions, also a tower adjoining, twenty-five by thirty feet. The goods which are sold principally in Boston are the output of one hundred and fifteen hands, aided by steam power. Mr. Tenney is a native of Stoughton and is well known both in social and business circles. He has built up one of the most prosperous trades in this town and devotes his entire time catering to the wants of his numerous customers.

George F. Walker, Stoughton, engaged in the manufacture of lasts for all kinds of boots and shoes is located on Summer street, where he occupies premises consisting of two buildings, frame and brick, with ell attached, covering an area of eighty-by twenty-nine feet. They are fully equipped with improved machinery run by steam power, and have a capacity of about four hundred pairs per day. Mr. Walker has been established for the past twenty-two years, and has built up an extensive trade with the numerous shoe factories throughout the United States. The work is done under the supervision of Geo. E. Belcher, foreman. The Boston office is situated at I 59 Summer street.

The J. G. Phinney Counter Co., Stoughton, was first established by S. C. Phinney in I 848 , after a time being succeeded by S. C. and J. G. Phinney, and in I 888 it was incorporated as the J. G. Phinney Counter Co., with a capital stock of one hundred and fifty thousand dollars. The officers of the campany are: president and general manager, C. W. Welch; vice-president, E. F. Baldwin; and treasurer, E. M. Elmes. The work consists in the manufacture of boot and shoe counters, and the premises embrace two four-story frame buildings fully equipped with all the modern appliances necessary for the production of all styles of leather counters.

J. \& H. Fitzpatrick, Stoughton, were established in 1865 , but during the years from 1874 to 1880 they operated as two firms. The business consists of fine calf shoes in all the leading styles for the retail trade. Mr. Fitzpatrick gives his entire time and attention to the business, and all shoes made in the factory are looked after carefully and are fully up to sample. The product of this factory is about twenty-five cases per day, which are sold to the New England, southern and western retail trade, all orders being promptly and carefully filled

\section{NORTH ATTLEBOROUGH BRANCH.}

Jowns and stations (Farmers, Falls Village and North Attleborough,) on this branch are referred to at sorne length under "Providence Division." 
INDIA POINT BRANCH.

$\mathrm{P}$

ERRINS, Rumford, Warren Avenue and India Point are stations embraced within the suburbs of Providence for the greater portion of the seven miles traversed by this line, Fox Point being the terminus in that city.

\section{WARREN AND BRISTOL BRANCH.}

7 HIS branch extends from Providence to Fall River, with stations at East Providence, Kettle Point, Silver Spring, Pornham, Riverside,

1 Bullock's Point, Drownville, Nayatt, Barrington, Hampden Meadows, Warren, Bristol, Coles, South Swansea, Brayton Point and Brayton, nearly all of which are noted summering places on the famous Narragansett Bay.

\section{GEORGE F. WALKER.}

\section{Office, 159 SUMMER STREET, BOSTON.}

MANUFACTURER OF

\section{Boot and Shoe Lasts. STOUGHTON, MASS.}

\section{Flexible Shoe Man'f'g Co.,}

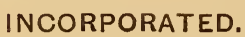

-.ese Manufacturers of The ofra.

$\rightarrow$ Folsom $*$ Patent $*$ Shoes

In all the Leading Styles for Men's wear

and from all the different kinds of stock.

FACTORY AT STOUGHTON, MASS.

H. FOLSOM, Pres. and Manager.

CHRISTOPHER FARRELL, Treas. 


\section{SUBURBAN SERVICE. CENTRAL DIVISION.}

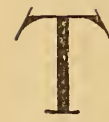

HE suburban service of the Old Colony Railroad has done much to relieve the congested portions of the city proper and make it possible for tens of thousands of business men, mechanics and others to build homes amid surroundings of the most cheerful and healthful character. The suburbs of Boston are acknowledged to be the most beautiful of any city in the East, and the facility with which the greater portion of them can be reached by the numerous trains of the Old Colony has developed these districts with surprising rapidity within a comparatively few years; not only has the transportation service been a potent agent in populating the suburban districts, but the railroad company has taken a deep interest in the work of making them attractive to residents by the beautifying, and the laying out of lawns and flower beds around the stations and otherwise giving a favorable impression to homeseekers.

Starting from the Kneeland Street Station of the Old Colony Railroad, the surroundings do not begin to assume a suburban appearance until South Boston and Crescent avenue are passed. At

\section{SAVIN HILL}

the district begins to take on the features which make the country desirable for residence, such as ample garden spots, fruit, etc., with broad and well-shaded streets. This station is three miles from the city and has 29 trains to, and 25 trains from that point week days, with a five-cent fare. Four trains are run each way on Sundays.

\section{HARRISON SQUARE,}

four miles out, is a fine section of the city, and has 35 trains to and 39 trains from the Kueeland Street Station every week-day, and four each way on Sundays. The fare is 7 cents, or roo-ride tickets can be had for 5 cents each.

F. A. Merriam \& Co., the most extensive dealers in masons' material in Harrison Square and vicinity, are located at 254 Freeport street, opposite Beach, where several large two-story frame buildings are occupied. This house carries a large and varied stock of the best class of goods for building purposes, such as bricks, line, cement, drain pipe, flagging stone, etc., and their stock can be relied upon for measure and quality. Their goods are sent all over Dorchester and arc in demand by the best class of builders. Mr. Merriam established here 


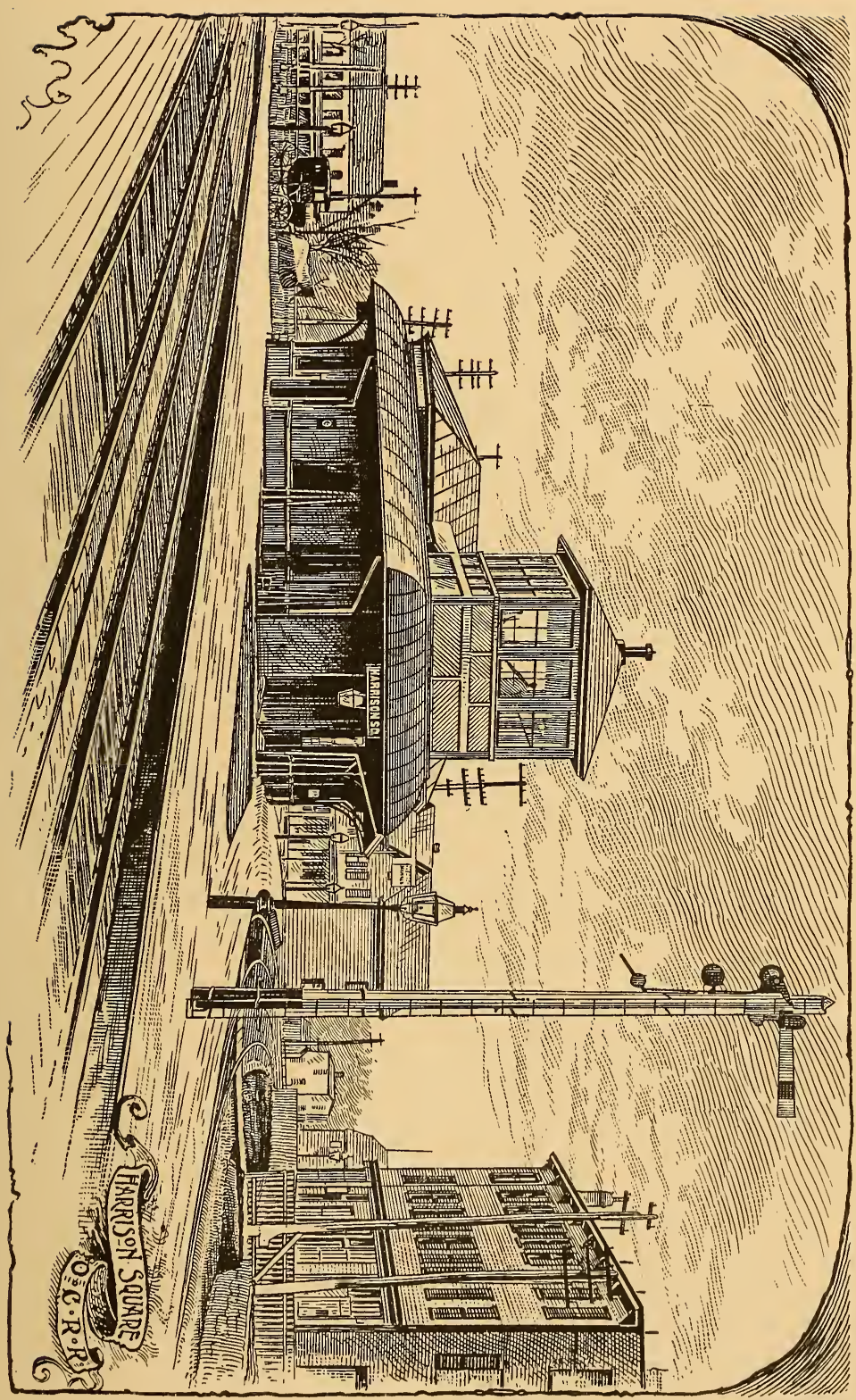



in 1885 and has by his good management, integrity and strict attention to all matters at hand, become a prominent and important adjunct of the trade facilities of this section of the country. He employs the services of twenty men and twenty-five horses and may well be looked upon as one of the representative business men of this district.

E. A. Huebener \& Co., Harrison Square, at $3{ }_{5} 5$ Adams street, near Park, can be relied upon for all kinds of furniture repairing upholstering, carpet and shade work. They occupy the lower floor of a two-story frame building $40 \times 30$ feet and have facilities for the best class of work. In addition to this are the extensice carpet cleaning works at Cedar Grove, which employs the services of eight hands. Mr. Huebener established this business eighteen years ago which together with his former experience in this kind of work enubles him to cater to the wants of the most fastidious. Harrison Square being his birth place and life long residence, he is well known and possesses a reputation for upright dealing and good judgment, as the prosperous condition of his constantly increasing business is ample testimony.

Abel Goss is located conveniently at the corner of Park and Adams streets, Harrison Square, Dorchester, where he conducts a well appointed livery boarding and hack stable. He has been established here for the past forty years, and devotes his entire attention catering to the wants of his numerous customers. In his neatly kept stable, we find a large variety of the various styles of carriages, which are furnished for parties, weddings and funerals, at short notice, also keeping fifty splendid horses, which are always managed by careful drivers. The stable is a two-story frame building where ten men find employment, including hostlers, drivers, and other assistants. Mr. Goss is well and favorably known in this district, as he has always been a resident of Har rison Square. He formerly drove the stage from Dorchester to Boston and was a constable before the anmexation to Boston.

POPE'S HILI

is the same distance from Boston as the last named station, and has 18 trains to and 15 trains from the city week days and four trains eacl way on Sundays; single fare 8 cents, roo-ride tickets $\$ 6$. The prospect from this place is fine and includes harbor, bay and country for many miles. Many wealthy people eside here who have beautiful estates.

\section{NEPONSET}

is a suburb in the Dorchester district, five miles from Boston, on the Neponset river and Dorchester bay, and from this point excellent views may be liad of the si.xlands and shipping in the harbor. Fare, single, ro cents; roo-ride ticket \$7. There are 27 trains to and from Boston week days and four on Sundays.

'The Putnam Horse Shoe Nail Co., is located conveniently on the corner of Walnut and Ericsson street, Neponset. This house was first established in I 859 as S. S. Putnam \& Co., but in 1878 it was incorporated with a capital stock of three hundred thousand dollars. 'The work consists in the manufac- 
ture of hot forged and hammer pointed shoe nails. The land occupied by them covers ten acres, on which are situated a large number of brick and stone buildings, where four-hundred diligent workmen are kept continually busy. The buildings are lighted by electricity, they having their own dynamo of one hundred twenty-five horse power. The daily products amount from six to ten tons, manufactured from the best imported Swedish iron, and they are the only hot forged hammer pointed horse shoe nails made by machinery and are sent to all parts of the world. Their branch offices are located in Chicago, IIl., San Francisco and Portland, Oregon.

The A. T. Stearns Lumber Company of Taylor strect, Neponset, was established in 1849 , but was incorporated in 1883 . The capital stock is one hundred fifty thousand dollars, the president is Mr. A. T. Stearns; and the treasurer is Mr. J. F. Dunbar. Besides being proprietors of the lumber and planning mills, they are also engaged as dealers in all kinds of lumber wholesale and retail. Their premises embrace fifteen acres. Steam power is used at the works and from one hundred twenty-five to one hundred fifty hands are engaged as help. The products are sent to all parts of New England, New Jersey and New York. Mr. A. T. Stearns was the first one to introduce Cypress lumber for general use into New England, and at present it has a large sale and the demand for it is increasing. A large stock of lumber is constantly on hand and business has increased to such an extent that Mr. Stearns has an extensive mill in operation in the South.

\section{FIELD'S CORNER}

is on the Shawmut \& Milton Branch, four miles from Kneeland Street station, Boston, and is a popular and growing section of the city for both residence and business.

\section{ASHMONT}

overlooks the Neponset river, is on high ground, with excellent sanitary conditions and many fine modern dwellings. It is a rapidly developing locality, and has a passenger service of $\mathrm{I} 7$ trains to and $\mathrm{I} 8$ trains from Boston week days and four each way on Sundays. The fare is ro cents one way, or Ioo rides for $\$ 7.25$. Shawmut Branch.

\section{CEDAR GROVE}

is six miles from the Kneeland Street station, overlonking Neponset river and in plain view of the Blue Hills of Milton. Has many fine residences and is a very desirable section of the city for residence. Train service consists of 16 trains to and $\mathrm{r} 7$ from Boston week days and three on Sundays. Single fare Io cents; roo rides, $\$ 8$. Shawmut Branch.

\section{MATTAPAN.}

is one of the finest of Boston's suburbs, and has a population of about $I, 000$ It is on the Neponset river and is the terminus of the Shawmut \& Milton Branch, with I 7 trains each way week days and three on Sundays. Single fare, I 5 cents; roo rides, $\$ 8$. 
C. A. Buck \& Son on River street is a well established firm, engaged in the manufacture of blocks and dies for ladies' and girls' hats and bounets. They receive orders from some of the largest manufacturer's of hats and bonnets, to make their blocks and dies. They have facilities for producing a large amount of work which is of the best, and orders are filled promptly and a short notice. The members of the firm are well known residents of Mattapan, and have a high reputation for the line of work they produce.

George S. Leed \& Co., Blue Hill avenue, Mattapan, are manufacturers and importers of ladies' and misses' French hat and bonnet frames. The wholesale trade in this business in the West and vicinity of Boston is largely supplied by them. Their styles are always the latest and this company is among the first to produce them for the following season. The goods produced by thir firm can be relied upon as being the best in quality and among the most populas in style. The constant demand for the production gives employment to from thirty to fifty persons the year round. The excellent system and facilities of their manufactory enables them to fill all orders at short notice. They import large quantities of fine frames, which with their own work are unquestionably unexcellell both in quality and price. Their salesroom is at 48 Summer street Boston.

\section{J. \& H. FITZPATRICK,}

- Manufacturers of. .

\section{Gents' Fine Calf Boots and Shoes.}

Machine and Hand Sewed.

STOUGHTON, $\quad-\quad \quad-\quad \quad-\quad$ MASS.

\section{A. BUICK \& SON}

\section{PLASTER HAT and BONNET BLOCKS,}

Also Dies for Straw, Felt, or Buckram, either Iron or Spelter.

ALL ORDERS PROMPTLY ATTENDED TO. MECHANIC'S B'L'D., - MATTAPAN, MASS. 


\section{PROVIDENCE DIVISION.}

B I the acqusition of the Boston \& Providence Railroad in April, I 888, the Old Colony system greatly increased its suburban territory and augmented the facilities for residence in the many desirable places to be found along that line. How well the people have appreciated this great advantage is best demonstrated by the vast throngs which may be seen every few minutes passing through its handsome and commodious station in Park Square, Boston, coming from or returning to the comfortable homes in the outlying districts of the city.

\section{CHICKERING}

is the the first station going by this line, one mile from the Park Square station, and as it is nearly in the heart of the city, it cannot properly be called a suburb. Not until

\section{ROXBURY}

is reached do we begin to find indications of the dividing line between the urban and suburban, and even here it is not altogether a well defined topographical mark. Roxbury Highlands is the nearest approach to country scenes in this pupulous district of Boston, and here the sanitary conditions are not only of the best, but the outlook from the many and constantly succeeding elevations are often of the grandest charcter. There are 43 trains to and 44 trains from Boston week days and nine each way Sundays, with a five-cent fare. Heath is a station in this suburb.

\section{BOYLSTON}

is three miles out from the city and has hills from which fine views of the surrounding country may be had. It is only a short distance from the Franklin Park in West Roxbury. There are 40 trains from Boston week days and nine each way Sundays. Single fare, 7 cents; roo-ride tickets, $\$ 5$.

\section{JAMAICA PLAIN}

is a delightful place for residence, its streets being broad and well shaded, and the surface broken by hills and dales. It has all the advantages of the city proper in the form of public institutions, etc., and fine drives in nearly every direction. Fare, one way, 8 cents; roo-ride ticket, $\$ 5$. Forty-seven trains to and 49 trains from Boston week days, nine trains each way Sundays. 
FOREST HILLS.

In this fine suburb are located the Bussey Institution of the Agricultural Department, the famous Arnold Arboretum of Harvard University and three of Boston's finest cemeteries, wth Bussey Park and Franklin Park handy by. It is a fast growing suburb and contains many handsome estates. Single fare, 9 cents; roo-ride tickets, $\$ 5.75$. Train service same as Boylston. Forty trains to and 4I from Boston week days, nine each way Sundays.

MOUNT HOPE.

This suburb is in Ward 23 of the city, and is six miles distant from Park Square station. It is a pleasant and growing section and has many fine residences of modern construction, is in the midst of picturesque scenery and has several excellent carriage ways among its wooded hills. The Arnold Arboretum is also an attraction here. Single fare, I 2 cents; roo-ride ticket, $\$ 6.75$. Twenty-fire trains to and 23 trains from Boston week days, four trains each way on Sundays.

\section{E. A. HUEBENER AND CO. FURNITURE}

REPAIRING \& UPHOLSTERING. CARPET AND SHADE WORK.

Furniture Packed, Moved and stored.

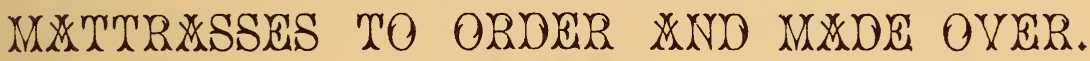

315 ADAMS ST., NEAR PARK, DORCHESTER, MASS.

\section{H. E, THOMPSON, \\ CASH · GROCER.}

Flour, Grain, Hay and Straw,

Boots, Shoes and Rubbers.

Plainville, - - $\quad$ Mass.
H. G. BACON,

D, O. SCOFIELD.

LINCOLN, BACON \& CO.; Manufacturers of

$\mathrm{J} * \mathrm{E} * \mathrm{~W}$ *E*L*R*Y.

Cffice, 2 I ana 23 Maiden Lane, $N$. Y.,

Plainville, Mass. 


\section{OTHER TOWNS AND VILLAGES.}

PLAINVILLE.

$\mathrm{P}$ LAINVILLE, a post office village of Wrentham (in the county of Norfolk) which is described elsewhere, is a prosperous village provided with churches, schools and the necessary adjuncts of a manufacturing centre, its only considerable industry being the manufacture of jewelry. It is two miles and a half from North Attleboro, and is six miles from Attleboro. Plainville has grown into considerable prominence through the enterprise of those who have built up the jewelry industry.

Lincoln, Bacon \& Company, prominently identified with the jewelry manufacturing interests of Plainville were first established in 1838 at West Attleboro, under the name of Bacon \& Holmes, which, in I84I was changed to Bacon, Hodges \& Mason. In 1844 the company removed to Plainville. In I 850 , Messrs. Mason and Hodges having in the meantime retired, Mr. Bacon formed a co-partnership with Messrs. Draper and Tiftt, doing business under the firm name of Draper, Tifft \& Bacon. Mr. Tifft died in 1851 , and his son, Francis L. 'Tifft, succeeded him as soon as he became of age. Mr. Draper retired, and his interests were continued bv his son, Frank S. Draper. L,ater on J. D. Lincoln was admitted as a partner and business was conducted under the name of Draper, Tifft \& Co. In $1860 \mathrm{Mr}$. Draper retired, and the firm name became Lincoln, Tifft \& Bacon. Mr. Francis L. Tifft died in 1876 , the firm continued the same name, his interest having been purchased by Messis. Lincoln \& Bacon. In $\mathrm{I} 882$ the business was changed to Lincoln, Bacon \& Co., and about this time $J$. D. Lincoln and J. T. Bacon retired from active membership but still held their interest, leaving the prosecution of the same chiefly in the hands of the younger partners. Joseph T. Bacon died in 1888 , and afterwards the business was conducted under the old name, Mr. Bacon's interest of the business going to his son, H. G. Bacon. July I, 1892. Mr. Lincoln withdrew and moved to California. 'The firm name remaining under the present style, H. G. Bacon and D. O. Scotield being the proprietors. The work they produce of gents' and ladies' gold and rolled plate jewelry is of an extra quality, for which they have a large demand. A force of about one hundred hands is enployed, and having the best facilities they are able to turn out a large amount each day. The factory is located on South street and their office is in New York at Nos. 21 and 23 Maiden Lane. 
J. B. Maintien \& Son conduct the business originally established by J. E. Maintien in I82 I at Providence, R. I., he moving to Plainville in I855, where he carried on a successful business under the firm name of J. E. Maintien \& Son, till his death in I889. He was succeeded by J. B. Maintien, of the present firm, who in I89r took into partnership his son William F.. who since the death of his father in October 1892 , has carried on the business under the same name. He occupies premises in the Lincoln, Bacon \& Co. building on the corner of South and Bacon streets, where he carries on the business of plain and fancy enameling of every description, a specialty being made of enameling flowers. A large and varied stock of enamels is kept on hand, and a force of twenty hands is employed, whose work is in demand throughout the country. Unusual facilities for producing first class work are at hand and Mr. Maintien enjoys the confidence of all.

The Knapp Warren Co., well and favorably known as manufacturers of fine jewelry succeeded Bisbee, Swift \& Co., I 892. Bisbee, Swift \& Co. conducted the business until August I 892, when the company was re-organized and incorporated under the present style with the following officers in charge: president, John H. Warren, treasurer and secretary, Ephraim M. Knapp. Possessed of superior facilities for first class work, and energy, ambition and enterprise, this house has succeeded in establishing a prosperous and growing business. The premises located on South street, Plainville, occupy the lower floor of a three-story building where are employed some 25 workmen, skilled in their particular line of work. The trade extends throughout the United States, and Canada. They guarantee all work to be of the best finish and as represented.

Wade, Davis \& Co. are among the enterprising firms of Plainville engaged in the manufacture of jewelry. The premises occupied by them is the lower and part of the upper portion of a three-story frame structure located on the corner of South and Bacon streets. The principal part of their business consists of bracelets, bar, cuff, lace and scarf pins in rolled plate jewelry, sterling silver ornaments and souvenir spoons of various styles, forks, etc. A leading specialty being, making from their own designs, bracelets, bangles, etc., in all the latest novelties in plate and silver. The trade of the firm reaches to the West and South and their annual sales amount to one hundred thousand dollars. The factory $\mathrm{i}$ : fitted up with all the latest improved machinery and employs seventy-five hands besides the designers, etc. They have on the road energetic salesmen and the firm are steadily extending their business to all parts of the country. They have obtained a high reputation for producing a fine quality of goods at low prices. The members of the firm are W. H. Wade, E. P. Davis and C. A. Whiting. Messrs. Wade and Davis have charge of the factory at Plainville, while Mr. Whiting has charge of their New York office at 198 Broadway.

The Plainville Stock Company among the largest jewelry manufacturers of Plainville was originally known as G. Demarest \& Co., who organized as a 
co-partnership with ten members in 1872 ; but in 1874 the company was reorganized under the present name, still being a co-partnership. Several changes in membership have since taken place until now four partners constitute the company, viz: D. H. Corey, W. S. Metcalf, A. W. Burton and E. P. Bennett. They occupy premises on the corner of Sauth and Bacon streets, fully equipped with all the latest improved machinery and appliances, which enable them to turn out a very large and choice line of scarf pins, bracelets, jersey and stick pins, ttc., in rolled plate, gold front, and solid gold jewelry. They employ only first class workmen and designers. All the stock, dies, tools, designs, and in fact everything that is used in their factory is manufactured by them. To protect their goods from imitations and to designate them they have adopted and registered the now well known trade mark "P.S. Co." which is stamped on all goods of their manufacture, which are in demand throughout the country. A branch office is conducted at I 76 Broadway, New York, where buyers are cordialiy invited to inspect their stock and compare prices.

Robinson Brother's, who are engaged in the manufacture of jewelers' findings were established in $\mathrm{I} 890$. They are located in Lincoln, Bacon \& Company's building on the corner of South and Bacon streets, Plainville, where constant employment is given to a large force of skilled operatives, and they are enabled to turn out a large amount of superior goods, with which they supply jobbers. jewelry manufacturers, and the trade generally. The leading specialties of the firm are silver and rolled gold swivels, bars, ete., besides producing alnost every thing coming under their line oî business. Being established but a short time comparatively speaking, yet they are building up a large and successful business. All orders are given prompt attention, and special pains are taken to fill them satisfactorily. E. Leroy and L. Eugene Robinson constitute the firm both of whom are experienced workers in metal and have a thorough knowledge of the trade requirements.

H. E. Thompson, located on South street, has been established here in Plainville about eighteen years and is well known as a dealer in groceries, hay and grain, boots and shoes, dry goods and a stock usually found in a variety store. Mr. Thompson has had a long experience and his thorough knowledge of the business has enabled him to build up a large trade with this and the surrounding towns. He is also prominently known in the town, having served as selectman and overseer of the poor.

\section{NORWOOD.}

Norwood which can be reached by the Old Colony Railroad is a beautiful town which was taken from parts of Dedham and Walpole and incorporated February 23, 1872. It lies in the centre of Norfolk county, I 4 miles southwest of Boston; and is bounded north by Dedham, east by Neponset river, south by Canton and Walpole and west by Walpole and Dedham. The town supports public schools which are in a good condition. Norwood has had 
a rapid growth, contains several handsome stores, and private residences, and has before it a brilliant prospect. The stations are Norwood and Norwood Central.

Frank A. Fales dealer in hay, grain, meal, lime, cement, etc. may be mentioned among the prominent houses of Norwood. The store is well stocked with a full and complete line of goods and he employs a number of men and teams to deliver all orders promptly. Every article in this line will be found to be first-class, and is supplied to the surrounding trade. Mr. Fales established the business in 1877 and has conducted it in a very successful manner from the beginning. He is a well-known citizen of the place, and is held in high esteem among the business men for his honest and fair dealing transactions with all parties. His able and popular management has succeeded in building up a large and prosperous trade. He is located opposite the depot in Norwood.

G. F. Bagley a well-known carpenter and builder in Norwood has a high reputation for prompt and thorough work in his line of business, as the large trade that he controls shows. He is prepared to furnish estimates on any work in his line, and is able to do the same in a prompt and thorough manner. The material used by him is of the best stock, and the prices given are at the lowest rates. Having had a number of years experience he is thoroughly posted in every branch of the business. His trade is increasing quite rapidly and covers ¿ large territory.

The Norwood Iron Foundry situated on Broadway, and carried on under the management of Bell \& Casey is one of the large iron foundries in Norwood. Though established but two years, they have built up a large trade in the manufacture of castings for light machinery, and work in coppering and japanning. The quarters occupied by them consist of a one story building eighty feet by forty feet, with complete facilities and all the latest improved machinery, where some seventeen skilled hands are given constant employment. Bell \& Casey are prepared to furnish estimates on anything in their line. A Boston office is located at ror Portland street. Both members of the firm are expert mechanics, energetic and practical business men.

The Excelsior Steam Laundry of Norwood was first established in Cannto in 1888 but moved to its present location on Broadway in I89I. C. J. Sullivan manager employs forty hands and has a large trade extending through the towns of Sharon, Canton, East Weymouth and the vicinity. He has all the latest improved machinery in every department of the establishment, and is able to meet every requirement of his patrons.

J. E. Plimpton \& Co. are iron founders, maehinists etc. in Norwood carrying on the business established in 1854 by E. D. Draper \& Son. who were succeeded in $189 \mathrm{I}$ by the present firm. A special department in their business is the manufacture of shoe machinery and light castings. They have built up a large and extensive trade, that extends all over the country. Aided by the latest improved machinery and some forty skilled workmen they are able to turn out 
seren hundred tons of iron per year. All material used by them is of the finest quality, and they have a reputation of turning out only the best work.

\section{ADDENDA.}

LEASE OF THE OLD COLONY RAILROAD TO THE NEW YORK, NEW HAVEN \& HARTFORD RAILROAD.

The publishers had just completed this work, so far as the historical details were concerned, when vague rumors began to be noised about of a railroad deal of the most colossal magnitude; but they little thought at that time that the rumors, even should they prove true, could have any effect upon this publication, as they could not be traced to any reliable source, nor could the interests to be affected by the reported change be definitely settled upon, owing to the reticence of officials who held the key to the situation. It has transpired, however, since the historical portion of the work was sent to press that the transaction is of vital concern in its relation to the Old Colony system, hence this addenda, and the non-appearance of the subject matter where it naturally belongs.

By the terms of the lease made the Old Colony Railroad becomes a portion of the New York, New Haven \& Hartford Railroad system, and will be known as the Old Colony Division of the Consolidated Railroad. At a meeting of the stockholders held at Horticultural Hall, Boston, in February of the present year (1893) the lease was ratified by a majority of 87,092 votes, and in referring to the subject President Choate of the Old Colony said :- " The Old Colony road has a long and honorable history, of which stockholders and directors are proud. No road stands better, and if the indications justified the hope that the record of the past could be continued, there 
would be no reason to change. But the spirit of consolidation is abroad, and the directors believe that these indications do not appear. The New York, New Haven \& Hartford is a strong corporation, and its policy points to an independent entrance to Boston, and it will have it by our road or by a new road. A new road means ruinous competition, from which the directors would retreat in time, and therefore have arranged this lease. The lease is not intended to be permanent, but only a bridge to serve until legislation for consolidation can be secured, when the stockholders will have the option of exchanging their shares."

The basis of the exchange which will be made as soon as the necessary legislation can be had authorizing the consolidation is ten shares of the Old Colony for nine of the new corporation. This new arrangement will prove most fortunate for Boston, as it gives better transportation facilities to New York, and that city can be reached now in five hours, or a saving of nearly one hour's time. Heretofore it was impossible to quicken the train service between these two cities, as the New York, New Haven \& Hartford was a toll road for the three lines out of Boston, and no advantage could be given either of them in the matter of running time. The consolidation has done away with this condition of things, and New England passengers will hereafter be carried between those two points with the least possible delay and in a more satisfactory manner than ever before. The deal has none of the features of stock jobbing transactions, but was brought about in the interest of Old Colony stockholders by seeking to avoid a ruinous competition which otherwise might have followed. The consolidation will take nothing away from Boston and southeastern Massachusetts, but on the other hand it will materially add to the importance and capacity of the Old Colony system. The large holdings of stock by the men who will go into the Consolidated board of directors, and their well-known character leave no reason to suppose that they will not work for the best interests of the entire line, without reference to local influences.

Under the new management great impetus will be given to the shore business of the Old Colony Division, and improvements are contemplated which will incur the expenditure of nearly $\$ 8,000,000$, divided as follows : About $\$ 3,000,000$, for the elevation of the Provi- 
dence division tracks from Boston to Forest Hills and laying four tracks, together with a new freight house and changes in the location of the Park square freight houses in that city: $\$ 3,000,000$ for the raising of South Boston tracks and the use of 9 or Io acres of land there for freight yards, and the removal of Kneeland street freight yards, with the erection of a new passenger station, and about $\$$ I, 500,000 for the abolition of Brockton crossings. The building of a new track between Clarendon Hills and Mattapan is also probable. It will be observed that the Old Colony Railroad will not lose its identity and be subjected to any material change in its management. Its name will be retained as a division of the Consolidated Road and its affairs will be directed from Boston to New London, Conn., by New England men.

The city of Providence has a vital interest in this consolidation also. Many will remember the troubles that have arisen and have existed there for many years over terminal facilities of the several roads that centre in Providence. Formerly the Providence \& Worcester, the Boston \& Providence, the Old Colony, the New York, Providence \& Boston (Stonington line), and the New York \& New England each had an interest in the depot property in that city. Consolidation has reduced the interests so that now all that remain are the New York, New Haven \& Hartford, and the New York \& New England.

All things considered, the Consolidated Road will present one of the grandest systems in the United States, and its importance to New England will manifest itself in many ways in the near future. Travel will be greatly stimulated under the new order of things, and renewed interest will be taken in the many beautiful summer resorts which abound on the shore lines of the Old Colony. The consolidation cannot be regarded otherwise than as a masterpiece of railroad policy and one which cannot fail to inure to the benefit of all the towns along the system and the general welfare of all concerned. 


\section{LIST OF STEAM RAILROADS OF THE UNITED STATES AND CANADA.}

\section{(Main office where address is given.)}

Addison \& Penna Ry., Addison, N. Y. Adrondack \& St. Lawrence, Herkimer, N. Y. Arizona \& New Mexico Ry., Clifton, Ariz. Alabama Midland Ry., Montgomery, Ala. Albemarle \& Pantego R. R. Consolidated with Norfnlk \& So. R. R., Norfolk, Va.

Albemarle \& Raleigh R. R. (See Atlantic Coast Line.)

Allegheny \& Kinzua R. R., Olean, N Y.

Allegheny Valley Ry. Co. Pittsburg, Pa.

Annapolis \& Balt. Short Line R. R., Annapolis, Md.

Annapolis, Wash. \& Balt. R. R. Annapolis, Md.

Arizona \& New Mexico Ry., Nlifton, Ariz.

Arkansas \& Louisianna Ry., St. Louis, Mo.

Arkansas Midland R. R., Helena, Ark.

Ashland Coal \& Iron Ry. Co., Ashland, Ky.

Ashtabula \& Pittsbureh Ry., Topeka, Kan.

Atchison, Topeka \& Santa Fe R. R., Topeka, Kàn.

Atlanta \& Florida Ry., Atlanta, Ga.

Atlantic City R. R. (See P. \& R. R.R.)

Atlantic Coact Line South of Welden; Wilmington \& Weldon; Northeastern; Cent. R. R. of S. C.; Cheraw \& Darlington; Cheraw \& Salisbury; Wilmington, Columbia \& Augusta Midland, N. C.; Albemarle \& Raleigh; Manchester \& Augusta and Florence R. Rs.

Atlantic \& Danville Ry., Portsmouth, Va. Atlantic \& No. Carolina R. R., Newberne, N. C. Atlantic \& Pacific R. R. Albuquerque N. M. Atlantic \& Western R. R.. Orange City, Fla. Atlanta \& West Point R. R. (See Westeru of $A l a)$

Atlantic, Tenn. \& Ohio R. R. (See Rich. \& Dan.)

Augusta, Gibson \& Sandersville R. R.,Augusta, Ga Au Sable \& Northwestern, Au Sable, Mich.
Austin \& North Western R. R., Austin Tex. Baltimore \& Delaware Bay R. R., Clayton, Del.

Baltimore \& Eastern Shore R. R. Co., Salisbury, Md.

Baltimore \& Potomac R. R., (See Penna. R.R)

Baltimore \& Lehigh R. R Co., Baltimore, Md.

Baltim ore \& Ohio R. R., Baltimore, Md.

Baltimore, Ohio \& Southwestern R. R. Co. Cincinnati, 0 .

Bangor \& Piscataquis R. R., Bangor, Me.

Bangor \& Portland Ry., Bangor, Pa.

Barclay R. R., Towanda. Pa.

Bath \& Hammond sport R. R., Hammond sport, N. $\mathbf{Y}$.

Bay of Quinte Ry., Deseronto, Ont.

Bear Lake \& Eastern R. R., Bear Lake, Mich.

Beech Creek R. R., Jersey Shore Pa.

Bellaire, Zanesville \& Cin. Ry. Co., Zanesville, 0 .

Bennington \& Rutlınd Ry., Bennington, Vt.

Birming., Salma \& N. O. Ry., Selma, Ala.

Birmingham \& Atlantic Ry., Talladega, Ala.

Birmingham, Sheffield \& Tenn. River Ry. Sheffield, Ala.

Blue Ridge \& Atlantic R. R., Tallulah, Ga.

Boston \& Albany R. R., Boston, Mass.

Boston \& Lowell R. R. (Leastd to Boston \& Maine.)

Boston \& Maine R. R., Boston, Mass.

Bostun \& Providence R. R., (see O.C.R.R.), Bust. n, Mass.

Boston, Revere Beach \& Lynn R. R., Boston, Mass.

Bradford, Bordell \& Kinzua R. R., Bradford, $\mathrm{Pa}$.

Brattlehoro \& Whitehall R. R. (See Cent. Vt. $R . R$.)

Bridgton \& Saco River R. R., Bridgton, Me.

Brooklyn \& Brighton Beach R. R., Flatbush, N. $\mathbf{Y}$. 
The Uniform Buttons used by the Old Colony Railroad Company are manufactured by

\section{EVANS \& CO.,}

Manufacturers of

Fine Quality
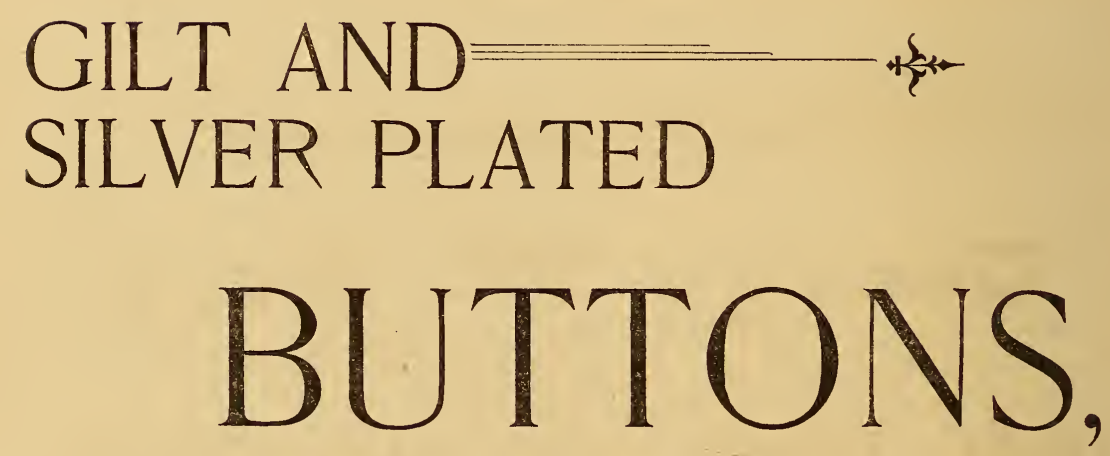

Plain, Fancy, Army, Navy, Military, Police,

Livery, Club, Steamboat, Railroad, Institutions, Etc.

POST OFFIOE BCX NO. 6.

\section{ATTLEBOROUGH FALLS, MASS.}




\title{
CUSHING HOUSE,
}

HINGHAM, MASS.

\section{GEORGE CUSHING, PROP.}

\author{
OPEN SUMMER AND WINTER.
}

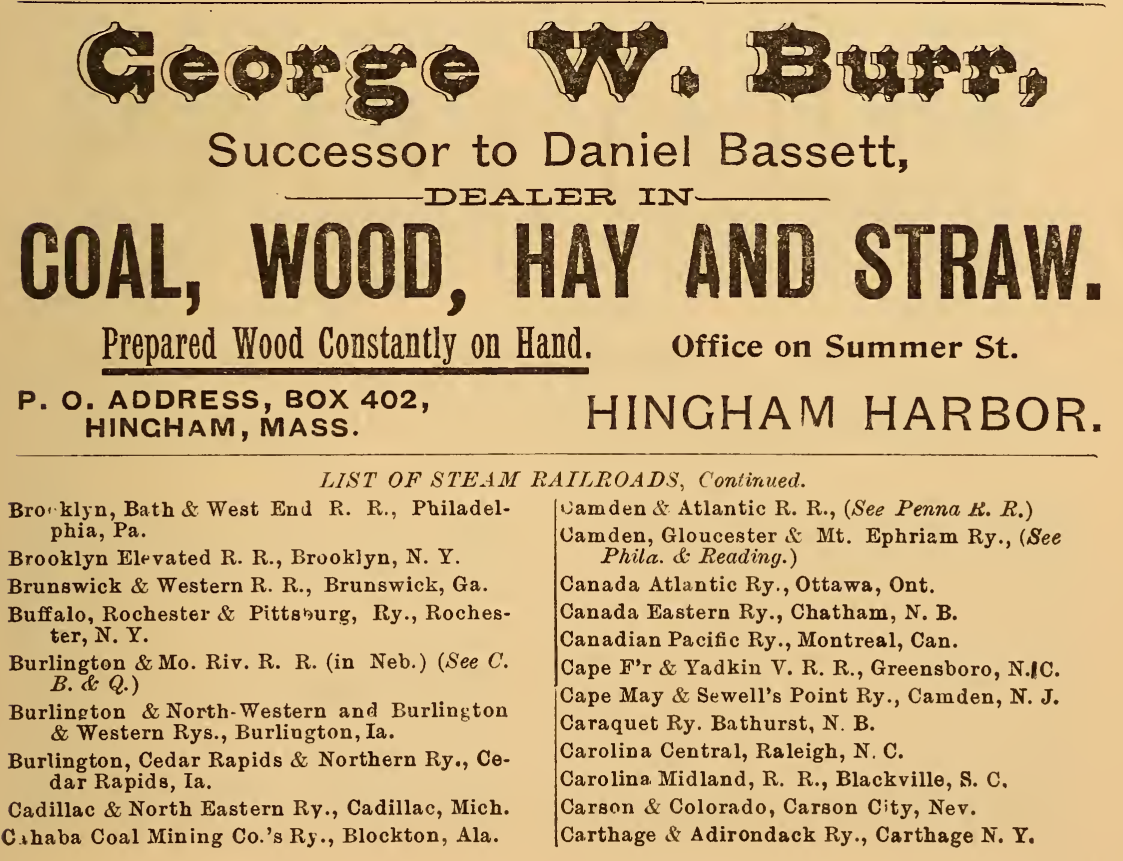




\section{Clark M'f'g Co, a, \\ Manufacturers and . . Wholesa Dealers in very desceip tion of . . . e}

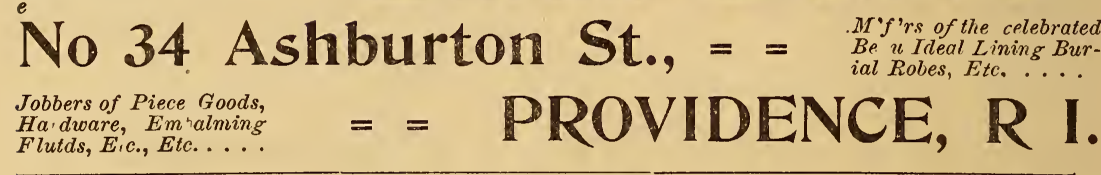

\section{George A. Peckham, PROPRIETOR OF}

\section{PECKHAM'S COUGH \& LUNG BALSAM.}

Strengthening Porous Piasters. Condition Powders and Spices. Grocers Shelf Goods a Specialty.

\section{Peck St., Providence, R. I.}

Peckham's Specialties:- BALSAMINE for Purns, pruiser and h.heumatism

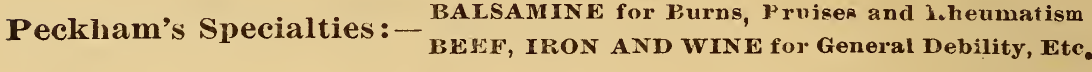

WOODWARD ENTERPRISE M'F'G. CO.,

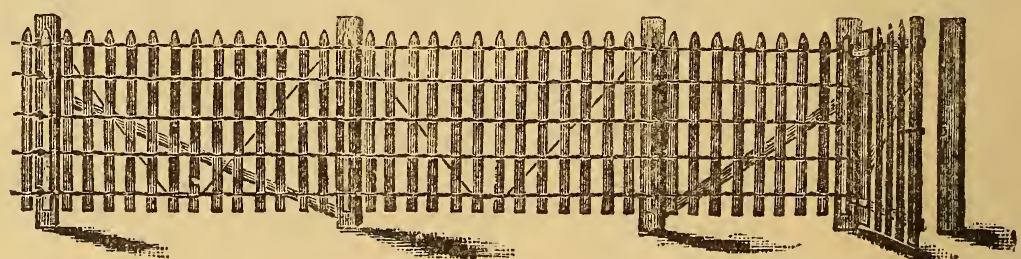

Only Manufacturers of the COMBINED WIRE and PICKET FENCE,

Our Fence is adapted for all general use. We make any required height and strength and make a Specialty of CWDAR PICKETS. Send for Price List.

RUBERT WOODWARD, Treas, 20 SABIN ST., PROVIDENCE, R. I,

LIST OF STEAM RAILROADS, Continued.

Catskill Mountain Ry, Catskill, N. Y.

Cedar Rapids \& Marion Ry., Cedar Rapids, Ia.

Central Arizona Ry. (See Atlantic \& Pacific.)

Central Branch Union Pac. (See Mo. Pac.: (3) Div.)

Central New England \& Western R. R., Hartford Conn.

Central Ontario Ry., Cleveland, O.

Central Pac. R. R. (See Southern Pacific Co.)

Central R. R. \& Banking Co. of Georgia, Savanah, Ga.

Central R. R. of New Jersey, Jersey City, N. J. Central R. R. of S. C. (See Atlantic Coast Line.)
Central Texas \& Northwestern R. R. (See Hous. \& Tex. Cen.)

Central Vermont R. R., St. Albans, Vt. S. S. and C. and M. P. \& B. Roads., St. Johns,
P. Q.

Charleston \& Savannah Ry., Charleston, S. C.

Charleston, Cincinnati \& Chicago R. R., Blacksburg, S. C.

Charleston, Sumter \& No. R. R., Sumter; S. C.

Charlotte, Columbia \& Augusta R. R. (See Rich. \& D.)

Chateaugay R. R., Plattsburg, N. Y. 


\section{OLIVER JOHNSON \& CO.,} SOLE MANUFACTURERS OF

\section{VILLA PAINTS,}

KING PHILIP WHITE LEAD,

EXCELSIOR READY MIXED PAINTS,

TOWNE'S EXCELSIOR BRONZE for Boat Bottoms.

\section{3 to 19 EXCHANGE STREET, * * PROVIDENCE, R. I.}

\section{Yantic Paper Mills, \\ Judge Bros., \& Co., \\ Eureka Ruling and Binding Co., \\ American Paper Pail \& Box Co., \\ Isaac Sexton \& Co \\ Smith Paper Co. \\ NEW ENGLAND AGENCY, \\ Manufacturer's' Products, \\ ROOM 26 WILC@X BUILDING, PROVIDENCE, R. I.}

Blank Books and Paper Boxes, Envelopes, Papeteries, Stationery, Manilla, Book, News and Straw Papers, Paper Bags, Tin and Wooden Ware, Oil Cans

and Kitchen Furnishings, etc, etc.
LIST OF STEAM RAILROADS, Continued.

Chattanooga \& Look. Mt. Ry., Chattanooga, Tenn.

Chat., Rome \& Colum. Ry., Rome. Ga.

Chattanooga Union Ry., Chattanooga, Tenn.

Cheraw \& Chester R. R., (See Rich. \& Dan.)

Cherry Valley Ry., Midland, Mu.

Chesapeake \& Ohio Ry., Richmoud, Va.

Chester \& Lenoir Ry. (See $R$ ch \& Dan.)

Chicago \& Alton R. R., Chucago, Ill.

Chicago \& Erie Ry., Chicage. Ill.

Chicago \& Eastern Illinois R. R., and Chicago \& Indiana Coal Ry., Chicago, IIl.

Chicago, Ft. Madison \& Des Moines R. R., Chicago, Ill.

Chicago \& Gr. Trunk and Dət., Gr. Haven \& Mil. Ry., Detroit, Mich.

Chicago \& Iowa R. R., Aurora, Ill.

Chicago \& Northwestern Ry., Chicago, Ill.

Chicago \& Ohio River R. R., Evansville, Ind.

Chicago \& West. Michigan, Grand Rapids Mich.

Chicago, Bur. \& Kan. City Ry. (See C., B. \& Q.)

Chicago, Burlington \& Northern, Chicago, Ill.

Chicago, Burlington \& Quincy R. R., Chicago, Ill.

Chicago, Iowa \& Dakota Ry., Eldora, Ia.

Chicago, Kalamazoo \& Saginaw Ry;, Kalamazoo, Mich.

Chicago, Milwaukee \& St. Paul R. R, Chicago, Ill.
Chicago, Rock Island \& Pac. Ry., Chicago, Ill.

Chicago, St. Louis \& Pittsburgh R. R., (See Penn Co.)

Chicago, St. Paul \& Kan. City Ry., St. Paul, Miun.

Chicago, St. Paul, Minneapolis \& Omaha Ry., Chicago, Ill.

Chicago \& Western Indiana R. R. Co. and The Belt Ry. Co. of Chicago, Chicago, Ill.

Cincinnati \& Kentucky Southern Ry., Cincinnati, 0 .

Cin. \& Muskingum Valley Ry., Zanesville, 0.

Cincinnati \& Northwestern Ry., Cincinnati, 0.

Uiucinnati \& Westwood R. R., Cincinnati, 0 .

Cin., Georgetown \& Portsmouth, Cincinnati, 0 .

Cincinnati, Hamilion \& Dayton; Dayton \& Mich; Cin., Ham. \& Ind.; Cincinnat 1, Dayton \& Ironton R. R.; Cincinuati, Dayton \& Chicago R. R ; Columbus, Findlay \& Northern; Bowling Green, Cincinnati \& Dayton R. R's., Cin cinnati, 0 .

Cincinnati, Hamilton \& Ind. R R., (See C., H. \& D.)

Cincinnati, Jackson \& Mackinaw R. R., Toledo, 0 .

Cinciunati, New Orleans \& Texas Pacific Ry. Co. (See E. Tenn., Va. \& Ga. R.R.)

Cin. Leb, \& North. Ry., Cincinnati, 0 .

Cincinnati, Portsmouth \& Virginia R. R., Cincinnati, 0 . 

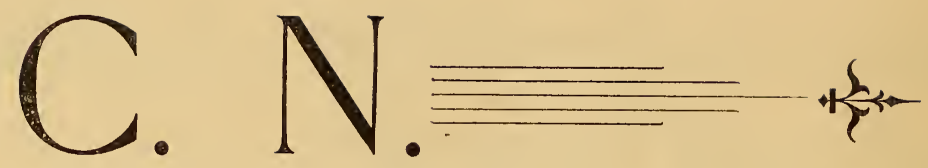

\section{ATwood,}

Manufacturer and Dealer in

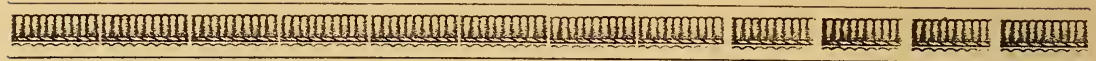

\section{Boxes, ******}

\section{* * Box Shooks, \\ Cranberry Crates, * Trunk Woods,}

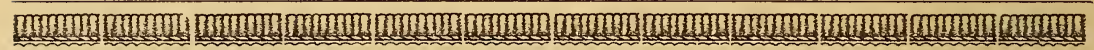
SHINGLES,
$S L A B S$,
BOARDS,
SAWDUST.

*

Rock, Mass. 


\section{ABEL GOSS,}

\section{Livery * and * Sale * Stable,}

COR. PARK AND ADAMS STREETS

Dorchester District, - - BOSTON.

Carriages for Parties, Weddings and Funerals

FURNISHED AT SHORT NOTICE.

Telephone No. 9156.

Near Depot.

\section{EDMUND CARPENTER,}

\section{EASTERN, WESTERN AND WHITEWOOD LUMBER,}

Spruce Timber and Joist. Spruce Boards and Flooring, Hemlock. Rough and Dressed Pine, Hard Pine Flooring, Cypres Ceilings,

White Wood Boards and Planks, White Wood Joist, Pine Ceiling, White Wood Ceiling, $3 / 8,1 / 2,7 / 8, x 6$,

White Wood Base, $53 / 4,63 / 4,73 / 4$, Shingles.

Clapboards, Lathes, Pickets, Mouldings.

270 DYER STREET, - $\quad$ - $\quad$ - PROVIDENCE, R. I.

* RHODE ISLAND PERKINS *

\section{HORSE SHOE CO., \\ MANUFACTURERS OF}

PERKINS HORSE AND MULE SHOES AND TOE CALKS. PROVIDENCE, R. I., U. S. A.
F. W. CARPENTER, PRESIDENT.
C. H. PERKINS, Gen. MANAGer.
R. W. COMSTOCK, SECRETARY. C. R, STARK, TREASURER,

\section{LIST OF STEAM RAILROADS, Continued.} Cincinnati, Richmond \& Chi. R. R. (See C., $S$.
L. \& P.)

Cincinnati, Saginaw \& Mackinaw R. R., E. Saginaw, Mich.

Cincinnati, Selma \& Mobile, (See West Ry. of Ala.)

Cin., Wabash \& Mich. Ry., Wabash, Ind.

Claredon \& Pittsford Ry., West Rutland, Vt.

Cleveland, Akron \& Columbus Ry., Columbus, 0 .

Cleve., Cant. \& South. R. R, Cleveland, O.

Cleveland \& Marietta, Cambridge, 0 .

Cleveland \& Pittsburgh. (See Penna. Co.)
Clev., Ciu., Chic. \& St. Louis, Cincinnati, O. P. \& E. Ry., Urbana, Ill.

Cleveland, Lorain \& Wheeling Ry., Cleveland, 0 .

Colorado Eastern Ry., Denver, Col.

olorado Midland Ry., Colorado Springs, Col.

Columbia \& Greenville R. R., (Rich. \& Danville.)

Columbia \& Puget Sound R. R., Seattle, Wash.

Columbus, Shawnee \& Hocking Ry., Columbus, 0 .

Columbus \& Rome, R. R., (See Cent. of Ga)

Columbus \& Western Ry., (See Cent. of Ga.) 


\section{The Providence Coal Co., \\ DEALERS IN ANTHRACITE and BITUMINOUS COALS,}

* WhOlEsale AND RETAIL. *

Our y ards being connected by rail with the New York \& New England New York, New Haven \& Hartford and Old Colony Railroads, enables us to deliver Coal to any point in New England at the lowest market rates.

We are Agents for the "BARTON MINE," Cumberland and "NEW RIVER" Steam Coals which are unsurpassed for Smithing and Steam purposes.

Lackawanna,

Lehigh,

Plymouth,

and Franklin.

COALS IN ALL SIZES CONSTANTLY ON HAND.

Yards, Corner of DORRANCE AND DYER STREET,

Central Office, Corner of CUSTOM HOUSE AND WEYBOSSET STS., a PROVIDENCE, R. I.

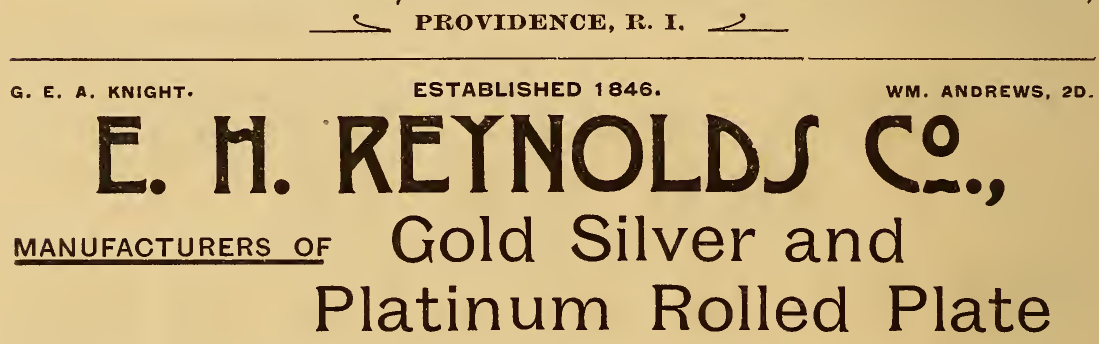

Gold, Silver and Square, Flat and Fancy Plated Wires. Wide Plate and Ring Wires, Specialties. Striped Plate and Watch Case Stock on hand and made to order.

II7 Dorrance St., cor. Friendship, PROVIDENCE, R. I. $\checkmark$ TELEPHONE.

LIST OF STEAM RAILROADS, Continued.

$\begin{gathered}\text { Columbus, Hocking Valley \& Toledo Ry., Col- } \\ \text { umbus, O. }\end{gathered}$
Route, Cressen, Pa. umbus, 0 .

Colusa \& Lake R. R., Colusa, Cal.

Concord \& Montreal R. R., Concord, N. H.

Conn. Riv. R. R., Springfield, Mass.

Cooperstown \& Charlotte Valley R. R., Cooperstown, N. Y.

Cornwall \& Lebanon R. R., Lebanon, Pa.

Cornwall R. R., Lebanon, $\mathrm{Pa}$.

Coudersport \& Port Allegheny R. R., Coudersport, $\mathrm{Pa}$. Covington \& Macon Ry. (See Richmond \& Danv. $R . R$.)

Crown Point Iron Co.'s R. R., Plattsburg, N. $\bar{Y}$.

Cumberland \& Maurice River Ry. (Sre Cent $R y$. of $N . J$.

Cumberland Ry. \& Coal Co., Spring Hill, N. S.

Cumberland \& Penn. R. R., Cumberland, Md.

Cumberland Valley R. R., Chambersburg, Pa. 


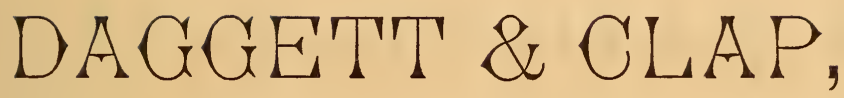

- MANUFACTURE NOVELTIES IN-

LADIES' GOODS, BADGES, BUTTONS,

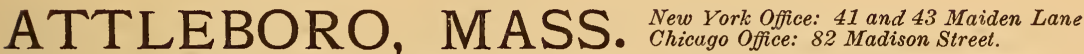

\section{PROVIDENCE CREAMERY.}

The Oldest in the State. No Finer or Better

\section{ICE CREAM **}

Can be found in New England than is sold at the Creamery.

89 \& 91 NORTH MAIN ST., Providence, R. I.

Packed either in Bulk or Bricks. All flavors same price. Sweet Cream and Milk in their purest condition. Orders large or small filled at short notice.
EVANS, COBB \& CO.,

-Manufacturers of -

\section{JEWELERS' * * FINDINGS,}

Swivels, Seamless Balls, Spring Rings, Push and Spiral Drops, Chain Bars, Charms, Chain Trimmings, . . . Fancy Turnings

In Rolled Plate, Sterling Silver, Fire Gilt and Brass.

FACTORY, MANSFIELD, MASS

P. A. DREW.

W. C. WINTER.

\section{P. A. DREW AND Dealers in}

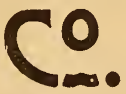

COAL, HAY, LMEE, HAlR, CEMEENT and BRICK.

All Kinds of Jobbing and Contracting Promptly Attended to. MANSFIELD, MASs., Office Near the Depot.

LIST OF STEAM RAILROADS, Continued.

Danville \& Western R. R., Danville, Va.

Dayton \& Michigan R. R. (See Cin. Ham. \& Day.)

Delaware \& Hudson Canal Co., Albany, N. Y. Del. Lackawanna \& Western R. R., Scranton, $\mathbf{P a}$.

Delaware River R. R., Pedricktown, N. J.

Denver \& Rio Grande Ry., Denver, Col.

Des Moines \& Kansas City Ry., Des Muines, Ia.

Des Moines, Northern \& Nurthwestern R. R. Des Moines, Ia.

Det., Bay City \& Alpena R. R., Deıroit, Mich.

Det., Gr. H. \& Mil. Ry. (See Chi. \& Gr. Truuk.)
Det., Lansing \& No'n and Saginaw Valley \& St. Louis Rys., Detroit, Mich.

Diamond Valley Ry., Barre Forge, Pa.

Duluth \& Iron Range R. R., Duluth, Minn.

Duluth. South Shore \& Atlantic Ry., Marquette, Mich.

Dunkirk, Allegheny Valley \& Pittsburgh R. R. N Y. Cen. \& H. R. R. R. Lesse, Dunkirk, N. $Y$.

East Alabama Ry. (See Central of Ga.)

East \& West R. R. of Ala., Cartersville, Ga.

East Broad Top R. R., Rockhill Furnace, Pa.

Eastern Kentncky R. R., Greenup, Ky. 


\section{F. H. SADLER \& CO.,
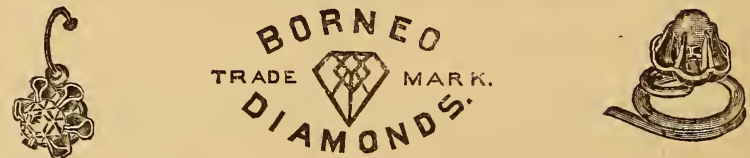

\section{ATTLEBORO, MASS.}

Mamufacturers of Gold and Plated Jewelry and the sole proprietors of the celebrated Borneo Diamond which is acknowledged to be the finest in the world.

\section{HOTEL DERBY,}

Mrs. Joseph N. MaDan.

Cor. Shawmut and Broad Sts, EAST WEYMOUTH, - - - - MASS

Regular Board with or without Rooms.

LIST OF STEAM RAILROADS, Continued.

East Line and Red River R. R., Greenville, Tex.

East Louisiana Ry., New Orleans, La.

Eastern Ry. Co. of Minnesota, St. Paul, Minn.

East St. Louis Connecting Railway and St. Louis Transfer Ry., St. Louis, Mo.

East Tenn. \& Western North Car. R. R., Cranberry, N. C.

East Tennessee, Virginia \& Georgia Ry., Cincinuati, 0 .

Eastern Ohio R. R., Cumberland, O.

Elgin, Joliet \& Eastern Ry. and leased lines. New York, N. Y.

Elgin, Petitcodiac \& Havelock Ry., Petitcodiac, N. B.

Elmira, Cortland \& Northern R. R., Cortland, N. $Y$.

Erie \& Huron Ry., Toronto, Ont.

Erie \& Pittsburgh R. R. (See Penna. Co.)

Erie \& Wyoming Valley R. R., Dunmore, Pa.

Eureka \& Palisade R. R., Eureka, Nev.

Eureka Springs Ry., Eureka Springs, Ark.

Evansv. \& Terre Haute and Evansville \& Indianopolis and Richmond R's., Evansville, Ind.

Fall Brook Coal Co.'s Rys., Corning, N. Y. Farmville \& Powhatan R. R., Richmond, Va. Findlay, Fort Wayne \& Western R. R., New York.

Fitchburg R. R., Boston, Mass.
Flint \& Pere Marq. Pt. Huron \& No. Western Div., Saginaw, E. S., Mich.

Florida Midland Ry., Kissimmee, Fla.

Florida, Central \& Peninsular R. R., New York, N. Y.

Fonda, Johnst'n \& Gloversv., Gloversville, N. $\mathrm{Y}$.

Ft. Worth \& Denver City Ry., (See Texas Panhandle Route.)

Fort Worth \& Rio Grande Ry., Fort Worth, Tex.

Franklin \& Megantic R. R., Boston, Mass.

Fremont, Elkhorn \& Mo. Val. R. R. (See Sioux C. \& Pac.)

Fulton County N. J. Ry., Lewiston, Ill.

Gainsville, Jefferson \& So. R. R., Gainsville, $\mathrm{Ga}$.

Gal. Harrisburg \& San Antonio Ry., (See So. $P(a c$.)

George's Creek \& Cumberland R. R., Cumberland, Md.

Georgia R. R., Augusta, Ga.

Georgia, Midland \& Gulf R. R., Columbus, Ga.

Georgia, Southern \& Florida R. R., Macon, Ga.

Gettysburg \& Harrisburg R. R., Carlisle, Pa.

Grafton \& Upton R. R., Grafton, Mass.

Grand Rapids \& Indiana, Grand Rapids, Mich.

Grand Tower \& Carbondale, Murphysboro, IIl.

Grand Trunk Ry. Montreal, Can. 


\section{DAWSON \& COMPANY,}

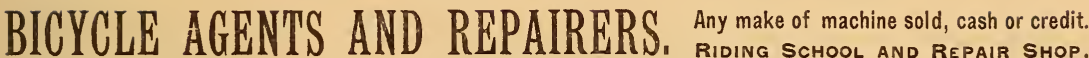

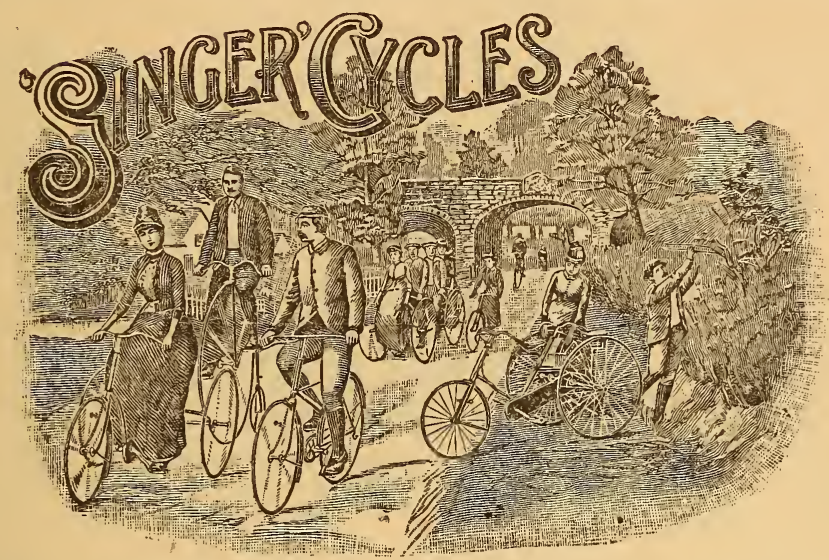

122 BROAD STREET, ********* PAWTUCKET, R. I.

A. E. TENNEY M'F'G CO., Manufacturers of

Patent Adjustable, Barrel, Rod, Martden and Simmons

\section{Cloth Stretchers.} Pattern Making, Model Work.

General Machinery and Specialties. PAWTUCKET, R. I.

A. E. Tennet, M'g'r. Geo. A. Sanders, Supt.
. F. A. MERRIAM \& CO.,

$\sim$ Dealers in $\longleftarrow$

Masons”* Materials.

Bricks, Lime, Cement, Plaster, Hair, Sand, Drain Ripe, North River Flagging, Stone, Etc.

254 Freeport St, opp, Beach,

DORCHESTER, . - MSASS.

Telephone, Dorchester 654 .

\section{LIST OF STEAM RAILROADS, Continued.}

Great Northern R. R., St. Paul, Minn.

Green Bay, Winona \& St. Paul R. R, Green Bay, Wis.

Green Pond, Walterboro \& Branchville Ry., Savannah, Ga.

Greenwich \& Johnsonville Ry., Greenwich, N. Y.

Gulf \& Chicago R. R., Ripley, Miss.

Gulf, Col. \& Santa Fe Ry., Galveston, Tex.

Gulf, W'n Texas \& Pac. Ry., (See Southern Pacific.)

Hancock \& Calumet and Mineral Range R.R's., Hancock Mich.

Hannibal \& St. Jo. R. R., St. Joseph, Mo.
Hoosac Tunnel \& Wilmington R. R., Holyoke, Mass.

Housatonic, R. R., Bridgeport, Ct.

Houston \& Tex. Cen. Ry., Houston, Tex.

Houston, E. \& W. Tex. and Houston \& Shreveport Ry's, Houston, Tex.

Humeston \& Shenandoah R. R., Clarinda, Ia. Huntingdon \& Br. Top Mt . Huntingdon, Pa . Illinois Central R. R., Chicago, Ill.

Indiana \& Illinois Southern R. R., Sullivan, Ill. Indiana, Illinois \& Iowa R. R., Chicage, Ill. Indianapolis \& St. Lou is R. R., (See C., C., C. (. I.) 


\section{THE HENRY W. HudSON CO.}
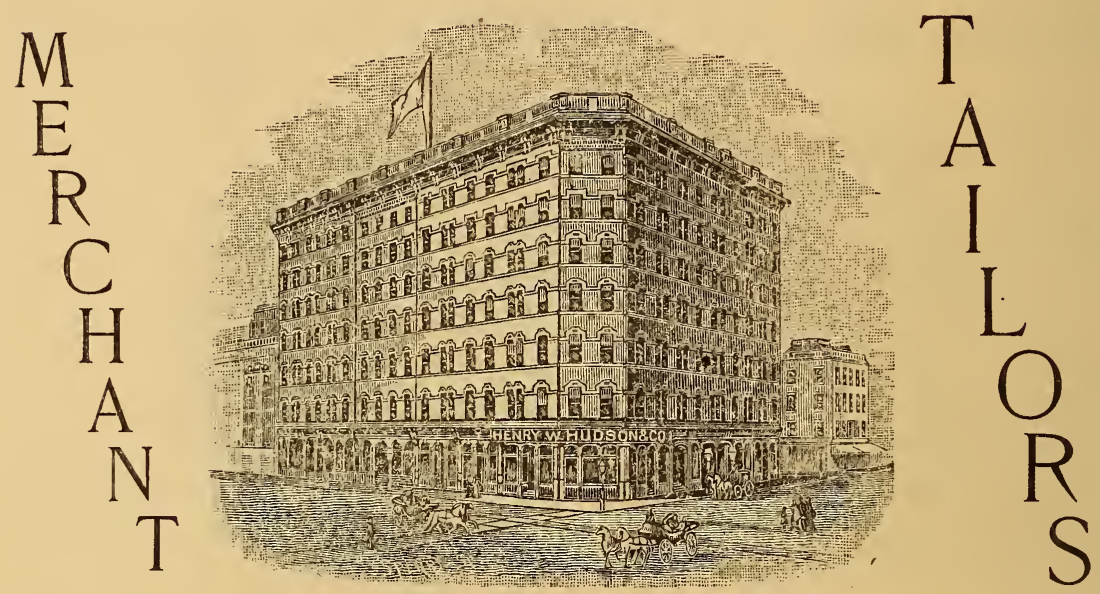

62 Dorrance Street,

Providence, R. I.

\section{THE PUTNAIM NAIT GO., Manntatures of}

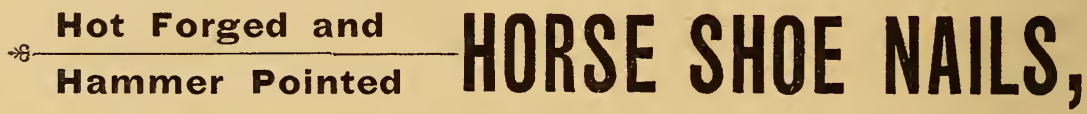

President:

W. H. Goodwin. . .
.

ce-President:

J. H. BUTTRICK. .

Treasurer:

W. W. WhitMarsh.

Secretary:

JoHN Mrars. ....
BOSTON, MASS., Directors:

W. H. GoodwIN. .

W. W. WhITMARSH.

JoHn Mears. ...

JoHN H. BUTtRICK.

Branch Office: - - CHICAGO, ILL.

\section{LIST OF STEAM RAILROADS, Continued.}

Indianapolis \& Vincennes R. R. (See P. C.\& St. L.)

Indianapolis, Decatur \& Western Ry., New York.

Ingalls, White Rapids \& Northern R. R., Ingalls, Mich.

Intercolonial Ry., Ottawa, Can.

International \& Great Northern Ry., Palestine, Tex.
Interoceanic Ry., Texcoco, Mex.

Iowa Central Ry., Marshalltown, Ia.

Iowa Northern Ry., Colfax, Ia.

Iron Ry., Ironton, 0.

Irondale, Bancroft \& Ottawa Ry., Irondale, Ont.

Ironton R. R., Allentown, Pa. 
LIST OF STEAM RAILROADS, Continued.

Ithaca, Auburn \& Western Ry. (See Lehigh Valley.)

Jacksonville \& Atlantic R. R., Jacksonvllle, Fla.

Jacksonville, Mayport, Pablo Ry. \& Nav. Co., Jacksonville, Fla.

Jacksonville, St. Augustine \& Halifax River Ry., New York.

Jacksonville South-eastern Lines: Comprising Jacksonville, Louisville \& St. Louis, Chicago, Peoria \& St. Louis and Litchfield, Carrollton \& Western Rys., Jacksonville, Ill.

Jacksonville, Tampa \& Key West System, Jacksonville, Fla.

Jeffersonville, Madison \& Indiana R. R. ( $P$. C. C. \& St. L. Ry.)

Kanawha \& Coal River Ry., Spring Hill, W. Va.

Kanawha \& Michigan R. R., Toledo, o.

Kansas City, St. Joseph \& Council Bluffs, St. Joseph, Mo.

Kansas City, Wyandotte \& N. Western R. R., Wyandotte, Kan.

Kansas City \& Independence Rapid Transit Ry., Kansas City, Mo.

Kansas City, Osceola \& Southern Ry., Kansas City, Mo.

Kansas City, Fort Scott \& Memphis, Kansas City, Clinton \& Springfield and Current River Rys., Kansas City, Mo.

Kansas City, Memphis \& Birmingham R. R., Kansas City, Mo.
Kansas City, Nevada \& Ft. Smith Ry., Kansas City, Mo.

Kansas City, Watkins \& Gulf Ry., New York, N. Y.

Kent, Northern and St. Louis Rys., Richibucto N. B.

Kentucky \& Indiana Bridge Co. Louisville, Ky.

Kentucky Midland Ry., Frankfort, Ky.

Kentucky \& South Atlantic Ry. (See Chesapeake \& Ohio Ry. C.)

Kentucky Central Ry. (Operated by L. \& N. R. R.)

Kentucky Union Ry., Clay City, Ky.

Keokuk \& Western R. R., Keokuk, Ia.

Kings Co. Elevated Ry., Brooklyn, N. Y.

Kingston \& Pembroke Ry., Kingston, Ont.

Knoxville \& Augusta R. R., Knoxville, Tenn.

Lack. \& So.-W'n R. R., Angelica, N. Y.

Lake Champlain \& Moriah Ry., Poughkeepsie, N. Y.

Lake County R. R., Ludington, Mich.

Lake Erie, Alliance \& So'n Ry., Alliance, 0.

Lake Erie \& Detroit River Rd., Walkerville, Ont.

Lake Erie \& West'n R. R. and Ft. Wayne, Cin. \& Louisville Ry., Indianapolis, Ind.

Lake Shore \& Michigan So'n Ry., Cleveland, O.

Lakeside \& Marblehead Ry., Cleveland, 0.

\section{D. IYONS \& CO.,}

- MANUFACTURERS OF -

Seamless Rolled Plate Chain.

- SOLE MANUFACTURERS -

Lorimer Patent Bracelet and Glove Buttoner.

WEST MANSFIELD, . . . . . . . MASS.

C. A. RICHARDSON.

JOHN BOTTOMLEY.

RICHARDSON \& BOTTOMLEY,

- MANUFACTURERS OF -

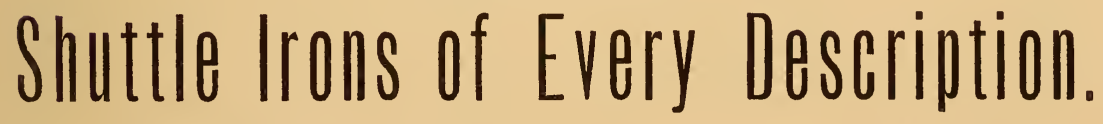

WEST MANSFIELD, . . . . . MASS. 


\section{BLOOD BROTHERS,}

M. H. BLOOD

\section{Flour and Grain : .}

DEALERS IN

\section{Baled Hay and Coal.}

MEDFIELD, MASS.

\section{H. CUSHING \& CO.}

W W OLESALE AND RRTAIL DEALERS IN-

Grain, * Flour, * Groceries, * Hay, Lime, Cement and Hair. MIDDLEBORO, MASS.

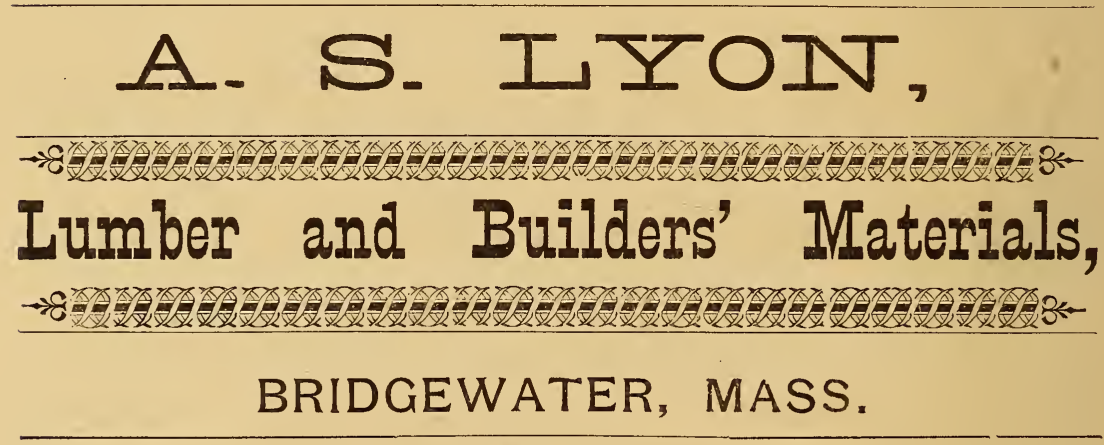

LIST OF STEAM RAILROADS, Continued.

Lancaster, Oxford \& Southern R. R., Ox - (Long Lake \& Muskegon Riyer Ry. Muskegon, ford, $\mathbf{P a}$.

Lebanon Springs R. R., Bennington, Vt.

Lehigh \& Hudson River Ry., Warwick, N. Y.

Lehigh \& Lackawanna R. R. (See Cent. R. R. of $N . J_{.}$)

Lehigh Valley R. R., So. Bethelehem, Pa.

Ligonier Valley R. R., Pittsburgh, Pa.

Little Miami Ry. (See P. C. \& S. L.)

Little Rock \& Fort Smith. (See Mo. Pac.)

Little Rock \& Memphis R. R., Little Rock, Ark.

Little Saw Mill Run R. R., Pittsburgh, Pa.

Long Island R. R., Long Island City, N. Y.

\section{Mich.}

Los Angeles \& Pacific Ry., Los Angeles, Cal. Louisville \& Nashville R. R., Louisville, Ky. Louisville, Evansville \& St. Louis Consolidated R. R., Huntingdon, Ind.

Louisville, New Albany \& Chicago Ry., Chiago, Ill.

Louisville, New Orleans \& Texas Ry., Memphis, Tenn.

Louisville, St Louis \& Texas, Ry., Louisville, Ky.

C. nchburgh \& Durham R. R., Lynchburg, Ta.

M tine Central R, R., Portland, Me. 


\section{H. A. Lothrop Manufacturing Co.,}

(Successors to J. Ames), Manufacturers of

\section{AMES' SHOE and BUTCHER KNIVES.}

- Brick, Plastering, Pointing, Corner and Garden Trowels and Mincing Knives.

Sharon,

\section{BRIDGEWATER BOX CO.,}

\section{Wooden Packing Boxes and Shooks.}

Lock Corner and Printed Boxes a Specialty.

H. O. LitTLE, PRES.

ELIJAH B. GAMMONS, TREAS.

DIRECTORS:-DR. L. G LOWE, S. P. GATES,

H. O. LITTLE, E. B. GAMMONS.
Estimates cheerfully given on above work by single lots or by the year.

\section{BRIDGEWATER, MASS.}
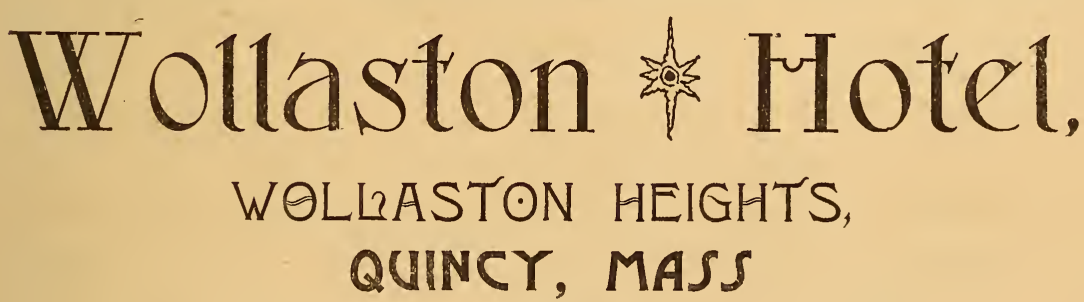

Capt. S. A. MERRILL, Proprietor. DISTANCE FROM BOSTON ON OLD COLONY R. R, 6 1-2 MILES

LIST OF STEAM RAILROADS, Continued.

Manhattan Ry., New York, N. Y.

Manistee \& Luther Ry., Eastlake, Mich.

Manistee \& North Eastern Ry., Manistee, Mich.

Maricopa \& Phœnix R. R., Phœnix, Ariz. Marietta \& North Georgia R. R., Marietta, Ga.

Mason \& Oceana Ry., Ludington, Mich.

Mason City \& Ft. Dodge R. R., Mason City, Ia. Massillon \& Cleve. Ry, (See Penn. Co.)

Meadville \& Linesville Ry., Meadville, Pa.
Meherrin Valley Ry, Norfolk, Va.

Memphis \& Charleston R. R., (See E. Tenn., Va. \& Ga.)

Meriden, Waterbury \& Conn. River R. R., Meriden, Conn.

Mexican Ry., Mexico, Mex.

Mexican Central Ry., Boston, Mass.

Mexican International Ry., Piedras Negras Mex.

Mexican National Ry., City of Mexico.

Michigan Central R. R., Detroit, Mich. 
A. H. Church, President.

\section{F. G. RusselL, Sec. and Treas. \\ The Church \& Russell Co. \\ N. E. Agents for} Sterling Steel Co. Pittsburg, Pa. Sterling Tool Steels.

Linden Steel Co. Pittsburg, $\mathrm{Pa}$.

Cpen Hearth BarSteel, Etc.

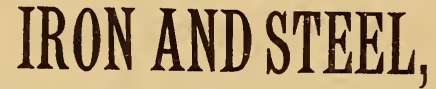

Office and Warehouse: 125 Dyer St.,

PROVIDNECE, R. I.

In connection with the E. C. Church Co., we will carry in Stock a Full Assortment of Carbon Steel Co.

Pittsburg, $\mathbf{P a}$ Boiler, Tank and Ship Plate. Kidd Steel Wire CO., Ltd Sharpsburg, $\mathrm{Pa}$. Drill Rods and Drawn Wire.

\section{Lockhart Iron \& Steel Co} Pittsburg, Pa.
Tool Steel, Polished Drill Rods, "Vulcan" Bar Iron, Band Iron, Etc.
La Belle Iron Works, Wheeling, West Va. Tack Plate:
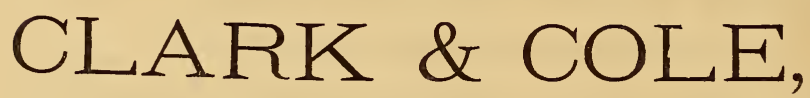

\section{ВOT, SHOE and $\mathrm{P} H \mathrm{C} C \mathrm{ING}$
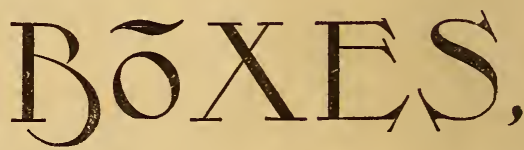 MIDDLEBORO, MASS.}

\section{FRANK A. FALES, - Dealer in- \\ - Flour, Grain, Meal, Feed, Hay, . \\ - Scraps, Oyster Shells, Lime. Ce- . \\ . . . . . ment, Sand, Etc. . . . . .}

\section{NORWOOD, MASS.}

\section{LIST OF STEAM RAILROADS, Continued.}

Midland No. Car Ry., (See Atl. Coast Line.) Milwaukee \& Northern R. R., Chicago, Ill. Midland Ry., Lebanon, Ind.

Milwaukie \& No. R. R., Chicago, Ill.

Milwaukee, Lake Shore \& Western Ry. Co. Milwaukee, Wis.

Mineral Range R. R., (See Hancock \& Calumet.)

Minneapolis \& St. Louis Ry., Minneapolis, Minn.

Minneapolis, St. Paul \& Sault Ste. Marie, Minneapolis, Minn.

Mississippi River \& Bonne Terre Ry., Bonne Terre, Mo.
Mississippi R. \& No. West Ry., Arkansas City, Ark.

Missouri, Kansas \& Texas Ry., Sedalia, Mo. Missouri Pacific Ry. (Leased and operated and independent lines.) St. Louis, Mo.

Mobile \& Ohio R. R., Mobile, Ala.

Mohassuck Valley, Ry., Saylesville, R. I.

MonongahelaRiver R R., Monongahela, W. Va.

Monson R. R., Lowell, Mass.

Mont Alto R. R., Chambersburg, Pa.

Montana Ceatral Ry., Helena, Mont.

Montana Union Ry, Co., Butte, Mont. 


\section{G. A. ROBINSON,}

$\therefore$ SUCCESSOR TO MORAN \& SONS, :

\section{Manufacturer * of * Cutlery,}

\section{West Mansfield, . . . . . Mass.}

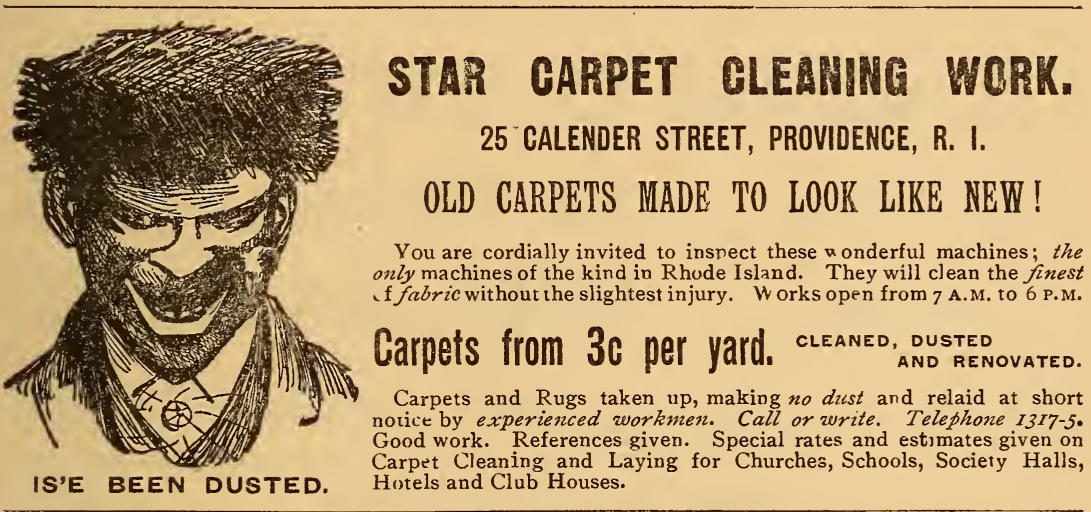

LIST OF STEAM RAILROADS, Continued.

Monterey \& Mex. Gulf Ry., Wall St., N. Y.

Montour R. R., Pittsburgh, Pa.

Montpelier \& Wells Riv. R. R. and Barre Branch R. R, Montpelier, Vt.

Montreal \& Sorel Ry., Montreal, Can.

Morgan's, Louis. \& Tex. R. R., (See Southern Pacific.)

Mount Washington R. R., Franklin, N, H.

Narragansett Pier R. R., Peacedale, R. I.

Nashville, Chattanooga \& St. Louis Ry., Nashville, Tenn.

Natchitoches Ry., Natchitoches, La.

Nevada, California and Oregon Ry., Reno, Nev.

Nevada Central R. R., Austin, Nev.

Nevada County N. G. R. R., Grass Valley, Cal.

New Brunswick \& Prince Edward Island Ry., Sackville, N. B.

Newburg, Dutchess \& Conn. R.R., Matteawan, N. Y.

New Jersey \& New York Ry., New York.

New London Northern R. R. (See Contral Ver.)

New Mexico \& Arizona, Topeka, Kan.

New Orleans, Fort Jackson \& Grand Isle R. R., Algiers, La.

New Orleans \& Southern R. R., New Orleans, La.
Newrort News, Miss. Valley Co., Cincinnati, 0.

N. Y. \& Greenwood Lake Ry. (N. Y., L. E. \& iW.)

New York \& Massachusetts Ry., Poughkeepsie, N. Y.

New York \& New England R. R., Philadelphia, $\mathrm{Pa}$.

New York \& Northern, High Bridge, N. Y.

New York \& Sea Beach Ry., New York, N. Y.

N. Y. Central \& Hudson River R: R., New York, N. Y.

N. Y., Chic. \& St. L. R. R., Cleveland, O.

New York, Lake Erie \& Western R. R., New York, N. Y.

New York, New Haven \& Hartford R. R., New Haven, Ct.

N. Y., Ontario \& West. Rv., New York, N. Y.

N. Y., Pennsylvania \& Ohio R. R. (See N. Y., L. E. \& W.)

New York, Philadelphid \& Norfolk R. R., Philadelphia, Pa.

New York, Providence \& Boston R. R. Leased to N. Y., N. H. \& H. R. R., Providence, R. I.

N. Y., Susqueh'na \& W'n, Jersey City, N. J.

Norfolk, Albermarle \& Atl., Norfolk, Va.

Norfolk \& Western R. R., Roanoke. V, 


\section{J. E. PLIMPTON \& 요, \\ [SUCCEssors to E. D. DRAPER \& Son.] \\ IRON FOUNDERS, MACHINISTS,}

JAPANNING, COPPERING, Etc.

BOSTON OFFICE : 154 PEARL ST. TELEPHONE NO. 33-3.

NORWOOD, MASS

Near Norwood Station.

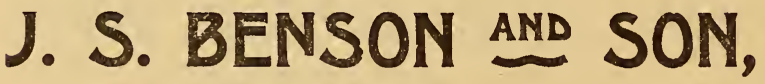 \\ mannatacurers of BOX WOOD. FOR TRUNKS and Deales in LUWBER, ALSO HARD \& SOPT WOOD.}

\section{SOUTH MIDDLEBORO, MASS.}

\section{LIST OF STEAM RAILROADS, Continued.}

Norfolk Southern R. R., Norfolk, Va.

North-Eastern R. R. (S. C.) (See A. Coast Line.) Northern Adirondack Ry, Santa Clara, N, Y,

Northern California R. R. (See So. Pac. Co.)

Northern Central Ry. See Penna R. $R$.

Nnrthern Pacific Ry., St. Paul, Minn.

North Pacific Coast R. R., San Francisco, Cal.

North-western Ohio Ry., (See Pa. Co.)

('hi) \& Big Sandy R. R., Lexington, Ky.

Ohio \& Mirsissippi Ry., Cin sinnati, o.

Ohio River R. R., Parkersburg, Va.

Ohio Southern R. R., Indianapolis, Ind.

Ohio Valley Ry.(Operated by Newport News \&

Miss. Valley Ry.,) Louisville, Ky.

Old Colony R. R., Boston, Mass.

Omaha \& St. Louis Ry., Council Bluffs, Ia.

Orange Belt Ry., Oakland, Fla.

Oregnn \& California R. R. (See Southern Pac. Co.)

Ore. Imp. Co., Seattle, Wash.

Oregon Pauific R. R., Corvallis, Ore.

Pacific Coast Ry. Co., San Luis Obispo, Cal.

Pacific Short Line Ry., Sioux City, Ia.

Paducah, Tennessee \& Alabama R. R., Padu$\mathrm{cah}, \mathrm{Ky}$

Panama R. R., Colon, U. S. Col.

Pennsylvania \& Northwestern R. R., Phil., Pa.
Pennsylvania Cnmpany operating Pitts., Fort Wayne \& Chicago; Massillon \& Clev.; So. Chi. \& South'n; Pittsburgh, Youngstown \& Ashtabula; Cleve. \& Pitts.; Erie \& Pitts.; Newcastle \& Bea. Val., and T. W. V. \& O., Pittsburgh, Pa.

Pennsylvania R R. Co.'s Roads,Seven Gen. Div's, Philadelphia, Pa.

Penn., P'k'psie \& Bost. R. R., Phila., Pa.

Pensacoia \& Perdido Ry., Pensacola, Fla.

Peoria \& Pekin Union Ry., Peoria, Ill.

Peoria, Decatur \& Evansville Ry., Mattonn, IIl.

Perkiomen Ry., Perkiomen Junction, Pa.

Philade'phia \& Erie R. R. (See Penna R. R. 5 Div.)

Phil., Harrisb. \& Pittsb. R, R. (See Phila. \& Read. R. R.)

Philadelphia \& Readng R. R., Philadelphia, $\mathrm{Pa}$.

Phila., Newtown \& New York R. R., Philadelphia, $\mathrm{Pa}$.

Phila., Wilmington \&. Balt. R. R. (See Penna R. R.)

Piedmont Air Line. (See Rich. \& Danville.)

Pittsburgh, Akron \& Western R. R, Allegheny,

Pitts. \& Castle Shann'n R. R., Pittsburgh, Pa.

Pitts. \& L, Erie R. R. Cleveland, 0 .

Pitts. \& Western Ry. Allegheny, Pa. 


\section{G. F. BAGLEY, CONTRACTOR AND BUILDER,}

NORWOOD, MASS.

Estimates and Plans Furnished. . . . Work Promptly Done.

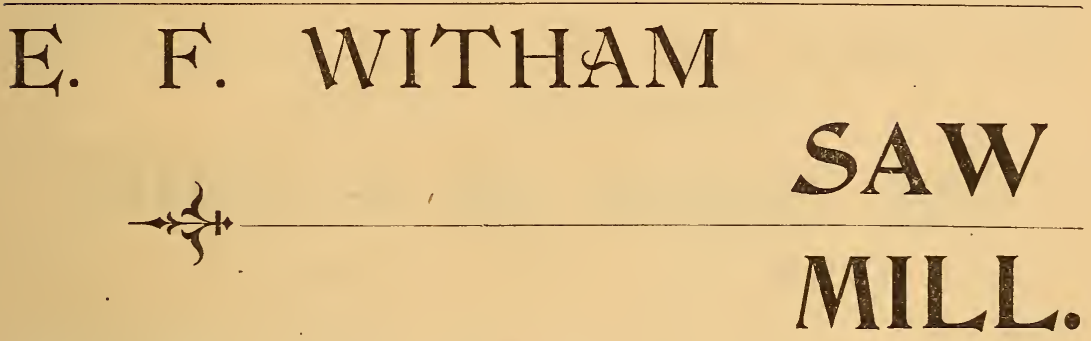

\section{South Middleboro", Mass.}

\section{LIST OF STEAM RAILROADS, Continued.}

Pittsburgh, Chartiers \& Youghiogheny Ry., Pittshurgh, $\mathrm{Pa}$.

Pittsburgh, Bradford \& Buffalo Ry. (See Pitts. \& West.)

Pittsburgh, Ft. Wayne \& Chicago Ry. (See Penn.a. Co.)

Pittsburgh, Marion \& Chicago, New Lisbon, 0.

Pitts., McK. \& Yough. (See P. \& L. E.)

Pittsburgh, Shenango \& Lake Erie Ry., Greenville, $\mathrm{Pa}$.

Pittsburgh, Youngstown \& Ashtabula. (See Penn. Co.)

Pontiac, Oxford \& Northern R. R., Pontiac, Mich.

Pontiac Pacific Junc. Ry., Montreal, Dan.

Portland \& Rochester R. R., Portland, Me.

Portland \& Rumford Falls Ry., Canton, Me.

Potomac, Fred.'g \& Pied. R. R., Fredericksburg, Va. Prescott \& Arizona Cent. Ry., New York,
N.Y.

Prince Edward Island Ry., Ottiawa, Ont.

Profile \& Franconia Notch R. R. Concord, N. H.

Prospect Park \& Coney Island, R. R., Brooklyn, N. Y.

Prov. \& Springfield R. R. Leased to N. Y. \& N. E. R. R.

Pullman Palace Car Co. Chicago, ill.

Quebec \& Lake St. John Ry., Quebec, Can.

Quebec Central Ry., Sherbrooke, P. Q.

Quincy, Omaha \& Kan. City Ry, Quincy, Ill.

Raritan River R. R., South Ainboy, N. J.

Richmond \& Danvill R. R. Co., Atlanta, Ga .

Richmond \& Petersburg R.R., Wilmingt: n, N. C.

Richmond, Fredericksburg \& Potomac R. R., Richmoud, Va.

Rio Grande Western Ry. Denver, Colo.

Rio Grande \& Eagle Pass Ry., Laredo, Tex.

Rio Grande R. R., Brownsville, Tex.

Rochester \& Lake Ontario Ry, Rochester, N. Y.

Rock Island \& Peoria Ry., Rock Island, Ill.

Rome \& Decatur Ry., Atlanta, Ga.

Rome (Ga.) R. R., Rome, Ga.

Rome, Watertown \& Ogdensburg R. R., (N. Y. C. \& H.R.R.R. Lessee, ) Oswego, N. Y.

Sabine \& East Texas Ry. (See So. Pac.)

Saginaw, Tuscola \& Huron R. R., Saginaw, E. S. Mich.

Saginaw Valley \& St. Louis R. R. (Det. Lan. \&. Northern.)

St. Augustine \& South Beach Ry., St. Augustine, Fla.

St. Croix \& Penobscot R. R., Calais, $M_{\infty}$ 


\section{CHAMBERS, CALDER \& CO., Estralasent 1853. $* * * * * *$ Wholesale Druggists}

PATENT MEDICINES, DRUGGISTS' SUNDRIES, DRUGGISTS' GLASS WARE, CHEMICALS, PAINTS, OIL, VARNISHES AND

WINDOW GLASS.

\section{II and 12 Exchange Place,}

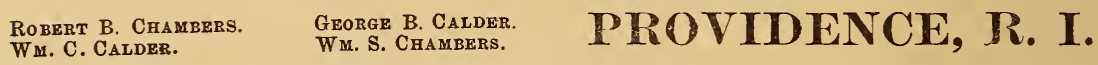
NORWOOD IRON FOUNDRY, NORWOOD, MASS. IRON FOUNDERS AND MACHIIISTS, COPPERING AND JAPANNING.

WORKS:

Near Norwood Central Station. BOSTON OFFICE:

101 Portland Street.

\section{LIST OF STEAM RAILROADS, Continued.}

St. Johnsbury \& Lake Champlain R. R., Lyndonville, Vt.

St. Joseph Valley Ry., Berrien Springs, Mich.

St. Louis, Cape Girardeau \& Ft. Smith Ry., Cape Girardeau, Mo.

St. Louis, Cape Girardeau \& Southwestern Ry., Cape Girardeau, Mo.

St. Louis \& Hannibal, Hannibal, Mo.

St. Louis \& San Francisco Ry., St. Louis, Mo.

St. Louis, Aiton \& Springfield R. R., St.Louis, Mo.

St. Louis, Alton \& Terra Haute R. R., St. Louis, Mo.

St. Louis Southwestern Ry. Co., St. Louis, Mo.

St. Louis Bridge and Tunnel R. R. (See Terminal $R$. R. Asso. of St. Louis.)

St. Louis Coble \& Suburban Ry., St. Louis, Mo.

St. Louis, Iron Mt. \& So'n Ry. (See Mo. Pac. (4) Div.)

St. Louis, Kan. City \& Colorado R. R., St. St. L., Keokuk \& No-W'n. Ry. (See C. B.\& Q.) St. Paul \& Duluth R. R., St. Paul, Minn.

Salisbury \& Harvey Ry., Hillsboro, N. B.

San Antonio \& Aransas Pass Ry., San Antonio, Tex.

Louis, Mo.

Sandersville \& Tennille R. R, Sandersville, Ga.
Sandy River R. R., Phillips, Me.

San Francisco \& No. Pac. Ry., San Francisco, Cal.

San Pete Valley R. R., Salt Lake City, U. T. Santa Fe Southern Ry., Santa Fe, N. Mex. Sault Ste. Marie \& Southwestern R. R., Fairchild, Wis.

Savannah, Americus \& Montgomery, Americus, Ga.

Savannah, Florida \& W'n Ry., Savannah, Ga.

Sav., Griffin \& No. Ala. R. R. (Op. by Central Ga.)

Seaboard Air Line, Raleigh, N, C.

Seaboard \& Roanoke and Roanoke \& Tar River, Raleigh, N. C.

Raleigh \& Gaston and Louisburg R. R., Raleigh, N. C.

Raleigh \& Augusta Air Line, Portsmouth, Va.

Georgia, Carolina \& Northern, Raleigh, N, C.

Seattle, Lake Shore \& Eastern Ry. Operate the Northern Pac. Co., Seattle, Wash.

Sharpsville R. R., Pittsburgh, Pa.

Shepaug, Litchfield \& Northern R. R., Litchfield, Ct.

Shreveport \& Houston. (See Hous., E. \& W. Tex.)

Shore Line Ry., St. John, N. B.

Silver Lake Ry., Perry, N. Y.

Silver Springs, Ocala \& Gulf R. R., Ocala, 


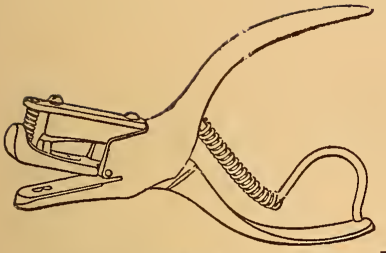

Patents.

April 30, 1867. Sept. 21, 1869 Oct. 9,1877 , July 18,1882 . Oct. 5,1886 . July 28,1890

Aug. $4,1891$.
ESTABLISHED 1865 .

\section{O. GROCKER,}

- Manufacturer of -

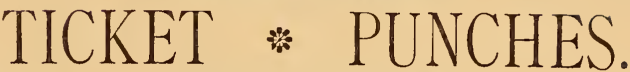

The Original Inventor of Fancy and Complicated Dies for Ticket Punches.

PLEASE SEND FOR CIRCULARS.

EAST BRAINTREE, . . . . . . . MASS.

\section{EXCELSIOR NORWOOD STEAMI LAUNDRV, BROADWAY.}

\section{J. SULLIVAN, MANAGER.}

Cleansing of Kid Gloves, and Ladies and Gent's Suits a Specialty SATISFACTION GUARANTEED.

Norwood, $==-$ - Mass.

\section{LIST OF STEAM RAILROADS, Continued.}

Sinnemanoning Valley R. R., Austin, $\mathrm{Pa}$

Sioux City \& Northern R. R., Sioux Dity. Ia.

Sioux City \& Pacific and Fremont, Elkhorn \& Mo. Val. R. R. Omaha, Neb.

Skaneateles R. R., Skaneateles. N. Y.

Slate Run R. R., Slate Run, Pa.

Somerset Ry., Oakland, Me.

Sonora Ry., Topeka, Kan.

South Atlantic \& Ohio R. R., Bristol, Tenn.

South Bound. R R., Savannah, Ga.

South Carolina Ry., Charleston, S. C.

South Chicago \& Southern Ry., (See Penna. Co.)

Southern California Ry., Los Angeles, Cal.

Southern Pacific Company, San Francisco.

Southern Pacific Co. Coast Division, San Francisco, Cal.

South Florida R. R., Sanford, Fla.

South Manchester R R., So. Manchester, Conn.

South \& North Carolina R. R., Atkins, S. C.

South Pacific Coast R. R., San Francisco.

Spokane Falls \& Northern R. R. Co., Spokane, Wash.

Staten Island Rapid Transit R. R., New York. Sterling Mountain Ry., Sterlington, N. Y.

Stewartstown R. R., Stewartstown, Pa.

Stony Clove \& Catskill Mountain R. R., Rondout, N. Y.

Sturgis, Goshen \& ISt. Louis Ry. (See Battle Creek \& Sturgis Ry.)

Suffolk \& Carolina Ry., Suffolk, Va.
Suwannee River Ry., Ellaville, Fla.

Syracuse, Geneva \& Corning. (See Fall B. Coal Co.)

Tacoma \& Puyallup. R R. Co., Tacoma, Wash. Talbotton Ry., Talbotton, Ga.

Tav., Orl \& Atl. R. R. (Op. by Fla. Cen. \& Penn. R. R.)

Tennessee MidlandRy., Memphis, Tenn. Terminal Ry. Association of St. Louis, St.
Louis, Mo.

Terre Haute \& Indianapolis R. R ., Terre Ha u te, Ind.

Terre Haute \& Peoria R. R., Decatur, Ill.

Tex ^rkana \& Ft. Smith Ry., Texarkana, Tex.

Texas Central Ry., Waco, Tex.

Texas \& N. Orleans. R R. (See So. Pac.)

Ttxas C. Pacific R. R., Marshall. Tex.

Texas Panhandle Route, comprising Fort Worth \& Denver City, Denver, Texas Gulf, and Denver, Texas \& Fort Worth Rys. (Op. oy Un. Pac.)

Texas, Sabine Valley \& Northwestern Ry. Longview, Tex.

Texas Trunk R. R., Dallas, Tex.

Texas Western Ry., Houston, Tex.

Tionesta Valley R. R., Sheffleld, Pa.

Toledo \& Ohio Central Extension R. R., Marietta, 0 .

Toledo, Ann Ar., \& No. Mich. Ry., Toledo, Ohio. Toledo, Columbus \& 'Ci"cinnati Ry., Toledo,
Ohio.

Toledo \& Obio Central Ry., Toledo, o. 


\title{
STEVENS \& WILLIS,
}

MANUFACTURERS OF ALL KINDS OF

\section{Iron, Zine and Copper Shoe Nails and Tacks, and Steel Shanks.}

\section{HUNGARIAN, CLOUT, CHANNEL, CHAIR, CIGAR-BOX AND FINISHING NAILS.}

Upholstery, Carpet, Gimp, Brush, Lace,

Carriage, Saddlery and Matting Tacks.

\author{
NAILS FOR \\ MCKAY, AMERICAN, NATIONAL AND BIGELOW HEELING MACHINES
}

Shoe Tacks for Machine driving Made a Specialty.

GEO. D. WILLIS.

\section{LIST OF STEAM RAILROADS, Continued.}

Toledo, Peoria \& Western Ry., Peoria Ill.

Toledo, Saginaw \& Muskegon Ry. See C. \& $G$. T. $R . R$.

Toledo, St. Louis \& Kan. City R. R., New York, N. Y.

Tuckerton R. R., Tuckerton, N. J.

Ulster and Delaware R. R., Rnndout, N. Y.

Union Pacific Ry., Boston, Mass.

Union Tank Line Co., New York, N. Y.

Upper Coos \& Hereford R. R. Colebrook, N. H.

Valley Ry., Cleveland, Ohio.

Vermont Valley R. R., (See Conn. River R.R.)

Vicksburg \& Meridian R. R., (See Cin., N. O.\& Tex. Pac.)

Vicks., Shreve., \& Pac. R. R., (See C., N. O. \& $T, P$.)

Virginia \& Truckee R. R., New York, N. Y.

Virginia Midland Ry. (See Rich. \& Dan., (4)Div.)

Wabash R. R., St. Louis, Mo.

Wabash, Chester \& Western R. R., Chester, Ill.

Wagner Palace Car Co., New York, N. Y.

Walden's Ridge R. R. (East Tenn. Va. \& Ga., Lessee.) Knoxville, Tenn.

Wallkill Valley, New York, N. Y.

Washington S uthern Ry. Co., Seattle, Wash.

Waynesburg \& Washington R. R., Waynesburg, Pa.

Webster City and Southwestern R. R., Lehigh, Ia.

Western \& Atlantic R. R., Atlanta, G».

Western Counties' Ry., Yarmouth, N. S.

Western Maryland R. R., Baltimore, Md.

Western New York and Pennsylvania R. R., Buffalo, N. Y.

Western No. Carolina R. R., (see Rich \& Danville.)

Western R. R. (of Ala.) and Cin., Cel. \& Mob. Montgomery, Ala.

West Jersey R. R. (see Penn. R. R., $3 d$ Div.)

West Shore R. R., (N. Y. C. \& H. R. R. Lessee.) New York, N. Y.

W. Va. Cent. \& Pittsburgh Ry., Cumberland, Md.

W. Va. \& Pittsburgh R. R., Weston, W. Va.

White and Black River Valley Ry., Little Rock, Ark.

Wheeling \& L. E. Ry. Toledo, 0 .

Wichita \& Western Ry. (Operated by A. T. \& S. F. Ry., Wichita, Kan.)

Wilkesbarre \& Western Ry., Watsontown, Pa. Williamsport \& No. Br. R. R., Hughesville, Pa. Wilmington \& No'n R. R., Wilmington, Del.

Windsor \& Annapolis Ry., Kentville, N. S.

Winifrede R. R., Philadelphia, Pa.

Winona and South Western, Winona, Minn.

Wisconsin Central Co. (Northern Pac. Co. Lessee.) Chicago, Ill.

Wood River Branch Ry., Hope Val., R. I.

Woodruff Sleeping\&Parlor Coach Co., Chicago.

Worcester \& Shrewsbury R. R., Worcester, Mass.

Yougiogheny R. R., Irwin, Pa.

Zょnesville \& Ohio River Ry., Zanesville, 0.

Zealand Valley Ry, Zealand, N. H. 


\section{PROMINENT HOUSES, AND INDEX TO DESCRIPTIVE ARTICLES.}

Aberogwen Monumental Works

Adams, John

Alden \& Pratt

Alpaugh, J.M., \& Co.

Allen's Print Works

Allen \& Walker

Ambler \& Hobart

American Chemical Co.

American Heeling Machine Co

American House, The, E. Bridgewater

American Ring Traveler Co., The

American Screw Co.

American Tool \& Machine Co.

Ames, Oliver, \& Sons Corporation

Ashley, Charles S., Hon.

Atlantic House, The, Nantasket

Atlantic House, The, Provincetown

Atlas Tack Corporation

Attleboro Watch Case Pendant Co.

Atwood Brothers

Atwood, C. N.

Auburn Last Co.

Averell \& Thayer

Avery, W. W.

Badger Bros.

Bagley, G. F.

Baker, Walter, \& Co.

Baker, Walter,

Barkes, Delbert L.

Barker Manufacturing Co.

Barnes, A. S.

Barnicoat, S. Henry

Bates \& Bacon

Bates Button Co.

Bates, James E.

Battles, A. A

Baxendale \& Co.

Baxendale, T. A.

Bay State Carpet Co.

Bay State Hammock Co.

Bay State Shirt Co.

Belcher Malleable Iron Co.

Bens, William

Benson \& Austin

Benson, J. S., \& Son

Bent \& Co.

Bicknell, George $\mathrm{H}$.

Bigelow Carpet Co.

Bird, F.W., \& Son

Bizzozero, E., \& Co.

Blackinton, R., \& Co.

Bliss Bros.

Bliss \& Nye

Blood Bros.

Blossom Bros.

Bonney, George H., Jr.

Bosworth, W.F.

Bowker \& Tripp

Bradford Joint Company

Brady J. William

Braintree House, So. Braintree

Bridgewater Box Co.

Bridgewater \& Boston Express Co.

Briggs, J. \& Sons Co. The,

Briggs, D. F. Co.

Brightman, Charles 0.

Brightman \& Washburn

Bristol Printing Co.

Brockton Last Company
Brockton Mallet Co.

Brockton Marble \& Granite Works

Brown \& Sharpe Manf'g Co. $\quad 498$

$\begin{array}{ll}\text { Buck, C. A., \& Son. } & 473 \\ \text { Burke, Thomas F., \& Bros. } & 269\end{array}$

Burns \& Cormack \& Bros. 275

Burr \& Kingman $\quad 155$

Burr, George W. $\quad 339$

Burton, David 213

$\begin{array}{ll}\text { Buswell, C. H, \& Co. } & 416 \\ \text { Callahan, William } & 257\end{array}$

Callahan, Wiliam $\quad \mathbf{2 5 7}$

Carey, A. C.

Card, S. W .\& Co.,

Carpenter, Edmund $\quad 223$

Carpenter \& Company $\quad 461$

Cashman, John 275

Carter, George A.

Central House, The, Plymouth, 362

$\begin{array}{ll}\text { Central House, The, Provincetown, } & 405 \\ \text { Chambers, Calder, \& Co. } & 225\end{array}$

Chambers, Calder, \& Co. $\quad 225$

Chase, E. B., \& Co. $\quad 312$

Chipman, Calley \& Co. $\quad 365$

Church \& Russell Co. 201

Churchill \& Alden $\quad 165$

Claflin, George L., \& Co. $\quad 209$

Clapp, Edwin $\quad 337$

Clark, Alexander 253

Clark \& Cole 378

$\begin{array}{ll}\text { Clark Manufacturing Co. } & 211 \\ \text { Clifford, Robert } & 167\end{array}$

$\begin{array}{ll}\text { Clifford, Robert } & 167 \\ \text { Clinton House, Clinton } & 419\end{array}$

Clinton Wire Cloth Co. $\quad 417$

Cobb, Wendell H. 311

Codding Bros. \& Heilborn $\quad 454$

Codding, D. E., \& Co.

Colburn, A. W. $\quad 416$

Cole, H. C. \& W. S. 348

Cole, John 273

$\begin{array}{ll}\text { Columbian Manufacturing Co. } & \mathbf{1 4 3} \\ \text { Combination Ladder Co. } & \mathbf{2 1 1}\end{array}$

Copeland, Ellis F. $\quad 171$

Covel \& Osborn 321

Craig \& Richards $\quad 265$

Cranda1l, J. E.

Crocker Harness Co. $\quad 213$

Crocker, L. 0 . 333

Cummings, E. D., \& Co. $\quad 229$

Curtis, William S. $\quad 368$

Cushiug, M. H., \& Co. 377

$\begin{array}{ll}\text { Cushing House, The, Hinghan } & 338 \\ & 297\end{array}$

Cushman, H. L., \& Co. $\quad 297$

Darling, G. B.

Darling, G. B.
Davis, J. S. \& C. W,

Dawson \& Co. 459

Deacon Bros.

Dell, Lewis, \& Co. $\quad 253$

Deane, A. M., \& Co. $\quad 261$

Dean, T. H. 388

$\begin{array}{ll}\text { Denison Bros. \& Co. } & 303 \\ \text { Derby Hotel, E. Weymouth } & 338\end{array}$

Desmond, James F.

Diamond Tack \& Nail Works 388

Dighton Furnace Co. 391

Dighton Stove Lining Co. $\quad 389$ 
Drake Local Express

Draper, O. M

Drew, P. A. \& Co.

Duff, David, \& Son

Duffy, John P.

Dun var, Willard L., \& Co.

Eagle Stove Foundry Co.

Edson, W. H.

Einstein, S. M.

Elcock \& Son

Eldridge \& $\mathrm{Co}$.

Elizabeth Poole Mills, The

Ellis, Livsey \& Co.

Elm Tree Inn, Medfield

Emery \& Packard

Erickson, Andrew

Evans, D.

Evans Cobb \& Co.

Excelsior Steam Laundry

Fales, A., \& Sons

Fales, Frank A.

Fall River Machine Co.

Fallon, John, \& Sons

Farwell, W. M. \& Co.

Fegan \& Ballou

First National Bank, Provincetown

Fisher, J. M., \& Co.

Fisher, W. D., \& Co.

Fitzgerald \& Elcock,

Fitzpatrick, J. \& H.

Flexible Shoe Mfg. Co.

Flint, Blood \& Co.

Folsom, A., \& Sons

Ford, L. E., \& Co.

Fore River Engine Co.

Fox boro Foundry \& Machine Co

French, John

French \& Hall Co., The

Frizzell, J. E.

Frye, George W

Fuller, J. S.

Galvin Granite Co.

Gannett \& Co.

Gardiner, Ezekiel

Gay, F. J., \& Co.

Giffurds Hotel

Gifford, Charles H.

Girard Hotel, Providence,

Gladding, B. H., \& Co.

Glencoe Granite Co.

Goddard \& Rogers

Gold Medal Braid Co.

Goss, Abel,

Gove's Express.

Granite Railway Co.

Grant, J. W. \& Co.

Gray, Charles A.

Gray, s., \& Co.

Gray, T. H. \& Co

Gray, W. H.

Greenwood, C. B.

Greenwood, Sidney

Grover, R. B. \& Co.

Guy's Furniture Co.

Hamilton, T. J.

Hammond \& Richmond,

Hardwick, C. H. \& Co.

Hardwick, Franklin, \& Son.

Hargraves Manufacturing Co.

Harper, C. S.

Hart \& Akin

Hart, J. W., \& Co.

Hart, J. W., \& Co.

Hathaway, H. C. Capt.

Hathaway, J. R.

Hayden, F. W.

Hayes, D., \& Sons

Hay ward Carriage Co.

Healey \& Welch

Herrod, A. M.

Hewins, L G.

Heywood, M., \& Co.

Hildreth, Milo
229

454

431

314

259

155

323

362
451

271

297

424

145

263

455

433

479

438

479

405

449

455

263

468

467

203

443

347

335

429

461

36

348

323

213

257

215

311

198

(12

(203

205

205
257

149

455

471

382

249

215
307

427

427
442

145

423

351

163
145

145
219

373

255

259

321

445

310

335

298

310

331

377

271

385
351

149

312

325

421
Hitchcock, George H., \& Co. 253

Hodges, A. B. \& Co.

Hollis \& Dearborn

Hooper \& Co. $\quad 372$

Horn \& Supply Co. 415

Hotel Aumann, $\quad 462$

Hotel Nantasket, The, Nantasket, $\quad 344$

Household Sewing Machine Co.

Howard \& Foster 163

Hub Gore Makers 143

Hudson, H. W. Co. The, 225

Huebener, E. A., \& Co. 471

Hughes, P. F., \& Son 273

Inman, M. M., \& Co. $\quad 227$

Inman, J. T., \& Co. 449

Jackson \& Campbell 367

Jenkins, Z. A. 369

Jenney, James L. $\quad 377$

Jenney, William S. $\quad 315$

Jillson \& Folsom. 219

Johnson. C., \& Bros. $\quad 257$

Johnson, C. E., \& Co. 155

Johnson, Oliver, \& Co. 225

ohnson \& Porter,

Jones, George A. $\quad 357$

Jordan, W. H.

Joss Bros, 253

Keith, Edwin 165

Keith, George E. 143

Keith, Preston B. 151

Keith, Ziba C., Hon. $\quad 159$

Keith \& Pratt 373

Kelley, Orick H. 359

Kelley, T. F., \& Co. 351

Kelley, Zeno H. 388

Kemp, Joñn F. $\quad 265$

Kennedy, M. F. 309

Kimball Bros. \& Co. 149

King, J. B. 385

Kingman, E. B., \& Co. 415

Kingman, H. M.

Knapp Warren Co., The 477

Knight, Geo., \& Co. 169

Kyle, Bradford, \& Co. $\quad 360$

Lane, C. E. $\quad 366$

Lane, George A. $\quad 461$

Langelier Manufacturing Co. 231

Leach, Wendell \& Co. $\quad 147$

Le rned, A. C. J. 217

Le Baron Foundry Co. $\quad 376$

Le Valley, H. E. $\quad 235$

Leeds, George S., \& Co. $\quad 473$

Leominster Shirt Co. 411

Lincoln Bros., 340

Lincoln, Bacon \& Co. $\quad 476$

Lippard, Willi.ım C.

Littlefield, L. G. $\quad 179$

Littlefield, Ralph R. $\quad 167$

Lockey, J. H. , Piano Case.Co. 413

Long \& Saunders, 265

Lothrop, H. A., Mf'g. Co.

Luther,C. A., \& Co. 459

Luther, J.W., \& Co. 449

Lyons, A. S. $\quad 372$

Lyons, C. D., \& Co.

Lyon, William E. $\quad 353$

Maguire \& O'Heron, 466

Maintein, J. B., \& Son, 477

Mansfield, G. H., \& Co. 443

Mansfield'News, 433

Mansion House, The, New Bedford, $\quad 311$

Marlboro Dye House, 423

Marnock, A., \& Co. 267

Marshall, H. T. 161

Marsh \& Bigney, $\quad 449$

Mason, Chapin \& Co. . $\quad 205$

225

Mason Machine Works, $\quad 287$

Mason, Volney W., \& Co. $\quad 217$

Massasoit Mf'g. Co. $\quad 325$

Mathaurs Bros.

Matheson, D. A. 
Maxim, C. W

McCabe, B. H.

McComber, J. B.

McDonnell Bros.,

McDonnell \& Sons,

McDonnell \& Kelley.

McGillvray \& Jones.,

McGrath Bros.

McIntosh \& Sons,

McKenzie \& Paterson,

Mechanics National Bank, New Bedford

Melpi, R. A.

Melleu \& Leach

Merchants National Bank, New Bedford,

Merriam, F. A., \& Co.

Merry Mount Granite Co.

Milne \& Chalmers,

Miller, George L.

Miller, Henry J.

Miller, O. A.

Miller, William H., \& Sons,

Mitchell Granite Co.

Mitchell, Isam, \& Co.

Monahan \& Breen,

Moore \& Booth,

Moore, Charles H.

Morrison, A. S., \& Bros.

Mosso Brothers,

Mount Hope Iron Co.

Mount Vernon Granite Co.

Nemasket House, The, Middleboro'

Nesmith F. E., \& Co.

New Bedford Cordage Co.

New Bedford Steam Laundry

New Bedford Tow Boat Co.

New England Rattan Co.

New England Specialty Co.

New Process Twist Drill Co.

Nichols, S. H.

Nicoll's Granite Works

Nilec \& Wilbur.

Norwood Iron Foundry

Nourse, Fred F.

O'Brien \& McNeil,

O'Brien, W. P.

Old Colony Cotton Mills,

old Colony National Bank, Plymouth,

old Colony Steam Laundry,

O'Neil \& Howes

Opera House Hotel \& Cafe, Attleboro Oswald \& Moyle,

Owens, M.

Packard, Andrew F.

Packard, D. S., \& Co.

Packard, N. R.

Packard \& Field,

Paine, Stephen,

Paisler, Charles S.

Pairpoint Manufacturing Co.

Parker House, The, New Bedford,

Paton Manufacturing Co.

Patten, O. O., \& Co.

Paluxet House, The, Kingston,

Pawtucket Funiture Co.,

Pearce, John R., \& Son,

Pearse, W. G.

Peckham, George A.

Perkins \&' Joyce,

Phenix Iron Foundry.

Phillips, E. W.

Phillips, Thomas, \& Co.

Phinney, J. G., Counter Co.

Phoenix Manufacturing Co., The

Pierce, Charles $\mathrm{S}$.

Piper, Cottle \& Co.

Plainville Stock Co.

Plimpton, J. E., \& Co.

Plymouth Cordage Co.

Plymouth Foundry Co.

Plymouth Woolen Co.
Poole's Granite \& Marble Go. 419

Possner, A. P. 235

Powers, E. S.,Dr.

Powers, F. J.

Pratt, T, D. $\quad 207$

Presbrey Stove Lining Co. $\quad 291$

Prophet Spring, The, 229

Prout Bros. Granite Co. $\quad 269$

Providence Belting Co. 199

Providence Coal Co. 199

Providence Creamery, 213

Providence Gas Co. 205

Providence Machine Co. $\quad 199$

Puritan Shirt Factory, 403

Putman Horse Shoe Nail Co. $\quad 471$

Ransden, N. A. W. 161

Rathbone \& Smith, 219

Reed, E. P. 353

Reed, H.B., \& Co,

Reed \& Barton Corporation, $\quad 289$

Regnell, Bigney \& Co, $\quad 450$

$\begin{array}{ll}\text { Reinhaiter, A. } & 269 \\ \text { Reinhalter, J. B. } & 271\end{array}$

$\begin{array}{ll}\text { Reinhalter, J. B. } & 271 \\ \text { Reynolds, A. P. } & 147\end{array}$

Reynolds, Bion F. $\quad 161$

Reynolds, E. H.

$\begin{array}{ll}\text { Reynolds, E. H., Co., The, } & 225 \\ \text { Reynolds, L. M. } & 165\end{array}$

$\begin{array}{ll}\text { Reynolds, L. M. } & 165 \\ \text { Rhode Island Ceinent Drain Pipe Co. } \quad 217\end{array}$

Rhode Island Perkins Horse Shoe Co. 197

Richardson \& Bottomley

Richmond, L., \& Co. 149

Ripley \& Bartlett $\quad 361$

Rising Sun Stove Polish $\quad \mathbf{4 4 3}$

$\begin{array}{ll}\text { Robbins, John S. } & 361 \\ \text { Robin } & 478\end{array}$

Robinson Bros. $\quad 478$

$\begin{array}{lr}\text { Robinson, George A. } & 433 \\ \text { Robinson, J. T. } & .442\end{array}$

Rockland Co., The $\quad .442$

Ryder, J. J., Co. $\quad 211$

Sadler, F. H., \& Co. $\quad 450$

$\begin{array}{ll}\text { Samoset House, The, Plymouth } & 361 \\ \text { Sandland \& Capron, } & 453\end{array}$

$\begin{array}{ll}\text { Sandland \& Capron, } & 453 \\ \text { Sargent, Anglim \& Keith } & 147\end{array}$

Sargent J. S., \& Son 149

Searle, Dailey \& Co. $\quad 425$

Sears, J. K. \& B., \& Co. $\quad 376$

Shea, William, \& Son. 253

$\begin{array}{ll}\text { Sherman, C. E. W., \& Son } & 453 \\ \text { Sherman, S. H. } & 337\end{array}$

Short, Nerney \& Co. $\quad 450$

Simmons, C. N. 389

Simpson, S. D., \& Son $\quad 387$

Simpson Spring $\quad 387$

Smithfield Granite Co. $\quad 215$

Smith Concrete Co. $\quad 219$

Smith \& Crosby $\quad 450$

Smith, Jason $\quad 366$

Smith, J. R.

Smith, J. S.

Smith \& Stoughton $\quad 355$

$\begin{array}{ll}\text { Smith, William A. } & 261 \\ \text { Smith \& Wade, } & 151\end{array}$

Snell \& Atherton $\quad 153$

Somerset \& Johnsonburg Mig. Co. $\quad 391$

Somerset Stove Foundry $\quad 303$

$\begin{array}{ll}\text { Soule Piano \& Organ Investment Co. } & 295 \\ \text { South Framingham Hotel } & 439\end{array}$

$\begin{array}{ll}\text { Sonth Framingham Hotel } & 439 \\ \text { Sowle, Nat. P. } & \mathbf{3 1 2}\end{array}$

Spargo, William T. $\quad 277$

Spencer, H. L. $\quad 459$

Spencer, J. L. $\quad 459$

Spier \& Coles, 450

Spooner, C. A., \& Co. $\quad 461$

Stand urd Rubber Mills $\quad 167$

Star Carpet Cleaning Works $\quad 215$

Star Tanning Co. $\quad \mathbf{4 5 7}$

Stearns, A. T., Lumber Co. $\quad 472$ 
Stetson, E. H., \& Co.

Stetson, Warren B.

Stevens, Thomas A.

Stevens \& Willis

Stone, C. F. \& A. W.

Stone, E. D.

Strange's Machine Works

Studley, Gideon, Jr.

Sullivan, J. D.

Sun Enamel Works

Swasey \& Grew

Sweetser, William A.

Swift, J. R.

Swingle \& Falconer

Swithin Bros.

Tannatt, James C.

Taunton Brick Co.

Taunton Copper Mfg. Co.

Taunton Crucible Co.

Taunton Lumber Co.

Taunton Stove Lining Co.

A. E. Tenney,

Tenney, Charles.

Terry, Ware \& Alley,

Thomas \& Miller,

Thomas, Myron F.

Thompson, A. C.

Thompson Bros,

Thompson, H. E.

Thompson, John, \& Sons,

Thompson, William M.

Thomson Bros.

Thurston, George H.

Tisdale, A. A. \& Co.

Torrey, Winfred A.

Tougas, J. $\mathrm{O}$.

Tower Bris. \& Co.

Tripp, U. T.

Turner, J. S

Turner, William

Twomey, \& Brennan

Twomey George W.

349
376
363
330
382
438
293
366
314
415
153
167
413
261
249
161
293
289
291
171
297
461
418
143
265
169
159
163
478
255
155
439
219
413
331
161
339
323
366
259
382
463

Union Hotel, Leominster.

Union Marble Works

Union Straw Works,

Universal Loom Cu.

Vanier.\& Slattery,

Wade, Davis \& Co.

Wade, Huram,

Wadsworth,

Walker, George F.

Walker \& Whitman

Wardle,'H. L., Ph. G.

Waterman, E. C.

Weaver, F. W., \& Co,

Webster, Charles

Weir Brick Co., The

Weir Stove Co.

Westmacott, J. M. \& Co.,

Weymouth Mitten Co.

Wheaton, Richards \& Co.

White, D. D., Shoe Co.

White, Frank E.

White, Stillman

Whitman Grain \& Coal Co.

Whitman Insurance Agency

Whitman \& Keith,

Whitten, C, L.

Wilmarthodding Cycle Co.

Willey, G. W.

171

Williams, Alex. H. \& Geo. F. 295

Willisou, E. C.

Williston, C. H.

Wilson Lace Clasp Co.

Wilton Mills,

Winkfield \& Gregg,

Witham, E. F.

Wood sum B. H, Wollaston

Woodward Fnterprise Mfg $\mathrm{Co}$.

Woodward \& Wright

$\begin{array}{ll}\text { Wood ward \& Wright } & 163 \\ \text { Young, A. H. \& A. F. } & 431\end{array}$

416

161

293

451

153

153

153

463
368

450

293

291

351

49

151

223

2

53

07

95

251

393

42 .

9

\section{INDEX TO ADVERTISEMENTS.}

Aberogwen Monumental Works 244

Adams, John

Alden \& Pratt

Allen \& Walker

Allen's Print Works

Alpaugh, J. M. \& Co.

Ambler \& Hobart

A merican Heeling $\mathrm{Machine}$ Co.

American House, 138 water,

American Ring Traveler Co. The 370

American Steam Guage Co. The. 316

American Tool \& Machine Co. The 230

Appleton, George B. \& Co. 234

Ashley \& Peirce 304

Atkinson, B. A. Co. $\quad$ I3 I

Atlantic House, The, Province'own, 402

Atlantic House, The, Nantasket, 342

Atlas Tack Corporation, The $\quad 282$

Attleboro Watch Case Pendant Co., 448 The

Atwood Brothers

Atwood, C. N.

Auburn Iast Co. The

Averell \& Thayer

Badger Bros.

Bagley, G. F.

Baker, Robert W.

Bancroft's Livery S'table
Barker, Delbert L. 216

Barker Mfg. Co. 220

Barnicoat, S. Henry $25^{2}$

Bates \& Bacon 444

Battles, A. A. I 75

Baxendale \& Co. I74

Bay State Carpet Co. I40

Bay Sıate Hammock Co. The 336

Belcher Malleable Iron Co. 395

Bemis, A. F., Hat Co. The 428

Bens, William 220

Benson \& Austin 322

Benson, J. S. \& Son 500

Bent \& Co., Front A

Bicknell, George H. 334

Big $\in$ low $r$ arpet Co. The $\quad 418$

Bird, F. W. \& Son $\quad 426$

Bizzoz`ro, E. \& Co. 270

Blackinton, R. \& Co. $\quad 452$

Bliss \& Nye 306

Blossom Bros. $\quad 302$

Blood Bros. $\quad 496$

Bosworth, W. P. I 50

Bowker \& Tripp 300

Bowman's Bridgewater \& Boston Express

Brady, J. William,

Bradford Joint Co. The $\quad 356$

Br'ggs, J. \& Sons Co. 2 I 4

Brightman, Charles O. 308 
Bristol Printing Co.

Bridgewater Box Co.

$3^{84}$

497

Brockton Button Hole Co.

Brockton Last Co.

Brockton Mallet Co.

Brockton Savings Bank

Brockton Stay Co.

Brockton Steam Laundry

Brown Bros., \& Co.

Buck, C. A. \& Son

Burke, Thomas F. \& Brothers

Burns \& Cormack

Burr, George W.

Burr, George W.

Burr \& Kingman

Burton, David

Burt \& Packard

Buswell, C. H. \& Co.

Callahan, Wm.

Callahan \& Daley

Carpenter, Edmund

Carter, George A.

Carpet Cleaning Works, Star

Cashman, John

Central House, Plymouth,

Central House, Provincetown,

Chambers, Calder \& Co.

Charnley, James A.

Chase, E. B. \& Co.

Church \& Russell Co., The

Chipman, Calley \& Co.

Clafin, Geo. L. \& Co.

Clapp, Edwin

Clark, Alexander

Clark Mfg. Co.

Clark \& Cole.

Clifford, Robert, \& Co.

Clinton House, Clinton,

Clinton Wire Cloth Co.

Codding, D. D.

Codding, D. E. \& Cก.

Codding Bros. \& Heilborn

Colburn, A. W. \& Co.

Cole, John

Cole, H. C. \& W. S.

Columbian Mfg. Co.

Combination Ladder Co.

Copeland, Ellis F.

Covel \& Osborn

Craig \& Richards Granite Co.

Cram, D. Henry

Crandall, J. E.

Crocker Harness Co.

Crocker, L. O.

Culver House, The, Nn. Abington,

Cummings, E. D \& Co.

Cushing House, Hingham,

Cushman, H. L. \& Co,

Cushing, M. H. \& Co.

Daggett \& Clap

Dawson \& Co.

Deacon Bros.

Dean, T. H. \& Co.

Deane, A. M. \& Co.

Dell, Lewis, \& Co.

Denison Bros., Co.
Derby Hotel

492

Desmond, Jas. F. $\quad 266$

I 50 Dighton Furnace Co. 390

I6o Drake's Local Express 208

I 77 Draper, O. M. $45^{2}$

I 58 Drew, P, A. \& Co. 434

I 52 Drew P. A. \& Co. 49I

I73 Duff, David, \& Son 308

I96 Duffy, J. P.

473 Eagle Stove Foundry Co. 322

268 Einstein, S. M. 448

266 Elcock \& Sons 272

336 Eldridge \& Co. 292

485 Elm Tree Inn, Back Inside Cover

I76 Ellis, Livsey \& Brown 448

I88 Emerson Piano Co., Front ii

I7 5 Erickson. Andrew 279

4 IO Evans, D. \& Co. 484

$240 \quad$ Evans, Cobb \& Co. 491

324 Excelsior Norwood St. Laundry 460, 503

489 Fales, A. \& Sons 439

146. Fales, Frank A. 498

499 Fallon, John \& Sons 238

280 Fall River Machine Co. 320

356 Farwell, W. M. \& Co. 420

404 Fegan \& Ballou 238

502 Fisher, J. M. \& Co. 446

I88 Fisher, W. D., \& Co 448

306 Fitzgerald \& Elcock 248

498 Fitzpatrick, J. \& H. 473

364 Flexible Shoe Mfg. Co. 469

206 Flint, Blood \& Co. 222

340 Folsom, A. \& Sons 444

$240 \quad$ Fore River Engine Co. 334

486 Ford, L. E. 332

498 Foxboro Foundry Co.

I48 French \& Hall Co., 368

420 French, John

4 I8 Freeman, H. A., \& Co. I88

444 Frye, George W. - 324

452 Fuller, J. S. 190

452 Galvin Granite Co., 279

$410 \quad$ Gannett \& Co. $\quad 192$

250 Gay, F. J., \& Co. 210

332 Gifford's Hotel. Provincetown, 402

170 Girard, Hotel, Providence, 2 I 2

$230 \quad$ Gladding B. H., \& Co. 184

I46 Glencoe Granite Co. 246

324 Glenwood Ranges 292

264 Goddard \& Rogers I 54

I78 Gold Medal Braid Co., Front B

I84 Goss, Abel 489

210 Gove, A. J. 380

503 Granite Railway Co. $\quad 256$

352 Grant, J. W., \& Cn. I84

222 Gray, W. H. I 42

$4 \delta_{5} \quad$ Gray, S., \& Co. $\quad 426$

284 Gray, T. H. \& Co. 440

496 Greenwood, C. B. 422

49I Grover, R. B., \& Co. I77

493 Guy's Furniture Mfg. Co. 138

252 Hager \& Handy 234

386 Hamilton, T. J. 182

266 Hammond \& Richmond 374

274 Hanson, Fred I 52

306 Hardwick, F., \& Son 272 
Hardwick, C. H., \& Co.

Hargraves Mfg. Co.,

Hart \& Akin

Hart, J. W., \& Co.

Hart, J. W., \& ro.

Hathaway, H. C.

Hayden, F. W.

Hayes, D., \& Sons

Hayward Carriage Co.,

Hayward \& Sweet

Healey \& Welch

Herrod, A. M.

Heywood, M., \& Co.

Hildreth, Milo, \& Co.

Hindle, William

Hitch cock, George H., \& Co.

Hodges, A. B., \& Co.

Hollis \& Dearborn

Houghton, A. E

Household Sew. Machine

Howard \& Foster

Hooper \& Co.

Horn \& Supply Co., The,

Hub Gore Makers

Hudson, Henry W. Co. The,

Huebener, E. A., \& Co.

Hughes, P. F., \& Son

Inman, M. M. \& Co.

Jackson, Hotel, Rockland,

Jenkins, Z. A.

Jenney, Wm. S.

Jillson \& Folsom

Johnson, I. S. \& Co.

Johnson C. E. \& Co.

Johnson \& Porter

Johnson, Charles, \& Bros.

Johnson, Oliver, \& Co.

Jordan, Marsb \& Co.,

Toss Bros.

Keeler \& Co.

Keith, Preston B.

Keith \& Pratt

Kelley, T. F. \& Co.

Kelley, Zeno H

Kemp, John F.

Kennedy, Jos. P.

King, J. B

Kingman, Henry M.

Kingman, E. B. \& Co.

Kimball Bros. \& Cc.

Knapp Warren Co., The

Knight, Geo. \& Co.

Lane, C. E.

Lane, George A.

Langelier Mfg. Co.,

Leach, Wendell \& Co.,

Learned, A. C. J.

Le Baron Foundry Co.,

Le Valley, H. E. Mrs.

Leeds, Geo. S. \& Co.

Leominster Shirt Co., The, Front 462

Lincoln Bros.

Lincoln, Bacon, \& Co.

Lippard, Wm. C.
Littlefield, L. G.

Littlefield, Ralph R. $\quad$ I 44

Littlefield. L. G. $\quad 179$

Lockey J. H., Piano Case Co. 410

Long \& Saunders $\quad 236$

Lothrop, H. A. Mfg. Co. 497

Luther, Charles A. \& Co. 440

Lyon, Wm. E. 352

Lyons, C. D. \& Co. 495

Lyon, A. S. $\quad 496$

Maguire \& O'Heron $\quad 234$

Maintien J. B. \& Son $45^{8}$

Mansion House, New Bedford 304

Mansfield News 434

Marcy, Fred I. \& Co. $\quad 222$

Marlboro Dye House . 422

Marnock, A., \& Co. $\quad 248$

Marshall, H. T. $\quad$ I66

M.ason, Chapin \& Co. $\quad 196$

Mason, John 222

Mason, Volney W. \& Co. 230

Mason Machine Works, 296

Massasoit Mfg. Co. $\quad 3^{18}$

Mathaurs Bros. $\quad 277$

Matheson, D. A. $\quad 406$

Maxim, C. W. 374

Mc Cabe, B. H. $\quad 196$

McDonnell Bros. $\quad 23^{8}$

McDonnell \& Kelley $24^{8}$

McDonnell \& Sons 258

McGillvray \& Jones $\quad 236$

McGrath Bros. $\quad 23^{6}$

McIntosh \& Son $25^{\circ}$

McKenzie \& Paterson $\quad 278$

Mechanics Nat'l Bk. New Bedford $3^{\mathrm{O}^{2}}$

Mellen \& Leach $\quad{ }_{1} 3^{8}$

Melpi, R. A. $\quad 22^{2}$

Merchant's Nat'l Bank, New Bedford $30^{2}$

Merriam, F. A. \& Co. 493

Merry Mlount Granite Co. $25^{\circ}$

Milne \& Chalmers $\quad 260$

Miller O. A. $16^{2}$

Miller \& Luce $\quad 24^{6}$

Miller, Henry J. $\quad 37^{\circ}$

Miller, Wm. H. \& Sons. $\quad 196$

Mitchell, I., \& Co. 152

Mitchell Granite Go. . $\quad 246$

Monohan \& Breen 244

Moore, Charles H. 206

Moore \& Booth 286

Mosso Bros. $\quad 420$

Mount Vernon Granite Co. $\quad 246$

Nemasket House, The, 379

Nesmith, F. E. \& Co. 352

New Bedford Cordage Co. 302

New Bedford Steam Laundry, $\quad 304$

New England Rattan Co. 432

New York Biscuit Co., The, Front A

New England Specialty Co. $\quad 384$

New Process Twist Drill Co. $\quad 294$

New England Agency 487

Nichols, S. H. 173

Nicolls Granite Works $\quad 252$ 
Niles \& Wilbar

North, The

Nourse, Fred F.

Norwood Iron Foundry

O'Brien \& McNeil,

O'Brien, W. P., Estate

O'Neil \& Howes,

Oswald \& Moyle,

Owens, M.

Packard, Andrew F.

Packard, N. R. \& Co.,

Packard, D. S. \& Co.,

Paine, Stephen

Pairpoint Mfg., Co., The,

Paisler, Charles S.

rarker House, New Bedford,

Paton Mfg. Co.

Patten O. O. \& Co.,

Patuxet House, Kingston,

Pawtucket Furniture Co.,

Pearce, John R. \& Son,

Pearse, W. G.,

Peckham, Geo. A.,

Perkins \& Joyce,

Phenix Iron Foundry.

Phillips, Thomas \& Co.,

Phinney J. G. Counter Co.,

Phœnix Mfg., Co.,

Pierce, C. S.

Piper, Cottle, \& Co.

Plainville Stock Co.

Plymouth Foundry Co.,

Plymouth Rock House, Plymouth 356

Plymouth Woolen Co., $\quad 344$

Plimpton J. E., \& Co. 500

Poole's Granite \& Marble Co. 420

Possner, A. P.

Powers, E. S., Dr.

Pratt, T. D.

Pray, John H., Sons Co.

Presbrey Stove Lining Co.,

Prophet Spring,

Prout Bros.

Providence Belting Co.

" Creamery,

" Gas Co.,

"Machine Co.,

" Coal Co., The

Putnam Nail Co., The

Ransden, N. A. W.

Rathbone \& Smith,

Reed \& Barton,

Reed, E. P.

Reed, H. B. \& Co.

Regnell, Bigney \& Co.

Reinhalter, A.

Reinhalter, J. B.

Reynolds, E. H.

Reynolds, E. H. Co.

Reynolds, L. M. \& Co.

Reynolds, Bion F.
Rhode Island Cement Drain Pipe Co.

$2 \mathrm{I} 4$

Rhode Island Perkins Horse Shoe Co.

Richardson \& Bottomley 489

Richmond, L. \& Co. I36

Ripley \& Bartlett, $\quad 356$

Rising Sun Stove Polish, $\quad 430$

Robinson Bros. 458

Robinson, John T. \& Co. $\quad 3$ I6

Robinson, G. A. $\quad 499$

Rockland Company, $\quad 348$

Ryder, J. J. Co., The 220

Sadler, F. H., \& (o. 492

Samoset House, Plymouth, $\quad 356$

Sandland, Capron \& Co. $\quad 452$

Sargent, J.S.. \& Son I 38

Sargent, Anolim \& Keith

Scott, John 440

Sears, J. K. \& B., \& Co. 374

Seaver. H. L. 288

Shea, W. \& Son, 244

Sherman, S. H. $33^{2}$

Sherman, C. E. W. \& Son $45^{2}$

Short, Nerney \& Co. $\quad 448$

Simpson Spring Co. $\quad 386$

Simpson, S. D. \& Son 386

Smithfield Granite Co. $\quad$ I82

Smith Concrete Co. 216

Smith, Charles A. $\quad 356$

Smith, Jason 364

Smith, William A. 252

Smith \& Crosby 446

Smith \& Stoughton $\quad 354$

Smith \& Wade I 56

Snell \& Atherton $\quad 176$

Somerset \& Johnsonburg Mfg. Co. 392

Somerset Stove Foundry Co. 394

Soule Piano \& Organ Investment Co., The $\quad 296$

South Framingham Hotel 432

Sowle, Nat. P. 300

Spencer, H. L. $\quad 460$

Spencer, J. L. $\quad 460$

Spargo, Wm, T. 272

Spier \& Coles 448

Stafford, George, W. Mfg. Co. I80

Standard Company $\quad$ I6o

Star Tanning Co. $\quad 460$

Stevens \& Willis $\quad 504$

Stetson, E. H. \& Co, 350

Stetson, Warren B. 374

Stone, C. F. \& A, W. 380

Studley, Gideon $\quad 364$

Strange's Machine Works : 294

Sullivan, J. D. 308

Sun Enamel Works $\quad 4$ r 4

Swasey \& Grew I64

Sweetser, William A. $\quad$ I40

Swift, J. R. ․ 4 I4

Swithin Bros. $\quad 262$

Tannatt, J. C. I 52

Taunton Brick Co. $\quad 284$

Taunton Copper Mfg. Co. 290 
Taunton Crucible Co.

'Taunton Lumber Co.

Taunton Stove Lining Co.

Tenney, A. E. Mfg. Co.

Tenney, Charles

Tenney, J. L.

Terry, Ware \& Alley

Thumas, Myron F.

Thomas \& Miller

Thompson, A. C.

Thompson Bros.

Thompson, H. E.

Thompson, John \& Sons

Thompson, W. M.

Thomson Bros.

Thurston, George H.. \& Co.

Torrey, Winfred, A.

Tougas, J. O.

Tower Bros. \& Co.

Tripp, U. T.

Turner, J.S.

Turner, Wm.

Union Marble Wks.

Union Hotel, Leominster

Universal Loom Co.

Vanier \& Slattery

Wade, Huram

Wade, Davis \& Co.

Walker, Geo. F.

Walker \& Whitman $\quad 168$

Wakeling, C.

Webster File. Works

Westmacott, J. M. \& Co.

Weymouth Mitten Co.

Wheaton, Richards \& Co. $\quad 446$

White, D. D. Shoe Co. 288

White, Frank E.

White, Stillman $\quad 192$

Whitman Grain \& Coal Co. $\quad 354$

Whitman Insurance Agency 354

Whitten, C. L. 460

Whitten-Godding Cycle Co., The. 204

Wilson Lace Clasp Co. $\quad 402$

Williams Brick Co. 288

Willey, G..W. I60

Willison, E. C. $\quad 276$

Williston, C. $\mathrm{H}$. 320

Winkfield \& Gregg $\quad 328$

Witham, F. F.

Woodsum, B. H. \& Co.

Woodward, Alfred P. 308

Woodward Enterprise Mfg. Co. $\quad 486$

Wollaston Hotel 497 
NEW YORK.

BOSTON.

CHICAGO.

$\mathrm{RE} A \mathrm{D}$

T H E NORT H

A Monthly Illustrated Journal of

Industrial, * Inventive, * Commercial * and

Financial * Resources * of * the

United * States.

History, Biography, Science and Literature.

EDITED AND PUBLISHED BY

H A G E R \& H A N D Y ,

12 PEARL STREET, - - BOSTON, MASS.

Special Editions on the World's Fair by our Correspondents.

\section{ESTABLISHED 1881 . \\ HAGER \& HANDY,}

12 Pear! St., Boston, Mass.

\section{HISTORICAL \& ILLUSTRATIVE PUBLLSHERSS.}

ART ADVERTISING has its place and in

the front ranks are OUR SPECIALTIES:

- PUBLISHERS OF -

New England News, The North, History West End Street Railway, History Boston Yacht Club, History Old Colony Railroad. 
(F)

\section{THOMAS PHILLIPS \& CO.,}

George R. and George C. Phillips, Proprietors.

Office and Salesroom: 75,77 and 79 SOUTH MalN ST.

Factory : BENEPIT, PIKE, TRAVERSE and TOCKWOTTON STS.

\section{PROVIDENCE, R. I.}

*

Workers of -

Copper, Brass, Lead, Iron and Steel.

Machinists and Coppersmiths.

Builders of -

Drying and Finishing Machinery for Bleachers, Dyers, Finishers, Printers and Woolen Manufacturers. Cylinder Slashers, Tape Dressers, Sizing Machines, Dye Kettles, Print Rolls, Batchers, Folders, Etc.

Every description of Light and Heavy Copper Work for Cotton and Woolen Mills, Sugar Refiners and Brewers.

Manufacturers of -

Lead Pipe and Sheet Lead, Jobbers of Plumbers' Supplies.

*

Fine Sanitary Plumbing for Private and Public Buildingss. 


\section{STOP AT THE}

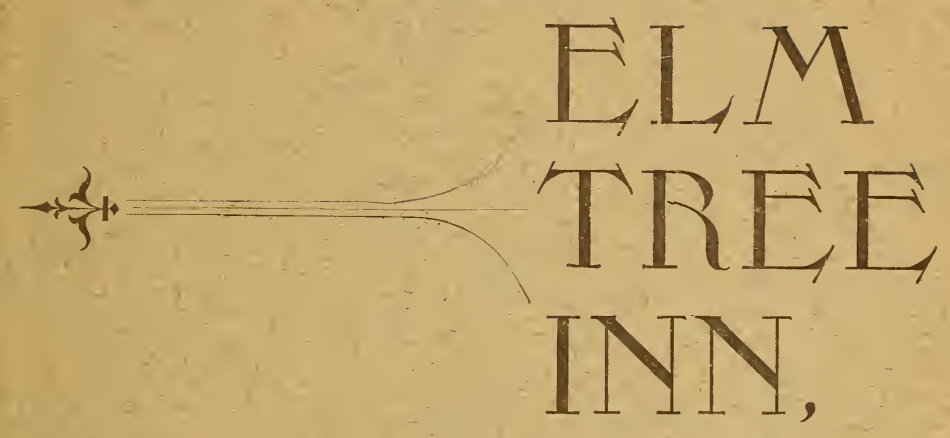

\section{WHEN IN MEDFIELD, MASS.}

$\rightarrow$ \& 30 W

THIS IS A FIRST-CLASS HOTEL, NEWLY FITTED WITH ALL THE MODERN CONVENIENCES, ELECTRIC BELLS, STEAM HEAT ETC., ETC.

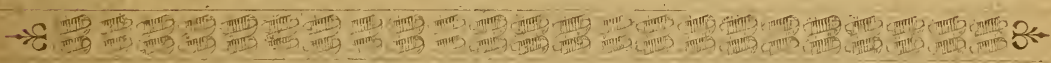

\section{ELM TREE INY}

A. O. GRANT, PROPRIETOR

MEDEIELD, MASS. 
SMITHSONIAN INSTITUTION LIBRARIES 